\title{
Microbiological and Food Safety Aspects of Tempeh Production in Indonesia
}

\author{
Dissertation \\ to obtain the Ph.D. degree \\ in the International Ph.D. Program for Agricultural Sciences in Göttingen (IPAG) \\ at the Faculty of Agricultural Sciences, \\ Georg-August-University Göttingen, Germany
}

Presented by

Riyan Anggriawan

Born in Purbalingga, Indonesia

Göttingen, December 2017 
D7

1. Name of supervisor: Prof. Dr. Petr Karlovsky

2. Name of co-supervisor: PD Dr. Franz Hadacek

Date of dissertation: January $25^{\text {th }} 2018$ 
"Food can not be cheap, local, green, safe and veried all at the same time" (The Economist, March 2001)

"Food for thought and thinking for food" (Crowther, J.R.)

"Knowing is not enough; we must apply. Willing is not enough; we must do"

(Goethe)

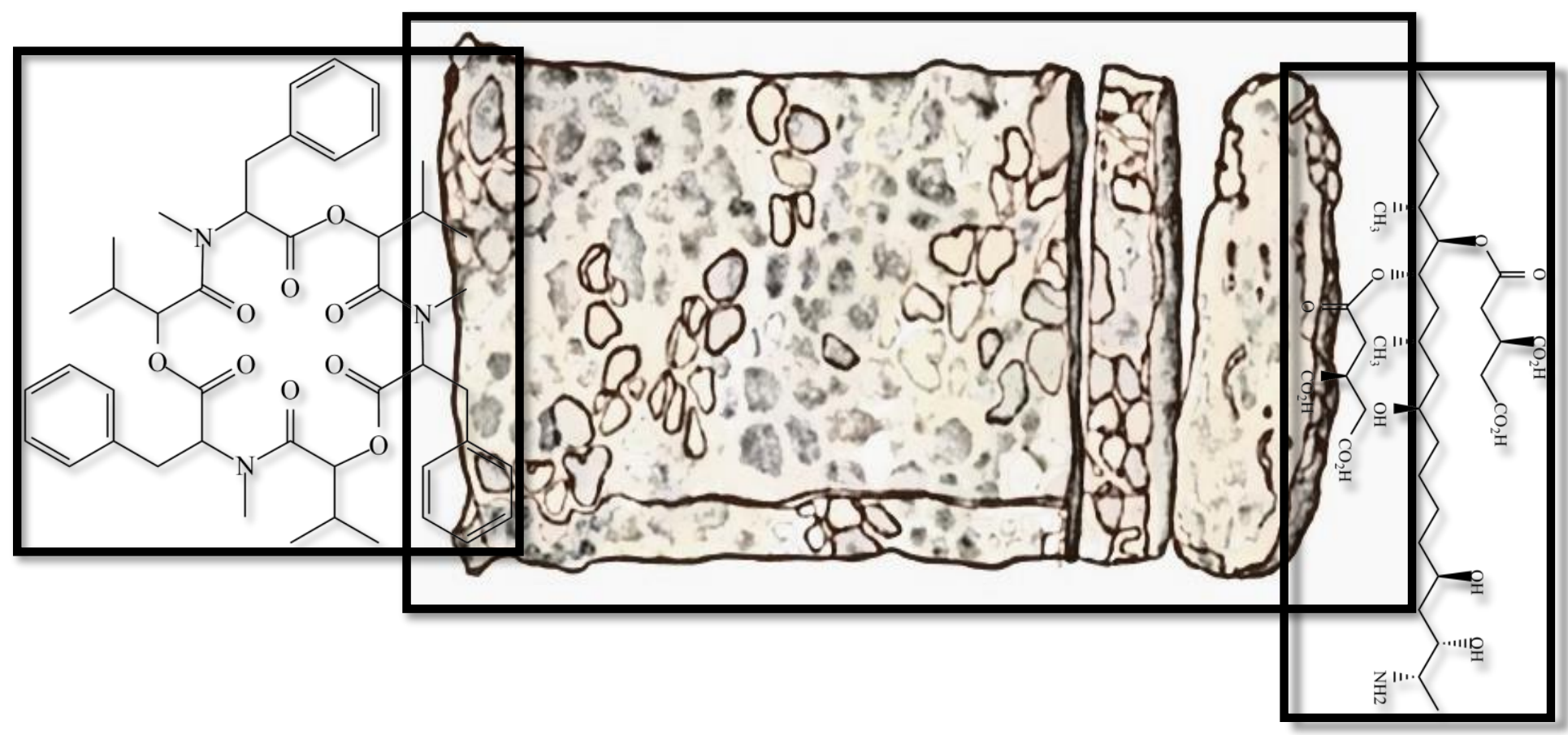




\section{Contents}

\section{Chapter 1}

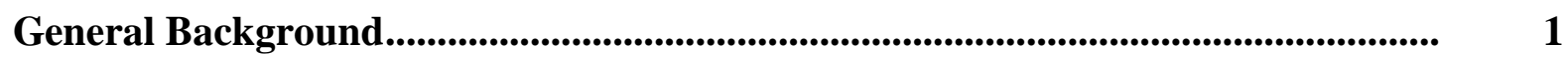

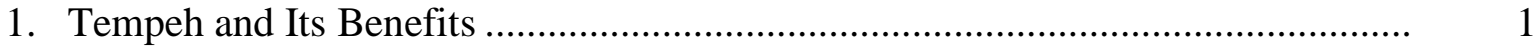

2. Tempeh Production ...................................................................................... 2

3. The Role of Microorganism in Tempeh Production .......................................... 3

4. Potential Biosafety Issues in Tempeh Production ............................................... 6

5. Could Masked Zearalenone be Generated during Food Fermentation ? ................ 9

6. Current Food Safety Conditions in Indonesia..................................................... 11

7. Aim of the Work ........................................................................................... 15

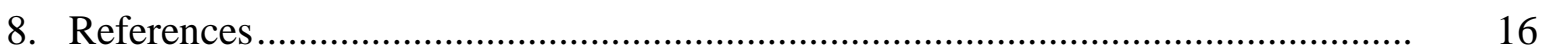

\section{Chapter 2}

REVIEW ARTICLE 01: Mycotoxins in Indonesian Foodstuffs: Occurrence, Prevention, and Remedial Methods .............................................................................................. 21

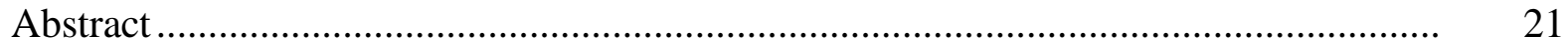

1. Introduction ............................................................................................. 21

2. Factors Promoting Mycotoxins Contamination in Indonesian Foods.................... 22

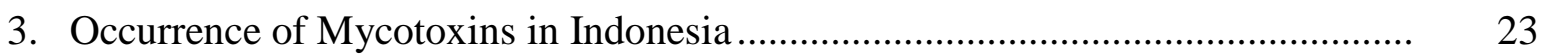

4. Health Impact of Mycotoxins in Indonesia.................................................... 31

5. Updated Risk Assessment of Maize and Peanut Consumption in Indonesia......... 32

6. Mycotoxin Regulation in Indonesia................................................................ 35

7. Mycotoxin Control in Indonesian Foodstuffs ................................................... 38

8. Challenges and Future Perspectives............................................................... 48

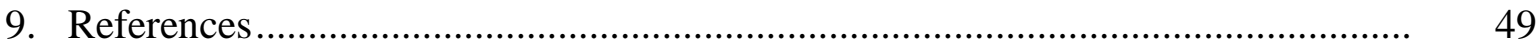

\section{Chapter 3}

RESEARCH ARTICLE 01: Determination of Fungal Diversity in Indonesian Tempeh, and Update on Their Safety Status ............................................................................. 56

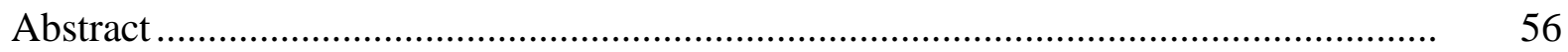

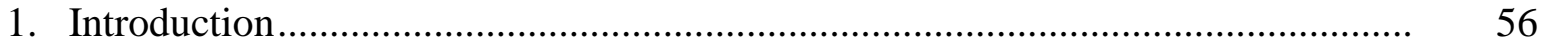

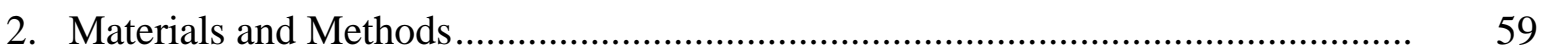

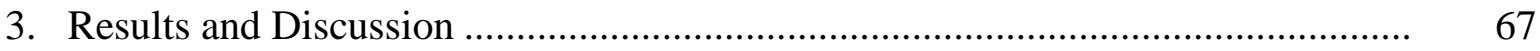

3.1. Results of Part I (Fungal Diversity and Identification)................................ 67

3.2. Discussion of Part I (Fungal Diversity and Identification) .......................... 85

3.3. Results of Part II (Safety Status of Tempeh Fungi) ................................... 89

3.4. Discussion of Part II (Safety Status of Tempeh Fungi) .............................. 96 
3.5. Results of Part III (Zearalenone Biotransformation by Tempeh Fungi)......... 99

3.6. Discussion of Part III (Zearalenone Biotransformation by Tempeh Fungi) .... 102

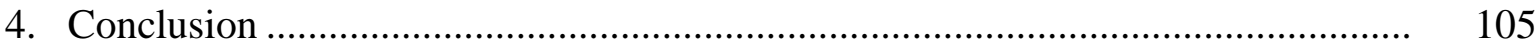

5. Acknowledgement ..................................................................................... 105

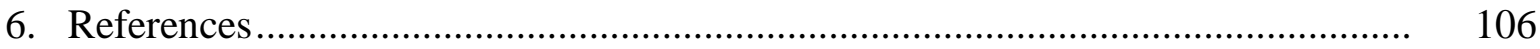

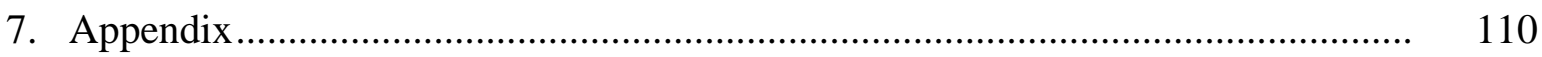

\section{Chapter 4}

RESEARCH ARTICLE 02: Mycotoxin Producing Fusarium Species in Indonesian

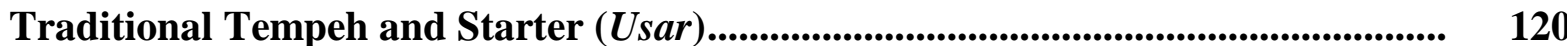

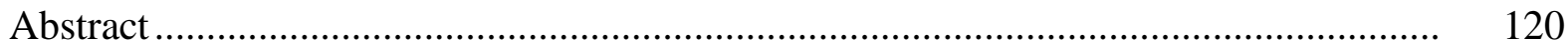

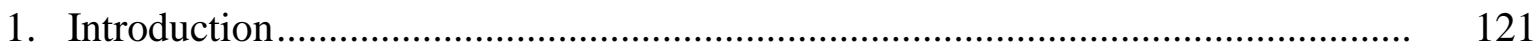

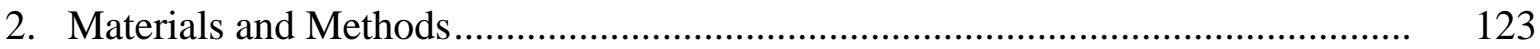

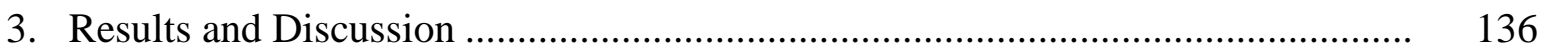

3.1. Results of Part I (Fusarium Isolates Identification and Their Mycotoxin Screening)

3.2. Discussion of Part I (Fusarium Isolates Identification and Their Mycotoxin Screening)

3.3. Results of Part II (Detection of Fusarium and Mycotoxin in Traditional Tempeh)

3.4. Discussion of Part II (Detection of Fusarium and Mycotoxin in Traditional Tempeh)

3.5. Results and Discussion of Part III (Traditional Tempeh Quality and Risk Assessment)

4. Conclusion

5. Acknowledgement

6. References.

7. Appendix

\section{Chapter 5}

REVIEW ARTICLE 02: Fighting Toxigenic Fungi in Food Industry by Applying Lactic Acid Bacteria: A Review of Established and Recent Research....................... 164

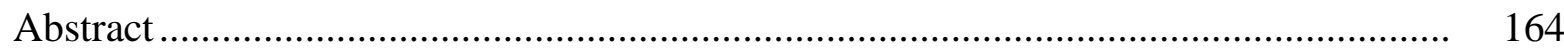

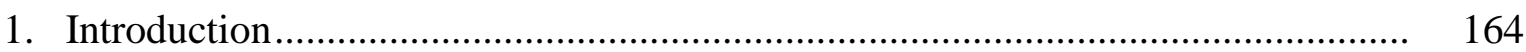

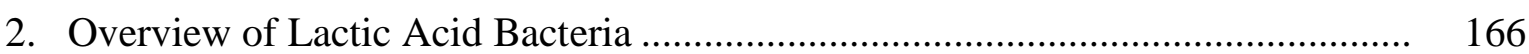

3. Lactic Acid Bacteria as Antifungal Agent ........................................................ 167

4. Antifungal Compounds Produced by Lactic Acid Bacteria................................. 169 
5. Genetic Engineering to Improve Lactic Acid Bacteria Antifungal Properties ...... 185

6. Application of Antifungal Lactic Acid Bacteria and Prospect in Food Industry.... 188

7. Future Research Trends .................................................................................. 190

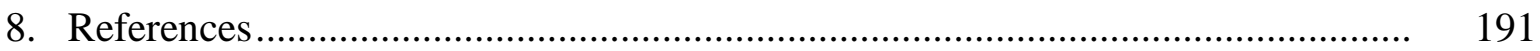

\section{Chapter 6}

RESEARCH ARTICLE 03: Diversity and Biological Activity of Yeast and Lactic Acid Bacteria from Soak Water in Tempeh Production ...................................................... 201

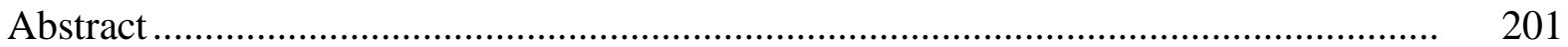

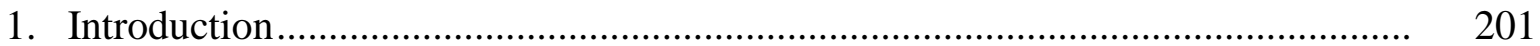

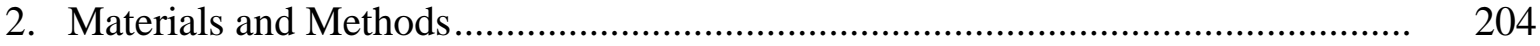

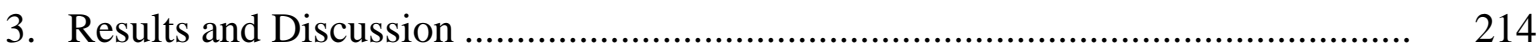

3.1. Results of Part I (Identification and Characterization of Tempeh Yeast and Lactic Acid Bacteria) ............................................................................... $\quad 214$

3.2. Discussion of Part I (Identification and Characterization of Tempeh Yeast and Lactic Acid Bacteria) ...................................................................... 221

3.3. Results of Part II (Antifungal Activity of Tempeh Yeast and Lactic Acid Bacteria)

3.4. Discussion of Part II (Antifungal Activity of Tempeh Yeast and Lactic Acid Bacteria)

3.5. Results of Part III (Zearalenone Biotransformation by Tempeh Yeast and Lactic Acid Bacteria)

3.6. Discussion of Part III (Zearalenone Biotransformation by Tempeh Yeast and Lactic Acid Bacteria)

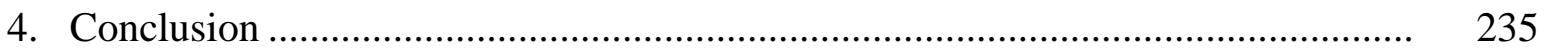

5. Acknowledgements .................................................................................... 235

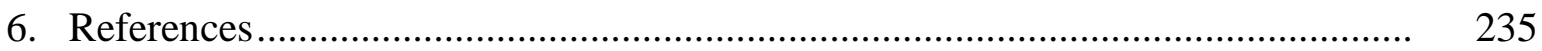

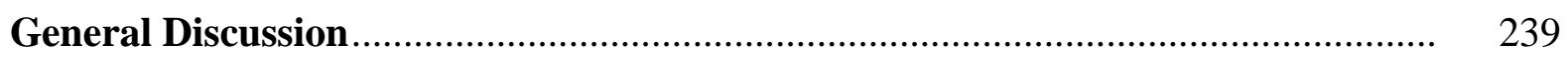

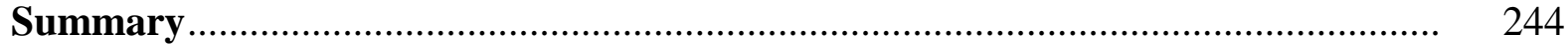

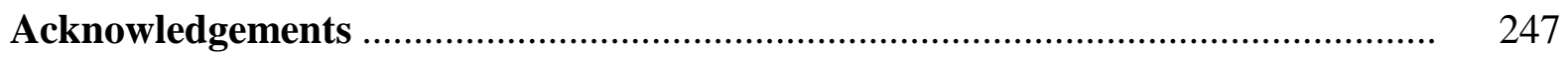

Curriculum vitae ............................................................................................. 249 


\section{List of Abbreviations}

\begin{tabular}{|c|c|}
\hline BEA & Beauvericin \\
\hline BMDL & Benchmark dose lower limit \\
\hline bw & Body weight \\
\hline CFS & Cell free supernatant \\
\hline CFU & Colony forming unit \\
\hline CTAB & Cetyl trimethylammonium bromide \\
\hline ENN & Enniatin \\
\hline ESI & Electrospray interface \\
\hline FUM & Fumonisin \\
\hline GAP & Good agricultural practices \\
\hline GMP & Good manufacturing practices \\
\hline GRAS & Generally recognized as safe \\
\hline HPLC-MS/MS & High performance liquid chromatography-tandem mass spectrometry \\
\hline ITS & Internal transcribed spacer \\
\hline LA & Lactic acid \\
\hline LAB & Lactic acid bacteria \\
\hline LD & Lethal dose \\
\hline LOD & Limit of detection \\
\hline LOQ & Limit of quantification \\
\hline MEA & Malt extract agar \\
\hline MRS & De Man, Rogosa and Sharpe \\
\hline PCR & Polymerase chain reaction \\
\hline PDA & Potato dextrose agar \\
\hline PDB & Potato dextrose broth \\
\hline PDI & Probable daily intake \\
\hline PLA & Phenyllactic acid \\
\hline RAPD & Random amplified polymorphic DNA \\
\hline RH & Room humidity \\
\hline RPM & Revolutions per minute \\
\hline SEM & Scanning electron microscopy \\
\hline SPC & Standard plate count \\
\hline TDI & Tolerable daily intake \\
\hline TEF & Translation elongation factor \\
\hline TTA & Titratable acidity \\
\hline UPLC-MS/MS & Ultra performance liquid chromatography-tandem mass spectrometry \\
\hline UV & Ultraviolet \\
\hline $\mathrm{v} / \mathrm{v}$ & Volume per volume \\
\hline $\mathrm{w} / \mathrm{v}$ & Weight per volume \\
\hline ZEN & Zearalenone \\
\hline
\end{tabular}




\section{Chapter 1: General Background}

\section{Tempeh and Its Benefits}

Tempeh is traditional food from Indonesia made by fermenting soybeans with mold Rhizopus spp. It has a solid form, distinctive aroma and is white and slightly gray in color (INCS, 2009). Besides of the Indonesian National Council for Standardization (INCS), the standard of tempeh is also defined in the Codex Alimentarius (CAC, 2013) as compact, white, cake-form product, prepared from dehulled-boiled soybeans by solid state fermentation with Rhizopus spp. Moreover, Codex Alimentarius also assesses the organoleptic quality of tempeh, among others: (1) compact texture and not easily disintegrated when cut 2) white color growth of Rhizopus spp., 3) nutty, meaty, and mushroom-like flavor, 4) fresh tempeh should not smell of ammonia.

Historical records reveal tempeh originates from ancient Javanese as mentioned in Serat Centhini vol. 3 (1814), depicting tempeh as royal menu of Sunan Giri served in Java during the $17^{\text {th }}$ century (Astuti, 1999a, Purwadaria et al., 2016) as follows: "Jangan menir ulur - pitik, brambang kunci sambel sinantenan, brambang jae santen Tempe, .... "(Chicken eggs sauteed with spinach, hot sauce with coconut milk, shallot and ginger root, Tempe in coconut milk with shallot and ginger ...). In 1950, research on the changes of the chemical, microbial and nutritional value during fermentation was conducted by Dutch researchers. Thus tempeh gained popularity in Europe. Tempeh was also known in the United States since 1946. American scientists have conducted research on tempeh since 1960, including Steinkraus, Hesseltine, and Wang who started their commercial tempeh company (Karyadi, 1996).

Indonesia is known for the largest tempeh production in the world and has the largest soyfood market in Asia. In 2012, approx. 60\% of soybean produced in Indonesia was for selfsufficiency as tempeh at a national level, with the annual consumption amounting to 8.5 $\mathrm{kgs} /$ person/year (BPS, 2012). About 2.4 million tons of tempeh produced a year by more than 81 thousand tempeh producers. Only 600 thousand of the 2.2 million tons soybeans used each year is grown in Indonesia, the rest is imported from USA to meet the demand (INCS, 2012).

Tempeh is beneficial, compared to other healthy food. Its raw materials, soybeans, contain on average $40 \%$ protein, $20 \%$ fat, $35 \%$ carbohydrates, and 5\% ash (Liu, 1997). The soybean processing into tempeh degrades macromolecules into smaller units, so that it can easily be digested and utilized by the body (Nout and Kiers, 2005). The concentrations of some vitamins of the B-group (B12, riboflavin, pyridoxine, niacin, biotin, and folic acid) are higher in tempeh than in soybeans (Denter et al., 1998). Besides, tempeh also heals chronic diarrhea in children quickly because of antibacterial compounds inhibiting the growth of Salmonella typhii, Shigella flexneri, and Escherichia coli 0125 K70 (Hermana, 1995; Roubos-van den Hil and Nout, 2011). According to Murata (1985), FAO considers tempeh as one of the best sources of protein.

Antioxidants are essential for protecting the body from free radicals that can cause carcinogenesis as well as other age-related diseases (Cutlar, 1992). 6,7,4-Trihydroxyisoflavone (factor 2) (Klus et al., 1993) and 3-hydroxyanthranilic acid (HAA) (Esaki et al., 1996) are antioxidants found in tempeh. Beta-carotene produced by Rhizopus strains during tempeh fermentation provide an alternative solution for those who suffer from vitamin A deficiency (Denter et al., 1998). Moreover, 
tempeh with iron fortification is able to overcome Anemia (Astuti, 1999b). Isoflavone aglycone (daidzein and genistein) and gamma amino butyric acid produced during tempeh fermentation are also beneficial for health (Nakajima et al., 2005; Handoyo and Morita 2006). A recent study in Malaysia showed that tempeh can be used as a non-dairy source of calcium (Haron et al., 2010). Intervention studies in humans also showed that tempeh provides hypolipidemic effects for hyperlipidemic patient (Roubos-van den Hil and Nout, 2011; Utari, 2011) and hypoglycemic activity for diabetic mellitus patient (Aitoman, 2011).

\section{Tempeh Production}

Tempeh-producing technology has been handed down through generations and was changed based on experience. It is diverse, but basic similarities are shared among producers, namely the boiling, dehulling, acidification, washing, inoculation, bagging, and incubation of soybeans (Figure 1). However, alterations in the processing is made in accordance means and resources which are available (Karyadi, 1996).

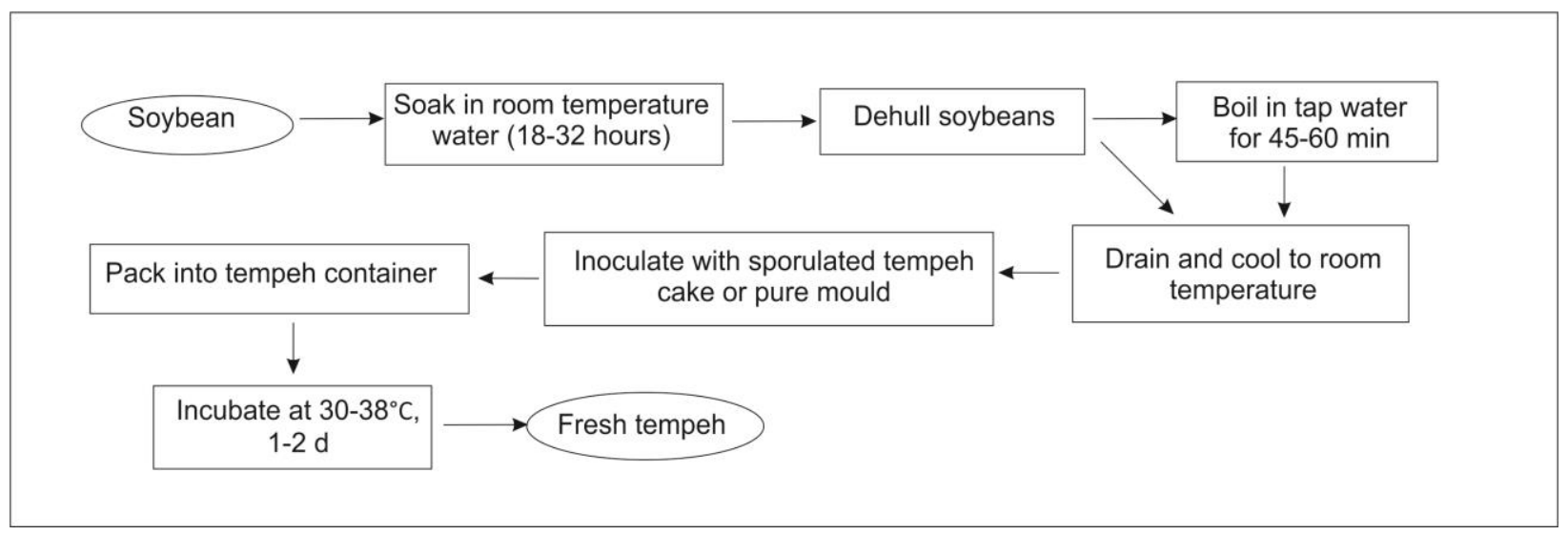

Fig 1. Production process of soybean tempeh in general.

During the first stage soybeans are boiled, dehulled, soaked, and washed. All producers use the same steps. The second stage may vary. Some drain the soybeans processed in the first stage directly and mix them with the mold inoculum, bag them, and go on to incubation. Others, reboil the soybeans, cool them, mix them with inoculum, bag them, and then go to the third stage, incubation. Other producers mix the inoculum together with soaked soybeans, after which the soybeans are drained, bagged, and incubated (Hermana, 1996). Incubation is the main stage of tempeh production (Kasmidjo, 1995). It varies not only in terms of stage but also the approach. Producers modify, for example, the soaking time, boiling time, inoculum type and the way inoculum is added, packaging materials, the methods of packaging, and methods of incubation (Hermana, 1996).

The procedure prior to fungal fermentation can support the growth of the mold on soybeans substrate. Boiling and soaking will hydrate soybeans, which in turn increase tenderisation of the cotyledons. Soybeans hydration results in the increasing water activity (aw) to 0.99 in environment, in which molds grow best. Boiling soybeans will also kill most microorganisms, 
tenderize the soybean tissue so that mycelia penetrate easily, and increase water (moisture) content of the soybeans in order to make soybean dehulling easier. During the soaking period, acidification by lactic acid bacteria (LAB) occurs, thus the $\mathrm{pH}$ drops to less than 5 . Washing is done to dehull the beans, eliminate the mucilage and lower the acidity during the soaking period. After inoculation with the starter culture, Rhizopus spp. is the main microorganism responsible for tempeh fermentation. Meanwhile, packaging does not only serve as an oxygen barrier but also provides optimum conditions for mold growth. When incubation temperature is between $20^{\circ}$ to $37^{\circ} \mathrm{C}$ mold growth is optimal (Hermana, 1996; Karyadi, 1996). During the incubation (fermentation), the mold mycelium grows and binds with bean cotyledons (Nout and Kiers, 2005). The fermentation may take 18 to 48 hours (Mulyowidarso et al., 1989). Sudarmadji (1977) divides the fermentation process into three phases:

1). Rapid growth phase (0-30 hours of fermentation) which is the initial phase. At this stage free fatty acids increase, the temperature increases, the mold grows rapidly and mycelia form on the surface of soybean.

2). Transition phase (30-50 hours of fermentation) is the optimal fermentation phase where fresh tempeh is formed that is ready to be consumed. In this step, the temperature decreases, some fatty acids are released and mold growth is almost constant or increases slightly, the specific tempeh flavor is formed, and the tempeh texture is more compact.

3). Further phases of fermentation (50-90 hours of fermentation). In this phase, there is a rise in the number of bacteria and the amount of free fatty acids, a reduction in mold growth, the mold stops growing at a certain water content and the flavor changes due to protein degradation into ammonia.

\section{The Role of Microorganisms in Tempeh Production}

Complex of microbial communities colonize in soybean tempeh, their development start during the soaking of the raw ingredients (Nout and Kiers, 2005). These microorganisms are involved in several stages. They are responsible for the acidification during the soaking stage, there may be cross-contamination through the handling during hand drying and packaging, during the incubation and in the composition of inoculum. The essential microorganisms involved in fermentation of tempeh comprise molds and bacteria. Mold mycelium is essential for tempeh production since tempeh is considered excellent when soybean cotyledons are bound together by the mycelium. Meanwhile, bacteria are required for the acidification of soybeans.

Tempeh is typically produced by home industry on a small-scale basis with poorly controlled fermentation. The fermentation is inadequately performed under aseptic conditions although the starter culture containing fungi is added at the beginning of the fermentation. Various organism contribute to tempeh fermentation (Barus et al., 2008; Seumahu et al., 2013). This causes variations in flavor and quality of tempeh in Indonesia.

Molds that play the most important role in fermentation include the genera Rhizopus belonging to the family Mucoraceae, of the order Mucorales, in the subclass Zygomycotina of the class Zygomycetes. This genus is classified into several species (Hesseltine, 1985). The most 
important ones are Rhizopus oligosporus, $R$. arrhizus, $R$. stolonifer, $R$. oryzae, Mucor $\mathrm{sp}$. and Aspergillus sp. (Pawiroharsono, 1994). During tempeh production, Rhizopus is responsible for the increase in soluble proteins, fats, and carbohydrates in soybeans (Jutono,1985). However, each species produces tempeh of varying quality. The highest concentration of free amino acids is found $R$. oligosporus tempeh, compared to $R$. stolonifer and $R$. oryzae (Keuth and Bisping, 1994). Rhizopus sp. produce enzyme that are found to be able to degrade soybean substrates, such as carbohydrases (polygalacturonase, endocellulase, xylase, and arabinose), besides lipases and proteases (Nout and Kiers, 2005). During tempeh fermentation by a single culture $R$. oligosporus, raffinose content is reduced by $60 \%$ and stachyose content by $10 \%$; sugar content increased by $700 \mathrm{mg} / 100 \mathrm{~g}$; free amino acids by $70 \mathrm{mg} / 100 \mathrm{~g}$ (Egounlety and Aworh, 2003).

Bacteria are important for soybeans acidification during tempeh production. However, it is not known whether bacteria are important in other processes during tempeh production. In subtropical regions, natural acidification of soybeans during soaking proceeds either very slowly or does not occur at all (Liu, 1997). During chilly weather, lactic acid fermentation does not work well. To obtain desired $\mathrm{pH}$, the dehulled beans are hydrated in water or $0.85 \%$ lactic acid solution for 2 hours at $25^{\circ} \mathrm{C}$ or 30 minutes at $100^{\circ} \mathrm{C}$ (Nout and Kiers, 2005), $\leq 0.5 \%$ lactic acid or $\leq 0.25 \%$ acetic acid is added. In the tropics the rapid growth of bacteria starts during soaking, with a bacteria plate count of up to $4.4 \times 10^{9} \mathrm{CFU} / \mathrm{g}$ (Nuraida et al., 2008). The soak water is rich in simple sugars such as glucose, fructose, and galactose. Glucose serves as primary substrate for microbial growth in soak water. Invertases and $\alpha$-galactosidases on soybean produce simple sugars in the soak water. Bacteria and yeasts are found in thesoak water (Mulyowidarso et al., 1991).

Moreno et al. (2002) investigated the growth of lactic acid bacteria during in tempeh production in Malaysia. Count of LAB, bacteria on raw beans were low $\left(<10^{2} \mathrm{CFU} / \mathrm{g}\right)$. The number of $\mathrm{LAB}$ on the soak water increased to 7.9-9.3 $\log \mathrm{CFU} / \mathrm{mL}$ at the end of the soaking process and 7.8-9.2 $\log$ CFU/g in the soaked soybean. Second boiling of the beans results in reductions of LAB populations to less than $4 \log \mathrm{CFU} / \mathrm{g}$. The number increased sharply to 6.8- $9.9 \log \mathrm{CFU} / \mathrm{g}$ in final product (tempeh) (Moreno et al. 2002). Nuraida et al. (2008) and Efriwati et al. (2013) reported change in LAB number during tempeh preparation at a lab scale. Nuraida et al. (2008) reported that LAB population on soaked soybeans reached $9 \log \mathrm{CFU} / \mathrm{g}$. However, the number decreased to $6 \log$ CFU/g on tempeh. Efriwati et al. (2013) reported two methods applied in producing LAB in tempeh preparation, namely one- and two-time boiling steps. At the end of soaking process, number of LAB produced from these two methods reached $6 \log \mathrm{CFU} / \mathrm{g}$. When soybeans were boiled once (one time boiling step), LAB number increased to $8 \log \mathrm{CFU} / \mathrm{g}$, greater than the population results in two-time boiling steps i.e. $6.5 \log \mathrm{CFU} / \mathrm{g}$.

According to Ashenafi and Busse (1991b), LAB have been shown to contribute to the safety of tempeh through the decrease in $\mathrm{pH}$, the production of organic acids, and metabolites that act as inhibiting agents against pathogens. The lower $\mathrm{pH}$ can only inhibit contamination of spoilage bacteria, but not the growth of Rhizopus sp. If the natural acidification does not occur, tempeh production is susceptible to undesirable contaminants, pathogens and spoilage microorganisms (Mulyowidarso et al., 1991b; Hidayat et al., 2006). During the soaking process, 
LAB will produce lactic acid as a major fermentation product besides of other organic acids (Table 1) (Nout and Kiers, 2005). Acidification can also provide a good environment for spore germination and result in a reduction of the lag time of $R$. oligosporus (Nour and Kiers, 2005). Moreno et al. (2002) reported that the LAB Enterococcus faecium isolated from overripe tempeh also produce of bacteriocins inhibiting the growth of Listeria monocytogenes, Bacillus pumilus and Clostridium sporogenes on growth medium. Further reports exist on the interaction between LAB and pathogenic bacteria in tempeh. For example, Lactobacillus plantarum and L. brevis that were isolated from soak water inhibited the growth of $S$. aureus and the production of Staphylococcus toxins (Tuncel and Goktan, 1990); co-cultures of L. plantarum (1) reduced the number of B. cereus by $1 \log$ CFU/g (Ashenafi and Busse, 1991); (2) inhibits the growth of Listeria monocytogenes significantly (Ashenafi, 1991a); and (3) also inhibits Salmonella infantis and E. coli in soybean (Ashenafi, 1991b) but the origin of the isolates of L. plantarum has not been revealed.

Table 1. Organic acid accumulation $(\% \mathrm{w} / \mathrm{v})$ on the soak water with a natural fermentation, pureculture innoculation and back-slopping ${ }^{\mathrm{a}}$.

\begin{tabular}{ccccc}
\hline Fermentation $^{\mathbf{b}}$ & $\mathbf{p H}$ & Lactic acid & Malic acid & Acetic acid \\
\hline Spontaneous & 4.5 & 0.6 & 0.2 & 0.07 \\
Enterococcus faecium & - & 1 & 0.02 & 0.15 \\
Lactobacillus acidophilus & 4.2 & 1.61 & - & 0.14 \\
L. casei & - & 1.1 & 0.2 & 0.05 \\
L. plantarum & 4.15 & 1.78 & - & 0.14 \\
Pediococcus pentosaceus & 4.24 & 1.56 & - & 0.16 \\
Back-slopping & 4.12 & 2.14 & - & 0.29 \\
\hline
\end{tabular}

${ }^{\mathrm{a}}$ source: Nout and Kiers (2005), Soaking was carried out with $300 \mathrm{~g}$ soybeans in $900-1000 \mathrm{~mL}$ tapwater during 24 hours at $30^{\circ} \mathrm{C}$, without inoculum (natural), with addition of $10^{4} \mathrm{CFU} / \mathrm{mL}$ soak water of pure cultures of lactic acid bacteria, or with addition of $3 \% \mathrm{v} / \mathrm{v}$ previously fermented soak water (back-slopping).

Lactic acid bacteria contribute positively to the safety of tempeh because the fermentation results in the formation of organic acids that inhibit the growth of pathogens and spoilage microorganisms in soybean. Microorganisms that are commonly found during the production process are from the genus Enterobacillus such as Lactobacillus spp., and L. plantarum (Pawiroharsono, 1994). Lactic acid bacteria which dominate during the soaking stage cause a significant increase of organic acids (Nout and Kiers 2005). The main organic acids contained in soybeans soak is lactic acid (Sparringa and Owens, 1999; Nout and Kiers, 2005). The main microorganisms for tempeh production are from Rhizopus species. However, fresh tempeh also contains mesophilic aerobic bacteria, enterobacteria, staphylococci, and yeasts. The presence of bacteria generally does not inhibit the fermentation process (Ko, 1985). In Indonesian tempeh, the levels of lactic acid bacteria were $10^{9}-10^{10} \mathrm{CFU} / \mathrm{g}$, and Enterobacteriaceae, bacterial spores and total aerobic mesophilic bacteria (except for LAB) were $10^{8}-10^{9}, 10-10^{2}$ and $10^{8}-10^{9} \mathrm{CFU} / \mathrm{g}$ respectively (Han et al., 1999).

Commonly, research on LAB and yeast at some stages of tempeh production process is conducted in the laboratory, not in the tempeh industry. The presence of these microbes in a sample 
of tempeh has been reported, but only from the final product (tempeh from a market). It was not reported during production process comprehensively, especially the soybean soaking process. Generally, research on LAB and yeast are based on conventional approach which takes time, expense much effort, and usually is limited on microbial assessment (Aslam et al., 2010). Up until now, LAB study of tempeh production is limited to the value of colony forming units (CFU). Lactic acid bacteria populations for tempeh production has been screened for tempeh producer in Malaysia (Moreno et al., 2002) and only laboratory research level in Indonesia (Nuraida et al., 2008). Neither Moreno et al. (2002) and Nuraida et al. (2008) did not specifically study about yeast population, which was included in the value of CFU fungi. Moreover, the study about the diversity of LAB and yeast during the soaking of mixture material (such as soybean-corn, soybean-rice) has never been investigated, except for a list of some types of LAB and yeast which ever found in tempeh and only characterized phenotypically (Samson et al., 1987; Mulyowidarso et al., 1990; Ashenafi, 1991; Ashenafi and Busse, 1991).

\section{Potential Biosafety Issues in Tempeh Production: Food, Toxication or Infection?}

Like many other traditional foods in Indonesia, tempeh is produced by a small scale home industry with poorly controlled fermentation that is carried out without sufficient hygienic precautions. Therefore, various types of microorganisms can participate in the process of fermentation, and natural contamination is always possible (Winarno, 1985; Barus et al., 2008; Seumahu et al., 2013). Moreover, there is no standard on making tempeh and its starter. This is the cause of many variations in the manufacture of tempeh in some areas (Astuti et al., 2000) which lead to nonhomogeneous quality and safety of traditional tempeh.

Although tempeh is characterized as safe for consumption, recently there have been cases of intoxication in Indonesia as a result of tempeh consumption. From 1998 until 2015 a dozen of cases were reported in the mass media, but complete data are still lacking. Many speculations may arise in line with any new discoveries such as that some Rhizopus strains could be agents of mucormycosis, and some strains are also capable of producing toxins that are dangerous to human health.

In recent years the clinical range of the infections caused by zygomycetes has changed dramatically because of the increase in the number of immune-system deficiencies (Meis and Chakrabarti, 2009). Among Mucorales, Rhizopus species, are the most common agent of mucormycosis (Ibrahim et al. 2012). Autopsy study showed that fungal infections as those caused by Aspergillus and Candida. They are 10-50 times more common in the inpatient population (Yamazaki et al., 1999) with 50\% or greater mortality of mucormycosis pneumonia (Quan et al., 2010) acute infection caused by Mucoralean Fungi. This arouses concern in clinical mycology. Clinical associated-strains often differ from food associated-strains (Jennessen et al., 2005), or are at least perceived as such because the latter has undergone domestication for centuries on rich substrates such as soybeans (Feng, 2006), also possibly as a consequence of selection and mutation mechanism. However, according to Dolatabadi et al. (2014), the clinical associated-strain has an identical genetic character to food and condiment associated-strains. 
Rhizoxin and rhizonin pose another threat to food safety associated with Rhizopus is posed by (Jennessen et al., 2005) (Figure 2). Rhizoxins are a family of macrolactones firstly isolated from a plant-borne isolate of $R$. microsporus by Iwasaki et al. (1984). These metabolites (myocotoxins) exhibit potent antitumor activity. The fungi can attack rice plants and trigger rice seedling blight. Symptoms of the infection include abnormal swelling of the roots possibly due to the inhibition of cell division (Lackner et al., 2011). Burkholderia rhizoxinica produces rhizoxin during soybeans fermentation by Rhizopus sp. on sufu preparation (Rohm et al., 2010). The rhizoxin derivatives are known as very strong antimycotic agents (Scherlach et al., 2006), also causing health hazards for human.
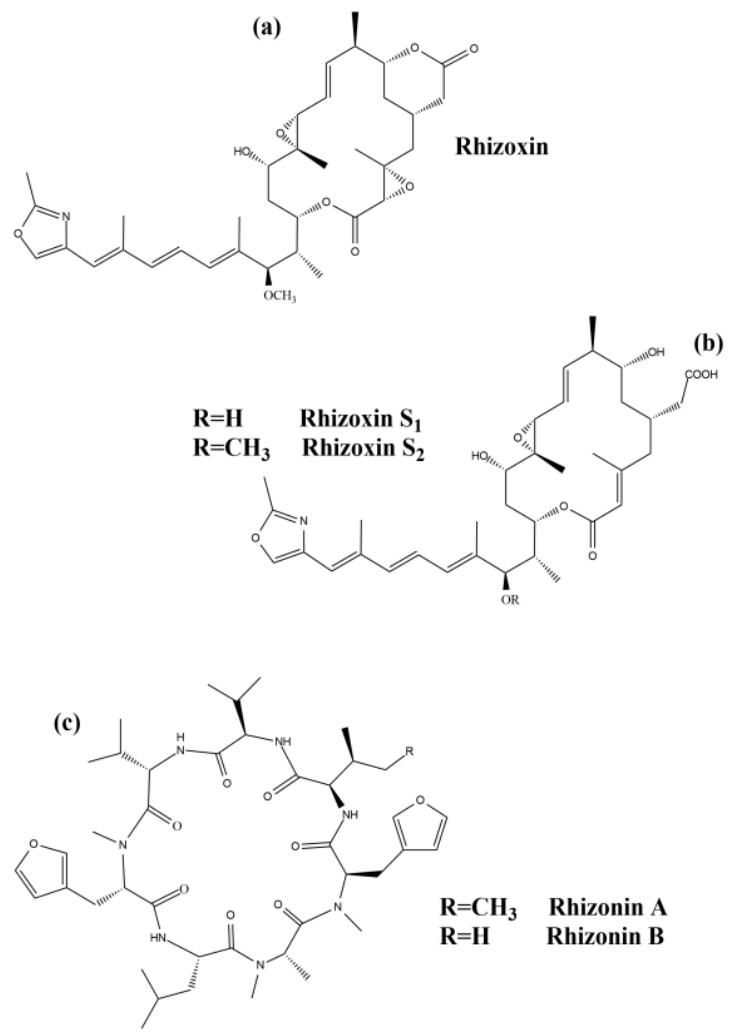

Fig 2. a) Rhizoxin; b) Rhizoxin S1 and S2; c) Rhizonin A and B.

Rhizonin A is acutely toxic for ducklings and rats (Wilson et al. 1984) and affects mainly the liver and kidneys causing $100 \%$ mortality (Rabie et al. 1985 ). It was initially reported as the first " mycotoxin " from lower fungi, but they are actually biosynthesized by the endosymbiotic bacteria Burkholderia rhizoxinica or Burkholderia endofungorum (Partida-Martinez et al. 2007) residing within the cytosol (Partida-Martinez et al., 2007, Scherlach et al., 2006). Strains carrying endosymbionts can be found as wild types as well as those that are used for the production of fermented foods (Dolatabadi et al., 2015). Because only some subspecies of $R$. microsporus are used for fermenting soybeans (such as for sufu and tempeh production), the potential risk to human health derives from this toxinogenic symbiosis. The cyclic peptide is highly toxic to mammals as they severely affect the liver (Wilson et al., 1984). For the sake of public health, attention should be given to toxins produced by $R$. microsporus in order to prevent any misuse. These results 
underline the urgent necessity to consider potential detrimental effects resulting from bacteriafungi interactions during food production to warrant food safety (Lackner and Hertweck, 2011). In order to increase food safety and for modernized tempeh industrial-scale processing, thus toxicological and clinical screening of Rhizopus strains from tempeh manufactures in Indonesia is needed.

The safety aspect of traditional tempeh is also threatened by possible contamination by the use of the traditional starter (usar). Usar is the microbial inoculum for traditional tempeh fermentation. It is prepared by placing pieces of matured tempeh between two hibiscus (or Tectona) leaves, which are then piled up and allowed to stand for a few days at room temperature $\left(30^{\circ}-34^{\circ} \mathrm{C}\right)$ (Figure 3). The leaves are then separated from the pieces of seed tempeh and dried. For the inoculation of the microorganisme from usar, the leaves are rubbed on the material to be inoculated.

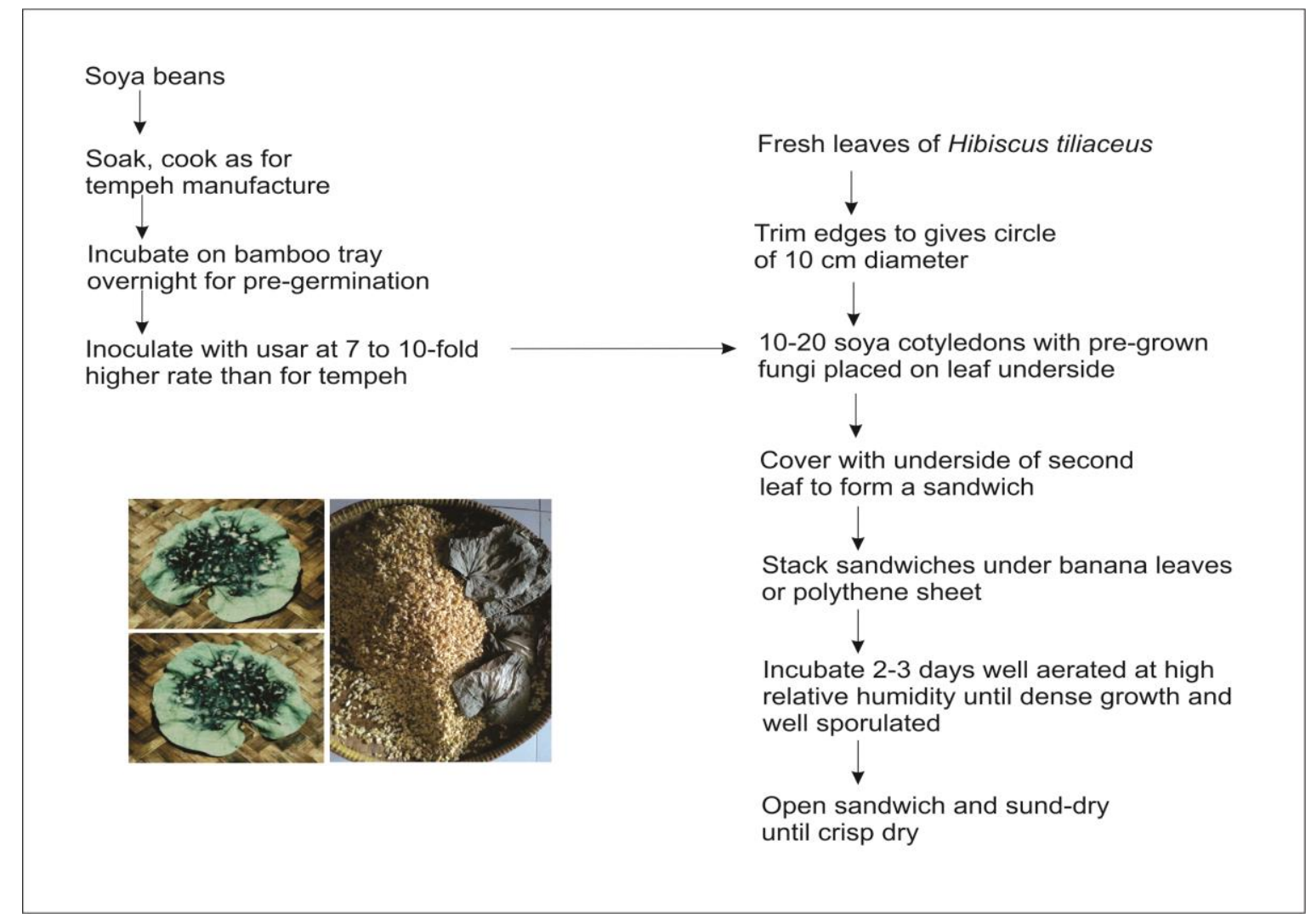

Fig 3. Flow-chart of usar manufacture as practised at traditional tempeh producer in Indonesia.

Standard of hygiene is not applied in usar production due to the lack of knowledge about good sanitation by the producers. Usar is produced from Rhizopus, which as Nout et al. (1992) report, may result in mycotoxins formed by fungi such as Fusarium spp. and Aspergillus flavus on waru lengis leaves, and which might act as contaminants during the fermentation process. As much as $35 \%$ of tempeh production in Indonesia still uses usar. The big question is whether the 800 thousand metric tons of traditional tempeh produced a year are safe for human consumption? So 
far, there has been no further research on the contamination from toxins produced by molds in usar as well as traditional tempeh.

Another safety problem in tempeh production is the use of corn as substitute for soybean. Producers involve corn substitution for 10-30 percent to reduce cost production because the price of soybean is high nowadays. This generates a health issue for thus produced tempeh because most Indonesian corn is contaminated by toxigenic fungi such as Aspergillus spp., Fusarium spp., Penicillium citrinum and P. chrysogenum (Purwoko et al., 1991; Ahmad et al., 1996; Gholib et al., 2004; Ahmad et al., 2009; Kusumaningrum et al., 2010; Rahmawati et al., 2013). Rahmawati et al. (2013) reported that toxigenic fungi are found in soaking corn, such as Fusarium spp. Consequently, food safety aspect of tempeh can not be guaranteed anymore.

\section{Could Masked Zearalenone (ZEN) be Generated during Food Fermentation?}

Masked mycotoxins are plant or fungal metabolites that contaminate food and feed (Dellafiora et al., 2017). Gareis et al. (1990) referred to a zearalenone-glycoside as a masked mycotoxin to emphasize the fact that it was not detected by routine analysis of food because it has different chemical behaviors than the origin but possibly contributed to total mycotoxin and subsequent effect. This masked mycotoxin can be hydrolyzed to their precursors in the animal digestive tract, thus showing similar toxicity than free mycotoxins (Gareis et al. 1990; De Saeger and van Egmond, 2012; Gratz et al., 2016). The mycotoxin conjugate could be generated by infected host plant (Engelhardt et al., 1988; Kovalsky et al., 2014) and some fungal species such as Fusarium graminearum, Rhizopus arrhizus, Aspergillus niger, Rhizopus spp. and A. oryzae (ElSharkawy et al., 1991; Plasencia and Mirocha, 1991; Berthiller et al. 2005; Jard et al., 2010; Brodehl et al., 2014) by transforming ZEN into different conjugated form. In infected plant, ZEN is transformed into more polar derivatives by conjugation with sugars, amino acids, or sulfate groups, which are then stored in the vacuoles (Gratz, 2017) (Figure 4).

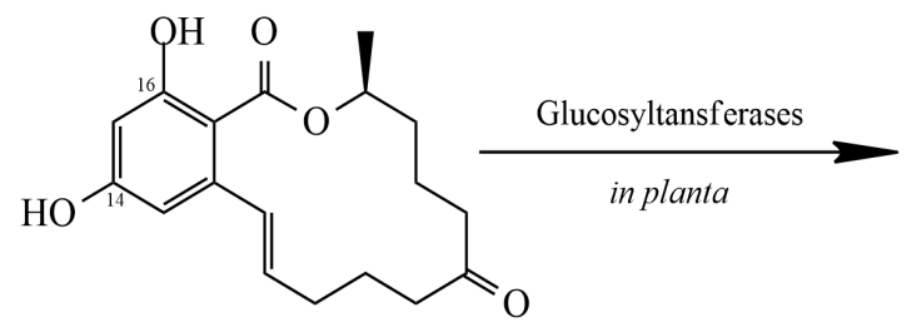

Zearalenone

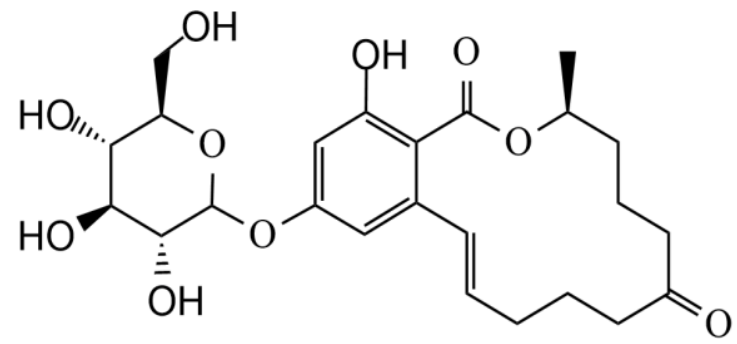

Zearalenone-14-O-ß-glucoside

Fig 4. Conversion of Fusarium mycotoxin ZEN into ZEN-14-8-glucoside by plants.

Conjugated ZEN derivatives have been detected in various cereal (foods) and animal feeds (Berthiller et al., 2005; Vendl et al., 2010; De Boevre et al., 2012; Kovalsky et al., 2016). ZEN14Glc and ZEN16Glc as $\beta$ linked glucose conjugates are found in food, and ZEN14S as sulfoconjugated form is found in naturally contaminated animal feed. ZEN14Glc can contribute to the 
total amount of mycotoxin up to $30 \%$ (Berthiller et al., 2013). ZEN14Glc has been reported in bread and breakfast cereals at relative proportions of 20-100\% of free ZEN (Wallace et al., 2016) and ZEN16Glc has recently been identified as a novel masked ZEN metabolite (Kovalsky et al., 2014). ZEN14Glc has been tested in vitro and found to be non-cytotoxic to MCF-7 human breast cancer cells ( $1 \mu \mathrm{M}, 6 \mathrm{~h}$ ) (Dellafiora et al. 2016), and Caco-2 cells (20 and $40 \mu \mathrm{M}, 6 \mathrm{~h})$ (Cirlini et al., 2016) and to exhibit reduced estrogen receptor binding capacity compared to ZEN (Poppenberger et al., 2006). ZEN16Glc is also non-cytotoxic in Caco-2 cells (Cirlini et al., 2016). ZEN14S is also non-estrogenic in MCF-7 cells (Drzymala et al., 2015) and 40\% less potent than ZEN in a rat uterus enlargement bioassay in vivo (Plasensica and Mirocha, 2006). Besides conjugated ZEN products, reductive metabolites are generated in plant and fungal metabolism, for example, $\alpha$ - and $\beta$-ZEL (zearalenol). $\beta$-ZEL is less toxic than ZEN, $\alpha$-ZEL possesses an about 10 fold higher estrogenicity than ZEN (Metzler et al., 2010).

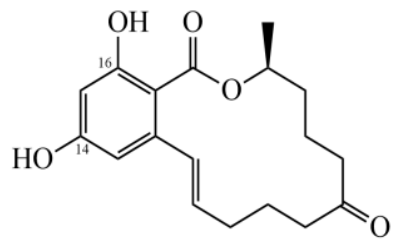

Zearalenone

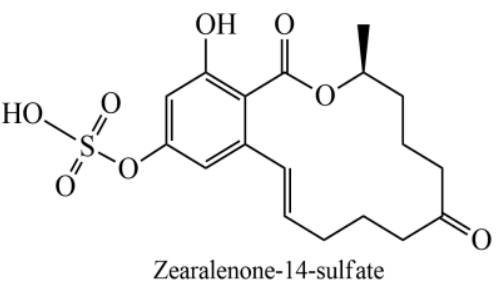

Zearalenone-14-sulfate

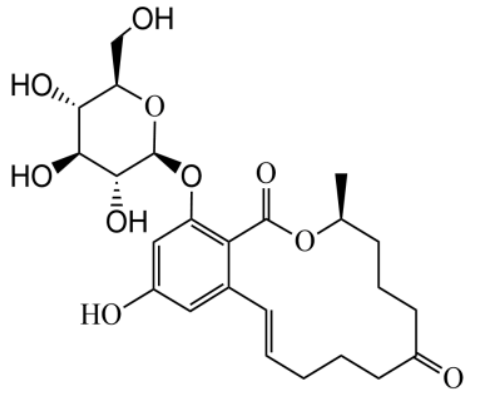

Zearalenone-16-O-ß-glucoside

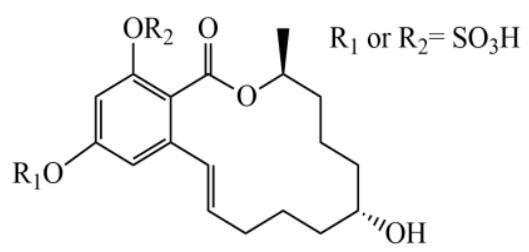

Zearalenol-sulfate

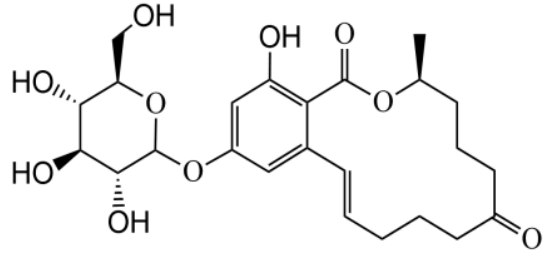

Zearalenone-14-O-B-glucoside

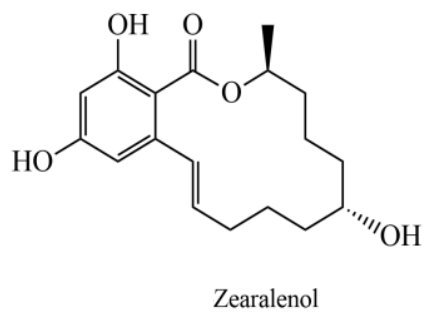

Zearalenol

Fig 5. ZEN and masked-ZEN structures

Food fermentation (e.g. tempeh, sufu or soy sauce) may also contribute to the production of masked mycotoxins because the process involved ZEN transforming fungi. Recent research by Brodehl et al. (2014) examined capability of some Rhizopus and Aspergillus strains to transform 
ZEN into some masked form e.g. $\alpha$-ZENS, ZEN14S, ZEN14Glc, ZEN16Glc, and $\alpha$-ZEL (Figure 5). Two Aspergillus oryzae strains and all seven Rhizopus species were able to convert ZEN into various metabolites, including ZEN14S as well as ZEN14Glc and ZEN16Glc. However, in vitro studies done so far are still very limited for fungal strains, especially strains derived from food fermentation. Further studies are needed by using more strains isolated from fermentation industry, for example, industrial tempeh. In situ trials involving fermentation process also needs to be done to see the extent of its influence on the masked-ZEN formation.

\section{Current Food Safety Conditions in Indonesia}

Food is of fundamental importance to life (De Vries et al., 1997) and the most essential for maintaining continued survival. The quality of human resources is determined by food safety. Given the importance of food safety, government issues Law of the Republic of Indonesia no. 23/1992 concerning Health, Law No. 23 of 1992 on health and Act No. 7 of 1996 on Food and Government Regulation No. 28 of 2004 on Food Safety, Quality and Nutrition. Food safety deals with requirements should be met in order to preserve food from contamination or food-borne illnesses.

There is no sense in talking about quality, nutritional value, sensory or functional properties if the food product is not safe for consumption. Act No. 7 of 1996 article 1 paragraph 4 stipulates food safety includes the condition and pursuits needed to prevent food from possible biological and chemical contamination as well as contamination by other objects which may disturb, harm, and endanger the human health. It also mentioned that safe conditions and efforts are needed to prevent food from possible contamination of biological, chemical and other substances that can disturb, harm and danger to people. Safe food is defined as food which does not have (1) biological or microbiological hazard, (2) chemical hazards, and (3) physical danger (Ardiansyah, 2006; Fardiaz, 2008).

Biological hazards include cockroaches and ants, and microbiological hazards by pathogens, microbial toxins, viruses and microbial spoilage. Organism growing and developing in food can be infectious or toxic to humans (Anggrahini, 1990; Anggrahini, 1992). Intoxication is a condition in which toxin is formed in foods. It is harmful to human health. Although food or ingredients can be treated with heat to minimize microbial activities, already formed toxins still could remain active (Ardiansyah, 2006; Tannenbaum, 1979).

As we enter the 21 st century, food safety faces a rapidly changing paradigm. As a result of the projected global demand for food source due to the increase in populations and expanding international travel and trade, consumers are shifting from regional commerce to global environment. Emerging infections and foodborne illness will continue to have a major impact. Negative health effects have a broad impact (Paige and Tollefson, 2003). Johnson (2003) cited a report WHO, globally, WHO has estimated approximately 1.5 billion cases of foodborne illness and more than 3 million deaths annually, with this number is likely to increase. Lund and O'Brien (2003) estimate foodborne illnesses are ranging 100-300 times, compared to the actual occurrence. 
Food industry in Indonesia consists of informal and formal sector. Informal sector includes small industries, domestic industry, street vendor, etc. Home food industry (IRT) is potentially vulnerable to food safety (Nda, 2004; Apriliana, 2006). Based on National Agency of Drug and Food Control (NA-DFC) data, only 54\% out of 1835 home industry (IRT), which already have permit number of home food industry (PIRT) in 2001-2013 (survey in 2011). The figure rose slightly to $59 \%$ in 2012 , and to $67 \%$ in 2013 . This means about that $33 \%$ still have not been able to implement good manufacturing process. This condition arouses serious concern since structure of food industry in Indonesian is dominated by small and medium-sized enterprises (SME), in which $99 \%$ of them are small industries, and rest is large industry.

NA-DFC reports that most of food poisoning is caused by the food that is produced by the domestic industry (39\%), followed by catering services (caterers) (20\%), comfort food industry (restaurant) (21\%), and processed food industry (13\%) (Figure 6). The data also indicates that most food poisoning is caused by a microbiological agent (46\%), followed by chemical agents (18\%) (Figure 7). The data provide important information, strongly indicating that food safety issues are more common in small and medium-sized enterprises (SMEs). The reason is that the most SMEs have not met the standards of sanitation and hygiene and good manufacturing practices (GMP) or good food processing method (GFPM). Food poisoning is an iceberg phenomenon, meaning that not all cases or incidents is reported. WHO states that only $1 \%$ out of $100 \%$ cases reported (NADFC, 2012).

The condition domestic food safety is reflected from the data of food poisoning (Table 2). Table 2 records food poisoning cases and a number of people who fall sick or are poisoned increased since 2004. It might be not associated with the food safety situation getting worse, but because of the increasing of survey intensity done by NA-DFC.

The condition of food safety in Indonesia is also reflected by the export rejection of Indonesian food products. This is because food safety has become an absolute prerequisites for international trade, and therefore the food safety will also directly affect the export performance of the country. Based on data collected from USFDA (US Food and Drug Administration) in 20112014 , the number of export rejection cases due to food safety reasons are 1.451 cases, or about 30 cases per month (Figure 8).

Table 2. Food poisoning case data in 2001-2006 by NA-DFC.

\begin{tabular}{ccccc}
\hline Year & $\begin{array}{c}\text { Poisoning case } \\
\text { number }\end{array}$ & Number of food & Severe illness & Death number \\
\hline 2001 & 26 & 1965 & 1183 & 16 \\
2002 & 43 & 6543 & 3635 & 10 \\
2003 & 34 & 8651 & 1843 & 12 \\
2004 & 164 & 22297 & 7366 & 51 \\
2005 & 184 & 23864 & 8949 & 49 \\
2006 & 159 & 21282 & 8747 & 38 \\
\hline
\end{tabular}


The reasons are slightly different for refusal concerning the export of Indonesian food to the European Union (EU). The trade with the EU is not as intensive as with the US. There are 64 border rejections on Indonesia's exports of food products based on data collected from the portal Rapid Alert System for Food and Feed (RASFF Portal, 2015) during 2011-2014 for several different reasons. The main difference was the level of mycotoxin contamination (28\%). In this case, the EU is very strict to determine maximum limit of mycotoxins in comparison with US and other countries. The next one is the level of pathogenic microbial contamination $(26 \%)$ followed by non-pathogenic microbial contamination (16\%) (Figure 9).

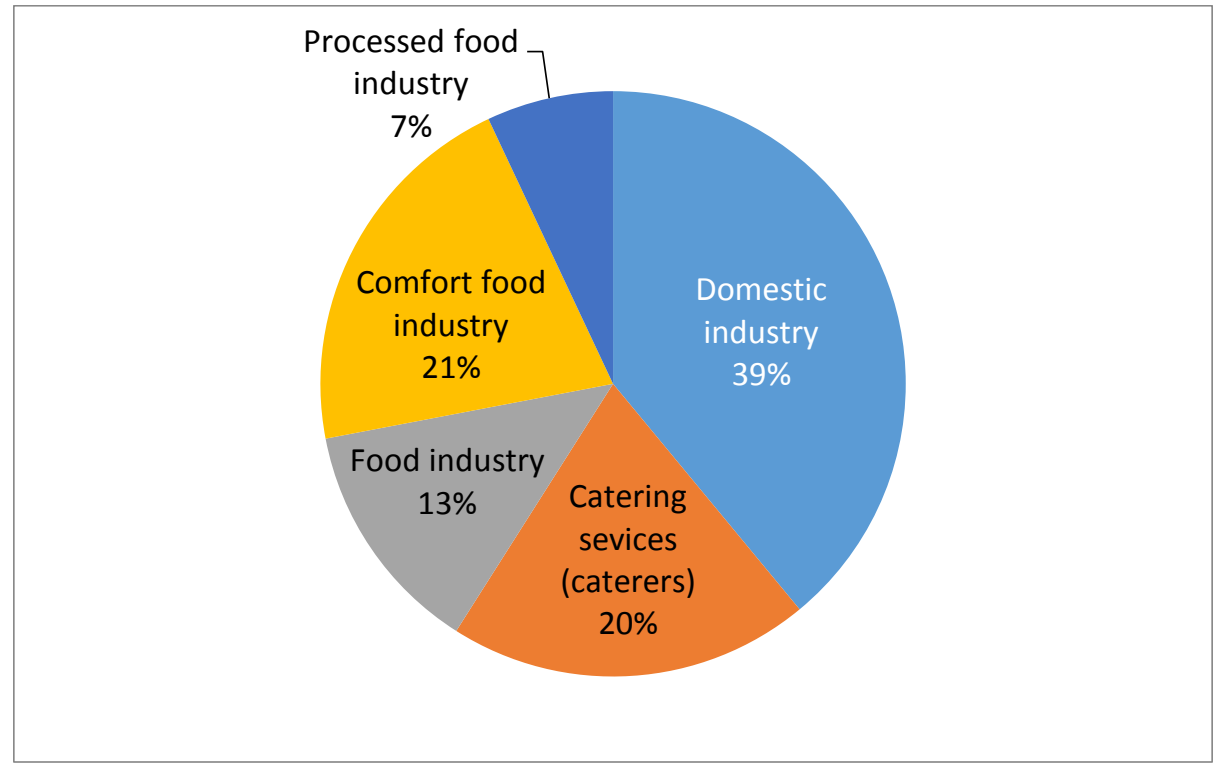

Fig 6. The source of food poisoning outbreaks in Indonesia by NA-DFC in 2011-2013.

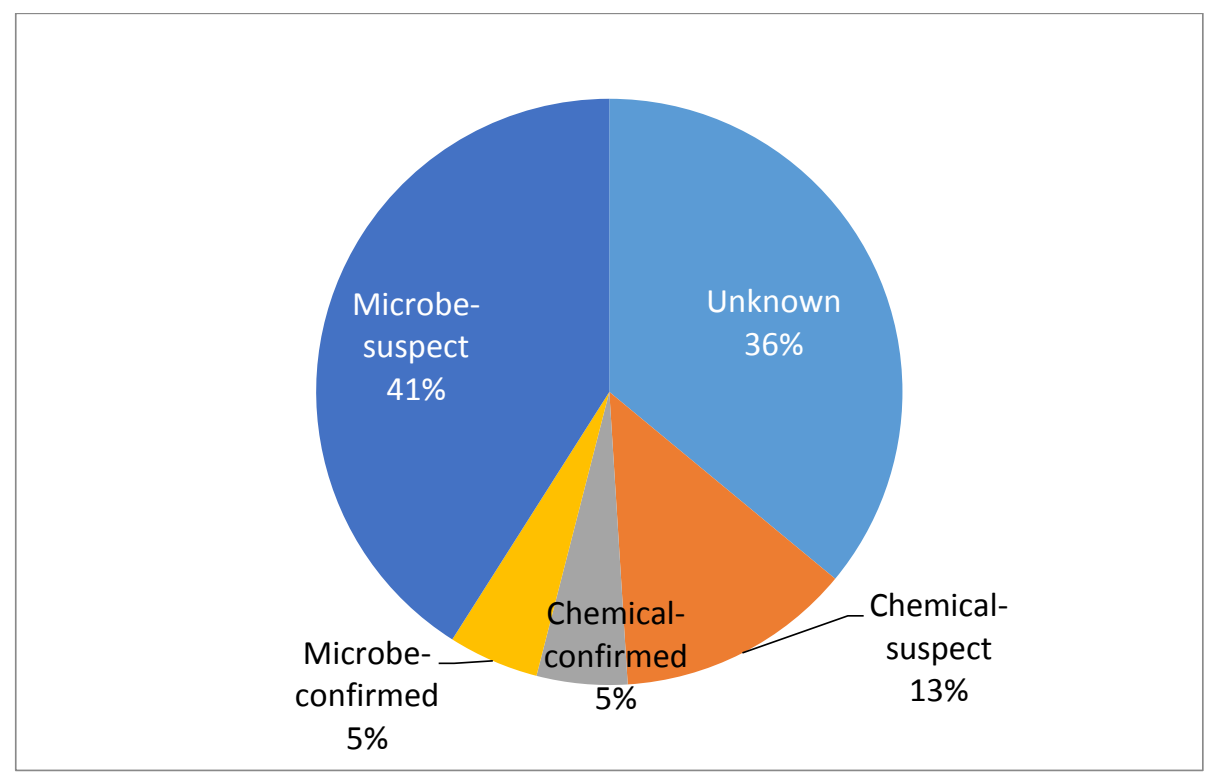

Fig 7. Causative agent profile of food poisoning outbreaks in Indonesia by NA-DFC in 2011-2013. 


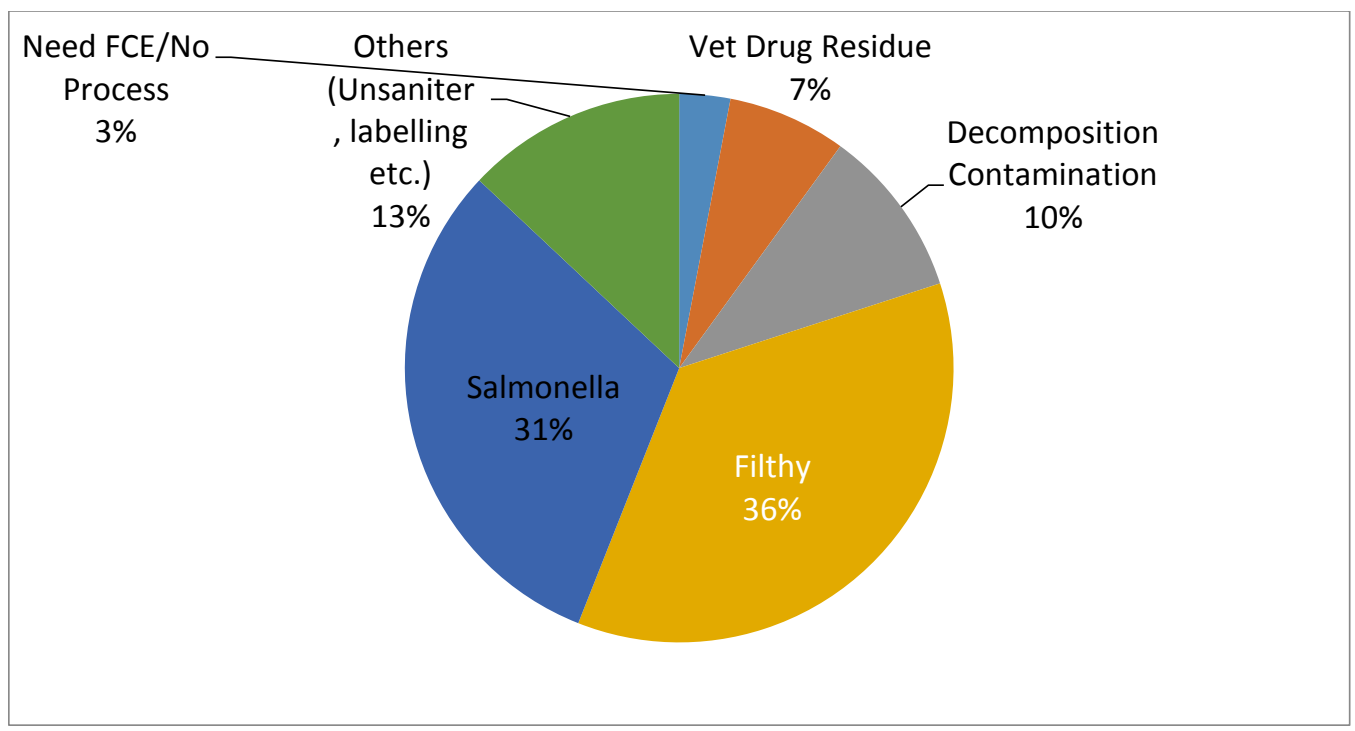

Fig 8. The reason for rejection of Indonesian food exports by USFDA in 2011-2014 (total: 1451 rejection cases).

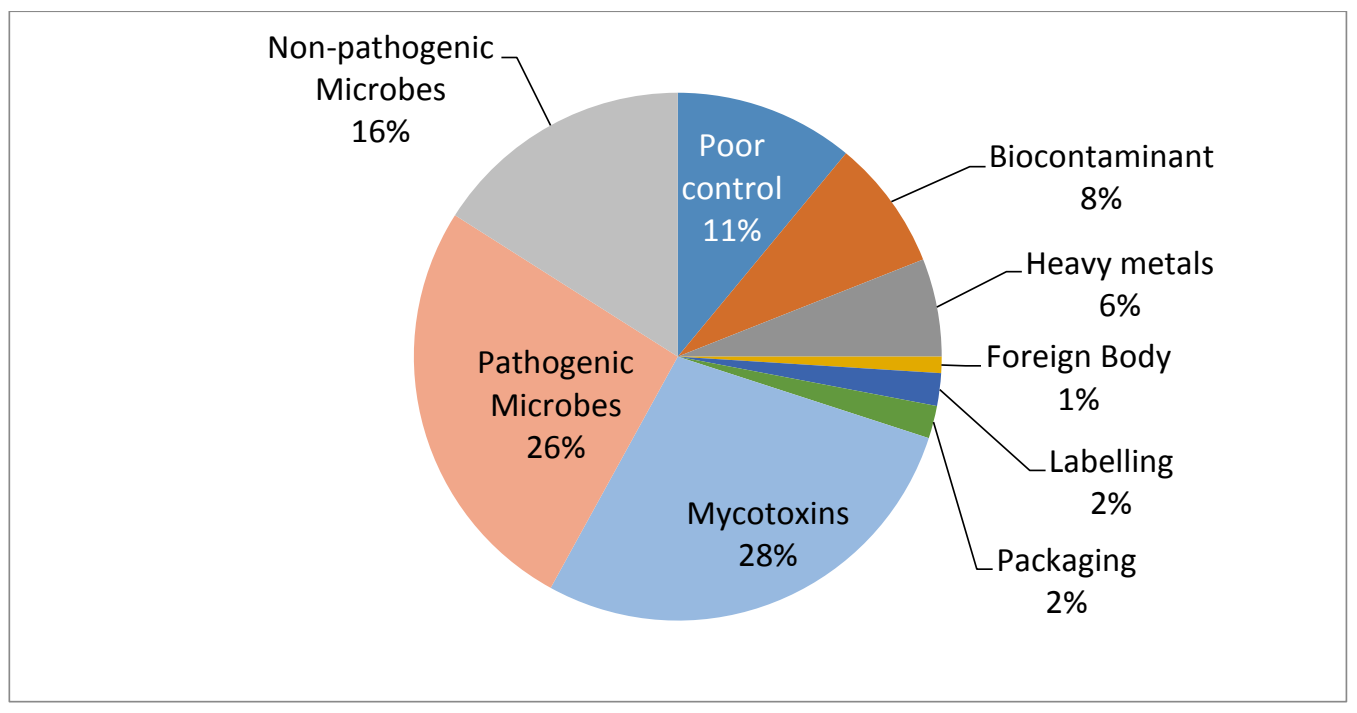

Fig 9. The reason for rejection of Indonesian food exports by the European Union in 2011-2014 (total: 64 rejection cases).

The high frequency of the export rejection because of microbial contamination, both pathogenic and non-pathogenic, indicates that food processing in Indonesia is still not appropriate to comply with good sanitation and hygiene. In conclusion at the outset that despite SMEs are major manufacturers of processed food in Indonesia, most of these SMEs have difficulties to implement good manufacturing practice (GMP). This condition requires stakeholders, especially the government to focus on SME food safety development. 


\section{Aim of the Work}

Food safety is a prerequisite for a food product. There is no sense in talking about quality, nutritional value, sensory or functional properties if the food product is not safe enough for consumption. Indonesia suffers a double burden of food safety problem. The first is related to fundamental issues of food safety; especially about the insufficient practice of good manufacturing practices (GMP) principles. The second is related explicitly to export-oriented food industries; they must face a variety of new food safety issues which always appear and change from time to time, also vary from one country to another (Hariyadi, 2008). One of the food products that need attention for its safety in Indonesia is tempeh.

Tempeh is produced mostly by a small scale home industry with poorly controlled fermentation procedures that in addition carried out without sufficient hygienic precautions. Therefore, there are various types of microorganisms that can participate during the process of fermentation, and natural contamination is always possible (Winarno, 1985; Barus et al., 2008; Seumahu et al., 2013). Moreover, there is no standard on making tempeh and its starter. This cause many variations in the manufacture of tempeh in many areas (Astuti et al., 2000) and lead to inconsistencies in quality and safety of tempeh. Tempeh, as important food is massively produced and consumed by Indonesian people. As a new export commodity, it really needs standardized starter and controlled processing to fulfill safety aspect.

The scope of this thesis was to address microbiological and food safety aspect of tempeh production in Indonesia. It was divided into 3 topics:

\section{Topic 1:}

This topic deals with the exploration of mucoralean fungi involved during tempeh production as well as solid fermentation process. Zygomycetes strains derived from Indonesian tempeh and starter are screened toxicologically and clinically to evaluate possible health risks for human consumption. In this part we also study the role of tempeh fungi on zearalenone (ZEN) biotransformation.

\section{Topic 2:}

To study about toxigenic fungal contamination on usar (traditional tempeh inoculum). We characterize the contaminants and detect their mycotoxin production. Mycotoxin contamination in traditional tempeh is also observed. We also study the effect of contamination on tempeh quality, and how to distinguish contaminated tempeh. The exposure levels of Indonesian infants, children, and adult to mycotoxin as a consequence traditional tempeh consumption also studied.

\section{Topic 3:}

To characterize and investigate the diversity of lactic acid bacteria (LAB) and yeast by analyzing soak water samples collected from different tempe manufactures in Java. We also screen and investigate their potential antifungal activities against Fusarium proliferatum. Their contribution to ZEN biotransformation also observed. 
Hypotheses were defined as follows:

\section{Topic 1:}

Diverse species possibly found in Indonesian tempeh and starter. Some zygomycetes strains used for tempeh manufacture possibly contribute to toxication or infection. Tempeh fungi also have activity to transform ZEN.

\section{Topic 2:}

Usar possibly contains microbial contaminant that could produce mycotoxins. Mycotoxins are also possibly found in traditional tempeh. Contamination will give effect to quality of traditional tempeh.

\section{Topic 3:}

Diverse microorganism is found during soaking process of tempeh manufacturing. Selected yeast and LAB have role to increase safety level in tempeh production. Lactic acid bacteria have potential application to produce antifungal compounds which could be used to protect traditional tempeh from the contaminant. Yeast and LAB from soak water also have ability to transform ZEN.

\section{Research outcome:}

Safe and defined starter for tempeh production could be selected and formulated afterward. In the near future, starter could be produced in mass scale and distributed to tempeh manufactures, thus tempeh production would be controlled from the beginning process and indeed increase its safety level.

\section{References}

Ahmad, R.Z., 2009. Cemaran kapang pada pakan dan pengendaliannya. J. Litbang pertanian, 28(1), pp.15-22.

Ahmad, R.Z., Gholib, D., Subiyanto, dan Hastiono, S., 1996. Tinjauan retrospektif kapang toksigenik pada berbagai sampel pakan dan komponennya. hlm. 339-353. Prosiding Pertemuan Ilmiah Nasional Bidang Veteriner, Bogor, 12-13 Maret 1996. Balai Penelitian Veteriner, Bogor.

Aitoman, M., 2011. pengaruh pemberian makanan cair yang diperkaya dengan tempe terhadap respons glukosa darah penyandang diabetes melitus di RSCM Jakarta. [Tesis]. Program Pascasarjana IPB. Bogor.

Anggrahini, 1990. Studi Kemungkinan Mencegah/Mengurangi Kontaminasi Aflatoksin pada Kacang Tanah Setelah Dipanen. Laporan Penelitian. Kerjasama Applied Agriculture Research Project. Badan Penelitian dan Pengembangan Pertanian Departemen Pertanian dengan Direktorat Jenderal.

Anggrahini, 1992. Ketahanan panas bakteri Bongkrek Pseudomonas cocovenenans X128 dan taksoflavin serta pengaruh komponen lemak terhadap produksi taksoflavin. (Doctoral dissertation, IPB).

Apriliana, D., 2006. Keamanan mikrobiologis produk jajanan Kaki Lima di lingkungan Sekolah Dasar Kecamatan Wonosari, Kabupaten Gunungkidul (Doctoral dissertation, Universitas Gadjah Mada).

Ardiansyah, 2006. Keamanan pangan fungsional berbasis pangan tradisional. Artikel Iptek-Bidang Biologi, Pangan dan Kesehatan.

Ashenafi, M., 1991a. Growth of Listeria monocytogenes in fermenting tempeh made of various beans and its inhibition by Lactobacillus plantarum. Food Microbiol. 8(4): 303-310.

Ashenafi, M., 1991b. Growth potential of Salmonella infantis and Escherichia coli in fermenting tempeh made from horsebean, pea and chickpea and their inhibition by Lactobacillus plantarum. J. Sci. Food Agric.55(4): 607-615.

Ashenafi, M. and Busse, M., 1991. Growth of Bacillus cereus in fermenting tempeh made from various beans and its inhibition by Lactobacillus plantarum. J. Appl. Microbiol. 70: 329-333.

Aslam, Z., Yasir, M., Khaliq, A., Matsui, K. and Ryun, Y., 2010. Mini Review: Too much bacteria still unculturable. Bioscience, 45, pp.600-609.

Astuti, M., 1999a. History of the development of Tempe. The complete handbook of Tempe: The unique fermented soyfood of Indonesia, pp.2-13. 
Astuti, M., 1999b. Iron availability of tempeh and uses in iron deficiency anemia. The Complete Handbook of Tempe: The Unique Fermented Soybean of Indonesia. The American Soybean Association.

Astuti, M., Andreanyta, M., Fabien, S.D. and Mark L.W., 2000. Tempeh, a nutritious and healthy food from Indonesia. Asia Pac. J. Clin. Nutr. 9(4):322-325.

Barus, T., Suwanto, A., Wahyudi, A.T. and Wijaya, H., 2010. Role of bacteria in tempe bitter taste formation: microbiological and molecular biological analysis based on 16S rRNA gene. Microbiology Indonesia, 2(1).

Barbara, M.L., Tony, C.B. and Grahame, W.G., 2000. The microbiological safety and quality of food. Gaithersburg, Maryland, USA: Aspen publishers.

Berthiller, F., Dall'Asta, C., Schuhmacher, R., Lemmens, M., Adam, G. and Krska, R., 2005. Masked mycotoxins: determination of a deoxynivalenol glucoside in artificially and naturally contaminated wheat by liquid chromatography- tandem mass spectrometry. Journal of agricultural and food chemistry, 53(9), pp.3421-3425.

Berthiller, F., Crews, C., Dall'Asta, C., Saeger, S.D., Haesaert, G., Karlovsky, P., Oswald, I.P., Seefelder, W., Speijers, G. and Stroka, J., 2013. Masked mycotoxins: a review. Molecular nutrition \& food research, 57(1), pp.165-186.

Brodehl, A., Möller, A., Kunte, H.J., Koch, M. and Maul, R., 2014. Biotransformation of the mycotoxin zearalenone by fungi of the genera Rhizopus and Aspergillus. FEMS microbiology letters, 359(1), pp.124-130.

[BPS] Badan Pusat Statistik, 2012. Berita Resmi Statistik No. 70/11/Th. XV, 1 November 2012. Jakarta (ID): Badan Pusat Statistik

[INCS] Badan Standardisasi Nasional, 2012. Tempe : Persembahan Indonesia untuk Dunia. Jakarta(ID) : Badan Standardisasi Nasional

[INCS] Badan Standarisasi Nasional, 2009. Tempe Kedelai (SNI 3144-2009). Jakarta (ID): INCS.

[CAC] Codex Alimentarius Commission, 2013. REGIONAL Standard For Tempe, Codex Stan 313R-2013. Rome: CAC.

Cutler, R.G., 1992. Genetic stability and oxidative stress: common mechanisms in aging and cancer. In Free radicals and aging (pp. 31-46). Birkhäuser Basel.

Denter, J., Rehm, H.J. and Bisping, B., 1998. Changes in the contents of fat-soluble vitamins and provitamins during tempe fermentation. International journal of food microbiology, 45(2), pp.129-134.

De Boevre, M., Di Mavungu, J.D., Landschoot, S., Audenaert, K., Eeckhout, M., Maene, P., Haesaert, G. and De Saeger, S., 2012. Natural occurrence of mycotoxins and their masked forms in food and feed products. World mycotoxin journal, 5(3), pp.207-219.

De Vries, F.P., Rabbinge, R. and Groot, J.J.R., 1997. Potential and attainable food production and food security in different regions. Philosophical Transactions of the Royal Society of London B: Biological Sciences, 352(1356), pp.917-928.

De Saeger, S. and van Egmond, H., 2012. Special issue: masked mycotoxins. World mycotoxin journal, 5(3), pp.203206.

Dellafiora, L., Galaverna, G., Righi, F., Cozzini, P. and Dall'Asta, C., 2017. Assessing the hydrolytic fate of the masked mycotoxin zearalenone-14-glucoside-A warning light for the need to look at the "maskedome". Food and chemical toxicology, 99, pp.9-16.

Dellafiora, L., Perotti, A., Galaverna, G., Buschini, A. and Dall'Asta, C., 2016. On the masked mycotoxin zearalenone14-glucoside. Does the mask truly hide?. Toxicon, 111, pp.139-142.

Dolatabadi, S., Hoog, G.S., Meis, J.F. and Walther, G., 2014. Species boundaries and nomenclature of Rhizopus arrhizus (syn. R. oryzae). Mycoses, 57(s3), pp.108-127.

Dolatabadi, S., Walther, G., Van Den Ende, A.G. and de Hoog, G.S., 2014. Diversity and delimitation of Rhizopus microsporus. Fungal Diversity, 64(1), pp.145-163.

Dolatabadi, S., Scherlach, K., Figge, M., Hertweck, C., Dijksterhuis, J., Samson, R.A., Menken, S.B. and de Hoog, G.S., 2015. Food preparation with potentially unsafe fungi: a new biosafety issue?. Mucorales between food and infection, p.151.

Drzymala, S.S., Binder, J., Brodehl, A., Penkert, M., Rosowski, M., Garbe, L.A. and Koch, M., 2015. Estrogenicity of novel phase I and phase II metabolites of zearalenone and cis-zearalenone. Toxicon, 105, pp.10-12.

Efriwati, E. and Nuraida, L., 2013. Effect of two production methods on macro nutrient and isoflavone-aglycone composition in tempeh produced by household industries. Health science journal of Indonesia, 4(2 Des), pp.6973.

Egounlety, M. and Aworh, O.C., 2003. Effect of soaking, dehulling, cooking and fermentation with Rhizopus oligosporus on the oligosaccharides, trypsin inhibitor, phytic acid and tannins of soybean (Glycine max Merr.), cowpea (Vigna unguiculata L. Walp) and groundbean (Macrotyloma geocarpa Harms). Journal of food engineering, 56(2), pp.249-254. 
Engelhardt, G., Zill, G., Wohner, B. and Wallnöfer, P.R., 1988. Transformation of the Fusarium mycotoxin zearalenone in maize cell suspension cultures. Naturwissenschaften, 75(6), pp.309-310.

Esaki, H., Onozaki, H., Kawakishi, S. and Osawa, T., 1996. New antioxidant isolated from tempeh. Journal of agricultural and food chemistry, 44(3), pp.696-700.

Esaki, H., Kawakishi, S., Morimitsu, Y. and Osawa, T., 1999. New potent antioxidative o-dihydroxyisoflavones in fermented Japanese soybean products. Bioscience, biotechnology, and biochemistry, 63(9), pp.1637-1639.

Fardiaz, D., 2008. Keamanan Pangan di Indonesia: Tantangan, Regulasi dan Pengawasan. Makalah dipresentasikan pada Seminar Nasional Pangan, PATPI Yogyakarta, di Yogyakarta 17 Januari 2008.

Feng, X., 2006. Microbial dynamics during barley tempeh fermentation (Vol. 2006, No. 59).

Gareis, M., Bauer, J., Thiem, J., Plank, G., Grabley, S. and Gedek, B., 1990. Cleavage of zearalenone-glycoside, a "masked" mycotoxin, during digestion in swine. Journal of veterinary medicine, Series B, 37(1-10), pp.236240.

Gholib, D., Ahmad, R.Z. dan Istiana, 2004. Evaluasi hasil pemeriksaan laboratorium mikologi pada sampel bahan pakan, litter dan organ. hlm. 776-781. Prosiding Seminar Nasional Teknologi Peternakan dan Veteriner. Bogor, 4-5 Agustus 2004. Pusat Penelitian dan Pengembangan Peternakan, Bogor.

Gratz, S.W., Dinesh, R., Yoshinari, T., Holtrop, G., Richardson, A.J., Duncan, G., MacDonald, S., Lloyd, A. and Tarbin, J., 2016. Masked trichothecene and zearalenone mycotoxins withstand digestion and absorption in the upper GI tract but are efficiently hydrolyzed by human gut microbiota in vitro. Molecular nutrition \& food research.

Gratz, S.W., 2017. Do plant-bound masked mycotoxins contribute to toxicity?. Toxins, 9(3), p.85.

Han, B., Kiers, J.L. and Nout, R.M., 1999. Solid-substrate fermentation of soybeans with Rhizopus spp.: Comparison of discontinuous rotation with stationary bed fermentation. Journal of bioscience and bioengineering, 88(2), pp.205-209.

Handoyo, T. and Morita, N., 2006. Structural and functional properties of fermented soybean (Tempeh) by using Rhizopus oligosporus. International journal of food properties, 9(2), pp.347-355.

Haron, H., Shahar, S., O'Brien, K.O., Ismail, A., Kamaruddin, N. and Rahman, S.A., 2010. Absorption of calcium from milk and tempeh consumed by postmenopausal Malay women using the dual stable isotope technique. International journal of food sciences and nutrition, 61(2), pp.125-137.

Hermana, K.M., 1996. Pengembangan teknologi pembuatan tempe. Bunga rampai tempe Indonesia. Yayasan Tempe Indonesia, Jakarta, pp.151-168.

Hesseltine, C.W., 1985, July. Genus Rhizopus and tempeh microorganism. In Proc. Asian Symposium on Non-Salted Soybean Fermentation. National Food Research Institute, Tsukuba Science City (pp. 20-26).

Hong, J. and White, J.D., 2004. The chemistry and biology of rhizoxins, novel antitumor macrolides from Rhizopus chinensis. Tetrahedron, 60(27), pp.5653-5681.

Ibrahim, A.S., Spellberg, B., Walsh, T.J. and Kontoyiannis, D.P., 2012. Pathogenesis of mucormycosis. Clinical infectious diseases, 54(suppl 1), pp.S16-S22.

Iwasaki, S., Kobayashi, H., Furukawa, J., Namikoshi, M. and Okuda S., 1984. Studies on macrocyclic lactone antibiotics. vii" structure of a phytotoxin "rhizoxin" produced by rhizopus chinensis. J. Antibiot. 37: 354-362.

Jard, G., Liboz, T., Mathieu, F., Guyonvarc'h, A., André, F., Delaforge, M. and Lebrihi, A., 2010. Transformation of zearalenone to zearalenone-sulfate by Aspergillus spp. World mycotoxin journal, 3(2), pp.183-191.

Jennessen, J., Nielsen, K.F., Houbraken, J., Lyhne, E.K., Schnürer, J., Frisvad, J.C. and Samson, R.A., 2005. Secondary metabolite and mycotoxin production by the Rhizopus microsporus group. Journal of agricultural and food chemistry, 53(5), pp.1833-1840.

Jutono, 1985. The microbiology of usar, a traditional tempe inoculum. In: Asian Symposium on non-salted soybean fermentation; Tsukuba, July. 1985.

Johnson, E.A., 2003. Bacterials Phatogens in Foodborne Disease. in Food Safety - Contaminants and Toxins, Edited by J.P.F.D' Mello. CABI Publishing, Oxon.

Karyadi, D., 1996. Perkembangan Tempe di Lima Benua. In Bunga Rampai Tempe Indonesia. Penerbit Yayasan Tempe Indonesia.

Karyadi, D. and Hermana, H., 1995. Potensi tempe untuk gizi dan kesehatan. Prosiding Simposium Nasional Pengembangan Tempe dalam Industri Pangan Modern, pp.25-38.

Kasmidjo, R.B., 1995. Teknologi Pembuatan Tempe Sebagai Dasar Pengembangan Industri Tempe Modern. Prosiding Simposium Nasional Pengembangan Tempe Dalam Industri Tempe Modern.

Keuth, S. and Bisping, B., 1994. Vitamin B12 production by Citrobacter freundii or Klebsiella pneumoniae during tempeh fermentation and proof of enterotoxin absence by PCR. Applied and environmental microbiology, 60(5), pp.1495-1499. 
Klus, K., Börger-Papendorf, G. and Barz, W., 1993. Formation of 6, 7, 4'-trihydroxyisoflavone (factor 2) from soybean seed isoflavones by bacteria isolated from tempe. Phytochemistry, 34(4), pp.979-981.

Ko, S.D., 1985. Some microbiological aspects of tempe. in: Asian Symposium on Non-Salted Soybean Fermentation. Tsukuba. July. 1985.

Kovalsky Paris, M.P., Schweiger, W., Hametner, C., Stückler, R., Muehlbauer, G.J., Varga, E., Krska, R., Berthiller, F. and Adam, G., 2014. Zearalenone-16-O-glucoside: a new masked mycotoxin. Journal of agricultural and food chemistry, 62(5), pp.1181-1189.

Kovalsky, P., Kos, G., Nährer, K., Schwab, C., Jenkins, T., Schatzmayr, G., Sulyok, M. and Krska, R., 2016. Cooccurrence of regulated, masked and emerging mycotoxins and secondary metabolites in finished feed and maize: An extensive survey. Toxins, 8(12), p.363.

Kusumaningrum, H.D., Suliantari, Toha, A.D., Putra, S.H. dan Utami, A.S., 2010. Contamination of Aspergillus flavus and $\mathrm{AF}$ at distribution chain of maize based food product and its influencing factors. Jurnal teknologi dan industri pangan, 21(2): 171-176.

Lackner, G. and Hertweck, C., 2011. Impact of endofungal bacteria on infection biology, food safety, and drug development. PLoS Pathog, 7(6), p.e1002096.

Liu, K. 1997. Soybeans: Chemistry, Technology, and Utilization. New York: International Thomson Publishing.

Lund, B.M. and O'Brien, S.J., 2011. The occurrence and prevention of foodborne disease in vulnerable people. Foodborne pathogens and disease, 8(9), pp.961-973.

Meis, J.F. and Chakrabarti, A., 2009. Changing epidemiology of an emerging infection: zygomycosis. Clinical Microbiology and infection, 15(s5), pp.10-14.

Metzler, M., Pfeiffer, E. and Hildebrand, A., 2010. Zearalenone and its metabolites as endocrine disrupting chemicals. World Mycotoxin journal, 3(4), pp.385-401.

Moreno, M.R.F., Leisner, J.J., Tee, L.K., Ley, C., Radu, S., Rusul, G., Vancanneyt, M. and De Vuyst, L., 2002. Microbial analysis of Malaysian tempeh, and characterization of two bacteriocins produced by isolates of Enterococcus faecium. Journal of applied microbiology, 92(1), pp.147-157.

Mulyowidarso, R.K., Fleet, G.H. and Buckle, K.A., 1989. The microbial ecology of soybean soaking for tempe production. International journal of food microbiology, 8(1), pp.35-46.

Mulyowidarso, R.K., Fleet, G.H. and Buckle, K.A., 1990. Association of bacteria with the fungal fermentation of soybean tempe. Journal of applied bacteriology, 68(1), pp.43-47.

Mulyowidarso, R.K. and Buckle, K., 1991. Changes in the concentration of carbohydrates during the soaking of soybeans for tempe production. International journal of food science and technology, 26(6), pp.595-606.

Murata, K., 1985. Formation of antioxidant and nutrient in tempe. In Asian Symposium on Non-salted Soybean Fermentation, Tsukuba, Japan, July (pp. 14-16).

Nda, 2004. Zat kimia masih ditemukan dalam makanan anak. Media Indonesia 8 Desember. Jakarta.

Nout, M.J., Martoyuwono, T.D., Bonné, P.C. and Odamtten, G.T., 1992. Hibiscus leaves for the manufacture of usar, a traditional inoculum for tempe. Journal of the science of food and agriculture, 58(3), pp.339-346.

Nout, M.J.R. and Kiers, J.L., 2005. Tempe fermentation, innovation and functionality: update into the third millenium. Journal of Applied Microbiology, 98(4), pp.789-805.

Nakajima, N., Nozaki, N., Ishihara, K., Ishikawa, A. and Tsuji, H., 2005. Analysis of isoflavone content in tempeh, a fermented soybean, and preparation of a new isoflavone-enriched tempeh. Journal of bioscience and bioengineering, 100(6), pp.685-687.

Nuraida, L., Suliantari, A.N., Adawiyah, D.R., Novier, R. and Agustin, D., 2008. Evaluation of soybean varieties on production and quality of tempe. Prosiding Perkembangan Terkini Tentang Tempe, pp.1-15.

Paige, J.C. and Tollefson, L., 2003. 13 Veterinary Products: Residues and Resistant Pathogens. Food safety, p.293.

Partida-Martinez, L.P., de Looß, C.F., Ishida, K., Ishida, M., Roth, M., Buder, K. and Hertweck, C., 2007. Rhizonin, the first mycotoxin isolated from the zygomycota, is not a fungal metabolite but is produced by bacterial endosymbionts. Applied and environmental microbiology, 73(3), pp.793-797.

Partida-Martinez, L.P., Groth, I., Schmitt, I., Richter, W., Roth, M. and Hertweck, C., 2007. Burkholderia rhizoxinica sp. nov. and Burkholderia endofungorum sp. nov., bacterial endosymbionts of the plant-pathogenic fungus Rhizopus microsporus. International journal of systematic and evolutionary microbiology, 57(11), pp.25832590.

Partida-Martinez, L.P., Monajembashi, S., Greulich, K.O. and Hertweck, C., 2007. Endosymbiont-dependent host reproduction maintains bacterial-fungal mutualism. Current biology, 17(9), pp.773-777.

Pawiroharsono, S., 1994. Penggunaan Isolat untuk Peningkatan kualitas Makanan Fermentasi Tempe. Makalah disampaikan pada presentasi ilmiah Peneliti BPP Teknologi, pada tanggal, 13. 
Plasencia, J. and Mirocha, C.J., 1991. Isolation and characterization of zearalenone sulfate produced by Fusarium spp. Applied and environmental microbiology, 57(1), pp.146-150.

Poppenberger, B., Berthiller, F., Bachmann, H., Lucyshyn, D., Peterbauer, C., Mitterbauer, R., Schuhmacher, R., Krska, R., Glössl, J. and Adam, G., 2006. Heterologous expression of Arabidopsis UDP-glucosyltransferases in Saccharomyces cerevisiae for production of zearalenone-4-O-glucoside. Applied and environmental microbiology, 72(6), pp.4404-4410.

Purwadaria, H.K., Fardiaz, D., Kardono, L.B.S. and McElhatton, A., 2016. Tempe from Traditional to Modern Practices. In Modernization of Traditional Food Processes and Products (pp. 145-160). Springer US.

Purwoko, H.M., Hald, B. and Wolstrup, J., 1991. Aflatoxin content and number of fungi in poultry feedstuffs from Indonesia. Letters in applied microbiology, 12(6), pp.212-215.

Quan, C. and Spellberg, B., 2010. Mucormycosis, pseudallescheriasis, and other uncommon mold infections. Proceedings of the American Thoracic Society, 7(3), pp.210-215.

Rabie, C.J., Lübben, A., Schipper, M.A.A., Van Heerden, F.R. and Fincham, J.E., 1985. Toxigenicity of Rhizopus species. International journal of food microbiology, 1(5), pp.263-270.

Rahmawati, Dewanti-Hariyadi, R., Hariyadi, P., Fardiaz, D., and Richana, N., Isolation and identification of microorganisms during spontaneous fermentation of maize. J. Teknol. dan industri pangan, 24:1.

Rohm, B., Scherlach, K., Möbius, N., Partida-Martinez, L.P. and Hertweck, C., 2010. Toxin production by bacterial endosymbionts of a Rhizopus microsporus strain used for tempe/sufu processing. International journal of food microbiology, 136(3), pp.368-371.

Roubos-van den Hil, P.J. and Nout, M.J.R., 2011. Anti-diarrhoeal aspects of fermented soya beans (pp. 383-406). InTech.

Samson, R.A., Van Kooij, J.A. and De Boer, E., 1987. Microbiological quality of commercial tempeh in the Netherlands. Journal of food protection, 50(2), pp.92-94.

Scherlach, K., Partida-Martinez, L.P., Dahse, H.M. and Hertweck, C., 2006. Antimitotic rhizoxin derivatives from a cultured bacterial endosymbiont of the rice pathogenic fungus Rhizopus microsporus. Journal of the American chemical society, 128(35), pp.11529-11536.

Sudarmadji, S., 1977. Certain chemical and nutritional aspects of soybean tempeh [doctoral thesis]. Michigan : Michigan State University.

Seumahu, C.A., Suwanto, A. and Suhartono, M.T., 2010. Dinamika populasi Acetobacter selama proses fermentasi nata de coco. Microbiology Indonesia, 10(2).

Sparringa, R.A. and Owens, J.D., 1999. Protein utilization during soybean tempe fermentation. Journal of agricultural and food chemistry, 47(10), pp.4375-4378.

Suwanto, A., Rahayu, G. and Nuraida, L., 2013. Population dynamics of yeasts and lactic acid bacteria (LAB) during tempeh production. HAYATI Journal of biosciences, 20(2), pp.57-64.

Tannenbaum, S.R., 1979. Nutritional and safety aspects of food processing. Marcel Dekker, New York and Basel

Tunçel, G. and Göktan, D., 1990. Effect of different methods of soaking soya beans on the growth of Bacillus cereus, Klebsiella pneumoniae and Staphylococcus aureus in tempeh. Journal of the science of food and agriculture, 53(3), pp.287-296.

Vendl, O., Crews, C., MacDonald, S., Krska, R. and Berthiller, F., 2010. Occurrence of free and conjugated Fusarium mycotoxins in cereal-based food. Food additives and contaminants, 27(8), pp.1148-1152.

Wallace, H., Jan, A., Barregård, L., Bignami, M., Ceccatelli, S., Cottrill, B., Dinovi, M., Edler, L., Grasl-Kraupp, B., Hogstrand, C. and Hoogenboom, L.R., 2016. Appropriateness to set a group health-based guidance value for zearalenone and its modified forms. EFSA Journal.

Wilson, T., Rabie, C.J., Fincham, J.E., Steyn, P.S. and Schipper, M.A.A., 1984. Toxicity of rhizonin A, isolated from Rhizopus microsporus, in laboratory animals. Food and chemical toxicology, 22(4), pp.275-281.

Winarno, F.G., 1985, July. Tempe Making on Various Substrates. In Di dalam: Asian Symposium on Non-Salted Soybean Fermentation Tsukuba.

Yamazaki, T., Kume, H., Murase, S., Yamashita, E. and Arisawa, M., 1999. Epidemiology of visceral mycoses: analysis of data in annual of the pathological autopsy cases in Japan. Journal of clinical microbiology, 37(6), pp.173217. 


\title{
Review Article 01
}

\section{Mycotoxins in Indonesian Foodstuffs: Occurrence, Prevention and Remedial Methods}

\author{
Riyan Anggriawan, Katharina Pfohl, and Petr Karlovsky
}

Molecular Phytopathology and Mycotoxin Research Unit, University of Goettingen, Göttingen, Germany

\begin{abstract}
Mycotoxins are secondary metabolites produced by toxigenic fungi which often contaminate various foods at any food chain level. Mycotoxin food contamination is a problem because of the negative impact, it causes not only on the health of humans or animals but also on the global economy. Contamination of agricultural products with mycotoxins in Indonesia is quite intensive because of the heavy rainfall throughout the year and high temperatures which are favorable for the growth and proliferation of mycotoxin-producing fungi on the field plantation or crops. Agricultural commodities such as corn and peanuts have been reported to be heavily contaminated with mycotoxins. In this present paper, we reviewed the data published since 1971 concerning the contamination of food with single or combinations of mycotoxins in Indonesia. Associated health risks, as well as stringent prevention and remedial strategies with decontamination or detoxification, are also discussed in detail. This comprehensive review gives a real insight into the progress that has been achieved and an outlook to further research required in Indonesia.
\end{abstract}

Keywords: Mycotoxins, foods, food safety, food chain, decontamination, detoxification

\section{Introduction}

Food safety is a prerequisite for a food product, which should be addressed in an integrated manner, involving various stakeholders; from the government, industry, and consumers. Food safety has priority over quality, nutritional value, sensory or functional properties of the food. Indonesia suffers a double burden of food safety problem. Food quality is related to the fundamental issues of food safety; it is particularly important to comply to the standards of Good Manufacturing Practices (GMP) to reduce the risk of food poisoning incidences. Indonesian food poisonings are commonly reported in the mass media. From 1998 until 2015 a dozen of cases were reported, but the cause was unknown, and these cases are presumably underreported. Based on the National Agency of Drug and Food Control (NA-DFC) data (2011-2013), the causative agent of food poisoning outbreaks in Indonesia is dominated by microbiological agents (41\%) and chemical agents (13\%). Export-oriented food industries must face a variety of new food safety issues which arise constantly, dynamically and vary from one country to another (Hariyadi, 2008). Based on data collected from the US Food and Drug Administration (US-FDA) during 2011-2014, there were many export rejections of Indonesian food products for food safety reasons, 1451 cases in the total period or about 30 refusal cases per month (Hariyadi, 2015). In the same period, Indonesia 
also had 64 border rejections from the European Union (EU) (RASSF portal, 2015). The data reflects the poor control and handling of food safety in Indonesia. One of the most significant food safety problems in Indonesia that should be solved and monitored is mycotoxin contamination.

Mycotoxin contamination on diet and feedstuff not only endangers the human health but also effects the economic situation in terms of international trade causing trade revenue loses up to hundreds of million dollars per year in many countries due to the rejection of their peanuts export by EU (Zanelli, 2000; Wu, 2006; Schmaile and Munkvold, 2009; Amaike and Keller, 2011). For Indonesia itself, mycotoxin contamination in economically important crops also have an adverse impact on the export rate. Acceptable mycotoxin limits are applied strictly in many of the export destination countries causing Indonesia lost revenue as a result of the detention on the exported commodities. For example, between 2009-2012 Indonesia lost revenue due to the refusal of nutmeg export to EU. Indonesia has received notifications about contamination up to 21 times from EU RASFF (Rapid Alert System for Food and Feed) (ITPC Milan, 2015). Therefore, more intensive studies on mycotoxins occurrence and control are necessary to improve Indonesian food safety conditions. So far, mycotoxins studies carried out in Indonesia from 1971 up to the present, focused primarily on surveillance and monitoring studies of aflatoxin (AF) contamination in foodstuffs and their products. Recently, mycotoxins studies in Indonesia are focused not only on the existence of mycotoxin problems but also searching ways of how to control the problem. This paper describes the published studies and reports on the different mycotoxins in Indonesia and discusses the occurrence and the associated health risks as well as strategies for prevention and decontamination.

\section{Factors Promoting Mycotoxins Contamination in Indonesian Foods}

Mycotoxin contamination rate in Indonesia is quite high and difficult to avoid because of the tropical climate in Indonesia which is very favorable for the growth and proliferation of mycotoxin-producing fungi (Benneth and Klich 2003; Mary et al., 2007). Moreover, Indonesia is one of the countries influenced by extreme climate conditions during the last decade. In August 2015, the temperature in Indonesia ranged from $22^{\circ}-38^{\circ} \mathrm{C}$, and $\mathrm{RH}$ (room humidity) ranged from 45-98\% (Indonesian Agency for Meteorological, Climatological, and Geophysical, 2015). Increasing global temperatures are predicted to occur in the future due to climate change which could lead to more mycotoxin-producing fungi contamination in foodstuffs during storage especially in developing countries. Some agricultural commodities in Indonesia such as rice, corn, peanuts, and soybeans are contaminated with mycotoxins. In Indonesian agriculture AF, ochratoxin (OCA), and fumonisin (FUM) are the most important mycotoxins (Dharmaputra, 2004).

The main factors that determine the fungal infestation and mycotoxin production are temperature and high humidity (Agag, 2004). Also, other factors that affect the growth of molds on foodstuffs are oxygen, moisture, time, degree of mold invasion, damage to the substrate, insects, and ticks (Medion, 1995; Dharmaputra, 1999). Dharmaputra (2004) stated that the presence of mycotoxins in grains in Indonesia is influenced by several factors, among others are: 1) biological 
factors, including grains contaminated with fungi and fungal toxins, 2) environmental factors, including temperature, humidity, and damage to the pods by insects, 3) harvesting, including the level of pods maturity, temperature, and humidity, 4) storage, including temperature and humidity of disk space, screening and separation of contaminated grains, and 5) processing, such as drying and sorting. Mold contamination in grains led to a decrease in viability, discoloration, and weight loss. These accumulated damages influence the levels of mycotoxins in food commodities.

According to Miller (1995), AF-producing fungi ecology in the tropics is different from other geographic areas. Aspergillus spores are widespread in the soil, creating high contamination level of AF in agricultural products in tropical countries. Also, the food products sold in the open market in the tropics are usually displayed under inappropriate conditions. Long term exposure to mold spores, dust and pollution from the environment for the, increase the mycotoxin production of fungi in contaminated food.

Dharmaputra et al. (2003) reported that $45 \%$ and $58 \%$ of AF is produced from 113 and 90 isolates of $A$. flavus respectively were found in the soil of peanut plantation in Wonogiri. Soil is the main source of inoculum for aflatoxigenic Aspergillus species and since peanut pods grow underground, they are in direct contact with the fungal population in the soil. In Indonesia, peanuts are often infected during pre-harvest, and the contamination becomes more intensive due to poor farming practice. According to Kasno (2004), pods filling phase is highly affected by temperature stress and drought. These factors are optimal for invasion fungal invasion. The optimum temperature in the field for A. flavus growth is between $25.70^{\circ} \mathrm{C}$ to $31.30^{\circ} \mathrm{C}$, and the plants that experience drought stress 4-6 weeks before harvest at this temperature are more susceptible to the fungal contamination. AF contamination occurs at a temperature of $26.30^{\circ} \mathrm{C}, \mathrm{AF}$ content will continue to increase in line by rising temperature until $31.20^{\circ} \mathrm{C}$.

According to Avivi (2005), peanut farmers and traders in Indonesia are still not paying attention to proper post-harvest handling. Farmers dry peanuts on cement floors with the help of sunlight. After that peanuts are stored at room temperature for days or even weeks with poor sanitation before reaching the consumers, during this time A. flavus can grow and produce AF intensively. Poor distribution handling will also increase the growth of mold on peanuts. The level of contamination is also increased during rainy season though the higher water content in the material (Dharmaputra et al., 1993). Therefore, it is necessary to improve postharvest handling which can be implemented easily by farmers and traders in Indonesia to suppress the growth of toxigenic fungi.

\section{Occurrence of Mycotoxins in Indonesian Foods}

From 1971 to 2015, 54 surveillance research projects have been conducted in Indonesia (Table 1). Most of the of mycotoxin analysis were done using HPLC, followed respectively by TLC and ELISA (Figure 1a). The limited budget, high throughput and user-friendly character of ELISA make this method also chosen among laboratories in Indonesia. Most of the data collected were from maize and peanut (either processed or raw material), followed by milk and other food 
products (Figure 1b). Most of the samples from the report were obtained by purchasing products from local markets.
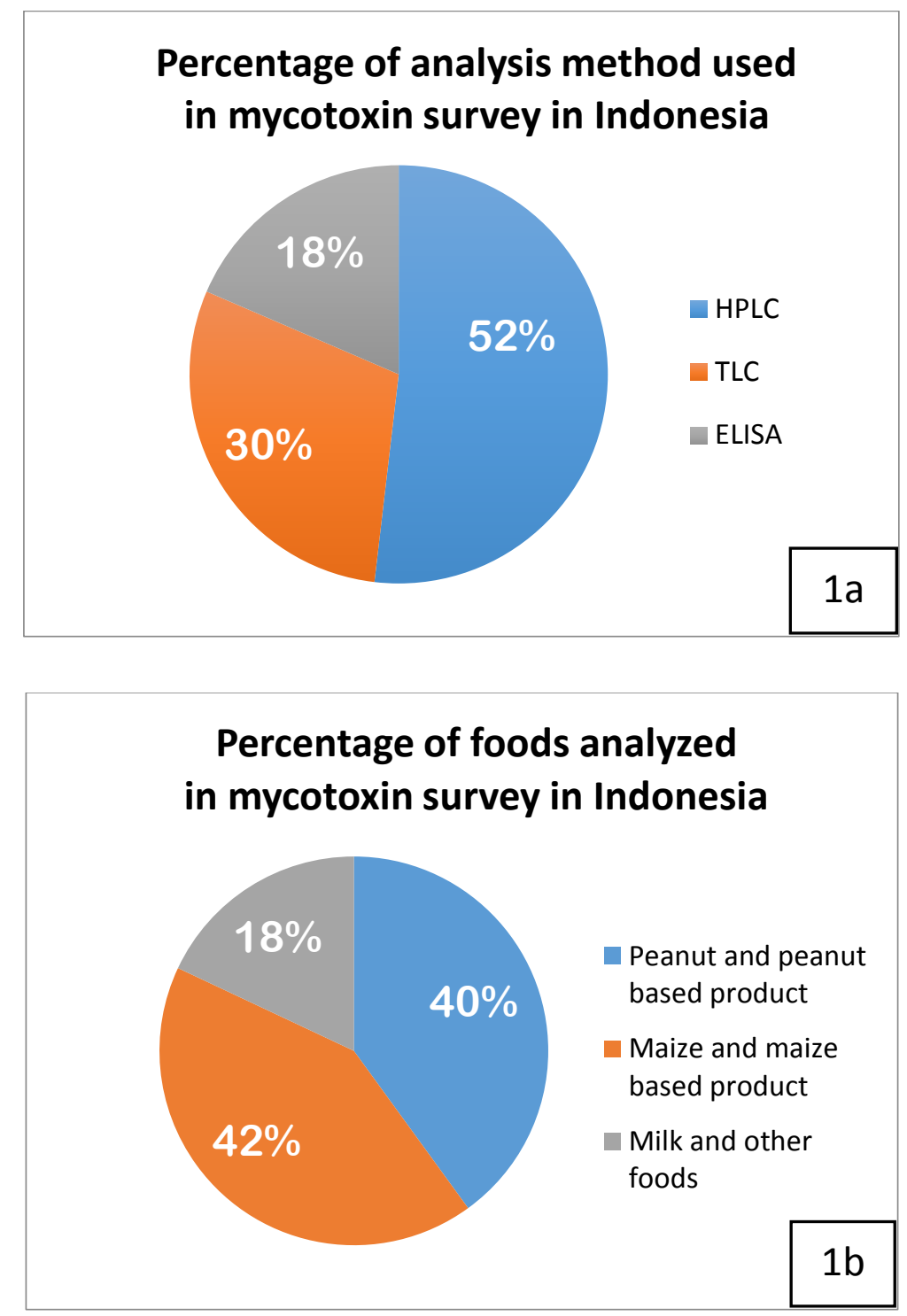

Figure 1. a) Percentage of analysis method used for mycotoxin detection in Indonesia; b)

Percentage of analyzed foods related with mycotoxins in Indonesia.

Up to now, other important food products in Indonesia such as fruits, jamu (Indonesian traditional medicine), drinks (coffee, tea, and chocolate), fermented foods and animal-derived products (such as milk, sausage, meat products, etc.) have not been well studied. Moreover, the research so far is limited to AF, although other mycotoxins may also be present in many food commodities, for example patulin in fruits (Miskiyah, 2010). Therefore, more surveillance and monitoring are required. 


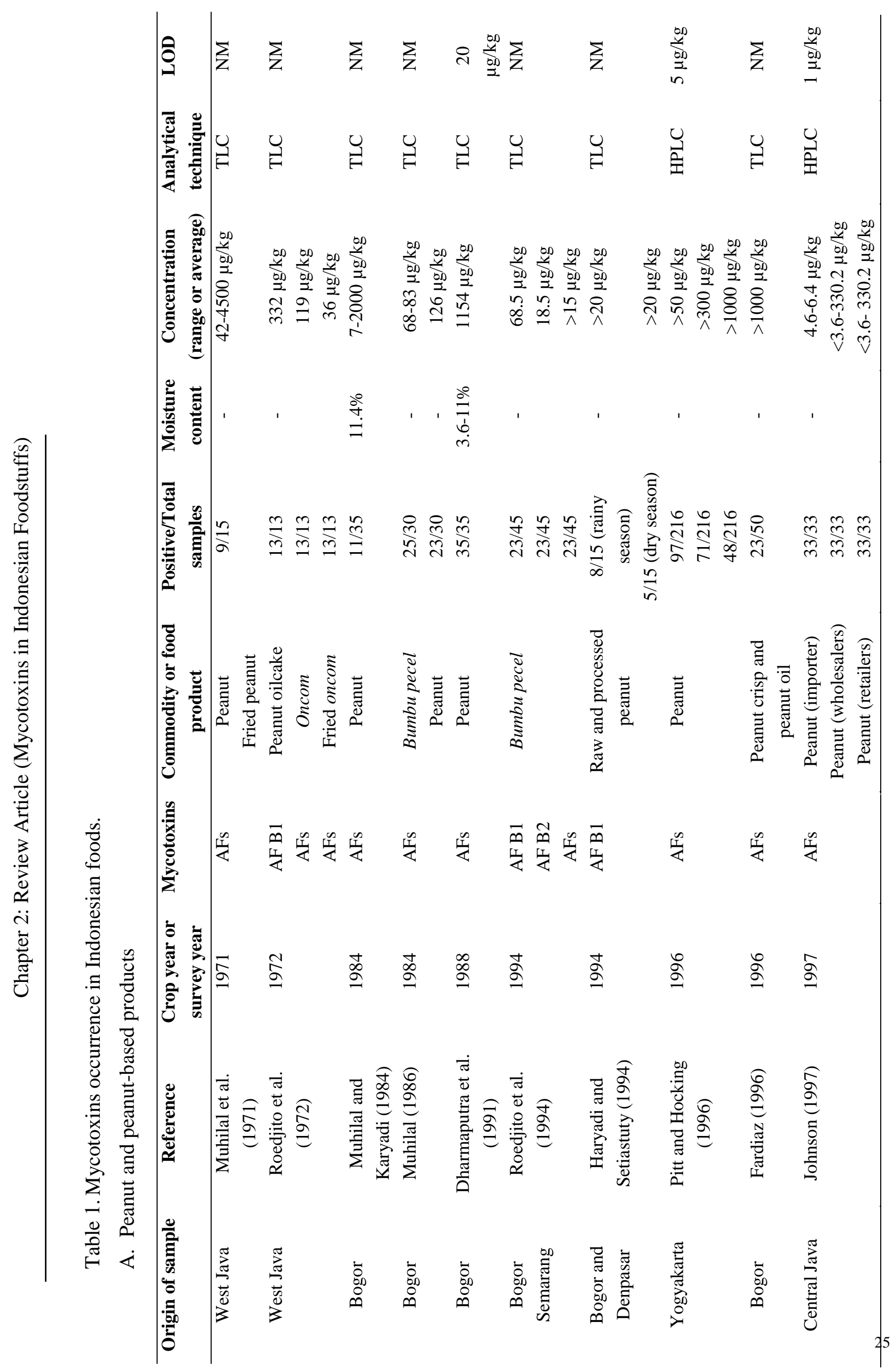




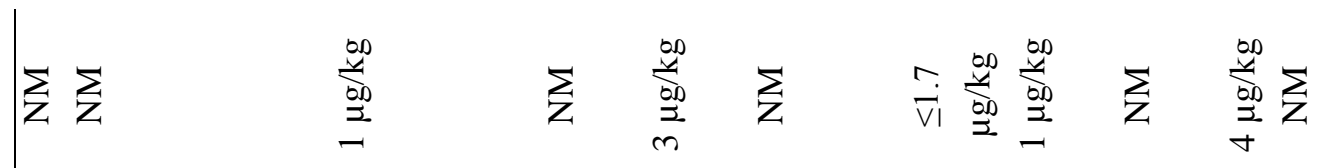

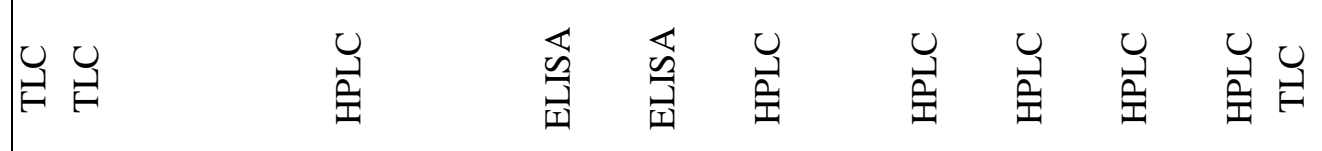

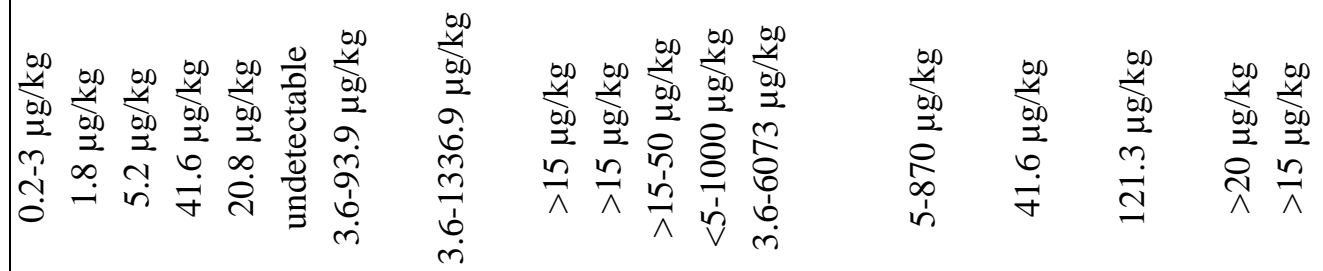

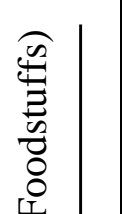

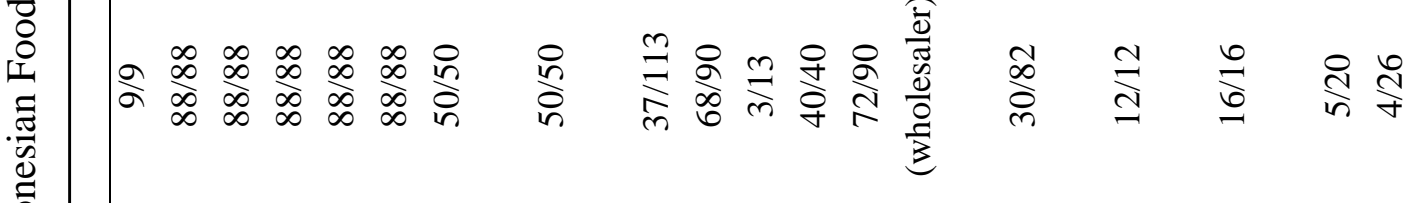

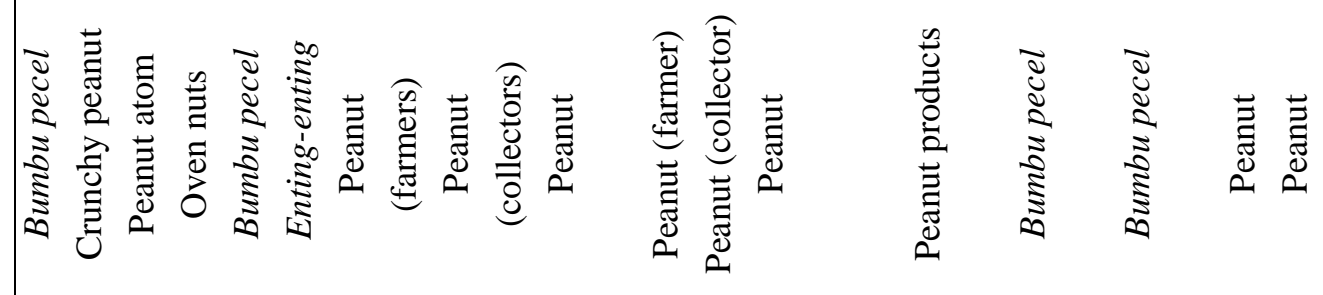

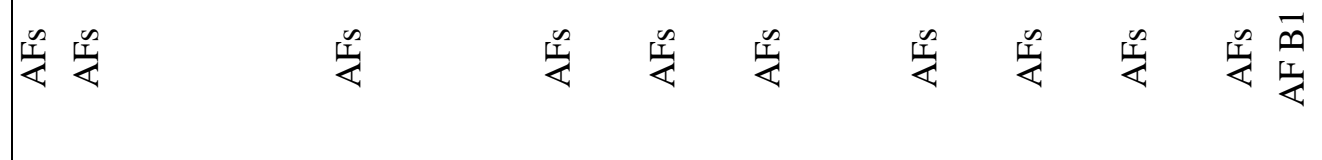

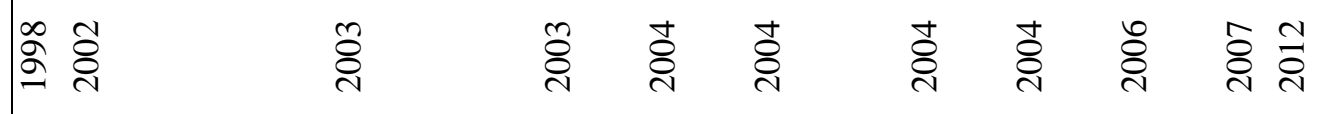

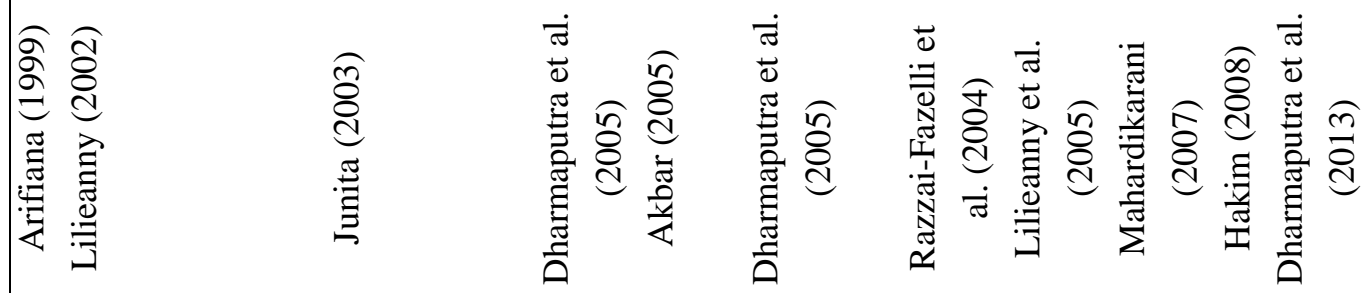

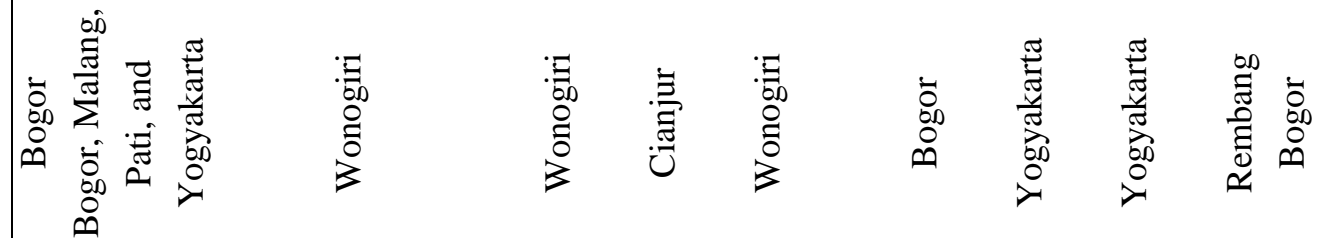




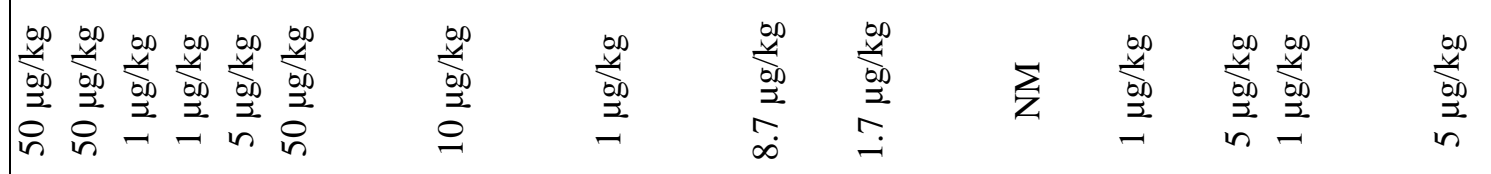

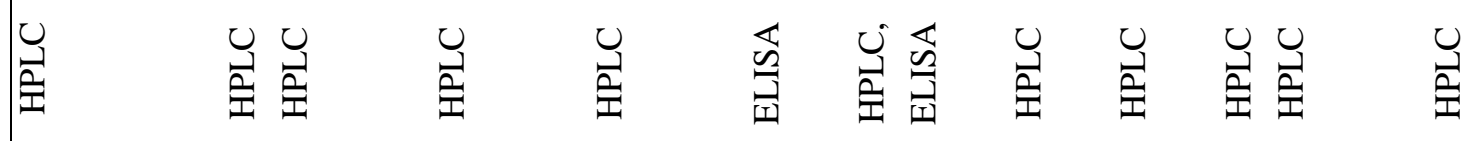

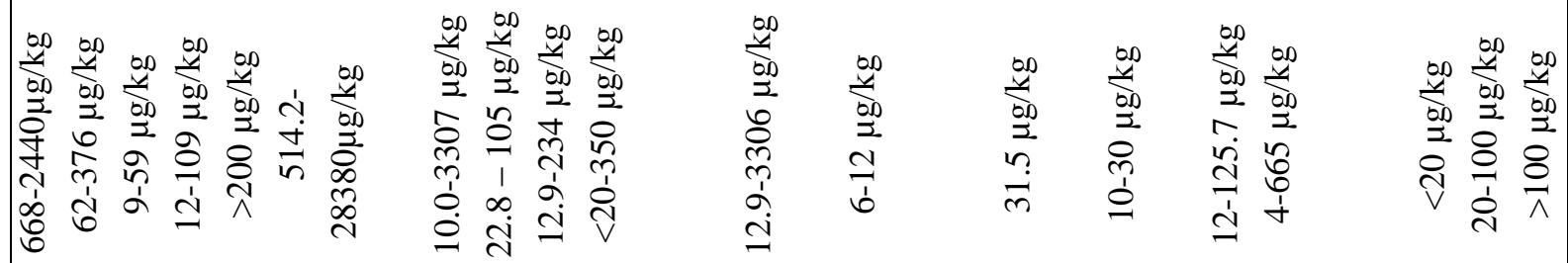

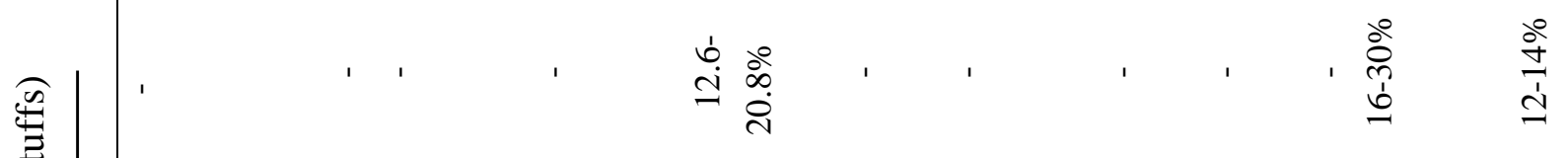

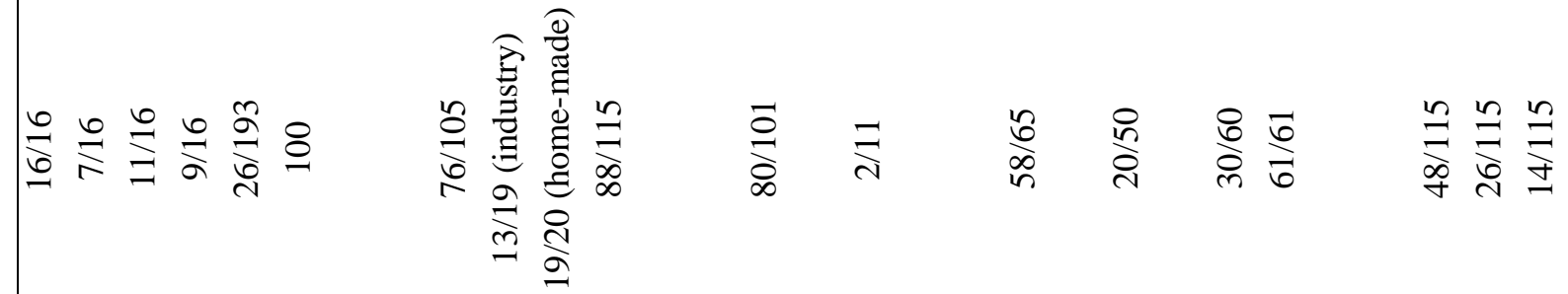

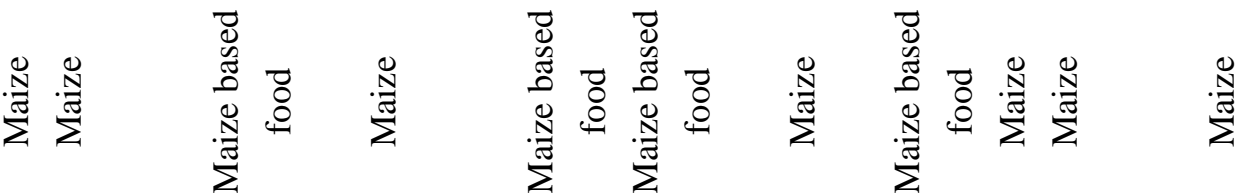

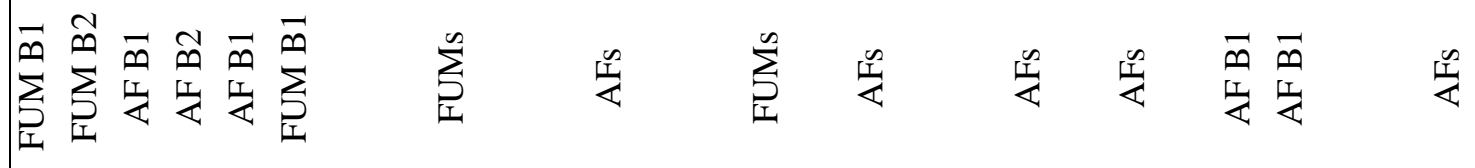

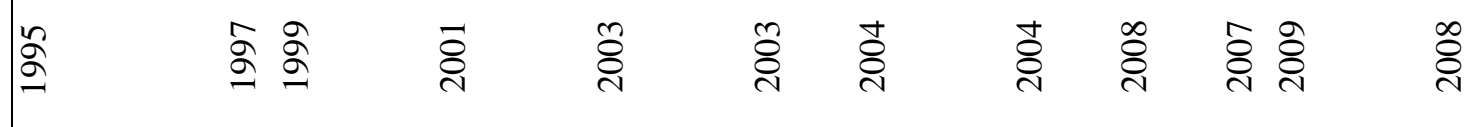

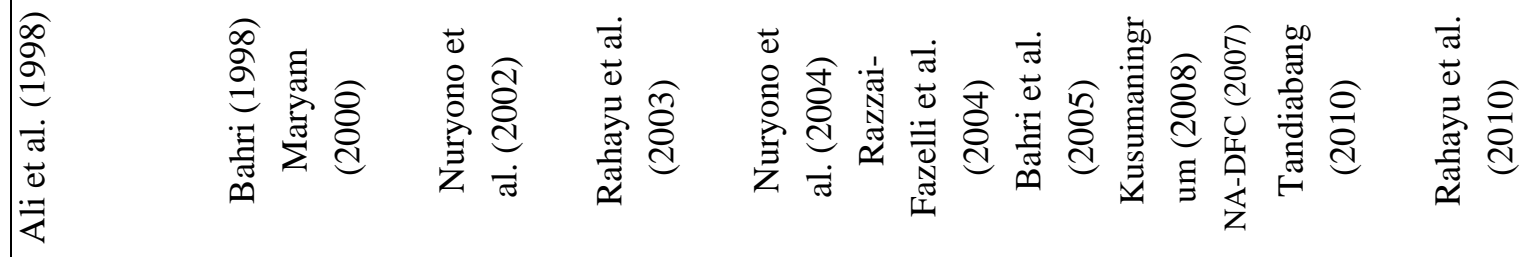

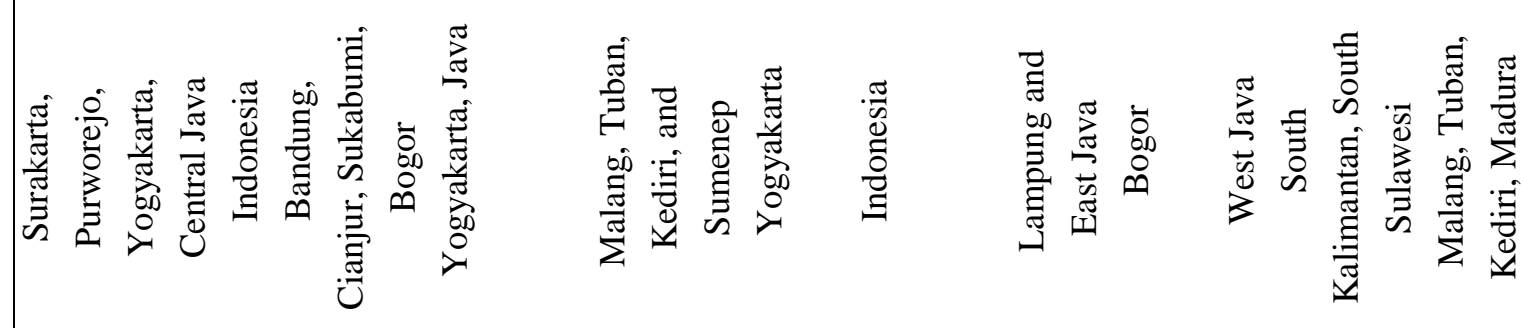




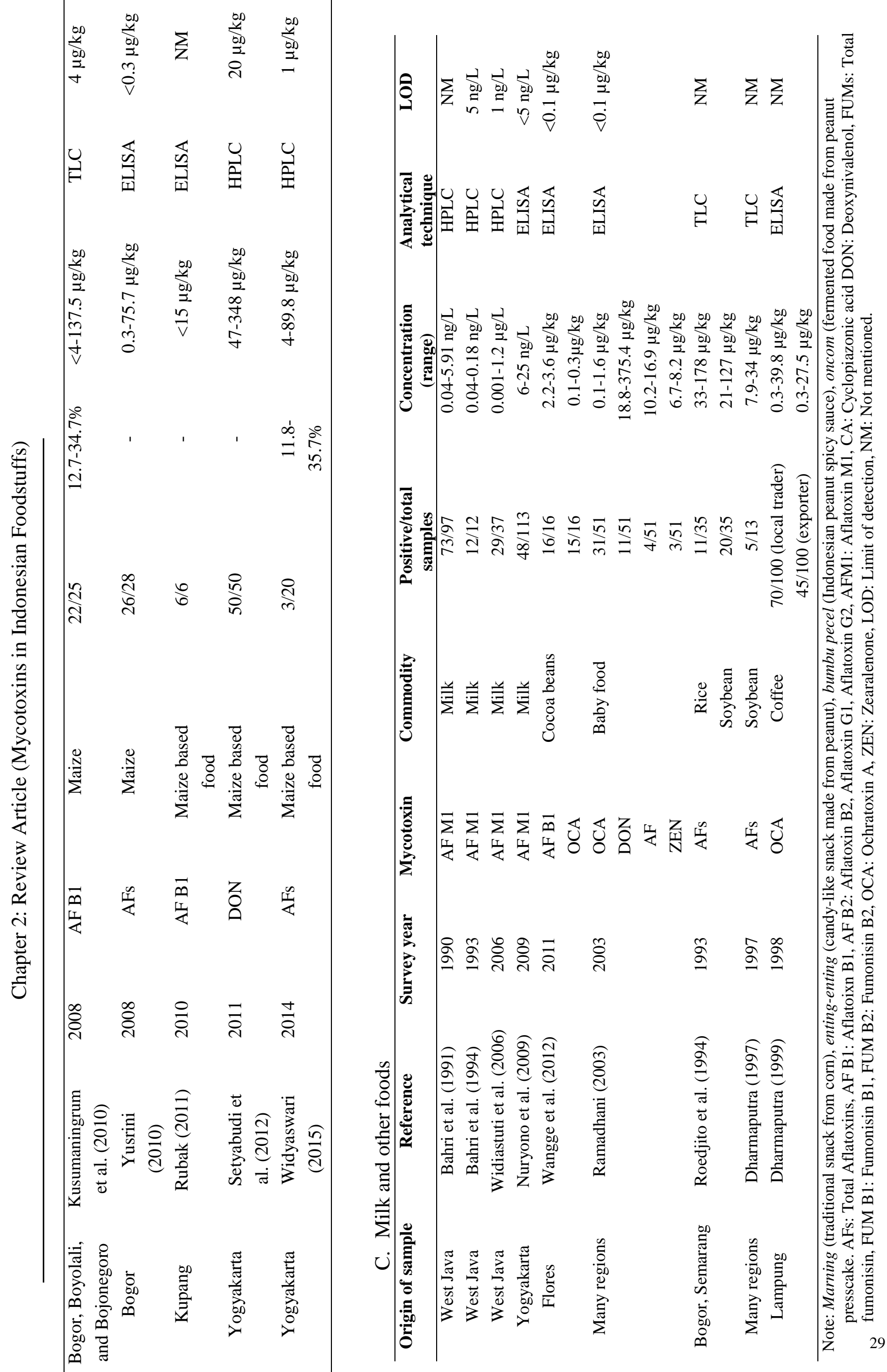


Although rice is the main product and staple food in Indonesia, research about this commodity was very limited and only conducted by Roedjito 24 years ago. Most Indonesian researchers assume rice is already safe for consumption, because there is no intoxicaton case in this commodity. Most data on AF contamination in Indonesia deal with two other commodities, namely maize and peanut (Table 1). The data showed a decrease in mycotoxin contamination level from year to year; this suggests that government already gave effort to address AFs contamination problem, but it has not been optimal since the contamination level is still above the regulatory limit.

Peanut is the most popular bean in Indonesia. They are consumed as dietary supplements and processed into various snack food. The rate of peanuts consumption in Indonesia is about 7.3 gram per day (BPS, 2016). According to studies in the last decade, range of AFs contamination level is $2-1337 \mu \mathrm{g} / \mathrm{kg}$. About $42 \%$ of total sample, its level of AF contamination were above the regulatory limits, mainly in bumbu pecel paste. It should get attentions since the paste is always served as dressing for vegetable salad that is consumed by most Indonesian people, mainly in Java. It also arises attention in many researchers on how to reduce the AF level during processing stage.

In Indonesia, AF contamination of maize, according to data, have the same tendency to peanuts. The data shows the contamination level is relatively high. From last decade reports, AF contaminations were in the range of $10-1375 \mu \mathrm{g} / \mathrm{kg}$. About $45 \%$ of studied samples exceeded the acceptable limit, mainly for corn kernel. The contamination level varies widely because postharvest treatment and storage condition in each region also varies from farmers to distributors level. Studies also suggest that improper storage, mainly provided by local stores, thrive on the growth of aflatoxigenic molds.

Besides peanut and maize, AF or AFM1 level of other commodities such milk, soybeans, and chocolate, were also reported. However, the contamination level was lower than the former ones. Chocolate and dairy products are considered safe because the mycotoxin level is much lower than permissible limit.

In addition to the information presented before (Table 1), several other dangerous mold contaminated Indonesian foods are listed below:

1. Dharmaputra et al. (1999) reported that 18 out of 20 black pepper samples obtained from markets and supermarkets in Bogor, and 16 out of 20 samples of white pepper from exporters or collectors in Bangka Island and Lampung province were infected with A. flavus. Seventeen toxigenic fungal species were isolated from black pepper.

2. Aminah and Supraptini (2003) reported that some fruits from the traditional and modern markets were infected by mycotoxigenic fungi. Fusarium, Penicilium, and Aspergillus were the dominant fungal genus.

3. Yani (2004) reported that 15 species of toxigenic fungal species were found in coffee bean from Bengkulu province.

4. Yani (2008) reported that 17, 13 and 15 fungal species had been isolated from coffee beans obtained from farmers, collectors in Bengkulu Province. The dominant fungal species was $A$. 
niger. The percentage of samples infected by A. ochraceous (OCA-producing fungus) in farmers, collectors in district and regency level were 23.3, 46.7 and 46.7\%, respectively.

5. Rukmi (2009) reported the presence of Aspergillus sp. in herbs commonly consumed by Javanese people as a traditional medicine. Isolates found in this study were A. parasiticus, $A$. flavus, A. oryzae, A. tamari, and A. clavato-flavus.

6. Rahmadi and Graham (2010) reported that all cocoa beans sampled from Indonesia were contaminated by mycotoxin producing fungi. The main species were Aspergillus flavus, A.niger, A. wentii, A. clavatus, Penicillium citrinum, and P. spinolosum.

7. Anggriawan et al. (2017) discovered the fungus Fusarium spp. which can produce mycotoxins in the traditional tempeh starter in Central Java and Yogyakarta provinces.

\section{Health Impact of Mycotoxins in Indonesia}

High level of AF contamination in agricultural products has a significant impact to food safety and human health in Indonesia. In 1991, Cipto Mangunkusumo Hospital (RSCM) in Jakarta reported that $20 \%$ of liver cancer cases were not correlated with hepatitis B or hepatitis C virus infection but was thought to be caused by AF B 1 (Noer, 2002). Sudjadi et al. (1999) reported that 80 out of 81 patients ( 66 men and 15 women) suffered liver cancer because of the consumption of contaminated oncom, tempeh, roasted peanuts, peanut sauce, soy sauce and salted fish. AF B1, AF G1, and AF M1 were detected in the liver of $58 \%$ of these patients with concentrations above 400 $\mu \mathrm{g} / \mathrm{kg}$. Pitt and Hocking (1996) mentioned that the level of AFs in foodstuffs in some tropical countries exceed the tolerance limits. Estimation number of deaths due to liver cancer caused by AF in Indonesia is more than 20000 people per year. Recent study under ASEAN (The Association of Southeast Asian Nations)-Australia Development Cooperation Program Stream in 2007 showed that Indonesia has the fourth highest estimated cancer cases in ASEAN (0.27-mean exposure for hepatitis B population and 0.009-mean exposure for non-hepatitis B, as shown in Table 2).

Table 2. Estimated cancer number due to AF exposure in ASEAN (Rahayu, 2010).

\begin{tabular}{|c|c|c|}
\hline \multirow[t]{2}{*}{ Country } & \multicolumn{2}{|c|}{$\begin{array}{l}\text { Estimated cancer number due to AF exposure } \\
\text { (cancer/year/100000 population) }\end{array}$} \\
\hline & Hepatitis B & Non-Hepatitis B \\
\hline Brunei Darussalam & 0.03-mean exposure & 0.001-mean exposure \\
\hline Cambodia & 0.18 -mean exposure & 0.006-mean exposure \\
\hline Indonesia & 0.27 -mean exposure & 0.009-mean exposure \\
\hline Laos & NA & NA \\
\hline Malaysia & 1.5-mean exposure & 0.05-mean exposure \\
\hline Myanmar & 0.36-mean exposure & 0.012-mean exposure \\
\hline Philipines & 3.8-mean exposure & 0.13-mean exposure \\
\hline \multirow[t]{2}{*}{ Singapore } & 0.0264-mean exposure & 0.0009-mean exposure \\
\hline & 0.0798-high exposure & 0.0027-high exposure \\
\hline \multirow[t]{2}{*}{ Thailand } & 0.006 -mean exposure & 0.0002-mean exposure \\
\hline & 0.6-high exposure & 0.02-high exposure \\
\hline \multirow[t]{2}{*}{ Vietnam } & 0.12 -mean exposure & 0.004-mean exposure \\
\hline & 10.3-high exposure & 0.01-high exposure \\
\hline
\end{tabular}

Note: NA (not available). 
Rahayu (2010) estimated that about 227 new cases of cancer per year due to peanut and peanut sauce consumption. Furthermore, Pitt and Hocking (1997) suggested that from the epidemiological data from several African countries and Thailand, there is a logarithmic relationship between AF intake and the incidence of liver cancer.

\section{Updated Risk Assessment of Maize and Peanut Consumption in Indonesia}

Risk assessment is the process of quantifying the magnitude and exposure, or probability, of a harmful effect on individuals or populations from specific agents or activities (KuiperGoodman, 2004). Until now, literature is lacking information on exposure and risk assessment of mycotoxins in Indonesia. Here, we update risk assessment of peanut and maize consumption in Indonesia. We used secondary data of mycotoxin contamination taken from last decade literature or reports. We determined the exposure levels of Indonesian infants, children, and adult to aflatoxin through maize and peanut consumption and assessed the associated risks as a result of its consumption.

Table 3 shows the exposure and risk assessment data for AFs among the different population groups that consume peanut in Indonesia. The results showed quite high exposure levels to aflatoxins among Infants, children and adult with PDI (national) of 51.2, 20.5 and 8.5 ng. $\mathrm{kg}^{-1} \mathrm{bw} \cdot \mathrm{day}^{-1}$ respectively. The exposure levels of all categories of maize consumers to AFs exceeded the 0.017 ng. $\mathrm{kg}^{-1}$ bw.day ${ }^{-1}$ permissible exposure threshold by more than 531 fold. This is indicating a public health risk even though it is much less than PDI in African countries and other developing countries.

Table 4 shows the exposure and risk assessment data for aflatoxins among the different population groups that consume maize in Indonesia. The results also showed quite high exposure levels to aflatoxins among infants, children, and adult with PDI (national) of 21.1, 8.4 and 8.1 ng. $\mathrm{kg}^{-1} \mathrm{bw} . \mathrm{day}^{-1}$ respectively. The exposure levels of all categories of maize consumers to AFs exceeded the 0.017 ng. $\mathrm{kg}^{-1}$ bw.day ${ }^{-1}$ permissible exposure threshold by more than 506 fold. This is also indicating a public health risk even though it is much less than PDI in African countries.

Risk exposure level for maize consumption is less than peanut. This in line on the data population risk for primary liver cancer. This also indicates that peanut is more susceptible to AF contamination than maize. The PDI data across the population showed a similar trend of infants > children > adults for both foods. This explains that infants are the most susceptible to be exposed to the effect such as stunting (impaired growth), and immune suppression.

By doing comparison data, Indonesia has higher PDI compared with Korea (5.79 ng.kg${ }^{1}$ bw.day ${ }^{-1}$ ) (Park et al., 2004), France (0.345.79 ng.kg-1 bw.day ${ }^{-1}$ ) (Leblanc et al., 2005), Australia and USA (0.15 and $0.26 \mathrm{ng} . \mathrm{kg}^{-1}$ bw.day ${ }^{-1}$, respectively) (WHO, 1998), but has almost same level with Brazil (59.1 ng.kg ${ }^{-1}$ bw.day ${ }^{-1}$ ) and lower level compare to China (91 ng. $\mathrm{kg}^{-1}$ bw.day ${ }^{-1}$ ) (WHO, 1998). 


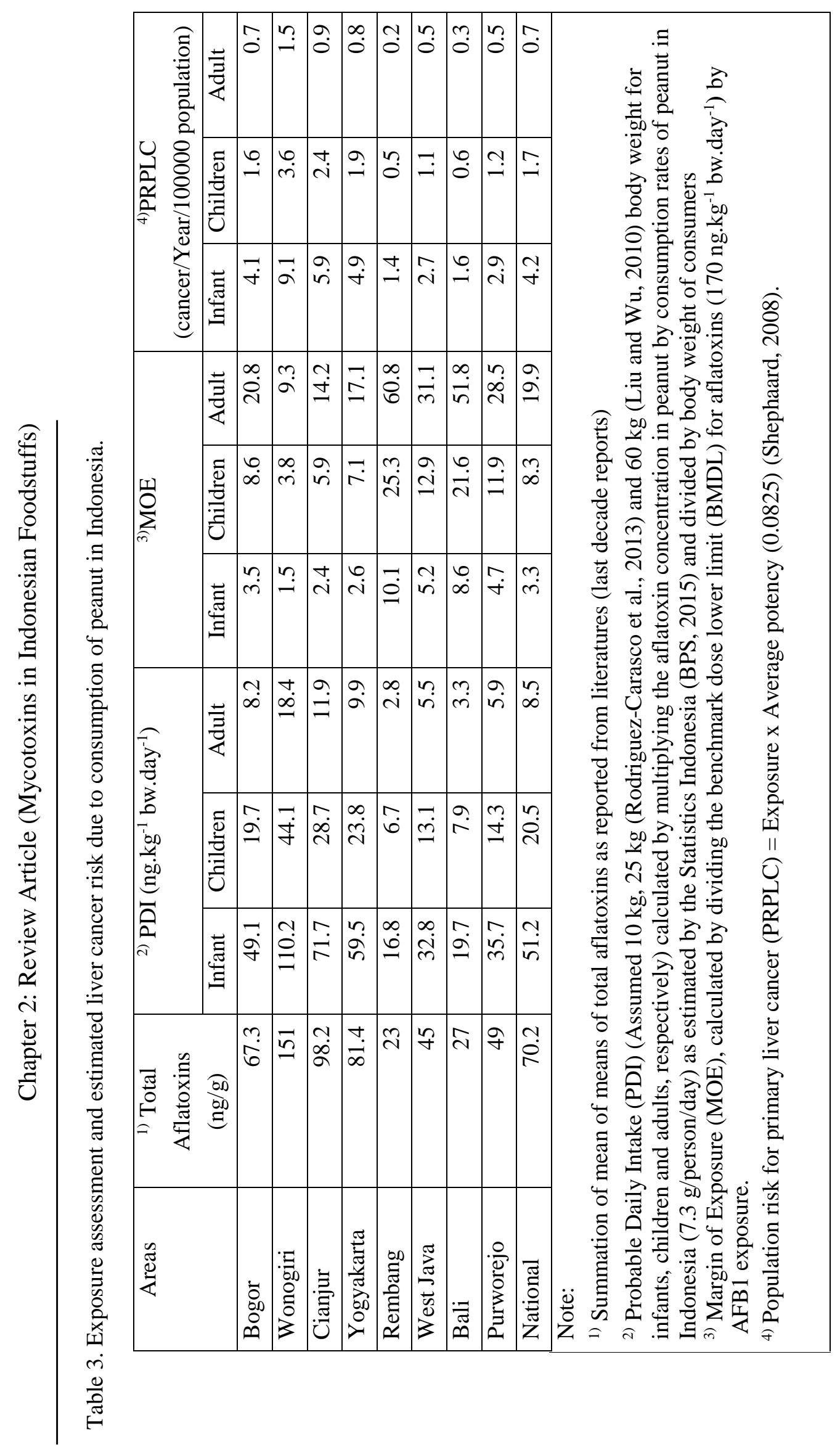




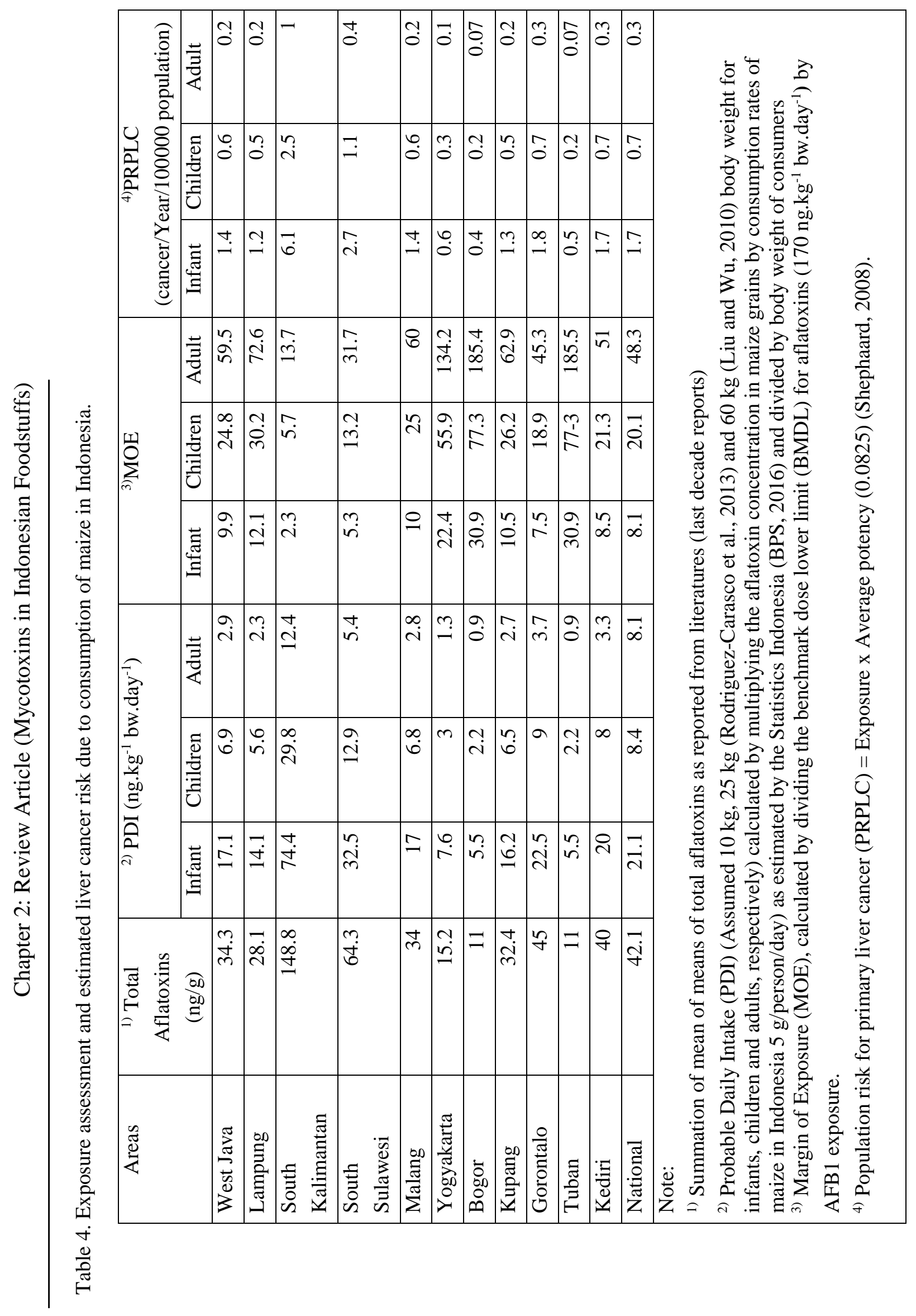




\section{Mycotoxin Regulation in Indonesia}

Mycotoxin regulation in Indonesia is still very limited. Mycotoxins were first mentioned in the Food Act (No. 7, 1996) and improved in 2004 by Government Regulation (No. 28, 2004). The regulation was developed because of the increase in awareness about the relationship between food safety and health. In 2004, NA-DFC issued regulations on the maximum limit of AFs in food products. The regulation stated that the maximum contamination of AF B1 and total AF in peanutbased food products and corn are $15 \mu \mathrm{g} / \mathrm{kg}$ and $20 \mu \mathrm{g} / \mathrm{kg}$ respectively. This limit is similar to the regulations that apply in Hong Kong, Thailand and the Philippines. In the meantime, Indonesia has more stringent regulation of the AF limit compared to other Asian countries like India (30 $\mu \mathrm{g} / \mathrm{kg})$, Malaysia $(35 \mu \mathrm{g} / \mathrm{kg})$ and Sri Lanka $(30 \mu \mathrm{g} / \mathrm{kg})$. Indonesian dairy products have a maximum limit of AF M1 of $0.5 \mu \mathrm{g} / \mathrm{kg}$ which is more stringent than in Malaysian and Sri Lankan regulations. In 2009, Indonesian National Council for Standardization (INCS) launched a comprehensive regulation (SNI 7385-2009) about the limits of mycotoxin contamination in food products (Table 3 , details chemical structure in Figure 2). This new regulation includes 5 types of mycotoxins (AF, DON, FUM $B_{1}+B_{2}$, OCA, and patulin). The maximum limit established for AF in various food products are the same as in the regulations issued by NA-DFC in 2004. Unfortunately in the newest regulations, zearalenone is still not included.

The maximum limit of AF content in foods:

\begin{tabular}{cccc}
\hline No. & Food Products & Type & $\begin{array}{c}\text { Maximum Level } \\
\text { (ppb or } \mathbf{\mu g} / \mathbf{k g})\end{array}$ \\
\hline 1 & Milk and milk drink products & M1 & 0.5 \\
2 & Fermented milk and rennin hydrolyzed milk products & M1 & 0.5 \\
3 & Concentrated milk and analog products & M1 & 0.5 \\
4 & Cream and related products & M1 & 0.5 \\
5 & Milk powder and analog products & M1 & 5 \\
6 & Cheese and analog products & M1 & 05 \\
7 & Desserts made from milk (pudding, yogurt) & M1 & 0.5 \\
8 & Whey and its processed products & M1 & 0.5 \\
9 & Peanuts and its processed products & B1 & 15 \\
& & Total & 20 \\
10 & Corn and its processed products & B1 & 15 \\
& & Total & 20 \\
11 & Spice powder & B1 & 15 \\
& & Total & 20 \\
\hline
\end{tabular}


The maximum limit of DON content in foods:

\begin{tabular}{ccc}
\hline No. & Food Products & $\begin{array}{c}\text { Maximum Level } \\
\text { (ppb or } \boldsymbol{\mu g} / \mathbf{k g})\end{array}$ \\
\hline 1 & Wheat & 1750 \\
2 & Corn & 1750 \\
3 & Corn processed product as a raw material & 1000 \\
4 & Wheat processed product as a raw material & 1000 \\
5 & Wheat processed products ready for consumption & 500 \\
& (pastry, bread, biscuits, snacks) & 750 \\
6 & Pasta and noodles and similar products & 200 \\
\hline
\end{tabular}

The maximum limit of FUM $\mathrm{B}_{1}+\mathrm{B}_{2}$ content in foods:

\begin{tabular}{ccc}
\hline No. & Food Products & $\begin{array}{c}\text { Maximum Level } \\
(\mathbf{p p b} \text { or } \boldsymbol{\mu g} / \mathbf{k g})\end{array}$ \\
\hline 1 & Corn & 2000 \\
2 & Corn processed product as a raw material & 2000 \\
3 & Corn processed products ready for consumption & 1000 \\
\hline
\end{tabular}

The maximum limit of OCA content in foods:

\begin{tabular}{ccc}
\hline No. & Food Products & $\begin{array}{c}\text { Maximum Level } \\
\text { (ppb or } \boldsymbol{\mu g} / \mathbf{k g})\end{array}$ \\
\hline 1 & Cereals (rice, maize, sorghum, wheat) & 5 \\
2 & Processed cereal products as raw materials & 5 \\
3 & Processed cereal products ready for consumption & 3 \\
4 & MP-ASI (complementary food for infant)- cereal based & 0.5 \\
5 & Dried grapes, including raisins & 10 \\
6 & Grape juice & 2 \\
7 & Roasted coffee, coffee powder & 5 \\
8 & Instant coffee & 10 \\
9 & Beer & 0,2 \\
\hline
\end{tabular}

The maximum limit of patulin content in foods:

\begin{tabular}{ccc}
\hline No. & Food Products & $\begin{array}{c}\text { Maximum Level } \\
\text { (ppb or } \boldsymbol{\mu g} / \mathbf{k g})\end{array}$ \\
\hline 1 & Apple & 50 \\
2 & Canned apple & 50 \\
3 & Apple puree & 25 \\
4 & Extract apple & 50 \\
5 & Nectar apple & 50 \\
6 & Apple purees for babies and children & 10 \\
7 & Alcoholic beverages-apple based & 50 \\
\hline
\end{tabular}




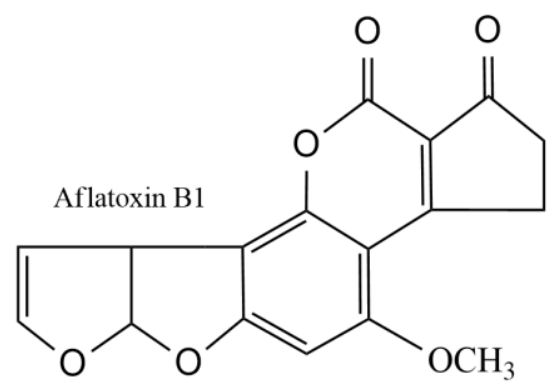<smiles>COc1cc2c(c3oc(=O)c4c(c13)CCOC4=O)[C@H]1C=COC1O2</smiles><smiles>COc1cc2c(c3oc(=O)c4c(c13)CCC4=O)[C@H]1CCOC1O2</smiles><smiles>COc1cc2c(c3oc(=O)c4c(c13)CCOC4=O)C1CCOC1O2</smiles>

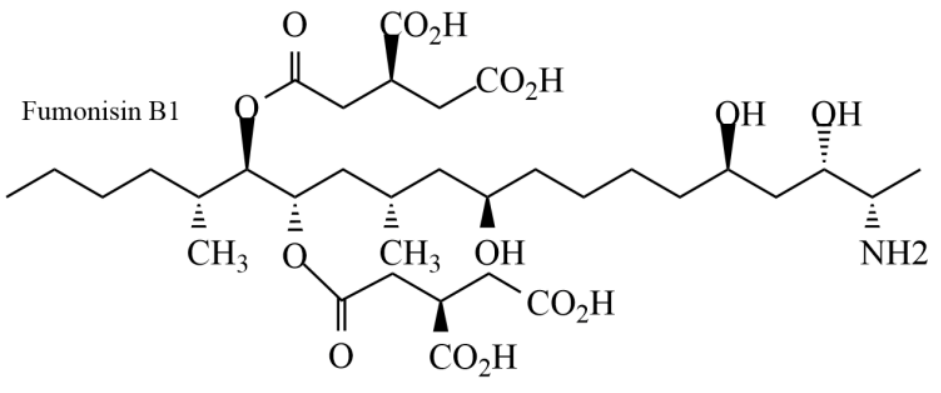<smiles>O=C1C=C2C(=CCOC2O)O1</smiles><smiles>CCCC[C@H](C)[C@H](OC(=O)C[C@@H](CC(=O)O)C(=O)O)[C@@H](C[C@@H](CCCCCC[C@H](O)C[C@H](O)[C@H](C)N)C[C@@H](CC(=O)O)C(=O)O)OC(=O)[C@H](C)N</smiles><smiles>CC1=CC2O[C@H]3C[C@H](O)[C@@](O)(C[C@@H]3O)[C@H]2[C@H](O)C1=O</smiles><smiles>CC1CC(=O)c2c(O)c(C(=O)NC(Cc3ccccc3)(Cc3ccccc3)C(=O)O)cc(Cl)c2C1</smiles><smiles>C[C@H]1CCCC(=O)CCC/C=C/c2cc(O)cc(O)c2C(=O)O1</smiles>

Figure 2. Chemical structure of important mycotoxins in Indonesia. 


\section{Mycotoxin Control in Indonesian Foodstuffs}

Considering the danger resulting through mycotoxin contamination, it is necessary to establish effective preventative steps from pre-harvest to storage, or remedial actions including decontamination or detoxification. AF control will be the main focus of attention since Indonesian research has focused most on this.

\section{A. Preventive Strategies (Pre-harvest, Harvest, and Post-harvest)}

\section{Pre-harvest}

The critical point of mycotoxin contamination is in the pre-harvest stage when crops are in the pods or fruit filling phase. Seed filling phase is a phase of plant growth which is very sensitive, mainly to temperature stress and drought. The optimum soil temperature for Aspergillus flavus ranges from $25.7^{\circ} \mathrm{C}$ to $31.3^{\circ} \mathrm{C}$. Plants under drought stress are easily exposed to such high temperature during the maturation stage which is about 4-6 weeks before harvest (Kasno, 2004). At a temperature of $25.7^{\circ} \mathrm{C}$, the intact peanut seeds infection with A. flavus is low, since A. flavus favors a temperature of $26.3^{\circ} \mathrm{C}$, furthermore the fungal growth proliferates with increased temperature up to $31.2^{\circ} \mathrm{C}$. Soil temperatures over $31.2^{\circ} \mathrm{C}$ dramatically inhibit the growth of $A$. flavus (Ginting and Beti, 1996). In Indonesia, peanuts are usually planted during dry season and suffering drought stress in addition to high temperature. Therefore, the chances for plant infection or contamination with A. flavus are very common. During the seed filling phase, plants need a sufficient supply of water and calcium (Ca) (Taufik, 2000). Plants which are exposed to water and $\mathrm{Ca}$ deficiencies usually produce small pods with seeds wrinkles, where the latter might encourage a successful A. flavus infection. Approximately $60 \%$ of Indonesian peanut plants are grown on dry land. Though this land is alfisol, alkaline and calciumrich, it is has low concentrations of iron nutrients which results in chlorosis which is very similar to chlorosis resulting from Ca deficiency (Taufik 2000; Sudaryono 2001).

Abiotic stress (e.g. drought, lack of nutrients) and biotic stress (e.g. herbivores or insect attack, and fungal contamination) in addition to harvest-timing have a direct effect on mold growth in plant tissues and subsequently on mycotoxin production (Kasno, 2004). Good Agricultural Practices (GAP) can minimize the fungal occurrence and plant infection in the field as follows:

Crop rotation: to break the cycle of toxigenic fungi proliferation in the soil. This is a very effective method to prevent the spread of toxigenic fungi in the field. For instance, a crop rotation of corn-soybean can reduce Fusarium spp. attack compared to regular corn planting (Lopez-Garcia and Park, 1998; Kasno, 2004).

Selection of resistant varieties: is an effective strategy to avoid toxigenic fungi attack on commodities. Kasno (2004) discovered the existence of chromosomes related to the resistant to A. flavus in some agricultural commodities such as corn and peanuts. The peanut varieties of Jerapah, Sima, and Turangga were more resistant to A. flavus infection than Tigers and J11 varieties. These three resistant varieties have been introduced in Indonesia through local varieties and derivatives which have been examined for resistance 
to A. flavus (Kasno, 2004). However, there are not enough resistant seeds available at the farm level (Kasno, 1994).

Pests, diseases and weed control: Insect infestations cause damage to the plant and make it susceptible to fungal infection. Control strategy using insecticides and fungicides will help to prevent mold growth and mycotoxin production. In susceptible varieties, disease control with spraying fungicides Topsin M, Daconil, and Baycor 4-6 times to avoid production loss of up to $55.1 \%$. Control of leaf disease with chemicals increased the yield of dry pods (2.48-2.70 t/ha) as compared to non-control (1.30-1.60 t/ha) (Hardaningsih et al. 1992). Kasno (1993) reported that the use of tolerant varieties can prevent yield losses up to $20 \%$. Leaf diseases can also increase the intensity of A. flavus contamination. According to Kasno (2002a), control of foliar diseases can reduce the intensity of $A$. flavus from $13 \%$ to $7 \%$. Meanwhile, weeds can also be a vector for toxigenic fungal infections, especially soil-borne pathogens, such as Fusarium graminearum and F. moniliforme. Weeds should be removed mechanically or by using herbicides or other safer means (Noor, 1997).

Soil and irrigation management: Drought and soil fertility influence intensity of fungal infection in the soil (Kasno, 2004). Temperature and soil moisture control play an important role in mycotoxin management. Peanut crop grown under drought stress during the reproductive stage is very sensitive to A. flavus infection (Kasno, 2004). Moreover, drought stress and high levels of humidity are ideal conditions for the proliferation of $F$. moniliforme and fumonisins production in corn plants (Lopez-Garcia and Park, 1998). The deficiency of soil nutrients like iron was found to increase invasion of A. flavus to peanut plants (Kasno, 2004).

Mehan (1989) made a selection of resistant peanut plants on sandy soil under drought stress during the seed filling stage. Peanuts selection was also carried out in Indonesia by providing optimum and sub-optimum irrigation conditions at the reproductive stage. The results showed that the lack of irrigation significantly increased the rate of $A$. flavus infection. Optimum irrigation during the reproductive stage can suppress fungal attack intensity from $28 \%$ (without irrigation) to $3 \%$ (with irrigation) (Kasno et al., 2002). Biological control: Prevention of toxigenic mold infestation in plants can also be done using biological methods by spreading non-toxigenic Aspergillus sp. which will compete with toxigenic A. flavus and A. parasiticus so that the toxigenic fungal growth is be hampered. This method showed satisfactory results on peanut plants, where AF contamination can be reduced by up to $90 \%$ (Cole and Dorner, 1999). To ensure this success, Pitt (1999) suggested that the spore ratio of non-toxigenic to toxigenic fungi in the field should be 100:1. However, the challenge is to achieve this ratio practically in the field. The United States of America has commercial bio-control products to control pathogens such as A. flavus in particular plants. The product is "AF36" which is a sterile wheat seed colonized with A. flavus AF36 to cope up A. flavus attack in cotton plants. Product "afla- 
guard" that is a granola with $0.01 \%$ A. flavus NRRL 21882 which is applied to peanut plants (Gardener, 2005; Dharmaputra et al., 2005).

Research about A. flavus antagonistic fungi was carried out in Indonesia by Dharmaputra et al. in 2002. Aspergillus niger was the most promising antagonistic mold because growth of $A$. flavus was inhibited and showed $80 \%$ of AF reduction. Non-toxigenic isolates of A. flavus $6 \mathrm{I} 2$ reduced AF production by $61 \%$, while using A. tamarii and nontoxigenic A. flavus 361 showed a reduction of $\mathrm{AF}$ by $60 \%$ and $59 \%$ respectively. Dharmaputra et al. (2003) used Trichoderma harzianum in soil to control A. flavus. The results showed that $T$. harzianum is able to prevent $A$. flavus attack, thus preventing AF contamination.

The use of biological control agents was tested to prevent $F$. oxysporum contamination. Fusarium oxysporum is able to produce fusaric acid, which is also toxic for animals. This pathogen is one of the main problems of plant diseases, especially banana plants in Indonesia. Effendi (2013) conducted experiments using some Trichoderma species showing antagonistic effects. All the strains had direct and indirect inhibitory effects (with producing volatile compounds) in the antagonistic test to F. oxysporum f.sp. cubense. The highest inhibition was shown by T. laughter IPBCC 13.1031 (85.63\%). In the volatile test, the three best strains of $T$. harzianum LIPIMC namely 0572, $T$. ovalisporum LIPIMC 0571, and Trichoderma sp. LIPIMC 0570 showed antagonistic activity due to volatile compounds showing inhibition values of $45.25 \%, 45.65 \%$, and $45.38 \%$ respectively. Nurbailis (2008) demonstrated that Trichoderma strains from the center of the banana production in West Sumatra were able to overcome Panama wilt disease. Sudantha et al. (2011) also described several Trichoderma strains that effectively inhibit the growth of $F$. oxysporum in vitro. Despite the fact that the use of biocontrol agents are successful in the laboratory, their commercialization depends on whether they can consistently control the mycotoxigenic fungus in different field conditions.

\section{Harvest}

At the harvest stage, there are several issues to be considered in order to prevent mycotoxin contamination: (i) Harvesting has to be done at the optimal maturity level of grain followed by rapid drying (1-2 days) so that the moisture content of grain quickly reaches $14 \%$ to the prevent the development of toxigenic fungi; (ii) separation of damaged grains; (iii) the moisture content and surrounding temperature should be maintained in the appropriate range; (iv) insect and rodent control (Rahayu, 2009).

Harvesting at the optimum stage of grain maturity can reduce or prevent infection of A. flavus. The maturity level of peanut can be recognized visually from the slightly darker skin color of the pods when they are peeled, the black skin sketch will appear with a white background. Quantitatively, the optimum maturity level is achieved when the seed ratio (seed-hull) is at its maximum level (Trustinah 1987). Earlier harvest will produce many young pods and dried seeds as the pods shrivel because the drying time is too long for the small seeds. The unripe seed is more susceptible to A. flavus infection compared to 
the mature seed (Rucher et al. 1994). Conversely, at late harvest, skin pods are attached tightly to endosperm which results in many broken seed when peeled (Trustinah and Kasno 1992). Wrinkled and damaged seeds are susceptible to A. flavus infection (Ginting dan Beti 1996). If the damaged and wrinkled pods are kept at low as possible at this stage, further contamination can be reduced significantly.

Harvesting should be done in the dry season and when seeds are ready to be harvested. Unripe seeds or grains (containing large amounts of water) are beneficial for the mold infection. The water content at harvest time should be set in a certain range, such as $23-25 \%$ for maize grain, in sorghum this should be between $12-17 \%, 11-15 \%$ in soybeans and $35-50 \%$ in peanuts (Kasno, 2004). Harvesting at the wrong stage leads to fungal infection in farming products. Tools used during harvesting, transport, drying and storage should be clean, free from insects and mold. Mechanical damage and contact with the infected plant parts should be avoided during harvest.

\section{Post-harvest}

Prevention through pre-harvest management is the best method to control mycotoxin contamination; however, if contamination has occurred at that stage, the potential dangers associated with the toxin must be monitored during post-harvest procedures, especially if the product is intended for human consumption. Sorting, drying, storage and processing of grains after crop harvesting are necessary steps to prevent contamination. Drying should be done under good conditions, sufficient light, cleanliness, dust protection (because dust can increase the spread of fungal spores), insect- and rodentfree (Rahayu, 2009).

A delay in drying after harvest can lead to A. flavus growth. Food industries are only willing to buy wet peanut which has been stored for less than 24 hours after harvesting because this storage process or period will produce crunchy peanut with a rancid flavor due to oil oxidation. AF contamination can occur if the crop is not dried within 48 hours after harvest (Cardona et al. 1989). In Indonesia, traditional drying is held with smoke or fogging at rainy season. Drying should reduce the moisture content of grain by $35-40 \%$ after harvest (depending on the age of maturity) which is a safer moisture content. Grain with moisture content about $15-20 \%$ is very conducive for $A$. flavus AF production, and on moisture content of 5-8\%, grains were contaminated with AF after being stored for three months (Cardona et al. 1989; Ginting and Beti 1996). Therefore, drying must be performed until the moisture content is less than 5\%. Although this can be done, temperature and relative air humidity in Indonesia is the limiting factor and usually a balanced grain moisture content in the range of $7-9 \%$ is achieved. This suggests that storage is a critical stage in preventing infection of A. flavus as grains should be kept at very low levels of absolute water content, but this requires sophisticated storage facilities with relatively expensive costs. Practical solutions that can be considered are to shorten the time of distribution from farmers to consumers in Indonesia which usually takes 40-110 days (Machmud, 1989; Kasno 2004). 
Furthermore, storage at the farm, collectors, retailers or merchants is critical. The lack of storage facilities, and improper packaging of the product can cause an increase in mycotoxin contamination. The accumulation of moisture, heat and physical damage to plant materials can trigger the growth of fungi which then produce mycotoxins. To prevent fungal growth maize, it must be ensured that the stored grains remain dry (water content $<12 \%)$. Moreover, rodents and insects should not be present around the storage area. The hygiene procedures inside packing houses and the use of pesticides can minimize fungal contamination. The temperature and humidity must be measured regularly throughout the storage period. An increase in temperature of $2^{\circ}-3^{\circ} \mathrm{C}$ may indicate the presence of mold or insect infestation. Packaging containers which have pores are recommended for air circulation, and the packages should be stored on pedestal boards (Rahayu, 2009).

Besides temperature regulation, air circulation and proper moisture inside store rooms, chemicals or natural materials can also be applied for mycotoxin control of agricultural products during storage. The use of chemicals is primarily designed to protect animal feed (Muller and Thaler, 1981), but not for foodstuffs intended for human consumption. The use of natural preservatives to inhibit fungal growth are preferred to protect foods. Gowda et.al. (2004) used spices to inhibit AF biosynthesis by A. parasiticus. The study showed that clove oil was the best compound to inhibit the growth of $A$. parasiticus and AF production was inhibited by by $100 \%$, followed by turmeric, garlic, onion oil each with respective concentrations of $0.5-1.0 \%$ provided $77-85 \%, 73-77 \%$, and $80-84 \%$ inhibition respectively. Juglaletal (2002) also mentions that clove oil provided the highest inhibition activity against the growth of $A$. parasiticus and $F$. moniliforme, followed by cinnamon, oregano, and nutmeg flower oil. Ethanolic extract from China onion (Welsh Onion) could prevent the growth of A. parasiticus at $10 \mathrm{mg} / \mathrm{mL}$ (Chen, 1999). Essential oil extracted from thyme species show MIC (minimum inhibitory concentration) on solubility level to $1 / 8$ and MFC (minimum fungicidal concentration) at the rate of $1 / 4$ (Rasooli and Abyaneh, 2004).

To the present, there are few studies in Indonesia that use natural substances and biocontrol agents to prevent fungal contamination during storage. In 1984, the use of spices was evaluated for mycotoxin control. Clove was the most effective compound against mold growth inhibition of A. flavus. At a concentration of $0.4 \%(\mathrm{w} / \mathrm{v})$ of cloves, mold growth was inhibited by extending the adaptation phase another three days contact time. With the use of powdered nutmeg, AF produced ranged between $0-10.8 \mu \mathrm{g} / \mathrm{kg}$, which is lower than in controls. The addition of garlic powder in medium could reduce AF levels $0-6.7 \mu \mathrm{g} / \mathrm{kg}$. The contact with cinnamon for seven days reduced AF to $0-5.4 \mu \mathrm{g} / \mathrm{kg}$, while ginger reduced AF production to $0-3.3 \mu \mathrm{g} / \mathrm{kg}$. Turmeric and cloves delayed AF production until seven days of contact time.

In 2015, Hidayah used chitosan to prevent mycotoxin contamination during storage. Chitosan is a cationic polymer, non-toxic and biodegradable, that has potential as an antifungal agent. Chitosan has been used during the storage of peanuts to inhibit growth 
of A. flavus. The lowest content of AF B1 was obtained with $1 \%$ chitosan soaking treatment on day 30. In addition, Lisangan (2014) also examined the use of extracted kebar leaves. Kebar grass, leaves-extract were extracted using the solvents hexane, ethyl acetate, methanol, and distilled water. The results showed that the hexane-ethyl acetate-methanol (HEM) extracts of kebar grass leaf which were added at a concentration of $20 \mathrm{mg} / \mathrm{mL}$ in a rich media with carbohydrates, fat and protein caused growth inhibition of A. flavus of $96.2,100$, and $96.1 \%$ respectively. AF B1 reduction in media with a concentration of corn $100 \%$ ranging from $7.0-91.3 \%$, while in the media with a concentration of peanut $100 \%$ were at 19.3-59.4\%. Further Anggriawan et al. (2014) reported the use of brown seaweed to inhibit the growth of A. flavus. The nonpolar extract produced by nonpolar extraction (solvent-solvent extraction) showed the highest inhibition. In contrast, sulfate polysaccharide produced using a water boiling extraction method promoted the fungal growth. The most effective brown seaweed species for A. flavus inhibition were Turbinaria decurrens and T. conoides.

Biocontrol methods use microorganism to compete with toxigenic fungi. Rahayu (2014) reported the use of yeast to inhibit contamination combined with temperature control and storage humidity. At $40{ }^{\circ} \mathrm{C}$ with a relative humidity of 70,80 and $90 \% \mathrm{~F}$. verticillioides BIO 957 was unable to grow, thus the production of FUM B1 can be avoided. F. verticillioides BIO 957 growth can be inhibited by $S$. cerevisiae ATCC 9376 by 44,44 and $38 \%$ on CDA, corn, and soybeans media respectively. The following year, Pratiwi used the same yeast to reduce A. flavus contamination. The growth of A. flavus BIO 2237 and BCC F0213 were also controlled by S. cerevisiae ATCC 9376. The reduction of growth of A. flavus BIO 2237 by $S$. cerevisiae ATCC 9376 on PDA, corn, and soybean were 46, 47, and $45 \%$ respectively, while for A. flavus BCC F0213 it was 52, 52 and 38\% respectively. The ability of $S$. cerevisiae to act as an antimicrobial agent is due to the secretion of a proteinaceous compound called killer protein (Ray, 2001). Selitrennikoff (2001) mentioned that S. cerevisiae, Hanseniaspora uvarum, Z. Bailii, Phichia rhodozyma, Kluveromyces lactis and Pichia species secrete these killer proteins. Twenty killer toxins have been successfully identified with molecular weights ranging from 10.7 to $156.5 \mathrm{kDa}$. Ray (2001) mentioned that yeast can attach strongly on mycelia and produce the enzyme glucanase to degrade part of the fungal cell wall.

The use of microbes as a competitor for A. flavus have also been reported by Edi (1988) and Fardiaz et al. (1993) using the fungus Neurospora sitophila and Rhizopus oligosporus. The use of a competitor mold inhibited the growth of A. flavus and decreased AF production by 77 and $41.1 \%$ respectively in corn media. Until now, there are some microbes that have also been described to reduce the growth of A. flavus among of them are $R$. oligosporus and Candida sp. which were isolated from tempeh. The yeast inhibits AF production by 37.21 and $99.96 \%$ respectively (Purwijatiningsih et al., 2005). Aspergillus flavus can be controlled by $S$. cerevisiae not only in synthetic media but also on the feed (Kusumaningtyas et al. 2006). Dewanti-Hariyadi et al. (2008) reduced the 
amount of AF from A. parasiticus using Mucor rouxii and Saccharomyces sp. by 99.7 and $98.1 \%$ respectively.

Lactic acid bacteria has also been studied and has been proven to inhibit the growth of mycotoxigenic fungus, this also has potential for application in grains storage. Lactobacillus plantarum sa28k reduced the growth of A. flavus (Hidayat, 2001). Lactobacillus plantarum pi28a inhibited Penicillium citrinum growth (Handy, 2001) and L. plantarum reduced the growth of Fusarium graminearum (Pramasari, 2001). Rohmawati (2001) reported the ability of L. plantarum and Leuconostoc sp. to inhibit mold growth and AF production due to the decrease in $\mathrm{pH}$ media. Suspension of L. coryneformis was better for the inhibition of A. flavus growth, while suspensions of L. plantarum isolates were useful to inhibit P. citrinum (Ismail, 2002). Magnusson and Schnurer (2001) reported protein compounds that are antimycotic with a broad spectrum produced by $L$. coryneformis subsp. coryneformis strain Si3. Ridawati (2003) found the results of ultrafiltration fractions of $L$. coryneformis to be the most effective in reducing the levels of AFs in peanuts. The fraction had $<1 \mathrm{kDa}$ molecular weight with the ability to reduce AF by $87.5 \%$.

\section{B. Detoxification Strategies}

Food that has been contaminated by mycotoxins need to be detoxificatied before consumption. Detoxification or decontamination not only reduces the toxins concentration to safe levels but can also inactivate the toxins by transformation. Fungal spores and mycelia should also be totally destroyed to avoid new toxins production. The nutritional value, taste and physical properties must be maintained during this process, and the process must be economically feasible (Park, 1993). Moreover, the process has to be simple, and its implementation can be carried out using existing technology. Detoxification can be done in three ways: physical, chemical, and biological (Smith et al., 1994).

\section{Physical Detoxification}

Detoxification can physically take place during food processing, by milling, heating, and irradiation.

a. Milling and sorting

Wet milling begins with cleansing followed by soaking grains in warm water plus $\mathrm{SO}_{2}$ for 24-36 hours. Grains are separated from the endosperm dried and separated from the oil, gluten and endosperm are dried and milled. Starch and oil are the main products of the wet milling process. The results of laboratory studies indicate that most of the AF B1 is in the water immersion (39-42\%) and fiber (30-38\%), with some in gluten (13-17\%), germ (6-10\%), and starch (1\%) (Wood et al., 1982). Wet milling does not change AF much. While the dry milling will divide AF into factions. When dry milling corn, the highest concentration of AF B1 is in the germ and the skin, and about 6-10\% of the initial contamination ends up on the major products (low-fat flour, grain maize). The same happens to the rice contaminated with $\mathrm{AF}$, most of the toxin( $>95 \%)$ will be on the skin or bran fraction after grinding (Achroder et al., 1986). 
There are several important notes to be considered during grinding and sorting for mycotoxins decontamination: (i) Peeling the skin, because the food surface can be a source of contaminants; (ii) Separation of defect grains, because they are more likely to be contaminated and can act as source of contamination; (iii) Sorting by color or appearance; (iv) Separation based on density of grains, because the defect grains have lower density; and (v) Desired component (e.g., oil or starch) have to be separated for further processing (Rahayu, 2009).

b. Heating

Heating treatment during food processing can be done by autoclaving, drying, boiling and roasting. Some studies reported that baking (roasting) is a good method to reduce AFs in certain commodities. Conway et al. (1978) reported that when maize is baked at a temperature of $145^{\circ}-165^{\circ} \mathrm{C}$ there is a reduction $40-80 \%$ of $\mathrm{AF}$ B1. Rice cooking can eliminate $40 \%$ of AF B1, with pressure cooking or cooking with excess water will more eliminate AFs by $73 \%$ and $82 \%$ respectively. These results prove the influence of water on the stability of AF during heating. This method is generally applicable to agricultural products and processed products. Heating effectiveness depends on the type of mycotoxin, heating time, temperature, and moisture content of the material. AFs, zearalenone, and tricothecene are very stable at high temperatures, but citrinin and ergot alkaloids are relatively easily degraded by heating (Mobiuddin, 2000).

Cooking methods also largely determine the degradation level of mycotoxin. Kaimura (1999) suggest frying at temperatures between $150^{\circ}-180^{\circ} \mathrm{C}$ decompose mycotoxins. Direct roasting on the fire with temperatures around $210^{\circ} \mathrm{C}$ is more helpful to degrade mycotoxins such as nivalenol which was reduced by $90 \%$ with baking for 15 minutes. AFs are stable to heat even above $100^{\circ} \mathrm{C}$ (Makfoeld, 1993). AF B1 was removed from peanut or corn oil by heating to a temperature of $250^{\circ} \mathrm{C}$. However, a combination factors between water content and heat have a role in AF degradation Heat degradation of nuts for AF degradation is more efficient when there is a high water content. With $30 \%$ water content and heating for 2.5 hours at $100^{\circ} \mathrm{C}$ could reduce $\mathrm{AF}$ up to $85 \%$ (Davis et al., 1966).

Based on the research results of Roedjito et al. (1994), washing the corn with water at $50^{\circ} \mathrm{C}$ can reduce $\mathrm{AF}$ content by $47 \%$ and soaking for 24 hours can reduce $\mathrm{AF}$ content by $75 \%$. Steaming heat treatment and boiling can reduce AFs by $35 \%$ and $63 \%$ respectively. The effect of wet heating conditions to decreased levels of AF was also reported by Novia (1994) who determined the effect of steaming $\left(95^{\circ} \mathrm{C}\right)$, boiling $\left(100^{\circ} \mathrm{C}\right)$ and the heating pressure (autoclave $121^{\circ} \mathrm{C}$ ) against $\mathrm{AF}$ content. Pressurized heating is the fastest way to reduce AF. According to Novia (1994) steaming for 125 minutes can reduce AF to $37.38 \%$, 50 minutes boiling to $68.25 \%$ and heating pressure for 25 minutes to $42.74 \%$. While, according to Fardiaz (1992) roasting at $160^{\circ} \mathrm{C}$ for 15 minutes could reduce AF B1 to about 21.9-39.2\%. For AF effective degradation, the heating temperature should be below its melting point $\left(237^{\circ}-289^{\circ} \mathrm{C}\right)$ and sufficient moisture content is required. 
c. Irradiation

The effect of irradiation on most mycotoxins is not well known and due to its highcost facility, thus this technology is difficult to apply in most food industries (Irawati, 2013). Fueel (1966) reported that gamma irradiation (2.5 M rad) did not affect AF content in peanut products. However, the treatment of peanut oil with short wave and ultraviolet light was able to reduce levels of AF.

Irradiation with sunlight or light was reported be effective in degrading AF in unpurified peanut oil. When peanut flakes with a thickness of $0.5 \mathrm{~mm}$ were exposed to sunlight for 14 hours 77-90\% of AF was degraded. While with the same treatment on the nuts $(0.5 \mathrm{~mm}$ thick) exposed for 14 hours AF was reduced by only 50\% (Samarajeewa et al., 1990). Irradiation by the sun rays can damage AF in just a few hours, but this has not been tested on an industrial scale. The mechanism of decontamination by irradiation showed that $\mathrm{AF}$ is very sensitive to oxidation reactions induced by light. One possibility is that AF is oxidized by singlet oxygen formed by the light, sensitizer, and triplet oxygen. However further research in this topic isrequired.

Ultraviolet rays and radiation can also degrade mycotoxins, including lowering the content of AF M1 in milk (Yousef and Marth, 1985). However, ultraviolet light and radiation can damage the nutrients compounds in food (Mobiuddin, 2000). Radiation and ground nuts heating in the microwave for 3 and 5 minutes can show a reduction in AF content of respectively up to 25 and $49.25 \%$ (Chinaputi, 1999).

\section{Chemical Detoxification}

Chemical AF degradation has been widely studied. Some of the chemical compounds which are able to detoxify AF includes chlorine (sodium hypochlorite, chlorine gas), hydrogen peroxide, ozone, sodium bisulfite, calcium hydroxide, acetic acid, ammonium or ammonia gas (Suttajit, 1989).

Detoxification with ammonia is efficient and can degrade AF up to $95 \%$. The effectiveness of AF degradation using ammonia is influenced by the levels of given ammonia, the moisture levels of the product, temperature, contact duration with ammonia, and the level of AF contamination (Smith et al., 1994). Detoxification with ammonium hydroxide $\left(\mathrm{NH}_{4} \mathrm{OH}\right)$ at high temperatures and pressure opens the lactone ring in the AF. At high $\mathrm{pH}$, the lactone ring in the AF molecule is hydrolyzed. The use of ammonia to detoxify AF has been applied in various countries including USA, France, Senegal, Sudan, Brazil, Mexico, and South Africa. Based on research results, ammonium treatment can be used to reduce the potential hazards of AF mainly when treated together with high temperature or pressure.

Sodium chloride also has an effect on the reduction of AF contamination of unskinned peanuts, followed by boiling with pressure for 30 minutes; the reduction of AF concentration by $80-100 \%$ with $5 \%$ sodium chloride, but only $35 \%$ reduction reached if without salt (Scott, 1984). Sodium bisulfite also reacts with AF B1, G1, M1, and aflatoxicol at different temperatures and using different concentrations, to form a water-soluble product 
(Hagler et al., 1982). Treatment of AF B1 for 24 hours with hydrochloric acid at $\mathrm{pH}$ of 2.0 can degrade AF by $19.3 \%$, while at $\mathrm{pH} 3.0$ only $6.4 \% \mathrm{AF}$ degradation was observed (Doyle et al., 1981). Tabata et al. (1994) reported the ability of some food additives on AF degradation. Food additives were grouped into acidic materials such as sodium bicarbonate, sodium carbonate, sodium hydroxide, sodium sulfite and sodium hypochlorite; food additives which are neutral as potassium metabisulfite, sodium bisulfite, sodium hydrosulfite, hydrogen peroxide, sodium chloride and ammonium ferodisulfat. The ability of these food additives in degrading AFs was observed under different temperature conditions, incubation times and concentrations. The result showed that $0.25 \%$ sodium chloride at $\mathrm{pH} 4$ after a 48 hour incubation was most effective in degrading AF.

Research conducted by Nugroho (2005), indicate that a combination of physical and chemical methods, such as the use of lime water during boiling could further increase the AF B1 reduction efficiency in the processing of contaminated corn chips. Based on the logarithmic equation, to reduce $90 \%$ of $\mathrm{AF} B 1$ contamination, $1.52 \%$ concentration of lime water is needed. Chemical detoxification can also be accomplished by the addition of acid, in this case AF B1 will be converted into AF B2a and showing a lower toxicity than the original (Suttajit, 1989). During acid fermentation ( $\mathrm{pH} \leq 4.0), \mathrm{AF}_{1}$ also can be converted into AF B2a.

\section{Biological Detoxification}

Biological detoxification is regarded as the biotransformation or degradation of the toxin by microorganisms or enzymes to produce metabolites that are either non-toxic or less toxic than the parent toxin molecule when ingested by animals (Karlovsky, 1999; Boudergue et al., 2009). Biological detoxification is seen as a better alternative way than the physical and chemical detoxification with regards to the presence of nutrients in a food product as well as the impact on human health.

The study of biological detoxification of mycotoxins is still very limited in Indonesia. A preliminary study on degradation of $\mathrm{AFB}_{1}$ by proteolytic fungi Aspergillus oryzae isolated from Koji has done by Mashuri and Sardjono (2001). Results showed the formation of several compounds that fluoresce under UV light with different Rf values. The formation of the new compound proves that $\mathrm{AF} \mathrm{B}_{1}$ was converted into other compounds. In liquid glucose medium of ammonium nitrate (GAN) the reduction levels of $A F B_{1}$ in line with the growth of the mycelia was demonstrated (Sardjono et al., 1992). Sardjono et al. (2004) proved that the extracellular enzymes produced by A. oryzae KKB4 are able to detoxify AF B1. Based on the analysis of IR spectra they demonstrated the ability of these enzymes to degrade the lactone ring, the reduction of cyclopentanone, and open the difuran ring of AF molecule.

Setyabudi (2002) also found that the degradation of AF B1 in oncom fermentation occurred enzymatically and involves the fungus Neurospora sp. Sandhi (2005) reported the ability of isolates of Rhizopus oligosporus MK-1 to reduce AF content in liquid media and the manufacture of soy tempeh. During tempeh production, reduction of $A F B_{1}$ by these 
strains reached $41.47 \%$. Visual decrease or reduction of AF B1 appeared to be related with the growth of $R$. oligosporus $\mathrm{MK}-1$. The longer the fermentation, the more bushy the growth was and the greater was the reduction of $\mathrm{AF} \mathrm{B}_{1}$. AF degradation mechanisms by $R$. oligosporus MK-1 happened enzymatically through the transformation of cyclopentanone bond forming aflatoxicol. Jensen et al. (1997) suggested that the presence of Rhizopus spp. can change $87 \%$ of $A F B_{1}$ into compounds that are non-fluorescent and further explained that the process of fermentation using $R$. oryzae and $R$. oligosporus could transform AF B1 into aflatoxicol $\mathrm{A}$, which is ten times less toxic than $\mathrm{AF} \mathrm{B}_{1}$.

\section{Challenges and Future Perspectives}

To protect consumers from the risk of mycotoxin contamination in Indonesia, the government should launch regulations on more diverse food products. So far, there is a lack of studies on fruits, jamu (Indonesian traditional medicine), drinks (coffee, tea, and chocolate), fermented foods and the animal-derived products (such as milk, sausage, meat products, etc.), all of which are products that are heavily consumed by Indonesian people. Moreover, the research so far is limited to AF, although it is extremely likely that other mycotoxins can also be found in many food commodities, for example patulin in fruits. Therefore, more surveillance and monitoring is required in more diverse foods and in a larger mycotoxin spectrum.

The government also needs to do an economic analysis of the annual cost of mycotoxin contamination regarding products spoilage, losses in livestock and plant productivity, and human health effects (mortality, morbidity, hospitalization and other variables). With the analysis, government could observe the progression of the implementation program in every year.

Although many attempts to prevent the formation of mycotoxins have been made, the contamination still occur and found in many agricultural commodities. Therefore, it is necessary to develop practical, efficient and safe decontamination methods that can be widely applied to the contaminated food products on a large scale in cluster areas which are prone to mycotoxins contamination.

The emergence of the phenomenon of "chasing zero" in which lower permissible limits of mycotoxin contamination is demanded, is a big challenge for Indonesia as a food exporter. Indonesia needs to conduct internal restructuring to create a system to prevent the contamination of mycotoxins at different levels of the food production chain with a supportive integrated system and with regular monitoring in various areas. The poor sanitary conditions for the storage of raw materials in farmer, trader and food industries show the difficulties in implementing GAP or GHP (Good Handling Practices) or GMP or HACCP (Hazard Analysis Critical Control Point) principles. The government needs to focus more on the development of food safety methods at all food production chain levels by mentoring programs and intensive education. Various stakeholders; from government, industry and consumers, should sit together in one focus group discussion establishing how to implement effectively proper pre- and post-harvest mycotoxins management strategies. 
Every stage of the pre-harvest, harvest and post-harvest has to be monitored and the implementation of GAP and GMP has to be controlled. This concept could be applied if there is a proper coordination and cooperation among farmers, governments, and food producers. The active role of food industry is important to provide appropriate incentives so that farmers will have more motivation to produce good raw materials. The government has to supervise the safety aspect of each manufactured food product through easy, quick and inexpensive mycotoxins detection methods. Methods of monitoring and mitigation of mycotoxins on storage in shops and houses should also be developed. Coordination of analytical techniques for each mycotoxin analysis laboratory owned by the government is necessary, to reduce the data deviation as well as to facilitate comparison of analysis results obtained from different places and from different researchers. Indonesia also should be prepared to deal with various updated mycotoxin research topics such as masked mycotoxin, epidemiology research relating to risk assessment based on hazard and exposure evaluation, as well as the development of multi-mycotoxins analysis methods. Government authorities involved in policy making should recognize research work as a necessity for transforming research results into practical applications.

\section{Acknowledgement}

This paper was supported financially by Indonesia Endowment Fund for Education, Ministry of Finance, The Republic of Indonesia (Ref:1064/LPDP/2013).

\section{Conflict of Interest}

The authors declare no conflict of interest.

\section{References}

Achroder, H.W., Boller, R.A. and Hein, H., 1968. Reduction in aflatoxin contamination of rice by milling procedures. Cereal chemistry, 45: 574.

Agag, B., 2004. Mycotoxins in foods and feeds: 1-AFs. Assoc. Univ. Bull. Environ. Res., 7:173-205.

Ali, N., Sardjono, Yamashita, A. and Yoshizawa, T., 1998. Natural occurrence of AF and Fusarium mycotoxins (fumonisins, deoxynivalenol, nivalenol, and zearalenone) in corn from Indonesia. Food Add. Contaminant, 15 : 337-348.

Amaike, S. and Keller N.P., 2011. Aspergillus flavus. Annu Rev. Phytopathol., 49:107-33.

Aminah, N.S. dan Supraptini, 2003. Jamur pada buah-buahan, sayuran, kaki lalat dan lingkungan di pasar tradisional dan swalayan. Jurnal Ekologi Kesehatan 2(3): 299-305.

Anggriawan, R., Insan, A.I., Praiboon, J., Karseno, Chirapart, A. and Soesanto, L., 2014. Antifungal activity of Indonesian selected brown seaweeds extract against Aspergillus flavus. Proc. $36^{\text {th }}$ Mycotoxin Workshop, Göttingen, Germany 16-18 June 2014.

Anggriawan, R., Pfohl, K. and Karlovsky P., 2017. Mycotoxin-producing Fusarium species in Inonesia traditional tempeh and starter (usar). 39 $9^{\text {th }}$ Mycotoxin Workshop, Bydgoszcz, Poland 19-21 June 2017.

Arifiana, T., 1999. Analisis aflaktosin pada bumbu kacang tanah dari dua jenis makanan. Skripsi. IPB, Bogor.

Avivi, S., 2005. Pengaruh perlakuan sortasi, natrium hipoklorit dan fungisida pada kacang tanah untuk mengeliminasi kontaminasi Aspergillus flavus. Jurnal hama dan penyakit tumbuhan tropika, 5(1): 58-65.

Bahri, S, Zahari, P., Maryam, R. and Ginting, N., 1991. Residu AF M1 pada susu sapi asal beberapa daerah di Jawa Barat. Kumpulan Makalah Kongres Persatuan Dokter Hewan Indonesia X1 Yogyakarta, Juli 1991. Yogyakarta (Indonesia): PDHI. 
Bahri, S., Ohim, S. and Maryam, R., 1994. Residu AF M1 pada air susu sapi dan hubungannya dengan keberadaan AF B1 pada pakan sapi. Dalam: Sulaeman JR, Wahyuningsh R, Bramono K, Hastiono S, Setiawan ED, penyunting. Kumpulan Makalah Lengkap Kongres Nasional Perhimpun Mikologi Kedokteran Manusia dan Hewan Indonesia I dan Teтu Ilmiah. Bogor 21-24 Juli 1994. Jakarta (Indonesia): Balai Penerbit Fakultas Kedokteran Universitas Indonesia. p. 269-275.

Bahri, S., Maryam, R. dan Widiastuti R., 2005. Cemaran AF dan bahan pakan di beberapa daerah propinsi Lampung dan Jawa Timur. JITV Vol. 10.

Benneth, J.W. and Klich, M., 2003. Mycotoxins. J. Clin. Microbiology Rev., 16:497-516.

Boudergue, C., Burel, C., Dragacci, S., Favrot, M.C., Fremy, J.M., Massimi, C., Pringent, P., Debongnie, P., Pussemier, L., Boudra, H. and Morgavi, D., 2009. Review of mycotoxin-detoxifying agents used as feed additives: mode of action, efficacy and feed/food safety. EFSA journal.

Chinaphutti, A. 1999. Decontamination of AF in food using microwave oven. In: Mycotoxin contamination: Health Risk and Prevention Project. Proc. International Symposium on Mycology, Chiba, Japan. September 9-10, 1999. pp. $272-276$.

Christensen, C.M., Mirocha, C.I. and Meronuck, R.A., 1977. Mold, mycotoxin and mycotoxicosis. Agricultural Experiment Station Report. Univ. Of Minesota.

Cole, R.J. and Dorner, J.W., 1999. Biological control of aflatoxin and cyclopiazonic acid contamination : Health Risk and Prevention Project . Proc . of International Symposium on Mycology, Chiba, Japan . September 9 - 10, 1999. pp . $70-73$.

Conway, H.F., Anderson, R. and Bagley, E.B., 1978. Detoxification of AF contaminated corn by roasting. Cereal Chemistry 55: 115.

Davis, N.D., Diener, V.L. and Eldridge, D.W., 1966. Production of AFB1 and G1 by Aspergillus flavus in a semi synthetic medium. J. Appl. Microbiol., 14(2):378-385.

Dewanti-Hariyadi, R., Raharjanti, D.S., Nurwitri, C.C. dan Kusumaningtyas E., 2008. Inhibition of Aspergillus parasiticus growth and reduction of aflatoxin by yeast isolated from ragi, an Indonesian traditional culture starter. Di dalam: Lessons Learned from Current Food Crisis. International Conference Proceeding Investing in Food Quality, Safety \& Nutrition. Jakarta, October 27-28, 2008. Hlm 211-226.

Dharmaputra, O.S., Tjitrosomo, H.S.S., Susilo, H. and Sulaswati, 1991. Aspergillus flavus and aflatoxin of peanuts collected from three markets in Bogor, West Java, Indonesia. Di dalam Naewbanij JO, editor. Proceedings of the Twelfth ASEAN Seminar on Grain Postharvest Technology, Surabaya, Indonesia, 29-31 August, 1989,110123.

Dharmaputra, O.S., Retnowati, I., Sunjaya, dan Ambarwati, S., 1993, Populasi Aspergillus Jlavus dan Kandungan AF pada Jagung di Tingkat Petani dan Pedagang di Propinsi Lampung. Risalah Kongres Nasionai XII dan Seminar limiah Perhimpunan Fitopatologi Indonesia, Yogyakarta, 6-8 September 1993. p. 560- 566.

Dharmaputra, O.S., Retnowati, I., Sunjaya, dan Ambarwati S., 1995. Aspergillus flavus population and AF content in maize collected from farmers and traders in Lampung Province, South Sumatra. Di dalam: Proceeding cf the International Conggress and Scientific Seminar, Indonesian Society for Phytopathology; Yogyakarta, Indonesia, 6-8 September 1993. hlm 560-566.

Dharmaputra, O.S., Retnowati, I., Purwadaria, H. dan Sidik, M., 1996. Surveys on postharvest handling, Aspergillus flavus infection and AF contaminant on maize collected from fanners and traders. Paper presented at the $17^{\text {th }}$ ASEAN Technical Seminar on Grain Postharvest Technology; Lumut, Perak, Malaysia, 25-27 July 1995. ACIAR Technical Report 37. hlm 38-53.

Dharmaputra, O.S., Susilo, H. and Sidik, M., 1997. Population of storage fungi and aflatoxin content of soybean meal. Proceedings of the 14th National Congress and Scientific Seminar, Indonesian Society for Phytopathology, Palembang, Indonesia, Vol. 2:241-249. (In Indonesian).

Dharmaputra, O.S., Putri, A.S.R. and Setiawati, W., 1999. Fungal infection and possibility of aflatoxin contamination in black and white pepper. Hayati 6(3): 70-73.

Dharmaputra, O.S., Retnowati, I., Ambarwati, S. dan Ismayadi, C., 1999, The occurrence of fungi and ochratoxin in stored coffee beans in Lampung. Laporan Penelitian. SEAMEO-BIOTROP. Bogor.

Dharmaputra, O.S., 1999. Review on fungi and mycotoxins in Indonesian commodities. Proc. Seventh International Working Conference on Stored-Product Protection, 14-19 October 1998. Sichuan Publ., China., 1: 199-216.

Dharmaputra, O.S., 2002. Review on AF in Indonesian food and feedstuffs and their products. Biotropia. $19: 26-46$.

Dharmaputra, O.S., Putri, A.S.R., Retnowati, I. and Saraswati, S., 2003. Penggunaan Trichoderma harzianum untuk mengendalikan Aspergillus flavus penghasil AF pada kacang tanah. J. Fitopatologi Indonesia,7(1):28-3. 
Dharmaputra, O.S., Retnowati, I. and Ambarwati, S., 2003. Toxigenic Aspergillus flavus in the soils of peanut farms in Wonogiri regency, Central Java. Australian Centre for International Agriculture Research Project PHT 97/017. Seameo Biotrop, Bogor.

Dharmaputra, O.S., 2004. Control of Storage fungi. Training Course on Prevention and Control of Mycotoxin in Food and Feedstuff. SEAMEO BIOTROP, Bogor, Indonesia, 21-26 June 2004. 17 pp.

Dharmaputra, O.S., Retnowati I., Ambarwati, S. and Maysra, E., 2005. Aspergillus flavus infection and AF contamination in peanuts at various stages of delivery chain in Cianjur regency, West Java, Indonesia. Biotropia. 24 : 1-19.

Dharmaputra, O.S., Ambarwati, S., Retnowati, I. and Windayarani, A., 2013. Physical uality, Aspergillus flavus population and aflatoxin B1 content of raw peanut kernels. JFITI, 9, pp.99-106.

Doyle, M.P., Applebaum, R.S., Brackett, R.E. and Marth, E.H., 1982. Physical, chemical and biological degradation of mycotoxins in foods and agricultural commodities. Journal of food protection, 45(10), pp.964-971.

Effendi, V.O., 2013. Identifikasi Molekuler Trichoderma spp. dan Aktivitas Antagonisnya terhadap Fusarium oxysporum f.sp. cubense. Thesis. IPB, Bogor.

Fan, J.J. and Chen J.H., 1999. Inhibition of aflatoxin-producing fungi by Welsh Onion extract. Journal of food protection. 62(4) : 414-417.

Fardiaz, S., 1996. Destruksi AF selama proses pengolahan beberapa produk pangan. Laporan Penelitian. PAU Pangan dan Gizi, Institut Pertanian Bogor, Bogor

Fardiaz, S., 1992. Mikrobiologi Pangan. PT. Grame dia Pustaka Utama, Jakarta.Gardener, B.M.S. 2005. Commercial Biocontrol Products Available in The USA for Use against Plant Pathogens. http://www.oardc.ohiostate. edu/apsbcc/productlist2005USA.htm [10 Juni 2015]

Feuell, A.J., 1966. AF in groundnuts. Problems of detoxification. Trop. Sci., 8, 61-70.

Ginting, E. dan Beti, J.A.,1996. Upaya penyediaan bahan baku bebas AF mendukung agroindustri kacang tanah, p. 388-406. Dalam N. Saleh, K.H. Hendroatmodjo, Heriyanto, A. Kasno, A.G. Manshuri, dan A. Winarto (Eds.). Risalah Seminar Nasional Prospek Pengembangan Agribisis Kacang Tanah di Indonesia. Malang, 18-19 Desember 1995. Edisi Khusus Balitkabi No. 7 tahun 1996.

Gowda, N.K.S., Malathi, V. and Suganthi R.U., 2004. Effect of some chemical and herbal compounds on growth of Aspergillus parasiticus and aflatoxin production. Animal feed science and technology $116: 281-291$.

Hagler, W. M., Jr., Hutchins, J. E. and Hamilton, P.B., 1982. Destruction of aflatoxin in corn with sodium bisulfite. Journal food protection, 45:1287-1291.

Hakim, L., 2007. Tingkat Cemaran AF B1 Pada Kacang Tanah (Arachis hypogea L.) di Kabupaten Rembang Propinsi Jawa Tengah. Skripsi. Fakultas Teknologi Pertanian UGM. Yogyakarta.

Handayani, A.N., 2001. Sifat Antimikotik Isolat Bakteri Asam Laktat yang berasal dari Kecap Ikan terhadap kapang Penicillium citrinum. Skripsi. IPB, Bogor.

Hardaningsih, S., Saleh, N. dan Neering K.E., 1992. Pengendalian kimiawi penyakit bercak daun dan karat kacang tanah di Tuban. hlm. 77-81. Dalam T. Adisarwanto, Sunardi, dan A. Winarto (Penyunting). Risalah Seminar Hasil Penelitian Kacang Tanah di Tuban 1991. Balai Penelitian Tanaman Pangan, Malang.

Haryadi, Y. and Setiastuty E., 1994. Characterisation of aflatoxin $\mathrm{B}_{1}, \mathrm{~B}_{2}, \mathrm{~d}$ and $\mathrm{G}_{2}$ in groundnuts and groundnut products. Proceeding of the 6th International Working Conference on Stored-product Protection, Canberra, Australia, Vol. 2:996-998.

Hariyadi, P., 2008. Beban Ganda: Permasalahan Keamanan Pangan di Indonesia. Pangan, Edisi No. 51/XVIII/JuliSeptember/2008.

Hariyadi, P., 2015. Keamanan Pangan: Tantangan Ganda bagi Indonesia. SNI Valuasi, volume 91 No 5.

Hidayah, N., 2015. Aplikasi Kitosan untuk Mencegah Kontaminasi AF B1 pada Kacang Tanah (Arachis hypogaea L.) saat Penyimpanan Suhu Ruang. Skripsi. IPB, Bogor.

Hidayat, A., 2001. Sifat antimikotik isolat bakteri asam laktat yang berasal dari sauerkraut terhadap kapang Aspergillus flavus. Skripsi. IPB, Bogor.

INCS, 2009. National standard of maximum mycotoxin content in food (SNI 7385:2009). (In Bahasa Indonesia). Indonesian National Council for Standarization, Jakarta.

Irawati, Z., 2013. Pengembangan teknologi nuklir untuk meningkatkan keamanan dan daya simpan bahan pangan. Jurnal Ilmiah Aplikasi Isotop dan Radiasi, 3(2).

ITPC Milan, 2015. Market Brief Peluang Usaha Produk Buah Pala (HS 090811) di Italia. Ministry of Industry, Jakarta.

Indonesian Agency for Meteorological, Climatological, and Geophysical, 2015. Weather forecast. Downloaded from http://www.bmkg.go.id on 23/08/2015. 
Ismail, 2002. Sifat Antimikotik Bakteri asam Laktat yang berasal dari Dadih dan Tempoyak terhadap Beberapa Jenis Kapang. Skripsi. IPB, Bogor.

Jager, A.V., Tedesco, M.P., Souto, P.C.M.C. and Oliveira, C.A.F., 2013. Assessment of aflatoxin intake in São Paulo, Brazil. Food Control, 33(1), pp.87-92.

Jannsen, M.M.T., Put, H.M. dan Nout, C., 1997. Natural toxins. Dalam: de Vries, J. (ed.). Food Safety and Toxicity. CRC Press, Boca Raton.

Johnson, G., 1997. Reducing aflatoxin in Peanut Using Agronomic Management and Biocontrol Strategies in Indonesia and Australia. Australian Centre for International Agricultural Research, Australia.

Juglal, S., Govinden, R. and Odhav B., 2002. Spice oils for the control of cooccuring mycotoxin -producing fungi. Journal food protection. 65(4):683-687.

Joint FAO/WHO Expert Committee on Food Additives. Meeting and World Health Organization, 2006. Safety evaluation of certain food additives (No. 56). World Health Organization.

Junita, A., 2003. Serangan cendawan pascapanen dan kontaminasi AF pada kacang tanah di tingkat petani dan pengumpul di kabupaten Wonogiri, Jawa Tengah. Skripsi. IPB, Bogor.

Karlovsky, P., 1999. Biological detoxification of fungal toxins and its use in plant breeding, feed and food production. Natural toxins, 7(1), pp.1-23.

Kasno, A., 1993. Toleransi galur-galur harapan kacang tanah terhadap penyakit daun. hlm. 141-147. Dalam Suharsono, B.S. Radjit, Y.A. Bety, A. Kasno, dan A. Winarto (Penyunting). Risalah Seminar Hasil Penelitian Tanaman Pangan Tahun 1993. Malang 17- 19 Februari 1993. Balai Penelitian Tanaman Pangan, Malang.

Kasno, A., 1994. Toleransi genotipe kacang tanah terhadap penyakit daun. Hlm. 141-147 Dalam Budhi Santoso R., Beti Y.A., Kasno A., dan Winarto A. (Eds.). Risalah Seminar Hasil Penelitian Tanaman Pangan Tahun 1993. Balittan, Malang.

Kasno, A., 2004. Pencegahan infeksi Aspergillus flavus dan kontaminasi AF pada kacang tanah. Jurnal penelitian dan pengembangan pertanian, 23(3):75-79.

Kasno, A., Trustinah, Purnomo, J. dan Moedjiono., 2002. Seleksi galur kacang tanah toleran kekeringan, tahan penyakit daun dan Aspergillus flavus. Laporan Teknik Tahun 2002 Balai Penelitian Kacang-kacangan dan Umbi-umbian, Malang

Kuiper-Goodman, T., 2004. Risk assessment and risk management of mycotoxins in food. In: Magan N, Olsen M, editors. Mycotoxins in food: detection and control. Boca Raton, Fla : CRC Press. p 1-31.

Kusumaningrum, H.D., 2008. AF contamination in production chain of maize product in Java and its relevance to the risk assessment. Seminar Nasional SELAMAT, SEAFAST centre dan IPB

Kusumaningrum, H.D., Suliantari, Toha, A.D., Putra, S.H. dan Utami, A.S., 2010. Contamination of Aspergillus flavus and $\mathrm{AF}$ at distribution chain of maize based food product and its influencing factors. Jurnal teknologi dan industri pangan, 21(2): 171-176

Kusumaningtyas, E., Widiastuti, R. and Maryam, R., 2006. Reduction of AFB1 in chicken feed by using Saccharomyces cerevisiae, Rhizopus oligosporus and their combination. Mycopathologia, 162(4): 307-311.

Leblanc, J.C., Tard, A., Volatier, J.L. and Verger, P., 2005. Estimated dietary exposure to principal food mycotoxins from The First French Total Diet Study. Food additives and contaminants.

Lilieanny, 2002. Populasi Cendawan Pascapaiien dan Kandungan AF pada Produk Kacang Tanah. Skripsi. IPB, Bogor.

Lilieanny, Dharmaputra, O.S., and Putri, A.S.R., 2005. Populasi kapang pascapanen dan kandungan AF pada produk olahan kacang tanah. J. Mikrobiologi Indonesia 17-20.

Lisangan, M.M., 2014. Ekstrak Daun Rumput Kebar (Biophytum petersianum) sebagai Antikapang Aspergillus flavus Toksigen dan AntiAF serta Aplikasinya pada Sistem Pangan. Thesis. IPB, Bogor.

Lopez-Garcia, R. and Park, D.L., 1998. Effectiveness of post-harvest procedures in management mycotoxin hazard. In : Mycotoxins in agriculture and food safety. Bhatnagar, D. and S. Sinha (eds.). New York, Marcel Dekker. Pp. 407-433.

Liu, Y. and Wu F., 2010. Global burden of aflatoxin-induced hepatocellular carcinoma: a risk assessment Environmental health perspectives, 118(6), p.818.

Machmud, M., 1989. Groundnut AF problems in Indonesia. p. 215-222. In D. McDonald and V.K. Mehan (Eds.). Aspergillus flavus AF Contamination of Groundnut. ICRISAT, India.

Mahardikarani, 2007. Peta Sebaran AF pada Produk Bumbu Pecel yang Diproduksi dan Dipasarkan di DIY. Skripsi. Universitas Gadjah Mada, Yogyakarta.

Makfoeld, D., 1993. Mikotoksin Pangan. Yogyakarta: PAU Univ. Gajah Mada.

Marth, E.H. and Doyle, M.P., 1979. Update on Molds : Degradation of AF. Food technology. 81-87. 
Maryam, R., 1994. Kontaminasi asam siklopiazonat dan AF pada jagung. Makalah dibawakan pada Kongres Nasional Perhimpunan Mikologi Kedokteran Manusia dan Hewan Indonesia I dan Temu Ilmiah. Bogor, 21-24 Juli 1994, 289-293.

Maryam, R., 2000. Laporan Penelitian TA 2000. Balai Penelitian Veteriner, Bogor.

Maryam, R. dan Zahari, P., 1994. Toksin Fusarium pada jagung yang berasal dari dataran tinggi dan dataran rendah. Makalah pada Kongres Perhimpunan Mikologi Kedokteran Manusia dan Hewan Indonesia I dan Temu Ilmiah. Bogor, 21-24 Juli 1994:289-293.

Maryam, R., Verarytha, Djuariah, S. and Sulastri, L., 2007. Produksi fumonisin oleh F. verticillioides dan F. nygamai pada medium jagung. J. Mikol. Ked. Indon., 7(1-2):3-8.

Medion, 1995. Pencemaran AF dalam pakan ayam. Info Medion, 1-4.

Mehan, V.K., 1989. Screening groundnut for resistance to seed invasion by and to aflatoxin production, p. $324-334$. In D. McDonald, and V.K. Mehan (Eds.). Aspergillus flavus Contamination of Groundnut. ICRISAT, India.

Miller, J.D., 1995. Fungi and mycotoxins in grain: Implications for stored product research. J. Stored Pro. Res., 31:116.

Mobiuddin, S.M., 2000. Handling mycotoxin in contaminated feedstuffs. Poult. Int. pp. 46-5.

Muhilal, 1986. Cemaran AF pada Hasil Olah Kacang Tanah dan Kedelai. GMSK- Penelitian Gizi dan Makanan, Bogor.

Muhilal, D., Karyadi, dan Prawiranegara, D.D., 1971. Kadar AF dalam Kacang Tanah dan Hasil Olahannya, hlm. 87-93. Didalam Hermana (Penyunting). Penelitian Gizi dan Makanan. Jilid 1. Pusat Penelitian dan Pengembangan Gizi, Bogor.

Muhilal, and Karyadi, D., 1984. AF in Nuts and Grains. The $7^{\text {th }}$ Annual Workshop on Grain post harvest Technology, Kuala Lumpur, August, 21-24 1984.

Muller, H.M. and Thaler, M., 1981. Propionic acid preservation on corn following inoculation with molds and yeast. Arch. Tierernahr. 31(11):789 - 799.

NA-DFC, 2004. Standard of maximum AF content in food (No. HK.00.05.1.4057). National Agency of Drug and Food Control, Jakarta.

NA-DFC, 2007. Direktorat Surveilan dan Penyuluhan Keamanan Pangan Foodwatch, Sistem Keamanan Pangan Terpadu, AF Vol.2. National Agency of Drug and Food Control, Jakarta.

Noer, S., 2002. Ancaman kanker hati dari makanan tercemar jamur. Kompas 11 September 2002:11.

Noor, E.S., 1997. Pedoman pengendalian gulma di lahan pasang surut. Laporan Proyek Penelitian Pengembangan Pertanian Rawa Terpadu-ISDP. Badan Penelitian dan Pengembangan Pertanian . $11 \mathrm{hlm}$.

Novia, N., 1994. Pengaruh Kondisi Pemanasan Basah terhadap Penurunan Kadar AF. Skripsi. IPB, Bogor.

Nugroho, D.A., 2005. Penurunan cemaran AF B1 pada pengolahan emping jagung. Thesis. UGM, Yogyakarta.

Nurbailis, M., 2008. Karakterisasi genetik Trichoderma spp. indigenus rizosfir pisang yang berpotensi pengendalian Fusarium oxysporum f.sp. cubense penyebab penyakit layu Fusarium pada pisang. Jurnal sains dan teknologi 11 (1): 59-63.

Nuryono, Noviandi, C.T., Bohm, J., Agus, A., Wedhastri, S., Maryuandi, Y.B. and Razzazi, E., 2004. Occurrence of fumonisins (B1, B2, B3) in maize based food and feed samples from Indonesia. Mycotoxin Res., 20(1): 2-10.

Nuryono, N., Agus, A., Wedhastri, S., Maryudani, Y.B., Sigit Setyabudi, F.M.C., Böhm, J. and Razzazi-Fazeli, E. 2009. A limited survey of AF M1 in milk from Indonesia by ELISA. Food control, 20:721-724.

Park, D.L., 1993. Controlling aflatoxin in Food and Feed. Food technology 47:92-96.

Park, J.W., Kim, E.K. and Kim, Y.B., 2004. Estimation of the daily exposure of Koreans to aflatoxin B1 through food consumption. Food additives and contaminants, 21(1), pp.70-75.

Pitt, J., 1999. Controlling aflatoxins in peanuts by competitive exclusion of toxigenic fungi in Elimination of Atlatoxin Contamination in Peanut. ACIAR Proc., $89: 21$-22.

Pitt, J.I. and Hocking, A.D., 1996. Current knowledge of fungi and mycotoxins associated with food commodities in Southeast Asia. In Highley, E., and Johnson GI. (Eds) Mycotoxin Contamination in Grains. Canberra. Australian Centre for International Agricultural Research. ACIAR Technical Reports, 37: 5-10.

Pitt, J.I. and Hocking, A.D., 1997. Fungi and food spoilage. Blackie Academic and Professional, London.

Pramasari, 2001. Sifat Antimikotik Isolat Bakteri Asam Laktat yang berasal dari pikel terhadap kapang Fusarium graminearum. Skripsi. IPB, Bogor.

Pratiwi, C., 2014. Pertumbuhan Aspergillus flavus BIO 2237 dan BCC F0213 pada Jagung dan Kedelai serta Pengendaliannya oleh Saccharomyces cerevisiae ATCC 9376. Thesis. IPB, Bogor.

Purwijatiningsih, E., Dewanti-Hariyadi, R. dan Istiana., 2005. Penghambatan pertumbuhan dan produksi AF dari A. flavus oleh kapang dan kamir ragi tempe. Biota 10(3): 146-153. 
Purwoko, H.M., Hald, B. and Wolstrup, J., 1991. Aflatoxin content and number of fungi in poultry feedstuffs from Indonesia. Letters in applied microbiology, 12: 212-215.

Rahayu, E.S., 2009. Mengantisipasi Bahaya Mikotoksin. Food Review, Bogor.

Rahayu, E.S., Raharjo, S. and Rahmianna, A.A., 2003. Cemaran AF pada produksi jagung di daerah Jawa Timur. Agritech, 23: 174.

Rahayu, R.S., 2007. Laporan Kegiatan Peningkatan Produksi dan Keamanan Pangan pada Komoditi Jagung dan Kacang Tanah. Kerjasama antara Fakultas Teknologi Pertanian UGM dan Dinas Pertanian Tanaman Pangan Provinsi Jawa Tengah.

RASSF portal, 2015. www. ec.europa.eu/food/food/rapidalert/index_en.htm.

Rahayu, D., 2014. Pertumbuhan Fusarium verticillioides BIO 957 dan Produksi fumonisin B1 pada Suhu dan Kelembaban Relatif Berbeda serta Pengendalian Pertumbuhannya oleh Saccharomyces cerevisiae ATCC 9376. Thesis. IPB, Bogor.

Ramadhani, I., Sudarwanto, M., Wibawan, I.W.T. and Usleber, E., 2004. The incidence of mycotoxin in baby food from Indonesia. Forum pascasarjana, 27(2):97-108.

Rasooli, I. and Abyaneh M.R., 2004. Inhibitory effects of Thyme oils on growth and AF production by Aspergillus parasiticus. Food Control., $15: 479-483$.

Ray, B., 2001. Fundamental Food Microbiology. 2nd ed. CRC Press, New York.

Razzazi-Fazeli, E., Noviandi, C.T., Porasuphatana, S., Agus, A. and Böhm, J., 2004. A survey of AF B1 and total AF contamination in baby food, peanut and corn products sold at retail in Indonesia analysed by ELISA and HPLC. Mycotoxin research, 20(2):51-58.

Ridawati, 2003. Penghambatan pertumbuhan A. flaws dan penurunan kadar AF oleh Lactococcus lactis subsp cremoris dan Lactobacillus coryneformis pada pasta kacang tanah. Thesis. IPB, Bogor.

Rodríguez-Carrasco, Y., Ruiz, M.J., Font, G. and Berrada H., 2013. Exposure estimates to Fusarium mycotoxins through cereals intake. Chemosphere, 93(10), pp.2297-2303.

Roedjito, D., Muhilal, Harlinah, S.P.W. dan Karyadi, D., 1972. AF dalam kacang tanah, minyak bungkil dan oncom. Penelitian gizi dan makanan, $2: 80-87$.

Roedjito, D., Anwar, F. dan Damayanthi, E., 1994. Studi Analisis Kandungan AF Komoditi Serealia, Kacangkacangan dan Hasil Olahan di pasar dan Rumah Tangga. [laporan penelitian]. Bogor : Fakultas Teknologi Pertanian, Institut Pertanian Bogor.

Rohmawati, A.M., 2001. Kemampuan Lactobacillus plantarum dan Leuconostoc sp. Dalam Menghambat Produksi AF dari Aspergillus flavus. Skripsi. IPB, Bogor.

Rubak, Y.T., 2011. Tingkat cemaran aflatoksin B1 pada produk olahan jagung dan kacang tanah di Kabupaten Kupang dan Timor Tengah Selatan (NTT). Media Exacta 11 no 1.

Rucher, K.S., Kiven, C.K., Velidis, G., Hill, N.S. and Sharpe, J.K., 1994. A visual method of determining maturity of shelled peanuts. Peanut Sci., 21(2): 143-146.

Rukmi, I., 2009. Keanekaragaman Aspergillus pada berbagai simplisia jamu tradisional. Jurnal Sains \& Matematika, $17(2): 82-89$.

Salim, A.B., Zohair, A., Hegazy, A.E. and Said, A., 2011. Effect of some strains of probiotic bacteria against toxicity induced by AFs in vivo. Journal of American Science, 7(1):772-783.

Samarajeewa, U., Sen A.C., Cohen, M.D. and Wei, C.I., 1990. Detoxification of AF in food and feed by physical and chemical method. Journal of food protection, 35: 489-501.

Sanders, T.H., Cole, R.J., Blankenship, P.D. and Hill, R.A., 1985. Relation of environment stress duration to Aspergillus flavus invasion and AF production in preharvest peanuts. Peanut Sci., 12(2): 90.

Sandhi, P.A., 2005. Kemampuan Rhizopus oligosporus MK-1 Menurunkan AFB1. Thesis. UGM, Yogyakarta.

Schmaile, D.G. and Munkvold G.P., 2009. Mycotoxin in crops: a threat to human and domestic animal health. The Plant Health Instructor DOI: 10.1094. PHI-I-2009-0715-01.

Sardjono, Rahayu, K. and Sudarmadji, S., 1992. Growth and aflatoxin production by Aspergillus flavus in mixed culture with Aspergillus oryzae. Asean food journal, 7: 30-33.

Sardjono, S., Raharjo, Rahayu, E.S. and Rahayu, K., 2004. The role of extracelluler enzymes produced by Aspergillus oryzae KKB4 in biodegradation of AF B1. Indonesian food and nutrition progress 11: 30-34.

Scott, P.M., 1984. Effect of food processing on mycotoxins. Journal of Food Protection, 47: 489-499.

Sellitrennikoff, C.P., 2001. Antifungal proteins. Appl. Environ. Microbiology 67(7) : 2883-2894.

Setyabudi, F.M.C.S., 2002. Kemampuan Neurospora sp. oncom untuk menurunkan cemaran AF B1 pada media cair sintetik dan proses fermentasi oncom. Thesis. UGM, Yogyakarta. 
Setyabudi, F.M.C.S., Nuryono, N., Wedhastri, S., Mayer, H.K. and Razzazi-Fazeli, E., 2012. Limited survey of deoxynivalenol occurrence in maize kernels and maize-products collected from Indonesian retail market. Food control, 24(1):123-127.

Shephard, G.S., 2008. Risk assessment of aflatoxins in food in Africa. Food additives and contaminants, 25(10), pp.1246-1256.

Smith, J.E., Lewis, C.W., Anderson, J.G. and Solomon G.L., 1994. Mycotoxin in human nutrition and health. Directorate-General XII. Science research and development.

Sudaryono, 2001. Pemberdayaan Alfisol dengan ZK plus untuk meningkatkan hasil kacang tanah. Buletin Palawija, $1: 50-58$.

Sudantha, I.M., Kesratarta, I. dan Sudana, 2011. Uji antagonisme beberapa jenis jamur saprofit terhadap Fusarium oxysporum f. sp. cubense penyebab penyakit layu pada tanaman pisang serta potensinya sebagai agens pengurai serasah. Jurnal agroteksos., 21 (2): 2-3.

Sudjadi, S., Machmud, M., Damardjati, D.S., Hidayat, A., Widowati S. and Widiati, A., 1999. AF research in Indonesia. Elimination of AF Contamination in Peanut. Australian Centre for International Agricultural Research. Canberra, pp.23-25.

Sumantri, I., Murti, T.W., van der Poel, A.F.B, Boehm, J. and Agus A., 2012. Carry-over of AFB1-feed into AFM1milk in dairy cows treated with natural sources of AF and bentonite. J. Indonesia Trop. Anim. Agric., 37:271277.

Suttajit, M., 1989. Prevention and control of mycotoxins. Edited by Semple, R.I., Frio, A.S., Hicks, P. A, and Lozare, J.V., 1989. Mycotoxin prevention and control in foodgrain (I). A Colaborative Publication of the UNDP/FAO, Regional Network Inter-Country Coorperation on Preharvest Tecnology and Quality Control of Foodgrain (REGNET) and the ASEAN grain postharvest programme.

Tabata, S., Kamimura, H., Ibe, A., Hashimoto, H. and. Tamura, Y., 1994. Degradation of aflatoxins by food additives. Journal of Food Protection, 57:43-47.

Tandiabang, J., 2010. Pengendalian AF untuk perbaikan kualitas biji jagung. Prosiding seminar ilmiah dan pertemuan tahunan PEJ dan PFJ komisariat daerah Sulawesi selatan, hal: 176-182.

Taufik, A., 2000. Status hara makro dan mikro tanah Alfisol di sentra produksi kacang tanah. Penelitian pertanian 19:81-90.

Thomas, P.R., 1984. Mempelajari pengaruh rempah-rempah terhadap pertumbuhan kapang Aspergillus flavus. Skripsi. IPB, Bogor

Trustinah, 1987. Perkembangan polong kacang tanah (Arachis hypogaea L.) pada berbagai umur panen. Penelitian palawija, 2: 56-60.

Trustinah, dan Kasno A., 1992. Indeks masak galur kacang tanah F6. Penelitian palawija, 7(1): 70-78.

Widiastuti R., Maryam, R., Blaney, B.J. and Salfma and Stoltz, D.R., 1988. Cyclopiazonic acid in combination with aflatoxin, zearalenone and ochratoxin A in Indonesia corn. Mycopath., 104:135-156.

Widiastuti, R., Maryam R. dan Bahri, S., 2006. AF M1 pada susu sapi segar Pangalengan dan Bogor, Jawa Barat. Dalam: Mathius IW, Sendow I, Nurhayati, Suparyanto A, Prasetyo LH, Wina E, penyunitng. Cakrawala baru IPTEK menunjang revitalisasi peternakan. Prosiding Seminar Nasional Teknologi Peternakan dan Veteriner. Bogor, 5-6 September 2006. Bogor (Indonesia): Puslitbangnak. p. 239-243.

Widyaswari, D.R., 2015. Pengaruh Penyimpanan dan Pengolahan Terhadap Kandungan AF Jagung dan Produk Olahannya di Provinsi DI Yogyakarta. Skripsi. IPB, Bogor.

Wood, G.M., 1982. Effects of processing on mycotoxin in maize. Chem. Ind., 972-974.

$\mathrm{Wu}, \mathrm{F} ., 2$ 2006. Mycotoxin reduction in Bt corn: potential economic, health, and regulatory impacts. Transgenic research, 15(3), pp.277-289.

Yamashita, A., Yoshizawa, T., Aiura, Y., Sanchez, P.C., Dizon, E.I., Arim, R.H. and Sardjono, 1995. Fusarium mycotoxins (fumonisins, nivalenol, and zearalenone) and aflatoxins in corn from Southeast Asia. Bioscience, biotechnology, and biochemistry, 59(9), pp.1804-1807.

Yani, A., 2008. Infeksi cendawan pada biji kopi selama proses pengolahan primer (studi kasus di propinsi Bengkulu). Jurnal akta agrosia, 11(1):87-95.

Yousef, A.E. and Marth E.H., 1985. Degradation of AFM1 in milk by ultraviolet energy. Journal food protect., 48:697-698.

Yusrini, H., 2010. Teknik pengujian kadar AF B1 pada jagung menggunakan kit ELISA. Buletin Teknik Pertanian, 15(1):28-32.

Zanelli, L., 2000. Molds, Bacteria and Solutions. Feed Industry Service, Italia. 


\title{
Research Article 01
}

\section{Determination of Fungal Diversity in Indonesian Tempeh and Update on Their Safety Status*}

*) This research has been presented partly in $37^{\text {th }}$ Mycotoxin Workshop 2015, Bratislava, Slovakia.

\author{
Riyan Anggriawan', Ratna S. Dewi ${ }^{2}$, Maryeni Auliyati' ${ }^{1}$, Antje Borzekowski ${ }^{3}$, Ronald Maul ${ }^{4}$ \\ and Petr Karlovsky ${ }^{1}$ \\ ${ }^{1}$ Molecular Phytopathology and Mycotoxin Research, University of Goettingen, Göttingen, Germany \\ ${ }^{2}$ Graduate School of Natural Science (Biology), Gadjah Mada University, Yogyakarta, Indonesia \\ ${ }^{3}$ Department of Analytical Chemistry, Reference Materials, BAM Federal Institute for Materials Research and \\ Testing, Berlin, Germany \\ ${ }^{4}$ Nationalen Referenzlabor für Mykotoxine am Bundesinstitut für Risikobewertung (BfR), Berlin, Germany
}

\begin{abstract}
Tempeh is a popular food in Indonesia that is prepared by fermenting soybean. Fungi play an important role in the making of tempeh. In this study, fungi were isolated from tempeh and subjected to diversity analysis using DNA fingerprinting and identified with sequencing analysis. A total of 557 pure fungi isolates were obtained from 247 samples fresh tempeh and inocula in 16 different provinces in Indonesia. Diverse fungal species found in Indonesian tempeh and inocula. RAPD typing was capable of producing discriminating DNA fingerprints of Rhizopus isolates and indicated there was genetic differences among them. Many distinct patterns were observed indicating that tempeh and inocula from different location in Indonesia composed of a quite wide number of strains. Combination of origin or geographical data and molecular identification showed that isolates (identified as Rhizopus oryzae, R. delemar, and $R$. stolonifer) dominantly used by tempeh producer from outside Java, whereas isolates (Rhizopus microsporus complex isolates, identified as $R$. microsporus var. chinensis, $R$. microsporus var. microsporus and $R$. microsporus var. oligosporus) were mostly used by tempeh producer from Java. Tempeh fungi isolates are safe for human consumption since they are not mucormycosis or toxication agent, but food safety supervision has to be given to some tempeh producer that applied unhygienic practice in tempeh production because we found few sample contaminated with bacteria classified as a human pathogen causing gastroenteritis. Fungal strains used in production of tempeh in Indonesia also could convert ZEN to conjugated ZEN and ZEL derivatives in vitro. More attention needs to be given to tempeh made with mix soybean-maize. If the unprocessed grains for tempeh fermentation like mix soybeansmaize are contaminated with ZEN, upon analysis ZEN content of the final tempeh product may be underestimated, because ZEN has been conjugated during fermentation.

Keywords: tempeh, Rhizopus, DNA fingerprinting, ACT sequencing, morphology, physiology, taxonomy, virulence, ZEN biotransformation
\end{abstract}

\section{Introduction}

Zygomycetes surround us in our daily life, not only as agents of human disease and a toxin producer, but also as starters in the production of oriental fermented foodstuffs (in Indonesia, China, Japan, and Korea), biocatalysts in food industry and as pioneer degraders in food spoilage (Martens et al., 2006; Voigt et al., 2013; Doggett and Wong 2014; Dolatabadi et al., 2015). They are well spread and can be encountered in several different niches from the warm and moist Southern Asia to the colder Northern Europe. Like other fungi, zygomycetes are heterotrophic and grow inside the substrate, dissolving it by excreting extracellular enzymes and taking up degraded 
substrate as nutrients by absorption. The zygomycetes are characterized by a fast growth on high sugar content substrates in the early stage of decay. Some zygomycetes are known in industry and biotechnology as biocatalysts in the production of steroids, carotenoid compounds (Hesseltine 1965; Certik and Shimizu, 1999), organic acids (citric and gluconic) and for ethanol, biodiesel and lipase production (Khare et al., 2000; Hiol et al., 2000; Ghosh and Ray, 2011), and also as biodegradable plastics decomposer (Oda et al., 2000).

Since ancient times fungi also have played a significant role, especially in Asian countries where many foods processed via fungal fermentation, mostly based on ground soybeans (Steinkraus et al., 1960; Hesseltine and Ellis, 1973). One of popular fermented food involved the fungi in its process is tempeh. There are 120 varieties and species of moulds could producing tempeh according to Shurtleff and Aoyagi (1979). The principal genus important for the manufacture of tempeh is $R$. microsporus, with microsporus varieties, oligosporus, rhizopodiformis, and chinensis (Nout and Rombouts, 1990). An additional variety tuberosus is also described (Zheng and Chen 1998). Some others are also produced by genus Mucor. However, the primary one is $R$ microspores var. oligosporus. Dwidjoseputro dan Wolf (1970) discovered mold growth on tempeh are vary in by the region. Unfortunately, not all species are completely identified, and sampling number was also insufficient.

In Indonesia, Rhizopus spp. have been known as one of most economically important mold due to their role as inoculum source for making tempeh, but their information on diversity has been confusing due to limited information, and outdated determination approach previously applied by Indonesian mycologists. As example, Rhizopus oligosporus has still commonly been regarded as inoculant name of tempeh in Indonesia until now (Prihatna and Suwanto, 2007; Dewi and Aziz, 2011), although, this name was, a long time ago, transferred as var. oligosporus within $R$. microsporus group by Schipper and Stalpers (1984). Moreover, the taxonomy and natural systematics within the Mucorales is extremely problematic due to insufficient in distinguishing morphological characters and by the high intra-specific variability of those that do exist. Their characters are also dependent upon physiological growth parameters (Schipper, 1973; Voigt and Wöstemeyer, 2001). Benny (1995) pointed out the limitations of the morphological features in the species delimitation within certain zygomycetes, suggesting the use of molecular tools for solving existing taxonomic controversies. Combination morphological, physiological and molecular features would be the best way and very useful to address the problem.

To develop a standardization of tempeh quality in Indonesia, it is important to have an accurate name and valid identification of Rhizopus species. This research deals with the role of mucoralean fungi in tempeh production as well as solid fermentation process. In this research, sample of fresh tempeh and its inoculums from various places in Indonesia are isolated, its diversity is tested using DNA fingerprinting technique and identified, using phenotypic and genotypic approaches to gain valid and accurate information about Rhizopus spp. taxonomy of fresh Indonesian tempeh and its inoculum. The re-identification of the Rhizopus producing tempeh and its inoculum is required to set tempeh quality standard, namely modern inoculum with a 
distinctive identity. The strains of the research are also expected to be part of the long-term ex-situ conservation effort of fungi.

Although tempeh is characterized as safe for consumption by FDA, recently there have been cases of intoxication in Indonesia as a result of tempeh consumption. From 1998 until 2015 a dozen of cases was reported in mass media, but complete data regarding the cause is still lacking, and the cases are probably underreported. Many speculations may arise in line the recent findings that Rhizopus strain isolated from food could be agents of toxin producer and possibly also as mucormycosis agent. According to Dolatabadi et al. (2014), the clinical associated-strain also has an identical genetic character to food and condiment associated-strain. Some species like Mucor circinelloides, Rhizopus oryzae, and Rhizopus stolonifer are able to infect both immunocompromised and immunocompetent people (Roden et al., 2005). Some strains are also capable of producing toxins that are dangerous to human health. Some Rhizopus species harbor endosymbiont bacteria of the genus Burkholderia which are able to produce several extracellular metabolites. Rhizoxin and rhizonin resulting from Burkholderia rhizoxinica are produced during soybeans fermentation by Rhizopus sp. strain CBS 111563, on sufu preparation (Rohm et al., 2010). The rhizoxin derivatives are known as powerful antimycotic agents (Scherlach et al., 2006), a compound that prevents the formation of new blood vessels (angiogenesis). None of these metabolites should be permitted to occur in foods, even at pico- or femtogram amounts, as they cause health hazards for human (Rohm et al. 2010). In this study, zygomycetes strains derived from Indonesian tempeh fermentation and starter are screened toxicologically and clinically to evaluate possible health risks for human consumption. This research is important to answer questions and to clarify about the safety status of Indonesian tempeh and inocula.

Another safety problem in tempeh production is the use of corn as a substitute for soybean. Producers involve corn substitution for 10-30 percent to reduce cost production because the price of soybean is high nowadays. This generates a healthiness issue of produced tempeh because most Indonesian corn has been contaminated by toxigenic fungi such as Alternaria spp., Aspergillus flavus, A. fumigatus, A. parasiticus, A. candidus, A. glaucus, A. tamari, A. terreus, A. niger, A. nomius, Fusarium spp., Penicillium citrinum and P. chrysogenum (Purwoko et al., 1991; Ahmad et al., 1996; Gholib et al., 2004; Ahmad et al., 2009; Kusumaningrum et al., 2010; Rahmawati et al., 2013). Rahmawati et al. (2013) also reported that toxigenic fungi are found in soaking corn, such as Fusarium spp. It is high possibly happens that those fungi produce mycotoxins during soaking process, then the toxins absorbed into the material that is used to produce tempeh. Moreover mycotoxins content in raw material itself also endangers consumer health. Fumonisin and zearalenone were found in some cereals in Indonesia especially corn (Maryam and Zahari, 1994; Yamashita et al. 1995; Ramahani 2003). Therefore safety aspect of tempeh cannot be guaranteed anymore. In this research, we also study tempeh fungi's contribution to biotransformation of zearalenone. 


\section{Materials and Methods}

\section{Part I (Fungal diversity and identification)}

\subsubsection{Sampling, isolation and purification}

Fresh tempeh and inocula were collected from many markets (traditional, semi-traditional and modern markets) and centre of tempeh producers in different areas in Indonesia (on 2013-2015). Samples were transported in sterile plastic container to nearby laboratory in each location (provinces). Samples were maintained at $10^{\circ} \mathrm{C}$ until direct plating done. Details information of sampling can be seen on Table 1 and Figure 1. Locations were coloured in the map.

Fresh tempeh size was reduced into small particle then transferred with sterile forceps onto Potato Dextrose Agar (PDA) medium and incubated for five days in incubator (Thermofisher) at $30^{\circ} \mathrm{C}$. For inocula samples, 5 gram of each sample (powder) was suspended in $10 \mathrm{~mL}$ sterilized tap water in a sterile falcon tube, homogenized with vortex (VM-300), then one mL of each solution was spread onto PDA medium, and incubated in the same condition.

Purification of isolates: A spore suspension is prepared by transferring a loopful of the fungal mass from PDA slant into $10 \mathrm{~mL}$ sterile Tween®20 (Applichem, Darmstadt, Germany) (0.05\% v/v) kept in a sterilized falcon tube followed by vigorous shaking with vortex for a few minutes in order to disperse the spores from the spore-bearing structures, continued with single spore isolation method (modification of Zhang et al., 2013). All the procedures were done in sterile condition inside clean bench. About 578 pure isolates were collected. Isolates were stored as spore suspension in $25 \%(\mathrm{v} / \mathrm{v})$ glycerol (Carl Roth, Karlsruhe, Germany) at $-60^{\circ} \mathrm{C}$. All isolates were grown in PDA at $30^{\circ} \mathrm{C}$ for a week and maintained in malt extract agar (MEA) (Oxoid). One-weekold cultures on MEA were used for morphology, culture, and metabolic examinations.

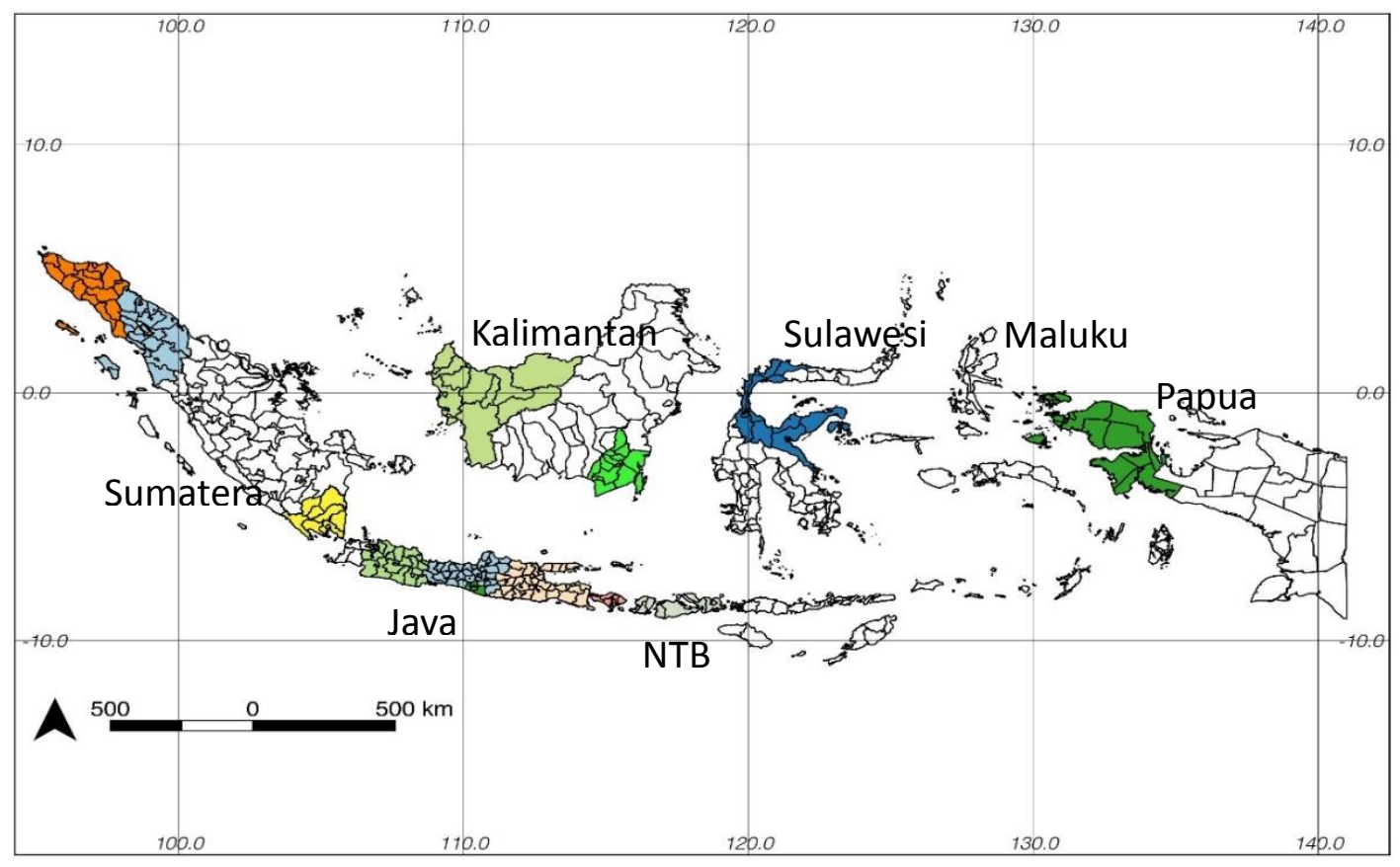

Figure 1. Sampling map (Indonesia) 
Table 1. Information of sampling locations

\begin{tabular}{|c|c|c|c|}
\hline Location & Source & Sample amount & Year \\
\hline Lhokseumawe; Aceh & Fresh tempeh, and inocula & 7 & 2015 \\
\hline Medan, North Sumatera & Fresh tempeh, and inocula & 8 & 2015 \\
\hline Jambi, Central Sumatera & Fresh tempeh, and inocula & 7 & 2015 \\
\hline Lampung Metro, Lampung & Fresh tempeh, and inocula & 9 & 2015 \\
\hline South Jakarta, DKI Jakarta & Fresh tempeh, and inocula & 7 & 2015 \\
\hline Bogor, West Java & Fresh tempeh, and inocula & 13 & 2014,2015 \\
\hline Bekasi, West Java & Fresh tempeh, and inocula & 12 & 2015 \\
\hline Sukabumi, West Java & Fresh tempeh, and inocula & 12 & 2015 \\
\hline Banuyumas, Central Java & Fresh tempeh, and inocula & 26 & $2013,2014,2015$ \\
\hline Gombong, Central Java & Fresh tempeh, and inocula & 11 & 2015 \\
\hline Magelang, Central Java & Fresh tempeh, and inocula & 11 & 2015 \\
\hline Kutoarjo, Central Java & Fresh tempeh, and inocula & 9 & 2015 \\
\hline Cilacap, Central Java & Fresh tempeh, and inocula & 9 & 2015 \\
\hline Kudus, Central Java & Fresh tempeh, and inocula & 9 & 2015 \\
\hline Yogyakarta, DIY & Fresh tempeh, and inocula & 15 & $2013,2014,2015$ \\
\hline Malang, East Java & Fresh tempeh, and inocula & 15 & 2014,2015 \\
\hline Surabaya, East Java & Fresh tempeh, and inocula & 5 & 2015 \\
\hline Jember, East Java & Fresh tempeh, and inocula & 9 & 2015 \\
\hline Denpasar, Bali & Fresh tempeh, and inocula & 5 & 2015 \\
\hline Mataram, NTB & Fresh tempeh, and inocula & 5 & 2015 \\
\hline Pontianak, West Kalimantan & Fresh tempeh, and inocula & 7 & 2015 \\
\hline Banjarmasin, South Kalimantan & Fresh tempeh, and inocula & 7 & 2015 \\
\hline Palu, Central Sulawesi & Fresh tempeh, and inocula & 11 & 2015 \\
\hline Ambon, Maluku & Fresh tempeh, and inocula & 7 & 2015 \\
\hline Manokwari, Papua & Fresh tempeh, and inocula & 9 & 2015 \\
\hline \multicolumn{2}{|c|}{ Total of sample } & 247 & \\
\hline
\end{tabular}

\subsubsection{Morphological and physiological analysis Morphological characteristics}

The key characteristics, such as sporangiophore, sporangium (conidia), sporangiospore, columellae, zygospore, rhizoid type and colony appearance were examined according to an established taxonomic system of Rhizopus was used (Schipper 1973; Schipper \& Stalpers 1984; Liou, et al.,1990; Zheng et al., 2007; Samson, 2010). Measurements of sporangiophore length and sporangio- spore size were made in 15 replications. The strains were cultured on MEA at $25^{\circ} \mathrm{C}$. Slide mounts were prepared and examined under a light microscope (Leica Leitz DMRB) equipped with a color camera (Leica DFC420). Response to temperature was determined by measuring the diameters of colonies on agar plates incubated at temperatures of $25^{\circ} \mathrm{C}, 30^{\circ} \mathrm{C}, 33^{\circ} \mathrm{C}$, and $35^{\circ} \mathrm{C}$ with vernier caliper or ruler. Sporulation was determined in cultures on $5 \%$ MEA (Oxoid) derived from inocula as mycelial parts of growing colonies, as well as from fresh spores from 3 days old cultures, 
incubated at $30{ }^{\circ} \mathrm{C}$ for 4 days. Levels of sporulation were graded in five grades varying from 0 (no spores) to 4 (fully covered plate with spores). It is defined macroscopically according to the color on the plate.

\section{Physiology test}

For selected strains, tests for enzyme activities, including gelatin liquefaction, presence of urease, siderophores,lipase (Maas et al.,2008), amylase (Caldwell et al., 2000), cellulose (Caldwell et al., 2000), laccase (Nawange et al., 2012), and tyrosinase (Mandyam et al., 2010), were performed.

\section{Determination of carbon assimilation profiles}

To obtain sufficient sporulation, all strains were cultured for 7 days on Sabouraud agar slants at $30^{\circ} \mathrm{C}$. Stock suspensions were prepared in $1 \mathrm{~mL} 0.9 \% \mathrm{NaCl}$ and were counted in a Thoma Chamber $\left(0.0025 \mathrm{~mm}^{2}\right)$. Spore suspensions were kept on ice and homogenized well before using.

A commercial identification kits were used, ID32C (bioMe'rieux, Marcy l'Etoile, France). With ID32C strips, the assimilation of 29 carbon sources are evaluated. For ID32C strips, an adequate volume of spore stock suspension was transferred to $7 \mathrm{~mL}$ of API C medium (bioMe'rieux) to achieve a final spore concentration of $5 \times 10^{5}$ spores $/ \mathrm{mL}$. The suspension was vigorously vortexed, and $135 \mu \mathrm{L}$ was distributed into each well of the strips and incubated for $72 \mathrm{~h}$ at $28^{\circ} \mathrm{C}$. After incubation, the strips were read visually and growth or lack of growth was noted. Weak growth was considered a positive result. Duplicate experiments were carried out for $50 \%$ of the tested isolates. Duplicate testing was performed on randomly chosen isolates.

\subsubsection{Molecular analysis}

Identification of zygomycetes isolates were performed according to the combination of morphological, physiology and molecular characters. Morphological and physiological observation were accomplished as described above. Then DNA fingerprinting was employed to distinguish identical and non identical isolates. Screened isolated then confirmed at species level by the results of DNA sequence of the Actin gene, which is taxonomically most informative part in this fungal genus. ACT is known as a housekeeping gene, as its expression is relatively stable under variable conditions. ACT encodes actin, a protein that is abundant in all eukaryotic cells, in which it is the major component of cytoplasmic microfilaments. The ACT gene has been used extensively to infer interspecies relationships across broad evolutionary distances, as the ACT gene of many species contains highly conserved (i.e. exon) and less well-conserved (i.e. intron) sequences, which are grouped as nuclear pre-mRNA introns (Donnelly et al., 1999).

\section{DNA extraction and gel electrophoresis}

Fungal strains used in this study are listed in Table 2. The cultures were grown on potato dextrose broth (PDB) (Roth, Karlsruhe, Germany) in Erlenmeyer flasks in darkness at $25^{\circ} \mathrm{C}$ for 5 days. Mycelium was harvested by filtration onto sterile paper disks, froze in $-70^{\circ} \mathrm{C}$, freeze-dried in a freeze drier (Christ, Beta 1-8) and stored at room temperature till extracting genomic DNA. Fifty milligrams of lyophilized mycelium were ground in $2 \mathrm{~mL}$ Eppendorf tubes with round bottom containing 4-5 wolfram carbide spheres (diameter $3 \mathrm{~mm}$, Retsch, Haan, Germany) in a reciprocal 
mill (Mixer Mill MM 200, Retsch, Haan, Germany). Genomic DNA was extracted by a CTAB method with little modification (Brandfass and Karlovsky, 2008), as described detail below.

One $\mathrm{mL}$ of the CTAB-buffer, $1 \mu \mathrm{L}$ Proteinase K (AppliChem Bio Cemica, Darmstadt) and $2 \mu \mathrm{L}$ Mercaptoethanol (SERVA Electrophoresis $\mathrm{GmbH}$ ) were added to the sample and the mixture was vortexed until everything was well mixed. The samples were incubated first for $10 \mathrm{~min}$ in a $42^{\circ} \mathrm{C}$ water bath and afterwards for another ten min in a $65^{\circ} \mathrm{C}$ water bath (GFL). The samples were mixed every three minutes during the two 10 -minutes incubation periods. $0.8 \mathrm{~mL}$ of chloroform /isoamylalcohol (24:1) was added to each sample, the samples were shaken thoroughly and incubated on ice for ten min. Then the samples were centrifuged for ten min at 10000 RPM until no cell material was left in the upper phase. About $600 \mu \mathrm{L}$ of the upper phase was transferred to a $1.5 \mathrm{~mL}$ Eppendorf tube. Precipitation was completed for all samples with PEG. About $200 \mu \mathrm{L}$ PEG 6000 (30\%) and $100 \mu \mathrm{L} 5 \mathrm{M} \mathrm{NaCl}$ (Carl Roth GmbH \& Co) was added and mixed thoroughly. In a second separate extraction, the precipitation was done with isopropanol instead of PEG.

Afterwards the samples were incubated for $20 \mathrm{~min}$ at room temperature again, and then centrifuged for $15 \mathrm{~min}$ at $14800 \mathrm{RPM}$. Supernatant was carefully poured off and $500 \mu \mathrm{L}$ Ethanol (80\%) was added without disturbing the pellet. The samples were centrifuged again for five min at 14800 RPM and the washing step was repeated twice. After the cleaning the pellets were dried for ten to fifteen min at $30^{\circ} \mathrm{C}$ in the vacuum drier (Eppendorf AG). The last step for the DNA extraction was to add $50 \mu \mathrm{L}$ of TE-buffer and shake the tube until the pellet was released from the bottom and the DNA was dissolved. Samples were then incubated at room temperature about $30 \mathrm{~min}$. The tubes were kept in a refrigerator until the next day to control the quality of the DNA extraction by gel electrophoresis. The DNA of every sample was diluted 1:20, 1:50 and 1:100. For further usage the DNA was kept in a freezer $\left(-20^{\circ} \mathrm{C}\right)$.

In order to check the efficiency of DNA extraction and the purity of extracted DNA, a $5 \mu \mathrm{L}$ DNA sample were mixed with $2 \mu \mathrm{L}$ Blue juice and loaded on a $0.8 \%(\mathrm{w} / \mathrm{v})$ agarose gel (Cambrex, Rockland, ME, USA), prepared in TAE buffer (40 mM Tris, 1mM EDTA (ethylene diamine tetra acetic acid), pH set to 8.5) (both substances were obtained from Carl Roth, Karlsruhe, Germany). The electrophoresis was carried out at $60 \mathrm{~V}$ for $60 \mathrm{~min}$. After staining with ethidium bromide $(0.5$ $\mu \mathrm{g} \mathrm{mL}^{-1}$ ) and destaining in demineralized water (each for $10 \mathrm{~min}$ ), DNA bands were visualized in UV light using a CCD camera (Vilber Lourmat, Marne La Vallee, France).

\section{DNA fingerprinting}

In the preliminary experiments, four arbitrary primers were tested with Random Amplified Polymorphic DNA (RAPD) with DNA extracted from pure cultures. List of primers can be seen on Table 2. Preliminary test determined the optimal concentration of the component in the PCR reaction mixture, amplification conditions and primer selection. Strong, unique, sharp and clearly reproducible bands were produced by primer C6.2_introns_2_R and C7_1_seq_f2. For further analysis C7_1_seq_f2 was used. 
Chapter 3: Determination of fungal diversity in Indonesian tempeh

Table 2. Primer and their sequences tested in preliminary RAPD analysis

\begin{tabular}{ll}
\hline \multicolumn{1}{c}{ Primers } & \multicolumn{1}{c}{ Sequence 5'-3' } \\
\hline C6.2_introns_2_R (C6_2_int_R3) & TGGCTCACGCAAGGGTGTAG \\
C2_1++inv_f & TGACGTCCTAGTTGATATCCTCG \\
C2_1++inv_r & ACCGTTATGATCAATAAATATTTGACCA \\
C7_1_seq_f2 & AGGTTAGCTCGCGACTATCGGATC \\
\hline
\end{tabular}

In brief, the optimal condition of PCR as described below:

The amplification reaction was carried out in a volume of $25 \mu \mathrm{L}$ containing $18.45 \mu \mathrm{L}$ water, 2.5 $\mu \mathrm{L}$ 10x reaction buffer (Bioline, Luckenwalde, Germany), $1.5 \mu \mathrm{L}$ dNTPs $150 \mu \mathrm{M}$ (Amersham Biosciences), $0.75 \mu \mathrm{L}$ of primer $0.3 \mu \mathrm{M}$ (GenXpress), $0.05 \mu \mathrm{L}$ of Taq DNA polymerase $0.25 \mathrm{U}$ (New England BioLabs, Ipswich, MA, USA) and $1 \mu \mathrm{L}$ of DNA sample. For detection of any other kinds of DNA contaminants, a negative control of PCR-mix without any template DNA was used. The PCR program had initial denaturation at $94^{\circ} \mathrm{C}$ for $2 \mathrm{~min}, 2 \times 45$ cycles of: $20 \mathrm{~s}$ at $94^{\circ} \mathrm{C}, 20 \mathrm{~s}$ at $37^{\circ} \mathrm{C}, 20 \mathrm{~s}$ at $72^{\circ} \mathrm{C}$ and followed by final extension at $72^{\circ} \mathrm{C}$ for $5 \mathrm{~min}$, storage $15^{\circ} \mathrm{C}$ for $5 \mathrm{~min}$ (peQ STAR Thermocycler). Eight microliters of the PCR products was mixed with $2 \mu \mathrm{L}$ of blue juice and pipetted into the slots. The electrophoresis is carried out at $60 \mathrm{~V}$ for $90 \mathrm{~min}$. After staining with ethidium bromide $\left(0.5 \mu \mathrm{g} \mathrm{mL}^{-1}\right)$ and destaining in demineralized water (each for $10 \mathrm{~min}$ ), DNA bands were visualized in UV light using a CCD camera (Vilber Lourmat, Marne La Vallee, France).

The RAPD banding patterns were compared and a matrix based on the presence or absence of amplification products observed. From this, Jaccard (SJ) coefficients were calculated and a dendogram was produced with UPGMA linkage (Sneath and Sokal, 1973).

\section{Polymerase chain reaction and phylogenetic analysis}

Identification at species level was confirmed by the results of DNA sequence of Actin gene, which is taxonomically most informative part in this fungal genus. Hot start PCR protocol was used to amplify the ACT gene region using the fungal specific primer set: Act-1 (5'-TGGGA CGATATGGAIAAIATCTGGCA-3') and Act-4ra (5'-TCITCGTATTCTTGCTTIGAIATCCAC AT-3') described by Voigt et al. (2000). The reaction mixture consisted of reaction buffer (16 mM (NH4)2SO; $67 \mathrm{mM}$ Tris-HCl; $0.01 \%$ (v/v) Tween-20, pH: 8.8 at $25^{\circ} \mathrm{C}$ ), $0.1 \mathrm{mM}$ concentration of each of the four deoxynucleoside triphosphates (Bioline, Lükenwalde, Germany), $2 \mathrm{mM}$ of $\mathrm{MgCl}_{4}$ (Bioline), 1.75 U of hot-start DNA polymerase (New England BioLabs, Ipswich, MA, USA) and), $0.3 \mu \mathrm{M}$ concentration of each primer (Invitrogen by Thermo Fisher Scientific). Every reaction contained $1 \mu \mathrm{L}$ template DNA or $1 \mu \mathrm{L}$ sterile water as negative control. The PCR reactions were performed in a total volume of $25 \mu \mathrm{L}$ reactions with a peQ STAR Thermocycler (96 Universal Gradient). The cycling conditions were as follows: 1 cycle of $10 \mathrm{~min}$ at $95^{\circ} \mathrm{C}, 30$ cycles of $60 \mathrm{~s}$ at $94^{\circ} \mathrm{C}$ (denaturalization), $45 \mathrm{~s}$ at $58.5^{\circ} \mathrm{C}$ (annealing), $60 \mathrm{~s}$ at $72^{\circ} \mathrm{C}$ (extension) and followed by a final extension cycle at $72^{\circ} \mathrm{C}$ for $5 \mathrm{~min}$.

Lambda DNA was digested with the restriction enzyme PstI and used as a size standard. For agarose gel electrophoresis of the PCR products, $2 \mu \mathrm{L}$ blue juice were mixed with $2 \mu \mathrm{L}$ digested lambda DNA $(25 \mathrm{ng} / \mathrm{mL})$. The checking of the PCR product was performed on agarose gel 
electrophoresis as described above. The PCR products were purified using isopropanol precipitation and $5 \mu \mathrm{L}$ of the PCR product were sent to LCG Genomics GmbH (Ostendstr. 25. TGS Haus 8, 12459 Berlin, Germany) for sequencing. Similarity searches in the sequences of the sequenced regions were done using BLAST in NCBI database (http://blast.ncbi.nlm.nih.gov/ Blast.cgi). Alignments and phylogenic analysis of the above mentioned sequences were performed and phylogenetic trees were constructed using the software MEGA 7 (Kumar et al., 2016).

\section{Part II (Safety status of tempeh fungi strains)}

\subsubsection{Virulence test}

\section{Ethic statement}

All experiments were performed in compliance with European and German animal protection laws. No ethic statement is necessary for insect models.

\section{Virulence test}

Method of virulence test followed Fallon et al. (2012) and Kaerger et al. (2015) with small modification. Galleria mellonella (wax moth) were acquired in the larval stage. G. mellonella received were a mixture of larvae with and without grey color markings on the cuticle. $G$. mellonella larva used for experiments were selected to be similar in size (approx. 275-330 mg) and absent of any grey markings. We have found that we achieve the best results by using only larva that were light-colored; therefore we select larva without grey markings to be used for experiments. The selected larva were inoculated with the pathogen of interest.

Our preferred delivery route for microbial pathogens is delivery of a known quantity of pathogen directly to the hemocoel. With this delivery method, G. mellonella larva were infected by injecting (Myjector syringe, Terumo Europe) the inoculum into the hemocoel.

Larva of G. mellonella were stored in the dark at $18^{\circ} \mathrm{C}$ prior to use (Schütt Lichtthermostat). Ten of healthy larvae were placed on Whatman filter paper in sterile 9-cm petri dishes. Enterobacter cloacae was grown to stationary phase $\left(1-2 \times 10^{9} / \mathrm{mL}\right)$ in nutrient broth (Merck, Darmstadt, Germany) at $30^{\circ} \mathrm{C}$, with shaking at 200 RPM (Innova44, New Brunswick Scientific Co). Bacterial cells were harvested by centrifugation (Rotixa 120R centrifuge, Andreas Hettich Co), washed in phosphate buffered saline (PBS) (Carl Roth Co) and re-suspend in PBS with cell density at $1 \times 10^{6}$ per $20 \mu \mathrm{L}$. Zygomycetes strains were grown in PDA (Merck, Darmstadt, Germany) for 5 days, spores were harvested by centrifugation, washed with PBS and re-suspend in PBS with $1 \times 10^{6}$ spores per $20 \mu \mathrm{L}$. Larva were inoculated by injecting $20 \mu \mathrm{L}$ through the last left proleg into the haemocoel using a Myjector syringe and place at $30^{\circ} \mathrm{C}$ in the dark for up to $96 \mathrm{~h}$. Untouched larva and larva were injected with $20 \mu \mathrm{L}$ of water or PBS should be included as controls. Assessing larva at regular intervals (every $24 \mathrm{~h}$ for 4 days) for viability and disease progression. For assessment of viability, larvae should be gently probed with a needle, and if no response is observed, the larvae may be considered to be dead. Changes in cuticle melanisation can also be used to monitor the severity of an infection. Significance of mortality rates was evaluated by using Kaplan-Meier survival curves with the PRISM statistics software (Mantel-Cox log rank test) using pooled data. All experiments were performed three times, each time with duplicates. 


\subsubsection{Detection of bacteria producing rhizonin}

Fungal mycelia were transferred to LB (Luria broth; Oxoid) bottles and were incubated at $30^{\circ} \mathrm{C}$ for $4 \mathrm{~d}$ under 200 RPM rotation. Using mechanical stress (pipetting) and physical stress (freezingthawing), fungal mycelia were broken and submitted to centrifugation (30 min, $3000 \mathrm{RPM}, 10^{\circ} \mathrm{C}$ ). Five hundred $\mu \mathrm{l}$ of supernatant was added on $25 \mathrm{~mL}$ sterilized nutrient broth and incubated at $30^{\circ} \mathrm{C}$ for $3 \mathrm{~d}$ with shaking mode. After 3 days, sample then checked with plating in NA medium and checked with light microscopy. Only sample had bacterial colonies were then extracted its DNA (Ausubel et al., 1986) and followed with amplification partial sequence 16S rRNA genes using the bacterial universal primers 27F (5'-AGAGTTTGATCMTGGCTCAG) (Lane, 1991) and bacterial primer 1100R (5'-AGGGTTGCGCTCGTTG) (Turner et al., 1999). with cycling conditions of $94^{\circ} \mathrm{C} 30 \mathrm{sec}, 10 \times\left(94^{\circ} \mathrm{C} 30 \mathrm{sec} ; 62^{\circ} \mathrm{C}-53^{\circ} \mathrm{C}-1^{\circ} \mathrm{C} /\right.$ cycle $\left.40 \mathrm{~min} ; 72^{\circ} \mathrm{C} 1 \mathrm{~min}\right)$, close loop $30 \times(30 \mathrm{x}$ $94^{\circ} \mathrm{C} 30 \mathrm{sec} ; 56^{\circ} \mathrm{C} 40 \mathrm{~min} ; 72^{\circ} \mathrm{C} 1 \mathrm{~min}$ ), close loop $72^{\circ} \mathrm{C} 5 \mathrm{~min}$. The DNA was diluted $1 / 100$ and 1/1000. PCR was carried out with a total volume of $25 \mu \mathrm{L}$ composed of $18.45 \mu \mathrm{L}$ water, $2.5 \mu \mathrm{L}$ 10x reaction buffer (New England BioLabs, Ipswich, MA, USA), $1.5 \mu \mathrm{L}$ dNTPs $150 \mu \mathrm{M}$ (Bioline, Luckenwalde, Germany), $0.75 \mu \mathrm{L}$ of each primer $0.3 \mu \mathrm{M}$ (Invitrogen by Thermo Fisher Scientific), $0.05 \mu \mathrm{L}$ of Taq DNA polymerase $0.25 \mathrm{U}$ (New England BioLabs, Ipswich, MA, USA and $1 \mu \mathrm{L}$ of DNA sample. A control PCR without DNA was set up to check for nonspecific amplification. The expected PCR products' size was $1000 \mathrm{bp}$.

A marker of 1000 bp (Forever 100 bp Ladder Personalizer, Seegene) was used as a size standard. $2 \mu \mathrm{L}$ blue juice were mixed with $2 \mu \mathrm{L}$ marker $(25 \mathrm{ng} / \mathrm{mL})$. The PCR product was checked on a gel, prepwered for sequencing and sequenced as described above. Similarity searches in the sequences of the sequenced 16S rRNA gene, alignments and phylogenic analysis were performed as described before.

\section{Part III (Zearalenone biotransformation by tempeh fungi)}

\subsubsection{Microorganism and in vitro test (in liquid culture)}

Seventy strains of tempeh fungi used for in vitro test could be seen on Suplemental Table 3. In brief, Stock cultures were grown in PDA (Merck, Darmstadt, Germany) for 5 days at $30^{\circ} \mathrm{C}$ (Schütt Lichtthermostat). A spore suspension was prepared by transferring a loopful of the fungal mass from PDA slant into $10 \mathrm{~mL}$ sterile Tween®20 (Applichem, Darmstadt, Germany) (0.05\% v/v) kept in a sterilized falcon tube followed by vigorous shaking with vortex for $3 \mathrm{~min}$ in order to disperse the spores from the spore-bearing structures. Spores were harvested by centrifugation (Rotixa 120R centrifuge, Andreas Hettich Co). Spores of fungi previously isolated were counted using a Thoma chamber $\left(0.1 \mathrm{~mm}\right.$ depth, $0.0025 \mathrm{~mm}^{2}$ square area) and the suspension was diluted to certain concentration with sterile tap water.

Potato Dextrose Broth (PDB) was used as media in in vitro screening. Fifty milliliters of PDB was poured into the $250 \mathrm{~mL}$ Erlenmeyer flask, the flask was closed with a cellulose plug and then autoclaved $\left(120^{\circ} \mathrm{C}, 15 \mathrm{psi}, 15 \mathrm{~min}\right.$; Autoclave $\left.3870 \mathrm{EL}\right)$. The sterile liquid media was inoculated with $2 \mathrm{~mL}$ spore solution $\left(10^{6}-10^{7}\right.$ spores $\left./ \mathrm{mL}\right)$ and then incubated at $30^{\circ} \mathrm{C}$ for 5 days in a rotary shaker (Innova44, New Brunswick Scientific Co) at 150 RPM. For the treatment, $1 \mathrm{~mL}$ working 
solution of zearalenone (Sigma-Aldrich Chemie GmbH, Steinheim, Germany) (c = $5 \mu \mathrm{g} / \mathrm{mL}$; methanolic solution) was added to the liquid culture of the fungal strains R1 - R70. Medium without culture was added with $1 \mathrm{~mL}$ working solution of zearalenone as positive control. Instead of zearalenone, $1 \mathrm{~mL}$ methanol was added to the culture as negative control. The incubation was continued in the rotary shaker for 2 days. Five hundred microliters of the liquid media was transferred into a 1.5-mL Eppendorf tube and $500 \mu \mathrm{L}$ ice-cold acetonitrile was added for protein precipitation. Samples were then stored overnight at $4{ }^{\circ} \mathrm{C}$ and centrifuged at $9800 \mathrm{RPM}$ for 5 min. The supernatant was transferred to a HPLC (high performance liquid chromatography) vial and analyzed by HPLC hyphenated to tandem mass spectrometry (HPLC-MS/MS).

\subsubsection{HPLC-MS/MS analysis}

Mycotoxin separation and analysis was carried out by high pressure liquid chromatography coupled with electrospray ionization and tandem mass spectrometry detection. HPLC-MS/MS was performed on an API 4000 mass spectrometer (AB Sciex, MA) connected to an Agilent 1100 series HPLC (Agilent Technologies GmbH, Böblingen, Germany). The analytical column was a

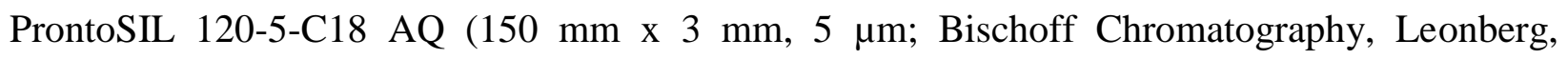
Germany), preceded by a ProntoSIL 120-5-C18 AQ guard column (10 mm x 3 mm, $5 \mu \mathrm{m})$. Mobile phase A was water with $5 \mathrm{mM}$ ammonium acetate and as mobile phase B acetonitrile/water (99: $1 \mathrm{v} / \mathrm{v}$ ) with $5 \mathrm{mM}$ ammonium acetate was used. Detailed protocol was according to Brodehl et al. (2014). 


\subsection{Results of Part I (Fungal diversity and identification)}

Identification of zygomycetes isolates were performed according to the combination of morphology, physiology and molecular characters.

\section{Distribution of mould genera from Indonesian tempeh}

As shown in Figure 2, the moulds isolated from tempeh and inocula were broadly represented by 9 genera. In total, 557 fungi and 5 fungi-like isolates were obtained from 247 samples. Rhizopus was the most frequently detected genera, found in $84 \%$ of total samples, followed by Mucor (5.5\%), Neurospora (4.1\%) and Syncephalastrum (3\%). Other very minor genera that found as contaminants were Chaetomium, Phoma, Acremonium, Aspergillus and Geotrichum (less than 1\%).

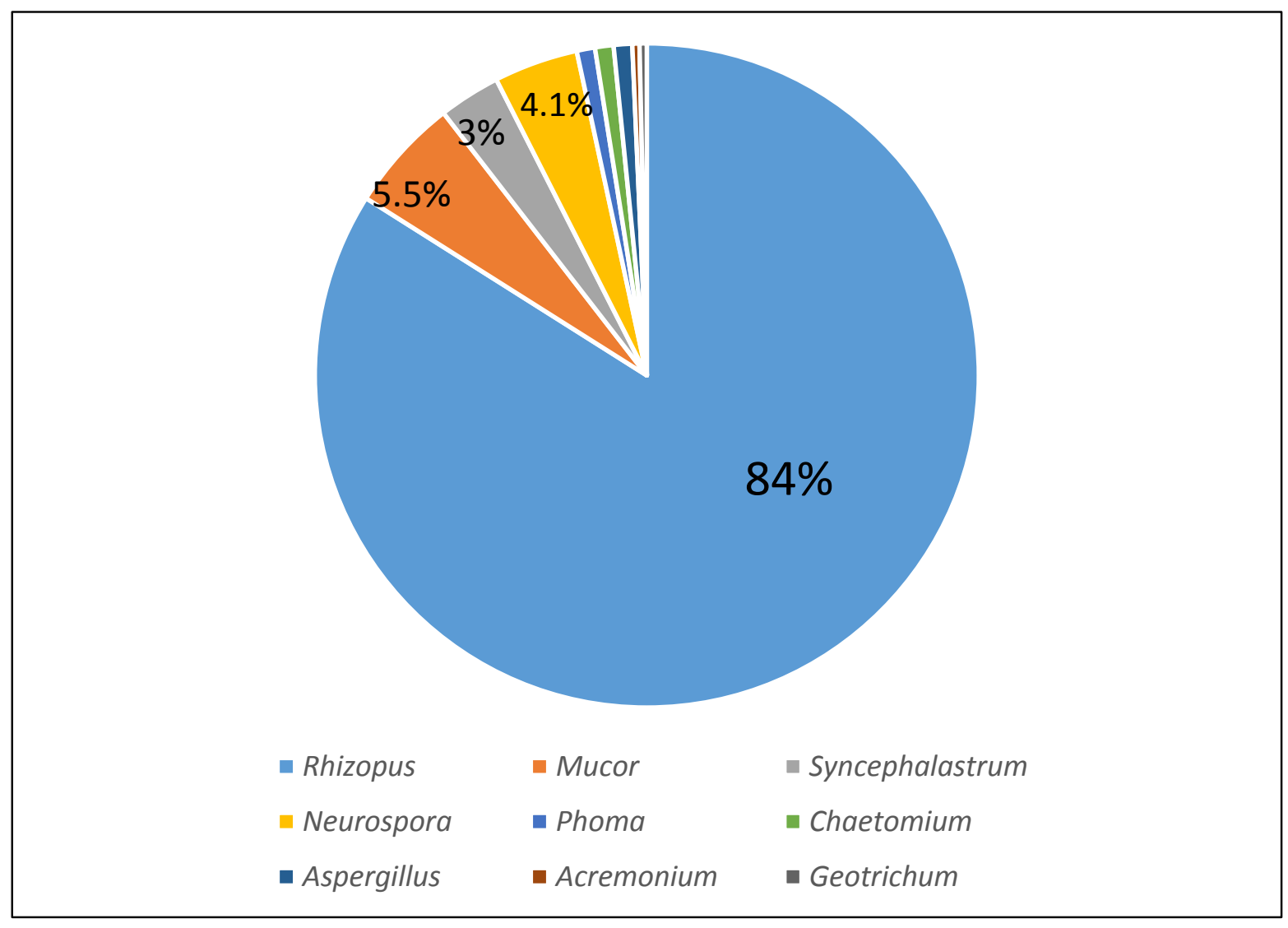

Figure 2. Distribution of mould genera isolated from Indonesian tempeh.

\section{Morphological and physiological features}

Identification of zygomycetes isolates from tempeh based on morphology and physiology characteristics supported the results from the phylogenetic analyses. The key characteristics, such as sporangiophore, sporangium, sporangiospore, columellae, zygospore, rhizoid type and colony appearance were examined according to an established taxonomic system of Rhizopus was used 
(Schipper 1973; Schipper and Stalpers 1984; Liou et al. 1990; Zheng et al., 2007; Samson, 2010). In total, 562 samples were checked via microscopy approach. Measurements of sporangiophore length and sporangio-spore size were made in 15 replications. We also observed non-zygomycetes fungi found in this study. Detail of morphological result can be seen on Table 3. Main fungal species isolated from tempeh are also described below. Detail morphological structures is shown in Figure 3.

\section{Rhizopus microsporus complex}

Sporangiophores borne singly or in groups of two to three from clusters of poorly formed rhizoids, stipes unbranched, relatively short, commonly 150-300 $\mu \mathrm{m}$ long, with brown walls; sporangia black, 50-150 $\mu \mathrm{m}$ diameter, usually spherical; columellae 25-30 $\mu \mathrm{m}$ in diameter, spherical, some remaining so in age, others collapsing downwards, to form umbrella shapes; sporangiospores ellipsoidal, 3-5 $\mu \mathrm{m}$ long, with thin, striate walls. Distinctive features from this species are: Rhizopus microsporus differs from $R$. stolonifer by shorter stipes and smaller columellae, by the absence of white immature sporangia and by strong growth at $33^{\circ} \mathrm{C}$. It is distinguished from $R$. oryzae by production of smaller columellae and smaller spores.

\section{Rhizopus oryzae}

Sporangiophores borne in clusters of one to three from rhizoids, with stipes up to $1300 \mu \mathrm{m}$ long, usually unbranched; sporangia spherical, up to $190 \mu \mathrm{m}$ in diameter, white at first then becoming greyish black at maturity; columellae usually spherical, up to $100 \mu \mathrm{m}$ in diameter, pale brown, in age often collapsing downwards to form umbrella shapes; sporangiospores brown, of variable shape, ellipsoidal to broadly fusiform or irregularly angular, commonly 5-8 $\mu \mathrm{m}$ long, with striate walls. Distinctive features. This species is distinguished from Rhizopus stolonifer by its smaller sporangia and spores and by much faster growth at $30^{\circ} \mathrm{C}$. It differs from $R$. microsporus by longer stipes, larger collumellae and larger spores. It differs from $R$. delemar because could produce lactic acid.

\section{Rhizopus delemar}

Colonies on MEA at young are white, becoming grey to blackish grey when mature, covering the plate about 3-4 days at room temperature. Stolons well-developed, subhyaline to grayish brown, septate or not septate. Rhizoids sometimes absent, or fingerelike or branched when present, unequal in length, grayish brown, paler at the tip. Sporangiophores arising from stolon and opposite rhizoids, sometimes arising directly from mycelia and without rhizoids, solitary or simple, straight to slightly curved, light brown to dark brown, aseptate, smooth to verruculose, sometimes forked or trifurcate at the apex and swollen at the middle apophyses conspicuous. Sporangia globose to subglobose yellowish to dark brown, without collar. Columellae ovoid, smooth, light brown. Sporangiospores angular, subglobose to ellipsoidal, with ridges on the 


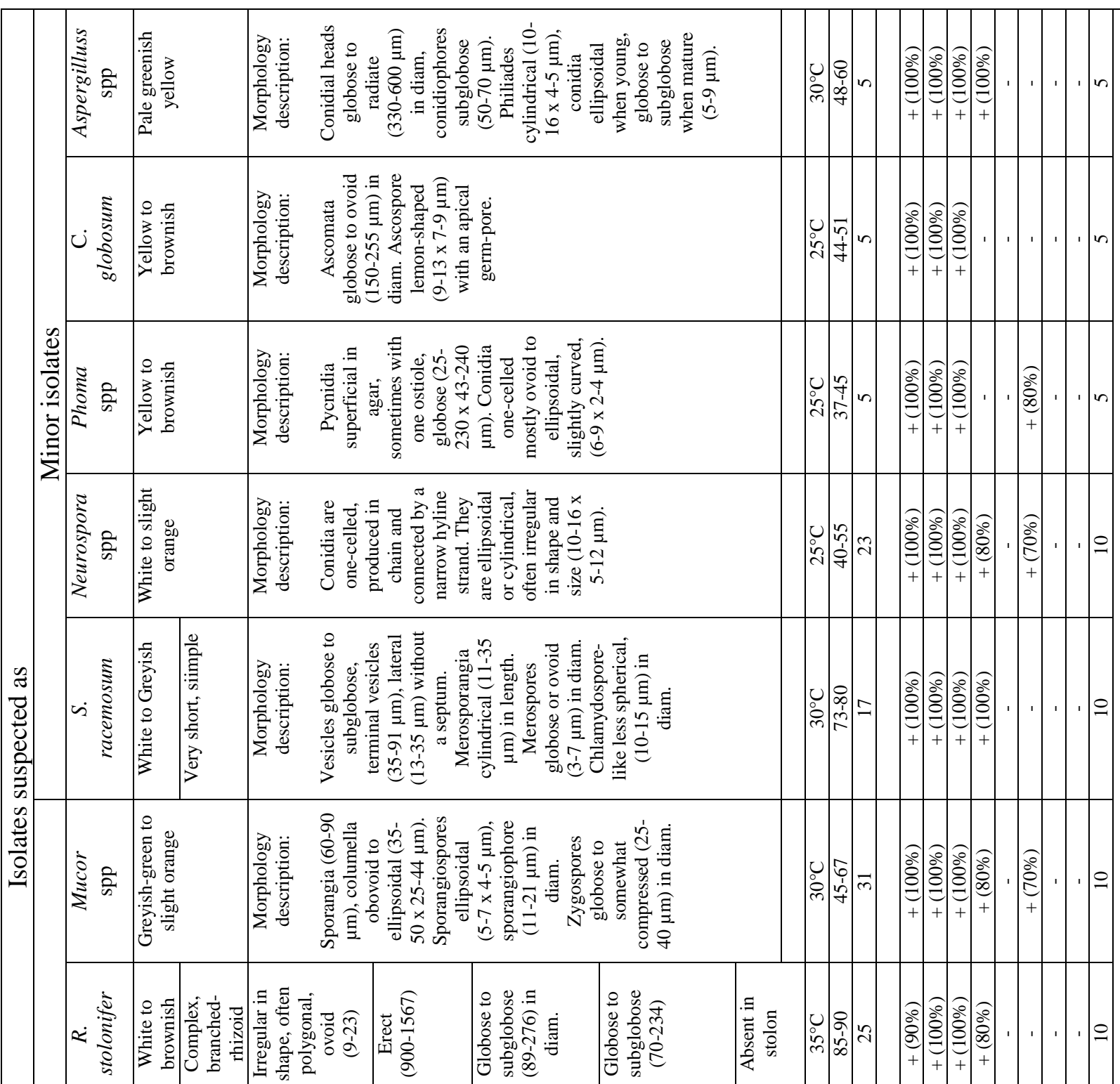

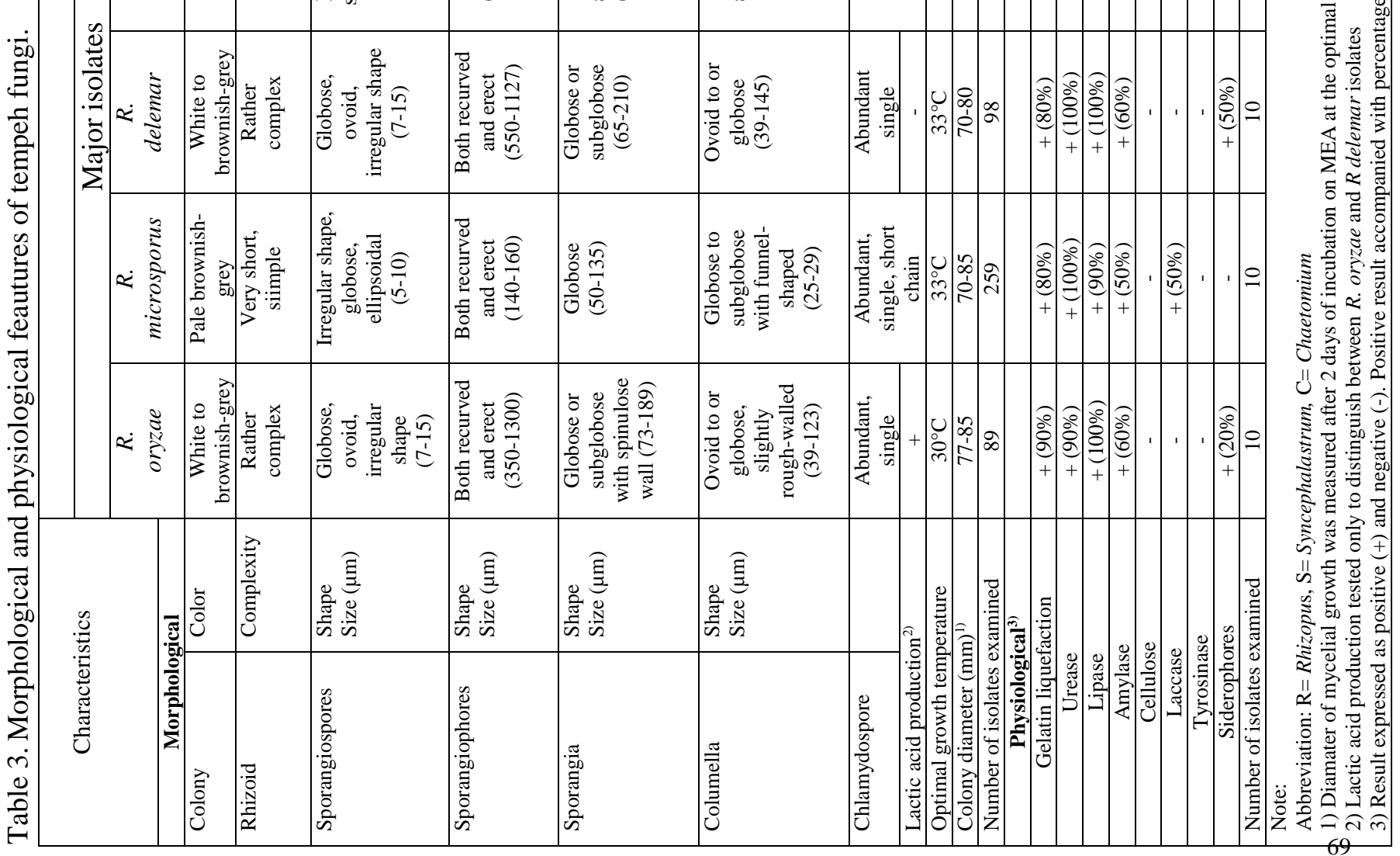




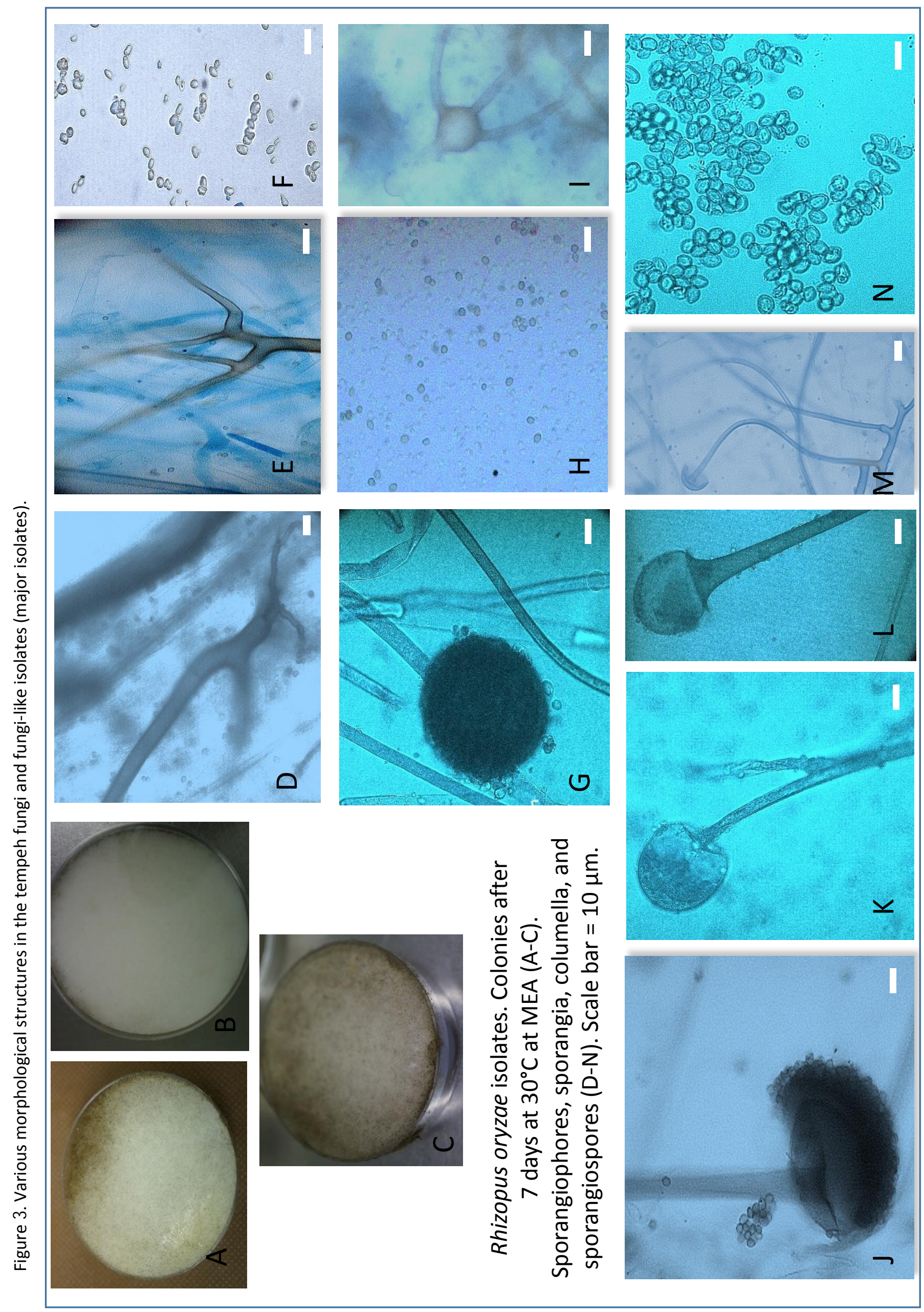




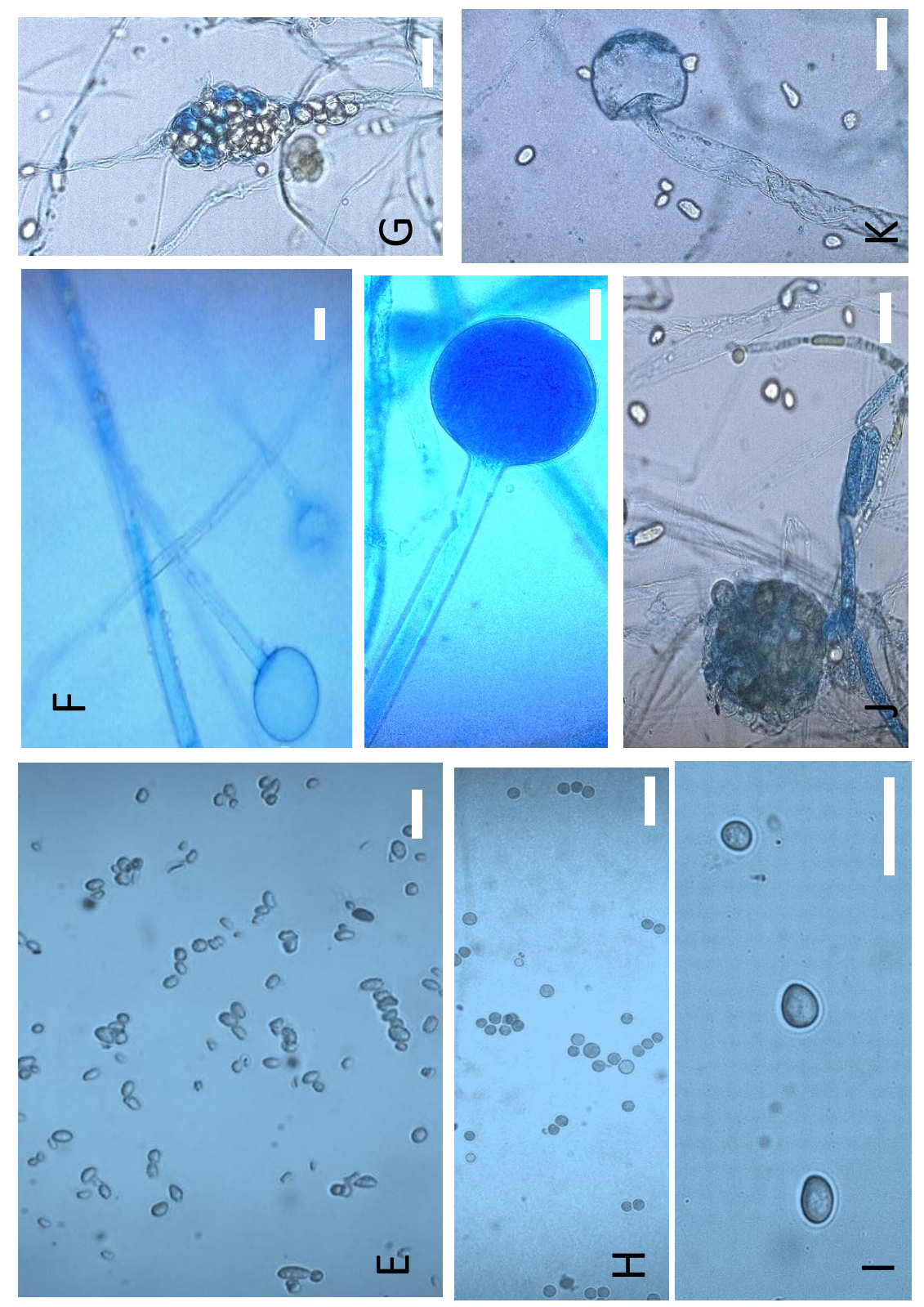




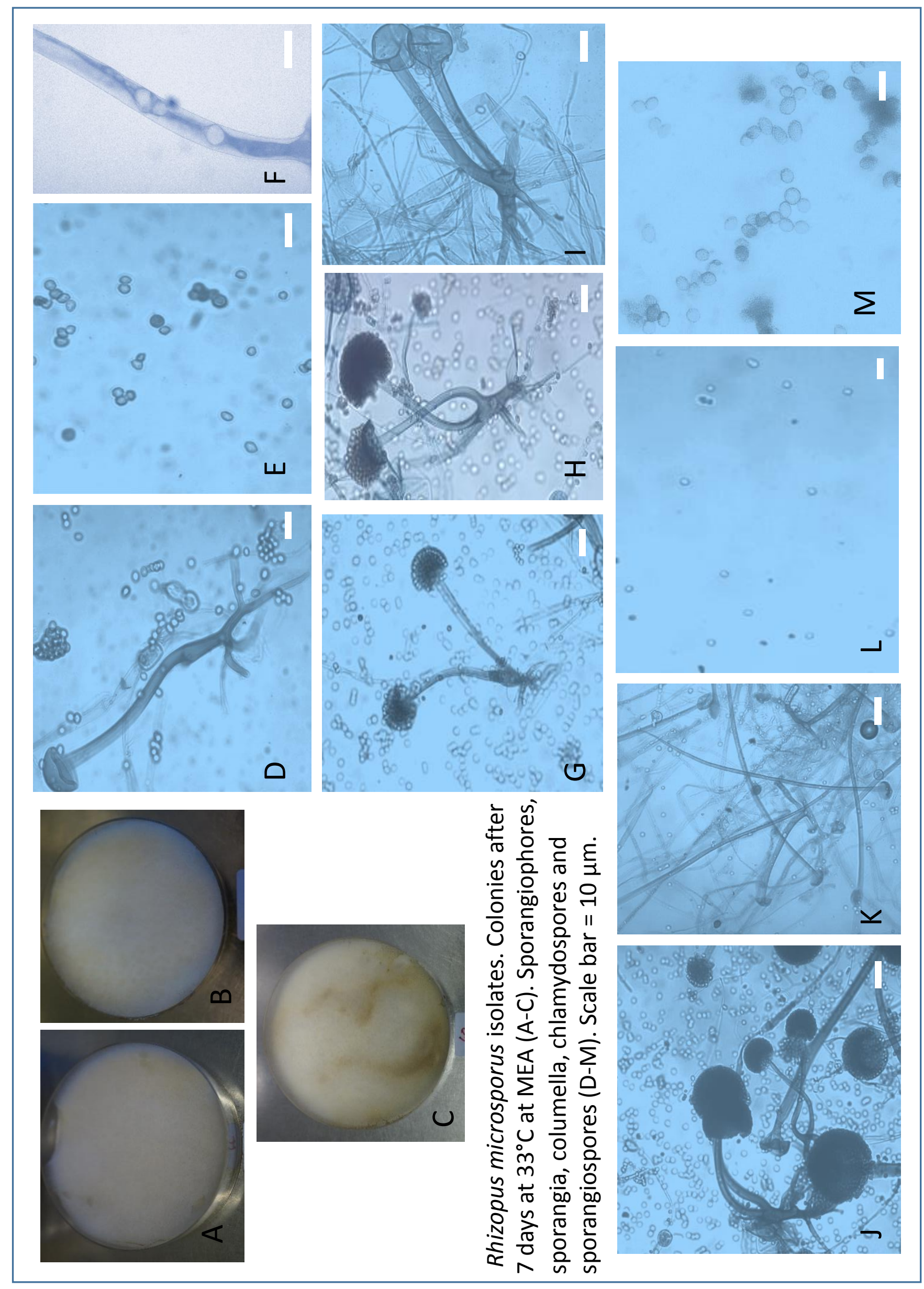




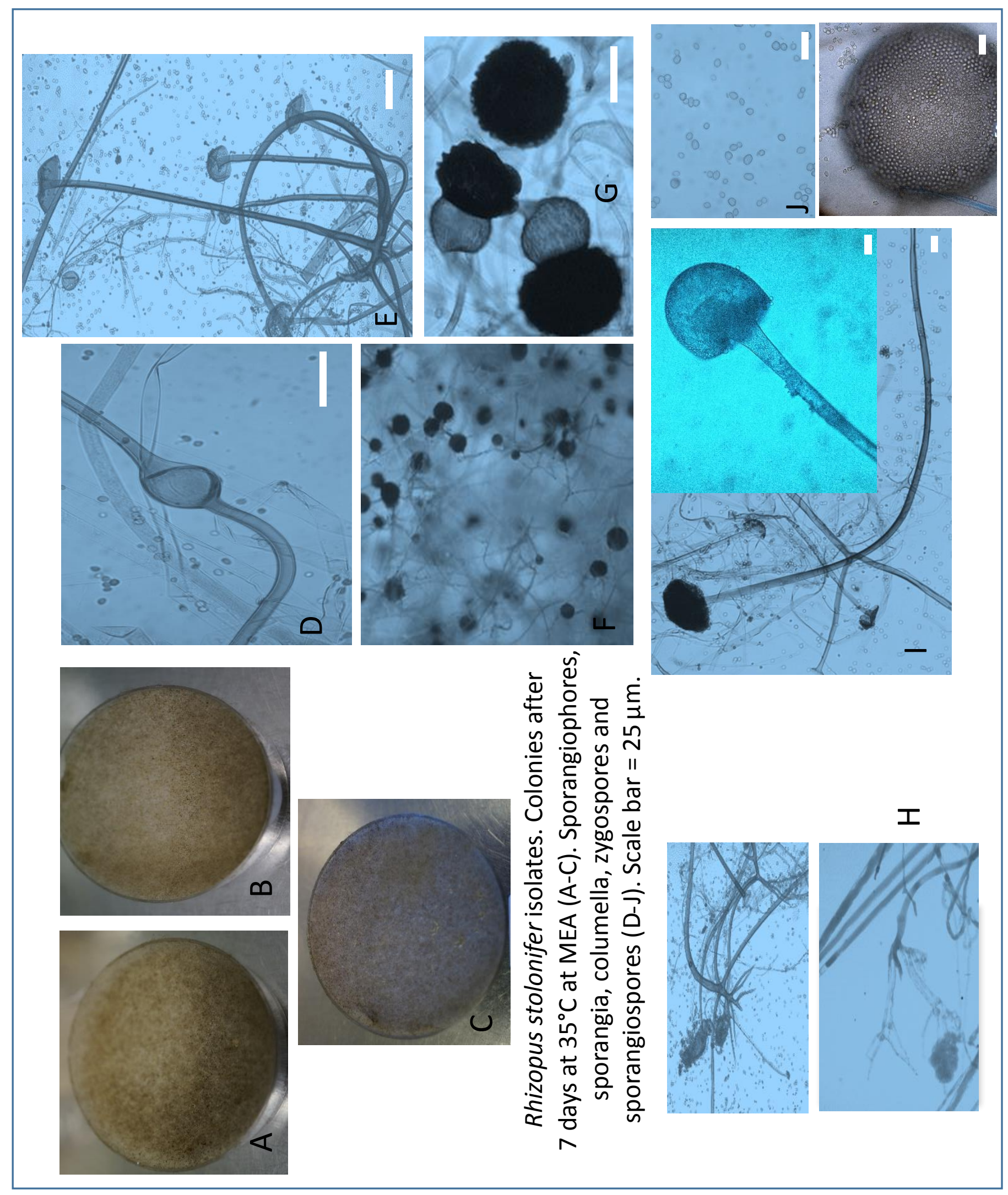




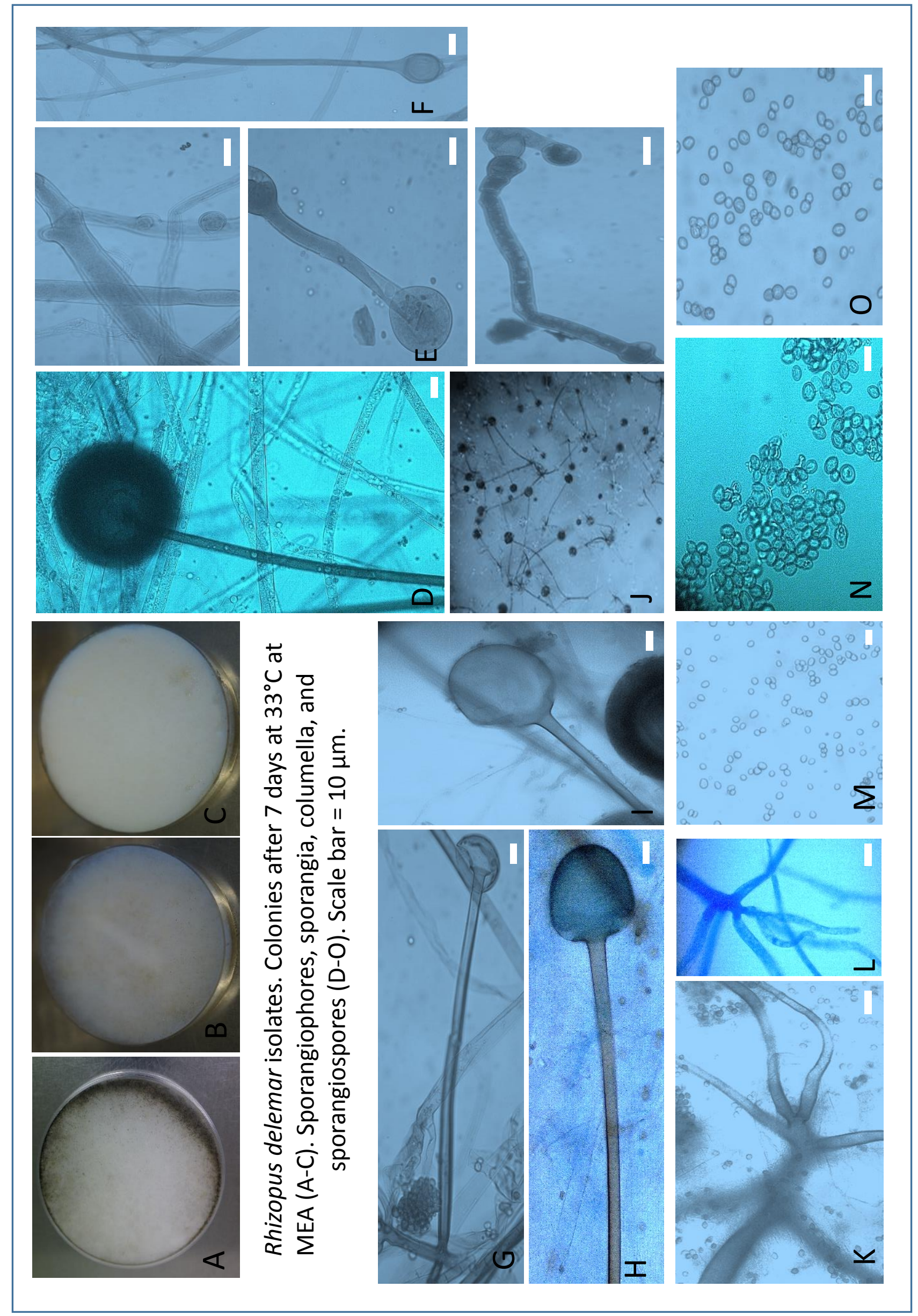




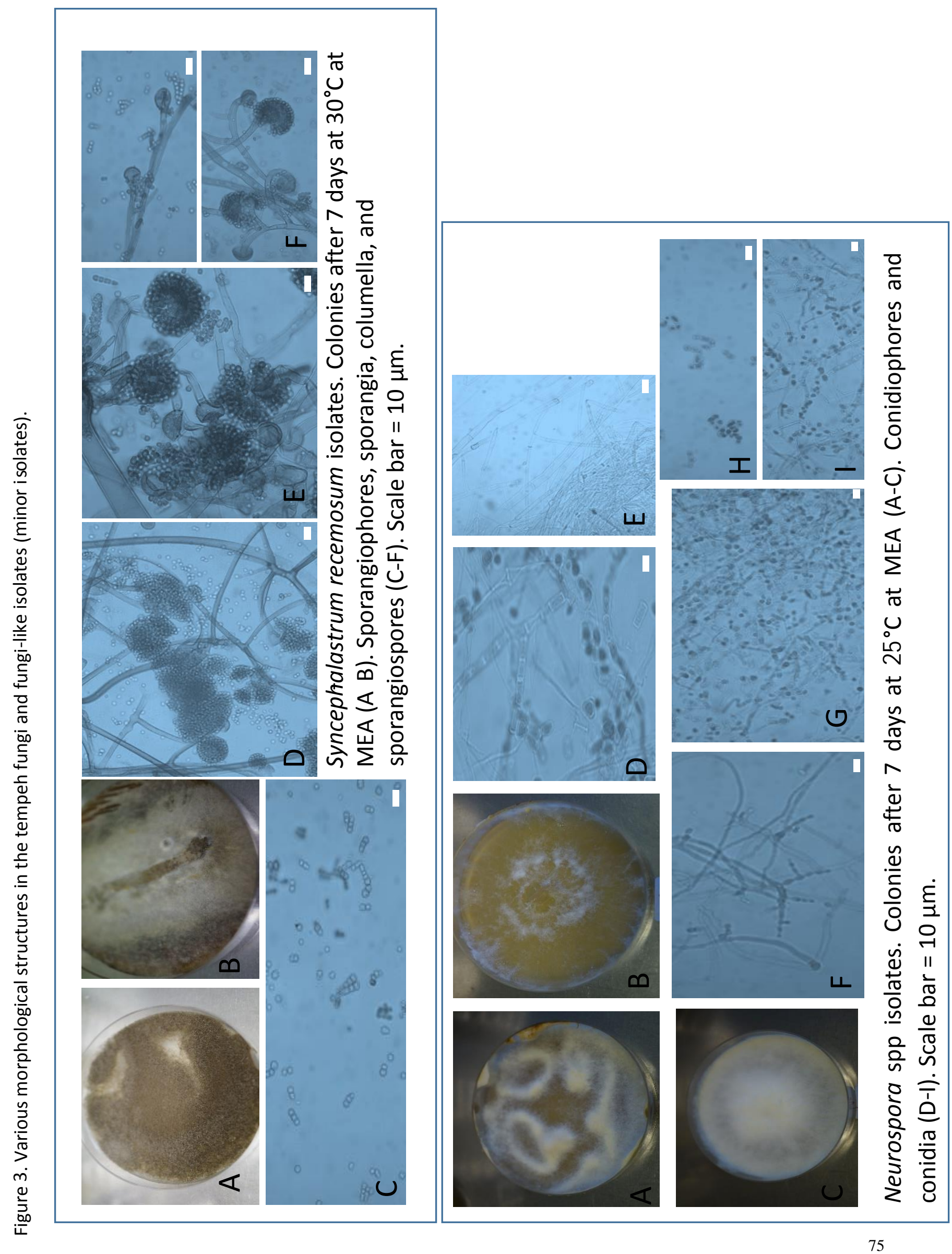




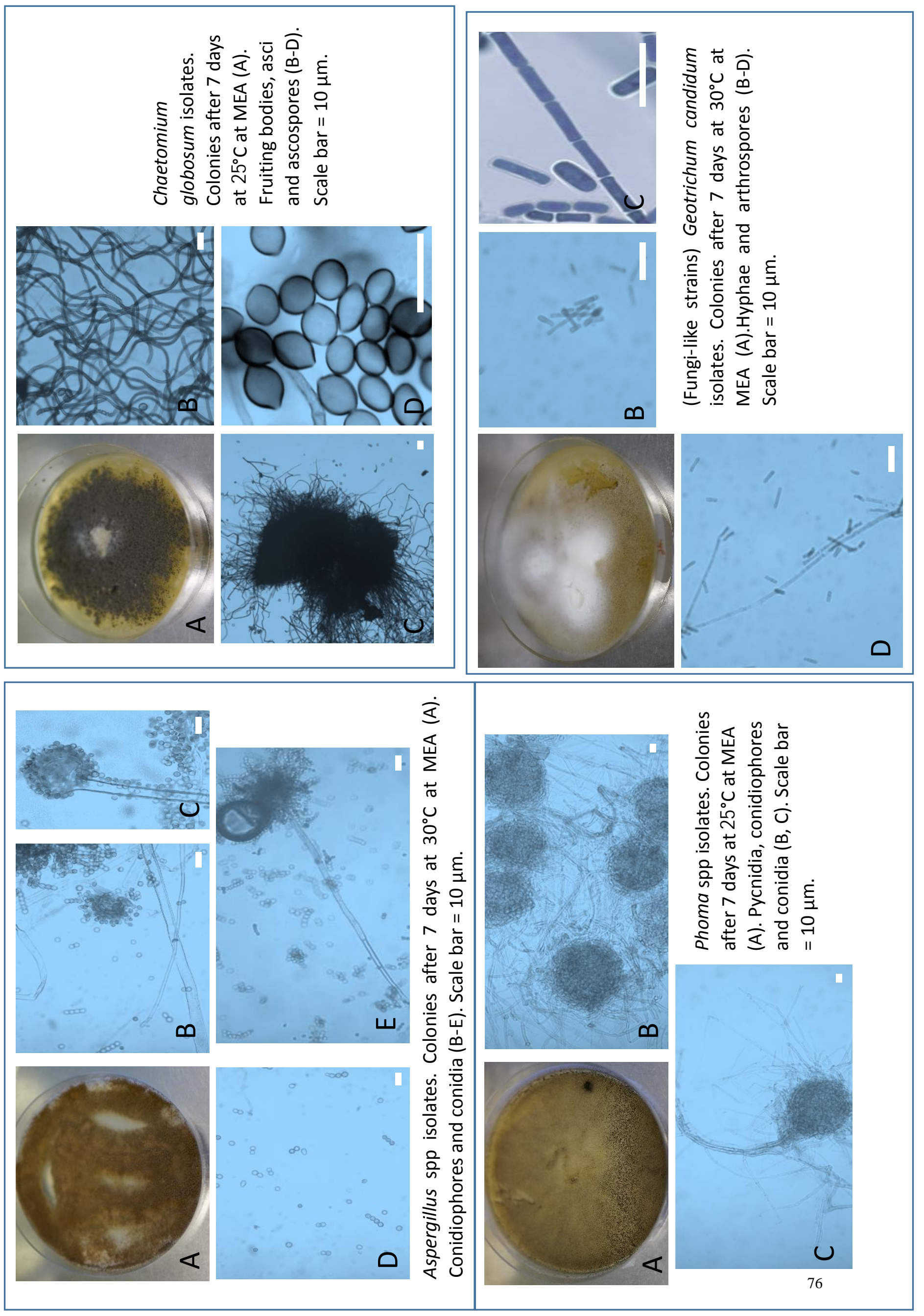


surface, up to $12 \mu \mathrm{m}$ long. No growth at $45^{\circ} \mathrm{C}$, growth at $33^{\circ} \mathrm{C}$. Almost in all morphological aspect this species looks similar with Rhizopus oryzae, but this species could not produce lactic acid.

\section{Rhizopus stolonifer}

Sporangiophores borne in groups of three to five from clusters of rhizoids, stipes unbranched, robust and up to $1600 \mu \mathrm{m}$ long, with brown walls; sporangia 100-300 $\mu \mathrm{m}$ diameter, usually spherical; columellae roughly spherical, up to $200 \mu \mathrm{m}$ diam, in age often collapsing downwards and outwards to produce umbrella shapes; sporangiospores commonly $8-20 \mu \mathrm{m}$ in long axis, pale brownish, with striate walls. Distinctive features from this species are:

Rhizopus stolonifer is distinguished by its habit, with coarse hyphae and rampant growth at 30$35^{\circ} \mathrm{C}$, and by sporangia which are white when first formed but which change to black with maturity. Sporangiospores are large, with striate walls. This species has most complex and branched rhizoid form.

Some strains also tested for enzymes activities including gelatin liquefaction, presence of urease, siderophores, lipase, amylase, cellulose, laccase and tyrosinase. Results of physiological tests are shown also in Table 3. All strains analyzed were positive for lipase production. Most strains were able to liquefy gelatin. They also could produce urease, lipase and amylase. Some strains were able to produce laccase. All strains were negative for tyrosinase and cellulase. Only few strains (assumed as $R$. oryzae and $R$. delemar) showed siderophores.

Carbon assimilation profiles of the different species of zygomycetes and from other fungal division identified with ID32C strips are presented in Table 4. All species assimilated D-galactose, $N$-acetylglucosamine, D-maltose, D-trehalose, and D-glucose and were esculin positive. None of the tested species was able to use methyl D-glucoside, L-rhamnose, erythritol, glucuronate, levulinate, inositol, or L-sorbose as a sole source of carbon. DL-Lactate were assimilated only by some isolates of Aspergilus spp. Every species has different pattern in assimilation indicate their specific capability in using some carbon as source of energy. Those various pattern also show diversity especially among zygomycetes strains. The difference between zygomycetes and nonzygomycetes isolates could be seen obviously from the ability to assimilate D-cellobiose. 
Chapter 3: Determination of fungal diversity in Indonesian tempeh

Table 4. Carbon assimilation profiles of selected fungi isolates with ID32C.

\begin{tabular}{|c|c|c|c|c|c|c|c|c|c|c|}
\hline \multirow[b]{3}{*}{ Carbon source } & \multicolumn{10}{|c|}{ Carbon assimilation profiles of fungi isolates with ID32C strips } \\
\hline & \multicolumn{10}{|c|}{ Isolates suspected as } \\
\hline & $\begin{array}{c}R . \\
\text { oryzae }\end{array}$ & $\begin{array}{c}R . \\
\text { microsporus }\end{array}$ & $\begin{array}{c}R . \\
\text { delemar }\end{array}$ & $\begin{array}{c}R . \\
\text { stolonifer }\end{array}$ & $\begin{array}{c}\text { Mucor } \\
\text { spp }\end{array}$ & $\begin{array}{c}S . \\
\text { racemosum }\end{array}$ & $\begin{array}{l}\text { Neuropsora } \\
\text { spp }\end{array}$ & Phoma spp & C. globosum & $\begin{array}{c}\text { Aspergilluss } \\
\text { spp }\end{array}$ \\
\hline D-galactose & $+(100 \%)$ & $+(100 \%)$ & $+(100 \%)$ & $+(100 \%)$ & $+(100 \%)$ & $+(100 \%)$ & $+(100 \%)$ & $+(100 \%)$ & $+(100 \%)$ & $+(100 \%)$ \\
\hline Actidione & $+(60 \%)$ & - & $+(70 \%)$ & - & $+(100 \%)$ & $+(100 \%)$ & $+(100 \%)$ & - & - & $+(100 \%)$ \\
\hline D-saccharose & $+(50 \%)$ & - & $+(70 \%)$ & - & - & $+(70 \%)$ & $+(100 \%)$ & - & - & $+(100 \%)$ \\
\hline $\begin{array}{l}N \text {-acetyl- } \\
\text { glucosamine }\end{array}$ & $+(100 \%)$ & $+(100 \%)$ & $+(100 \%)$ & $+(100 \%)$ & $+(100 \%)$ & $+(100 \%)$ & $+(100 \%)$ & $+(100 \%)$ & $+(100 \%)$ & $+(100 \%)$ \\
\hline DL-lactate & - & - & - & - & - & - & - & - & - & $+(50 \%)$ \\
\hline L-arabinose & $+(100 \%)$ & - & $+(100 \%)$ & - & $+(100 \%)$ & $+(100 \%)$ & - & - & - & $+(100 \%)$ \\
\hline D-cellobiose & $+(100 \%)$ & $+(100 \%)$ & $+(100 \%)$ & $+(100 \%)$ & $+(100 \%)$ & $+(100 \%)$ & - & - & - & - \\
\hline D-raffinose & $+(70 \%)$ & - & $+(50 \%)$ & - & - & $+(100 \%)$ & - & - & - & $+(100 \%)$ \\
\hline D-maltose & $+(60 \%)$ & $+(100 \%)$ & $+(50 \%)$ & $+(100 \%)$ & $+(100 \%)$ & $+(100 \%)$ & $+(100 \%)$ & $+(100 \%)$ & $+(100 \%)$ & $+(100 \%)$ \\
\hline D-trehalose & $+(100 \%)$ & $+(100 \%)$ & $+(100 \%)$ & $+(100 \%)$ & $+(100 \%)$ & $+(100 \%)$ & $+(100 \%)$ & $+(100 \%)$ & $+(100 \%)$ & $+(100 \%)$ \\
\hline $\begin{array}{l}\text { Potassium 2-keto- } \\
\text { gluconate }\end{array}$ & - & - & - & - & $+(100 \%)$ & - & $+(100 \%)$ & - & - & - \\
\hline $\begin{array}{l}\text { methyl- } \alpha-\mathrm{D}- \\
\text { glucopyranoside }\end{array}$ & - & - & - & - & - & - & - & - & - & - \\
\hline D-sorbitol & $+(100 \%)$ & $+(100 \%)$ & $+(100 \%)$ & $+(100 \%)$ & $+(100 \%)$ & $+(100 \%)$ & & $+(100 \%)$ & - & $+(100 \%)$ \\
\hline D-xylose & $+(100 \%)$ & $+(100 \%)$ & $+(100 \%)$ & $+(100 \%)$ & $+(100 \%)$ & $+(100 \%)$ & $+(100 \%)$ & $+(100 \%)$ & $+(100 \%)$ & $+(100 \%)$ \\
\hline D-ribose & $+(100 \%)$ & $+(100 \%)$ & $+(100 \%)$ & $+(100 \%)$ & $+(100 \%)$ & $+(100 \%)$ & $+(100 \%)$ & - & $+(100 \%)$ & - \\
\hline Glycerol & $+(100 \%)$ & $+(60 \%)$ & $+(100 \%)$ & $+(60 \%)$ & - & - & - & - & - & - \\
\hline L-rhamnose & - & - & - & - & - & - & - & - & - & - \\
\hline Palatinose & - & - & - & - & $+(100 \%)$ & $+(100 \%)$ & $+(100 \%)$ & $+(100 \%)$ & $+(100 \%)$ & $+(100 \%)$ \\
\hline Erythritol & - & - & - & - & - & - & - & - & - & - \\
\hline D-melibiose & - & - & - & - & - & $+(100 \%)$ & - & - & - & $+(100 \%)$ \\
\hline sodium glucuronate & - & - & - & - & - & - & - & - & - & - \\
\hline D-melezitose & $+(70 \%)$ & & $+(100 \%)$ & $+(100 \%)$ & $+(100 \%)$ & - & $+(100 \%)$ & $+(100 \%)$ & $+(100 \%)$ & $+(100 \%)$ \\
\hline $\begin{array}{l}\text { Potassium } \\
\text { gluconate }\end{array}$ & - & $+(100 \%)$ & - & $+(100 \%)$ & $+(100 \%)$ & - & - & - & - & - \\
\hline Levulinate & - & - & - & - & - & - & - & - & - & - \\
\hline D-mannitol & $+(100 \%)$ & $+(100 \%)$ & $+(100 \%)$ & $+(100 \%)$ & $+(40 \%)$ & $+(100 \%)$ & $+(100 \%)$ & $+(100 \%)$ & $+(100 \%)$ & $+(100 \%)$ \\
\hline D-lactose & - & - & - & - & - & - & - & - & - & $+(100 \%)$ \\
\hline Inositol & - & - & - & - & - & - & - & - & - & - \\
\hline D-glucose & $+(100 \%)$ & $+(100 \%)$ & $+(100 \%)$ & $+(100 \%)$ & $+(100 \%)$ & $+(100 \%)$ & $+(100 \%)$ & $+(100 \%)$ & $+(100 \%)$ & $+(100 \%)$ \\
\hline L-sorbose & - & & - & - & - & - & - & - & - & - \\
\hline Glucosamine & $+(100 \%)$ & $+(80 \%)$ & $+(80 \%)$ & $+(50 \%)$ & $+(100 \%)$ & - & - & - & - & - \\
\hline Esculin & $+(100 \%)$ & $+(100 \%)$ & $+(100 \%)$ & $+(100 \%)$ & $+(100 \%)$ & $+(100 \%)$ & $+(100 \%)$ & $+(100 \%)$ & $+(100 \%)$ & $+(100 \%)$ \\
\hline $\begin{array}{l}\text { Number of isolates } \\
\text { examined }\end{array}$ & 10 & 10 & 10 & 10 & 10 & 10 & 10 & 5 & 5 & 5 \\
\hline $\begin{array}{l}\text { Note: } \\
\text { Abbreviation: } \mathrm{R}=R h \\
\text { Strips were read visu }\end{array}$ & $\begin{array}{l}u \text { s, } S=S y \\
\text { Weak gr }\end{array}$ & was cons & $80 \mathrm{pe}$ & C. & & & & & & \\
\hline
\end{tabular}




\section{Molecular results}

In this study, identification of zygomycetes isolates were performed according to the combination of morphological, physiology and molecular characters. To confirm morphological identification, representative isolates were observed with molecular approach. First, DNA fingerprinting was employed to distinguish identical and non identical isolates. Second, non identical isolates with distinct band were selected and confirmed at species level by the results of DNA sequence of the Actin gene, which is taxonomically most informative part in this fungal genus.

ACT is known as a housekeeping gene, as its expression is relatively stable under variable conditions. ACT encodes actin, a protein that is abundant in all eukaryotic cells, in which it is the major component of cytoplasmic microfilaments. The ACT gene has been used extensively to infer interspecies relationships across broad evolutionary distances, as the ACT gene of many species contains highly conserved (i.e. exon) and less well-conserved (i.e. intron) sequences, which are grouped as nuclear pre-mRNA introns (Donnelly et al., 1999).

\section{DNA fingerprinting}

In the preliminary experiments, four arbitrary primers were tested with Random Amplified Polymorphic DNA (RAPD) with DNA extracted from pure cultures. Preliminary test determined the optimal concentration of the component in the PCR reaction mixture, amplification conditions and primer selection. Strong, unique, sharp and clearly reproducible bands were produced by primer C6.2_introns_2_R and C7_1seq (Figure 4). For further analysis C7_1seq was used. The number of DNA bands in these profiles ranged from six to 10 with sizes ranging from 250 to 850 bp. Although the primer generated some common bands, sufficient numbers of polymorphic bands were obtained to detect diversity among the test strains and most of them can be asily distinguished. The experimental procedure was repeated at least three times with the same condition to confim the reproducibility of RAPD analysis. No siginificant differences were observed in the patterns, although some bands varied in intensity.

The RAPD patterns of 471 Rhizopus isolates obtained with the primer are shown partly in Figure 5. Fourty distinct RAPD patterns were obtained and clustered. A dendrogram was generated by using UPGMA (unweighted pair-group method using arithmetic averages) linkage clustering of the Jaccard coefficients. Cluster analysis of the banding patterns revealed six different clustered groups (in Figure 6). Cluster 1, 2 and 3 were Rhizopus isolates dominantly from Java, whereas cluster 4, 5 and 6 were dominantly from outside Java. This means Rhizopus isolates used for tempeh fermentation in Java and outside Java are different from genetic perspective.

Comparison between clustering and morphological data showed that cluster 1,2 and 3 were isolates from Rhizopus microsporus. This species has 3 main groups, they are var. microsporus, var.oligosporus and var.chinensis. High possibility that those 3 cluster are representative from the groups. Based on morphological data, cluster 4, 5 and 6 are possibly as representative of $R$. delemar, $R$. oryzae, and $R$. stolonifer isolates, respectively). This result would be further confirmed with ACT sequencing result. 


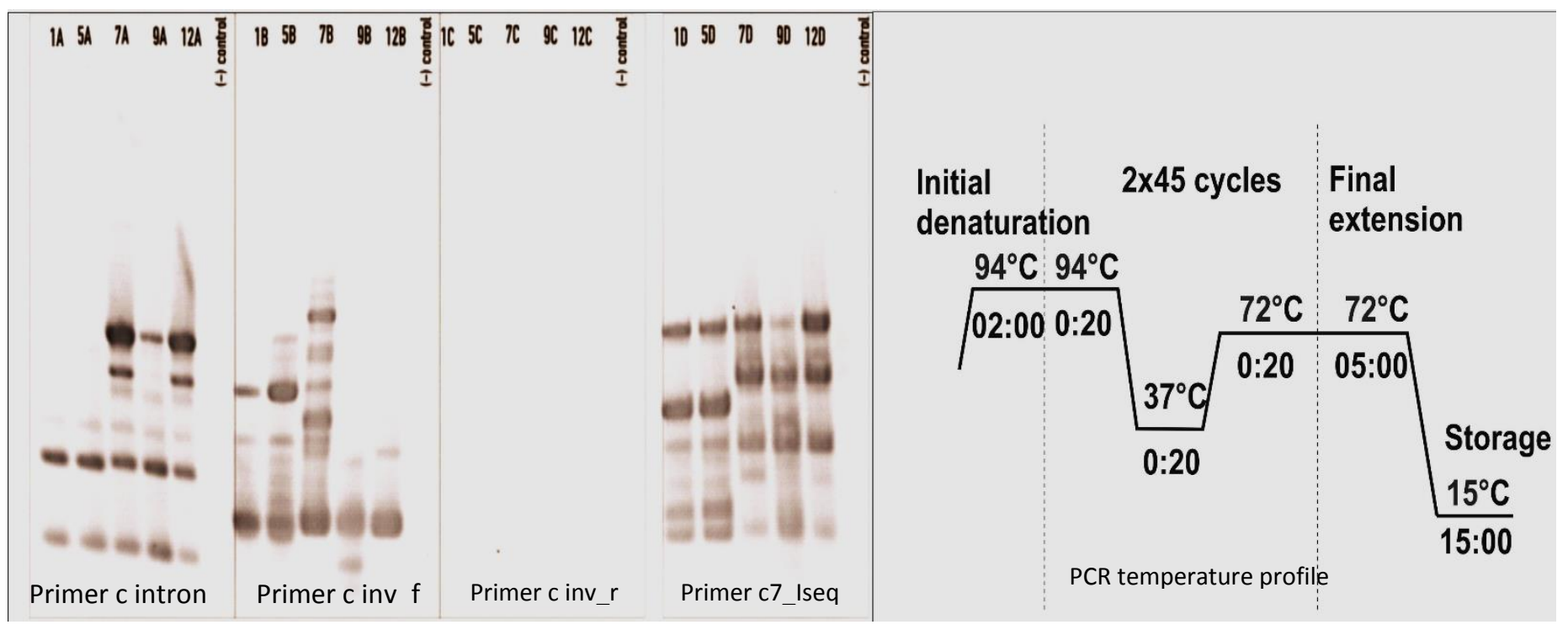

Figure 4. Preeliminary result (primers selection) and its PCR temperature profile.
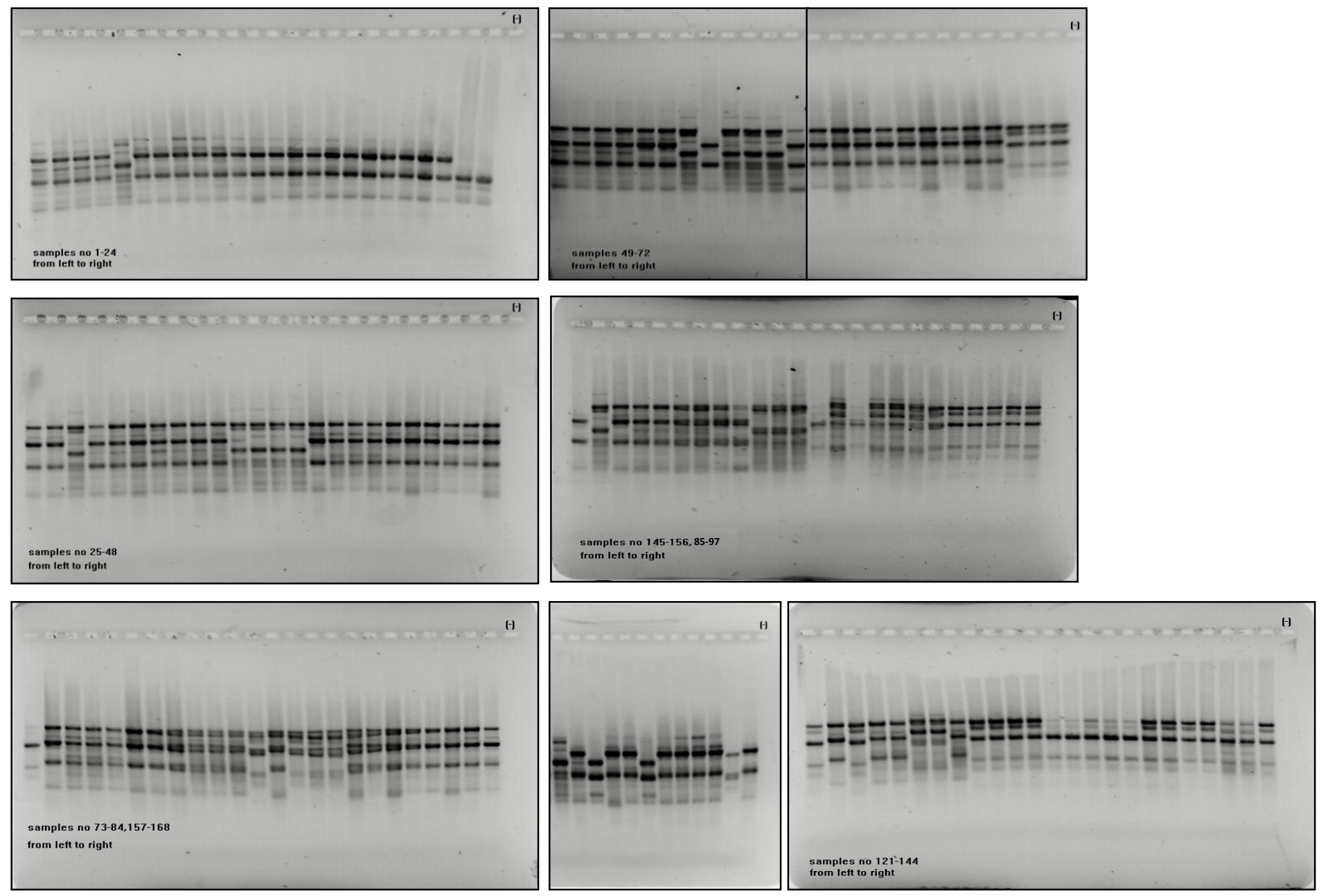

Figure 5. Some results of DNA fingerprinting from tempeh fungi isolates (isolate no 1-168, part 1) 


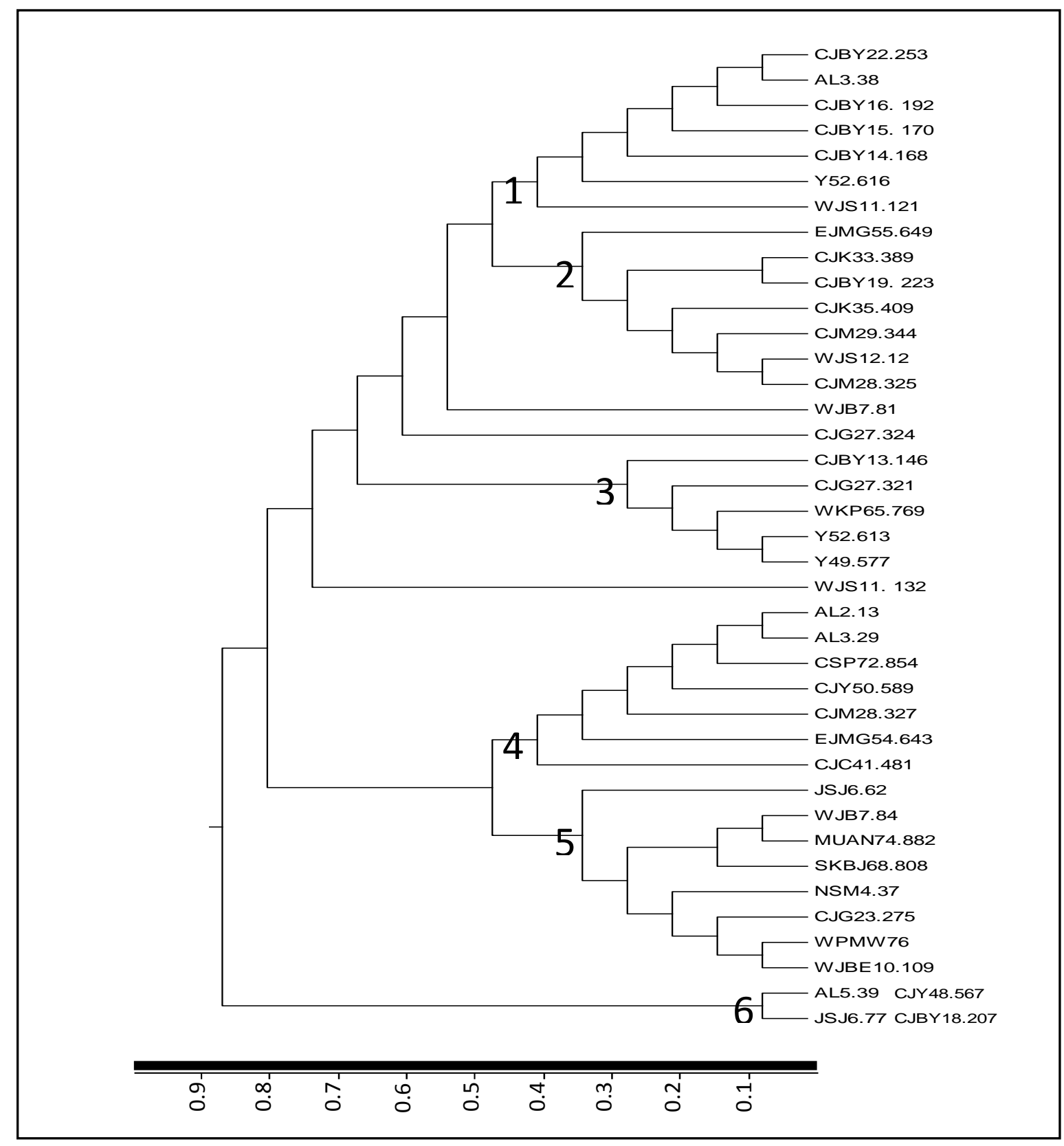

Figure 6. Dendrogram created by UPGMA linkage with clustering of Jaccard coefficients calculated from RAPD data on 42 Rhizopus isolates.

RAPD typing was capable of producing discriminating DNA fingerprints of Rhizopus isolates and indicated there were genetic differences among them. Fourty distinct pattern were observed indicating that tempeh and inocula from different location in Indonesia composed of quite wide number of strains. Genetic diversity was measured as the Shannon-Wiener H' index and the average HS index. HS was estimated to be 0.23 and Shannon's information index was maximum, 1.5. Our result suggest existence of significant genetic variation among these Rhizopus isolates. 


\section{DNA sequencing of tempeh fungi isolates}

To confirm morphological identification, 42 representative isolates from RAPD selection were sequenced based on the ACT gene which has been widely used for species identification. Thermal PCR conditions suggested by Geiser et al. (2004), lead to a mixture of specific and nonspecific products. The situations were achieved by running a gradient $\mathrm{PCR}$ in the range of $53-63^{\circ} \mathrm{C}$ under "Hot start PCR". Hot start PCR protocol was used to amplify the ACT gene region using the fungal specific primer set: Act-1 (5'-TGGGA CGATATGGAIAAIATCTGGCA-3') and Act4ra (5'-TCITCGTATTCTTGCTTIGAIATCCAC AT-3') described by Voigt et al. (2000).

At the annealing temperature of $58.5^{\circ} \mathrm{C}$, a single band in the size range of 810 to $853 \mathrm{bp}$ was successfully amplified from all isolates. After DNA sequencing, each unknown Rhizopus strain was identified according to the deposited sequences in NCBI database which had a high homology $(=99 \%)$ with them. The first three hits for the sequence of each isolate have been assigned in Supplemental Table 1. The studied sequences were, then, aligned with ACT sequences of $R$. microsporus var. chinensis, $R$. oryzae, $R$. delemar, $R$. stolonifer, $R$. microsporus var. microsporus and $R$. microsporus var. oligosporus retrieved from sequence database (Supplemental Table 2) and exposed to phylogenetic analysis (Fig. 7 and 8).

PCR amplification and DNA sequencing using the primer were successful, the blast of the sequenced regions gave conclusive results concerning the molecular taxonomy of the fungi. The UPGMA dendrogram clearly clustered distinct clades regarding to Rhizopus spp. studied. Identification was well supported with bootstrap values. The studied strains, therefore, were placed into groups matching with those determined by NCBI database.

UPGMA dendrogram showed that Rhizopus spp. from Indonesian tempeh and inocula were placed into $R$. stolonifer clade (4 strains), $R$. delemar clade (7 strains), $R$. oryzae clade (8 strains), $R$. microsporus var. microsporus clade (10 strains), $R$. microsporus var. oligosporus clade (8 isolates) and $R$. microsporus var. chinensis clade (4 isolates). The $R$. delemar clade was sister to $R$. oryzae clade with $99 \%$ BS. The $R$. microsporus var. chinensis clade was sister to $R$. microsporus var. microsporus, and $R$. microsporus var. oligosporus clade with $100 \% \mathrm{BS}$. The data are also in line with morphological and physiological characters which previously described. As example, the strain MUAN74.882 which was identified morphologically as $R$. delemar, obviously identified NCBI database also as $R$. delemar. Similarly, isolates identified morphologically as $R$. stolonifer placed in stolonifer clade. The phylogenetic tree (Figure 7) clearly showed that the resolution of sequence from ACT region was sufficient in determining Rhizopus species into variety level, particularly in $R$. microsporus complex, dividing into var. chinensis, var. microsporus (often not written in dendogram) and var. oligosporus, whereas morphological and physiological data only recognize until species level ( $R$. microsporus). This prove that the DNA sequencing gave better taxonomy information until level of variety than morphological approach in this genus.

Combination of origin or geographical data and molecular identification (Figure 8) showed that isolates (identified as Rhizopus oryzae, $R$. delemar, and $R$. stolonifer) dominantly used by tempeh producer from outside Java, whereas isolates (Rhizopus microsporus complex isolates, identified as $R$. microsporus var. chinensis, $R$. microsporus var. microsporus and $R$. microsporus 
var. oligosporus) were mostly used by tempeh producer from Java. This suggest that's why Rhizopus microsporus strain was the main and most important species for tempeh industry in Java where best tempeh quality produced.

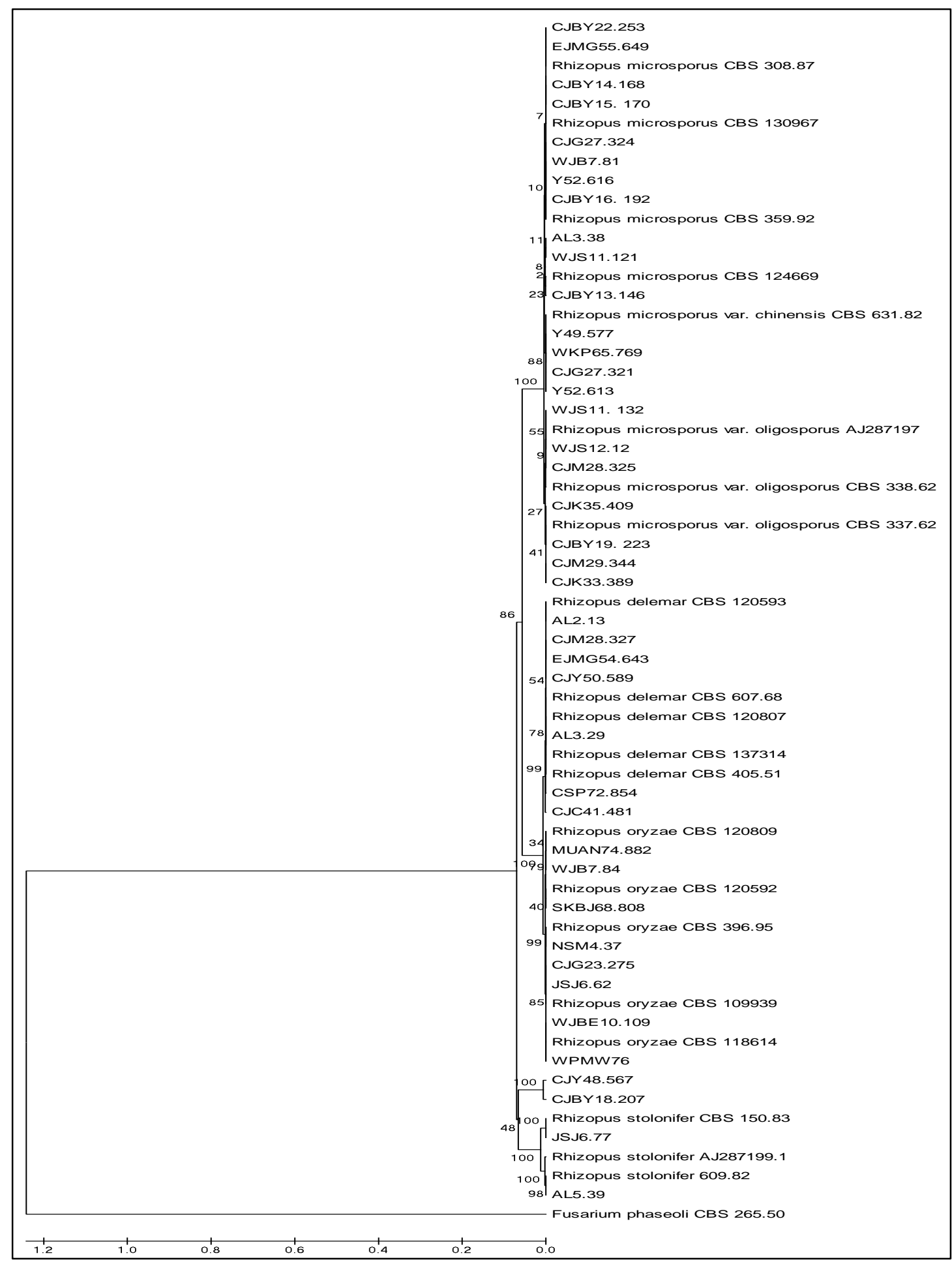

Figure 7. The tree was inferred from Actin sequence and constructed using UPGMA method. Numbers at nodes indicate levels of bootstrap support calculated from 1000 trees. 


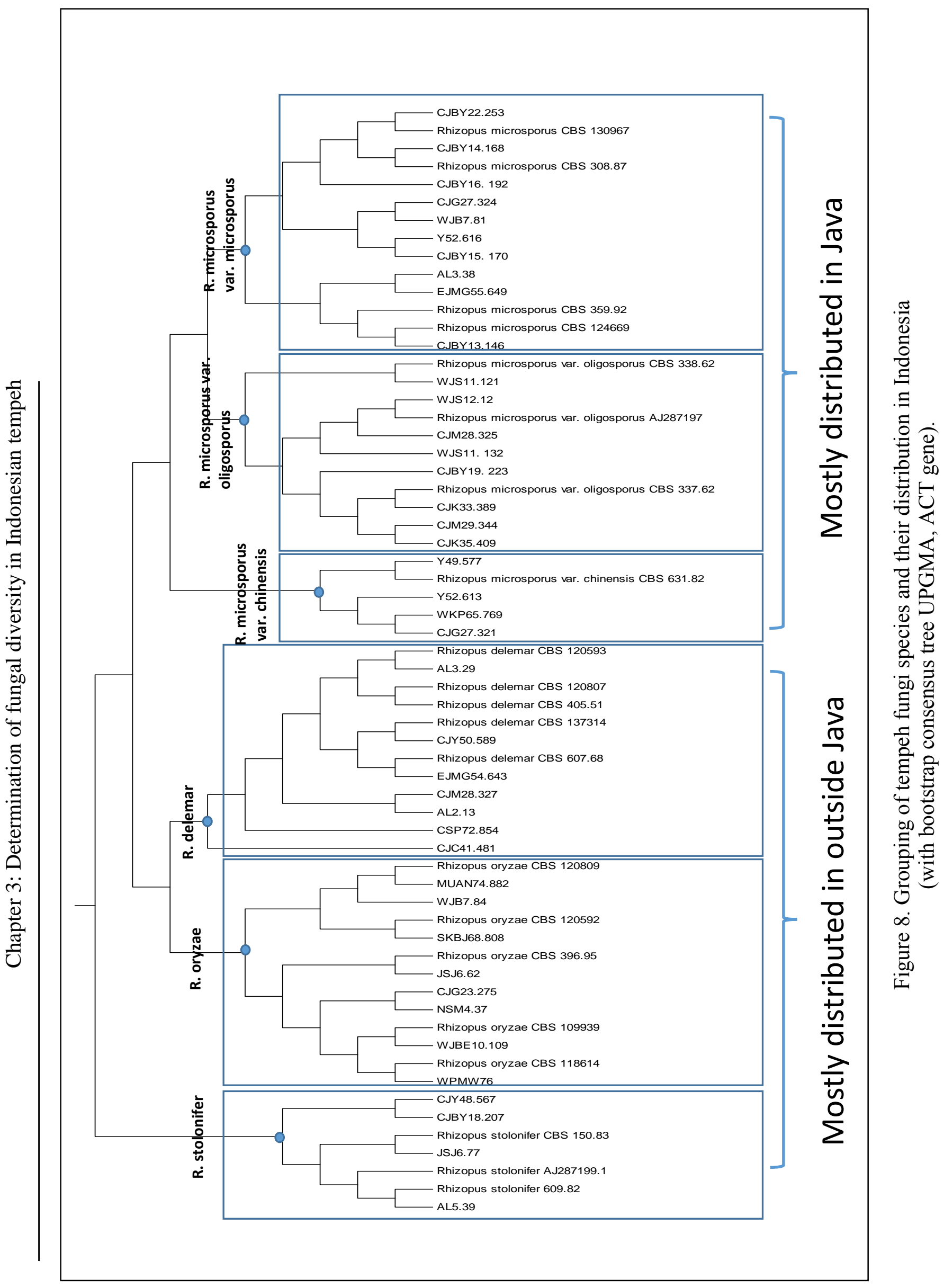




\subsection{Discussion of Part I (Fungal diversity and identification)}

In Indonesia, Rhizopus spp. have been known as one of most economically important mold due to their role as inoculum source for making tempeh, but their information on diversity has been confusing due to limited information, and outdated determination approach previously applied by Indonesian mycologists. As example, Rhizopus oligosporus has still commonly been regarded as inoculant name of tempeh in Indonesia until now (Prihatna and Suwanto, 2007; Dewi and Aziz, 2011), although, this name was, a long time ago, transferred as var. oligosporus within $R$. microsporus group by Schipper and Stalpers (1984). Moreover, the taxonomy and natural systematics within the Mucorales are extremely problematic due to insufficient in distinguishing morphological characters and by the high intra-specific variability of those that do exist. Their characters are also dependent upon physiological growth parameters (Schipper, 1973; Voigt and Wöstemeyer, 2001). Benny (1995) pointed out the limitations of the morphological features in the species delimitation within certain zygomycetes, suggesting the use of molecular tools for solving existing taxonomic controversies. Combination morphological, physiological and molecular features would be the best way and very beneficial to address the problem

In this study, identification of zygomycetes isolates was performed according to the combination of morphological, physiology and molecular characters. To confirm morphological identification, representative isolates were observed with molecular approach. First, DNA fingerprinting was employed to distinguish identical and non-identical isolates. Second, non identical isolates with distinct band were isolated and confirmed at species level by the results of DNA sequence of the Actin gene, which is taxonomically most informative part in this fungal genus.

The moulds isolated from tempeh and inocula in this study were broadly represented by nine genera. In total, 557 fungi and five fungi-like isolates were obtained from 247 samples. Rhizopus was the most frequently detected genera, found in $84 \%$ of total samples, followed by Mucor (5.5\%), Neurospora (4.1\%) and Syncephalastrum (3\%). Other very minor genera that found as contaminants were Chaetomium, Phoma, Acremonium, Aspergillus and Geotrichum (less than $1 \%$ ). Nout and Kiers mentioned that there is a complex of microorganisms in soybean tempeh, their development start during the soaking of the raw ingredients. Those contaminant might be from raw material itself, environment of local factories, tools or cross contamination from human. However, to distinguish between tempeh fungi and contaminant could be done by quick checking their assimilation pattern. We found that the difference between zygomycetes and contaminant isolates could be seen obviously from the ability to assimilate D-cellobiose. Mostly all the contaminant could not assimilate D-cellobiose.

Classical work on the circumscription and identification of Rhizopus species has primarily been based on morphological criteria (Inui et al., 1965). The identification by traditional methods, however, is not clear-cut as there are few character suites to use to classify taxa. This has resulted in an excessive number of species, with few character differences, having been described. There is a need for an alternative approach in the precise naming of fungal strains. Schipper and Stalpers 
(1984) suggested that a useful approach to Rhizopus taxonomy was to classify species based on the combination of maximum growth temperature rates and sporangiospores characteristics. This approach is very effective for initial species identification. It enables the division of the genus Rhizopus into several large groups. The followings are the characteristics adopted by most scientist: branching pattern and abundance of rhizoiud, length, width and straightness of sporangiophores, diameter and color of sporangia, size and striatiuon of sporangiospores, size and color of zygosporangia and equalitys of the two suspensor also taken into consideration. Those criteria well observed also in this study. With detail morphological, growth and physiological criteria, we succesfully identified tempeh fungi into four main groups, but we failed to identify $R$. microsporus-group into variety level. Therefore RAPD and DNA sequencing approach were then used.

The RAPD patterns of 471 Rhizopus isolates obtained with the selected primer. Forty two distinct RAPD patterns were obtained and clustered. A dendrogram was generated by using UPGMA (unweighted pair-group method using arithmetic averages) linkage clustering of the Jaccard coefficients. In general, Rhizopus isolates form several clusters with a medium level of genetic variability. Dissimilarity values higher than 0.6 were detected between these six groups, indicating species-level differences. These results indicate a genetic heterogeneity within the species Rhizopus. Cluster analysis of the banding patterns revealed six different clustered groups. Cluster 1, 2 and 3 were Rhizopus isolates dominantly from Java, whereas cluster 4, 5 and 6 were dominantly from outside Java. This means Rhizopus isolates used for tempeh fermentation in Java and outside Java are different from genetic perspective. A combination of clustering and morphological data showed that cluster 1, 2 and 3 were isolates from Rhizopus microsporus. This species has three main varieties, they are var. microsporus, var.oligosporus and var.chinensis. High possibility that those 3 cluster are representative from the variety. Based on morphological data, cluster 4, 5 and 6 are possibly as representative of $R$. delemar, $R$. oryzae, and $R$. stolonifer isolates, respectively. The difference in the RAPD patterns reveals also a high, practically interspecific distance between the clusters of the R. stolonifer with another cluster of Rhizopus species. This suggests that $R$. stolonifer is most different compared with other Rhizopus species from Indonesian tempeh. This supported also with morphological data which reveal that $R$. stolonifer has most distinct features than the other Rhizopus species, for example complex-branched rhizoid, big sporangiospores, black sporangia in mature and longest sporangiophores.

RAPD typing was capable of producing discriminating DNA fingerprints of Rhizopus isolates and indicated there was genetic differences among them. Many distinct patterns were observed indicating that tempeh and inocula from different location in Indonesia composed of a quite wide number of strains. Genetic diversity was measured as the Shannon-Wiener H' index and the average HS index. HS was estimated to be 0.23 and Shannon's information index was maximum, 1.5. Our result suggest existence of significant genetic variation among these Rhizopus isolates. These result were in line with several previous works related to mucoralean diversity. RAPD analysis has proved to be an effective method for the revelation of genetic variations in various species of mucorales (Williams et al., 1990). The investigation of seven strains of the 
facultative mycoparasite Parasitella parasitica by means of RAPD, restriction fragment length polymorphism RFLP analysis and electrophoretic karyotyping showed that they are highly diverse, creating two intraspecific groups(Burmester and Wöstemeyer,1994). RAPD markers correlating with the mating competency have been described in the post-harvest pathogens Mucor piriformis (Papp et al., 1997) and Gilbertella persicaria (Papp et al., 2001). RAPD analysis was used successfully to characterize the genetic variability in the mainly heterothallic Rhizomucor pusillus and the homothallic Rhizomисor miehei: the latter revealed substantially lower intraspecific polymorphism (Vastag et al., 2000).

DNA sequences of genes such as ACT have been widely used for supporting morphological traits of mucoralean species (Voigt and Wonstemeyer, 2001; Abe et al., 2010; Dolatabadi et al., 2014). The results of sequence alignment by BLAST and phylogenetic analysis have proven that ACT sequencing is suitable for accurate identification of tempeh fungal isolates. All the phylogenetic trees with high bootstrap supports have revealed that the isolates are successfully identified at species level and further differentiated as particular strains within the same species. The UPGMA dendrogram clearly clustered distinct clades regarding to Rhizopus spp. studied. The dendrogram showed that Rhizopus spp. from Indonesian tempeh and inocula were placed into $R$. stolonifer clade (4 strains), $R$. delemar clade ( 7 strains), $R$. oryzae clade (8 strains), $R$. microsporus var. microsporus clade (10 strains), $R$. microsporus var. oligosporus clade (8 isolates) and $R$. microsporus var. chinensis clade (4 isolates). The $R$. delemar clade was sister to $R$. oryzae clade with $99 \% \mathrm{BS}$. The $R$. microsporus var. chinensis clade was sister to $R$. microsporus var. microsporus, and $R$. microsporus var. oligosporus clade with $100 \% \mathrm{BS}$. The data are also in line with morphological and physiological characters which previously described. The result clearly showed that the resolution of sequence from ACT region was sufficient in determining Rhizopus species into variety level, particularly in $R$. microsporus complex, dividing into var. chinensis, var. microsporus (often not written in dendogram) and var. oligosporus, whereas morphological and physiological data only recognize until species level (R. microsporus). This prove that the DNA sequencing with ACT gene gave better taxonomy information until level of variety than morphological approach in this genus. ACT is known as a housekeeping gene, as its expression is relatively stable under variable conditions. ACT encodes actin, a protein that is abundant in all eukaryotic cells, in which it is the major component of cytoplasmic microfilaments. The ACT gene has been used extensively to infer interspecies relationships across broad evolutionary distances, as the ACT gene of many species contains highly conserved (i.e. exon) and less well-conserved sequences, which are grouped as nuclear pre-mRNA introns (Donnelly et al., 1999).

Combination of origin or geographical data and molecular identification showed that isolates (identified as Rhizopus oryzae, $R$. delemar, and $R$. stolonifer) dominantly used by tempeh producer from outside Java, whereas isolates (Rhizopus microsporus complex isolates, identified as $R$. microsporus var. chinensis, $R$. microsporus var. microsporus and $R$. microsporus var. oligosporus) were mostly used by tempeh producer from Java. Indeed, long time ago many members of Rhizopus and Mucor genera were previously reported in Java from inocula of tempeh 
(ragi) and fresh tempeh (Dwidjoseputro and Frederick, 1970; Saono et al., 1974). However, to verify whether some species ( $R$. sexualis, $R$. arrhizus, $R$. microsporus var. azygosporus etc.) have lost from tempeh in Indonesia, it is necessary to examine more samples in more other regions of Indonesia. This finding indicates that commercialization of tempeh inocula by using certain Rhizopus species in Java possibly threatens the genetic diversity of Rhizopus associated with this traditionally soybean-based fermented foods. The impact of heavy commercialization of tempeh inocula using particular species of Rhizopus has shifted the diversity of Rhizopus species associated with tempeh in Java. Interestingly, in our result, we also found many different strains of some variety of $R$. microsporus. This is probably because many producers in Java also develop their starter strains which composed of those variety. Therefore genetic variation of Java's isolates expressed intraspecies ( $R$. microsporus). In contrast, commercialization of tempeh inocula is limited in outside Java. Therefore, many species of Rhizopus still could be found, and genetic variation of non-Java's isolates expressed in interspecies $(R$. stolonifer, $R$. delemar, $R$ oryzae and $R$. microsporus complex) level. Differences in the use of fungi species by producer in outsideJava have more significant impact on various (heterogenous) nutritional and sensory quality of the tempeh than in Java`s tempeh at least, various in the texture, aroma and the color of tempeh. 


\subsection{Results of Part II (Safety status of tempeh fungi strains)}

Food safety is a prerequisite for a food product. There is no sense in talking about quality, nutritional value, sensory or functional properties if the food product is not safe for consumption. There is two possible hazards from Rhizopus species, first related to their role as mucormycosis agent and second as toxication agent. In this study, we tried to answer about current safety status of tempeh fungi from Indonesia. Tempeh fungi isolates were tested for their virulence potency and also checked for their possibility role as host for bacteria producing rhizoxin or rhizonin.

\section{Virulence test}

Tempeh is important traditional Indonesian fermented food made from soybeans employing Rhizopus species. However, Rhizopus species also known as opportunistic pathogens causing mucormycosis in human. Rhizopus oryzae (arrhizus) and R. microsporus predominantly described as potential agents of severe mucormycosis (Ribes et al.,2000; Roden et al., 2005).In this study, the virulence potential of the different Rhizopus species from tempeh was determined in an invertebrate model host, Galleria mellonella. This organism has advantages as it is economical, ethically expedient and easy to handle. For assessment of viability, larvae should be gently probed with a needle, and if no response is observed, the larvae may be considered to be dead. Changes in cuticle melanisation can also be used to monitor the severity of an infection. Significance of mortality rates was evaluated by using Kaplan-Meier survival curves. Mortality rates at four days were found as $100 \%$ for the larvae infected with E. cloacae (positive control), 0$20 \%$ for the larvae infected with Rhizopus strains (Figure 9). As a result of this study, potential evidence provided that tempeh fungi isolates are not virulent for G. mellonella larvae model.

To distinguish between mucormycosis and non- mucormycosis agent, some more test must be tried. They are thermotolerance, sporulation level, and genetic comparison test. Thermotolerant character, is a prerequisite for colonization of warmblooded hosts by opportunistic agent. Thermotolerance of Mucorales has classically been considered as a prime virulence factor in human infection (Scholer, 1970). Most of mycormycosis agent proved to be thermotolerant and only produce high sporulation at high temperature $\left(50-55^{\circ} \mathrm{C}\right)$. Mucormycosis agent has low ability to produce spores at moderate temperature $\left(30^{\circ} \mathrm{C}\right)$. For measuring thermotolerance, MEA plates were inoculated with small blocks taken from the edge of 3 days-old colonies. Plates were incubated at the following temperatures: $30^{\circ} \mathrm{C}, 37^{\circ} \mathrm{C}, 40^{\circ} \mathrm{C}, 45^{\circ} \mathrm{C}, 50^{\circ} \mathrm{C}, 52^{\circ} \mathrm{C}$, and $55^{\circ} \mathrm{C}$. Diameters were measured twice a day for three days. The growth rate, measured in millimeters per hour, was calculated for each strain and each temperature.

We have checked tempeh fungi isolates with mentioned test above. The results can be seen in Table 5 and Figure 10. None of the tempeh fungi isolates has thermotolerant character. All of them can not grow in temperature over $40^{\circ} \mathrm{C}$. Five distinguishable levels of sporulation were checked among strains. The results showed that all tempeh fungi strains have high sporulation character in moderate temperature setting. The isolates have significant higher sporulation level than mucormycosis agent. The results indicated that tempeh isolates are not mucormycosis agent. 


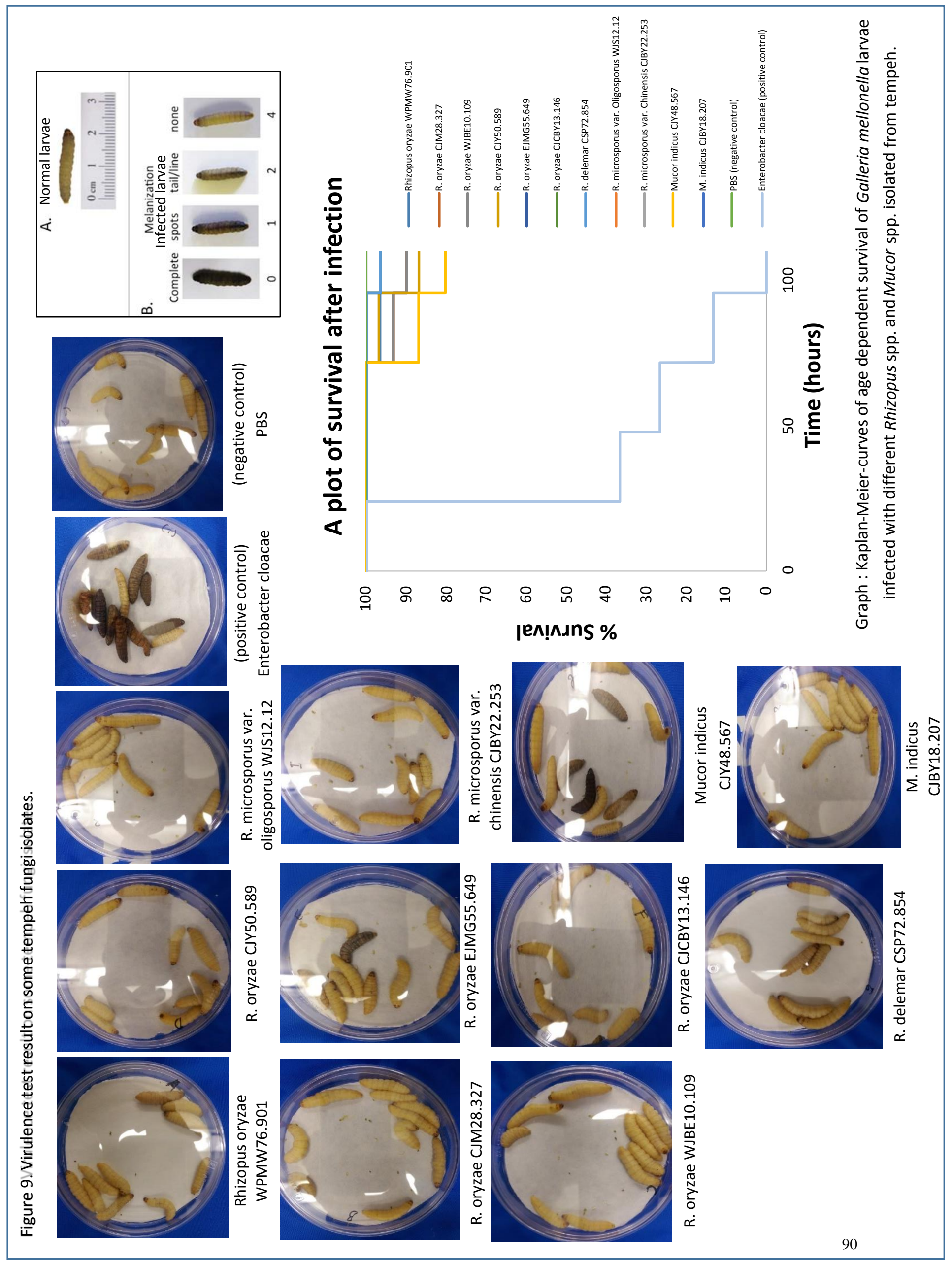


Those result also supported by genetic comparison data. The clustering dendrogram showed two separate clusters representing tempeh fungi isolates from tempeh or inocula and the medical isolates. The dendrogram showed unambiguously that tempeh isolates were genetically different from medical isolates (Figure 10). That figure showed that medical isolates were clearly separated in a different group. Our results suggested that tempeh fungi isolates could be a distinctive nonpathogenic group of this species. This is also in line with the facts that tempeh production and consumption have been practiced in Indonesia for centuries and, to our knowledge, there is no single report on infectious disease associated with tempeh.

Table 5. Comparison of physiology character between some isolated zygomycetes from tempeh (present study) with mucormycosis agents studied by Dolatabadi et al. (2014).

\begin{tabular}{|c|c|c|c|c|c|}
\hline Obsolete name & Geography & Source & Thermotolerance & $\begin{array}{c}\text { Optimal growth } \\
\left({ }^{\circ} \mathrm{C}\right)\end{array}$ & Sporulation \\
\hline \multicolumn{6}{|l|}{ Rhizopus oryzae } \\
\hline \multicolumn{6}{|l|}{$\begin{array}{l}\text { Mucormycosis } \\
\text { agent* }\end{array}$} \\
\hline CBS 109939 & Ontario & Dermal lesion of black & + & 55 & B \\
\hline CBS 118614 & Turkey & Palate & + & 50 & B \\
\hline CBS 120591 & France & Sinus & + & 55 & B \\
\hline CBS 120592 & France & Sinus & + & 49 & B \\
\hline CBS 120594 & France & Skin & + & 55 & B \\
\hline CBS 120806 & France & Rhino-cerebral & + & 55 & B \\
\hline CBS 120809 & France & Sputum & + & 55 & B \\
\hline \multicolumn{6}{|l|}{ Present study } \\
\hline MUAN74.882 & Indonesia & Tempeh inoculum & - & 30 & $\mathrm{E}$ \\
\hline WJB7.84 & Indonesia & Tempeh inoculum & - & 30 & E \\
\hline SKBJ68.808 & Indonesia & Tempeh inoculum & - & 30 & $\mathrm{E}$ \\
\hline JSJ6.62 & Indonesia & Tempeh inoculum & - & 30 & $\mathrm{D}$ \\
\hline CJG23.275 & Indonesia & Tempeh inoculum & - & 30 & $\mathrm{D}$ \\
\hline NSM4.37 & Indonesia & Tempeh inoculum & - & 30 & $\mathrm{D}$ \\
\hline WJBE10.109 & Indonesia & Tempeh inoculum & - & 30 & $\mathrm{E}$ \\
\hline WPMW76 & Indonesia & Tempeh inoculum & - & 30 & $\mathrm{D}$ \\
\hline \multicolumn{6}{|l|}{$R$ delemar } \\
\hline \multicolumn{6}{|l|}{$\begin{array}{l}\text { Mucormycosis } \\
\text { agent* }\end{array}$} \\
\hline CBS 395.54 & Georgia & Diabetic patient & + & 55 & B \\
\hline CBS 120593 & France & Lung & + & 50 & B \\
\hline CBS 120807 & France & Sputum & + & 55 & B \\
\hline \multicolumn{6}{|l|}{ Present study } \\
\hline AL3.29 & Indonesia & Tempeh inoculum & - & 33 & $\mathrm{E}$ \\
\hline CJBY50.559 & Indonesia & Fresh tempeh & - & 33 & $\mathrm{E}$ \\
\hline EJMG54.643 & Indonesia & Tempeh inoculum & - & 33 & E \\
\hline
\end{tabular}


Chapter 3: Determination of fungal diversity in Indonesian tempeh

\begin{tabular}{|c|c|c|c|c|c|}
\hline CJM28.327 & Indonesia & Fresh tempeh & - & 33 & $\mathrm{E}$ \\
\hline AL2.13 & Indonesia & Tempeh inoculum & - & 33 & $\mathrm{E}$ \\
\hline CSP72.854 & Indonesia & Fresh tempeh & - & 33 & $\mathrm{E}$ \\
\hline CJC41.481 & Indonesia & Tempeh inoculum & - & 33 & $\mathrm{E}$ \\
\hline \multicolumn{6}{|l|}{ R. microsporus } \\
\hline \multicolumn{6}{|l|}{$\begin{array}{l}\text { Mucormycosis } \\
\text { agent* }\end{array}$} \\
\hline CBS 118987 & France & Human & + & 50 & $\mathrm{C}$ \\
\hline CBS 124669 & Greece & Human, soft palate & + & 55 & $\mathrm{~B}$ \\
\hline CBS 359.92 & Australia & Liver, premature infant & + & 50 & $\mathrm{~B}$ \\
\hline CBS 357.92 & Australia & Human & + & 55 & $\mathrm{~B}$ \\
\hline CBS 308.87 & Australia & Human, cutaneous necrosis & + & 50 & $\mathrm{~B}$ \\
\hline CBS 712.73 & Netherland & Skin & + & 55 & $\mathrm{C}$ \\
\hline CBS 102277 & Unknown & Human rhinocerebral & + & 55 & $\mathrm{~B}$ \\
\hline \multicolumn{6}{|l|}{ Present study } \\
\hline CJBY22.253 & Indonesia & Fresh tempeh & - & 33 & $\mathrm{E}$ \\
\hline CJBY14.168 & Indonesia & Tempeh inoculum & - & 33 & $\mathrm{E}$ \\
\hline CJBY16.192 & Indonesia & Tempeh inoculum & - & 33 & $\mathrm{E}$ \\
\hline CJG27.324 & Indonesia & Tempeh inoculum & - & 33 & $\mathrm{E}$ \\
\hline WJB7.81 & Indonesia & Tempeh inoculum & - & 33 & $\mathrm{E}$ \\
\hline Y52.616 & Indonesia & Tempeh inoculum & - & 33 & $\mathrm{E}$ \\
\hline CJBY15.170 & Indonesia & Fresh tempeh & - & 33 & $\mathrm{E}$ \\
\hline AL3.38 & Indonesia & Fresh tempeh & - & 33 & $\mathrm{E}$ \\
\hline EJMG55.69 & Indonesia & Fresh tempeh & - & 33 & $\mathrm{E}$ \\
\hline CJBY.13.146 & Indonesia & Fresh tempeh & - & 33 & $\mathrm{E}$ \\
\hline WJS11.121 & Indonesia & Tempeh inoculum & - & 33 & $\mathrm{E}$ \\
\hline WJS12.12 & Indonesia & Fresh tempeh & - & 33 & $\mathrm{E}$ \\
\hline CJM28.325 & Indonesia & Fresh tempeh & - & 33 & $\mathrm{E}$ \\
\hline WJS11.132 & Indonesia & Fresh tempeh & - & 33 & $\mathrm{E}$ \\
\hline CJBY19.223 & Indonesia & Tempeh inoculum & - & 33 & $\mathrm{E}$ \\
\hline CJK33.389 & Indonesia & Tempeh inoculum & - & 33 & $\mathrm{E}$ \\
\hline CJM29.344 & Indonesia & Tempeh inoculum & - & 33 & $\mathrm{E}$ \\
\hline CJK35.409 & Indonesia & Fresh tempeh & - & 33 & $\mathrm{E}$ \\
\hline Y49.577 & Indonesia & Tempeh inoculum & - & 33 & $\mathrm{E}$ \\
\hline Y52.613 & Indonesia & Tempeh inoculum & - & 33 & $\mathrm{E}$ \\
\hline CJG27.321 & Indonesia & Tempeh inoculum & - & 33 & $\mathrm{E}$ \\
\hline
\end{tabular}

Note:

Sporulation criteria (Based on Dolatabadi et al. 2014): Level (A-E) of sporulation.
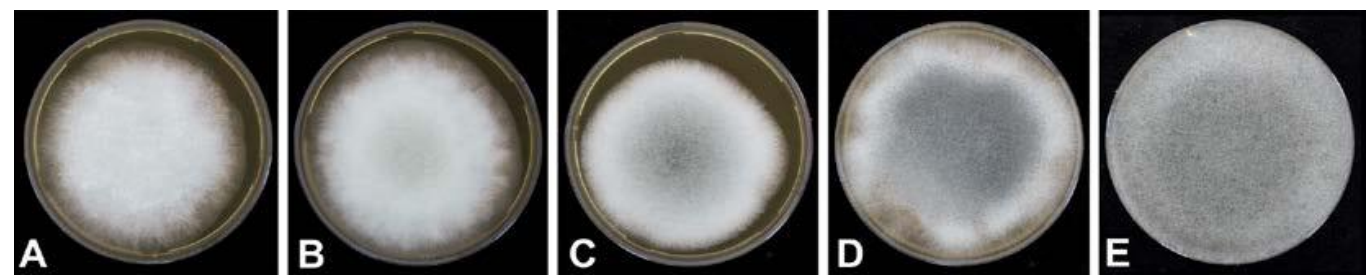


\section{Comparison between tempeh and clinical isolates by molecular similarity}
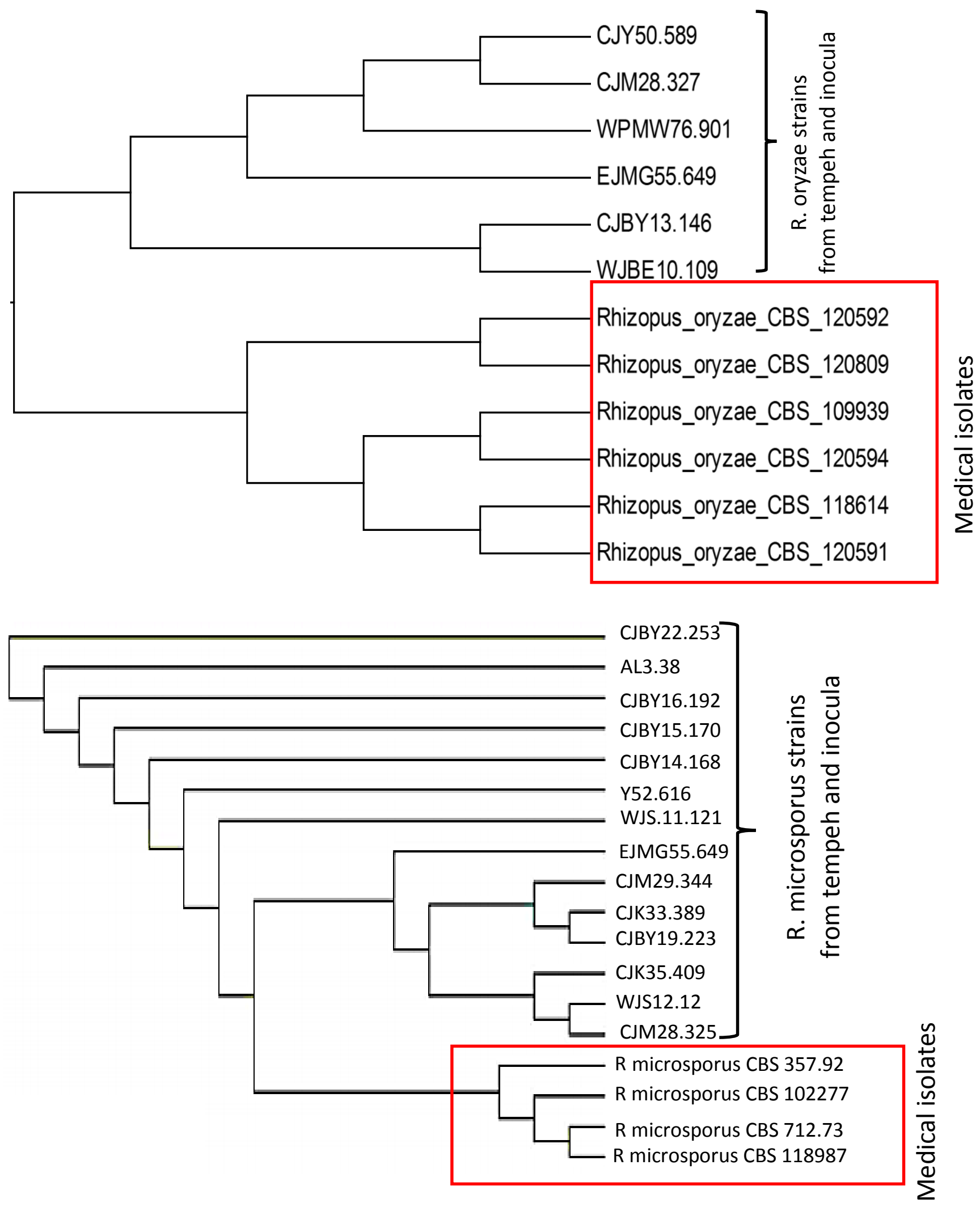

Figure 10. The tree was inferred from Actin sequence and constructed using maximum likelihood method. Numbers at nodes indicate levels of bootstrap support calculated from 1000 trees. 


\section{Detection of bacteria producing rhizonin}

Another threat to food safety associated with Rhizopus is posed by rhizoxin and rhizonin. None of these metabolites should be permitted to occur in foods, even at pico- or femtogram amounts, as they are toxic for human consumption. The compounds are however not produced by the fungus itself, but by symbiotic bacteria (Burkholderia rhizoxinica) that reside within the fungal cytosol (Lackner et al., 2009). Burkholderia is gram-negative, a rod-shaped endosymbiotic bacterium (Partida Martinez et al., 2007).

In this study, we used mechanical stress (pipetting) and physical stress (freezing-thawing) to break fungal mycelia and isolate any possible symbiotic bacteria. Samples were checked with plating in NA medium and checked with light microscopy. Only sample had bacterial colonies were then extracted its DNA and followed with amplification partial sequence 16S rRNA genes using the bacterial universal primers 27F (5' -AGAGTTTG ATCMTGGCTCAG) (Lane, 1991) and bacterial primer 1100R (5'-AGGGTTGCGCTCGTTG) (Turner et al., 1999). The identification result was shown in Table 7 and Figure 11. The physiological and biochemical characterization of the bacterium (including Gram staining, starch hydrolysis, Sulfide-Indole-Motility, nutrient gelatin, citrate, urease and catalase tests, growth on different media) are also tested and summarized in Table 6 . All bacteria detected as gram-negative, their cell were rod-shaped (Length: $3.21 \pm 0.40 \mu \mathrm{m}$ and Width: $0.55 \pm 0.12 \mu \mathrm{m}$ ), arranged singly or in pairs.

Table 6. Biochemical characteristics of isolated bacteria from tempeh fungi.

\begin{tabular}{lccc}
\hline Biochemical tests & $\begin{array}{c}\text { BMSR12, } \\
\text { BASC02 }\end{array}$ & BKSM1 & $\begin{array}{c}\text { BMSR10, } \\
\text { BBSC01 }\end{array}$ \\
\hline Gram staining & - & - & - \\
Starch hydrolysis & + & + & + \\
Sulfide & - & - & + \\
Indole & - & - & - \\
Motility & - & - & - \\
Nutrient gelatin stab & - & - & + \\
Citrate & + & - & - \\
Urease & - & + & + \\
Catalase 3\% & + & + & + \\
Growth on & & + & + \\
$6.5 \%$ NaCl & + & + & + \\
Nutrient broth & + & + & + \\
Starch agar & + & + & + \\
Pectine agar & + & & \\
Casein agar & + & & + \\
\hline
\end{tabular}


Table 7. Isolation of bacteria from tempeh fungi (zygomycetes strains)

\begin{tabular}{|c|c|c|c|c|c|}
\hline No & Fungal species & $\begin{array}{c}\text { Amount of tested } \\
\text { strains }\end{array}$ & $\begin{array}{c}\text { Postive fungal } \\
\text { containing } \\
\text { bacteria }\end{array}$ & $\begin{array}{c}\text { Result of 16S rRNA } \\
\text { sequence }\end{array}$ & $\begin{array}{l}\text { Additional } \\
\text { Information }\end{array}$ \\
\hline 1 & Rhizopus oryzae & 30 & $1(3.3 \%)$ & $\begin{array}{c}\text { Enterobacter } \\
\text { cloacae }\end{array}$ & $\begin{array}{l}\text { Non-rhizonin } \\
\text { producing bacteria }\end{array}$ \\
\hline 2 & R. microsporus & 30 & $1(3.3 \%)$ & $\begin{array}{l}\text { E cloacae, and } \\
\text { C. testosteroni }\end{array}$ & $\begin{array}{l}\text { Non-rhizonin } \\
\text { producing bacteria }\end{array}$ \\
\hline 3 & R. delemar & 30 & $1(3.3 \%)$ & $\begin{array}{l}\text { Ochrobacterum } \\
\text { intermedium }\end{array}$ & $\begin{array}{l}\text { Non-rhizonin } \\
\text { producing bacteria }\end{array}$ \\
\hline 4 & R. stolonifer & 10 & - & - & $\begin{array}{l}\text { Not found any } \\
\text { bacteria }\end{array}$ \\
\hline 5 & Mucor indicus & 5 & - & - & $\begin{array}{l}\text { Not found any } \\
\text { bacteria }\end{array}$ \\
\hline
\end{tabular}

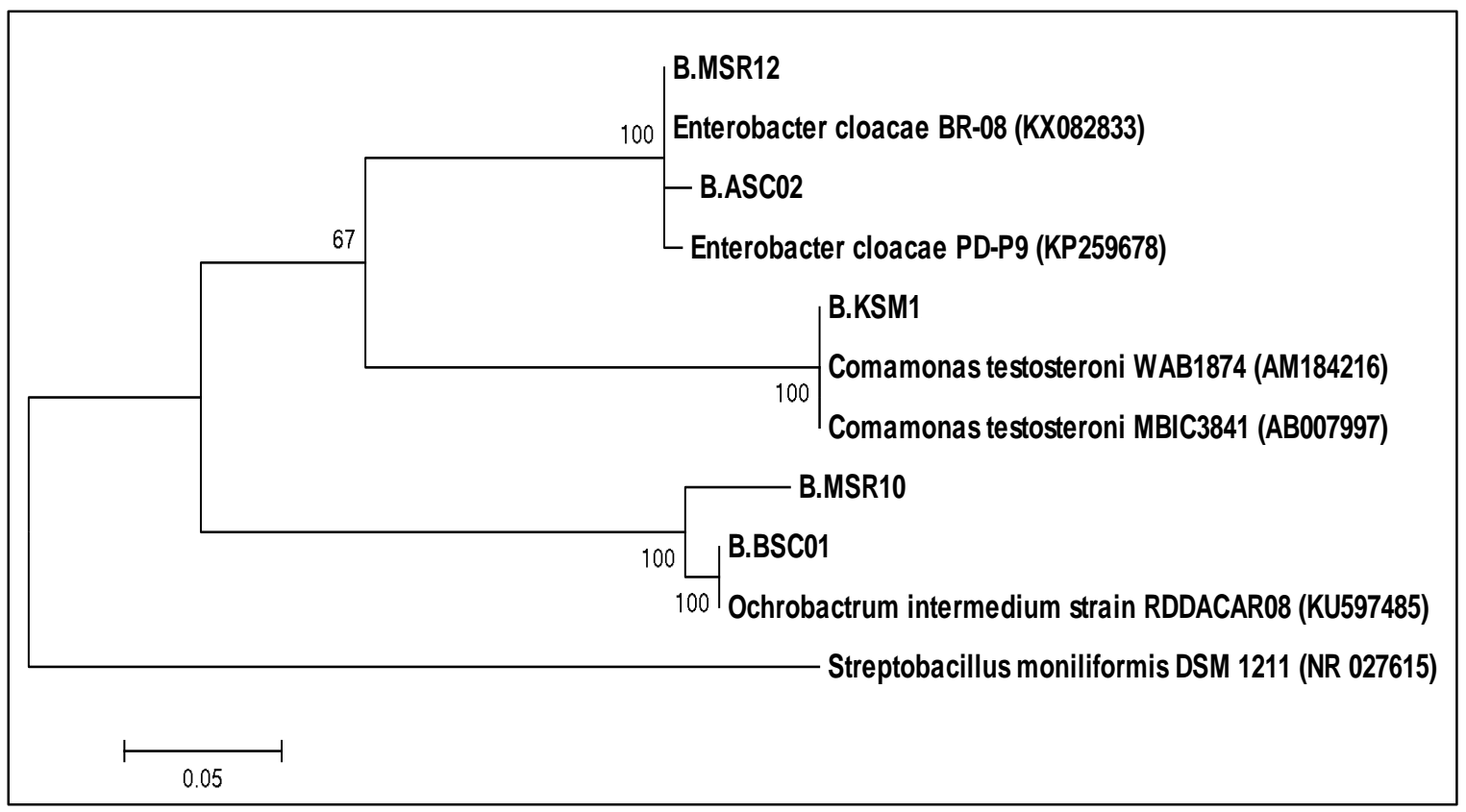

Figure 11. The tree was inferred from 16s RNA sequence and constructed using maximum likelihood method. Numbers at nodes indicate levels of bootstrap support calculated from 1000 trees.

The phylogenetic tree of the isolated bacteria is shown in Figure 11. Bacterial strains (BMSR12, BASC02), revealed 100\% identity with Enterobacter cloacae strain BR-08 and strain PD- P9. Bacterial strain (BKSM1), revealed 100\% identity with Comamonas testosteroni strain WA B1874 and MBIC3841. Bacterial strains (BMS10, BBSC01) showed 100\% identity with Ochrobactrum intermedium strain RDDACAR08. In this study, we could not find any Burkholderia species. Most of the tempeh fungi isolates are clean from any contamination of bacteria. Only three fungal samples were contaminated, those samples were isolated from fresh tempeh where produced at non-hygienic workshop in Java. Those bacteria known do not produce any harmful toxin. 


\subsection{Discussion of Part II (Safety status of tempeh fungi strains)}

In recent years the clinical range of the infections caused by zygomycetes has changed dramatically, because of the increase in the number of the immunocompromised patients (Meis and Chakrabarti, 2009). Most of the clinically important zygomycetes are in the order Mucorales and comprise approximately 60 genera. The genus Rhizopus exhibits the largest impact on mankind, being important in agriculture and industry and is furthermore the main causing agent of mucormycosis, followed by Lichtheimia and Mucor. The three genera are responsible for 70 to 80 $\%$ of the reported infections, predominantly as rhinocerebral, pulmonary or disseminated manifestations, and associated with high mortality rates (Skiada et al., 2011;Gomes et al., 2011). Roden et al. (2005) established that the most prevalent species were Rhizopus oryzae (nearly half of all isolates), followed by $R$. microsporus, Mucor circinelloides, Absidia (= Lichtheimia) corymbifera, Rhizomucor pusillus, Cunninghamella bertholletiae, Mucor indicus, Cunninghamella echinulata, and Apophysomyces elegans. Three recent retrospective studies carried out in the USA (Kontoyiannis et al., 2000, 2005; Sims et al., 2007) included a significant number of cases (24, 27 and 26, respectively). However, one of these (Sims et al., 2007) distinguished only between Mucor spp. and Rhizopus spp., and in the others two (Kontoyiannis et al., 2000), only the genera were mentioned (Cunninghamella, Mucor, Rhizopus, and Syncephalastrum).

The agents of mucormycosis are unable to penetrate through unbroken skin to produce cutaneous infection; however, burns, traumatic disruptions or macerations of the skin (Ledgard et al., 2008; Vega et al., 2006), insect bites or stings, (Lechevalier et al., 2008; Saravia-Flores et al., 2010), birds pecks (Wilson, 2008), traumatic inoculations (Andresen et al., 2005; Snell and Tavakoli, 2007), and any process of skin disruption can facilitate the implantation and colonization of tissues by the spores. Cutaneous infections can be very invasive, also affecting subcutaneous tissues and the adjacent fat, fascia, muscle, and finally bone. Besides, the fungus can affect deep solid organs by hematogenous dissemination. Gastrointestinal mucormycosis is very uncommon. The ingestion of food or fermented drinks contaminated with spores may play a role in promoting gastric infections and, although it is rare in humans, it can significantly affect animals, i.e. amphibians, bovines and rodents (Creeper et al., 1998; Jensen et al., 1994; Speare et al., 1997).

Rhizopus species also are among the mucoralean fungi that are most often involved in the production of Asian fermented foods, both as a natural invader of soybean-based condiments (Hong et al., 2012) and as starter culture (Nout and Rombouts, 1990). This study tried to answer current safety status of tempeh fungi from Indonesia. Tempeh fungi isolates were tested for their virulence potency and also checked for their possibility role as host for bacteria producing rhizoxin or rhizonin. Although nearly all patients with mucormycosis have severe underlying metabolic or innate immune disorders, this contrasting behavior and usage of Rhizopus species necessitate the development of methods to determine the intrinsic virulence of individual strains and comparative virulence between species. We used G. melonella as infection model. Larvae are bred commercially as live food for captive reptiles and amphibians. The larvae are the caterpillar stage 
of the moth, 1-2 cm in length and survive as supplied for up to 3 weeks before pupating. During this time they do not need feeding and require minimal maintenance. Infection is accompanied by the generation of melanin, which is available in the haemocoel and becomes deposited in tissues (Nappi and Christensen, 2005). Infected G. mellonella larvae change from their normal cream color to pale or dark brown.

Summary of overall test was shown in Table 8. Our result showed that Rhizopus isolates from tempeh did not display a virulence potential. Mortality rates at four days were found very low in the range 0-20\% at G. mellonella model. Many reports explained that mucormycosis agent from Rhizopus genera causes high mortality rate in range 80-100\% (Ribes et al., 2000; Dolatabadi et al., 2014), but this behavior not found in any tempeh fungal isolates. Tempeh fungal isolates are also non-thermotolerant and genetically distinct from medical isolates. They have high sporulation character in moderate temperature setting. The isolates have significant higher sporulation level than mucormycosis agent. These result indicated that tempeh fungal isolates are not mucormycosis agent. This is also in line with the facts that tempeh production and consumption have been practiced in Indonesia for centuries and, to our knowledge, there is no single report on mucormycosis case associated with tempeh.

Ribes et al. (2000) mentioned that from the mesophilic species of the genus Rhizopus, only $R$. stolonifer can be found in clinical settings, but is rarely seen; mostly as agents of allergic alveolitis or superficial infections but being predominantly non-invasive. Only thermotolerant species of $R$. arrhizus and $R$. microsporus are reported more frequently in severe infections than any other species from the Rhizopodaceae (Wimander et al. 1980, Scholer et al. 1983).

Table 8. Summary of safety status from tempeh fungi strains (zygomycetes isolates).

\begin{tabular}{|c|c|c|c|c|c|c|}
\hline No & Isolates & Amount & $\begin{array}{c}\text { Classified as } \\
\text { thermotolerance } \\
\text { strains* }\end{array}$ & Virulence test* & $\begin{array}{l}\text { Rhizonin } \\
\text { producing } \\
\text { bacteria }\end{array}$ & $\begin{array}{c}\text { Status } \\
\text { (food safety } \\
\text { perspective) }\end{array}$ \\
\hline \multirow[t]{2}{*}{1} & Rhizopus & 30 & None & Negative & Not found & Safe \\
\hline & oryzae & & & & & \\
\hline 2 & R. microsporus & 30 & None & Negative & Not found & Safe \\
\hline 3 & R. delemar & 30 & None & Negative & Not found & Safe \\
\hline 4 & R. stolonifer & 10 & None & Negative & Not found & Safe \\
\hline 5 & Mucor indicus & 5 & None & Negative & Not found & Safe \\
\hline \multicolumn{7}{|c|}{ Note: } \\
\hline
\end{tabular}

Another threat to food safety associated with Rhizopus is posed by rhizoxin and rhizonin. None of these metabolites should be permitted to occur in foods, even at pico- or femtogram amounts, as they are toxic for human consumption. The compounds are however not produced by the fungus itself, but by symbiotic bacteria (Burkholderia rhizoxinica) that reside within the fungal cytosol (Lackner et al., 2009). Burkholderia is a gram-negative, rod-shaped endosymbiotic 
bacterium (Partida Martinez et al., 2007). In this study, we used mechanical stress (pipetting) and physical stress (freezing-thawing) to break fungal mycelia and isolate any possible symbiotic bacteria from tempeh fungi isolates. Samples were checked with plating in NA medium and checked with light microscopy. Only sample had bacterial colonies were then extracted its DNA and followed with amplification partial sequence 16S rRNA genes using the bacterial universal primers 27F (5'-AGAGTTTG ATCMTGGCTCAG) (Lane, 1991) and bacterial primer 1100R (5'AGGGTTGCGCTCGTTG) (Turner et al., 1999).

We could not find any Burkholderia species from Indonesian tempeh fungi isolates. Most of them are clean from any contamination of bacteria. Only three fungal samples were contaminated, those samples were isolated from fresh tempeh where produced at non-hygienic workshop. Those bacteria known do not produce any harmful toxin, but they are classified as human pathogen causing gastroenteritis. They were identified as Enterobacter cloacae, Comamonas testosteron, and Ochrobactrum intermedium. More attention should be given since there were several gastroenteritis outbreaks regarding unpasteurized tempeh consumption reported recently in Indonesia.

In conclusion, tempeh fungi isolates are safe for human consumption since they are not mucormycosis agent or toxication agent. Indeed, there is no doubt to consume soybean-tempeh anymore. Attention only needs to be given to some tempeh-soybean producer that applied unhygienic practice in the production because we found few sample contaminated with bacteria classified as a human pathogen causing gastroenteritis. 


\subsection{Results of Part III (Zearalenone biotransformation by tempeh fungi)}

In this study, a total of 70 strains of fungal species from Part 1 that commonly found in tempeh fermentation were screened for Zearalenone (ZEN) metabolite formation in vitro (list of strains could be seen in supplemental Table 3). Nine different species were presented from the total strains; they are Rhizopus oryzae, $R$. delemar, $R$ microsporus, $R$. microsporus var. oligosporus, $R$. microsporus var. chinensis, Synchepalastrum racemosum, Aspergillus oryzae, Neurospora sitophila, and Neurospora crasssa. The fungal strains were isolated from inocula or fresh tempeh from different tempeh producers and market areas in Indonesia.

ZEN $(c=0.3 \mu \mathrm{M})$ was added to liquid cultures of the fungi. After two days of incubation, the media were analyzed for metabolite formation by HPLC-MS/MS. Semi-quantitative measurements were conducted for ZEN-14-S, $\alpha$-ZEL-S, ZEN-14-Glc, and ZEN-16-Glc. ZEN- 14$S$ and a-ZEL-S were determined using relative response factors of ZEN-14-S to ZEN and $\alpha$-ZEL$S$ to $\alpha$-ZEL. Response factors were estimated by comparing the MS/MS peak area before and after quantitative sulfate ester cleavage. ZEN and $\alpha$-ZEL were determined by external calibration using the commercially available standard substances. Matrix-matched calibration was applied for semiquantification of ZEN -14 -Glc and ZEN-16- Glc. Detail semi- quantification data can be seen in Supplemental Table 4.

The conjugate formation varied with the fungal strain. Interestingly, we found four main groups of fungi based on their ZEN metabolization type (Table 9). Their extracted ion chromatogram could be seen in Figure 13. Most of the samples belong to group 1 (36\%), followed by group 3 (27\%), group 4 (24\%), and group 2 (13\%). In group 1, strong decrease of ZEN, no (or only very small) formation of ZEN metabolites were observed. Unknown transformation products of ZEN may be formed because some fungal isolates rapidly reduced ZEN content without producing known metabolites. Seven different species from two genera (Rhizopus and Neurospora) gave contribution in this group. Reduction of ZEN was in range 69 to $96 \%$. In group 2, strong decrease of ZEN (95-100\%) and diverse formation of ZEN metabolites were found. Only species from Rhizopus genera belong to this group. In group 3, strong decrease of ZEN were detected (86-100\% reduction), ZEN-14-sulfate is the only formed metabolite (others in very small amounts). R. microsporus var. chinensis, Synchepalastrum racemosum, and Aspergillus oryzae strains contributed to this group. Five different species from two genera (Rhizopus and Synchepalastrum) gave contribution in this group. This result also showed that Rhizopus strains have ability to produce diverse ZEN transformation. This genera is more active on ZEN transformation compared to other genera tested in this study. Combination with geographical data revealed that all groups can be found in west area of Indonesia,and only group 1 can be found in central and east area of Indonesia as shown in Figure 12.

In most cultures ZEN-14-sulfate was the major metabolite accompanied (64\% of total samples) by rapid disappearance of ZEN; also, formation of $\alpha$ - and $\beta$-ZEL, ZEN-16-glucoside and two ZEL-sulfates has been observed. The in vitro-screening showed that fungal strains used in tempeh fermentation have the potential for ZEN conversion leading to ZEN and ZEL conjugate formation. 
Table 9. Categorization of tempeh fungi isolates based on ZEN metabolization types.

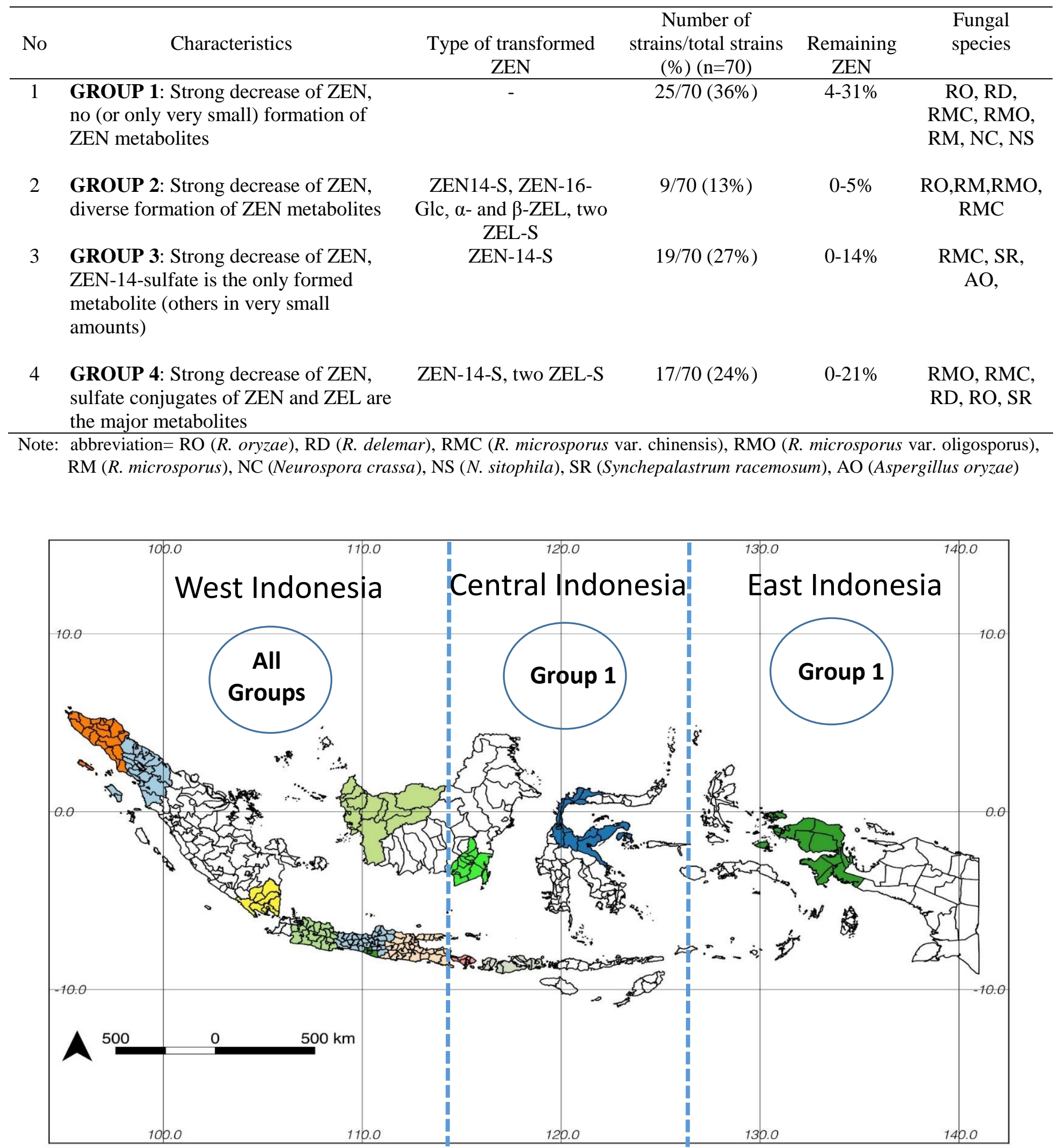

Figure 12. Distribution of tempeh fungi based on ZEN transformation ability 


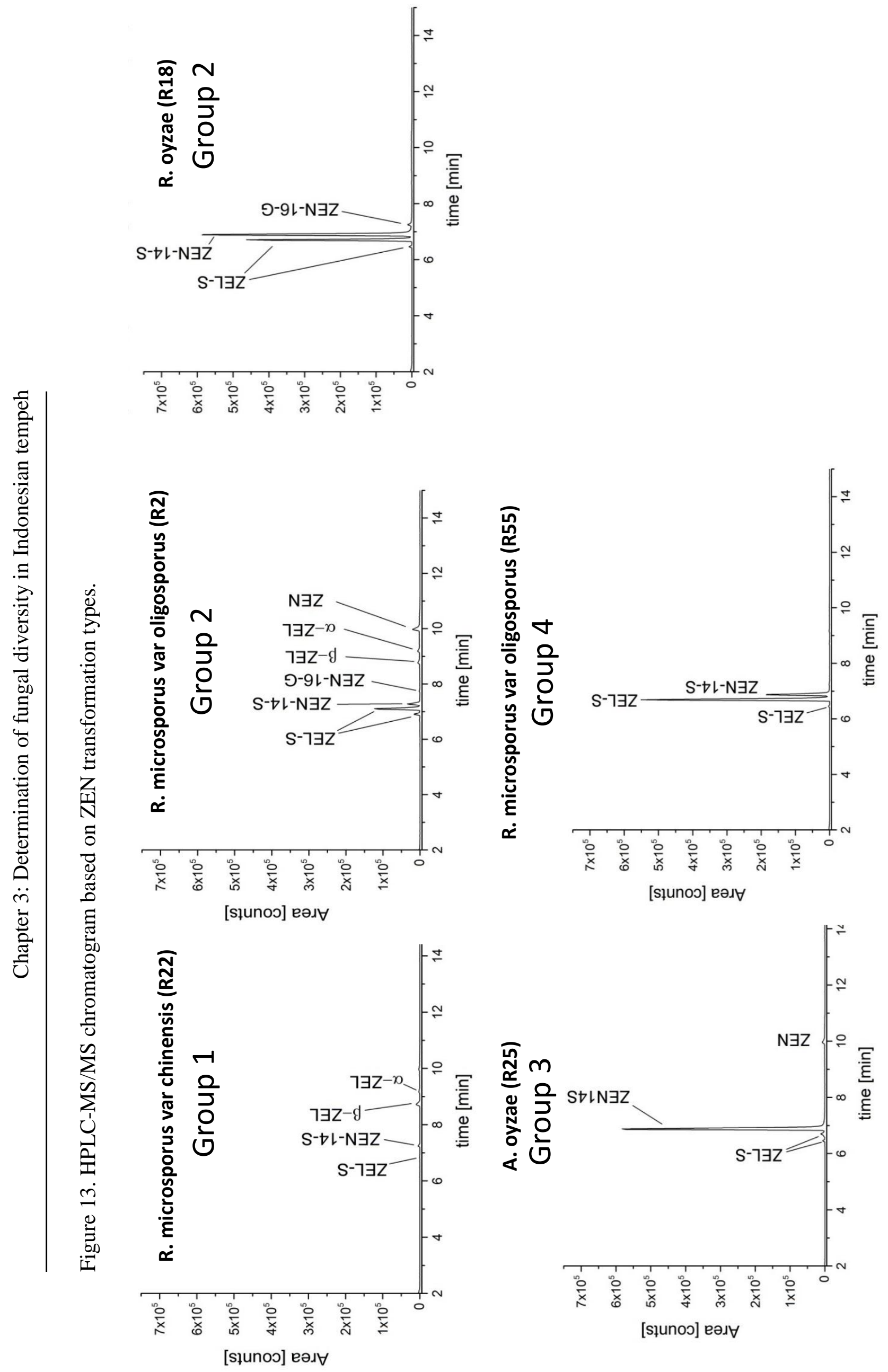




\subsection{Discussion of Part III (ZEN biotransformation by tempeh fungi isolates)}

The term "masked mycotoxin" was used for the first time in 1990, referring to a glycosidic derivative of zearalenone found in corn and cleaved to its parent compound in the gastrointestinal tract. Recently, masked mycotoxins defined as plant or fungal metabolites of mycotoxins that contaminate food and feed (Dellafiora et al., 2017). Gareis et al. (1990) referred to a zearalenoneglycoside as a masked mycotoxin to emphasize the fact that it was not detected by routine analysis of food because it has different chemical behaviors than the origin but possibly contributed to total mycotoxin and subsequent effect. This masked mycotoxin can be hydrolyzed to their precursors in the animal digestive tract, thus showing similar toxicity than free mycotoxins (Gareis et al. 1990; De Saeger and van Egmond, 2012; Gratz et al., 2016). This mycotoxin conjugate could be generated by infected host plant (Engelhardt et al., 1988; Kovalsky et al., 2014) and some fungal species such as Fusarium graminearum, Rhizopus arrhizus, Aspergillus niger, Rhizopus spp. and A. oryzae (El-Sharkawy et al., 1991; Plasencia and Mirocha, 1991; Berthiller et al. 2005; Jard et al., 2010; Brodehl et al., 2014) by transforming ZEN into different conjugated form. A variety of microorganisms like Penicillium sp., Rhodoturula sp., Arthrobacter sp., Saccharomyces sp., Candida sp. were also reported to be able to transform ZEA to $\alpha$-zearalenol and $\beta$-zearalenol (McMullen, 1977). In infected plant, ZEN is transformed into more polar derivatives by conjugation with sugars, amino acids, or sulfate groups, which are then isolated into the vacuoles (Gratz, 2017).

Due to the fact that conjugated ZEN derivatives can be efficiently hydrolyzed into their parent compound by human colonic microbiota (Dall'Erta et al., 2013; Kovalsky Paris et al., 2014), the exposure of ZEN might be underestimated. Because of its estrogenic effects that may lead to severe hormonal disorder and infertility, a tolerable daily intake (TDI) for ZEN of $0.25 \mu \mathrm{g} \mathrm{kg}^{-1}$ body weight has been established (Shier et al., 2001; EFSA, 2011). Besides conjugated ZEN products, reductive metabolites are formed in plant and fungal metabolism, for example, $\alpha$ - and $\beta$ ZEL. Whereas $\beta$-ZEL is less toxic than ZEN, $\alpha$-ZEL possesses an about 10 -fold higher estrogenicity than ZEN (Metzler et al., 2010). For further toxicological investigations of ZEN and ZEL conjugates, the availability of pure standard substances is required. Very recently, the EUCONTAM Panel found it appropriate to set a group tolerable daily intake (TDI) expressed as ZEN equivalents for ZEN and its modified forms (phase I and phase II metabolites).

Zearalenone (ZEN) and its metabolites such as the phase II sulfate and glucoside conjugates have been detected in food and feed commodities (Berthiller et al., 2005; Vendl et al., 2010; De Boevre et al., 2012; Kovalsky et al., 2016). In addition to these naturally occurring ZEN conjugates, food fermentation by fungi may also lead to conjugate formation. Fungal strains of the genera Rhizopus and Aspergillus are used in tempeh fermentation, and it is known that some strains can conjugate ZEN. Moreover, during this process the reductive phase I metabolites $\alpha$ - and $\beta$ zearalenol $(\alpha-\beta-Z E L)$ and their conjugates are formed by the same microorganisms in vitro. In present study, a total of 70 food-grade strains of fungal species (partly from Part I) that commonly found in tempeh fermentation were screened for Zearalenone (ZEN) metabolite formation in vitro 
(list of strains could be seen in supplemental Table 3). Nine different species were presented from the total strains; they are Rhizopus oryzae, $R$. delemar, $R$ microsporus, $R$. microsporus var. oligosporus, $R$. microsporus var. chinensis, Synchepalastrum racemosum, Aspergillus oryzae, Neurospora sitophila, and Neurospora crasssa. The fungal strains were isolated from inocula or fresh tempeh from different tempeh producers and market areas in Indonesia.

ZEN $(c=0.3 \mu \mathrm{M}$ ) was added to liquid cultures of the fungi. After two days of incubation the media were analyzed for metabolite formation by HPLC-MS/MS. An assessment of the formed metabolite quantity is hampered by the lack of analytical standards of sufficient purity. To get an approximate idea of the quantitative dimensions of ZEN conversion, a semi-quantification of the formed ZEN metabolites was carried out. Semi-quantitative measurements were conducted for ZEN-14-S, $\alpha$-ZEL-S, ZEN-14-Glc, and ZEN-16-Glc. ZEN-14-S and a-ZEL-S were determined using relative response factors of ZEN-14-S to ZEN and $\alpha$-ZEL-S to $\alpha$-ZEL. Response factors were estimated by comparing the MS/MS peak area before and after quantitative sulfate ester cleavage. The resulting response factors (i.e., peak area of conjugate divided by peak area of the free form) are 11 for ZEN-14-S compared to ZEN and 16 for a-ZEL-S compared to a-ZEL. These data are in accordance with previously published findings, stating that for ESI-MS analysis, ZENsulfate is detectable even at very low levels caused by its high ionization efficiency (Vendl et al., 2010). ZEN and $\alpha$-ZEL were determined by external calibration using the commercially available standard substances. Matrix-matched calibration was applied for semi-quantification of ZEN-14Glc and ZEN-16-Glc.

The conjugate formation varied with the fungal strain. Interestingly, we found four main groups of fungi based on their ZEN metabolization type (Table 10). Their extracted ion chromatogram could be seen in Figure 13. Most of the samples belong to group 1 (36\%), followed by group $3(27 \%)$, group 4 (24\%), and group $2(13 \%)$. In group 1, strong decrease of ZEN, no (or only very small) formation of ZEN metabolites were observed. Unknown transformation products of ZEN may be formed, because some fungal isolates rapidly reduced ZEN content without producing known metabolites. Seven different species from two genera (Rhizopus and Neurospora) gave contribution in this group. Reduction of ZEN was in range 69 to $96 \%$. In group 2, strong decrease of ZEN (95-100\%) and diverse formation of ZEN metabolites were found. Only species from Rhizopus genera belong to this group. In group 3, strong decrease of ZEN was detected (86-100\% reduction), ZEN-14-sulfate is the only formed metabolite (others in very small amounts). R. microsporus var. chinensis, Synchepalastrum racemosum, and Aspergillus oryzae strains contributed to this group. Five different species from two genera (Rhizopus and Synchepalastrum) gave contribution in this group. This result also showed that Rhizopus strains have ability to produce diverse ZEN transformation. This genera is more active in ZEN transformation compared to other genera tested in this study. The results are in accordance with Varga et al. (2005) who observed a decrease in ZEN concentration in liquid culture of numerous strains of the species $R$. stolonifer, $R$. oryzae, and $R$. microsporus (Varga et al., 2005). Combination with geographical data revealed that all groups can be found in west area of Indonesia, and only group 1 can be found in central and east part of Indonesia. 
The glycosylation of ZEN could be observed from the strains especially in group 2. ZEN14-Glc is known to be a natural metabolite formed by Rhizopus species (Kamimura, 1986). Also, the formation of ZEN- 16-Glc, a substance discovered by Berthiller and coworkers (Kovalsky Paris et al., 2014). In most cultures ZEN-14-sulfate was the major metabolite accompanied (64\% of total samples) by rapid disappearance of ZEN; also, formation of $\alpha$ - and $\beta$-ZEL, ZEN-16glucoside and two ZEL-sulfates has been observed. A recent study by Kovalsky Paris et al. (2014) has reported the conversion of ZEN into a mixture of ZEN-14-O-b-glucoside (ZEN-14-Glc) and ZEN-16-O-b-glucoside (ZEN-16-Glc) in barley. Studies on the metabolism of ZEN by Rhizopus and Thamnidium species have shown the formation of ZEN-14-Glc and ZEN-14,16-O-bdiglucoside (Kamimura, 1986; El-Sharkawy, 1989). ZEN-14- sulfate (ZEN-14-S) was found to be a natural metabolite of Fusarium graminearum, Rhizopus arrhizus, and Aspergillus niger (ElSharkawy et al., 1991; Plasencia and Mirocha, 1991; Jard et al., 2010). To date, a-ZEL-S has not been described as a microbial metabolite. As the cleavage of ZEN from its sulfate and glucose conjugates was shown recently (Dall'Erta et al., 2013; Kovalsky Paris et al., 2014). All these derivatives are not covered by most routine analysis due to the lack of the pure compounds. The development of reference standards is required to allow for the quantitative measurement of ZEN metabolites. We consider the exploitation of the metabolic capabilities of the fungi demonstrated in our study as an option for providing such standards.

In conclusion, fungal strains used in production of tempeh in Indonesia could convert ZEN to conjugated ZEN and ZEL derivatives in vitro. This study showed that the investigated fungal strains have a high potential for ZEN conjugation by metabolic processes. These transformations may also occur during fermentation of tempeh. As the conjugates can be hydrolyzed by human intestinal microbiota, also sulfates and glucosides represent a relevant source for the human exposure to ZEN. If the unprocessed grains for tempeh fermentation like mix soybeans-maize are contaminated with ZEN, upon analysis ZEN content of the final tempeh product may be underestimated, because ZEN has been conjugated during food processing. Thus, transformation products of ZEN in authentic tempeh should also be analyzed. Reference substances of ZEN conjugates are urgently needed for monitoring food safety of tempeh and other fermented products manufactured from grains that can be contaminated with ZEN. It must be taken into account that the estrogenic potency of ZEN derivatives differ. Potency factors assigned to these derivatives by EFSA CONTAM Panel are 0.2 for $\beta$-ZEL and $\beta$-ZEL-sulfate but 60 for $\alpha$-ZEL and $\alpha$ ZEL-sulfate. 


\section{Conclusion}

The present study revealed the following points:

- The moulds isolated from tempeh and inocula in this study were broadly represented by nine genera. In total, 557 fungi and five fungi-like isolates were obtained from 247 samples. Rhizopus was the most frequently detected genera, found in $84 \%$ of total samples, followed by Mucor (5.5\%), Neurospora (4.1\%) and Syncephalastrum (3\%). Other very minor genera that found as contaminants were Chaetomium, Phoma, Acremonium, Aspergillus, and Geotrichum (less than $1 \%)$. With detail morphological, growth and physiological criteria, we succesfully identified tempeh fungi into four main groups, but we failed to identify $R$. microsporus-group into variety level with only those criteria.

- RAPD typing was capable of producing discriminating DNA fingerprints of Rhizopus isolates and indicated there was genetic differences among them. Many distinct patterns were observed indicating that tempeh and inocula from different location in Indonesia composed of a quite wide number of strains.

- Combination of origin or geographical data and molecular identification showed that isolates (identified as Rhizopus oryzae, $R$. delemar, and $R$. stolonifer) dominantly used by tempeh producer from outside Java, whereas isolates (Rhizopus microsporus complex isolates, identified as $R$. microsporus var. chinensis, $R$. microsporus var. microsporus and $R$. microsporus var. oligosporus) were mostly used by tempeh producer from Java.

- Tempeh fungi isolates are safe for human consumption since they are not mucormycosis agent or toxication agent. Indeed, there is no doubt to consume soybean-tempeh anymore. Attention just needs to be given to some tempeh producer that applied unhygienic practice in tempeh production because we found few sample contaminated with bacteria classified as human pathogen causing gastroenteritis.

- Fungal strains used in production of tempeh in Indonesia could convert ZEN to conjugated ZEN and ZEL derivatives in vitro. These transformations may also occur during fermentation of tempeh. If the unprocessed grains for tempeh fermentation like mix soybeans-maize are contaminated with ZEN, upon analysis ZEN content of the final tempeh product may be underestimated, because ZEN has been conjugated during food processing.

\section{Acknowledgement}

This research was supported financially by Indonesia Endowment Fund for Education, Ministry of Finance, The Republic of Indonesia (Ref:1064/LPDP/2013). 


\section{References}

Abe, A., Asano, K. and Sone, T., 2010. A molecular phylogeny-based taxonomy of the genus Rhizopus. Bioscience, biotechnology, and biochemistry, 74(7), pp.1325-1331.

Abe, A., Oda, Y., Asano, K. and Sone, T., 2007. Rhizopus delemar is the proper name for Rhizopus oryzae fumaricmalic acid producers. Mycologia, 99(5), pp.714-722.

Benny, G.L., 1995. Classical morphology in zygomycete taxonomy. Canadian journal of botany, 73(S1), pp.725-730.

Berthiller, F., Dall'Asta, C., Schuhmacher, R., Lemmens, M., Adam, G. and Krska, R., 2005. Masked mycotoxins: determination of a deoxynivalenol glucoside in artificially and naturally contaminated wheat by liquid chromatography- tandem mass spectrometry. Journal of agricultural and food chemistry, 53(9), pp.3421-3425

Brodehl, A., Möller, A., Kunte, H.J., Koch, M. and Maul, R., 2014. Biotransformation of the mycotoxin zearalenone by fungi of the genera Rhizopus and Aspergillus. FEMS microbiology letters, 359(1), pp.124-130.

Burke, R. and Cairney, J., 2002. Laccases and other polyphenol oxidases in ecto-and ericoid mycorrhizal fungi. Mycorrhiza, 12(3), pp.105-116.

Certik, M. and Shimizu, S., 1999. Biosynthesis and regulation of microbial polyunsaturated fatty acid production. Journal of bioscience and bioengineering, 87(1), pp.1-14.

Creeper, J.H., Main, D.C., Berger, L., Huntress, S. and Boardman, W., 1998. An outbreak of mucormycosis in slender tree frogs (Litoria adelensis) and white-lipped tree frogs (Litoria infrafrenata). Australian veterinary journal, 76(11), pp.761-762.

Dall'Erta, A., Cirlini, M., Dall'Asta, M., Del Rio, D., Galaverna, G. and Dall'Asta, C., 2013. Masked mycotoxins are efficiently hydrolyzed by human colonic microbiota releasing their aglycones. Chemical research in toxicology, 26(3), pp.305-312.

De Saeger, S. and van Egmond, H., 2012. Special issue: masked mycotoxins. World mycotoxin journal, 5(3), pp.203206.

De Boevre, M., Di Mavungu, J.D., Landschoot, S., Audenaert, K., Eeckhout, M., Maene, P., Haesaert, G. and De Saeger, S., 2012. Natural occurrence of mycotoxins and their masked forms in food and feed products. World mycotoxin journal, 5(3), pp.207-219.

Dellafiora, L., Galaverna, G., Righi, F., Cozzini, P. and Dall'Asta, C., 2017. Assessing the hydrolytic fate of the masked mycotoxin zearalenone-14-glucoside-A warning light for the need to look at the "maskedome". Food and chemical toxicology, 99, pp.9-16.

Dewi, R.S. and Azis, S., 2011. Isolasi Rhizopus oligosporus pada beberapa inokulum tempe di Kabupaten Banyumas. Molekul, 6(2), pp.93-104.

Doggett, J.S. and Wong, B., 2014. Mucormycosis. In Endocrine Emergencies (pp. 57-63). Humana Press.

Dolatabadi, S., Hoog, G.S., Meis, J.F. and Walther, G., 2014. Species boundaries and nomenclature of Rhizopus arrhizus (syn. R. oryzae). Mycoses, 57(s3), pp.108-127.

Dolatabadi, S., Walther, G., Van Den Ende, A.G. and de Hoog, G.S., 2014. Diversity and delimitation of Rhizopus microsporus. Fungal diversity, 64(1), pp.145-163.

Dolatabadi, S., Scherlach, K., Figge, M., Hertweck, C., Dijksterhuis, J., Samson, R.A., Menken, S.B. and de Hoog, G.S., 2015. Food preparation with potentially unsafe fungi: a new biosafety issue?. Mucorales between food and infection, p.151.

Donnelly, S.M., Sullivan, D.J., Shanley, D.B. and Coleman, D.C., 1999. Phylogenetic analysis and rapid identification of Candida dubliniensis based on analysis of ACT1 intron and exon sequences. Microbiology, 145(8), pp.18711882.

Dwidjoseputro, D. and Wolf, F.T., 1970. Microbiological studies of Indonesian fermented foodstuffs. Mycopathologia, 41(3), pp.211-222.

EFSA Panel, E.C., 2011. Scientific Opinion on the risks for public health related to the presence of zearalenone in food. EFSA journal, 9(2).

El-Sharkaway, S.H., Selim, M.I., Afifi, M.S. and Halaweish, F.T., 1991. Microbial transformation of zearalenone to a zearalenone sulfate. Applied and environmental microbiology, 57(2), pp.549-552.

Engelhardt, G., Zill, G., Wohner, B. and Wallnöfer, P.R., 1988. Transformation of the Fusarium mycotoxin zearalenone in maize cell suspension cultures. Naturwissenschaften, 75(6), pp.309-310.

Fallon, J., Kelly, J. and Kavanagh, K., 2012. Galleria mellonella as a model for fungal pathogenicity testing. HostFungus interactions: methods and protocols, pp.469-485.

Feng, X.M., Passoth, V., Eklund-Jonsson, C., Alminger, M.L. and Schnürer, J., 2007. Rhizopus oligosporus and yeast co-cultivation during barley tempeh fermentation-nutritional impact and real-time PCR quantification of fungal growth dynamics. Food microbiology, 24(4), pp.393-402. 
Gareis, M., Bauer, J., Thiem, J., Plank, G., Grabley, S. and Gedek, B., 1990. Cleavage of Zearalenone-Glycoside, a "Masked" Mycotoxin, during Digestion in Swine. Journal of veterinary medicine, Series B, 37(1-10), pp.236240.

Ghosh, B. and Ray, R.R., 2011. Current commercial perspective of Rhizopus oryzae: a review. J. Appl. Sci., 11(14), pp.2470-2486.

Gomes, M.Z., Lewis, R.E. and Kontoyiannis, D.P., 2011. Mucormycosis caused by unusual mucormycetes, nonRhizopus,-Mucor, and-Lichtheimia species. Clinical microbiology reviews, 24(2), pp.411-445.

Gratz, S.W., Dinesh, R., Yoshinari, T., Holtrop, G., Richardson, A.J., Duncan, G., MacDonald, S., Lloyd, A. and Tarbin, J., 2016. Masked trichothecene and zearalenone mycotoxins withstand digestion and absorption in the upper GI tract but are efficiently hydrolyzed by human gut microbiota in vitro. Molecular nutrition \& food research.

Gratz, S.W., 2017. Do Plant-Bound Masked Mycotoxins Contribute to Toxicity?. Toxins, 9(3), p.85.

Heckman, D.S., Geiser, D.M., Eidell, B.R., Stauffer, R.L., Kardos, N.L. and Hedges, S.B., 2001. Molecular evidence for the early colonization of land by fungi and plants. Science, 293(5532), pp.1129-1133.

Hesseltine, C.W., 1965. A millennium of fungi, food, and fermentation. Mycologia, 57(2), pp.149-197.

Hesseltine, C. W. and Ellis, J.J., 1973. Mucorales. The Fungi: An Advanced Treatise. Vol. 4B: A Taxonomic Review with Keys: Basidiomycetes and Lower Fungi. G. C. Ainsworth, F. K. Sparrow, and A. S. Sussman, Academic Press, London, 187-217.

Hiol, A., Jonzo, M.D., Rugani, N., Druet, D., Sarda, L. and Comeau, L.C., 2000. Purification and characterization of an extracellular lipase from a thermophilic Rhizopus oryzae strain isolated from palm fruit. Enzyme and microbial technology, 26(5), pp.421-430.

Inui, T., Takeda, Y. and Iizuka, H., 1965. Taxonomical studies on genus Rhizopus. The journal of general and applied microbiology, 11(Supplement), pp.1-121.

Jard, G., Liboz, T., Mathieu, F., Guyonvarc'h, A., André, F., Delaforge, M. and Lebrihi, A., 2010. Transformation of zearalenone to zearalenone-sulfate by Aspergillus spp. World mycotoxin journal, 3(2), pp.183-191.

Jensen, H.E., Olsen, S.N. and Aalbaek, B., 1994. Gastrointestinal aspergillosis and zygomycosis of cattle. Veterinary pathology, 31(1), pp.28-36.

Kaerger, K., Schwartze, V.U., Dolatabadi, S., Nyilasi, I., Kovács, S.A., Binder, U., Papp, T., Hoog, S.D., Jacobsen, I.D. and Voigt, K., 2015. Adaptation to thermotolerance in Rhizopus coincides with virulence as revealed by avian and invertebrate infection models, phylogeny, physiological and metabolic flexibility. Virulence, 6(4), pp.395-403.

Kamimura, H., 1986. Conversion of zearalenone to zearalenone glycoside by Rhizopus sp. Applied and environmental microbiology, 52(3), pp.515-519.

Khare, S.K. and Nakajima, M., 2000. Immobilization of Rhizopus japonicus lipase on celite and its application for enrichment of docosahexaenoic acid in soybean oil. Food chemistry, 68(2), pp.153-157.

Kovalsky Paris, M.P., Schweiger, W., Hametner, C., Stückler, R., Muehlbauer, G.J., Varga, E., Krska, R., Berthiller, F. and Adam, G., 2014. Zearalenone-16-O-glucoside: a new masked mycotoxin. Journal of agricultural and food chemistry, 62(5), pp.1181-1189.

Kovalsky, P., Kos, G., Nährer, K., Schwab, C., Jenkins, T., Schatzmayr, G., Sulyok, M. and Krska, R., 2016. Cooccurrence of regulated, masked and emerging mycotoxins and secondary metabolites in finished feed and maize: An extensive survey. Toxins, 8(12), p.363.

Kumar, S., Stecher, G. and Tamura, K., 2016. MEGA7: Molecular Evolutionary Genetics Analysis version 7.0 for bigger datasets. Molecular biology and evolution, 33(7), pp.1870-1874.

Lackner, G. and Hertweck, C., 2011. Impact of endofungal bacteria on infection biology, food safety, and drug development. PLoS Pathog., 7(6), p.e1002096.

Lane, D.J. 1991. 16S/23S rRNA sequencing. In: Nucleic acid techniques in bacterial systematics. Stackebrandt, E. and Goodfellow, M., eds., John Wiley and Sons, New York, NY: 115-175.

Lechevalier, P., Hermoso, D.G., Carol, A., Bonacorsi, S., Ferkdadji, L., Fitoussi, F., Lortholary, O., Bourrillon, A., Faye, A., Dannaoui, E. and Angoulvant, F., 2008. Molecular diagnosis of Saksenaea vasiformis cutaneous infection after scorpion sting in an immunocompetent adolescent. Journal of clinical microbiology, 46(9), pp.3169-3172.

Ledgard, J.P., van Hal, S. and Greenwood, J.E., 2008. Primary cutaneous zygomycosis in a burns patient: a review. Journal of burn care \& research, 29(2), pp.286-290.

Liou, G-Y., Chen, C-C., Chien, C-Y. and Hsu, W.H., 1991. Sporangiospore ornamentation of some species in the genus Rhizopus. Transactions of the mycological society of Japan, 32: 535-540. 
Maas, R.H., Springer, J., Eggink, G. and Weusthuis, R.A., 2008. Xylose metabolism in the fungus Rhizopus oryzae: effect of growth and respiration on $\mathrm{L}(+)$-lactic acid production. Journal of industrial microbiology \& biotechnology, 35(6), pp.569-578.

McMullen, J.R., 1977. Microbiological reduction of zearalenone and related compounds. U.S. patent 4,004,978

Mandyam, K., Loughin, T. and Jumpponen, A., 2010. Isolation and morphological and metabolic characterization of common endophytes in annually burned tallgrass prairie. Mycologia, 102(4), pp.813-821.

Meis, J.F. and Chakrabarti, A., 2009. Changing epidemiology of an emerging infection: zygomycosis. Clinical microbiology and infection, 15(s5), pp.10-14.

Mertens, J.A., Skory, C.D. and Ibrahim, A.S., 2006. Plasmids for expression of heterologous proteins in Rhizopus oryzae. Archives of microbiology, 186(1), pp.41-50.

Metzler, M., Pfeiffer, E. and Hildebrand, A., 2010. Zearalenone and its metabolites as endocrine disrupting chemicals. World mycotoxin journal, 3(4), pp.385-401.

Nappi, A.J. and Christensen, B.M., 2005. Melanogenesis and associated cytotoxic reactions: applications to insect innate immunity. Insect biochemistry and molecular biology, 35(5), pp.443-459.

Nawange, S.R., Singh, S.M., Naidu, J., Jain, S., Nagpal, T., Behrani, D.S., Mellado, E. and Tudela, J.R., 2012. Zygomycosis caused by Rhizopus microsporus and Rhizopus oryzae in Madhya Pradesh (MP) Central India: a report of two cases. Mycopathologia, 174(2), pp.171-176.

Nout, M.J.R. and Rombouts, F.M., 1990. Recent developments in tempe research. Journal of applied microbiology, 69(5), pp.609-633.

Oda, Y., Yonetsu, A., Urakami, T. and Tonomura, K., 2000. Degradation of polylactide by commercial proteases. Journal of polymers and the environment, 8(1), pp.29-32.

Omosebi, M.O. and Otunola, E.T., 2013. Preliminary studies on tempeh flour produced from three different Rhizopus species. Int. J. Biotechnol. Food Sci., 1(90), p.e6.

Papp, T., Vastag, M., Michailides, T.J., Ferenczy, L. and Vágvölgyi, C., 2001. Genetic variability of the postharvest pathogen Gilbertella persicaria: identification of randomly amplified polymorphic DNA (RAPD) markers correlating with (+) and (-) mating types. Antonie van Leeuwenhoek, 80(3), pp.301-309.

Partida-Martinez, L.P., Groth, I., Schmitt, I., Richter, W., Roth, M. and Hertweck, C., 2007. Burkholderia rhizoxinica sp. nov. and Burkholderia endofungorum sp. nov., bacterial endosymbionts of the plant-pathogenic fungus Rhizopus microsporus. International journal of systematic and evolutionary microbiology, 57(11), pp.25832590.

Plasencia, J. and Mirocha, C.J., 1991. Isolation and characterization of zearalenone sulfate produced by Fusarium spp. Applied and environmental microbiology, 57(1), pp.146-150.

Prihatna, C. and Suwanto, A., 2007. Phenotypic, metabolic, and genetic diversity of the Indonesian isolates of Rhizopus oligosporus. Microbiology Indonesia, 1(1), p.7.

Ribes, J.A., Vanover-Sams, C.L. and Baker, D.J., 2000. Zygomycetes in human disease. Clinical microbiology reviews, 13(2), pp.236-301.

Roden, M.M., Zaoutis, T.E., Buchanan, W.L., Knudsen, T.A., Sarkisova, T.A., Schaufele, R.L., Sein, M., Sein, T., Chiou, C.C., Chu, J.H. and Kontoyiannis, D.P., 2005. Epidemiology and outcome of zygomycosis: a review of 929 reported cases. Clinical infectious diseases, 41(5), pp.634-653.

Rohm, B., Scherlach, K., Möbius, N., Partida-Martinez, L.P. and Hertweck, C., 2010. Toxin production by bacterial endosymbionts of a Rhizopus microsporus strain used for tempe/sufu processing. International journal of food microbiology, 136(3), pp.368-371.

Samson, R.A., Houbraken, J., Thrane, U., Frisvad, J.C. and Andersen, B., 2010. Food and indoor fungi. CBS-KNAW Fungal Biodiversity Centre.

Saono, S., Gandjar, Indrawati, Basuki, T. and Karsono, H., 1974. Mycoflora of" ragi" and some other traditional fermented foods of Indonesia. In Annales bogorienses (Vol. 5, No. 4, pp. 187-204).

Saravia-Flores, M., Guaran, D.M. and Argueta, V., 2010. Invasive cutaneous infection caused by Apophysomyces elegans associated with a spider bite. Mycoses, 53(3), pp.259-261.

Scherlach, K., Partida-Martinez, L.P., Dahse, H.M. and Hertweck, C., 2006. Antimitotic rhizoxin derivatives from a cultured bacterial endosymbiont of the rice pathogenic fungus Rhizopus microsporus. Journal of the American chemical society, 128(35), pp.11529-11536.

Schipper, M.A.A., 1973. A study on variability in Mucor hiemalis and related species. Stud. Mycol. 4, 1-40.

Schipper, M.A.A. and Stalpers, J.A., 1984. A revision of the genus Rhizopus. 2. The Rhizopus microsporus group. Stud. Mycol., 25:20-34.

Scholer, H.J., Muller, E. and Schipper, M.A.A., 1983. Mucorales. Fungi pathogenic for humans and animals, part A. Biology. Marcel Dekker, New York, NY, pp.9-59.Producing rhizonin 
Schwarz, P., Bretagne, S., Gantier, J.C., Garcia-Hermoso, D., Lortholary, O., Dromer, F. and Dannaoui, E., 2006. Molecular identification of zygomycetes from culture and experimentally infected tissues. Journal of clinical microbiology, 44(2), pp.340-349.

Shier, W.T., Shier, A.C., Xie, W. and Mirocha, C.J., 2001. Structure-activity relationships for human estrogenic activity in zearalenone mycotoxins. Toxicon, 39(9), pp.1435-1438.

Shurtleff, W. and Aoyagi, A., 1979. The book of tempeh. Soyinfo Center.

Sims, C.R. and Ostrosky-Zeichner, L., 2007. Contemporary treatment and outcomes of zygomycosis in a nononcologic tertiary care center. Archives of medical research, 38(1), pp.90-93.

Skiada, A., Pagano, L.I., Groll, A., Zimmerli, S., Dupont, B., Lagrou, K., Lass-Florl, C., Bouza, E., Klimko, N., Gaustad, P. and Richardson, M., 2011. Zygomycosis in Europe: analysis of 230 cases accrued by the registry of the European Confederation of Medical Mycology (ECMM) Working Group on Zygomycosis between 2005 and 2007. Clinical microbiology and infection, 1;17(12):1859-67.

Sneath, P.H.A. and Sokal, R.R., 1973. Numerical Taxonomy. W.H. Freeman, San Fransisco, US.

Snell, B.J. and Tavakoli, K., 2007. Necrotizing fasciitis caused by Apophysomyces elegans complicating soft-tissue and pelvic injuries in a tsunami survivor from Thailand. Plastic and reconstructive surgery, 119(1), pp.448449.

Speare, R., Berger, L., O'Shea, P., Ladds, P.W. and Thomas, A.D., 1997. Pathology of mucormycosis of cane toads in Australia. Journal of wildlife diseases, 33(1), pp.105-111.

Steinkraus, K.H., Hwa, Y.B., Buren, J.P., Provvidenti, M.I. and Hand, D.B., 1960. Studies on tempeh-an Indonesian fermented soybean food. Journal of food science, 25(6), pp.777-788.

Turner, S., Pryer, K.M., Miao, V.P.W. and Palmer, J.D. 1999. Investigating deep phylogenetic relationships among cyanobacteria and plastids by small subunit rRNA sequence analysis, Journal of eukaryotic microbiology, 46: 327-338.

Varga, J., Péteri, Z., Tábori, K., Téren, J. and Vágvölgyi, C., 2005. Degradation of ochratoxin A and other mycotoxins by Rhizopus isolates. International journal of food microbiology, 99(3), pp.321-328.

Vastag, M., Papp, T., Kasza, Z. and Vagvolgyi, C., 2000. Intraspecific variation in two species of Rhizomucor assessed by random amplified polymorphic DNA analysis. Journal of basic microbiology, 40(4), pp.269-277.

Vega, W., Orellana, M., Zaror, L., Gené, J. and Guarro, J., 2006. Saksenaea vasiformis infections: case report and literature review. Mycopathologia, 162(4), pp.289-294.

Vendl, O., Crews, C., MacDonald, S., Krska, R. and Berthiller, F., 2010. Occurrence of free and conjugated Fusarium mycotoxins in cereal-based food. Food additives and contaminants, 27(8), pp.1148-1152.

Voigt, K., Vaas, L., Stielow, B. and de Hoog, G.S., 2013. The zygomycetes in a phylogenetic perspective. Persoonia: Molecular phylogeny and evolution of fungi, 30, p.i.

Voigt, K. and Wöstemeyer, J., 2001. Phylogeny and origin of 82 zygomycetes from all 54 genera of the Mucorales and Mortierellales based on combined analysis of actin and translation elongation factor EF-1 $\alpha$ genes. Gene, 270(1), pp.113-120.

Voigt, K. and Wöstemeyer, J., 2000. Reliable amplification of actin genes facilitates deep-level phylogeny. Microbiological research, 155(3), pp.179-195.

Williams, J.G., Kubelik, A.R., Livak, K.J., Rafalski, J.A. and Tingey, S.V., 1990. DNA polymorphisms amplified by arbitrary primers are useful as genetic markers. Nucleic acids research, 18(22), pp.6531-6535.

Wimander, K. and Belin, L., 1979. Recognition of allergic alveolitis in the trimming department of a Swedish sawmill. European journal of respiratory diseases. Supplement, 107, pp.163-167.

Zhang, K., Yuan-Ying, S. and Cai, L., 2013. An optimized protocol of single spore isolation for fungi. Cryptogamie, Mycologie, 34(4), pp.349-356.

Zheng, R.Y. and Chen, G.Q., 1998. Rhizopus microsporus var. tuberosus var. nov. Mycotaxon.69:181-186.

Zheng, R.Y., Chen, G.Q., Huang, H. and Liu, X.Y., 2007. A monograph of Rhizopus. Sydowia, 59(2), p.273. 


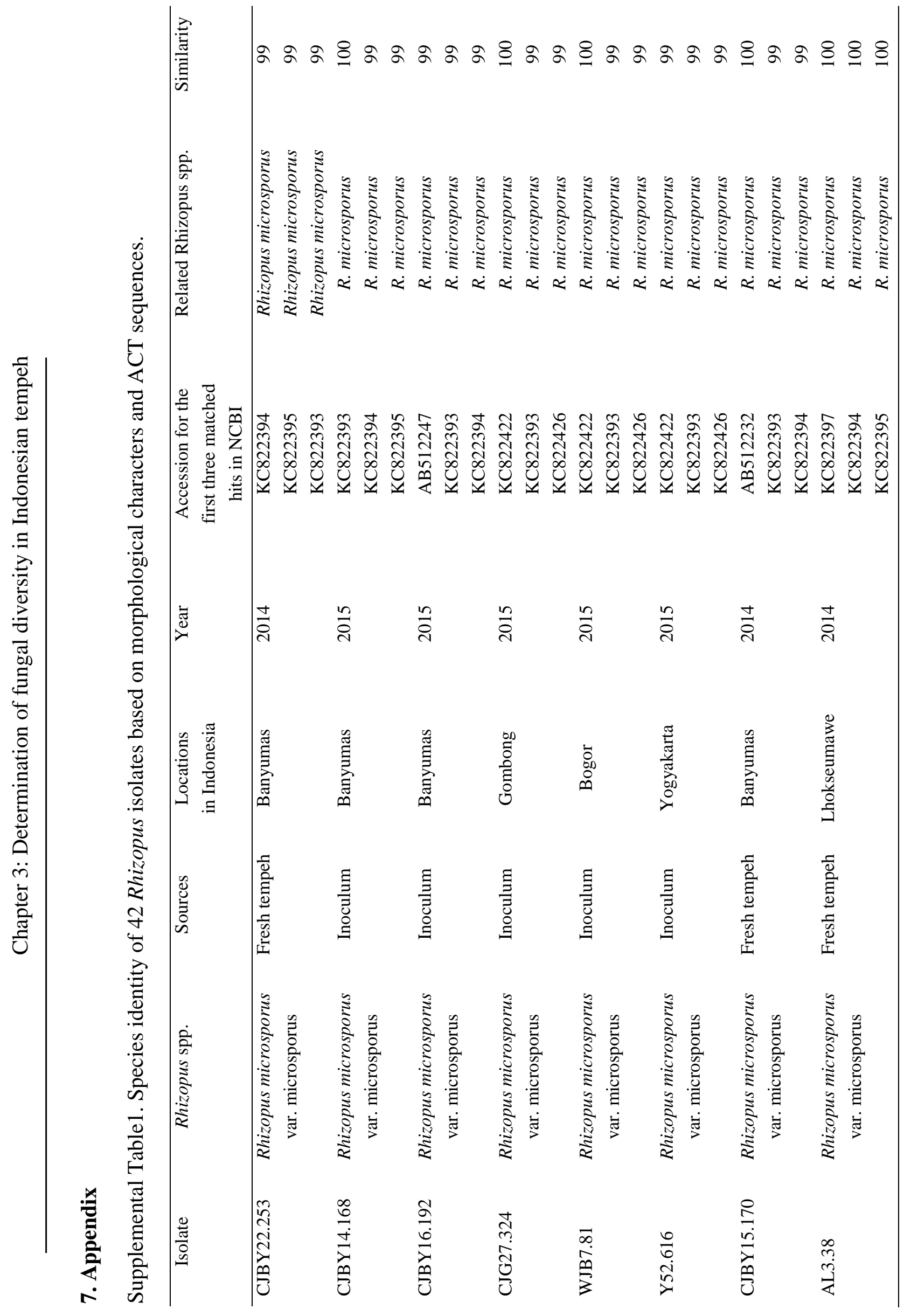




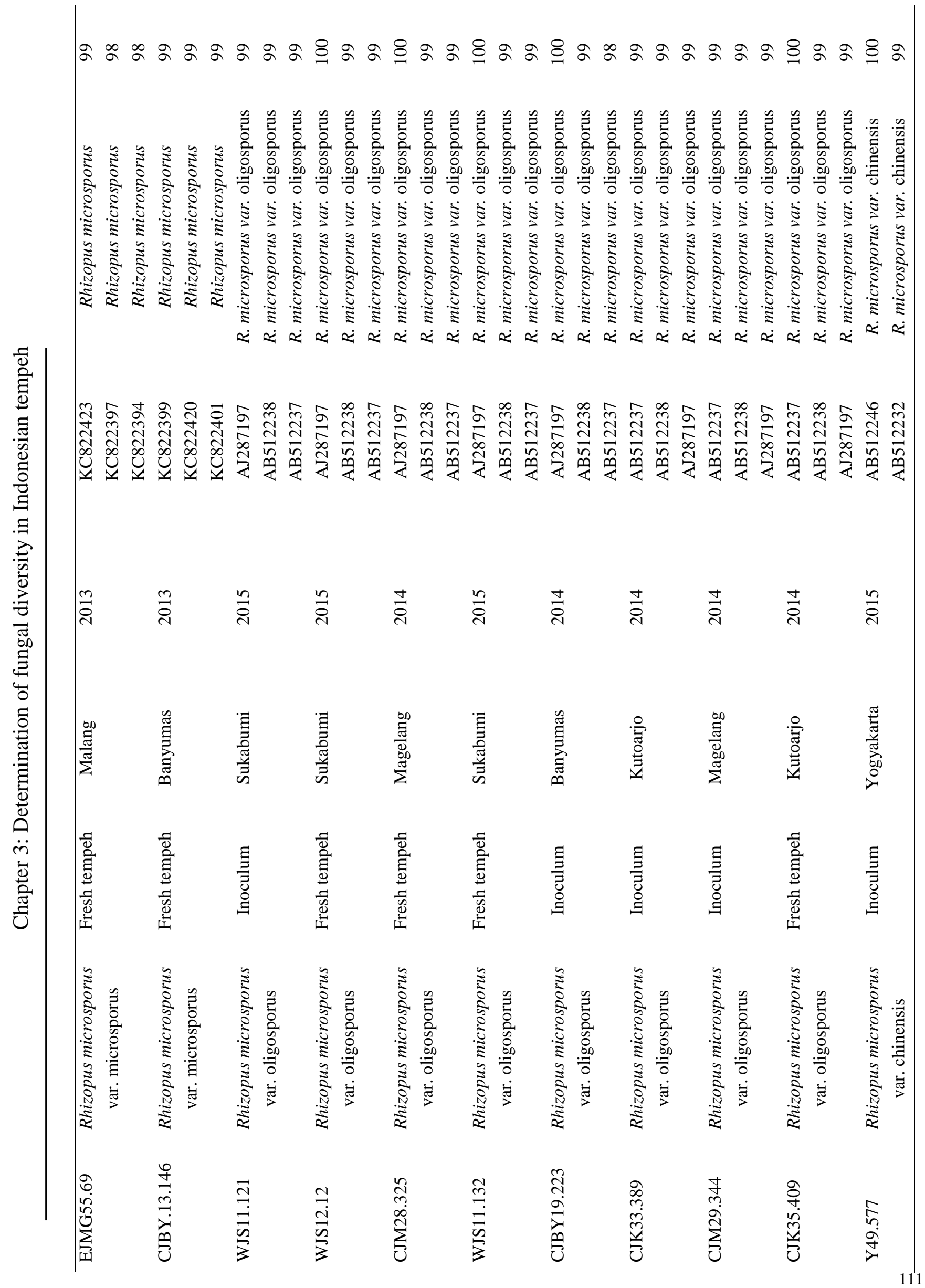




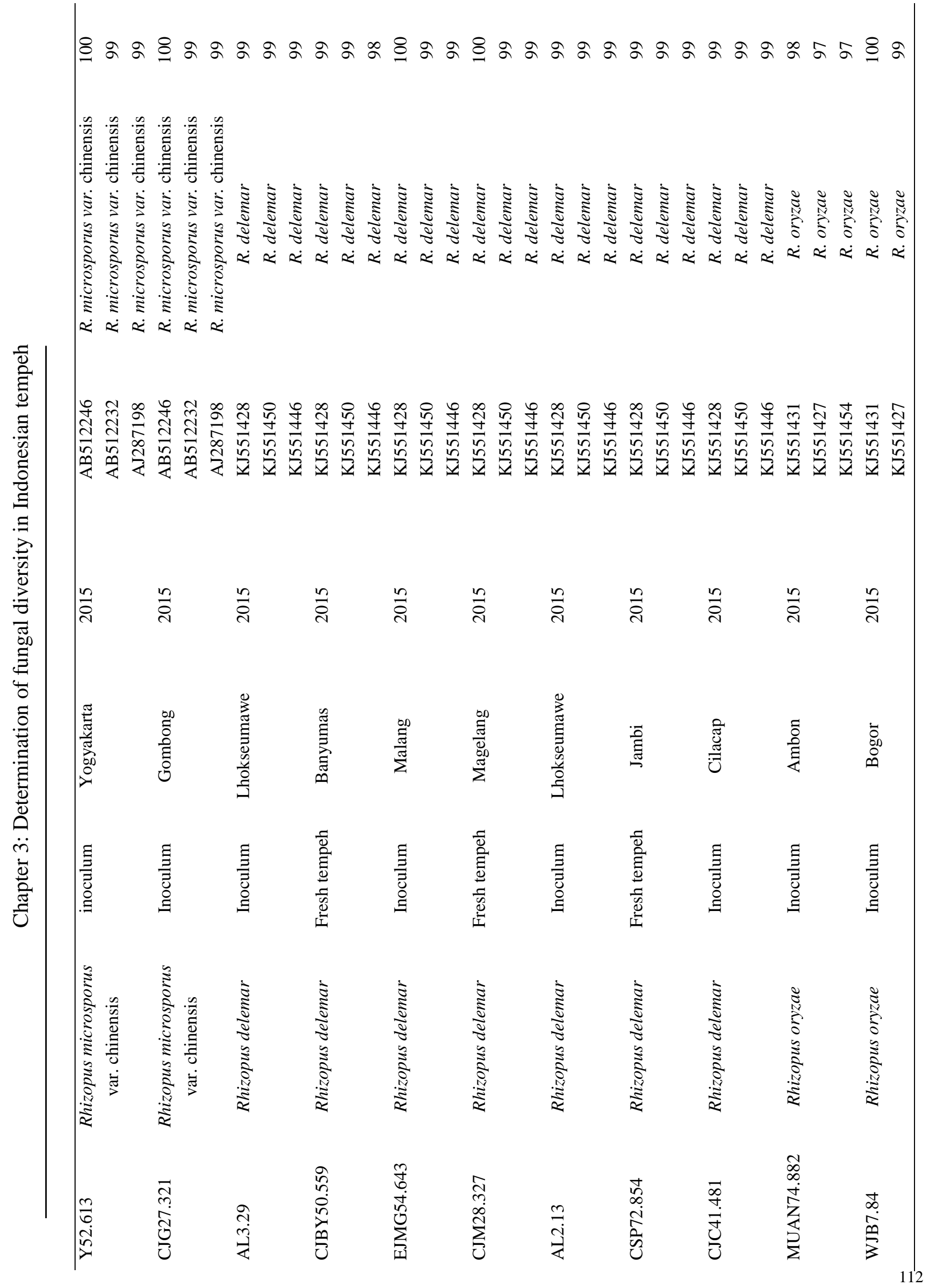




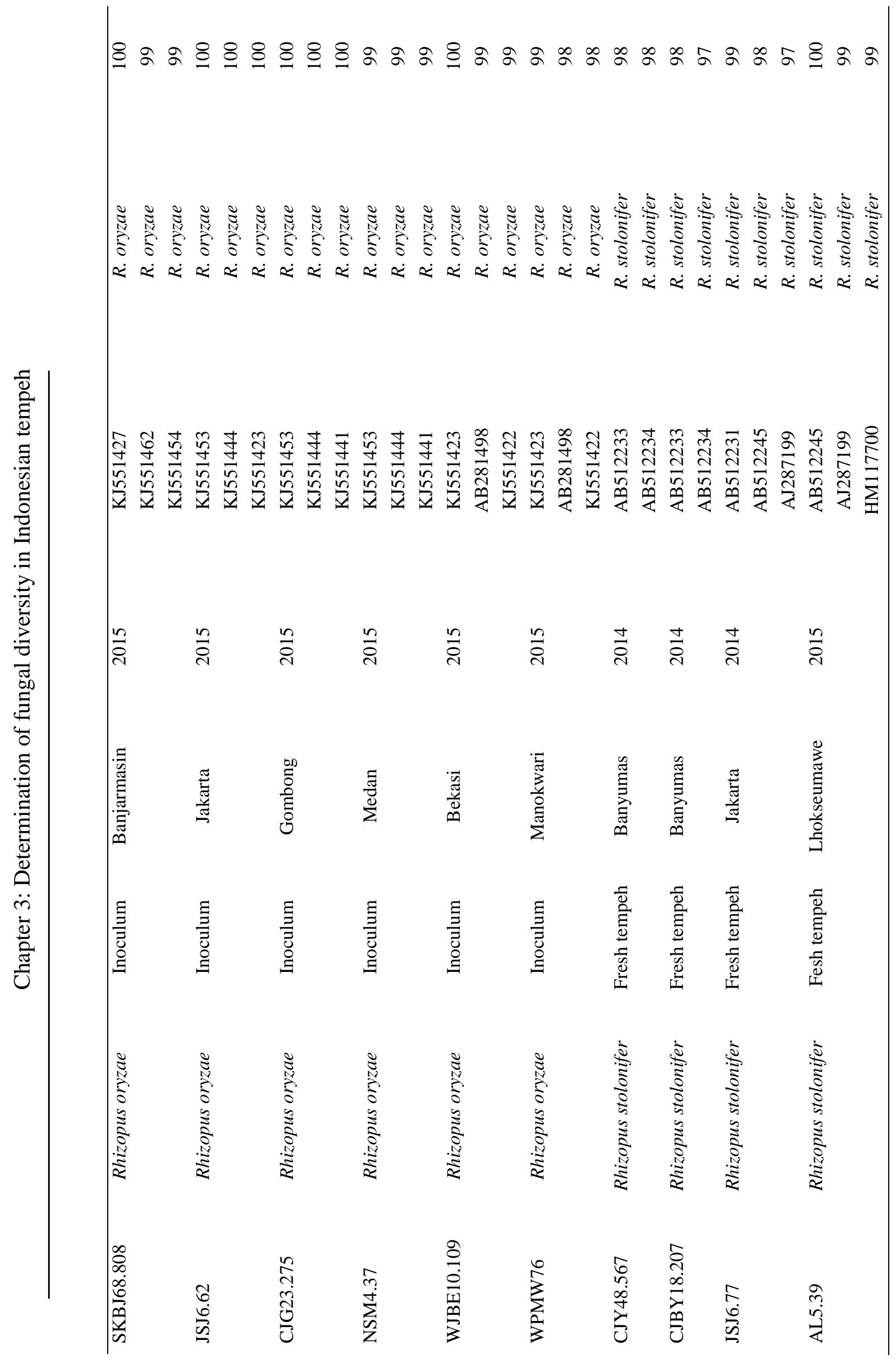


Supplemental Table 2. Discription of Rhizopus accessions for ACT sequence used in this study

\begin{tabular}{|c|c|c|c|}
\hline Accession No & Strain & Species & Reference \\
\hline KJ551424 & CBS 109939 & Rhizopus oryzae & Dolatabadi et al. (2014a) \\
\hline KJ551425 & CBS 118614 & Rhizopus oryzae & Dolatabadi et al. (2014a) \\
\hline KJ551427 & CBS 120592 & Rhizopus oryzae & Dolatabadi et al. (2014a) \\
\hline KJ551453 & CBS 396.95 & Rhizopus oryzae & Dolatabadi et al. (2014a) \\
\hline KJ551431 & CBS 120806 & Rhizopus oryzae & Dolatabadi et al. (2014a) \\
\hline KJ551459 & CBS 137314 & Rhizopus delemar & Dolatabadi et al. (2014a) \\
\hline KJ551460 & CBS 607.68 & Rhizopus delemar & Dolatabadi et al. (2014a) \\
\hline KJ551463 & CBS 405.51 & Rhizopus delemar & Dolatabadi et al. (2014a) \\
\hline KJ551428 & CBS 120593 & Rhizopus delemar & Dolatabadi et al. (2014a) \\
\hline KJ551432 & CBS 120807 & Rhizopus delemar & Dolatabadi et al. (2014a) \\
\hline KC822395 & CBS 130967 & Rhizopus microsporus & Dolatabadi et al. (2014b) \\
\hline KC822399 & CBS 124669 & Rhizopus microsporus & Dolatabadi et al. (2014b) \\
\hline KC822423 & CBS 359.92 & Rhizopus microsporus & Dolatabadi et al. (2014b) \\
\hline KC822396 & CBS 308.87 & Rhizopus microsporus & Dolatabadi et al. (2014b) \\
\hline KC822415 & CBS 712.73 & Rhizopus microsporus & Dolatabadi et al. (2014b) \\
\hline AJ287197 & PLN 01 & Rhizopus microsporus var. oligosporus & Voight and Wostemeyer (2001) \\
\hline AB512238 & CBS 338.62 & Rhizopus microsporus var. oligosporus & Abe et al. (2010) \\
\hline AB512237 & CBS 337.62 & Rhizopus microsporus var. oligosporus & Abe et al. (2010) \\
\hline AB512232 & CBS 262.28 & Rhizopus microsporus var. chinensis & Abe et al. (2010) \\
\hline AB512246 & CBS 631.82 & Rhizopus microsporus var. chinensis & Abe et al. (2010) \\
\hline AB512231 & CBS 150.83 & Rhizopus stolonifer & Abe et al. (2010) \\
\hline AJ287199 & PLN 02 & Rhizopus stolonifer & Voight and Wostemeyer (2001) \\
\hline AB512245 & CBS 609.82 & Rhizopus stolonifer & Abe et al. (2010) \\
\hline
\end{tabular}


Supplemental Table 3. List of tempeh fungi R1-R70 used for ZEN transformation test.

\begin{tabular}{|c|c|c|c|}
\hline & Fungi name & Original source & Year sampling \\
\hline R1 & R. microsporus WJB7.81 & Tempeh starter, West Java, Bogor & 2015 \\
\hline $\mathrm{R} 2$ & R. microsposrus var. oligosporus CJG27.324 & Tempeh starter, Central Java, Gombong & 2015 \\
\hline R3 & R. microsposrus var. oligosporus CJM28.325 & Tempeh starter, Central Java, Magelang & 2015 \\
\hline $\mathrm{R} 4$ & R. microsposrus var. oligosporus WJS11.121 & Tempeh starter, West Java, Sukabumi & 2015 \\
\hline R5 & R. microsposrus var. oligosporus CJBY13.145 & Tempeh starter, Central Java, Banyumas & 2015 \\
\hline R6 & R. microsporus var. oligosporus WJS11. 132 & Tempeh starter, West Java, Sukabumi & 2015 \\
\hline R7 & R. microsporus var. oligosporus WJBE10.114 & Tempeh starter, West Java, Bekasi & 2015 \\
\hline $\mathrm{R} 8$ & R. oryzae WJBE8.85 & Tempeh starter, West Java, Bekasi & 2015 \\
\hline R9 & R. microsporus var. chinensis WJBE8.89 & Tempeh starter, West Java, Bekasi & 2015 \\
\hline $\mathrm{R} 10$ & R. oryzae WJBE11. 120 & Tempeh starter, West Java, Bekasi & 2015 \\
\hline $\mathrm{R} 11$ & R. oryzae WJB7.77 & Tempeh, West Java, Bogor & 2015 \\
\hline $\mathrm{R} 12$ & R. microsporus var. chinensis CJK33.385 & Tempeh starter, Central Java, Kutoarjo & 2015 \\
\hline $\mathrm{R} 13$ & R. microsporus var. chinensis CJK37.444 & Tempeh starter, Central Java, Kutoarjo & 2015 \\
\hline $\mathrm{R} 14$ & R. microsporus var. oligosporus WJBE8.87 & Tempeh starter, West Java, Bekasi & 2015 \\
\hline $\mathrm{R} 15$ & R. microsporus var. oligosporus WJBE9.103 & Tempeh starter, West Java, Bekasi & 2015 \\
\hline $\mathrm{R} 16$ & R. delemar WJB7.73 & Tempeh, West Java, Bogor & 2015 \\
\hline $\mathrm{R} 17$ & R. oryzae WJBE10.109 & Tempeh starter, West Java, Bekasi & 2015 \\
\hline $\mathrm{R} 18$ & R. oryzae WJB7.84 & Tempeh, West Java, Bogor & 2015 \\
\hline R19 & R. microsporus var. oligosporus CJBY13.154 & Tempeh starter, Central Java, Banyumas & 2015 \\
\hline $\mathrm{R} 20$ & R. microsporus var. chinensis CJBY14.168 & Tempeh starter, Central Java, Banyumas & 2015 \\
\hline $\mathrm{R} 21$ & R. microsporus var. chinensis CJBY15. 170 & Tempeh starter, Central Java, Banyumas & 2015 \\
\hline $\mathrm{R} 22$ & R. microsporus var. chinensis CJBY16. 192 & Tempeh starter, Central Java, Banyumas & 2015 \\
\hline $\mathrm{R} 23$ & R. oryzae WJS11. 121 & Tempeh starter, West Java, Sukabumi & 2015 \\
\hline $\mathrm{R} 24$ & Synchepalastrum racemosum CJG23.273 & Tempeh starter, Central Java, Gombong & 2015 \\
\hline $\mathrm{R} 25$ & Aspergillus oryzae CJBY22. 260 & Tempeh starter, Central Java, Banyumas & 2015 \\
\hline $\mathrm{R} 26$ & A. oryzae CJM28.329 & Tempeh starter, Central Java, Magelang & 2015 \\
\hline $\mathrm{R} 27$ & Neurospora sitophila CJM30.353 & Tempeh starter, Central Java, Magelang & 2015 \\
\hline $\mathrm{R} 28$ & N. sitophila WJB7.75 & Tempeh starter, West Java, Bogor & 2015 \\
\hline $\mathrm{R} 29$ & R. oryzae CSP71.841 & Tempeh starter, Central Sulawesi, Palu & 2015 \\
\hline $\mathrm{R} 30$ & R. microsporus var. chinensis WKP65.769 & Tempeh starter, West Kalimantan, Pontianak & 2015 \\
\hline $\mathrm{R} 31$ & R. oryzae BDP59.700 & Tempeh, Bali, Denpasar & 2015 \\
\hline R32 & R. oryzae MUAN74.882 & Tempeh, Maluku, Ambon & 2015 \\
\hline $\mathrm{R} 33$ & R. oryzae WPMW76.901 & Tempeh, West Papua, Manokwari & 2015 \\
\hline R34 & R. oryzae SKBJ68.808 & Tempeh starter, South Kalimantan, Banjarmasin & 2015 \\
\hline
\end{tabular}


Chapter 3: Determination of fungal diversity in Indonesian tempeh

\begin{tabular}{|c|c|c|c|}
\hline R35 & R. microsporus CJBR43.505 & Tempeh starter, Central Java, Brebes & 2015 \\
\hline $\mathrm{R} 36$ & R. microsporus CJM30.349 & Tempeh starter, Central Java, Magelang & 2015 \\
\hline $\mathrm{R} 37$ & R. oryzae LLM5.50 & Tempeh starter, Lampung, Lampung Metro & 2015 \\
\hline $\mathrm{R} 38$ & R. microsporus var. chinensis LLM5.56 & Tempeh starter, Lampung, Lampung Metro & 2015 \\
\hline $\mathrm{R} 39$ & R. oryzae NSM4.37 & Tempeh starter, North Sumatera, Medan & 2015 \\
\hline $\mathrm{R} 40$ & R. delemar AL2.13 & Tempeh starter, Aceh, Lhokseumawe & 2015 \\
\hline $\mathrm{R} 41$ & R. delemar AL3.29 & Tempeh starter, Aceh, Lhokseumawe & 2015 \\
\hline $\mathrm{R} 42$ & R. oryzae NSM4.48 & Tempeh starter, North Sumatera, Medan & 2015 \\
\hline $\mathrm{R} 43$ & R. oryzae JSJ6.62 & Tempeh starter, South Jakarta, Jakarta & 2015 \\
\hline $\mathrm{R} 44$ & R. oryzae CJG23.275 & Tempeh starter, Central Java, Gombong & 2015 \\
\hline $\mathrm{R} 45$ & R. microsporus var. chinensis CJG27.321 & Tempeh starter, Central Java, Gombong & 2015 \\
\hline $\mathrm{R} 46$ & R. delemar CJBR44.517 & Tempeh starter, Central Java, Brebes & 2015 \\
\hline $\mathrm{R} 47$ & R. microsporus var. chinensis Y52.613 & Tempeh starter, Yogyakarta & 2015 \\
\hline $\mathrm{R} 48$ & R. microsporus var. chinensis Y51.603 & Tempeh starter, Yogyakarta & 2015 \\
\hline $\mathrm{R} 49$ & R. oryzae Y50.590 & Tempeh starter, Yogyakarta & 2015 \\
\hline $\mathrm{R} 50$ & R. microsporus var. chinensis Y49.577 & Tempeh starter, Yogyakarta & 2015 \\
\hline $\mathrm{R} 51$ & R. oryzae EJSU56.661 & Tempeh starter, East Java, Surabaya & 2015 \\
\hline $\mathrm{R} 52$ & R. oryzae EJSU57.673 & Tempeh starter, East Java, Surabaya & 2015 \\
\hline R53 & R. oryzae EJMG53.638 & Tempeh starter, East Java, Malang & 2015 \\
\hline $\mathrm{R} 54$ & R. microsporus var. oligosporus BDP60.710 & Tempeh, Bali, Denpasar & 2015 \\
\hline R55 & R. microsporus var. oligosporus CSP71.850 & Tempeh starter, Central Sulawesi, Palu & 2015 \\
\hline $\mathrm{R} 56$ & R. microsporus Y52.616 & Tempeh starter, Yogyakarta & 2015 \\
\hline R57 & R. delemar EJMG54.643 & Tempeh starter, East Java, Malang & 2015 \\
\hline $\mathrm{R} 58$ & R. delemar AL3.32 & Tempeh starter, Aceh, Leuksomawe & 2015 \\
\hline R59 & R. oryzae AL2.23 & Tempeh starter, Aceh, Leuksomawe & 2015 \\
\hline R60 & R. oryzae NSM4.41 & Tempeh starter, North Sumatera, Medan & 2015 \\
\hline R61 & R. delemar CJC41.481 & Tempeh starter, Central Java, Cilacap & 2015 \\
\hline R62 & Synchepalastrum racemosum CJC42.499 & Tempeh starter, Central Java, Cilacap & 2015 \\
\hline R63 & S. racemosum CJK34.400 & Tempeh starter, Central Java, Kutoarjo & 2015 \\
\hline R64 & S. racemosum CJG23.272 & Tempeh starter, Central Java, Gombong & 2015 \\
\hline R65 & S. racemosum CJBY 13.148 & Tempeh starter, Central Java, Banyumas & 2015 \\
\hline R66 & Aspergillus oryzae LLM5.53 & Tempeh starter, Lampung, Lampung Metro & 2015 \\
\hline R67 & A. oryzae AL3.35 & Tempeh starter, Aceh, Lhokseumawe & 2015 \\
\hline R68 & Neurospora crassa WJBE10.111 & Tempeh starter, West Java, Bekasi & 2015 \\
\hline R69 & N. sitophila WJS11. 137 & Tempeh starter, West Java, Sukabumi & 2015 \\
\hline $\mathrm{R} 70$ & N. sitophila WJS11. 144 & Tempeh starter, West Java, Sukabumi & 2015 \\
\hline
\end{tabular}


Chapter 3: Determination of fungal diversity in Indonesian tempeh

Supplemental Table 4. HPLC-MS/MS result of ZEN transformation by tempeh fungi (semi-quantitative data).

\begin{tabular}{|c|c|c|c|c|c|c|c|c|}
\hline & & & & & Masked ZI & & & \\
\hline Isolates & & & Are & count) afte & ljusted with & esponse & & \\
\hline & ZEN & $\alpha-Z E L$ & $\beta$-ZEL & ZEN14S & ZELS 1 & ZELS 2 & ZEN14G & ZEN16G \\
\hline $\mathrm{R} 1$ & $7,16 \times 10^{3}$ & $11,36 \times 10^{3}$ & $1,47 \times 10^{3}$ & $1,14 \times 10^{4}$ & 0 & $1,14 \times 10^{4}$ & 0 & $1,53 \times 10^{4}$ \\
\hline $\mathrm{R} 2$ & 0 & 0 & $8.98 \times 10^{2}$ & $5.65 \times 10^{5}$ & $1.33 \times 10^{2}$ & $1.34 \times 10^{5}$ & 0 & $1.45 \times 10^{4}$ \\
\hline R3 & $9.84 \times 10^{2}$ & 0 & $1.64 \times 10^{3}$ & $4.14 \times 10^{5}$ & $4.61 \times 10^{3}$ & $7.81 \times 10^{4}$ & 0 & $1.34 \times 10^{4}$ \\
\hline $\mathrm{R} 4$ & $1.25 \times 10^{5}$ & 0 & $1.81 \times 10^{3}$ & $1.08 \times 10^{5}$ & $1.37 \times 10^{2}$ & $1.03 \times 10^{3}$ & 0 & 0 \\
\hline R5 & $1.20 \times 10^{5}$ & 0 & 0 & $1.66 \times 10^{4}$ & 0 & $1.5 \times 10^{2}$ & 0 & 0 \\
\hline R6 & $1.88 \times 10^{4}$ & $6.53 \times 10^{2}$ & 0 & $6 \times 10^{5}$ & $8 \times 10^{2}$ & $8.0 \times 10^{4}$ & 0 & 0 \\
\hline R7 & 0 & 0 & 0 & $4.25 \times 10^{5}$ & $6.27 \times 10^{3}$ & $1.22 \times 10^{5}$ & 0 & $1.83 \times 10^{4}$ \\
\hline R8 & 0 & 0 & $7.14 \times 10^{2}$ & $5.30 \times 10^{5}$ & $6.73 \times 10^{3}$ & $8.84 \times 10^{4}$ & 0 & 0 \\
\hline R9 & 0 & 0 & $5.35 \times 10^{2}$ & $4.39 \times 10^{5}$ & $6.70 \times 10^{3}$ & $1.44 \times 10^{5}$ & 0 & $9.36 \times 10^{3}$ \\
\hline R10 & $8.05 \times 10^{3}$ & $1.11 \times 10^{4}$ & $1.47 \times 10^{3}$ & $5.22 \times 10^{4}$ & $2.16 \times 10^{2}$ & $3.85 \times 10^{4}$ & 0 & $3.93 \times 10^{4}$ \\
\hline R11 & $5.17 \times 10^{3}$ & $1.65 \times 10^{3}$ & $1.23 \times 10^{3}$ & $5.65 \times 10^{5}$ & $2.78 \times 10^{3}$ & $7.03 \times 10^{4}$ & 0 & 0 \\
\hline R12 & 0 & 0 & $4.49 \times 10^{2}$ & $4.19 \times 10^{5}$ & $8.66 \times 10^{3}$ & $1.33 \times 10^{5}$ & 0 & $1.30 \times 10^{4}$ \\
\hline $\mathrm{R} 13$ & 0 & 0 & $1.28 \times 10^{3}$ & $4.77 \times 10^{5}$ & $7 \times 10^{3}$ & $1.06 \times 10^{5}$ & 0 & $2.49 \times 10^{3}$ \\
\hline R14 & 0 & 0 & $6.28 \times 10^{2}$ & $4.40 \times 10^{5}$ & $1.01 \times 10^{4}$ & $9.74 \times 10^{4}$ & 0 & 0 \\
\hline R15 & $1.33 \times 10^{5}$ & 0 & 0 & $1.77 \times 10^{4}$ & 0 & $1.66 \times 10^{2}$ & 0 & 0 \\
\hline R16 & 0 & 0 & $1.42 \times 10^{3}$ & $3.74 \times 10^{5}$ & $3.96 \times 10^{3}$ & $7.42 \times 10^{4}$ & 0 & $8.55 \times 10^{3}$ \\
\hline R17 & $1.16 \times 10^{3}$ & 0 & $1.34 \times 10^{3}$ & $3.59 \times 10^{5}$ & $4.63 \times 10^{3}$ & $9.29 \times 10^{4}$ & $4.77 \times 10^{2}$ & $1.09 \times 10^{4}$ \\
\hline R18 & $5.98 \times 10^{3}$ & $3.68 \times 10^{3}$ & $5.07 \times 10^{2}$ & $2.67 \times 10^{5}$ & $2.75 \times 10^{2}$ & $4.05 \times 10^{2}$ & $2.42 \times 10^{3}$ & $5.74 \times 10^{4}$ \\
\hline R19 & 0 & 0 & $1.87 \times 10^{3}$ & $3.87 \times 10^{5}$ & $3.16 \times 10^{4}$ & $1.85 \times 10^{5}$ & 0 & 0 \\
\hline R20 & 0 & 0 & 0 & $5.34 \times 10^{5}$ & $1.02 \times 10^{4}$ & $1.25 \times 10^{5}$ & 0 & 0 \\
\hline R21 & 0 & 0 & $2.0 \times 10^{3}$ & $3.01 \times 10^{5}$ & $1.67 \times 10^{4}$ & $1.86 \times 10^{5}$ & 0 & 0 \\
\hline R22 & $4.76 \times 10^{4}$ & $1.24 \times 10^{3}$ & $1.49 \times 10^{4}$ & 0 & 0 & 0 & 0 & $2.78 \times 10^{3}$ \\
\hline R23 & 0 & 0 & $1.46 \times 10^{3}$ & $6.92 \times 10^{5}$ & $3.42 \times 10^{4}$ & $9.35 \times 10^{3}$ & 0 & 0 \\
\hline R24 & $1.61 \times 10^{3}$ & $3.31 \times 10^{2}$ & 0 & $4.63 \times 10^{5}$ & $3.23 \times 10^{3}$ & $1.09 \times 10^{5}$ & 0 & 0 \\
\hline R25 & $2.64 \times 10^{3}$ & 0 & 0 & $7.02 \times 10^{5}$ & $6.01 \times 10^{3}$ & $1.4 \times 10^{4}$ & 0 & 0 \\
\hline R26 & $2.18 \times 10^{3}$ & 0 & 0 & $7.09 \times 10^{5}$ & $7.26 \times 10^{3}$ & $1.29 \times 10^{4}$ & 0 & 0 \\
\hline R27 & $4.29 \times 10^{4}$ & $1.88 \times 10^{3}$ & $7.33 \times 10^{2}$ & 0 & 0 & 0 & 0 & 0 \\
\hline
\end{tabular}


Chapter 3: Determination of fungal diversity in Indonesian tempeh

\begin{tabular}{|c|c|c|c|c|c|c|c|c|}
\hline R28 & $2.88 \times 10^{4}$ & $3.34 \times 10^{3}$ & 0 & $4.35 \times 10^{2}$ & 0 & 0 & 0 & 0 \\
\hline R29 & $3.82 \times 10^{4}$ & 0 & 0 & $1.79 \times 10^{3}$ & 0 & 0 & 0 & 0 \\
\hline R30 & $1.05 \times 10^{4}$ & 0 & 0 & $7.14 \times 10^{3}$ & 0 & $1.12 \times 10^{2}$ & 0 & 0 \\
\hline R31 & $4.27 \times 10^{4}$ & 0 & 0 & $3.29 \times 10^{3}$ & 0 & 0 & 0 & 0 \\
\hline R32 & $2.91 \times 10^{4}$ & 0 & 0 & $5.95 \times 10^{4}$ & 0 & $6.11 \times 10^{2}$ & 0 & 0 \\
\hline R33 & $3.63 \times 10^{4}$ & 0 & 0 & $3.60 \times 10^{3}$ & 0 & 0 & 0 & 0 \\
\hline R34 & $2.50 \times 10^{4}$ & 0 & $4.80 \times 10^{2}$ & $8.05 \times 10^{2}$ & 0 & 0 & 0 & 0 \\
\hline R35 & $3.42 \times 10^{4}$ & 0 & 0 & $2.23 \times 10^{3}$ & 0 & $3.46 \times 10$ & 0 & 0 \\
\hline R36 & $1.23 \times 10^{3}$ & $3.28 \times 10^{3}$ & $2.94 \times 10^{2}$ & $3.86 \times 10^{4}$ & $2.23 \times 102$ & $5.56 \times 10^{4}$ & 0 & $1.41 \times 10^{4}$ \\
\hline R37 & 0 & 0 & 0 & $3.13 \times 10^{5}$ & $1.12 \times 10^{4}$ & $7.61 \times 10^{4}$ & 0 & 0 \\
\hline R38 & $1.01 \times 10^{4}$ & 0 & 0 & $3.05 \times 10^{5}$ & $3.64 \times 10^{2}$ & $1.43 \times 10^{4}$ & 0 & 0 \\
\hline R39 & $9.76 \times 10^{3}$ & $5.81 \times 10^{2}$ & $6.25 \times 10^{2}$ & $2.22 \times 10^{5}$ & $2,31 \times 10^{2}$ & $1.4 \times 10^{4}$ & 0 & 0 \\
\hline $\mathrm{R} 40$ & $3.79 \times 10^{4}$ & 0 & $5.08 \times 10^{2}$ & $1.02 \times 10^{4}$ & 0 & $2.76 \times 10^{2}$ & 0 & 0 \\
\hline R41 & $3.47 \times 10^{4}$ & 0 & 0 & 0 & 0 & 0 & 0 & 0 \\
\hline R42 & $3.02 \times 10^{4}$ & 0 & 0 & $4.59 \times 10^{4}$ & 0 & $7.70 \times 10^{2}$ & 0 & 0 \\
\hline R43 & $7.20 \times 10^{3}$ & $1.10 \times 10^{3}$ & $8.88 \times 10^{2}$ & $2.82 \times 10^{5}$ & $6.29 \times 10^{2}$ & $1.38 \times 10^{4}$ & 0 & $2.49 \times 10^{3}$ \\
\hline R44 & $2.53 \times 10^{4}$ & 0 & 0 & 0 & 0 & 0 & 0 & 0 \\
\hline R45 & $2.64 \times 10^{4}$ & 0 & 0 & $7.95 \times 10^{4}$ & $5.62 \times 10$ & $4.95 \times 10^{3}$ & 0 & 0 \\
\hline R46 & 0 & 0 & $3.19 \times 10^{2}$ & $2.06 \times 10^{5}$ & $1.16 \times 10^{4}$ & $9.52 \times 10^{4}$ & 0 & $6.01 \times 10^{3}$ \\
\hline R47 & $2.85 \times 10^{4}$ & 0 & 0 & $2.47 \times 10^{4}$ & 0 & $2.01 \times 10^{2}$ & 0 & 0 \\
\hline R48 & $8.52 \times 10^{2}$ & $1.33 \times 10^{3}$ & $2.94 \times 10^{2}$ & $7.85 \times 10^{4}$ & $6.59 \times 10^{2}$ & $8.83 \times 10^{4}$ & 0 & 0 \\
\hline R49 & $1.28 \times 10^{4}$ & $1.05 \times 10^{3}$ & $3.18 \times 10^{2}$ & $8.61 \times 10^{4}$ & $1.74 \times 10^{2}$ & $1.31 \times 10^{4}$ & 0 & 0 \\
\hline R50 & $1.94 \times 10^{4}$ & 0 & 0 & $5.38 \times 10^{4}$ & 0 & $4.91 \times 10^{3}$ & 0 & 0 \\
\hline R51 & $2.09 \times 10^{4}$ & 0 & 0 & $2.76 \times 10^{3}$ & 0 & 0 & 0 & 0 \\
\hline R52 & $3.80 \times 10^{3}$ & 0 & 0 & $2.38 \times 10^{5}$ & $1.23 \times 10^{2}$ & $1.07 \times 10^{4}$ & 0 & $5.45 \times 10^{3}$ \\
\hline R53 & 0 & 0 & 0 & $1.80 \times 10^{5}$ & $4.90 \times 10^{3}$ & $1.18 \times 10^{5}$ & 0 & 0 \\
\hline R54 & $2.73 \times 10^{4}$ & 0 & 0 & $6.05 \times 10^{3}$ & 0 & 0 & 0 & 0 \\
\hline R55 & 0 & 0 & $2.11 \times 10^{2}$ & $2.55 \times 10^{5}$ & $3.04 \times 10^{4}$ & $2.37 \times 10^{5}$ & 0 & 0 \\
\hline R56 & $3.25 \times 10^{3}$ & $1.59 \times 10^{3}$ & $7.13 \times 10^{3}$ & $3.4 \times 10^{2}$ & 0 & 0 & 0 & 0 \\
\hline R57 & $1.39 \times 10^{4}$ & 0 & $2.68 \times 10^{2}$ & 0 & 0 & 0 & 0 & 0 \\
\hline R58 & $1.28 \times 10^{4}$ & $2.47 \times 10^{2}$ & $4.99 \times 10^{3}$ & 0 & 0 & 0 & 0 & 0 \\
\hline R59 & $5.37 \times 10^{3}$ & $7.28 \times 10^{3}$ & 0 & 0 & 0 & 0 & 0 & 0 \\
\hline
\end{tabular}


Chapter 3: Determination of fungal diversity in Indonesian tempeh

\begin{tabular}{|l|c|c|c|c|c|c|c|c|}
\hline R60 & $9.59 \times 10^{3}$ & $9.51 \times 10^{2}$ & $5.01 \times 10^{3}$ & $6.54 \times 10^{3}$ & $3.82 \times 10^{2}$ & $3.88 \times 10^{2}$ & 0 & 0 \\
\hline R61 & $1.64 \times 10^{4}$ & 0 & 0 & 0 & 0 & 0 & 0 & 0 \\
\hline R62 & 0 & 0 & 0 & $4.22 \times 10^{5}$ & $2.93 \times 10^{3}$ & $4.95 \times 10^{2}$ & 0 & 0 \\
\hline R63 & $8.48 \times 10^{2}$ & 0 & 0 & $3.30 \times 10^{5}$ & $1.45 \times 10^{3}$ & $1.95 \times 10^{2}$ & 0 & 0 \\
\hline R64 & 0 & 0 & 0 & $4.05 \times 10^{5}$ & $2.85 \times 10^{3}$ & $1.76 \times 10^{3}$ & 0 & 0 \\
\hline R65 & 0 & 0 & 0 & $3.94 \times 10^{5}$ & $2.34 \times 10^{3}$ & $2.06 \times 10^{2}$ & 0 & 0 \\
\hline R66 & 0 & 0 & 0 & $4.27 \times 10^{5}$ & $2.92 \times 10^{3}$ & $4.63 \times 10^{3}$ & 0 & 0 \\
\hline R67 & 0 & 0 & 0 & $3.15 \times 10^{5}$ & $1.80 \times 10^{3}$ & $8.09 \times 10^{2}$ & 0 & 0 \\
\hline R68 & $6.83 \times 10^{3}$ & $4.28 \times 10^{2}$ & $1.33 \times 10^{3}$ & 0 & 0 & 0 & 0 & 0 \\
\hline R69 & $9.36 \times 10^{3}$ & 0 & $1.36 \times 10^{3}$ & 0 & 0 & 0 & 0 & 0 \\
\hline R70 & $1.53 \times 10^{4}$ & $9.30 \times 10^{2}$ & $2.22 \times 10^{3}$ & 0 & 0 & 0 & 0 & 0 \\
\hline $\begin{array}{l}(+) \\
\text { control }\end{array}$ & $1,37 \times 10^{5}$ & 0 & 0 & 0 & 0 & 0 & 0 & 0 \\
\hline $\begin{array}{l}(-) \\
\text { control }\end{array}$ & 0 & 0 & 0 & 0 & 0 & 0 & 0 & 0 \\
\hline
\end{tabular}

Abbreviation:

ZEN: Zearalenone, $\alpha$-ZEL: alpha-Zearalenone, $\beta$-ZEL: beta-Zearalenone, ZEN14S: Zearalenone 14-Sulfate,

ZELS 1: Zearalenol sulfate type 1, ZELS 2: Zearalenol sulfate type 2, ZEN14G: Zearalenone-14-Glucoside, ZEN16G:

Zearalenone-16-Glucoside. 


\title{
Research Article 02
}

\section{Mycotoxin Producing Fusarium Species in Indonesian Traditional Tempeh and Starter (Usar)*}

*) This research has been presented in $39^{\text {th }}$ Mycotoxin Workshop 2017, Bydgoszcz, Poland.

\author{
Riyan Anggriawan', Katahrina Pfohl ${ }^{1}$, Nur Aini ${ }^{2}$ and Petr Karlovsky ${ }^{1}$ \\ ${ }^{1}$ Molecular Phytopathology and Mycotoxin Research, University of Goettingen, Göttingen, Germany \\ ${ }^{2}$ Faculty of Agricultural Technology, Department of Food Science, Jenderal Soedirman University, \\ Indonesia
}

\begin{abstract}
Like many other traditional foods in Indonesia, tempeh is mainly produced as households or cottage industries with poorly controlled fermentation which is often carried out without sufficient hygienic precautions. Therefore, there are various types of microorganisms that can participate during the process of fermentation, and presence of natural contamination is always possible. In this study, usar and traditional tempeh were investigated for the presence of Fusarium spp and mycotoxin contamination. In total, 650 fungal isolates recovered from traditional tempeh inocula (usar) in Java. Traditional inocula (usar) were collected from many markets and center of tempeh producers in 9 different areas in Central Java and Yogyakarta provinces, Indonesia. Six clusters (Banjarnegara, Banyumas, Gombong, Kebumen, Kudus, and Yogyakarta) showed a Fusarium contamination in usar, while no contamination was found in other remaining clusters. About $8.4 \%$ of total fungal isolates recognized belongs to Fusarium genera. Fifty-five pure isolates of Fusarium sp were collected, then observed via microscopy and molecular approach. We found two main species of Fusarium, identified as $F$. solani and $F$. proliferatum.

All $F$. poliferatum isolates included in our study lacked the TRI5 gene and possessed the FUM1 gene, indicating that they are presumably trichothecene non-producers and potentially fumonisin producers. This result was confirmed by different set of primers (FUM8, and FUM12) with identical result. In other hands, F.solani isolates lacked in both kind of genes, indicating they are not trichothecene or fumonisin producers. LC-MS/MS screening showed $F$. solani isolates were not able to produce any important mycotoxins, whereas $F$. proliferatum positively produced BEA, FB1, and Enns. Fusarium proliferatum extracts showed about 10 -fold stronger activity as toxic agent toward $F$. solani extracts based on their value of $\mathrm{LD}_{50}$.

About 214 traditional tempeh samples from the six clusters mentioned above were screened for $F$. proliferatum and $F$. solani contamination by real-time PCR. Contamination of traditional tempeh samples with $F$. proliferatum was found in $12 \%$ of the samples with amounts of $10-175 \mathrm{ng} / \mathrm{mg}$ fungal DNA. In these samples, the amount of FB1 and BEA ranged between $170-2682 \mu \mathrm{g} / \mathrm{kg}$ and $20-50 \mu \mathrm{g} / \mathrm{kg}$, respectively. About $7 \%$ of the traditional tempeh samples were contaminated with $F$. solani in amounts of $20-129 \mathrm{ng} / \mathrm{mg}$ fungal DNA. All samples had lower FB1 contents than legal limit in Indonesia $(2000 \mu \mathrm{g} / \mathrm{kg}$; SNI 7385:2009), except for one sample from Yogyakarta area which contained FB1 above the allowed limit. Although mycotoxin contamination was detected below the legal limit, the presence of mycotoxin should be controlled in traditional tempeh production.

There were no differences between normal and contaminated tempeh on the compactness and physical characters (texture, $\mathrm{pH}$, and color). Interestingly we found that chemical contents were significantly different especially in protein and amino acid content. We suggest that consumer could distinguish contaminated tempeh by checking the taste of fresh tempeh before cooked. Contaminated tempeh is less umami than normal tempeh because of less L-aspartic acid and L-glutamic acid content, in other words, contaminated-tempeh is less delicious compared to the normal.
\end{abstract}

Keywords: traditional tempeh, usar, contamination, mycotoxin, Fusarium spp. 


\section{Introduction}

Among Asian fungal fermented foods, tempeh is a fermented soybean of high nutritional value, originally and traditionally produced in cottage industries in Indonesia. It has solid form, distinctive aroma and white and slightly gray (INCS, 2009). Tempeh-producing technology has been handed down through generations and changes with experience. Alterations in the processing are usually made by the means and resources which are available (Karyadi, 1996). It is a household art in Indonesia, and therefore its quality varies from place to place (Purwadaria et al., 2013).

The production of tempeh requires inoculum or starter containing sporangiospore to initiate the fermentation. Several types of tempeh inocula can be distinguished. Natural inoculum made with plant leaves and soybeans, known as usar are still widely used in Indonesia (Thanh, 2004). Usar is manufactured at the village scale (a few thousand leaves may be processed daily) and is obtained by cultivating Rhizopus spp. on a few inoculated soybeans sandwiched between two leaves. At the beginning, usar was made with leaves of Hibiscus similis, H. tiliaceus, Tectona grandis, Bambusa spp. or Musa paradisiaca (Jutono 1985). Whereas Tectona spp., Musa paradisiaca, and Bambusa spp. are regarded as unsuitable for usar making because they are brittle after drying, produce bitter taste and their surface are smooth. Hibiscus is more suitable and commonly leaves used for making usar, and some are specifically used for usar manufacture. The leaf structure of these plants are such that, enabling sufficient oxygen in the micro-environment are provided for the fermentation process. The rough surface of the underside of the leaves allows mycelial attachment. Hibiscus leaf possibly acts as one of its natural reservoirs. Jutono (1985) and Arbianto (1990) stated the leaf environment would stimulate the chlamydospores and zygospores formation. These features shall contribute to the viability and biological stability of the mixed population of Rhizopus spp. on usar. The natural occurrence of wild strains of Rhizopus species on the leaves should in any case increase the chance of zygospore formation. In 2004, Japanese research team, Yoshio Ogawa and his colleagues, suggested Rhizopus oryzae dwelling in those leaves would have fermented soybeans into an easily digestible and good-tasting food, producing the original form of tempeh. Those fresh leaves might be the original habitat of Rhizopus spp. or several other fungi which can penetrate into living plant tissue (Ogawa et al., 2004).

Usar is prepared by placing pieces of matured tempeh between two Hibiscus leaves. The leaves are turned over and piled one on top of the other, afterwards covered with banana leaves or cloth and left to undergo the first stage of fermentation for about 24-36 hours room temperature $\left(30^{\circ}-34^{\circ} \mathrm{C}\right)$. In the second stage of fermentation, the leaves now facing upwards, are separated individually and kept so for 3-7 days, partly to let the usar dry at room temperature. The leaves are then separated from the pieces of seed tempeh and dried. Sun drying may be applied at the end of the second stage of fermentation to ensure that usar reaches a sufficiently low moisture content that will secure its shelf life about seven days. For the inoculation of the microorganisms from usar, the leaves are rubbed on the material to be inoculated. Tempeh producers prefer to use freshly harvested usar for their own tempeh production process; they consider fresh usar to be of better quality than the dried one. 
Like many other traditional foods in Indonesia, traditional tempeh is mostly made with poorly controlled fermentation which is carried out without sufficient hygienic precautions. Therefore, there are various types of microorganisms that can participate in the process of fermentation, and natural contamination is always possible (Winarno, 1985; Barus et al., 2008; Seumahu et al., 2013). Standard of hygiene is also not applied in usar production due to the lack of knowledge about good sanitation by the producers. Until now traditional tempeh producers still involve waru lengis leaves (Hibiscus tiliaceus) for usar manufacture, even though as reported Nout et al., (1992) and Suliantari (1996) these leaves may serve as source of Fusarium spp. and Aspergillus spp. About 2.4 million tons of tempeh produced a year by more than 81 thousand tempeh producers. As much as $35 \%$ of tempeh production in Indonesia still uses usar. To date, only little attention has been given to microbiological and safety research of usar. The big question is whether about 800 thousand metric tons of traditional tempeh produced a year are still safe for human consumption? So far, there has been no further research on the contamination from toxins produced by molds in usar as well as traditional tempeh. Moreover, there is no standard for making tempeh and its starter. This is the cause of many variations in the manufacture of tempeh in some areas which lead to nonhomogeneous quality and safety of traditional tempeh.

Another safety problem in tempeh production is the use of corn as a substitute for soybean. Producers involve corn substitution for 10-30 percent to reduce cost production because the price of soybean is high nowadays. This generates a healthiness issue of produced tempeh because most Indonesian corn has been contaminated by toxigenic fungi such as Fusarium spp (Purwoko et al., 1991; Ahmad et al., 1996; Gholib et al., 2004; Ahmad et al., 2009; Kusumaningrum et al., 2010; Rahmawati et al., 2013). Rahmawati et al. (2013) also reported that toxigenic fungi are found in soaking corn, such as Fusarium spp. It is high possibly happens that those fungi produce mycotoxins during soaking process, then the toxins absorbed into the material that is used to produce tempeh. Moreover mycotoxin content in raw material itself also endangers consumer health. Therefore safety aspect of tempeh cannot be guaranteed anymore.

This study is conducted to explore and examine the innocuousness of usar for tempeh manufactures as well as the traditional method handed down through generation. The salient point in tempeh production is also needed to discuss to increase the safety of traditional tempeh production. 


\section{Materials and Methods}

\section{Part I (Fusarium identification from traditional inocula)}

\subsubsection{Sampling, isolation and purification}

Traditional inocula (usar) were collected from many markets and centre of tempeh producers in 9 different areas in Central Java and Yogyakarta provinces, Indonesia (on 2015). Samples were transported in sterile plastic container to nearby microbiological laboratory in each area. Samples were then freeze dried (Supermodulyo, Japan), powdered and maintained at $4{ }^{\circ} \mathrm{C}$ until analysis in refrigerator (Sanyo, Japan). Details information of sampling can be seen on Table 1.

Five gram of each sample (powder) was suspended in $10 \mathrm{~mL}$ sterilized tap water in a sterile falcon tube, homogenized with vortex (VM-300), then one $\mathrm{mL}$ of each solution was spread onto Potato Dextrose Agar (PDA) medium (Roth, Karlsruhe, Germany), and incubated in the same condition. Purification of isolates: A spore suspension is prepared by transferring a loopful of the fungal mass from PDA plate into $10 \mathrm{~mL}$ sterile Tween®20 (Applichem, Darmstadt, Germany) (0.05\% v/v), kept in a sterilized falcon tube followed by vigorous shaking with vortex for a few minutes in order to disperse the spores from the spore-bearing structures, and continued with single spore isolation method (modification of Zhang et al., 2013). All the procedures were done in sterile condition inside clean bench. Distinct fungal colonies temporarily identified as Fusarium were transferred on PDA and recorded for colony morphology, radial growth and pigmentation based on the visual inspection of the plates. About 55 pure isolates of Fusarium sp were collected.

Table 1. Information of sampling locations.

\begin{tabular}{clcc}
\hline Areas & \multicolumn{1}{c}{ Samples } & Amount & Year \\
\hline Banyumas (B) & Traditional inocula (usar) & 52 & 2015 \\
Banjarnegara (BJ) & Traditional inocula (usar) & 42 & 2015 \\
Cilacap (CL) & Traditional inocula (usar) & 37 & 2015 \\
Kebumen (KE) & Traditional inocula (usar) & 41 & 2015 \\
Kudus (KU) & Traditional inocula (usar) & 34 & 2015 \\
Purbalingga (PU) & Traditional inocula (usar) & 32 & 2015 \\
Tegal (TG) & Traditional inocula (usar) & 30 & 2015 \\
Gombong (G) & Traditional inocula (usar) & 32 & 2015 \\
Yogyakarta & Traditional inocula (usar) & 45 & 2015 \\
\hline Total of sample & & 345 & \\
\hline
\end{tabular}

\subsubsection{Morphological observation}

Morphological characteristics

Since Fusarium isolates produce uniform spores on SNA-Synthetic Nutrient Agar medium (1 g $\mathrm{KH}_{2} \mathrm{PO}_{4}, 1 \mathrm{~g} \mathrm{KNO}_{3}, 0.5 \mathrm{~g} \mathrm{MgSO}_{4} .7 \mathrm{H}_{2} \mathrm{O}, 0.5 \mathrm{~g} \mathrm{KCl}, 0.2 \mathrm{~g}$ glucose, $0.2 \mathrm{~g}$ sucrose and $15 \mathrm{~g}$ agar/liter distilled water) (Nirenberg, 1976), all single spores isolates were transferred to SNA plates and incubated at $25^{\circ} \mathrm{C}$ under near UV light for 5 days. Small pieces of sterile filter paper were placed on the surface of cooled agar to induce fungal sporulation. Microscopic analysis was used to observe the fungi. Lactophenol cotton blue and oil immersion were applied on preparing slide mounts. Observation was done using a light microscope (Leica Leitz DMRB) equipped with 
a color camera (Leica DFC420). Identification was carried out at species level based on the morphological descriptions with several parameters (colony, conidia and conidiophores, conidiogenous cells, perithecia, and chlamydospores) according to Booth (1971), Gerlach and Nirenberg (1982), Nelson et al. (1983), Burgess et al. (1994), and Leslie and Summerell (2006). At least 20 microconidia and macroconidia of each isolate were selected randomly for measurement. Fusarium strains were stored as spore suspension in 25\% (v/v) glycerol (Carl Roth, Karlsruhe, Germany) at $-60^{\circ} \mathrm{C}$.

\subsubsection{Molecular analysis}

Identification of Fusarium isolates was performed according to the combination of morphological and molecular characters. Microscopy observation were employed for morphological identification as described before. Afterward, DNA fingerprinting was employed to distinguish identical and non identical isolates. Screened isolated then confirmed at species level by the results of DNA sequence of the "Translation Elongation Factor 1-alpha" (TEF-1 $\alpha$ ) gene, which is taxonomically most informative part in this fungal genus.

\section{DNA extraction and gel electrophoresis}

The cultures were grown on potato dextrose broth (PDB) (Roth, Karlsruhe, Germany) in Erlenmeyer flasks in darkness at $25^{\circ} \mathrm{C}$ for 5 days. Mycelium was harvested by filtration onto sterile paper disks, froze in $-70^{\circ} \mathrm{C}$, freeze-dried in a freeze drier (Christ, Beta 1-8) and stored at room temperature till extracting genomic DNA. Fifty milligrams of lyophilized mycelium were ground in $2 \mathrm{~mL}$ Eppendorf tubes with round bottom containing 4-5 wolfram carbide spheres (diameter 3 mm, Retsch, Haan, Germany) in a reciprocal mill (Mixer Mill MM 200, Retsch, Haan, Germany). Genomic DNA was extracted by a CTAB method (Brandfass and Karlovsky, 2008). In order to check the efficiency of DNA extraction and the purity of extracted DNA, a $5 \mu \mathrm{L}$ DNA sample were mixed with $2 \mu \mathrm{L}$ Blue juice and loaded on a $0.8 \%(\mathrm{w} / \mathrm{v})$ agarose gel (Cambrex, Rockland, ME, USA), prepared in TAE buffer (40 mM Tris, $1 \mathrm{mM}$ EDTA (ethylene diamine tetra acetic acid), $\mathrm{pH}$ set to 8.5) (both substances were obtained from Carl Roth, Karlsruhe, Germany). The electrophoresis was carried out at $60 \mathrm{~V}$ for $60 \mathrm{~min}$. After staining with ethidium bromide $(0.5 \mu \mathrm{g}$ $\mathrm{mL}^{-1}$ ) and destaining in demineralized water (each for $10 \mathrm{~min}$ ), DNA bands were visualized in UV light using a CCD camera (Vilber Lourmat, Marne La Vallee, France).

\section{DNA fingerprinting}

In the preliminary experiments, four arbitrary primers were tested with Random Amplified Polymorphic DNA (RAPD) with DNA extracted from pure cultures of Fusarium. List of primers can be seen on Table 2. Preliminary test determined the optimal concentration of the component in the PCR reaction mixture, amplification conditions and primer selection. Strong, unique, sharp and clearly reproducible bands were produced by primer C6.2_introns_2_R and C7_1_seq_f2. For further analysis C7_1_seq_f2 was used. 
Table 2. Primer and their sequences tested in preliminary RAPD analysis.

\begin{tabular}{ll}
\hline \multicolumn{1}{c}{ Primers } & \multicolumn{1}{c}{ Sequence 5'-3' } \\
\hline C6.2_introns_2_R (C6_2_int_R3) & TGGCTCACGCAAGGGTGTAG \\
C2_1++inv_f & TGACGTCCTAGTTGATATCCTCG \\
C2_1++inv_r & ACCGTTATGATCAATAAATATTTGACCA \\
C7_1_seq_f2 & AGGTTAGCTCGCGACTATCGGATC \\
\hline
\end{tabular}

In brief, the optimal condition of PCR as described below:

The amplification reaction was carried out in a volume of $25 \mu \mathrm{L}$ containing $18.45 \mu \mathrm{L}$ water, 2.5 $\mu \mathrm{L}$ 10x reaction buffer (Bioline, Luckenwalde, Germany), $1.5 \mu \mathrm{L}$ dNTPs $150 \mu \mathrm{M}$ (Amersham Biosciences), $0.75 \mu \mathrm{L}$ of primer $0.3 \mu \mathrm{M}$ (GenXpress), $0.05 \mu \mathrm{L}$ of Taq DNA polymerase $0.25 \mathrm{U}$ (New England BioLabs, Ipswich, MA, USA) and $1 \mu \mathrm{L}$ of DNA sample. For detection of any other kinds of DNA contaminants, a negative control of PCR-mix without any template DNA was used. The PCR program had initial denaturation at $94^{\circ} \mathrm{C}$ for $2 \mathrm{~min}, 2 \mathrm{x} 45$ cycles of: $20 \mathrm{~s}$ at $94^{\circ} \mathrm{C}, 37 \mathrm{~s}$ at $37^{\circ} \mathrm{C}, 20 \mathrm{~s}$ at $72^{\circ} \mathrm{C}$ and followed by final extension at $72^{\circ} \mathrm{C}$ for $5 \mathrm{~min}$, storage $15^{\circ} \mathrm{C}$ for $5 \mathrm{~min}$ (peQ STAR Thermocycler). Eight $\mu \mathrm{L}$ of the PCR products, and $0.5 \mu \mathrm{L}$ of size marker (100bp), respectively, is mixed with $2 \mu \mathrm{L}$ of blue juice and pipetted into the slots. The electrophoresis is carried out at $60 \mathrm{~V}$ for $90 \mathrm{~min}$. The EtBr-stained DNA fragments are visualized under a UVtransilluminator.

\section{Polymerase chain reaction and phylogenetic analysis}

Identification at species level was confirmed by the results of DNA sequence of (TEF-1 $\alpha$ ) gene gene, which is taxonomically most informative part in this fungal genus. Hot start PCR protocol was used to amplify the TEF-1 $a$ gene region using the fungal specific primer set: ef1 (5'ATGGGTAAGGA(A/G)GACAAGAC-3') and ef2 (5'GA(G/A)GTACCAGT(G/C)ATCATGTT$\left.3^{\prime}\right)$ described by O'Donnell et al. (1998). The reaction mixture consisted of reaction buffer (16 mM (NH4)2SO; $67 \mathrm{mM}$ Tris-HCl; 0.01\% (v/v) Tween-20, pH: 8.8 at $25^{\circ} \mathrm{C}$ ), $0.1 \mathrm{mM}$ concentration of each of the four deoxynucleoside triphosphates (Bioline, Lükenwalde, Germany), $2 \mathrm{mM}$ of $\mathrm{MgCl}$, $1.75 \mathrm{U}$ of hot-start DNA polymerase (Immolase DNA Pol, Lükenwalde, Germany), $0.3 \mu \mathrm{M}$ concentration of each primer. Every reaction contained $1 \mu \mathrm{L}$ template DNA or $1 \mu \mathrm{L}$ sterile water as negative control. The PCR reactions were performed in a total volume of $25 \mu \mathrm{L}$ reactions with a peQ STAR Thermocycler (96 Universal Gradient). The cycling conditions were as follows: 1 cycle of $10 \mathrm{~min}$ at $95^{\circ} \mathrm{C}, 30$ cycles of $60 \mathrm{~s}$ at $94^{\circ} \mathrm{C}$ (denaturalization), $45 \mathrm{~s}$ at $58.5^{\circ} \mathrm{C}$ (annealing), $60 \mathrm{~s}$ at $72^{\circ} \mathrm{C}$ (extension) and followed by a final extension cycle at $72^{\circ} \mathrm{C}$ for $5 \mathrm{~min}$. The checking of the PCR product was performed on agarose gel electrophoresis as described above. The PCR products were purified using isopropanol precipitation and $5 \mu \mathrm{L}$ of the PCR product were sent to LCG Genomics GmbH (Ostendstr. 25. TGS Haus 8, 12459 Berlin, Germany) for sequencing. The sequences were, then, used as queries for Fusarium-ID v. 1.0 database (Geiser et al., 2004). In order to construct a phylogenetic tree sequences with the highest similarity to the query, together with some sequences retrieved from the GenBank database were aligned and constructed using the software MEGA 7 (Kumar et al., 2016). 


\subsubsection{Mycotoxin screening from isolates \\ Molecular approach}

PCR amplification of the FUM1, FUM8, FUM12 and TRI5 genes. To assess the ability of obtained Fusarium isolates to produce fumonisins and trichothecenes, the presence of the FUM and TRI genes was checked by PCR amplification using different primer sets as described below.

Table 3. Primers used for PCR amplification FUM1, FUM8, FUM12 and TRI5 genes.

\begin{tabular}{llc}
\hline \multicolumn{1}{c}{ Primer name } & \multicolumn{1}{c}{ Primer sequence $\left(5^{\prime}-3^{\prime}\right)$} & \multicolumn{1}{c}{ Source } \\
\hline FUM 1F & ACAAGTGTCCTTGGGGTCCAGG & Proctor et al. (2004) \\
FUM 1R & GATGCTCTTTGGAAGTGGCCTACG & \\
FUM 8R & TGAGAAGGATGTTCATGACGCCC & \\
FUM 8F & TTGGAACCCAGCTCTGCCA & \\
FUM 12R & GATAAGCCAGATTCTGTCCGATGC & \\
FUM 12F & GCAGCGTACTACTCCGACCTTG & \\
\hline TRI 5F & TCTATGGCCCAAGGACCTGTTTGA & Hallen-Adams et al. (2004) \\
TRI 5R & TGACCCAAACCATCCAGTTCTCCA & \\
\hline
\end{tabular}

PCR reaction components were the same as in the previous section. PCR cycling conditions were as follows: $95^{\circ} \mathrm{C}$ for $3 \mathrm{~min}$, then 35 cycles of $94^{\circ} \mathrm{C}$ for $10 \mathrm{~s}, 57^{\circ} \mathrm{C}$ for $15 \mathrm{~s}, 72^{\circ} \mathrm{C}$ for $40 \mathrm{~s}$. After electrophoresis, the presence or absence of PCR fragments at expected sizes was checked using a UV-transilluminator.

\section{Mycotoxin screening with HPLC-MS/MS}

\section{Microorganisms and solid culture}

Fusarium strains used in this study isolated from traditional tempeh inocula as described above. To examine their mycotoxin production, three agar plugs ( $5 \mathrm{~mm}$ of diameter) of each strains grown on potato dextrose agar (PDA, from Merck, Darmstadt, Germany) plates for 7 days at $25^{\circ} \mathrm{C}$ were inoculated on rice solid medium. Rice solid medium was prepared by autoclaving $\left(120^{\circ} \mathrm{C}, 15 \mathrm{psi}\right.$, $15 \mathrm{~min}$; Tuttnauer- Systec/ $3870 \mathrm{EL}$ ) 3 and $5 \mathrm{~mL}$ tap water in $50 \mathrm{~mL}$ falcon tube (water content around $40-50 \%$ ). The cultures were incubated at $21^{\circ} \mathrm{C}$ (Schütt Lichtthermostat) for 25 days. Samples froze in $-20^{\circ} \mathrm{C}$, dried in a freeze drier (Christ, Beta 1-8), powdered in a reciprocal mill (Mixer Mill MM 200, Retsch, Haan, Germany) and stored in freezer at $-20^{\circ} \mathrm{C}$.

\section{Mycotoxin extraction and HPLC-MS/MS analysis}

Two $\mathrm{g}$ of each ground sample was weighed into falcons $(50 \mathrm{~mL})$ and $20 \mathrm{~mL}$ of acetonitrile, water and acetic acid (84:15:1) were added. The falcons were thoroughly vortexed until the powdered sample was completely wet. Then it was shaken overnight using a shaker (Adolf Kühner AG Basel, Switzerland) at 175 RPM at room temperature. The samples were centrifuged for ten minutes at 4500 RPM. After that, $1 \mathrm{~mL}$ of the supernatant was transferred into $2 \mathrm{~mL}$ Eppendorf tubes and evaporated in the vacum drier (Martin Christ Gefriertrocknungsanlagen $\mathrm{GmbH}$, Osterode am Harz, Germany) at a temperature $40^{\circ} \mathrm{C}$. For storage the residues were kept in the freezer at $-20{ }^{\circ} \mathrm{C}$. To re-dissolve the evaporated samples, $1 \mathrm{~mL}$ methanol/water (1:1) was added. After two hours at room temperature the samples were vortexed and sonicated for approximately ten seconds. Half of each sample $(500 \mu \mathrm{L})$ was transferred to a new Eppendorf tube and stored at $-20{ }^{\circ} \mathrm{C}$ until analysis. Those were not defatted due to the loss of BEA and ENNs during the defatting step and 
were used to analyze beauvericin, fumonisin B1 and enniatin A, A1, B and B1. On the day of analysis the samples were mixed, centrifuged for five minutes at high speed (14800 RPM) and transferred to $200 \mu \mathrm{L}$ vials.

Mycotoxin separation and analysis was carried out by high pressure liquid chromatography coupled with electrospray ionization and tandem mass spectrometry detection. HPLC separation was carried out on a reverse-phase on a reverse phase Kinetex C18 column $(50.0 \times 2.1 \mathrm{~mm}, 2.6$ $\mu \mathrm{m}$ particle size) coupled with a C18 security guard cartridge $(4 \mathrm{~mm} \times 2 \mathrm{~mm}$ i.d., both from Phenomenex, Aschaffenburg, Germany) maintained at a temperature $40^{\circ} \mathrm{C}$ with a methanol-water gradient, followed by electrospray ionization essentially as described (Ratzinger et al., 2009), and detected using ion trap 500 MS (Varian, Darmstadt, Germany) as described by Nutz et al. (2011). The mobile phase consisted of water with $5 \%$ acetonitrile (A) and methanol (B), both containing $7 \mathrm{mM}$ of acetic acid. The injection volume was $10 \mu \mathrm{L}$ and the flow rate was set at $0.2 \mathrm{~mL} \mathrm{~min}^{-1}$. The binary gradient was from $40-98 \%$ B. Pure analytical standards (Sigma-Aldrich Chemie $\mathrm{GmbH}$, Steinheim, Germany) in methanol/water (1:1) were used to construct calibration curves. The evaluation of the chromatogram were done with the MS Workstation version 6.9.1.

Table 4. MS/MS parameters for the determination of mycotoxin.

\begin{tabular}{|c|c|c|c|}
\hline Mycotoxin & Ionisation modus & Precursor-Ion $(\mathrm{m} / \mathrm{z})$ & Product-Ion $(\mathrm{m} / \mathrm{z})$ \\
\hline Zearalenone (ZEN) & ESI- & 317 & $\begin{array}{l}175 \\
130.9\end{array}$ \\
\hline Fusarenone $\mathrm{X}$ (Fus X) & ESI- & 353 & $\begin{array}{l}204.8 \\
262.9\end{array}$ \\
\hline Nivalenol (NIV) & ESI- & 371 & $\begin{array}{l}311 \\
281\end{array}$ \\
\hline 15-ADON (15-acetyldeoxynivalenol) & ESI- & 337 & $\begin{array}{l}172.9 \\
150\end{array}$ \\
\hline 3-ADON (3-acetyldeoxynivalenol) & ESI- & 337 & $\begin{array}{l}307 \\
246.8\end{array}$ \\
\hline Deoxynivalenol (DON) & ESI- & 355 & $\begin{array}{l}295 \\
265\end{array}$ \\
\hline Neosolaniol (NEO) & ESI+ & 400.5 & $\begin{array}{l}215.3 \\
185.3\end{array}$ \\
\hline Diacetoxyscirpenol (DAS) & ESI+ & 384.5 & $\begin{array}{l}229.2 \\
307.2\end{array}$ \\
\hline HT2-toxin (Tricothecene) & ESI+ & 442 & $\begin{array}{l}215 \\
263\end{array}$ \\
\hline T2-toxin (Tricothecene) & ESI+ & 484 & $\begin{array}{l}185 \\
215\end{array}$ \\
\hline Beauvericin (BEA) & ESI+ & 806.4 & $\begin{array}{l}645.5 \\
545.3 \\
384.4\end{array}$ \\
\hline Fumonisin B1 (FB1) & ESI+ & 722.5 & $\begin{array}{l}686.4 \\
528.4 \\
352.5\end{array}$ \\
\hline Enniatin A & ESI+ & 704.5 & $\begin{array}{l}577.5 \\
477.4 \\
350.3\end{array}$ \\
\hline
\end{tabular}


Chapter 4: Mycotoxin-producing Fusarium in traditional tempeh and usar

\begin{tabular}{lccc}
\hline Enniatin A1 & ESI+ & 690.6 & 563.4 \\
& & & 463.4 \\
Enniatin B & \multirow{2}{*}{ ESI+ } & 662.6 & 350.5 \\
& & & 549.4 \\
\multirow{2}{*}{ Enniatin B1 } & & 449.4 \\
& ESI+ & \multirow{2}{*}{676.6} & 336.4 \\
& & & 563.4 \\
& & 463.4 \\
\hline
\end{tabular}

The limit of quantification (LOQ) values were $10 \mathrm{ng} / \mathrm{g}$ for ZEN, $1000 \mathrm{ng} / \mathrm{g}$ for Fus X, $200 \mathrm{ng} / \mathrm{g}$ for NIV, $250 \mathrm{ng} / \mathrm{g}$ for DON, $250 \mathrm{ng} / \mathrm{g}$ for 3-ADON, $1000 \mathrm{ng} / \mathrm{g}$ for 5-ADON, $100 \mathrm{ng} / \mathrm{g}$ for HT-2 toxin and T-2 toxin, $50 \mathrm{ng} / \mathrm{g}$ for DAS, $100 \mathrm{ng} / \mathrm{g}$ for NEO, $30 \mathrm{ng} / \mathrm{g}$ for FB1, $10 \mathrm{ng} / \mathrm{g}$ for BEA, 20 $\mathrm{ng} / \mathrm{g}$ for enniatin A, $10 \mathrm{ng} / \mathrm{g}$ for enniatin A1, $36 \mathrm{ng} / \mathrm{g}$ for enniatin B and $110 \mathrm{ng} / \mathrm{g}$ for enniatin B1. Limit of detection (LOD) values were $5 \mathrm{ng} / \mathrm{g}$ for ZEN, $500 \mathrm{ng} / \mathrm{g}$ for Fus X, $100 \mathrm{ng} / \mathrm{g}$ for NIV, 700 $\mathrm{ng} / \mathrm{g}$ for 15-ADON, $30 \mathrm{ng} / \mathrm{g}$ for DON, $100 \mathrm{ng} / \mathrm{g}$ for 3-ADON, $30 \mathrm{ng} / \mathrm{g}$ for HT-2 toxin and T-2 toxin, $10 \mathrm{ng} / \mathrm{g}$ for DAS, $30 \mathrm{ng} / \mathrm{g}$ for NEO, $30 \mathrm{ng} / \mathrm{g}$ for FB1, $3 \mathrm{ng} / \mathrm{g}$ for BEA, $8 \mathrm{ng} / \mathrm{g}$ for enniatin A, $3 \mathrm{ng} / \mathrm{g}$ for enniatin A1, $20 \mathrm{ng} / \mathrm{g}$ for enniatin B and $88 \mathrm{ng} / \mathrm{g}$ for enniatin B1.

\subsubsection{Toxicity test (brine shrimp)}

Growing brine shrimps: Three spoons of the ready-to-use shrimp egg/salt-mixture were dissolved into in a big glass petridish contained $500 \mathrm{~mL}$ tap-water. Then, stirred gently with a spatula to dissolve the salt. Petri-dish was placed under light at room temperature and incubate the eggs for 48 hours.

Preparation of crude mycotoxin solutions: Supernatants $(20 \mathrm{~mL})$ from each isolates (from part mycotoxin screening above) were used for this test. Solvent was initially evaporated in the rotary evaporator (Büchi 011, Switzerland, at $35^{\circ} \mathrm{C}$ ) equipped with a vacuum pump V-700 and vacuum controller V-855 (Büchi, Switzerland, at 150 mbar) and then in the SpeedVac (Christ RVC 2-25 $\mathrm{CD}$ plus, $35^{\circ} \mathrm{C}, 30 \mathrm{mbar}$ ) to obtain an concentrated crude extract and weighed.

Crude toxins extract were prepared on concentrations of 20,40, 60, 80 and 100 ppm in $100 \%$ methanol. One hundred microliter of each crude mycotoxin solution was transferred with micropipette into cavities of the 96-well microplate microplate (Sarstedt AG \& Co., Nuembrecht, Germany) in five repetitions, methanol without mycotoxins was used as negative control and the methanol was evaporated under a fumehood.

Toxicity assay: The brine shrimp (Artemia salina) bioassay procedure followed the microwell plate method. The brine shrimp culture was poured into a breaker and illuminate the glass from one side with a flashlight. Light source was aimed for attracting the shrimps to one side of the breaker. Two hundred microliter of the solution with 10-20 brine shrimps was transferred into cavities of microplate using $1000 \mu \mathrm{L}$ tips. Dead brine shrimps were counted with stereo microscope for 0,24 and 48 hours observations. The surviving shrimps were killed by freezing at $-20^{\circ} \mathrm{C}$ for at least 12 hours and count the total number of brine shrimps with stereo microscope. $\mathrm{LD}_{50}$ is the amount of a material, given all at once, which causes the death of $50 \%$ (one half) of a group of test animals. The $\mathrm{LD}_{50}$ is one way to measure the short-term poisoning potential (acute 
toxicity) of a material. Mean of mortality percentage was calculated in excel program. The $\mathrm{LD}_{50}$ values as concentrations at which half of the animal survived was estimated with 4 Parameter Logistic (4PL) nonlinear regression model using Sigmaplot ver11 program.

\section{Part II (Detection of Fusarium and mycotoxins in traditional tempeh)}

\subsubsection{Traditional tempeh sampling}

Traditional tempeh samples were collected in centre of tempeh producer where Fusarium found positively before in their traditional inocula (on end of 2015). Samples were transported in sterile plastic container to nearby laboratory in each location. Samples were then freeze dried (Supermodulyo, Japan), powdered and maintained at $4{ }^{\circ} \mathrm{C}$ until analysis in refrigerator (Sanyo, Japan). To determinate the water content of the different samples $5 \mathrm{~g}$ were weighed in falcons and analyzed with water content analyzer (Ohaus MB45, Germany). Details information of sampling can be seen on Table 5 .

Table 5. Information of traditional tempeh sampling.

\begin{tabular}{clcc}
\hline Areas & \multicolumn{1}{c}{ Samples } & Amount & Year \\
\hline Banyumas & Traditional fresh tempeh & 39 & 2015 \\
Kebumen & Traditional fresh tempeh & 37 & 2015 \\
Yogyakarta & Traditional fresh tempeh & 41 & 2015 \\
Banjarnegara & Traditional fresh tempeh & 33 & 2015 \\
Gombong & Traditional fresh tempeh & 33 & 2015 \\
Kudus & Traditional fresh tempeh & 31 & 2015 \\
\hline & Total of sample & 214 & \\
\hline
\end{tabular}

\subsubsection{Detection and quantification of Fusarium with qPCR from traditional tempeh}

This method is based on the classical Polymerase Chain Reaction (PCR) and the amplification of DNA. The difference of Real Time PCR (qPCR) is the possibility to quantify the DNA. The procedure runs through up to 40 cycles and each cycle passes through three different steps: Denaturation, Annealing and Elongation (Dorak, 2006). Detection of two Fusarium species ( $F$. proliferatum and $F$. solani) were the main focus in this analysis.

\section{Preparation of DNA standards for qPCR}

DNA quantification was carried out by densitometry of DNA bands after electrophoretic separation; because calculation of DNA concentration from absorbance of the solution in UV light is error-prone (Wilfinger et al., 1997). For this purpose, a range of dilutions of genomic DNA was separated electrophoretically on $1.2 \%$ (w/v) agarose gels prepared in TAE buffer (40 mM Tris, 1 mM EDTA, pH set to 8.5 with acetic acid, Riedel-de Haen, Hanover, Germany) along with a dilution series of lambda phage DNA of known concentration (methylated, from Escherichia coli host strain W3110). The electrophoresis was carried out at $60 \mathrm{~V}$ for $60 \mathrm{~min}$. After staining with ethidium bromide $\left(0.5 \mu \mathrm{g} \mathrm{mL}^{-1}\right)$ and destaining in demineralized water, DNA bands were visualized in UV light using a CCD camera (Vilber Lourmat, Marne La Vallee, France). The electrophoretic bands within the linear range of the densitometry were used for quantification using 
Multi Analyst-Software (BioRad, Hercules, CA, USA). Standards for qPCR were prepared in a range of $0.056 \mathrm{pg} \mu \mathrm{L}^{-1}$ to $1111 \mathrm{pg} \mu \mathrm{L}^{-1}$ by consecutive $1: 3$ dilutions, starting with the highest standard, in sterile distilled water.

\section{DNA extraction of samples}

DNA was extracted from $60 \mathrm{mg}$ samples following a protocol of Brandfass and Karlovsky (2008). Extracted samples were diluted to approximately $10-15 \mathrm{ng} \mu \mathrm{L}^{-1}$ of total DNA based on comparison of the intensity of DNA bands after agarose electrophoresis with DNA standards, the dilutions were recorded and DNA was subjected to qPCR. A thermocycler (CFX384TM Real-Time System, C1000TM Thermal Cycler, BioRad, USA) with 384-well microplates (Kisker Biotech GmbH, Steinfurt, Germany) was used for the qPCR analysis.

\section{Inhibition test}

To find out if there is a natural inhibition from tempeh material, one test with the real time PCR was done with Verticillium longisporum. For that purpose the forward and reverse primer OLG 70 (CAGCGAAACGCGATATGTAG) and OLG 71 (GGCTTGTAGGGGGTTTAGA) with 261 bp were used. Those were developed by Eynck et al. (2007). For that test some samples were used with a dilution of each $1: 10 ; 1: 20,1: 50$, and 1:100 and three replications each. Fifty pg of the fungal DNA $V$. longisporum was added. Furthermore there was a negative control with bi-distilled water. The result showed there is no natural inhibition from tempeh.

\section{Detection of $F$. solani}

Two kind of primers were tested their specificity. First primer was Fsol1 (CTCATCAACCC TGTGAACATACC) and Fsol2 (ATGCCAGAGCCAAGAGATCC) based on Bernal-martinez et al. (2012), second primer was TEF-Fs4f (ATCGGCCACGTCGACTCT) and TEF-FS4r (GG CGTCTGTTGATTGTTAGC) based on Arif et al. (2012). To check specificity of the primer, 63 DNA of Fusarium from different species were used (can be seen in Table 6, those DNA were kindly provided by Dr. Katharina Pfohl, and Maria Vinas). The result showed that the primer TEFFs4f has better specificity than Fsol primer. The melting temperature for the species specific evaluation is at $87 \pm 0.5^{\circ} \mathrm{C}$. But there was unspecific peak especially in low concentrations of DNA, then optimization was continued on annealing temperature $\left(50-63^{\circ} \mathrm{C}\right), \mathrm{MgCl}_{2}$ concentrations (2, 2.5, 3 and $3.5 \mathrm{mM}$ ), BSA, dNTP and primer concentration (BSA 2, 3 and $4 \mathrm{mg} \mathrm{mL}^{-1}$ (dNTP $300 \mathrm{mM}$ and primer $0.4 \mu \mathrm{M})$ ) and BSA 2, 3 and $4 \mathrm{mg} \mathrm{mL}^{-1}(\mathrm{dNTP} 400 \mathrm{mM}$ and primer $0.5 \mu \mathrm{M})$ ). Initial experiment showed that that $63^{\circ} \mathrm{C}$ of annealing temperature, $2.5 \mathrm{mM} \mathrm{MgCl} 2$ and BSA 2 $\mathrm{mg} / \mathrm{mL}$ (dNTP $300 \mathrm{mM}$ and primer $0.4 \mu \mathrm{M}$ ) found as the optimal qPCR conditions.

Table 6. Fungal strains used in the specifity test.

\begin{tabular}{ll}
\hline \multicolumn{1}{c}{ Fusarium species } & Source \\
\hline F. avenaceum DSM $62161^{1)}$ & Maria Vinas \\
F. oxysporum DSM $62296^{1)}$ & Maria Vinas \\
F. tricintum 063 & Maria Vinas \\
F. verticilioides Fv. Ita 1 & Maria Vinas \\
F. proliferatum DSM $62261^{1)}$ & Maria Vinas \\
F. subglutinans CBS $215.76^{3)}$ & Maria Vinas \\
\hline
\end{tabular}




\begin{tabular}{|c|c|}
\hline F. fujikuroi IMI 58289 & Maria Vinas \\
\hline F. oxysporum fsp asp BBA $62286^{2}$ & Maria Vinas \\
\hline F. oxysporum fsp lycop CBS $16730^{3)}$ & Maria Vinas \\
\hline$F$ avenaceum $64911 \mathrm{P}$ & Maria Vinas \\
\hline F. oxysporum fsp longl Foc $5 \mathrm{a}^{4)}$ & Maria Vinas \\
\hline F. oxysporum F11.1 ${ }^{4)}$ & Maria Vinas \\
\hline F. avenaceum DSM $21724^{1)}$ & Maria Vinas \\
\hline F. avenaceum CBS $121.73^{3)}$ & Maria Vinas \\
\hline F. subglutinans CBS 215.763) & Maria Vinas \\
\hline F. avenaceum $\mathrm{Fa} 1.2$ & Dr. Katharina Pfohl \\
\hline F. avenaceum $\mathrm{Fa} 9$ & Dr. Katharina Pfohl \\
\hline F. avenaceum $\mathrm{Fa} 3$ & Dr. Katharina Pfohl \\
\hline F. avenaceum $\mathrm{Fa} 1.3$ & Dr. Katharina Pfohl \\
\hline F. oxysporum Foxy $5^{4)}$ & Dr. Katharina Pfohl \\
\hline F. oxysporum $\mathrm{F}$ oxy $6^{4)}$ & Dr. Katharina Pfohl \\
\hline F. oxysporum $\mathrm{F}$ oxy $119 \mathrm{~S}^{4)}$ & Dr. Katharina Pfohl \\
\hline F. subglutinans $\mathrm{F}$ sub7 ${ }^{4)}$ & Dr. Katharina Pfohl \\
\hline F. subglutinans $\mathrm{F}$ sub $220^{4)}$ & Dr. Katharina Pfohl \\
\hline F. subglutinans $\mathrm{F}$ sub $6^{4)}$ & Dr. Katharina Pfohl \\
\hline F. subglutinans $\mathrm{F}$ sub $2215^{4)}$ & Dr. Katharina Pfohl \\
\hline F. subglutinans $\mathrm{F}$ sub $2202^{4)}$ & Dr. Katharina Pfohl \\
\hline Microdochium nivale 10 & Dr. Katharina Pfohl \\
\hline M. nivale GF-B2 & Dr. Katharina Pfohl \\
\hline M. nivale $\mathrm{GF}-\mathrm{B} 3$ & Dr. Katharina Pfohl \\
\hline M. nivale GF-B8 & Dr. Katharina Pfohl \\
\hline M. nivale GF-B11 & Dr. Katharina Pfohl \\
\hline F. culmorum $\mathrm{Fc} 21$ & Dr. Katharina Pfohl \\
\hline F. culmorum $\mathrm{Fc} 40$ & Dr. Katharina Pfohl \\
\hline F. culmorum $\mathrm{Fc} 11$ & Dr. Katharina Pfohl \\
\hline F. culmorum $\mathrm{Fc} 31$ & Dr. Katharina Pfohl \\
\hline F. culmorum $\mathrm{Fc} 22$ & Dr. Katharina Pfohl \\
\hline Microdochiae nivae GN 35 & Dr. Katharina Pfohl \\
\hline M. nivale GN 7 & Dr. Katharina Pfohl \\
\hline M. nivale GN 25 & Dr. Katharina Pfohl \\
\hline M. nivale GN 36 & Dr. Katharina Pfohl \\
\hline M. nivale GN 12 & Dr. Katharina Pfohl \\
\hline F. proliferatum Fpro 7 & Dr. Katharina Pfohl \\
\hline F. proliferatum Fpro 12 & Dr. Katharina Pfohl \\
\hline F. proliferatum Fpro11 & Dr. Katharina Pfohl \\
\hline$F$. proliferatum Fpro2 & Dr. Katharina Pfohl \\
\hline F. proliferatum Fpro5 & Dr. Katharina Pfohl \\
\hline F. verticillioides Fv2 & Dr. Katharina Pfohl \\
\hline F. verticillioides Fv3 & Dr. Katharina Pfohl \\
\hline F. verticillioides Fverti 1:10 & Dr. Katharina Pfohl \\
\hline F. verticillioides Fv IFA 420 & Dr. Katharina Pfohl \\
\hline F. verticillioides Fv3 & Dr. Katharina Pfohl \\
\hline F. verticillioides Fv IFA 429 & Dr. Katharina Pfohl \\
\hline F. graminearum FG 62722 & Dr. Katharina Pfohl \\
\hline F. graminearum FG 62217 & Dr. Katharina Pfohl \\
\hline F. graminearum FG 83699 & Dr. Katharina Pfohl \\
\hline F. graminearum FG 67638 & Dr. Katharina Pfohl \\
\hline
\end{tabular}


Chapter 4: Mycotoxin-producing Fusarium in traditional tempeh and usar

\begin{tabular}{ll}
\hline F. avenaceum FA5 & Dr. Katharina Pfohl \\
F. avenaceum FA 118 & Dr. Katharina Pfohl \\
F. avenaceum FA 7 & Dr. Katharina Pfohl \\
F. avenaceum FA 2 & Dr. Katharina Pfohl \\
F. avenaceum FA 39 & Dr. Katharina Pfohl \\
F. solani type 1 FS GS21.025) & Riyan Anggriawan \\
F. solani type 2 FS B25.075) & Riyan Anggriawan \\
F. solani type 1 FS GS21.025) & Riyan Anggriawan \\
F. solani type 2 FS B25.075) & Riyan Anggriawan \\
\hline Note: & \\
${ }^{1)}$ Sammlung von Mikroorganismen und Zellkulturen,Braunschweig, Germany, via E. Moller. \\
${ }^{2)}$ Nirenberg (BBA Berlin, Germany) via E. Moller. \\
${ }^{3)}$ Centraalbureau voor Schimmelcultures, Utrecht, The Netherlands. \\
${ }^{4)}$ Department of Crop Sciences, University of Gottingen, Germany \\
${ }^{5)}$ This present research. & \\
\hline
\end{tabular}

In brief, optimal assay described as follows:

The reaction mixture contained reaction buffer (16 mM (NH4)2SO4; $67 \mathrm{mM}$ Tris-HCl; $0.01 \%$ (v/v) Tween-20, pH 8.8 at $25^{\circ} \mathrm{C}$, Bioline, Lükenwalde, Germany), $0.1 \mathrm{mM}$ of each of the four deoxynucleoside triphosphates (dNTPs; Bioline, Lükenwalde, Germany), $2.5 \mathrm{mM} \mathrm{MgCl}_{2}, 0.025 \mathrm{U}$ of Taq DNA polymerase (BIOTaq, Bioline, Lükenwalde, Germany), $0.4 \mu \mathrm{M}$ of each primer, $0.1 \mathrm{x}$ SYBR Green I (Invitrogen, Karlsruhe, Germany). The cycling conditions were performed according to following protocol: 1 cycle of $2 \mathrm{~min}$ at $95^{\circ} \mathrm{C}$ (initial denaturation), 39 cycles of $30 \mathrm{~s}$ at $94^{\circ} \mathrm{C}$ (denaturation), $30 \mathrm{~s}$ at $72^{\circ} \mathrm{C}$ (annealing), $40 \mathrm{~s}$ at $72^{\circ} \mathrm{C}$ (extension) and followed by a final extension cycle at $72^{\circ} \mathrm{C}$ for $5 \mathrm{~min}$. Fluorescent data were obtained during the annealing phase to construct a melting curve at the end of assay. The qPCR was completed by running a melting curve analysis.

\section{Detection of $F$. proliferatum}

To quantitate the DNA of $F$. proliferatum the forward and reverse primer Fp3-F (CGGCCACCAGAGGATGTG) and Fp4-R (CAACACGAATCGCTTCCTGAC) with a size of $230 \mathrm{bp}$ were used. They were developed by Jurado et al. (2006). F. proliferatum strain DSM 62267 was used to generate the standard curve in a dilution series. The melting temperature for the species specific evaluation is at $89 \pm 0.5^{\circ} \mathrm{C}$. The species specific real time assay based on the method from Nutz et al. (2011).

In brief, the assay described as follows:

The reaction mixture contained reaction buffer (16 mM (NH4)2SO4; $67 \mathrm{mM}$ Tris-HCl; 0.01\% (v/v) Tween-20, pH 8.8 at $25^{\circ} \mathrm{C}$, Bioline, Lükenwalde, Germany), $0.1 \mathrm{mM}$ of each of the four deoxynucleoside triphosphates (dNTPs; Bioline, Lükenwalde, Germany), $2.5 \mathrm{mM} \mathrm{MgCl} 2,0.4 \mathrm{U}$ of Taq DNA polymerase (BIOTaq, Bioline, Lükenwalde, Germany), $0.6 \mu \mathrm{M}$ of each primer, $0.1 \mathrm{x}$ SYBR Green I (Invitrogen, Karlsruhe, Germany). The cycling conditions were performed according to following protocol: initial denaturation for $1.5 \mathrm{~min}$ at $95{ }^{\circ} \mathrm{C}$; followed by 35 cycles with $35 \mathrm{~s}$ at $95{ }^{\circ} \mathrm{C}, 30 \mathrm{~s}$ at $64{ }^{\circ} \mathrm{C}$, and $30 \mathrm{~s}$ at $72{ }^{\circ} \mathrm{C}$, with fluorescence measurement during the annealing step of each cycle; and a final elongation of $5 \mathrm{~min}$ at $72{ }^{\circ} \mathrm{C}$. The qPCR was completed by running a melting curve analysis. 


\subsubsection{Extraction of tempeh and HPLC analysis (Fumonisin, Beauvericin and Enniatins)}

In the beginning, inhibiton test was done before extracting the whole samples. Inhibiton test was aimed to know the effect of tempeh material to detection of mycotoxin. The result showed there was no inhibiton effect from the samples.

For the extraction of the mycotoxins from tempeh, $2 \mathrm{~g}$ of each ground sample was weighed into falcons $(50 \mathrm{~mL})$ and $20 \mathrm{~mL}$ of acetonitrile and water (84:16) were added. The falcons were thoroughly vortexed until the powdered tempeh was completely wet. Then it was shaken overnight using a shaker (Adolf Kühner AG Basel, Switzerland) at 175 RPM at room temperature. The samples were centrifuged for ten minutes at $4500 \mathrm{RPM}$. After that, $1 \mathrm{~mL}$ of the supernatant was transferred into $2 \mathrm{~mL}$ Eppendorf tubes and evaporated in the vacum drier (Martin Christ Gefriertrocknungsanlagen $\mathrm{GmbH}$, Osterode am Harz, Germany) at a temperature $40^{\circ} \mathrm{C}$. For storage the residues were kept in the freezer at $-20^{\circ} \mathrm{C}$. To re-dissolve the evaporated samples, 1 $\mathrm{mL}$ methanol/water (1:1) was added. After two hours at room temperature the samples were vortexed and sonicated for approximately ten seconds. Half of each sample $(500 \mu \mathrm{L})$ was transferred to a new Eppendorf tube and stored at $-20^{\circ} \mathrm{C}$ until analysis. On the day of analysis the samples were mixed, centrifuged for five minutes at high speed (14800 RPM) and transferred to $200 \mu \mathrm{L}$ vials.

Mycotoxin separation and analysis was carried out by high pressure liquid chromatography coupled with electrospray ionization and tandem mass spectrometry detection. HPLC separation was carried out on a reverse-phase on a reverse phase Kinetex C18 column $(50.0 \times 2.1 \mathrm{~mm}, 2.6$ $\mu \mathrm{m}$ particle size $)$ coupled with a $\mathrm{C} 18$ security guard cartridge $(4 \mathrm{~mm} \times 2 \mathrm{~mm}$ i.d., both from Phenomenex, Aschaffenburg, Germany) maintained at a temperature $40^{\circ} \mathrm{C}$ with a methanol-water gradient, followed by electrospray ionization essentially as described (Ratzinger et al., 2009), and detected using ion trap 500MS (Varian, Darmstadt, Germany) as described by Nutz et al. (2011). The mobile phase consisted of water with 5\% acetonitrile (A) and methanol (B), both containing $7 \mathrm{mM}$ of acetic acid. The injection volume was $10 \mu \mathrm{L}$ and the flow rate was set at $0.2 \mathrm{~mL} \mathrm{~min}^{-1}$. The binary gradient was from $40-98 \% \mathrm{~B}$. ESI was configured in the positive ionization mode. The mass transitions of FB1 were described by Bartók et al. (2006) and for BEA Döll (2013) and the Enniatins by Adejumo et al (2007). Pure analytical standards (Sigma-Aldrich Chemie GmbH, Steinheim, Germany) in methanol/water (1:1) were used to construct calibration curves. The limit of quantification (LOQ) was : $30 \mathrm{ng} / \mathrm{g}$ for FB1, $10 \mathrm{ng} / \mathrm{g}$ for BEA, $20 \mathrm{ng} / \mathrm{g}$ for enniatin A, $10 \mathrm{ng} / \mathrm{g}$ for enniatin A1, $36 \mathrm{ng} / \mathrm{g}$ for enniatin B and $110 \mathrm{ng} / \mathrm{g}$ for enniatin B1. Limit of detection (LOD) values were $30 \mathrm{ng} / \mathrm{g}$ for FB1, $3 \mathrm{ng} / \mathrm{g}$ for BEA, $8 \mathrm{ng} / \mathrm{g}$ for enniatin A, $3 \mathrm{ng} / \mathrm{g}$ for enniatin A1, 20 $\mathrm{ng} / \mathrm{g}$ for enniatin B and $88 \mathrm{ng} / \mathrm{g}$ for enniatin B1. 


\section{Part III (Risk assessment part)}

\subsubsection{Tempeh quality assessment}

Tempe making was done as follows: Sixty gram of soybeans as raw materials were washed and boiled for 30 minutes (ratio tap water:raw materials = 5:1), then dehulled manually. The raw materials were soaked in tap water overnight (18 hours) at room temperature (ratio tap water:raw material = 3:1). Furthermore, soybeans were boiled again 30 minutes (ratio tap water:raw material $=5: 1$ ), drained and dried-aired until ready at room temperature and inoculated with $3 \mathrm{~mL}$ of spore suspension $\left(10^{6}\right.$ spores $\left./ \mathrm{mL}\right)$ R. microsporus var. oligosporus WJBE8.87. After inoculation, raw materials were placed on petridish and incubated at a temperature $30^{\circ} \mathrm{C}$ for 48 hours (incubator ThermoFisher). Fresh tempeh directly used for all quality test except for amino acid composition analysis. For amino acid composition, samples then froze at $-20^{\circ} \mathrm{C}$ (Sanyo, Japan) and dried with freeze dryer (Supermodulyo, Japan). Samples were powdered (LG blender) and kept in $-20^{\circ} \mathrm{C}$ until extraction for UPLC-MS/MS analysis.

Treatment consists of: negative control (tempeh made only with pure $R$. microsposrus var. oligosporus WJBE8.87), and tempeh made with $R$. microsposrus var. oligosporus plus contamination of $F$. proliferatum BJ09.05.

To test whether the consumer can recognize contaminated tempeh, some physico-chemical and organoleptic test were done (control (normal tempeh/non-contaminated) and contaminated tempeh). Tests carried out include compactness observation, texture, color, $\mathrm{pH}$, protein content and content of amino acid determinants. Detailed testing can be seen in the following Table 7.

Table 7. Quality test on tempeh.

\begin{tabular}{clc}
\hline No & \multicolumn{1}{c}{ Quality test } & Method \\
\hline 1 & Compactness observation & Stereo-microscopy analysis \\
2 & Texture (with texture analyzer Rheometer) & Rubenthaler et al., (1990) \\
3 & Color $\left(L^{*}, a^{*}\right.$, and $\left.b^{*}\right)$ (with Minolta Chromameter) & Minolta, Inc. (2013) \\
4 & pH and protein content & AOAC (2001) \\
5 & Amino acid composition (with Waters UPLC-MS/MS) & AOAC (2005) \\
\hline
\end{tabular}

\subsubsection{Risk assessment traditional tempeh consumption in Indonesia}

Risk assessment is the process of quantifying the magnitude and exposure, or probability, of a harmful effect on individuals or populations from specific agents or activities (Kuiper-Goodman, 2004). Data of mycotoxin contamination taken from research part II. We determined the exposure levels of Indonesian infants, children, and adult to fumonisin B1 through traditional tempeh consumption.

$$
\mathrm{PDIm}=(\mu \mathrm{c} \times \mathrm{Cc}) / \mathrm{Bw}
$$

PDIm : Probable daily intake for mycotoxin $\left(\mu \mathrm{g} \cdot \mathrm{Kg}^{-1} \mathrm{bw} \cdot \mathrm{day}^{-1}\right)$

$\mu \mathrm{c} \quad$ : Mean of mycotoxin

Cc : Average consumption of traditional tempeh in Indonesia

$\mathrm{Bw} \quad$ : Body weight for the population groups (infants, children, and adults) 
The risk characterization for non-genotoxic and non-carcinogenic mycotoxins (\%Tolerable Daily Intake (TDI)) was determined by dividing the PDIm with the TDIm and multiplying the product with 100 as shown in the equation below.

$$
\% \mathrm{TDI}=(\mathrm{PDIm} / \mathrm{TDIm}) \times 100
$$

Probable Daily Intake (PDIm) (Assumed 10 kg, 25 kg (Rodriguez-Carasco et al., 2013) and $60 \mathrm{~kg}$ (Liu and $\mathrm{Wu}, 2010$ ) body weight for infants, children and adults, respectively) calculated by multiplying the fumonisin B1 concentration (mean) in traditional tempeh by consumption rates of traditional tempeh in Indonesia (20.7 g/person/day) as estimated by the Statistics Indonesia (BPS, 2014) and divided by body weight of consumers. 


\subsection{Results of Part I (Fusarium isolates identification and their mycotoxin screening)}

Identification of Fusarium isolates was performed according to the combination of morphology, and molecular characters. There are limits on the use of morphological characters for identification of Fusarium spp. These limitations increase when differentiation is within members belonging to a species complex with highly similar morphology. In this study, molecular techniques based mostly on DNA sequencing of genes have supported morphological identification of Fusarium species. Nucleotide sequencing of genes is performed particularly in informative parts of genome such as translation elongation factor 1-alpha (TEF-1 $\alpha$ ). In this work, typical Fusarium structures were utilized to identify the recovered isolates based on the morphological descriptions with several parameters (colony, conidia and conidiophores, conidiogenous cells, perithecia, and chlamydospores) according to Booth (1971), Gerlach and Nirenberg (1982), Nelson et al. (1983), Burgess et al. (1994), and Leslie and Summerell (2006). At least 20 microconidia and macroconidia of each isolate were selected randomly for measurement. Molecular information obtained from the DNA sequence of TEF- $1 \alpha$ and phylogenetic analysis was then employed to confirm the morphological identification and probably distinguish closely related strains.

\section{Fusarium identification from traditional tempeh inocula Morphological characteristic}

In total, 650 fungal isolates recovered from 345 traditional tempeh inocula (usar). Traditional inocula (usar) were collected from many markets and center of tempeh producers in 9 different areas in Central Java and Yogyakarta provinces, Indonesia (on 2015). Rhizopus was the most frequently detected genera, found in $90 \%$ of total samples. We also found contamination of Fusarium and this finding become our focus in present study concerning food safety problem. Distinct fungal colonies temporarily identified as Fusarium were transferred on PDA and recorded for colony morphology, radial growth, and pigmentation based on the visual inspection of the plates. About 55 pure isolates of Fusarium sp. were collected and observed via microscopy approach. Detail of morphological result can be seen in Table 8. We found two main species of Fusarium, they are suspected as $F$. solani and F. proliferatum. Morphological descriptions of these isolates are also described below. Morphological structures are shown in Figure 1.

F. solani

Macroscopic characteristics:

Colonies on PDA at $25^{\circ} \mathrm{C}$ reach a diameter of $31-39 \mathrm{~mm} 4$ days. Aerial mycelium sares or dense and floccose, sometimes leathery, greyish-white, cream to buff, conidial slime formed in sporodochia or pionnotes. Colony pigment on the reverse side of the plate was yellowish white to olive yellow or pale yellow and turning brownish yellow in aged cultures. Odor was not perceptible from the cultures.

Microscopic characteristics:

Conidiophores on SNA were unbranched or branched bearing monophialides. Macroconidia formed after 3-5 days from shorty branched conidiophores which may form 
sporodochia, usually three septates (1-4 septates), relatively wide, straight, stout and robust. Cream, blue or green sporodochia are common (cream sporodochia usually contain more macroconidia than do the blue or green ones). Apical cells were blunt and rounded. Basal cells have a distinct foot shape or be poorly developed, straight to almost cylindrical, usually with a notched or a rounded end. Microconidia were abundant, oval, ellipsoid, reniform and fusiform with 0 or 1 to occasionally 2 septates. Conidiogenous cells were monophialides, often quite long. Chlamydospores were abundant, hyaline, smooth or rough-walled, globose to ovoid, in hyphae or conidial cells, either terminal, on lateral branches, intercalary or in chains.

Table 8. Morphological chracteristics of Fusarium spp. isolated from traditional tempeh inocula.

\begin{tabular}{|c|c|c|c|}
\hline \multirow{2}{*}{\multicolumn{2}{|c|}{ Characters }} & \multicolumn{2}{|c|}{ Isolates suspected as } \\
\hline & & Fusarium solani & Fusarium proliferatum \\
\hline \multicolumn{4}{|c|}{ Macroscopic characteristics } \\
\hline \multicolumn{2}{|c|}{ Colony diameter, average (range) } & $3.4 \mathrm{~cm}(3.1-3.9 \mathrm{~cm})$ & $3.7 \mathrm{~cm}(3.5-4.1 \mathrm{~cm})$ \\
\hline \multicolumn{2}{|c|}{ Pigmentation on PDA } & White to yellow or green & White to purple violet \\
\hline \multicolumn{2}{|c|}{ Aerial mycelium } & Present & Present \\
\hline \multicolumn{2}{|c|}{ Radial growth rate, average (range) } & $8 \mathrm{~mm}(8.1-8.7 \mathrm{~mm})$ & $8.5 \mathrm{~mm}(8.3-8.9 \mathrm{~mm})$ \\
\hline \multicolumn{2}{|c|}{ Optimal growth temperature } & $25^{\circ} \mathrm{C}$ & $25^{\circ} \mathrm{C}$ \\
\hline \multicolumn{4}{|c|}{ Microscopic charateristics } \\
\hline Sporodochia & Shape & $\begin{array}{l}\text { Cream, or green sporodochia are common } \\
\text { in the agar and contain numerous } \\
\text { macroconidia }\end{array}$ & $\begin{array}{c}\text { Tan to pale orange sporodochia often } \\
\text { are produced infrequently }\end{array}$ \\
\hline \multirow[t]{4}{*}{ Microconidia } & Shape & Oval, ellipsoid, reniform and fusiform & Long chain, false head \\
\hline & Septa & $0-1$ & 0 \\
\hline & Length $(\mu \mathrm{m})$ & 14-18 & $15-22$ \\
\hline & Width $(\mu \mathrm{m})$ & $4.5-9$ & $3.5-8$ \\
\hline \multirow[t]{6}{*}{ Macroconidia } & General morphology & Relatively wide, straight, stout & $\begin{array}{c}\text { Slender, thin-walled, relatively } \\
\text { straight }\end{array}$ \\
\hline & Apical cell & Blunt and rounded & Curved \\
\hline & Basal cell & $\begin{array}{c}\text { Have a distinct foot shape } \\
\text { or be poorly developed, straight to } \\
\text { almost cylindrica }\end{array}$ & Poorly developed \\
\hline & Septa & $1-4$ & $2-5$ \\
\hline & Length $(\mu \mathrm{m})$ & $21-55$ & $19-69$ \\
\hline & Width $(\mu \mathrm{m})$ & $6-12$ & $5-10$ \\
\hline \multicolumn{2}{|c|}{ Chlamydospores } & Present & Present only in few isolates \\
\hline \multicolumn{2}{|l|}{ Sclerotia } & Absent & Present, blue-black color \\
\hline \multicolumn{2}{|c|}{ Conidiogenous cell } & Long monophiliades & $\begin{array}{l}\text { Long and branched mono or } \\
\text { polyphiliades }\end{array}$ \\
\hline \multicolumn{2}{|c|}{ Number of isolates examined } & 30 & 25 \\
\hline \multicolumn{4}{|l|}{ Note: } \\
\hline \multicolumn{4}{|c|}{ Colonies on PDA at $25^{\circ} \mathrm{C}$ in intermittent light after 4 days. } \\
\hline \multicolumn{4}{|c|}{ Colony color were determined by observing the upper surface of the colony. } \\
\hline \multicolumn{4}{|c|}{ Pigmentation were determined by observing the lower surface of the colony. } \\
\hline
\end{tabular}




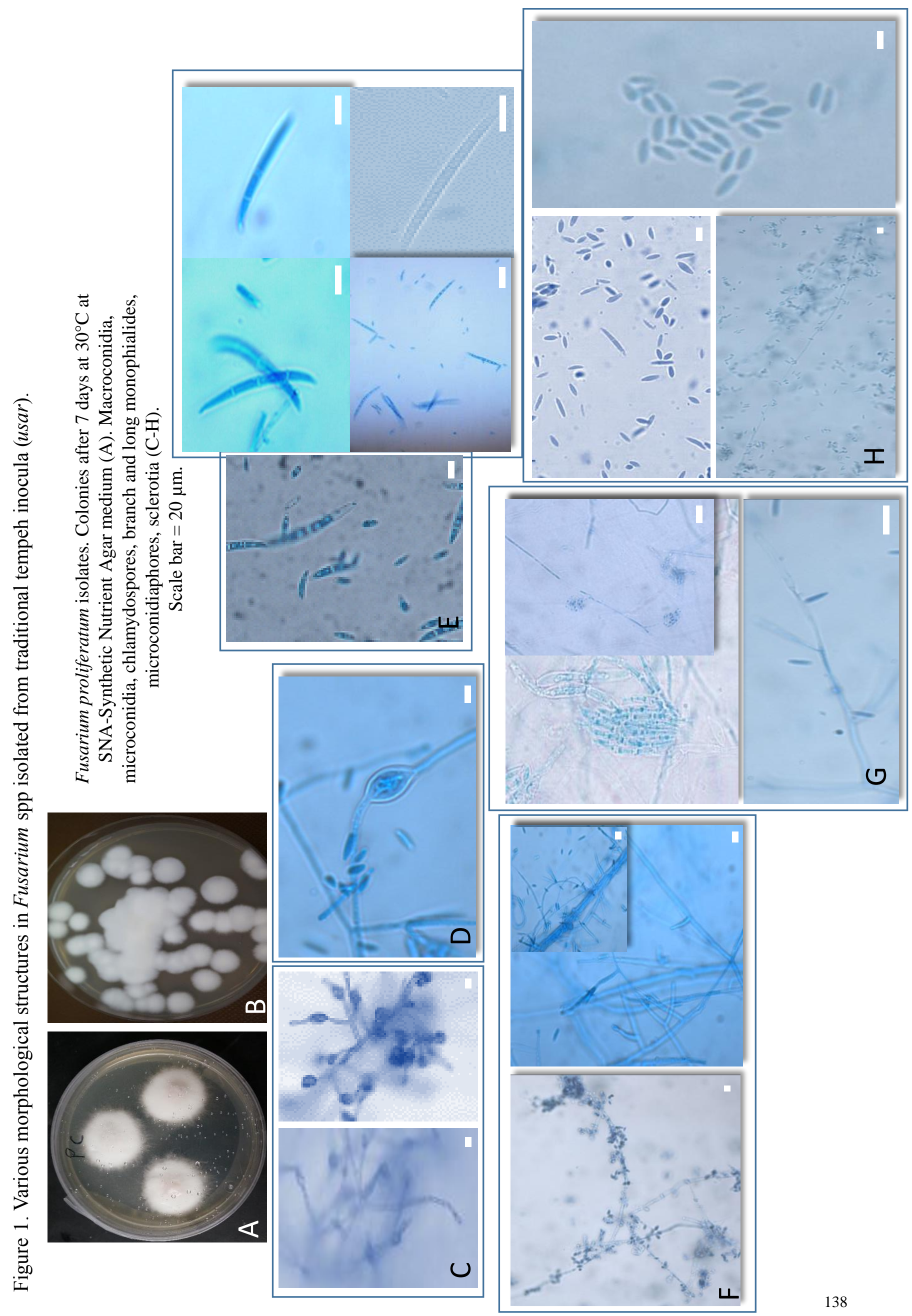



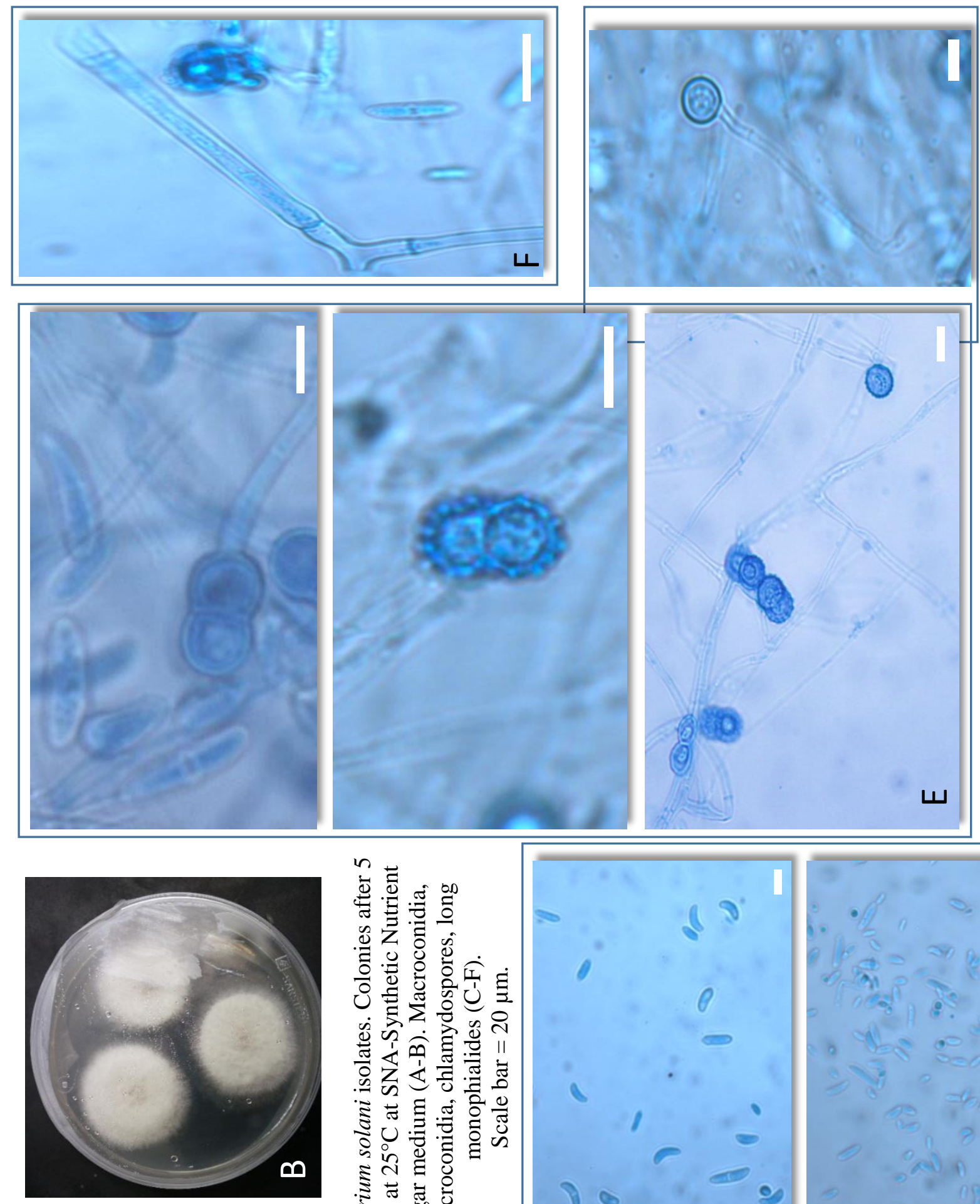

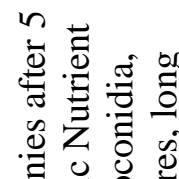

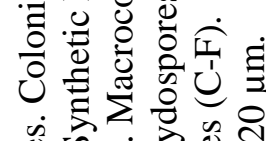

ये के

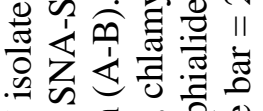

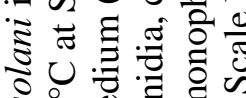

क in

돌

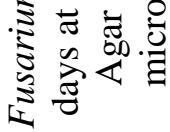
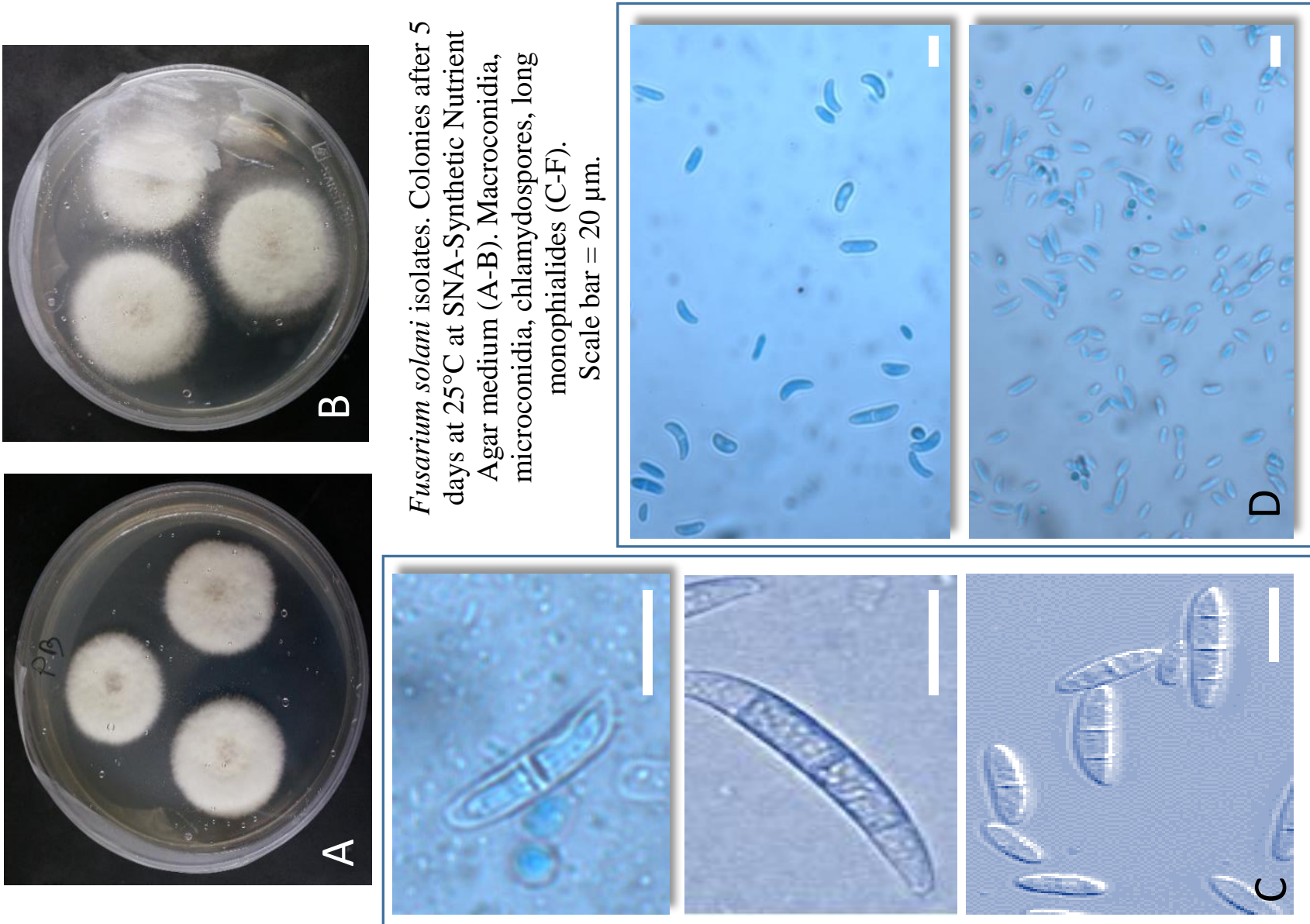


\section{F. proliferatum}

Macroscopic characteristics:

Colonies on PDA at $25^{\circ} \mathrm{C}$ reach a diameter of $35-41 \mathrm{~mm} 4$ days. The abundant aerial mycelium initially was white but may become purple-violet with age, with or without concentric rings. Sporodochia were present as discrete entities or nearly confluent over portions of the colony. Violet pigments usually were produced in the agar, but with overall pigmentation varying in intensity from nearly colorless to almost black. Blue-black sclerotia develop in some isolates. Microscopic characteristics:

Conidiophores on SNA were branched bearing mono- and polyphialides. Macroconidia were hyaline, delicate, slightly sickle-shaped, slender, relatively straight, thin-walled, 2-5 septates, with curved apical cell and poorly developed basal cell. Fresh cultures usually produce large numbers of macroconidia in sporodochia.

Microconidia abundant, clavate shaped with a flattened base; 0 - septate. The abundance of macroconidia varies since this character can be lost in this species following repeated subcultures. Pyriform microconidia also may occur but generally were rare. Microconidia found in chains of varying, but usually moderate, length or false heads, from mono- and polyphialidic conidiogenous cells. Club-shaped with a flattened base and 0-septate. Microconidia were produced mostly from polyphialides. Chlamydospores were big globose to ovoid, very rare and only found in few isolates.

\section{Molecular result}

To confirm morphological identification, representative isolates were observed with molecular approach. First, DNA fingerprinting was employed to distinguish identical and non identical isolates. Second, nonidentical isolates with distinct band were selected and confirmed at species level by the results of DNA sequence of the TEF gene, which is taxonomically most informative part in this fungal genus.

\section{DNA fingerprinting and sequencing of Fusarium isolates}

In the preliminary experiments, four arbitrary primers were tested with Random Amplified Polymorphic DNA (RAPD) with DNA extracted from pure cultures. A preliminary test determined the optimal concentration of the component in the PCR reaction mixture, amplification conditions and primer selection. Strong, unique, sharp and clearly reproducible bands were produced by primer C6.2_introns_2_R and C7_1seq. For further analysis, C7_1seq was used. In brief, the RAPD patterns of 55 pure Fusarium isolates obtained with the primer, and 12 distinct RAPD patterns were acquired. RAPD typing was capable of producing discriminating DNA fingerprints of Fusarium isolates and indicated there were genetic differences among them. The RAPD patterns of Fusarium isolates obtained with the primer are shown partly in Figure 2. 


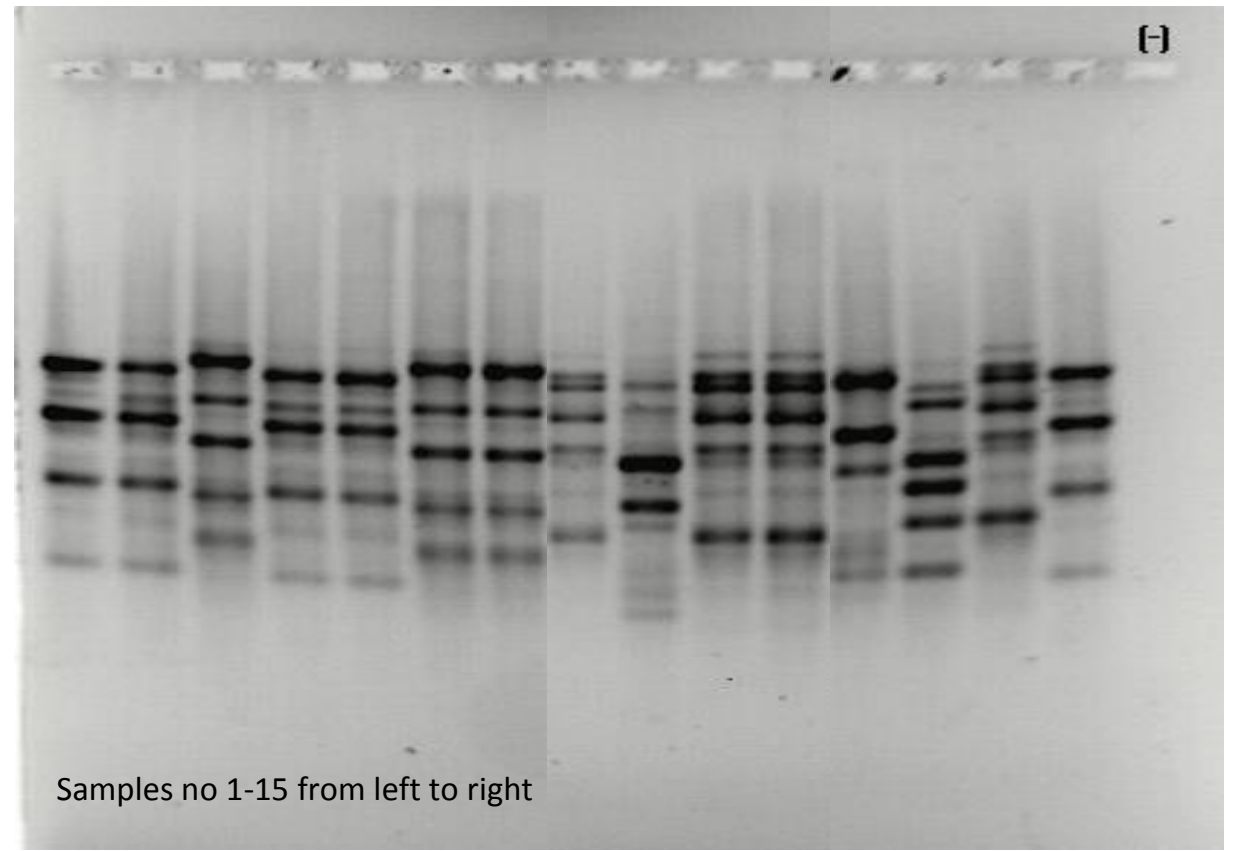

Figure 2. Some results of DNA fingerprinting from Fusarium isolates.

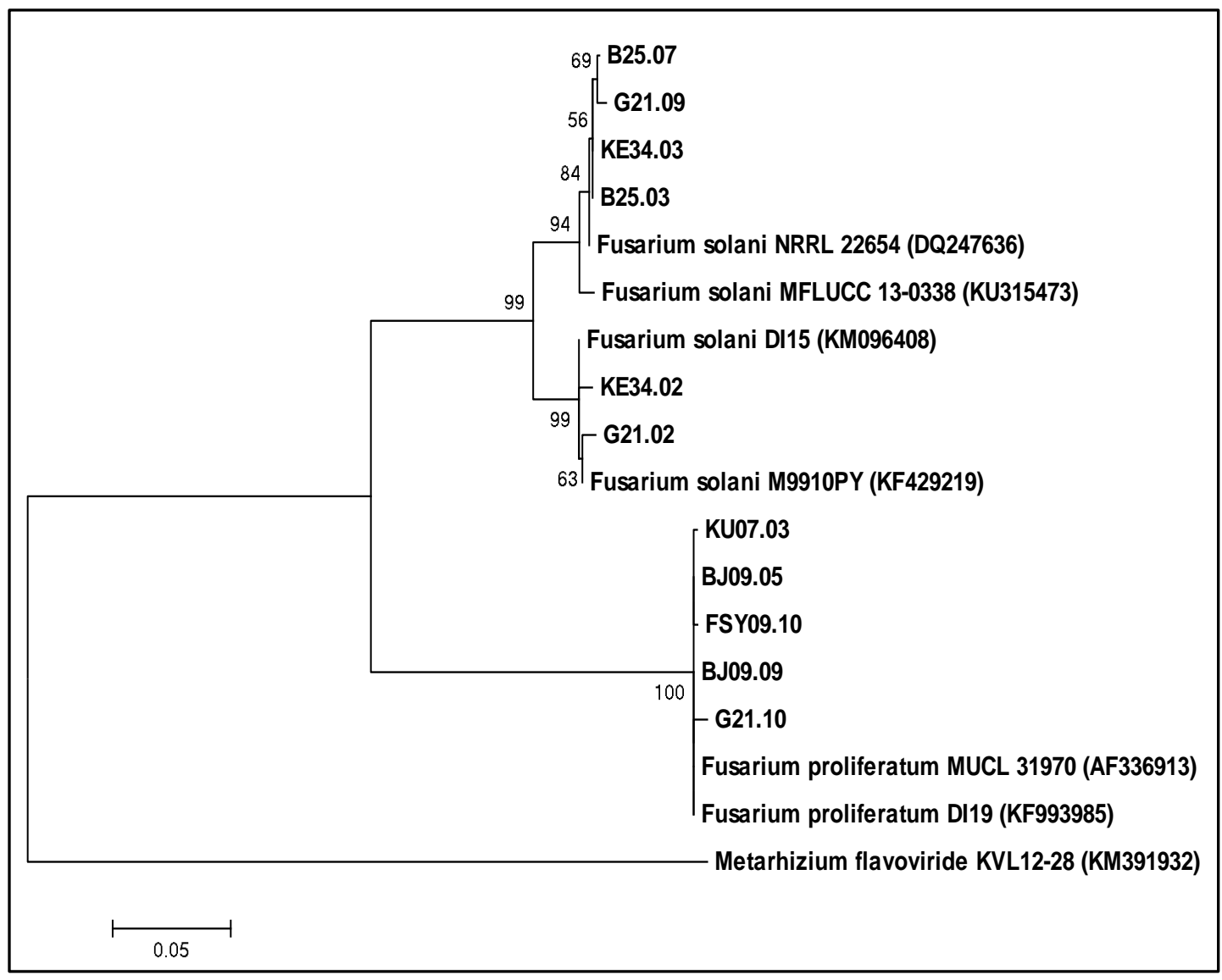

Figure 3. The tree was inferred from TEF- $1 \alpha$ sequence and constructed using maximum likelihood method. Numbers at nodes indicate levels of bootstrap support calculated from 1000 trees. 
Twelve representative isolates from RAPD selection were sequenced based on the TEF gene which has been widely used for species identification. Thermal PCR conditions suggested by Geiser et al. (2004) and Paul et al. (2010), lead to a mixture of specific and non-specific products. The situations were achieved by running a gradient PCR in the range of $53-63^{\circ} \mathrm{C}$ under "Hot start PCR". Hot start PCR protocol was used to amplify the TEF-1 $a$ gene region using the fungalspecific primer set: ef1 (5'-ATGGGTAAGGA(A/G)GACAAGAC-3') and ef2 (5'GA(G/A) GTACCAGT(G/C)ATCATGTT-3') described by O'Donnell et al. (1998). At the annealing temperature of $58.5^{\circ} \mathrm{C}$, a single band in size range of 600 to $650 \mathrm{bp}$ was successfully amplified from all isolates. After DNA sequencing, each unknown Fusarium strain was identified according to the deposited sequences in Fusarium-ID and NCBI database which had a high homology $(\geq$ 99\%) with them. The phylogenetic tree (Figure 3) clearly showed that the resolution of sequence from TEF region was sufficient in determining Fusarium species. Six isolates were identified as $F$. solani and five other isolates as $F$. proliferatum. The first three hits for the sequence of each isolate have been assigned in Supplemental Table 1.

\section{LDso and mycotoxin screening (molecular and LC-MS/MS analysis) of Fusarium isolated from traditional tempeh inocula (usar)}

All five $F$. proliferatum isolates included in our study lacked theTRI5 gene and possessed the FUM1 gene, indicating that they are presumably trichothecene non-producers and potentially fumonisin producers. This result was confirmed by different set of primers (FUM8 and FUM12) with identical result. Fusarium solani isolates lacked in both kind of genes, indicating they are not trichothecene or fumonisin producers. Screening of mycotoxin production showed that Fusarium proliferatum positively produced BEA, FB1, and Enns with range $23-41 \mu \mathrm{g} / \mathrm{g}, 215-288 \mu \mathrm{g} / \mathrm{g}$, and $2-5 \mu \mathrm{g} / \mathrm{g}$ respectively. These isolates did not produce other important mycotoxin except three mycotoxins mentioned before. Fusarium solani isolates were not able to produce any important mycotoxins.

Since there is no information about how toxic Fusarium solani isolates so far, then toxicity test done by brine shrimp. In our study, the brine shrimp assay has proven to be a convenient system, less time consuming and more cost-efficient bioassay for monitoring toxicity of mycotoxins. Analysis of $\mathrm{LD}_{50}$ can be done after $48 \mathrm{~h}$ incubation. We found that crude toxin extract from $F$. proliferatum is much more toxic than $F$. solani to brine shrimp. Fusarium proliferatum extract showed about 10-fold stronger activity as toxic agent toward $F$. solani extract based on their value of $\mathrm{LD}_{50}$. All screening result could be seen in Table 9. 
Table 9. LD 50 and mycotoxin screening (molecular and LC-MS/MS analysis) of Fusarium isolated from traditional tempeh inocula (usar).

\begin{tabular}{|c|c|c|}
\hline Characteristics & Fusarium solani & Fusarium proliferatum \\
\hline \multicolumn{3}{|l|}{ Molecular screening } \\
\hline FUM1 & - & $+(100 \%)$ \\
\hline FUM8 & - & $+(100 \%)$ \\
\hline FUM12 & - & $+(100 \%)$ \\
\hline TRI5 & - & - \\
\hline \multicolumn{3}{|l|}{$\begin{array}{l}\text { Screening of mycotoxin } \\
\text { production by HPLC-MS/MS }\end{array}$} \\
\hline $\mathrm{ZEN}$ & - & - \\
\hline Fus $\mathrm{X}$ & - & - \\
\hline NIV & - & - \\
\hline 15-ADON & - & - \\
\hline 3-ADON & - & - \\
\hline DON & - & - \\
\hline $\mathrm{NEO}$ & - & - \\
\hline DAS & - & - \\
\hline HT2-toxin & - & - \\
\hline T2-toxin & - & - \\
\hline BEA & - & $+(100 \%)$ \\
\hline FB1 & - & $+(100 \%)$ \\
\hline Enn A1 & - & $+(60 \%)$ \\
\hline Enn B & - & $+(60 \%)$ \\
\hline Enn B1 & - & $+(60 \%)$ \\
\hline \multicolumn{3}{|l|}{ Toxicity of crude mycotoxin } \\
\hline $\mathrm{LD}_{50}$ average (in range, $\mu \mathrm{g} / \mathrm{mL}$ ) & $134.8(125-141)$ & $14.8(12-18)$ \\
\hline Number of strains examined & 6 & 5 \\
\hline Origin of isolates & $\begin{array}{c}\text { Banyumas, Banjarnegara, } \\
\text { Gombong }\end{array}$ & $\begin{array}{c}\text { Banyumas, Kebumen, Kudus, } \\
\text { Banjarnegara, Gombong }\end{array}$ \\
\hline $\begin{array}{l}\text { (-) means negative result } \\
(+) \text { means positive result } \\
\text { Positive result accompanied with } \\
* \mathrm{LD}_{50} \text { was obtained from crude e } \\
\text { BEA concentration (range): } 23-4 \\
\text { FB1 concentration (range): } 215-2 \\
\text { Enns concentration (range): } 2-5 \mu\end{array}$ & $\begin{array}{l}\text { ntage of total positive samp } \\
\text { of each isolates, tested by } \\
\text { g }\end{array}$ & $\begin{array}{l}\text { bracket. } \\
\text { shrimp test. }\end{array}$ \\
\hline
\end{tabular}




\subsection{Discussion of Part I (Fusarium isolates identification and their mycotoxin screening)}

Like many other traditional foods in Indonesia, tempeh is produced as a small scale home industry with poorly controlled fermentation which is carried out without sufficient hygienic precautions even though the starter culture containing fungi are added at the beginning of fermentation. Therefore, there are various types of microorganisms that can participate during the process of fermentation, and natural contamination is always possible (Winarno, 1985; Barus et al., 2008; Seumahu et al., 2013). Moreover, there is no standard on making tempeh and its starter. This is the cause of many variations in the manufacture of tempeh in some areas (Astuti et al., 2000) which lead to nonhomogeneous quality and safety of traditional tempeh.

Several types of tempeh fermentation starters can be distinguished. Natural starters made with plant leaves (e.g., Hisbiscus spp.), and soybeans, known as "usar" are still widely used in Indonesia. Usar is prepared by placing pieces of matured tempeh between two Hibiscus leaves. The leaves are turned over and piled one on top of the other, afterward covered with banana leaves or cloth and left to undergo the first stage of fermentation for about 24-36 hours room temperature $\left(30^{\circ}-34^{\circ} \mathrm{C}\right)$. In the second stage of fermentation, the leaves now facing upwards, are separated individually and kept so for 3-7 days, partly to let the usar dry at room temperature. Standard of hygiene is also not applied in usar production due to the lack of knowledge about good sanitation by the producers. Until now traditional tempeh producers still involve waru lengis leaves (Hibiscus tiliaceus) for usar manufacture, even though as reported Nout et al., (1992) and Suliantari (1996) these leaves may serve as a source of Fusarium spp.

Identification of Fusarium isolates was performed according to the combination of morphology, and molecular characters. There are limits on the use of morphological characters for identification of Fusarium spp. These limitations increase when differentiation is within members belonging to a species complex with highly similar morphology. In this study, molecular techniques based mostly on DNA sequencing of genes have supported morphological identification of Fusarium species. In total, 650 fungal isolates recovered from traditional tempeh inocula (usar). Traditional inocula (usar) were collected from many markets and center of tempeh producers in 9 different areas in Central Java and Yogyakarta provinces, Indonesia (on 2015). About $8.4 \%$ of total fungal isolates recognized belongs to Fusarium genera. Fifty-five pure isolates of Fusarium sp were collected and observed via microscopy approach. We found two main species of Fusarium, suspected as $F$. solani and $F$. proliferatum. To confirm morphological identification, representative isolates were observed with molecular approach. DNA fingerprinting was employed to distinguish identical and non-identical isolates. Non-identical isolates with distinct band were selected and confirmed at species level by the results of DNA sequence of the TEF gene, which is taxonomically most informative part in this fungal genus. DNA sequences of genes such as TEF$1 \alpha$ have been widely used for supporting morphological traits of Fusarium species (Yli-Mattila et al., 2002; Harrow et al., 2010; Hsuan et al., 2011). In the present study, molecular investigation based on the TEF-1 $\alpha$ gene led to more precise identification of Fusarium isolates. After DNA sequencing, each unknown Fusarium strain was identified according to the deposited sequences in Fusarium-ID and NCBI database which had a high homology ( $\geq 99 \%)$ with them. The 
phylogenetic tree clearly showed that the resolution of sequence from TEF region was sufficient in determining Fusarium species. Six isolates were identified as F. solani and five other isolates as $F$. proliferatum.

All $F$. poliferatum isolates included in our study lacked the TRI5 gene and possessed the FUM1 gene, indicating that they are presumably trichothecene non-producers and potentially fumonisin producers. This result was confirmed by different set of primers (FUM8 and FUM12) with identical result. In other hands, F.solani isolates lacked in both kind of genes, indicating they are not trichothecene or fumonisin producers. Molecular screening for mycotoxin is limited with the primers that can be used, therefore study expanded with LC-MS/MS screening for many mycotoxins. The results showed $F$. solani isolates were not able to produce any important mycotoxins, whereas $F$. proliferatum positively produced BEA, FB1 and Enns with range 23-41 $\mu \mathrm{g} / \mathrm{g}, 215-288 \mu \mathrm{g} / \mathrm{g}$, and $2-5 \mu \mathrm{g} / \mathrm{g}$ respectively. These isolates did not produce other important mycotoxins except three mycotoxins mentioned before. This is in line with report from Jestoi et al. (2008) that mentioned $F$. proliferatum mainly produce BEA, fumonisins, and Enns.

FB1 is well known harmfull for human. It is proven carcinogens in rodents and suspected carcinogens in humans. So far, there are no reports about the association of BEA and Enns with mycotoxicoses (Jestoi et al., 2004) and because of this, it may be considered that they are not as relevant for human and animal health. However, recent research reported that these compound might also have adverse effect to human. Meca et al. (2010) found cytotoxic effects on human cells for enniatin A1 and B1 dependent on the concentration. The cell growth was stronger inhibited by enniatin A1 then enniatin B1. Also, Wätjen et al. (2009) found cytotoxic effects of the tested enniatins on human cells and induction of apoptotic cell death.

Since there is no information about how toxic $F$. solani isolates so far, then toxicity test done by brine shrimp. Toxicological tests conducted using crude extracts from the isolates. In our study, the brine shrimp assay has proven to be a convenient system, less time consuming and more cost-efficient bioassay for monitoring toxicity of mycotoxins. The brine shrimp are used in the laboratory bioassay of toxicity through estimation of lethal dosage (LD50). LD 50 is the amount of material, given all at once, which causes the death of $50 \%$ (one half) of a group of test animals. The $\mathrm{LD}_{50}$ is one way to measure the short-term poisoning potential (acute toxicity) of material. The brine shrimp assay consist of hatching and growing brine shrimps, incubation with mycotoxins at different concentrations and calculation of LD 50 . Analysis of LD50 can be done after $48 \mathrm{~h}$ incubation. We found that crude toxin extract from $F$. proliferatum is much more toxic than $F$. solani to brine shrimp. Fusarium proliferatum extract showed about 10-fold stronger activity as toxic agent toward $F$. solani extract based on their value of $\mathrm{LD}_{50}$. This result possibly related to mycotoxins content in each crude extract. Based on characterization of mycotoxins production, $F$. proliferatum isolates produce FB1, BEA and Enns; whereas $F$. solani isolates were not able to produce any important mycotoxins. Most of $F$. proliferatum isolates showed a high level of toxin production that might also related to their ability to be toxic toward brine shrimp larvae. Previous studies also found toxicity towards brine shrimp was significantly correlated with fumonisins 
content (Hlywka et al., 1997; Hartl and Humpf, 2000), BEA content (Moretti et al., 2007) and Enns content (Tan et al., 2011) of some Fusarium spp. extracts.

In conclusion, this study found important information about Fusarium contamination in traditional tempeh inocula (usar). More safety attention needs to be given to traditional tempeh made with usar. Harmfull metabolites produced by $F$. proliferatum might also present in the traditional tempeh. Producers should be aware of this food safety matter to improve their hygiene on producing of inocula, and also to not use anymore Hibiscus leaves. Contamination of traditional inocula by fumonisin producing fungi is therefore highly relevant for food safety concern. 


\subsection{Results of Part II (Detection of Fusarium and mycotoxins in traditional tempeh)}

Real-time PCR (qPCR) has become the standard method for species-specific quantification of fungal biomass in many kind of samples, including food product. The qPCR assays for major plant pathogens and decay fungi have been established and used extensively in the last decade. The majority of qPCR assays carried out in research laboratories and plant diagnostic services relied on real-time thermocyclers in 96-well or 384-well format; both SYBR Green-based detection of PCR products and hybridization probes (e.g., TaqMan) were extensively used.

In this study, quantification of two Fusarium species ( $F$. proliferatum and $F$. solani) were the main focus. This screening was done before mycotoxin analysis step. The DNA extraction and the following gel electrophoresis resulted in a good amount of DNA for the traditional tempeh samples. The yield of the DNA was so high that a dilution was needed to achieve a clean band for the gel electrophoresis. The inhibition test for the traditional tempeh samples for the real time PCR showed no natural inhibition of the plant material. Therefore, pure fungal DNA of each species in TE buffer without plant material was used as standards. Table 10 lists the results of the qPCR for the detection of fungal DNA of $F$. proliferatum, and $F$. solani in the samples. Results are shown for a dilution of 1:50.

The occurrence of $F$ proliferatum in Banyumas was the highest (20.5\%) followed with Kebumen (16.2\%), Yogyakarta (14.6\%),Kudus (12.9\%), Banjarnegara (12.1\%), and Gombong $(12.1 \%)$. The highest occurrence of F. solani was found in Gombong (18.2\%), followed by Kebumen (13.5\%) and Banyumas (12.8\%). Another three regencies are not found $F$. solani in their traditional tempeh. Contamination of traditional tempeh samples with $F$. proliferatum was found in $12 \%$ of the total samples with amounts of $10-175 \mathrm{ng} / \mathrm{mg}$ fungal DNA. Seven percent of total samples were contaminated with $F$. solani in amounts of $20-129 \mathrm{ng} / \mathrm{mg}$ fungal DNA. Since $F$. solani was found not harmfull (about 10-13 times less harmfull than F. proliferatum, and did not produce any important myotoxins), then, we only checked mycotoxins content on the samples containing $F$. proliferatum.

The results of the mycotoxin detection in the traditional tempeh samples are given in Table 11. HPLC-MS/MS analysis only applied to check samples were positively contaminated by $F$. proliferatum (based on previous $\mathrm{qPCR}$ data). Contamination of traditional tempeh samples with $F$. proliferatum was found in $12 \%$ of total samples with amounts of $10-175 \mathrm{ng} / \mathrm{mg}$ fungal DNA. In these samples, the amount of FB1, BEA, EnnB, EnnB1 and EnnA1 were in range 170-2682 $\mu \mathrm{g} / \mathrm{kg}, 20-45 \mu \mathrm{g} / \mathrm{kg}, 41-456 \mu \mathrm{g} / \mathrm{kg}, 16-67 \mu \mathrm{g} / \mathrm{kg}$, and 8-28 $\mu \mathrm{g} / \mathrm{kg}$ respectively. Most of the positives samples showed Fumonisin B1 in quantifiable amount. Many of positive samples contained BEA, and Enniatins in low or unquantifiable amount (<LOQ). All samples had lower FB1 contents than legal limit in Indonesia (2000 $\mu \mathrm{g} / \mathrm{kg}$; SNI 7385:2009), except for one sample from Yogyakarta (samples area Yogyakarta 22) which contained FB1 above the allowed limit. This sample also had highest amount of $F$. proliferatum DNA. We found positive liniear relationship $\left(\mathrm{R}^{2}=0.8\right)$ between the amount of $F$. proliferatum DNA with amount of FB1. The presence of ennatins maybe from the raw material such as soybean or corn which were contaminated during storage. 


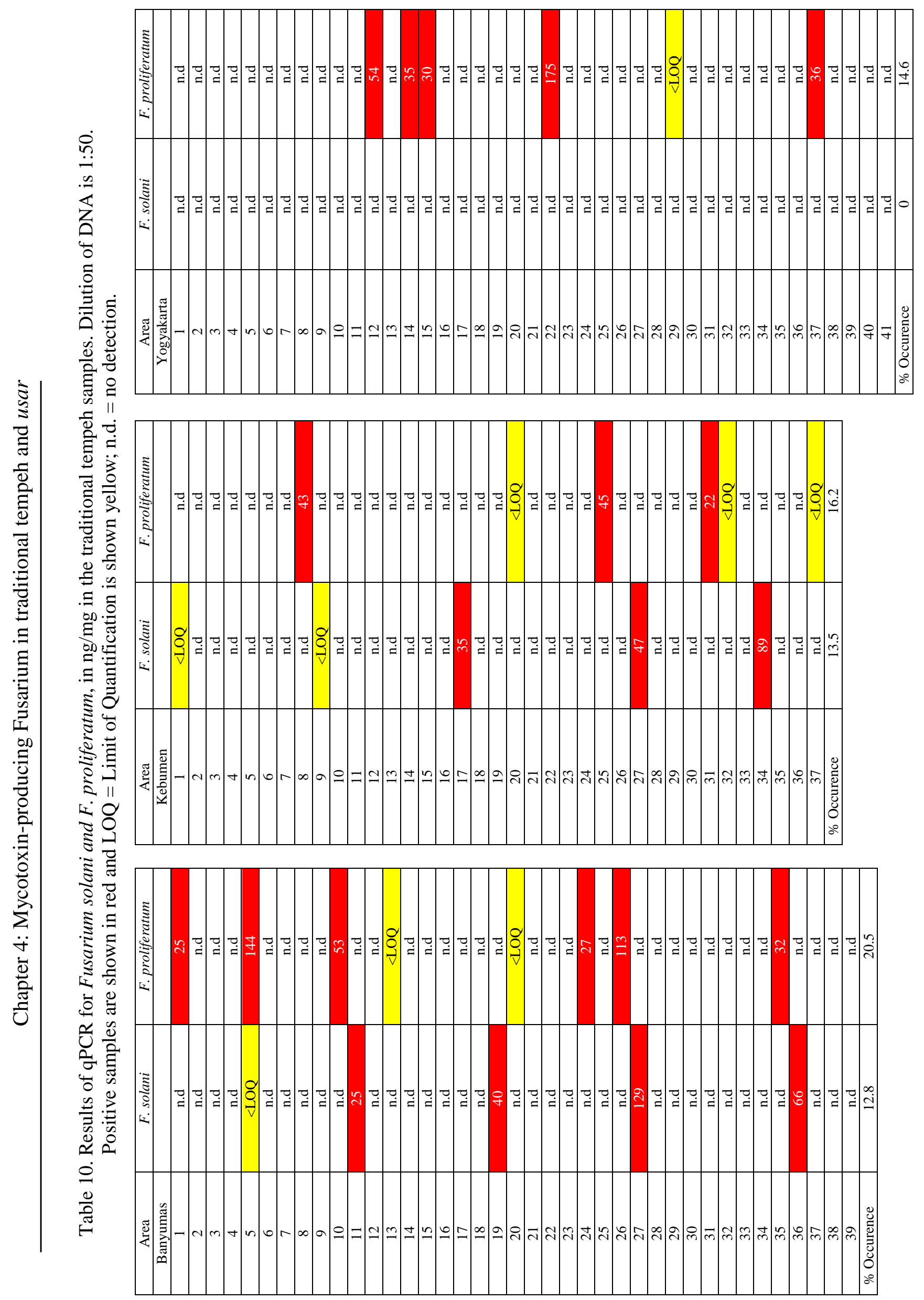




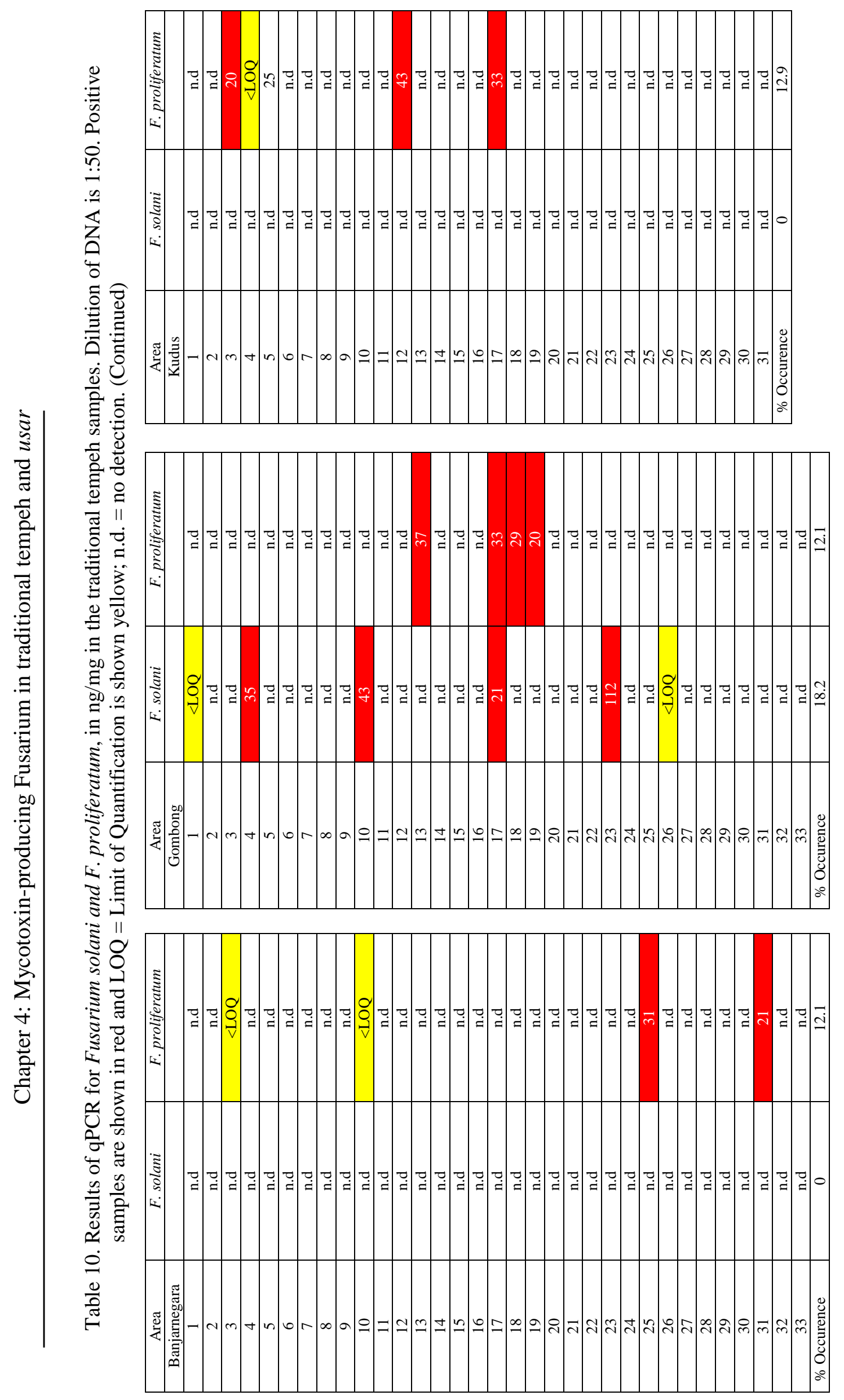


Table 11. HPLC-MS/MS result of BEA, FB1, and the Enniatins A1, B and B1 for positive samples (F. proliferatum present). Sample contained FB1 content higher than legal limit in Indonesia (2000 $\mu \mathrm{g} / \mathrm{kg}$; SNI 7385:2009) is shown in red.

\begin{tabular}{|c|c|c|c|c|c|c|}
\hline Locations & $\begin{array}{c}\text { F. proliferatum } \\
\text { (DNA ng/mg) }\end{array}$ & $\begin{array}{c}\text { BEA } \\
(\mu \mathrm{g} / \mathrm{kg})\end{array}$ & $\begin{array}{c}\text { FB1 } \\
(\mu \mathrm{g} / \mathrm{kg})\end{array}$ & $\begin{array}{c}\text { EnnB } \\
(\mu \mathrm{g} / \mathrm{kg})\end{array}$ & $\begin{array}{l}\text { EnnB1 } \\
(\mu \mathrm{g} / \mathrm{kg})\end{array}$ & $\begin{array}{l}\text { EnnA1 } \\
(\mu \mathrm{g} / \mathrm{kg})\end{array}$ \\
\hline Kebumen 08 & 43 & $<\mathrm{LOQ}$ & 320 & $<\mathrm{LOQ}$ & $<\mathrm{LOQ}$ & $<\mathrm{LOQ}$ \\
\hline Kebumen 25 & 45 & 17 & 361 & 367 & 51 & 19 \\
\hline Kebumen 31 & 22 & $<\mathrm{LOQ}$ & 212 & $<\mathrm{LOQ}$ & $<\mathrm{LOQ}$ & $<\mathrm{LOQ}$ \\
\hline Banyumas 01 & 25 & $<\mathrm{LOQ}$ & 337 & 41 & $<\mathrm{LOQ}$ & $<$ LOQ \\
\hline Banyumas 05 & 144 & 45 & 1407 & 95 & 16 & $<\mathrm{LOQ}$ \\
\hline Banyumas 06 & 45 & $<\mathrm{LOQ}$ & 362 & $<\mathrm{LOQ}$ & $<\mathrm{LOQ}$ & $<\mathrm{LOQ}$ \\
\hline Banyumas 10 & 53 & 37 & 566 & $<\mathrm{LOQ}$ & $<\mathrm{LOQ}$ & $<\mathrm{LOQ}$ \\
\hline Banyumas 24 & 27 & $<\mathrm{LOQ}$ & 170 & 164 & 19 & 12 \\
\hline Banyumas 26 & 113 & 34 & 776 & 174 & 34 & 14 \\
\hline Banyumas 35 & 32 & $<\mathrm{LOQ}$ & 381 & $<\mathrm{LOQ}$ & $<\mathrm{LOQ}$ & $<\mathrm{LOQ}$ \\
\hline Kudus 03 & 20 & $<\mathrm{LOQ}$ & $<\mathrm{LOQ}$ & $<\mathrm{LOQ}$ & $<\mathrm{LOQ}$ & $<$ LOQ \\
\hline Kudus 05 & 25 & 17 & 183 & 456 & 67 & 28 \\
\hline Kudus 12 & 43 & 25 & 437 & $<\mathrm{LOQ}$ & $<\mathrm{LOQ}$ & $<$ LOQ \\
\hline Kudus 17 & 33 & $<\mathrm{LOQ}$ & 284 & $<\mathrm{LOQ}$ & $<\mathrm{LOQ}$ & $<\mathrm{LOQ}$ \\
\hline Yogyakarta 12 & 54 & $<\mathrm{LOQ}$ & 526 & $<\mathrm{LOQ}$ & $<\mathrm{LOQ}$ & $<\mathrm{LOQ}$ \\
\hline Yogyakarta 14 & 35 & 20 & 217 & 131 & 19 & $<\mathrm{LOQ}$ \\
\hline Yogyakarta 15 & 30 & $<\mathrm{LOQ}$ & 214 & $<\mathrm{LOQ}$ & $<\mathrm{LOQ}$ & $<\mathrm{LOQ}$ \\
\hline Yogyakarta 22 & 175 & 163 & 2682 & $<\mathrm{LOQ}$ & $<\mathrm{LOQ}$ & $<\mathrm{LOQ}$ \\
\hline Yogyakarta 37 & 36 & 37 & 323 & 220 & 36 & 14 \\
\hline Banjarnegara 25 & 31 & 28 & 253 & 190 & 34 & 16 \\
\hline Banjarnegara 31 & 21 & $<\mathrm{LOQ}$ & 197 & 107 & 16 & $<$ LOQ \\
\hline Gombong 13 & 37 & 25 & 474 & $<\mathrm{LOQ}$ & $<\mathrm{LOQ}$ & $<\mathrm{LOQ}$ \\
\hline Gombong 17 & 33 & 20 & 220 & $<\mathrm{LOQ}$ & $<\mathrm{LOQ}$ & $<\mathrm{LOQ}$ \\
\hline Gombong 18 & 29 & $<\mathrm{LOQ}$ & 255 & 160 & 18 & 8 \\
\hline Gombong 19 & 20 & $<\mathrm{LOQ}$ & 179 & 154 & 27 & 10 \\
\hline
\end{tabular}




\subsection{Discussion of Part II (Detection of Fusarium and mycotoxins in traditional tempeh)}

Fumonisins (FBs) are important naturally present in environment mycotoxins formed mainly by Fusarium proliferatum and $F$. verticilioides. The occurrence, frequency, level of the contamination and implications of mycotoxins entering the food and feed chain have gained global attention over the last decade. There are at least 28 fumonisin analogues that have been identified and these have been classified into series A, B, F and P based on their chemical structures (Musser and Plattner, 1995), of which fumonisin B1 (FB1) is the most abundant of the group (Scott, 1993). FB1 has been shown to be hepatocarcinogenic and nephrocarcinogenic in the male rat and hepatocarcinogenic in the female mouse (Howard et al., 2001) and on the basis of available evidence, the International Agency for Research on Cancer (IARC) has declared the 'toxins produced by $F$. moniliforme' to be possibly carcinogenic to humans (Class 2B carcinogens). Present study is the first report about Fusarium and mycotoxin contamination in traditional tempeh. Many people believe that contamination never happen in the fermentation product like tempeh. In fact, there are a complex of microorganisms in soybean tempeh, their development start during the soaking of the raw ingredients (Nout and Kiers, 2005). Many microorganisms are involved in several stages of making tempeh, some of them are responsible for the acidification during the soaking stage and forming good taste-odor; there may be cross-contamination through the handling during hand drying and packaging, during the incubation and in the composition of inoculum. Therefore, contamination is always possible in this product.

The biomass of Fusarium spp. in traditional tempeh was estimated by species-specific realtime PCR analysis of DNA extracted from representative samples of traditional tempeh. The analysis was carried out for the two major Fusarium contaminant ( $F$. proliferatum and $F$. solani) which previously found in traditional tempeh inocula. This screening was done before mycotoxin analysis step. The DNA extraction and the following gel electrophoresis resulted in a good amount of DNA for the traditional tempeh samples. The yield of the DNA was so high that a dilution was needed to achieve a clean band for the gel electrophoresis. The inhibition test for the traditional tempeh samples for the real time PCR showed no natural inhibition of the food material. Therefore, pure fungal DNA of each species in TE buffer without food material was used as standards. Table 10 lists the results of the qPCR for the detection of fungal DNA of $F$. proliferatum, and $F$. solani in the samples. Results are shown for a dilution of 1:50.

The occurrence of $F$. proliferatum in Banyumas was the highest (20.5\%) followed with Kebumen (16.2\%), Yogyakarta (14.6\%), Kudus (12.9\%), Banjarnegara (12.1\%), and Gombong (12.1\%). The highest occurrence of F. solani was found in Gombong (18.2\%), followed by Kebumen (13.5\%) and Banyumas (12.8\%). Another three regencies are not found $F$. solani in their traditional tempeh. Contamination of traditional tempeh samples with $F$. proliferatum was found in $12 \%$ of the total samples with amounts of $10-175 \mathrm{ng} / \mathrm{mg}$ fungal DNA. Seven percent of total samples were contaminated with $F$. solani in amounts of 20-129 ng/mg fungal DNA.

Founding DNA of $F$. proliferatum in the total DNA extracted from traditional tempeh motivated us to extend the analysis of mycotoxin content to fumonisin and beauvericin, which are both produced by $F$. proliferatum. We also analyzed the content of enniatins, because according 
to Jestoi et al. (2008) F. proliferatum also the main enniatins producer. Since F. solani was found not harmfull (about 10-times less harmfull than $F$. proliferatum based on artemia test, and did not produce any important myotoxins based on HPLC-MS/MS analysis), then, we only checked mycotoxins content on the samples containing $F$. proliferatum.

The results of the mycotoxin detection in the traditional tempeh samples are given in Table 11. HPLC-MS/MS analysis only applied to check samples were positively contaminated by $F$. proliferatum (based on previous qPCR data). Contamination of traditional tempeh samples with $F$. proliferatum was found in $12 \%$ of total samples with amounts of 10-175 ng/mg fungal DNA. In these samples, the amount of FB1, BEA, EnnB, EnnB1 and EnnA1 were in range 170-2682 $\mu \mathrm{g} / \mathrm{kg}, 20-45 \mu \mathrm{g} / \mathrm{kg}, 41-456 \mu \mathrm{g} / \mathrm{kg}, 16-67 \mu \mathrm{g} / \mathrm{kg}$, and 8-28 $\mu \mathrm{g} / \mathrm{kg}$ respectively. Most of the positives samples ( $F$. proliferatum present) showed Fumonisin B1 in quantifiable amount. Daughter ions generated from the molecular ion possessed the same $\mathrm{m} / \mathrm{z}$ ratios and occurred in similar relative abundances as daughter ions of authentic fumonisin B1 standard. Together with the retention time and $\mathrm{m} / \mathrm{z}$ value of the molecular ion, these results proved convincingly that fumonisin B1 was present in traditional tempeh. The presence of beauvericin and enniatins A1, B and B1 was supported by their retention times, the molecular ions and three daughter ions for each analyte. Many of positive samples contained BEA, and enniatins in low or unquantifiable amount (<LOQ). Since tempeh is an important food in Indonesia these results represent an important human health issue that needs further monitoring.

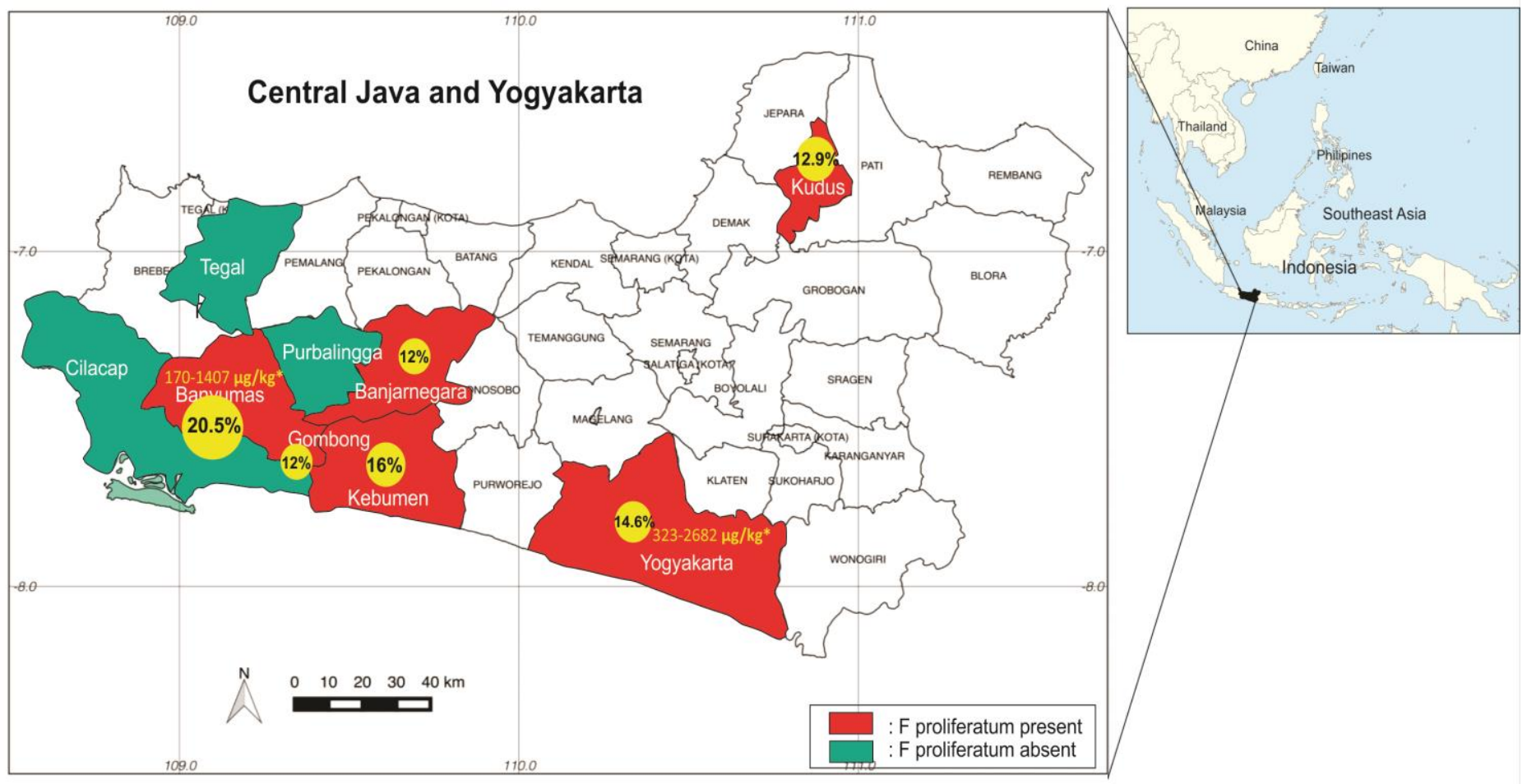

Figure 4. Contamination of $F$. proliferatum and Fumonisin B1 on traditional tempeh from central production of traditional tempeh at Central Java and Yogyakarta provinces. 
All samples had lower FB1 contents than legal limit in Indonesia $(2000 \mu \mathrm{g} / \mathrm{kg}$; SNI 7385:2009), except for one sample from Yogyakarta (samples area Yogyakarta 22) which contained FB1 above the allowed limit. Two samples contained FB1 higher than the recommended EFSA level $1000 \mu \mathrm{g} / \mathrm{kg}$. These samples were from Banyumas and Yogyakarta. These sample also had highest amount of $F$. proliferatum DNA. We found positive liniear relationship $\left(\mathrm{R}^{2}=0.8\right)$ between the amount of $F$. proliferatum DNA with amount of FB1, but we found low positive correlation between $F$. proliferatum DNA with amount of Enns. The presence of Enns maybe from the raw material such as soybean /corn which were contaminated during storage or because of other Fusarium species contamination. Although mycotoxin contamination was detected below the legal limit, the presence of mycotoxin should be controlled in traditional tempeh production.

Figure 4 shows contamination of $F$. proliferatum and mycotoxins was more prevalent in east area compare to west part of Central Java. East areas have more rainfall and warmer temperature based on Indonesian Meteorological Organization (BMKG). There are two possibilities of contamination source, first comes from contaminated traditional inocula which were also found in those area (as described in result part I), second maybe the use of corn as substitute in tempeh production. Producers involve corn substitution for 10-30 percent to reduce cost production because the price of soybean is high nowadays. This generates a healthiness issue of produced tempeh because most Indonesian corn has been contaminated by toxigenic fungi such as Fusarium spp. (Purwoko et al., 1991; Ahmad et al., 1996; Gholib et al., 2004; Ahmad et al., 2009; Kusumaningrum et al., 2010; Rahmawati et al., 2013). Rahmawati et al. (2013) also reported that toxigenic fungi such as Fusarium spp. are found in soaking corn during corn flour production.

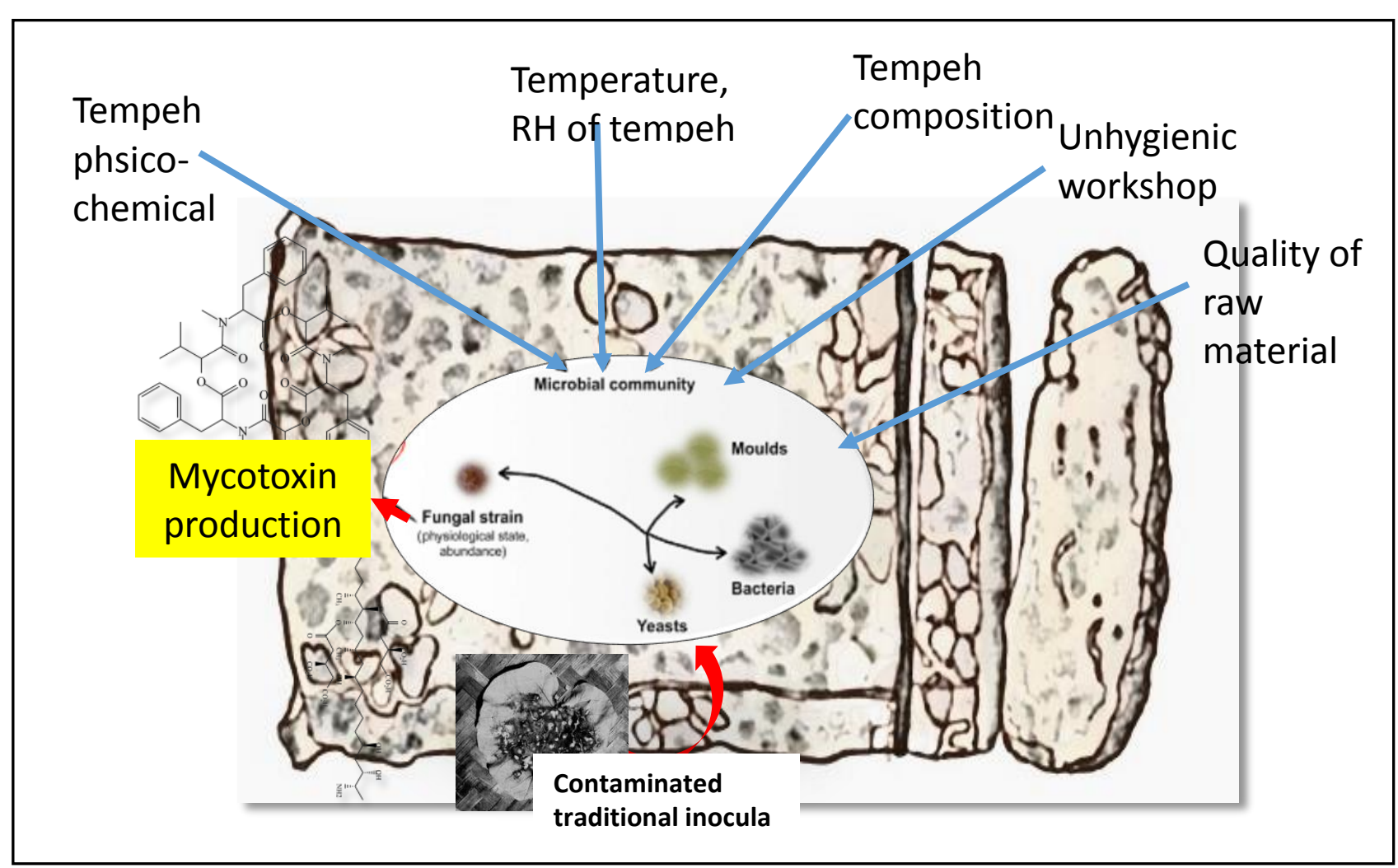

Figure 5. Mycotoxin production and possible factors might play role in the tempeh system. 
Furthermore, abiotic and biotic factors also may influence fungal and mycotoxin contamination in tempeh (Figure 5). Abiotic factors, such as normal room temperature, neutral $\mathrm{pH}$ and humid condition supported many microorganism to grow optimal. Biotic factors modulating mycotoxin production include the intrinsic capacity of contaminant to produce mycotoxins, its physiological state and the interactions that may occur between this organism and the other members of the tempeh microbiota. Our observation found that there is no antagonism interaction between main tempeh fungal (Rhizopus spp.) with $F$. proliferatum. They could grow together. Unhygienic environment of the workshop may also contribute to contamination problem. Most of the tempeh samples were positive in Fusarium and mycotoxin contamination isolated from unhygienic tempeh workshop. These condition make contamination is always possible in this product.

As mentioned in the beginning that FB1 is harmfull for human. It is proven carcinogens in rodents and suspected carcinogens in humans. Contamination of traditional tempeh with FB1 is therefore highly relevant for food safety. BEA and Enns were also detected in the samples. So far, there are no reports about the association of BEA and Enns with mycotoxicoses (Jestoi et al., 2004) and because of this, it might be considered that they are not as relevant for human and animal health. However, recent research reported that these compound may also have adverse effect to human. Meca et al. (2010) found cytotoxic effects on human cells for enniatin A1 and B1 denpendent on the concentration. The cell growth was stronger inhibited through enniatin A1 then enniatin B1. Also Wätjen et al. (2009) found cytotoxic effects of the tested enniatins on human cells and induction of apopotic cell death.

Occurrence of enniatins in food commodities have been reported in several countries. Enniatins B, B1, B4, A and A1 were quantified in baby food including infant formula milks, dairy products (cheese and yogurt), cereal based baby food, fruits and vegetables compotes, fruits and vegetable puree from the Italian market. The detected concentrations ranged from 11.8 to 832 $\mu \mathrm{g} / \mathrm{kg}$ in cereal-based baby food. The highest value was enniatin B (Juan et al., 2014). According to a study carried out by Serrano et al. (2013), organic pasta from Spain was more contaminated with enniatin (A, A1, B1 and B) than the conventional counterpart. Although the majority of the enniatin concentrations found in organic and conventional dry or fresh samples in Spain were below $25 \mu \mathrm{g} / \mathrm{kg}$, concentrations up to $979.56 \mu \mathrm{g} / \mathrm{kg}$ of enniatin $\mathrm{A}, \mathrm{A} 1 \mathrm{~B} 1$ and B were detected in conventional dry pasta. Nuts and dried fruits from Spain were screened for the occurrence of enniatins by Tolosa et al. (2013), the samples included peanuts fruit and shell, almonds fruit and shell, Pistachios fruits and shell, walnuts fruit and shell, fried maize, hazelnuts fruit and shell, sunflower seeds fruit and shell, dried fruits (dried apricots, dried figs, dried raisins, dried plums, blueberries and dates). Enniatin A and B were the most prevalent in the analyzed samples. The percentages of total enniatin contamination of samples analyzed ranged were $35.7 \%$, 50\% and $83.3 \%$ for dried fruits, nuts and dates respectively. The highest concentration of enniatins (A, A1, $\mathrm{B}$ and B1) was found in peanuts, almonds and dates reaching a maximum of $1.855 \mathrm{mg} / \mathrm{kg}, 1.323$ $\mathrm{mg} / \mathrm{kg}$ and $1.494 \mathrm{mg} / \mathrm{kg}$ respectively. 


\subsection{Results and Discussion of Part III (Tempeh quality and risk assessment) Tempeh quality assessment}

To test whether the consumer can recognize contaminated tempeh, some physico-chemical tests were done (control (normal tempeh/non-contaminated) and contaminated tempeh). Tests carried out include compactness observation, texture, $\mathrm{pH}$, color, and content of protein and amino acid determinants. Result of quality test was summarized in Table 12 .

Table 12. Summary of quality result between normal and contaminated tempeh.

\begin{tabular}{clc}
\hline No & \multicolumn{1}{c}{ Quality test } & \multicolumn{1}{c}{ Result } \\
\hline 1 & Compactness observation & Not different \\
2 & Texture (with texture analyzer Rheometer)* & Not different \\
3 & $\mathrm{pH}^{*}$ & Not different \\
3 & Color $(L, a$, and $b)$ (with Minolta Chromameter)* & Not different \\
4 & Protein content* & Significantly different \\
5 & Amino acid composition (with Waters UPLC-MS/MS)* & Significantly different \\
\hline
\end{tabular}

*Significant differences was checked by t-student test $(\mathrm{P}<0.05)$.

There is no differences between normal and contaminated tempeh on the compactness and physical characters (texture, $\mathrm{pH}$ and color). Both kind of tempeh showed good compactness and strong ramification of Rhizopus mold. Their texture are in range (weakness: 8.21-9.15 N; modulus elasticity: $2.12 \times 10^{9}-2.23 \times 10^{9} \mathrm{~Pa}$; surrender value: $\left.1.14 \times 10^{6}-3.27 \times 10^{6} \mathrm{~Pa}\right), \mathrm{pH}(6.4-6.7)$ and color in range (L:83.1-84.2; a:2.3-2.5; b:16.2-17.1, white color). Interestingly we found that chemical contents were significantly different especially in protein and amino acid content (Figure 6 and Table 13). This result suggest that Fusarium prolifratum contamination affects chemical content of tempeh (reduction of protein content, L-aspartic acid and L-glutamic acid content) but not changes any physical appearance and characteristics.

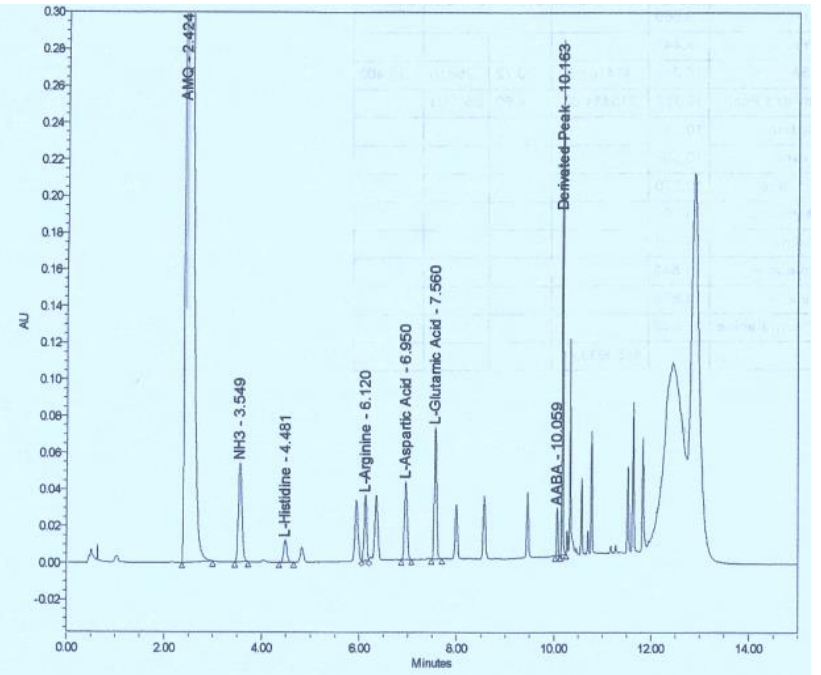

Normal tempeh (no contamination)

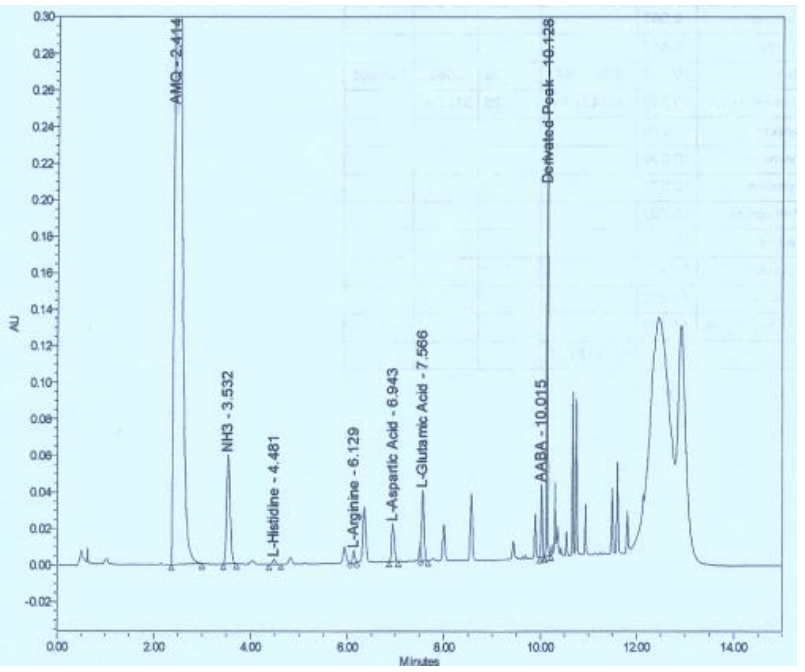

Contaminated-tempeh

Figure 6. UPLC-MS/MS chromatogram of amino acid between normal and contaminated-tempeh. 
Table 13. Protein, L-Aspartic acid and L-Glutamic acid content between normal and contaminated tempeh.

\begin{tabular}{|c|c|c|c|c|}
\hline \multirow[b]{2}{*}{ Samples } & \multirow[b]{2}{*}{$\begin{array}{c}\text { Protein content } \\
(\mathrm{g} / 100 \mathrm{~g} \mathrm{dw})\end{array}$} & \multicolumn{2}{|c|}{ Amino acids } & \multirow[b]{2}{*}{$\begin{array}{l}\text { Interpretation } \\
\text { for taste }\end{array}$} \\
\hline & & $\begin{array}{l}\text { L-Aspartic acid } \\
\text { (g/100g dw) }\end{array}$ & $\begin{array}{l}\text { L-Glutamic acid } \\
\text { (g/100g dw) }\end{array}$ & \\
\hline $\begin{array}{l}\text { Normal } \\
\text { tempeh }\end{array}$ & $42.2 \pm 0.42 \mathrm{a}$ & $5.23 \pm 0.45 \mathrm{a}$ & $8.55 \pm 0.79 a$ & Umami \\
\hline $\begin{array}{l}\text { Contaminated } \\
\text { tempeh }\end{array}$ & $35.34 \pm 1.27 \mathrm{~b}$ & $1.01 \pm 0.21 b$ & $2.17 \pm 0.32 b$ & Less umami \\
\hline
\end{tabular}

dw means dry weight.

Data are mean \pm SD (standard deviation) of $n=3$.

Significant by t-student test $(\mathrm{P}<0.05 ; \mathrm{n}: 3)$ are indicated by different letter.

In normal tempeh, color changed from white to black when stored for more than 8 days, the color changing is because of Rhizopus spores accumulation. In contrast, many white spots obviously appeared in contaminated tempeh, because of white color from Fusarium colonies. This indicator can be used by producer to check quality of their product monthly, to know whether their tempeh product are safe or not for consumption. Producer can do this small test before start to produce traditional tempeh in mass production.

We suggest that consumer could distinguish contaminated tempeh by checking the taste of fresh tempeh before cooked. Contaminated tempeh is less umami than normal tempeh because less L-aspartic acid and L-glutamic acid content, in other words contaminated-tempeh is less delicious compare to the normal. Umami or savory taste, is one of the five basic tastes (together with sweetness, sourness, bitterness, and saltiness). It has been described as brothy or meaty. People taste umami through taste receptors that typically respond to glutamate and aspartic acid.

\section{Risk Assessment}

Risk assessment is the process of quantifying the magnitude and exposure, or probability, of a harmful effect on individuals or populations from specific agents or activities (KuiperGoodman, 2004). The degree of exposure to chemical or toxin compounds is one of the most important parameters in the evaluation of risk (Moreno et al., 2009). In this study, we determined the exposure levels of Indonesian infants, children, and adult to fumonisin B1 through traditional tempeh consumption (Table 14). Data of mycotoxin contamination taken from research part II.

Table 14 reveals the risk of exposure of infant, children and adult to fumonisins with their corresponding \% TDIs. The risk of exposure of infants in the Banyumas regency to fumonisin was the highest (\%TDI: 10.2) compared to the risk in other regencies (\%TDI: 9.6 in Yogyakarta, 3.4 in Gombong, 2.9 in Kudus, 1.6 in Kebumen, and 1.4 in Banjarnegara respectively). These values are ten to sixty-fold lower than the $2000 \mathrm{ng} \cdot \mathrm{kg}^{-1} \mathrm{bw}$ provisional maximum TDI (PMTDI) established for fumonisin by JECFA (2011). Based on this study consumers in those regency had low risk of exposure to fumonisin. Although risk of the exposure was detected very low, fumonisin control still needed to guarantee safety on traditional tempeh consumption. 


\section{Conclusion}

From this study, the following conclusion can be drawn:

- In total, 650 fungal isolates recovered from 345 traditional tempeh inocula (usar) which collected from many markets and center of tempeh producers in 9 different areas in Central Java and Yogyakarta provinces, Indonesia. Six clusters (Banjarnegara, Banyumas, Gombong, Kebumen, Kudus, and Yogyakarta) showed a Fusarium contamination in usar, while no contamination was found in other remaining clusters. About $8.4 \%$ of total fungal isolates recognized belongs to Fusarium genera. Fifty-five pure isolates of Fusarium sp were collected, then observed via microscopy and molecular approach. We found two main species of Fusarium, identified as $F$. solani and $F$. proliferatum.

- All F. poliferatum isolates included in our study lacked the TRI5 gene and possessed the FUM1 gene, indicating that they are presumably trichothecene non-producers and potentially fumonisin producers. This result was confirmed by different set of primers (FUM8, and FUM12) with identical result. In other hands, F.solani isolates lacked in both kind of genes, indicating they are not trichothecene or fumonisin producers. LC-MS/MS screening showed $F$. solani isolates were not able to produce any important mycotoxins, whereas $F$. proliferatum positively produced BEA, FB1, and Enns. Fusarium proliferatum extracts showed about 10-fold stronger activity as toxic agent toward $F$. solani extracts based on their value of $\mathrm{LD}_{50}$.

- About 214 traditional tempeh samples from the six clusters mentioned above were screened for $F$. proliferatum and $F$. solani contamination by real-time PCR. Contamination of traditional tempeh samples with $F$. proliferatum was found in $12 \%$ of the samples with amounts of $10-175 \mathrm{ng} / \mathrm{mg}$ fungal DNA. In these samples, the amount of FB1 and BEA ranged between $170-2682 \mu \mathrm{g} / \mathrm{kg}$ and $20-50 \mu \mathrm{g} / \mathrm{kg}$, respectively. About $7 \%$ of the traditional tempeh samples were contaminated with $F$. solani in amounts of 20-129 ng/mg fungal DNA. All samples had lower FB1 contents than legal limit in Indonesia (2000 $\mu \mathrm{g} / \mathrm{kg}$; SNI 7385:2009), except for one sample from Yogyakarta area which contained FB1 above the allowed limit. Although mycotoxin contamination was detected below the legal limit, the presence of mycotoxin should be controlled in traditional tempeh production.

- There were no differences between normal and contaminated-tempeh on the compactness and physical characters (texture, $\mathrm{pH}$, and color). Interestingly we found that chemical contents were significantly different especially in protein and amino acid content. We suggest that consumer could distinguish contaminated tempeh by checking the taste of fresh tempeh before cooked. Contaminated tempeh is less umami than normal tempeh because of less L-aspartic acid and Lglutamic acid content, in other words, contaminated-tempeh is less delicious compare to the normal.

- The exposure levels of Indonesian infants, children, and adult to fumonisin B1 through traditional tempeh consumption are low. The risk of exposure of infants in the Banyumas regency to fumonisin was the highest (\%TDI: 10.2) compared to the risk in other regencies (\%TDI: 9.6 in Yogyakarta, 3.4 in Gombong, 2.9 in Kudus, 1.6 in Kebumen, and 1.4 in Banjarnegara respectively). These values are ten to sixty-fold lower than the $2000 \mathrm{ng} \cdot \mathrm{kg}^{-1} \mathrm{bw}$ provisional maximum TDI (PMTDI) established for fumonisin by JECFA (2011).

\section{Acknowledgement}

This research was supported financially by Indonesia Endowment Fund for Education, Ministry of Finance, The Republic of Indonesia (Ref:1064/LPDP/2013). 


\section{References}

Adejumo, T.O., Hettwer, U. and Karlovsky, P., 2007. Survey of maize from south-western Nigeria for zearalenone, $\alpha$-and $\beta$-zearalenols, fumonisin B1 and enniatins produced by Fusarium species. Food additives and contaminants, 24(9), pp.993-1000.

Ahmad, R.Z., 2009. Cemaran kapang pada pakan dan pengendaliannya. Jurnal litbang pertanian, $28(1)$, pp.15-22.

Ahmad, R.Z., Gholib, D., Subiyanto, dan Hastiono, S., 1996. Tinjauan retrospektif kapang toksigenik pada berbagai sampel pakan dan komponennya. hlm. 339-353. Prosiding Pertemuan Ilmiah Nasional Bidang Veteriner, Bogor, 12-13 Maret 1996. Balai Penelitian Veteriner, Bogor.

Alves, E., Lucas, G.C., Pozza, E.A. and Carvalho, A.M., 2013. Scanning electron microscopy for fungal sample examination. In: Gupta V.K., M.G. Tuohy (eds.), Laboratory Protocols in Fungal Biology: Current Methods in Fungal Biology. Springer, Heidelberg, pp. 133-150.

AOAC, 2005. Official method of analysis. 16th edition. Association Official Analytical Chemist's Technical Standard.

Arbianto, P., 1990. Preliminary studies on the genetic system of Rhizopus sp. Abstract No 15. Second Asian Symp Non-salted soybean fermentation, 13-15 February, Jakarta.

Arif, M., Chawla, S., Zaidi, M.W., Rayar, J.K., Variar, M. and Singh, U.S., 2012. Development of specific primers for genus Fusarium and F. solani using rDNA sub-unit and transcription elongation factor (TEF-1 $\alpha)$ gene. African journal of biotechnology, 11(2), pp.444-447.

Bartók, T., Szécsi, Á., Szekeres, A., Mesterházy, Á. and Bartók, M., 2006. Detection of new fumonisin mycotoxins and fumonisin-like compounds by reversed-phase high-performance liquid chromatography/electrospray ionization ion trap mass spectrometry. Rapid communications in mass spectrometry, 20(16), pp.2447-2462.

Barus, T., Suwanto, A., Wahyudi, A.T. and Wijaya, H., 2010. Role of bacteria in tempe bitter taste formation: microbiological and molecular biological analysis based on 16S rRNA gene. Microbiology Indonesia, 2(1).

Bernal-Martínez, L., Buitrago, M.J., Castelli, M.V., Rodríguez-Tudela, J.L. and Cuenca-Estrella, M., 2012. Detection of invasive infection caused by Fusarium solani and non-Fusarium solani species using a duplex quantitative PCR-based assay in a murine model of fusariosis. Medical mycology, 50(3), pp.270-275.

Booth, C., 1971. The genus fusarium. The genus Fusarium. CMI, Surrey UK.

Brandfass, C. and Karlovsky, P., 2008. Upscaled CTAB-based DNA extraction and real-time PCR assays for Fusarium culmorum and F. graminearum DNA in plant material with reduced sampling error. Int. J. Mol. Sci. 9:2306-2321.

Burgess, L.W., Summerell, B.A., Bullock, P. and Backhouse, D., 1994. Laboratory Manual for Fusarium Research, third ed., Department of crop science, University of Sydney, Sydney, Australia, p. 133.

Dorak, M.T., 2006. Real Time PCR (BIOS Advanced Methods). Taylor \& Francis Group, UK.

European Food Safety Authority, 2014. Evaluation of the increase of risk for public health related to a possible temporary derogation from the maximum level of deoxynivalenol, zearalenone, and fumonisins for maize and maize product. EFSA journal, 12(5):3699.

Eynck, C., Koopmann, B., Grunewaldt-Stoecker, G., Karlovsky, P. and Von Tiedemann, A., 2007. Differential interactions of Verticillium longisporum and V. ádahliae with Brassica napus detected with molecular and histological techniques. European journal of plant pathology, 118(3), pp.259-274.

Geiser, D. M., Jime'nez-Gasco, M. D. M., Kang, S., Makalowska, I., Veeraraghavan, N., Ward, T. J., Zhang, N., Kuldau, G. A. and O'Donnell, K., 2004. FUSARIUM-ID v. 1.0: A DNA sequence database for identifying Fusarium. Eur. Journal plant pathol., 110:473-479.

Gerlach, W. and Nirenberg, H., 1982. The genus Fusarium--a pictorial atlas. Mitteilungen aus der Biologischen Bundesanstalt fur land-und forstwirtschaft Berlin-Dahlem, (209).

Harrow, S.A., Farrokhi-Nejad, R., Pitman, A.R., Scott, I.A., Bentley, A., Hide, C. and Cromey, M.G., 2010. Characterisation of New Zealand Fusarium populations using a polyphasic approach differentiates the F. avenaceum $/ \mathrm{F}$. acuminatum $/ \mathrm{F}$. tricinctum species complex in cereal and grassland systems. Fungal biology, 114(4), pp.293-311.

Hartl, M. and Humpf, H.U., 2000. Toxicity assessment of fumonisins using the brine shrimp (Artemia salina) bioassay. Food and chemical toxicology, 38(12), pp.1097-1102.

Howard, P.C., Eppley, R.M., Stack, M.E., Warbritton, A., Voss, K.A., Lorentzen, R.J., Kovach, R.M. and Bucci, T.J., 2001. FB1 carcinogenicity in a two-year feeding study using F344 rats and B6C3F1 mice. Environmental health perspectives 109: 277- 82 .

Hsuan, H.M., Salleh, B. and Zakaria, L., 2011. Molecular identification of Fusarium species in Gibberella fujikuroi species complex from rice, sugarcane and maize from Peninsular Malaysia. International journal of molecular sciences, 12(10), pp.6722-6732. 
Hlywka, J.J., Beck, M.M. and Bullerman, L.B., 1997. The use of the chicken embryo screening test and brine shrimp (Artemia salina) bioassays to assess the toxicity of fumonisin B 1 mycotoxin. Food and chemical toxicology, 35(10), pp.991-999.

INCS (Badan Standarisasi Nasional), 2009. Tempe Kedelai (SNI 3144-2009). Jakarta (ID): INCS.

JECFA, 2011. Evaluation of Certain Food Additives and Contaminants: Seventy-Fourth Report of the Joint FAO/WHO Expert Committee on Food Additives; WHO Technical Report Series No 996; Food and Agriculture Organization of the United Nations. III. Joint FAO/WHO Expert Committee on Food Additives: Geneva, Switzerland.

Jestoi, M., 2008. Emerging Fusarium-mycotoxins fusaproliferin, beauvericin, enniatins, and moniliformin-A review. Critical reviews in food science and nutrition, 48(1), pp.21-49.

Jestoi, M., Rokka, M., Yli-Mattila, T., Parikka, P., Rizzo, A. and Peltonen, K., 2004. Presence and concentrations of the Fusarium-related mycotoxins beauvericin, enniatins and moniliformin in Finnish grain samples. Food additives and contaminants, 21(8), pp.794-802.

Juan, C., Raiola, A., Mañes, J. and Ritieni, A., 2014. Presence of mycotoxin in commercial infant formulas and baby foods from Italian market. Food control, 39, pp.227-236.

Jurado, M., Vázquez, C., Marín, S., Sanchis, V. and González-Jaén, M.T., 2006. PCR-based strategy to detect contamination with mycotoxigenic Fusarium species in maize. Systematic and applied microbiology, 29(8), pp.681-689.

Jutono, 1985. The microbiology of usar, a traditional tempe inoculum. In: Asian symposium on non-salted soybean fermentation; Tsukuba, July. 1985.

Karyadi, D., 1996. Perkembangan Tempe di Lima Benua. In Bunga Rampai Tempe Indonesia. Penerbit Yayasan Tempe Indonesia.

Kuiper-Goodman, T., 2004. Risk assessment and risk management of mycotoxins in food. In: Magan N, Olsen M, editors. Mycotoxins in food: detection and control. Boca Raton, Fla : CRC Press. p 1-31.

Kumar, S., Stecher, G. and Tamura, K., 2016. MEGA7: Molecular Evolutionary Genetics Analysis version 7.0 for bigger datasets. Molecular biology and evolution, 33(7), pp.1870-1874.

Kusumaningrum, H.D., Suliantari, A.D., Toha, S.H., Putra, and Utami, A.S., 2010. Contamination of Aspergillus flavus and AF at distribution chain of maize based food product and its influencing factors. Jurnal teknologi dan industri pangan, 21(2): 171-176.

Leslie, J.F. and Summerell, B.A., 2006. The Fusarium Laboratory Manual. Blackwell Publishing. 388 pp.

Liu, Y. and Wu, F., 2010. Global burden of aflatoxin-induced hepatocellular carcinoma: a risk assessment. Environmental health perspectives, 118(6), p.818.

Marasas, W.F.O., 1995. Fumonisins: their implications for human and animal health. Natural toxins 3:193-98.

Meca, G., Ruiz, M.J., Soriano, J.M., Ritieni, A., Moretti, A., Font, G. and Mañes, J., 2010. Isolation and purification of enniatins A, A 1, B, B 1, produced by Fusarium tricinctum in solid culture, and cytotoxicity effects on Caco2 cells. Toxicon, 56(3), pp.418-424.

Meilgaard, M.C., Carr, B.T. and Civille, G.V., 2006. Sensory evaluation techniques. CRC press.

Moretti, A., Mule, G., Ritieni, A. and Logrieco, A., 2007. Further data on the production of beauvericin, enniatins and fusaproliferin and toxicity to Artemia salina by Fusarium species of Gibberella fujikuroi species complex. International journal of food microbiology, 118(2), pp.158-163.

Musser, S.M. and Plattner, R.D., 1997. Fumonisin composition in cultures of Fusarium moniliforme, Fusarium proliferatum and Fusarium nygami. J. Agric. Food Chem. 45: 1169-73.

Nelson, P.E., Toussoun, T.A. and Marasas, W.F.O., 1983. Fusarium species: An Illustrated Manual for Identification. Pennsylvania State University Press, University Park. 193 pp.

Nirenberg, H.I., 1976. Untersuchungen über die morphologische und biologische Differenzierung in der Fusarium Sektion Liseola. Mitt. Biol. Bund. Land-Forst. (Berlin-1. Dahlem) 169:1-117.

Nout, M.J.R. and Kiers, J.L., 2005. Tempe fermentation, innovation and functionality: update into the third millenium. Journal of applied microbiology, 98(4), pp.789-805.

Nout, M.J., Martoyuwono, T.D., Bonné, P.C. and Odamtten, G.T., 1992. Hibiscus leaves for the manufacture of usar, a traditional inoculum for tempe. Journal of the science of food and agriculture, 58(3), pp.339-346.

Nutz, S., Döll, K. and Karlovsky, P., 2011. Determination of the LOQ in real-time PCR by receiver operating characteristic curve analysis: application to qPCR assays for Fusarium verticillioides and F. proliferatum. Analytical and bioanalytical chemistry, 401(2), pp.717-726.

O'Donnell, K., Kistler, H.C., Cigelnik, E., and Ploetz, R.C., 1998. Multiple evolutionary origins of the fungus causing Panama disease of banana: Concordant evidence from nuclear and mitochondrial gene genealogies. Proceedings of the National Academy of Sciences of the United States of America 95:2044-2049. 
Ogawa, Y., Tokumasu, S. and Tubaki, K., 2004. An original habitat of tempeh molds. Mycoscience, 45(4), pp.271276.

Proctor, R.H., Plattner, R.D., Brown, D.W., Jeong-Ah, S.E.O. and Yin-Won, L.E.E., 2004. Discontinuous distribution of fumonisin biosynthetic genes in the Gibberella fujikuroi species complex. Mycological research, 108(07), pp.815-822

Purwadaria, H.K., Fardiaz, D., Kardono, L.B.S. and McElhatton, A., 2016. Tempe from Traditional to Modern Practices. In Modernization of traditional food processes and products (pp. 145-160). Springer US.

Purwoko, H.M., Hald, B. and Wolstrup, J., 1991. Aflatoxin content and number of fungi in poultry feedstuffs from Indonesia. Letters in applied microbiology, 12(6), pp.212-215.

Rahmawati, Dewanti-Hariyadi, R., Hariyadi, P., Fardiaz, D. and Richana, N., 2013. Isolation and identification of microorganisms during spontaneous fermentation of maize. Jurnal teknologi dan industri pangan, 24:1.

Rodríguez-Carrasco, Y., Ruiz M.J., Font G. and Berrada, H., 2013. Exposure estimates to Fusarium mycotoxins through cereals intake. Chemosphere, 93(10), pp.2297-2303.

Rubenthaler, G.L., Huang, M.L. and Pomeranz, Y., 1990. Steamed bread. I. Chinese steamed bread formulation and interactions. Cereal chem., 67(5), pp.471-475.

Scott, P.M., 1993. Fumonisins. International journal food microbiol. 18: 257-70.

Serrano, A.B., Meca, G., Font, G. and Ferrer, E., 2013. Degradation study of enniatins by liquid chromatographytriple quadrupole linear ion trap mass spectrometry. Food chemistry, 141(4), pp.4215-4225.

Seumahu, C.A., Suwanto, A. and Suhartono, M.T., 2010. Dinamika populasi Acetobacter selama proses fermentasi nata de coco. Microbiology Indonesia, 10(2).

Suliantari, 1996. Pembuatan dan penanganan laru (inokulum) tempe. In: Syarief R (ed) Pengembangan industri kecil tempe. Kantor Menneg Urusan Pangan-IPB, Jakarta, pp 2.1-2.24

Tan, D.C., Flematti, G.R., Ghisalberti, E.L., Sivasithamparam, K. and Barbetti, M.J., 2011. Toxigenicity of enniatins from Western Australian Fusarium species to brine shrimp (Artemia franciscana). Toxicon, 57(5), pp.817-825.

Thanh, N.V. and Nout, M.J.R., 2004. Dormancy, activation and viability of Rhizopus oligosporus sporangiospores. International journal of food microbiology, 92(2), pp.171-179.

Tolosa, J., Font, G., Mañes, J. and Ferrer, E., 2013. Nuts and dried fruits: natural occurrence of emerging Fusarium mycotoxins. Food control, 33(1), pp.215-220.

Wätjen, W., Debbab, A., Hohlfeld, A., Chovolou, Y., Kampkötter, A., Edrada, R.A., Ebel, R., Hakiki, A., Mosaddak, M., Totzke, F. and Kubbutat, M.H., 2009. Enniatins A1, B and B1 from an endophytic strain of Fusarium tricinctum induce apoptotic cell death in H4IIE hepatoma cells accompanied by inhibition of ERK phosphorylation. Molecular nutrition \& food research, 53(4), pp.431-440.

Wilfinger, W.W., Mackey, K. and Chomczynski, P., 1997. Effect of pH and ionic strength on the spectrophotometric assessment of nucleic acid purity. Biotechniques, 22(3), pp.474-6.

Winarno, F.G., 1985. Tempe Making on Various Substrates. In: Asian Symposium on Non-Salted Soybean Fermentation Tsukuba, July.

Yli-Mattila, T., 2010. Ecology and evolution of toxigenic Fusarium species in cereals in northern Europe and Asia. Journal of plant pathology, pp.7-18.

Zhang, K., Yuan-Ying, S. and Cai, L., 2013. An optimized protocol of single spore isolation for fungi. Cryptogamie, mycologie, 34(4), pp.349-356. 


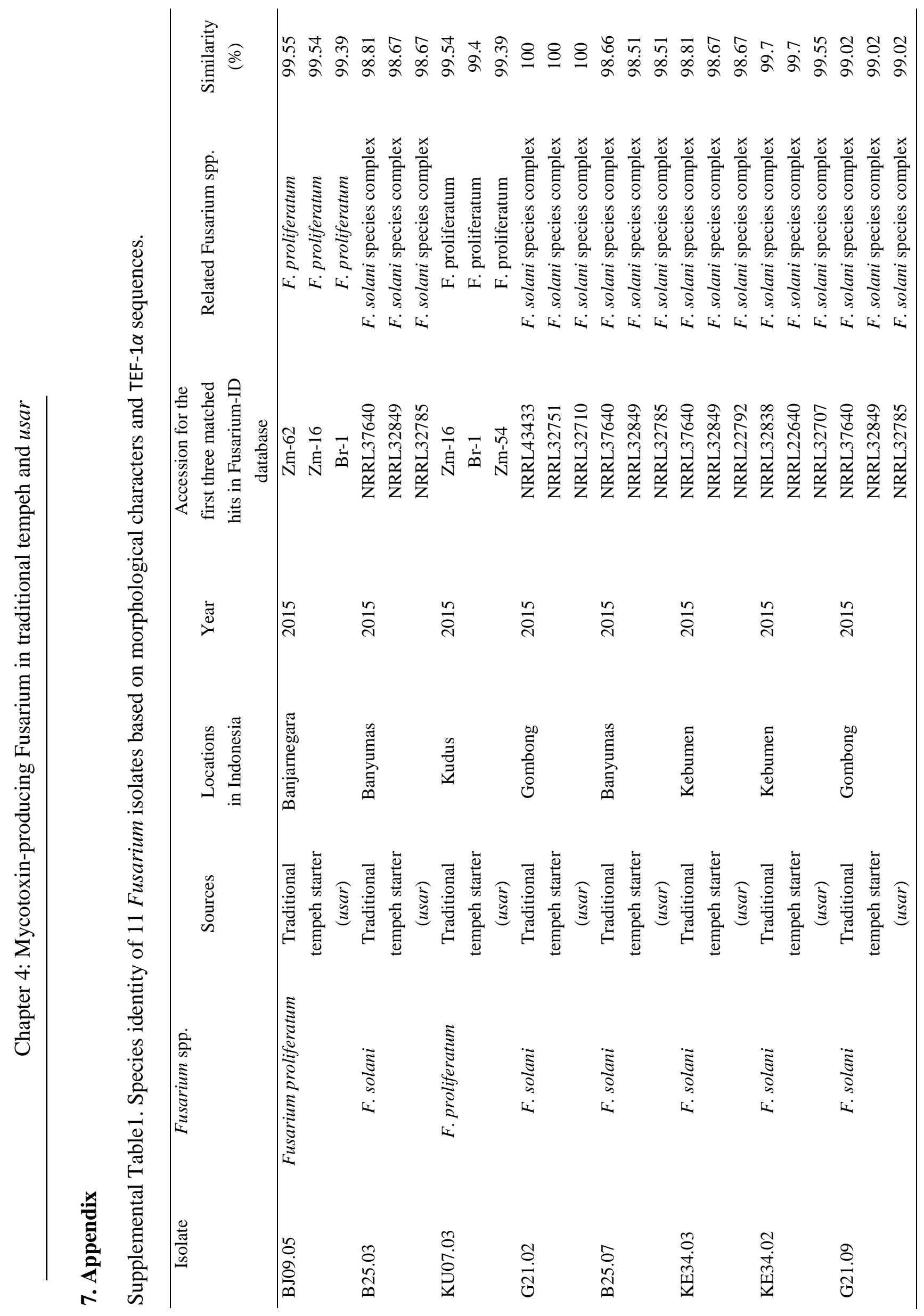




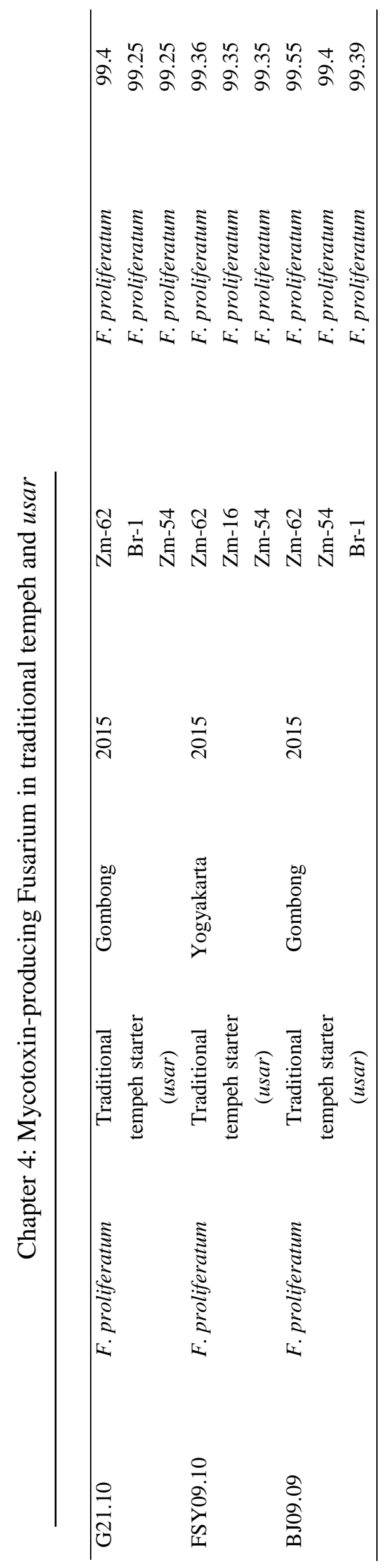




\title{
Review Article 02
}

\section{Fighting Toxigenic Fungi in Food Industry by Applying Lactic Acid Bacteria: A Review of Established and Recent Research}

\author{
Riyan Anggriawan, Maria Vinas, and Petr Karlovsky \\ Molecular Phytopathology and Mycotoxin Research, University of Goettingen, Göttingen, Germany
}

\begin{abstract}
Food spoilage by molds and the occurrence of mycotoxins produced by these molds represent a major concern for all stakeholders, not least researchers, and research and development divisions of the food manufacturing industry. Mycotoxins produced by fungi, e.g. aflatoxin, trichothecene, fumonisin, ochratoxin A, and patulin can pose a health risk due to their carcinogenic, immunotoxic, teratogenic, neurotoxic, nephrotoxic and hepatotoxic effects. Moreover, trends enforced by the customer, demand on natural labels, friendly preservatives have over the last few years stimulated research on antifungal lactic acid bacteria (LAB) as a bio-preservative. This article reviews current knowledge on antifungal LAB, their bioactive metabolites, genetic engineering applications to increase production of antifungal compounds and their application in the food system.
\end{abstract}

Keywords: lactic acid bacteria, antifungal metabolites, mycotoxins, food safety

\section{Introduction}

The history of the food industry is in part, also the history of the battle with toxigenic fungi. Mycotoxigenic molds such as Aspergillus, Fusarium, and Penicillium play an unavoidable role in the decline of the value, quality and hygiene of foodstuffs by the synthesis of highly toxic metabolites known as mycotoxins. They can penetrate into the food chain throughout the food production system - in the field, during shipping, handling, storage - and they are be found in various food products all over the world. Penicillium and Aspergillus are recognized as food contaminants introduced during storage, whereas Fusarium species are destructive plant pathogens producing mycotoxins before or immediately post-harvest (Rahayu, 2007; Rahayu 2009). Food mycotoxin contamination is becoming a serious problem, especially in tropical countries.

Six classes of mycotoxins are often found in food products: aflatoxins, fumonisins, ochratoxins, patulin, trichothecenes and zearalenone (Bhat et al., 2010). Mycotoxins cause a toxic response, called mycotoxicosis. When ingested by humans, mycotoxins can cause damage to kidney function (Fuchs and Peraica, 2005), disturb the development of fetus (Pitt, 2000), induce many kinds of cancer (IARC, 2002; Schwartz, 2002; Hamid et al., 2013), cause Kashin-Beck disease (Stone, 2009), alimentary toxic aleukia (Peraica et al., 1999), premature thelarche (Rodriguez et al., 1985), and human ergotism (Belser-Ehrlich et al., 2012). Some mycotoxins are neurotoxins (Leese-Haley, 2003), while others act by disrupting protein synthesis causing effects ranging from necrosis to immunodeficiency (Jiang et al., 2008; Meissonier et al., 2008; Jolly et al., 2011). 
Mycotoxin contamination of food and feedstuff is important also from an economic point of view. Apart from the obvious food and feed losses, they can have a negative affect on productivity, foreign exchange earnings, increase cost inspections before and after shipments, compensation payments in case of claims, research, and training program costs, detoxification costs, etc. When combined, these costs are certainly extremely high (Bhat and Miller, 1991; Wu, 2006). Many countries must spend money up to hundreds of million dollars per year to deal with this problem (Zanelli, 2000; Wu, 2006; Schmaile and Munkvold, 2009; Amaike and Keller, 2011).

Physical and chemical methods have been used to prevent toxigenic fungal growth in food commodities. The physical methods, i.e., drying, freezing, freeze-drying, modified atmosphere packaging, UV, microwave and infrared radiation usually require expensive multi-faceted approaches that limit their applicability. Chemical preservatives have been used as an additional constraint to restrict the number of microorganisms capable of growing within the food. However, the decline in consumer acceptance of the classical preservation methods and the undesirable allergenic potential of many additives have led researchers to look for natural inhibitors from plant or microbial sources. Some preservatives may be metabolized in the foodstuff or in vivo to produce toxic substances (Classen et al., 1987). Additionally, some fungi have acquired the ability to tolerate chemical preservatives. For example, some Penicillium can grow in the presence of potassium sorbate (Davidson, 2001), benzoic acids (Schnurer and Magnusson, 2005) while other molds have the ability to break down sorbate (Nielsen and de Boer, 2000).

The trend for using natural-label friendly preservatives has drastically increased over the last years and has been replacing the traditional preservation system. Biopreservation is an interesting alternative approach to physical and chemical preservation methods commonly applied in food. Biopreservation refers to the use of natural microflora or controlled microbiota or antibacterial products to extend shelf life and increase food safety (Stiles, 1996). Among natural biological antagonist, lactic acid bacteria (LAB) have potential applications as bio-preservative. LAB can play a vital role as preservatives since they have a long history in fermented food production, are generally recognized as safe (GRAS status) and they have a Qualified Presumption of Safety (QPS) status in the EU, consequently the scientific exploration of their potential as biocontrol agents have received a consistent and growing interest. These microorganisms occur naturally in many food systems and are also part of the intestinal microflora. Careful selection of specific strains of LAB with antifungal properties can be used as food preservatives reducing mold contamination, therefore, improving the shelf-life of many fermented food products (Corsetti et al., 2000; Clarke et al., 2002; Crowley et al., 2002; Arendt et al., 2007) and reducing health risks due to mycotoxins exposure (Gourama and Bullerman, 1995). Many research reports also indicate that LAB has beneficial health effects in humans (Perdigon, 2001; Masood et al., 2011; FlorouPaneri, 2013; Fernández et al., 2015; Nuraida et al., 2015). Moreover, due to certain specific metabolic properties, LAB are of particular interest in the food industry, since they can improve the sensory and nutritional value of food products (Crowley et. al., 2002; Arendt et al., 2007). 
In recent years, literature has accumulated on this topic, but so far there are only a limited number of comprehensive reviews. The focus of this review is to summarize the new findings in this research topic including new insights into new methods of improving antifungal properties such as genetic engineering. Application of antifungal LAB in the food system is also taken into account.

\section{Overview of LAB}

Lactic acid bacteria belong to the phylum Firmicutes. According to Hofvendahl and HahnHagerdal (2000), LAB are Gram-positive, microaerophilic, non-spore forming, and acid-tolerant bacteria, with DNA base composition of less than $50 \mathrm{~mol} \%(\mathrm{G}+\mathrm{C})$, they can survive at $\mathrm{pH} 5$ or lower and its broad optimal growth temperatures range from $20^{\circ} \mathrm{C}$ to $45^{\circ} \mathrm{C}$. They are generally catalase negative but sometimes pseudo-catalase has been detected when they grow on low sugar concentrations. The most important LAB property is the capacity to convert hexoses into lactic acid (LA) (Södergård and Stolt, 2002).

Lactic acid bacteria were initially classified into four classes, namely Lactobacillus, Leuconostoc, Streptococcus and Pediococcus (Wessels et al., 2004). The classification considers morphological characteristics, fermentation patterns, capability to grow at different temperatures, stereospecificicty (D or L-lactic), as well as acid and base-tolerance. Nowadays, each class includes several genera. Genus Lactobacillus comprises Lactobacillus and Carnobacterium. Genus Streptococcus consists of Streptococcus, Lactococcus, Vagococcus, and Enterococcus. Genus Pediococcus includes Pedicoccus, Tetragenococcus and Aerococcus. While, genus Leuconostoc remains the same (Ruas-Madiedo et al., 2012). The new classification is based on composition of fatty acid in cell membranes, motility and rRNA sequences, as well as guanine and cytosine percentage in DNA. For identification, sequencing of 16S rRNA gene is an important guideline in the classification of LAB (Wood and Holzapfel, 2012).

According to the fermentation patterns, LAB are grouped into two, homofermentative and heterofermentative (Prescott and Dunn, 1959; Davidson et al., 1983). During the cell metabolism, the homofermentative LAB produces LA from hexoses via glycolysis (Embden-MeyerhofParnas pathway). This LAB does not ferment pentoses and gluconate. They also do not produce gas from glucose and nor do they possess phosphoketolase (Surono, 2004). Homofermentative LAB is often used for food preservation because the high amount of LA produced, which inhibits the growth of other bacteria. Heterofermentative bacteria, ferments glucose to produce $\mathrm{LA}, \mathrm{CO}_{2}$, ethanol, acetaldehyde, diacetyl and other compounds (Mitsuoka, 1990). Aldolase enzyme is absent in this LAB. However, phosphoketolase is present in long and short rods type (Surono, 2004). In hetero-fermentation, pentose is converted into LA and acetic acid, via pentose phosphate pathway (Figure 1).

LAB can be found in many fermented foods such as meat, dairy products, vegetables, beverages, and bread. They are also present in soil, water, animal manure, waste, and plants. These bacteria are also members of microbiotas of the mucous membrane in the human, and animal digestive tract, mouth, skin, urinary tract and genital organs, and can have a beneficial impact on 
these tracts and organs. The bacteria can enter food via the environment, as naturally occurring microorganisms, or can be added into the food as cultures.

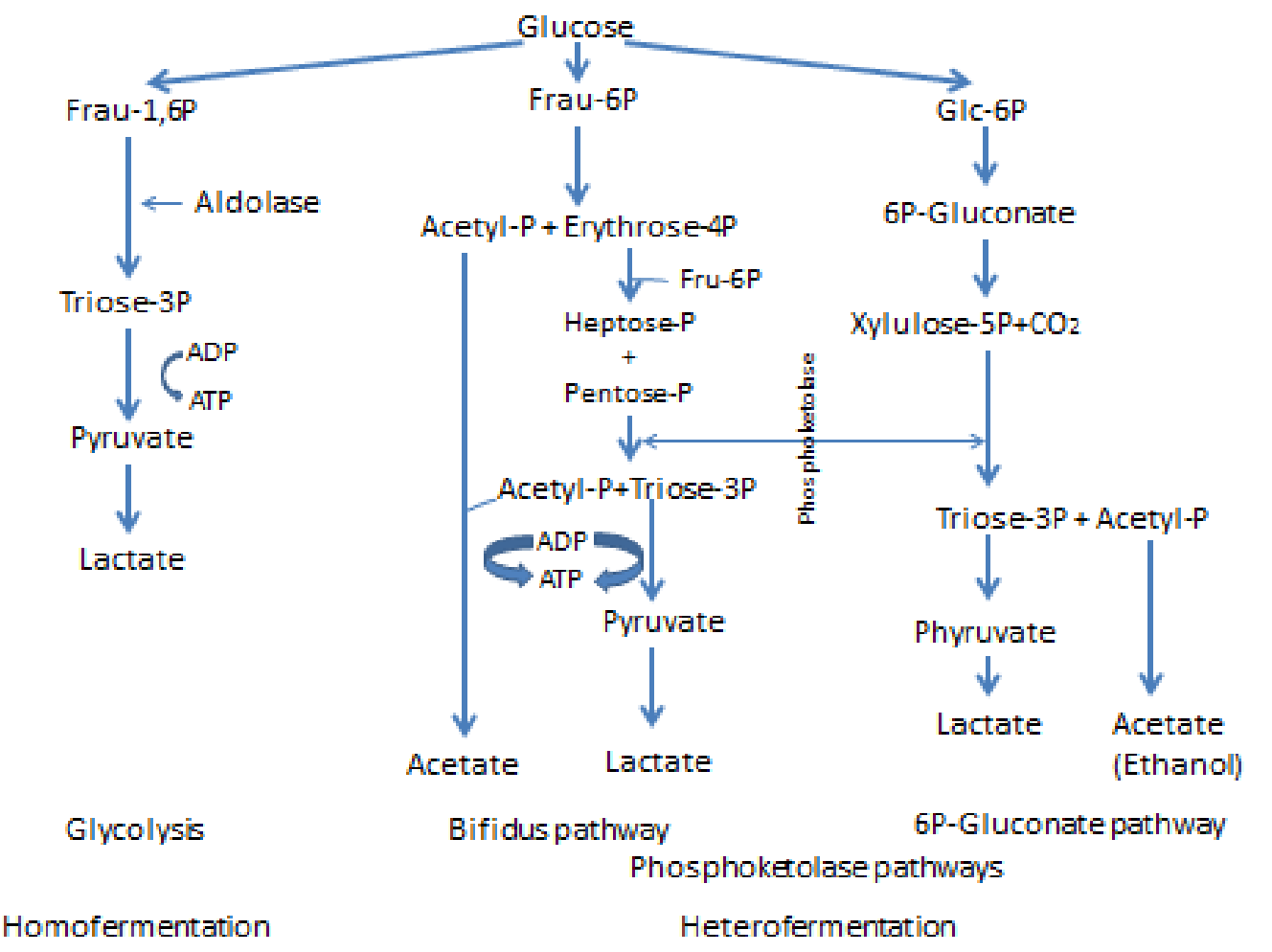

Fig 1. The main routes of hexose fermentation in LAB (Modified of Wood and Holzapfel, 2012)

LAB has gained attention because of the practical application for starter cultures in fermented food and feed, medicines, probiotics, and as a biological control agent. In food industry, LAB is widely utilized as a starter to make a pleasant change in the texture, aroma, flavour and acidity of foods (Harzallah and Belhadj, 2013). LAB is used in various ways such as a probiotic, bacteriocin producer and as a starter culture in fermented foods.

\section{LAB as Antifungal Agent}

An antifungal agent is an organism capable of inhibiting biodeterioration and preventing fungal disease. It can be produced during microbial fermentations (Carlile et al., 2001). In general, there are four mechanisms of antifungal action: inhibition of cell wall synthesis, perturbation of membrane function, inhibition of protein synthesis, and inhibition of cell division (Odds et al., 2003). The inhibition of $\beta$-glucans synthesis and chitin synthetase is the main mechanism in which antifungal compounds inhibit cell wall synthesis on mold. While, antimicrobial compounds can also disrupt cell membranes in several ways, for example by binding sterols to destroy membrane function or inhibiting sterol biosyntesis. Protein synthesis can also be disrupted since blasticidin (antimicrobial peptide) inhibits protein synthesis by binding ribosomes. Inhibition also occurs during cell division by interfering with microtubules (Ström, 2005). 
Bioactive compounds are secondary metabolites produced by microorganisms which are not essential for the growth of the microorganism. The production of secondary metabolites can act antimicrobial (Carlile et al., 2001). Over 80 years ago, LAB was described to produce antimicrobial compounds. The antifungal strains were isolated from different environments such as sourdough culture (Corsetti et al., 1996), salami (Coloretti et al., 2007), grass silage (Magnusson and Schnurer, 2001), cheeses and milk (Roy et al., 1996) and vegetable products (Sathe et al., 2007).

LAB antagonism refers to the inhibition of other microorganism, caused by competition for nutrients, and by the production of antimicrobial metabolites (Holzapfel et al., 1995). Extensive research has been done on the antifungal ability of LAB, and fungal inhibitory components have been isolated and identified So far, there are 114 research papers regarding antifungal LAB and, as shown in Figure 2, the genus Lactobacillus is the most frequently isolated and researched. Among Lactobacillus species, Lact. plantarum is the most important one regarding antifungal activity against toxigenic fungus. The identification of these LAB antifungal compounds started in 2007 and some of them are described below (Table 1, Figure 3). The antifungal compounds produced by LAB vary. The majority of the antifungal substances identified are low molecular weight compounds including organic acids, hydrogen peroxide, proteinaceous compounds, hydroxyl fatty acids and phenolic compounds.

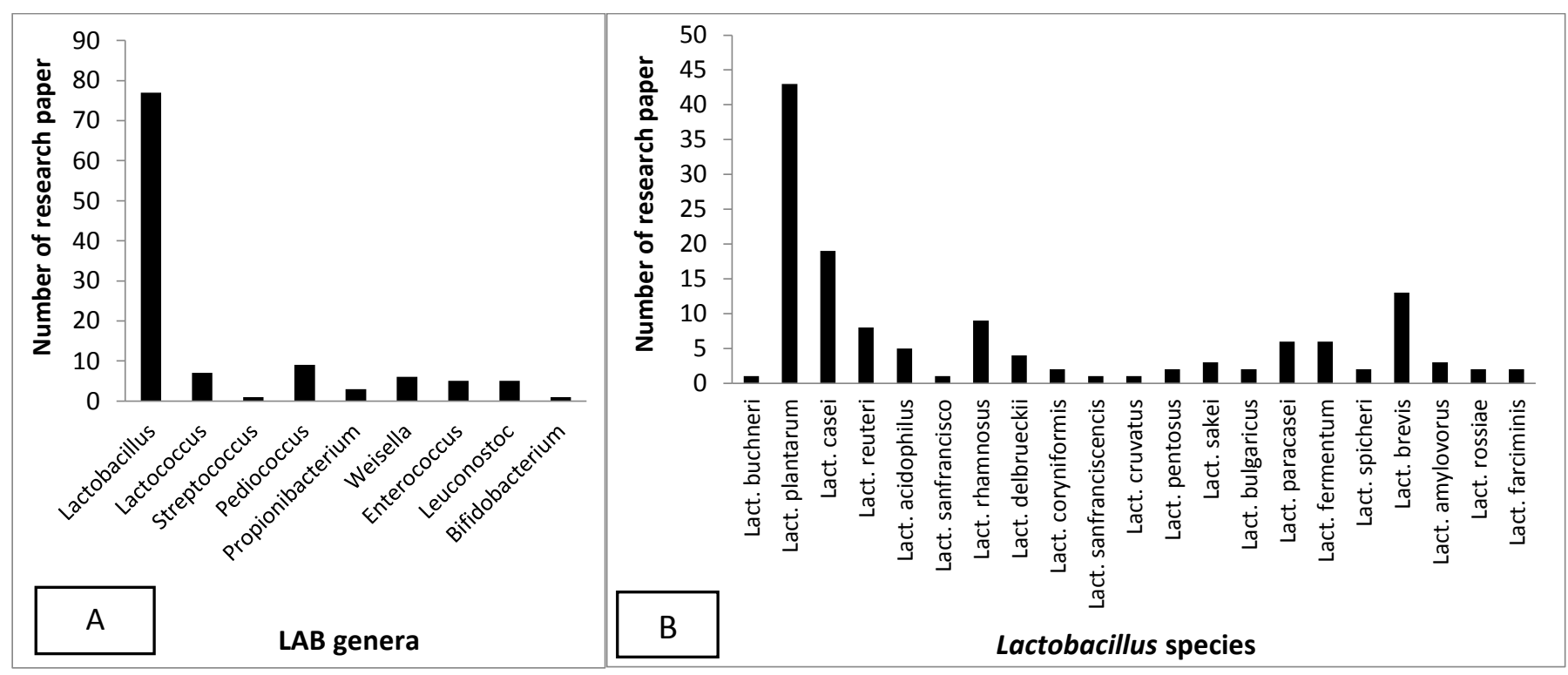

Fig 2. Number of research papers since 1981 based on antifungal properties of:

A) LAB genera, B) Lactobacillus species. 


\section{Antifungal Compounds Produced by LAB}

\section{Organic acids}

The antimicrobial effect of organic acids lies in the decrease of $\mathrm{pH}$ (Ammor et al., 2006).

De Vyust and Vandamme in 1994 stated that LAB has long been known toproduce organic acids, such as acetic acid, lactic acid, etc. Accumulation of acidic-end-products and the concomitant low $\mathrm{pH}$, results in a wide inhibitory spectrum against microbes. Both the dissociation constant and the acid concentration, determine the inhibitory activity level. In their undissociated form, lipophilic acids, such as lactic and acetic acid can penetrate the microbial cell, and dissociate to produce hydrogen ions at the higher intracellular $\mathrm{pH}$, reducing the intracellular $\mathrm{pH}$, thus interfering in essential metabolic functions such as substrate translocations and oxidative phosphorylation (Baird and Parker, 1980; Lindgren and Dobrogosz, 1990). Organic acids can only penetrate the microbial cell wall if their $\mathrm{pH}$ is beneath their $\mathrm{p} K_{\mathrm{a}}$. The $\mathrm{p} K_{\mathrm{a}}$ value of the most common acids produced by LAB are below 5.0. The $\mathrm{p} K_{\mathrm{a}}$ of lactic, acetic, 3-phenyl-L-lactic and caproic acids are 3.8, 4.7, 3.5 and 4.9, respectively (De Muynck et al., 2004). Inhibition of fungal pathogens by organic acids may involve inhibition of enzymes activity, and cell membrane disruption caused by undissociated active fractions of decomposed organic acids (Gerez et al., 2010).

Synthesis of LA and acetic acid are the main factors responsible for LAB use as biopreservatives (Trias et al. 2008a). Lactic acid is the main acid component produced by LAB. It could reduce $\mathrm{pH}$ in fermentation media; however when citrate is present in the medium together with glucose during the initial fermentation, the LA produced is degraded. Citrate is concomitantly degraded, resulting in the accumulation of formic, acetic and succinic acids along with $\mathrm{CO}_{2}$ (Lindgren et al., 1990). Acid production and the reduction of $\mathrm{pH}$ prolong the lag phase of the organism. A recent study reported that LA is the primary antifungal agent produced by Lact. plantarum UFG 108 and Lact. plantarum UFG 121, it inhibits the growth of various fungi, i.e. Aspergillus niger, A. flavus, Fusarium culmorum, Penicillium expansum and P. chrysogenum (Russo et al., 2016). Baek et al. (2012) and Lan et al. (2012) also described that a mixture of organic acids produced by Weissella sp. and Leuconostoc sp. can prevent the growth of mold spoilage.

Acetic acid is reported to be more inhibitory than LA against yeasts and molds (Eklund, 1989). This can be explained by its dissociation properties since acetic acid has between two to four times more of the acid in the undissociated state at a $\mathrm{pH}$ interval between 4.0 and 4.6 compared to LA (Lindgren and Dobrogosz, 1990; Batish et al., 1997). Heterofermentative LAB also produces propionic acid in very small amounts. Propionic acid can inhibit cell membranes by neutralizing the electrochemical proton gradient, it can cause bacteriostatic and fungistatic effects. However the effect of acetic and propionic acids depend on the $\mathrm{pH}$ decrease caused by LA (Lind et al., 2005; Le Lay et al., 2016). Propionic acid is known to be more inhibitory than acetic or lactic acid. Moon (1983) reported that a mixture of lactic, acetic and propionic acid results in a drastic reduction in yeast growth, while the yeast tends to grow well at relatively high acetic or lactic acids concentrations $(100 \mathrm{mmol} / \mathrm{L})$. 
Another organic acid that shows antifungal activity is phenyllactic acid (PLA) produced by Lact. plantarum with a broad spectrum antifungal activity (Lavermicocca et al., 2000, Magnusson and Schnürer 2001; Lavermicocca et al., 2003, Ström et al., 2002). Some LAB can synthesize PLA and 4-hydroxy-acid phenyllactic (Valerio et al., 2004). 3-PLA is derived from the metabolism of phenylalanine As follows, phenylalanine is transaminated to phenylpyruvic acid (PPA) (Li et al., 2007) and then PPA is converted to 3-phenyllactic acid (Mu et al., 2009). Supernatant of Lact. plantarum 21B inoculated with wheat starch hydrolysates reliably prevents the growth of several toxigenic fungi, namely A. niger, A. flavus, Monilia sitophila, $F$. graminearum, $P$. roqueforti, and $P$. expansum, (Lavermicocca et al., 2000; Lavermicocca et al., 2003). Broberg et al. (2007) reported that Pichia anomala and P. roqueforti are inhibited by Lact. plantarum strain MiLAB14 and Lact. coryniformis MiLAB 393 through their antifungal compounds, 3-PLA. Lavermicocca et al. (2000) reported that PLA was contained at the highest concentration in the bacterial culture filtrate and had the highest activity and inhibited all the tested fungi at a concentration of $50 \mathrm{mg}$ except for $P$. roqueforti IBT 18.687 and $P$. corylophilum IBT 6978 (166 mg/mL). PLA also inhibits the growth of Candida pulcherrima, C. parapsilosis and Rhodotorula mucilaginosa (Schwenninger et al., 2008). Prema et al. (2010) identified PLA in the culture supernatant of Lact. plantarum using NMR and IR spectroscopy, showing inhibitory effects against A. fumigatus and Rhizopus stolonifer. Ndagano et al. (2011) found PLA mixed with other organic acids and free fatty acids in the supernatant of Lact. plantarum VE56 and W. paramesenteroides LC11 inhibiting fungal growth Antifungal compounds from culture supernatant of Lact. plantarum 1.7 FST was isolated by Dal Bello et al. (2007), they were identified as cyclo (L-Leu-L-Pro), cyclo (L-Phe-L-Pro), and PLA. The main constituent of antifungal compounds were PLA and lactic acid. Gerez et al. (2010) revealed that PLA is the most effective organic acid.

Benzoic acid is one of the oldest chemical preservatives used in drug, cosmetic and food industries. This organic acid was isolated and identified in the culture filtrate of Lact. plantarum VTT E-78076 by Niku-Paavola group in 1999 and it was active against Fusarium avenaceum VTT D-80 147 (Niku-Paavola et al., 1999). The elimination of the electrochemical gradient across the cell membrane caused by benzoate is the reason for the microbial growth inhibition (Eklund, 1989).

Wang et al. (2012) managed to purify a new antifungal compound, benzeneacetic acid produced by Lact. plantarum IMAU10014, which was active against Botrytis cinerea, $F$. oxysporum, $P$. citrinum and $P$. digitatum. LAB also produce a mixture of organic acids during fermentation, including caproic acid, formic acid, butyric acid and n-valeric acid. Corsetti et al. (1998) identified a mixture of organic acids produced by Lact. sanfrancisco CB1 and found that the organic acids act in a synergic way with caproic acid during molds growth inhibition. 


\section{Free fatty acids}

Antifungal mechanism of free fatty acids is caused by the alteration of the membrane fluidity by partitioning the lipid bilayer of cells or by inclusion into fatty acyl chains of membrane phospholipids (Avis and Belanger, 2001). This increases membrane permeability and the release of intracellular electrolytes and proteins eventually, leading to the cytoplasmic disintegration of fungal cells (Sjögren et al., 2003). Some LAB can produce hydroxy fatty acids with potent antifungal activity. Sjögren et al. (2003) identified and characterized four types of antifungal substances namely 3-(R)-hydroxy decanoic acid, 3-hydroxy-5-cis-dodecenoic acid, 3-(R)-hydroxy dodecanoic acid and 3-(R)-hydroxy tetradecanoic acid, from Lact. plantarum MiLAB 14. Ryu et al. (2014) also have purified the antifungal 3-hydroxy decanoic acid, 5-oxododecanoic acid and 3hydroxy-5-dodecenoic acid from Lact. plantarum isolated from kimchi which are active against a broad fungal spectrum. Corsetti et al. (1998) reported that Lact. sanfrancisco CB1 can produce butyric acid, caproic, propionic and valeric acid which actively inhibits the growth of Aspergillus sp., Fusarium sp., Monilia sp., and Penicillium sp. Among these fatty acids, caproic acid was the key compound of the antifungal mixture. Ndagano et al. (2011) detected the presence of the antifungal 2-hydroxy-4-methylpentanoic acid in the culture supernatants of Lact. plantarum VE56 and $W$. paramesenteroides LC11.

\section{Peptides and Protein}

There is no clear explanation of the mechanism of proteins during the inhibition of the fungal growth. Many researchers reported that the antifungal metabolites are sensitive to protease. Initial research conducted by Roy et al. (1996) showed that antifungal supernatants are no longer able to inhibit fungi after being treated with protease. One year later Gourama and Bullerman (1997) also found something similar, the ability of culture supernatants from Lact. casei ssp. pseudoplantarum was decreased following treatment with trypsin or chymotrypsin. This antifungal protein has a molecular weight less than $1 \mathrm{kDa}$. Corsetti et al. (1998) isolated bacteriocin-like inhibitory substance from Lact. sanfrancisco C57 and found the antimicrobial compounds produced from strains of different species contained a protein moiety and showed varying sensitivity to proteases. Niku-Paavola et al. (1999) found the compound cyclo-(Gly-L-Leu) produced by Lact. plantarum and active against $F$. avenaceum. Antifungal protein compounds were also isolated by Magnusson and Schnurer (2001) from Lact. coryniformis ssp. coryniformis. This active compound has a molecular mass of approximately $3 \mathrm{kDa}$. In 2002, Ström et al. reported the first isolation of cyclic (Phe-Pro) and cyclic (Phe-trans-4-OH-Pro) from Lact. plantarum MiLAB 393, their chemical structures were composed ofboth $L$ and D forms, in a 9/1 ratio. The following year Magnusson et al. (2003) found a cyclic dipeptide produced by Lact. coryniformis, i.e., cyclic (Phe-Pro) and cyclo (Phe- 4-OH-Pro).

Coloretti et al. (2007) found that the antifungal compounds of lactobacilli culture from salami is sensitive to proteinase K. Coda et al. (2008) identified eight peptide mixtures from the water-soluble extract of sourdough Lact. brevis AM7, and five of these exhibited inhibitory activity with the range of MICs of 3.5 to $8.2 \mathrm{mg} / \mathrm{mL}$ against Aspergillus and Penicillium. Roy et al. (2009) isolated an antifungal protein with molecular mass of $11 \mathrm{kDa}$ from En. faecalis CHD 
28.3 using ultrafiltration and chromatographic techniques. Recent research from Muhialdin et al. (2015a) reported that five peptides from Leuconostoc mesenteroides are able to inhibit the growth of A. niger. Antifungal peptides have also been purified from MRS medium culture supernatant of Lact. plantarum IS10 strain. Most research suggests that antifungal peptides and proteins are purified from culture supernatants of Lact. plantarum.

\section{Hydrogen Peroxide}

Lactic acid bacteria have flavoprotein oxidases capable of producing hydrogen peroxide $\left(\mathrm{H}_{2} \mathrm{O}_{2}\right)$ in the presence of oxygen. The formation of hidrogen peroxide is catalyzed by a very active cytoplasmic flavoprotein (FAD) NADH oxidase which remove excess electrons from NADH thus competing with lactate dehydrogenase for available NADH (formed during glucose breakdown) (Condon, 1987). Antimicrobial effect due to the production of hydrogen peroxide led to hyperbaric oxygen toxicity, peroxidation of membrane lipids, and a strong oxidizing effect on the cells, which cause the destruction of basic molecular structures, such as nucleic acids and cell proteins (Dahl et al., 1989). Hydrogen peroxide can also react with another compound showing antimicrobial effects known as lactoperoxidase system (LP System). Raw milk thiocyanate at concentrations of 1-10 $\mathrm{mg} / \mathrm{L}$ is oxidized producing antibacterial hypothiocyanite compounds by the enzyme lactoperoxidase in the presence of hydrogen peroxide at a concentration of about $10 \mathrm{mmol} / \mathrm{L}$ (Reiter and Harnulv, 1984; Condon, 1987; Schnurer and Magnusson, 2005). Hypothiocyanite is an antimicrobial compound which is lethal or inhibitory to microorganisms. Venturini et al. (2002) studied in vitro antimicrobial activity and the MIC (minimum inhibitory concentration) of hydrogen peroxide activity against $P$. expansum using agar diffusion method, volatility and agar method. The effectiveness of 5 and $10 \%$ hydrogen peroxide on growth inhibition of $P$. expansum in the agar diffusion assay was total, and its MIC as determined by the agar and broth dilution assays was less than $0.025 \%$.

\section{Reuterin}

Reuterin produced by Lact. reuterii is part of the human and animal dygestive system. Its molecular weight is less than $200 \mathrm{Da}$ and is resistant to protease activity. Reuterin is an equilibrium mixture of monomeric, hydrated monomeric, and cyclic dimeric $\beta$-hydroxypropionaldehyde formed during anaerobic metabolism of glycerol and glyceraldehyde (Talarico et al., 1988; Talarico and Dobrogrosz, 1989). Reuterin is a broad-spectrum antimicrobiotic that is effective primarily against Gram-negative bacteria, yeast, molds, protozoa and viruses. It can inhibit the growth of Aspergillus spp. and Fusarium spp. (Axelsson et al., 1989). This compound inhibits sulfhydryl enzymes such as ribonucleotide reductase, an enzyme involved in DNA biosynthesis (Talarico and Dobrogosz, 1989). 


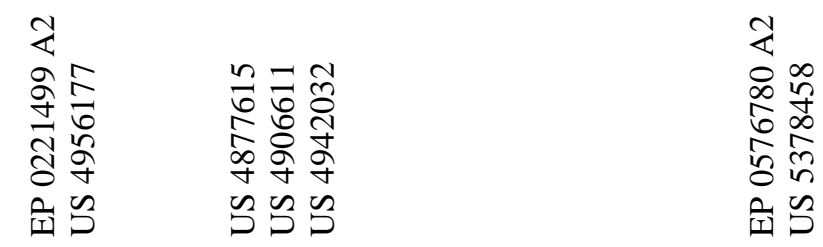

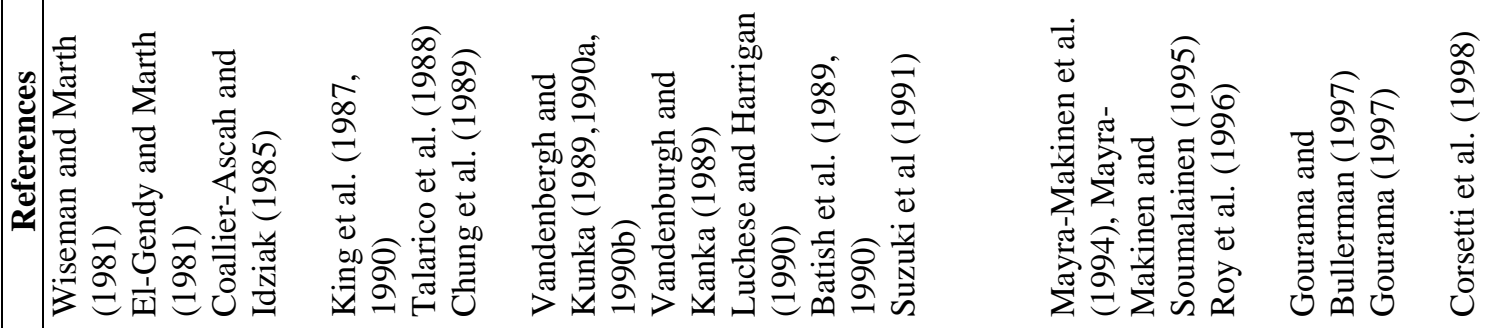

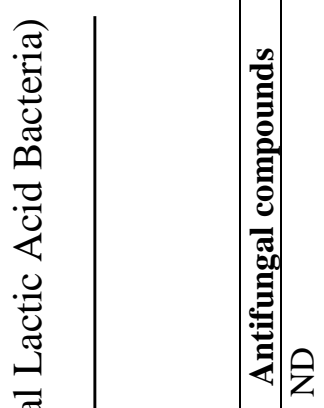

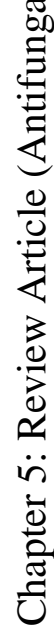
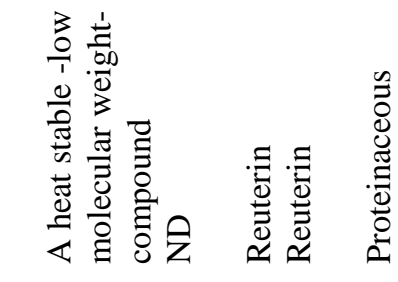

咅会会会

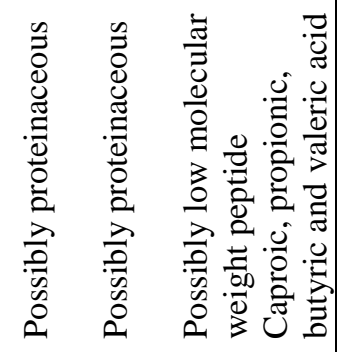

它

.

.
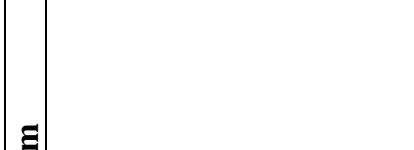

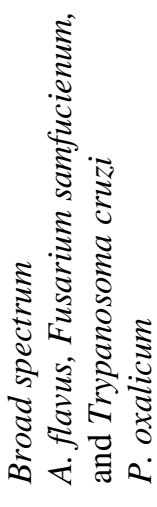

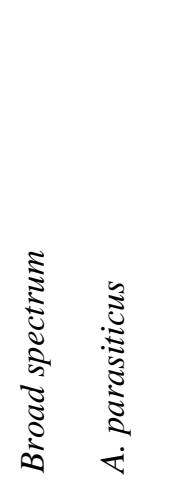

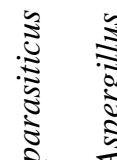

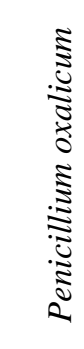

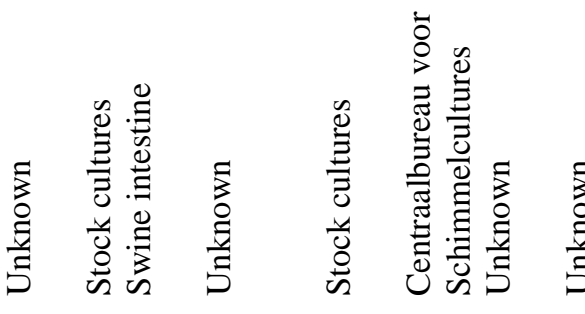

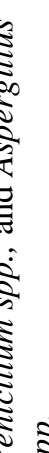

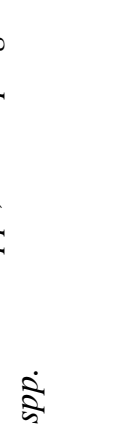

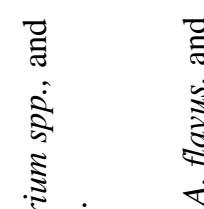

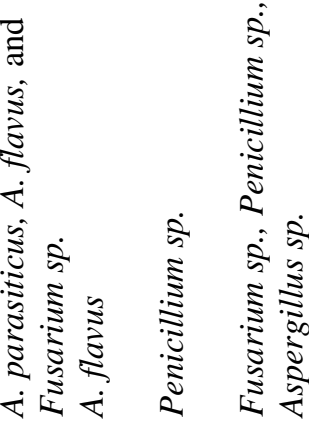

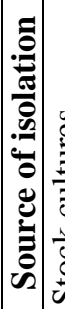

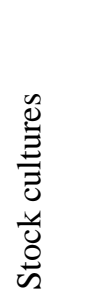

葛

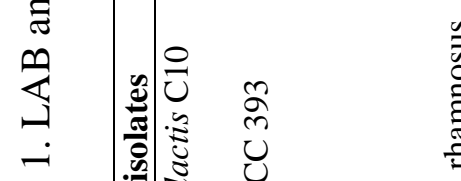

$\frac{2}{2}$

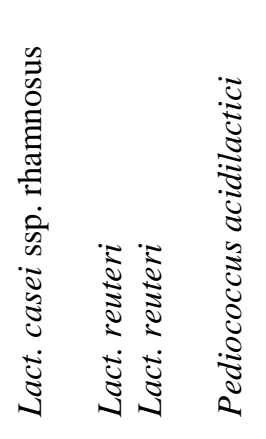

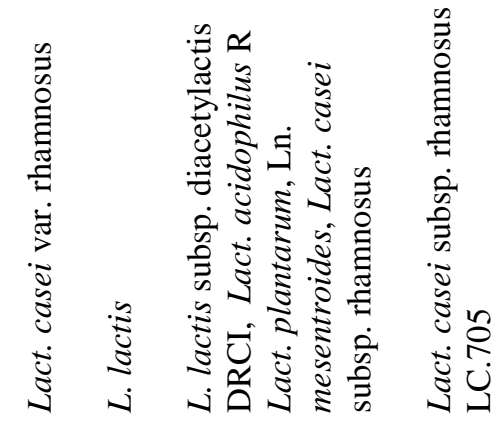

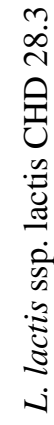

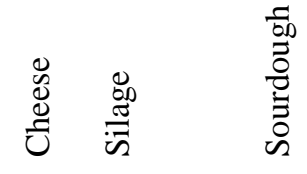

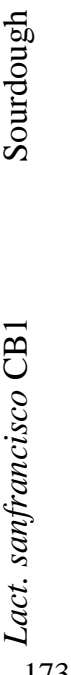




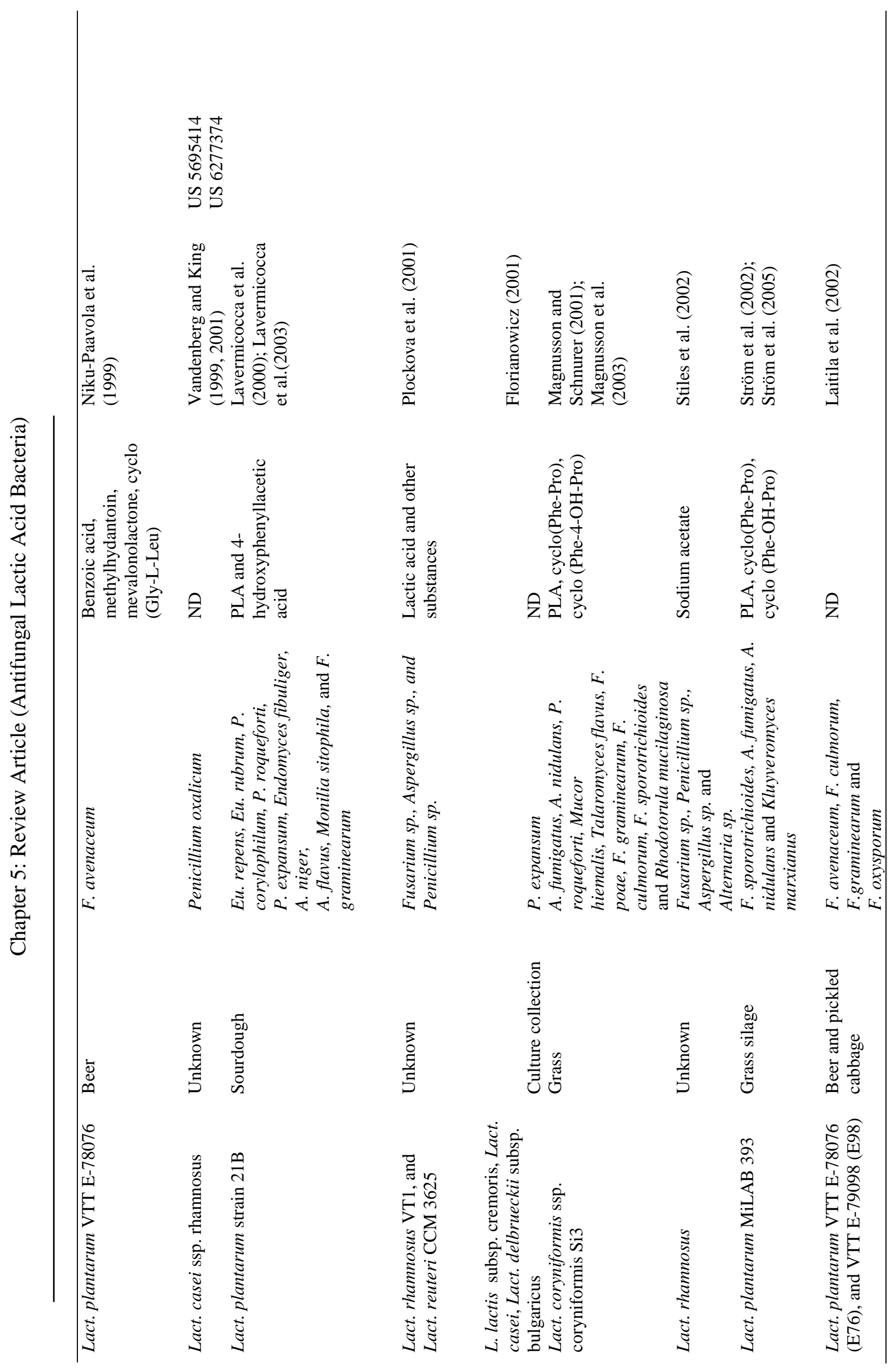




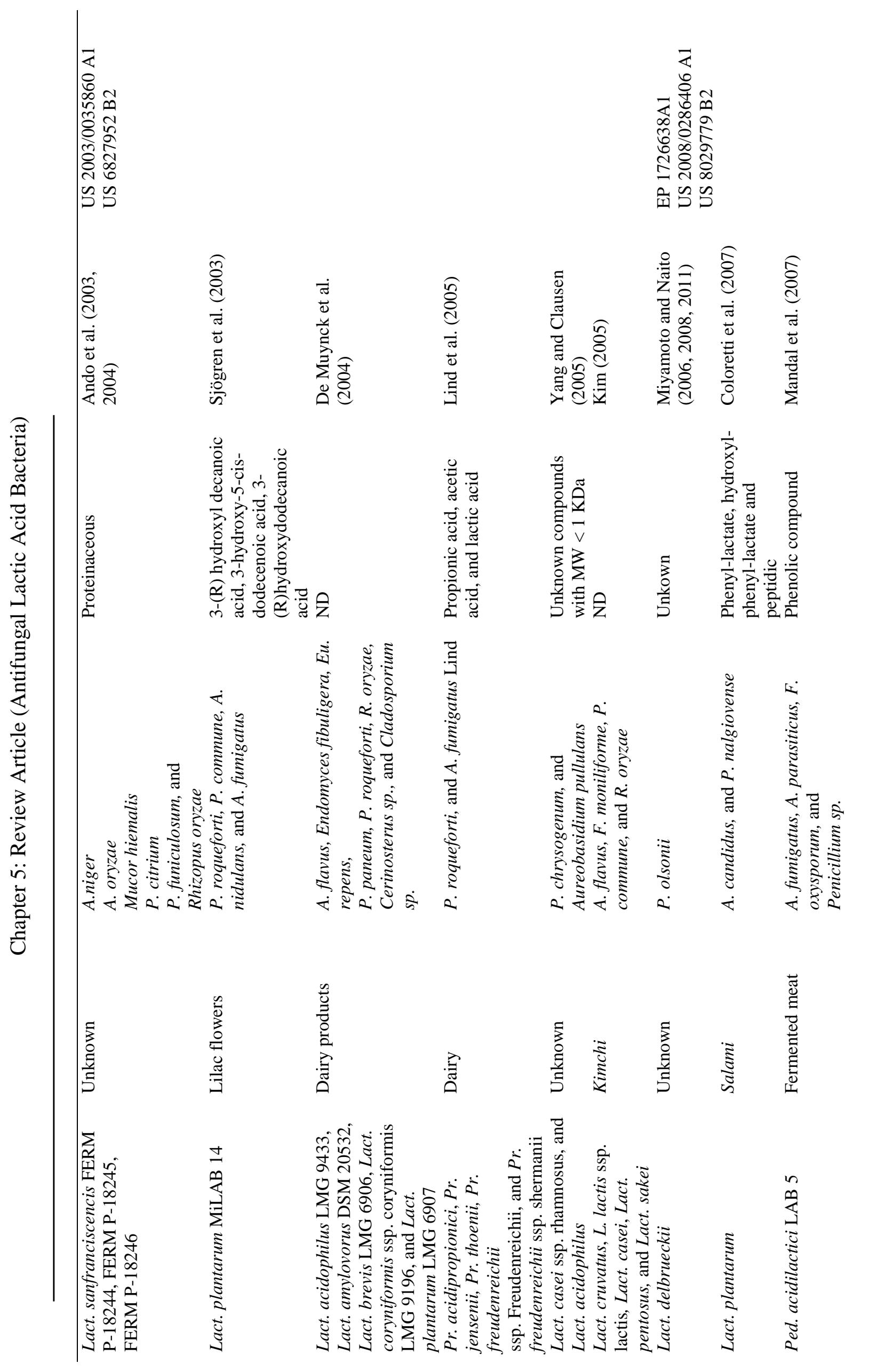




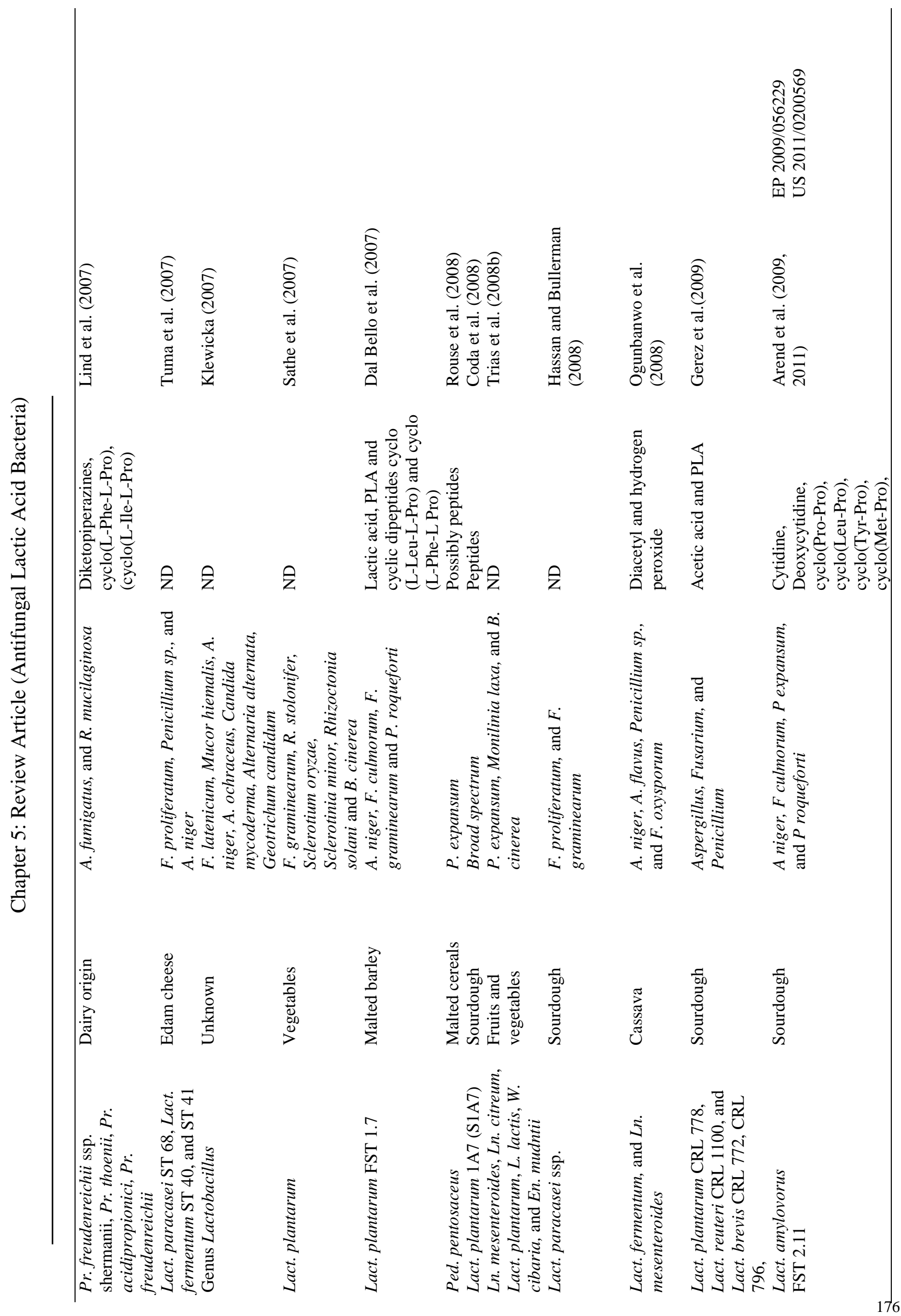




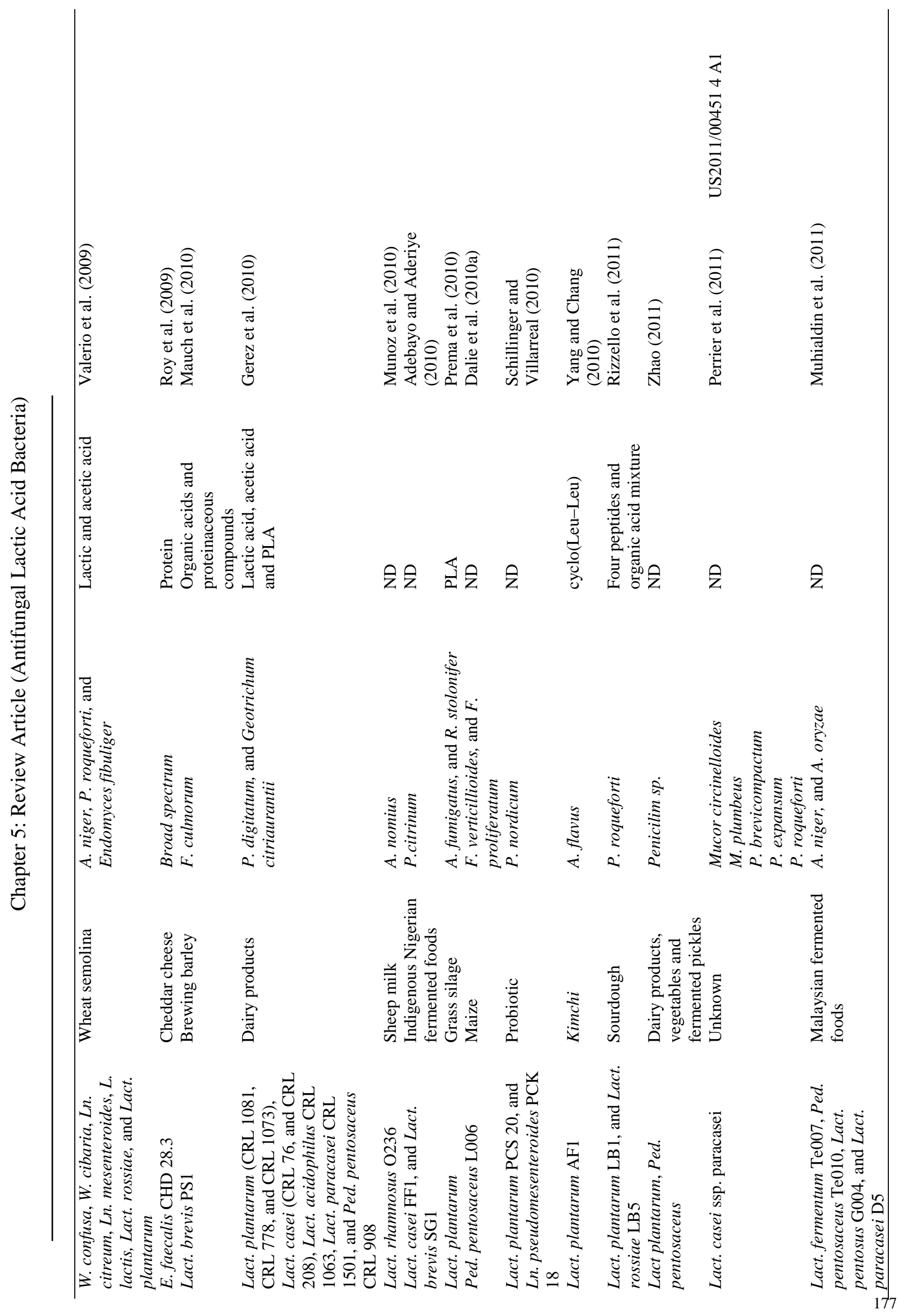




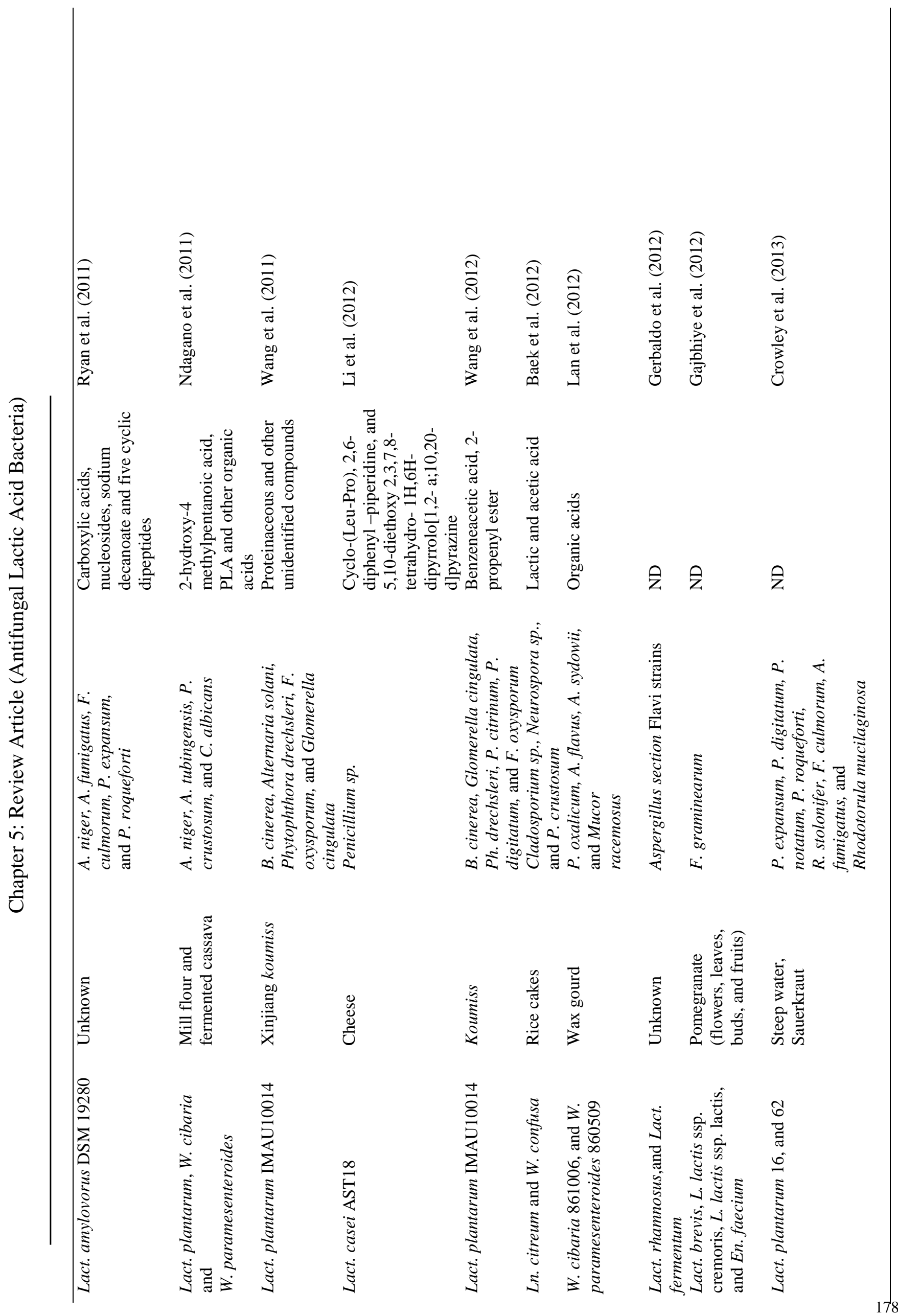




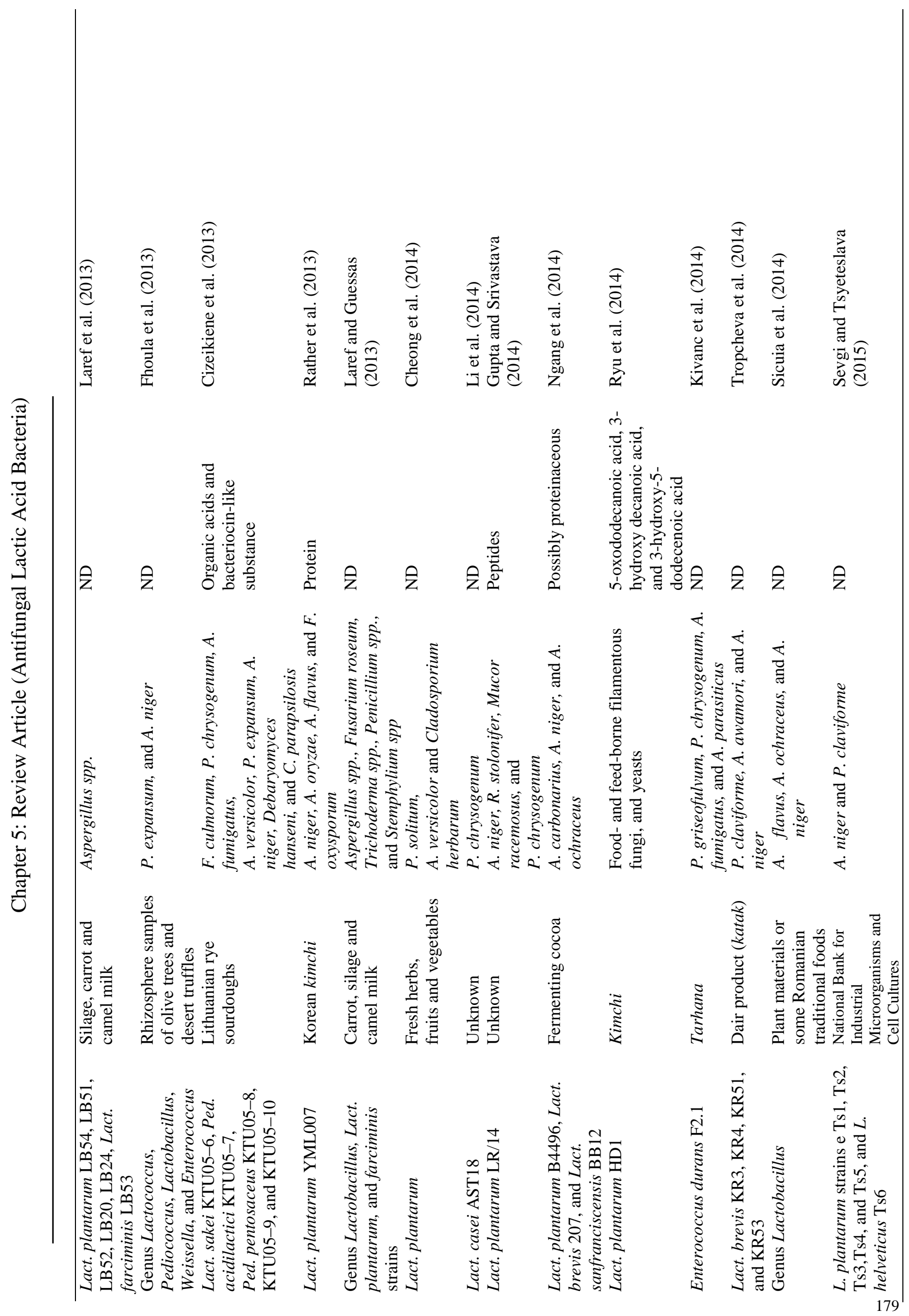




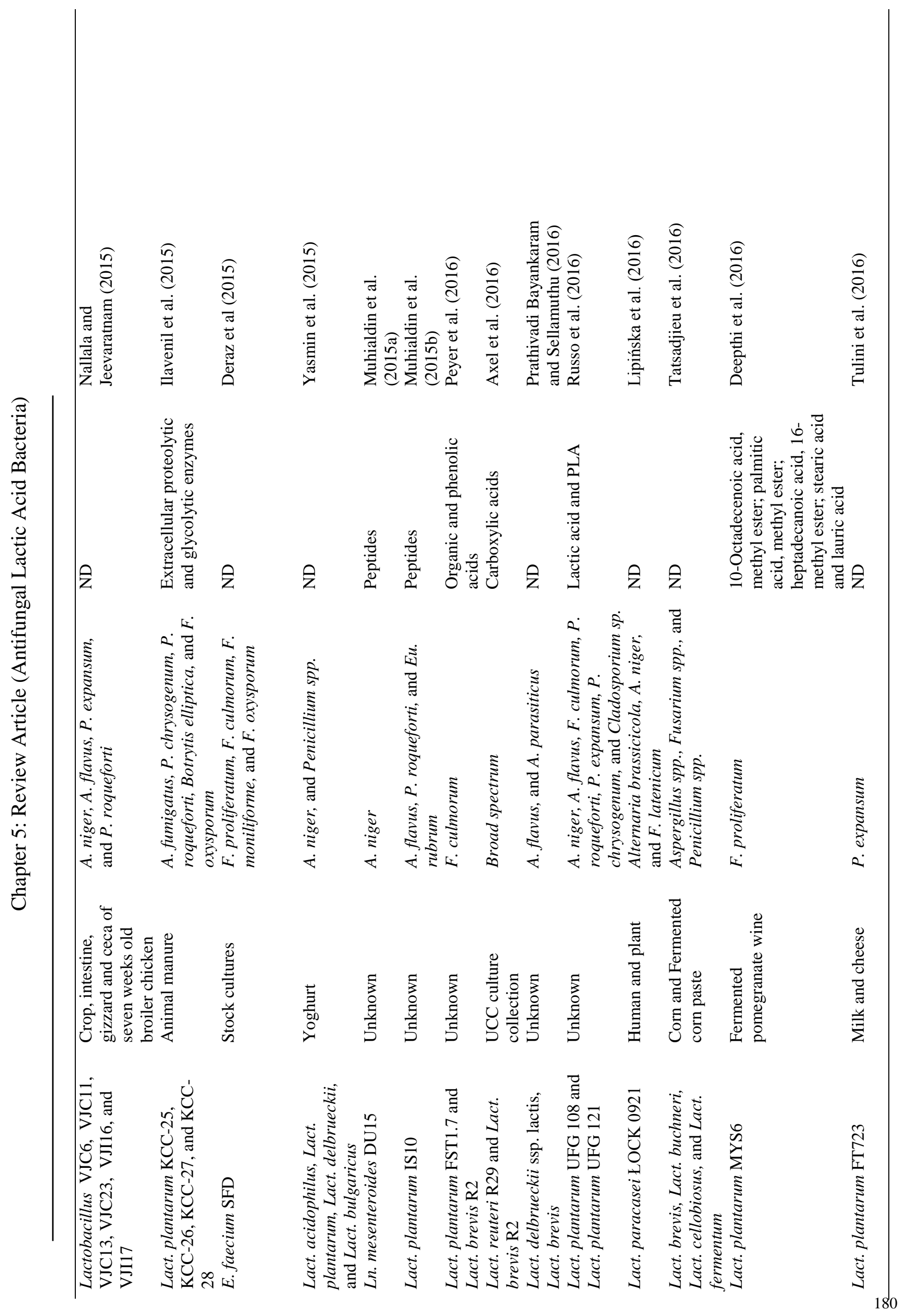




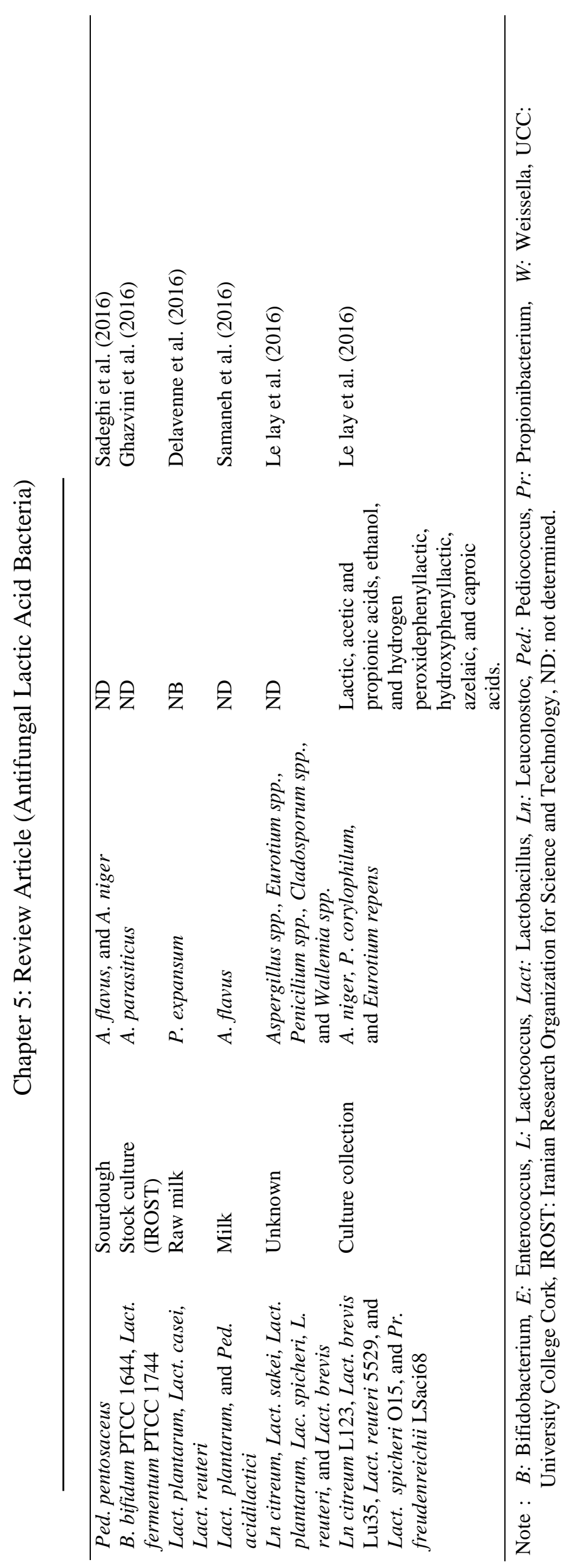


<smiles>CCCCCC(=O)O</smiles><smiles>O=C(O)C(O)Cc1ccccc1</smiles><smiles>O=C1C2CCCN2C(=O)C2CCCN12</smiles><smiles>CC1(O)CCOC(=O)C1</smiles><smiles>CCCCCC(=O)O[Na]</smiles><smiles>CC(=O)O</smiles><smiles>CCCC(=O)O</smiles><smiles>CCCCC(=O)O</smiles><smiles>C[C@H](O)C(=O)O</smiles><smiles>O=C(O)c1ccccc1</smiles><smiles>C=Cc1ccc(O)cc1</smiles><smiles>CN1CC(=O)NC1=O</smiles><smiles>CC(=O)O[Na]</smiles><smiles>CC(=O)OOC(C)=O</smiles><smiles>O=C(O)Cc1ccccc1</smiles><smiles>OO</smiles><smiles>O=C(O)Cc1ccc(O)cc1</smiles><smiles>O=CCCO</smiles><smiles>CCCCCCCC(=O)CCCC(=O)O</smiles><smiles>CCCCCCC[C@H](O)CC(=O)O</smiles><smiles>CCCCCCCCC[C@H](O)CC(=O)O</smiles><smiles>CCCCCCCCCCC[C@H](O)CC(=O)O</smiles><smiles>CC(C)CC(O)C(=O)O</smiles> 
<smiles>c1ccc([C@@H]2CCC[C@@H](c3ccccc3)N2)cc1</smiles><smiles>O=C1N[C@H](Cc2ccccc2)C(=O)N2CCC[C@H]12</smiles><smiles>CCCCCC/C=C\C[C@H](O)CC(=O)O</smiles><smiles>O=C1N[C@@H](Cc2ccccc2)C(=O)N2[CH][C@H](O)C[C@H]12</smiles><smiles>CCOC1=C2CCCN2C(OCC)=C2CCCN21</smiles><smiles>O=C1[C@H](Cc2ccccc2)NC(=O)N2CCC[C@H]12</smiles><smiles>CC(C)C[C@@H]1NC(=O)[C@H]2CCCN2C1=O</smiles><smiles>CCC(C)C1NC(=O)C2CCCN2C1=O</smiles><smiles>CC(C)C[C@H]1NC(=O)CNC1=O</smiles><smiles>CC(C)CC1NC(=O)C(CC(C)C)NC1=O</smiles> 
<smiles>O=C(O)Cc1ccc(O)cc1</smiles><smiles>C[C@]12CCCN1C(=O)[C@H](Cc1ccc(O)cc1)NC2=O</smiles><smiles>O=C1NC(Cc2c[nH]cn2)C(=O)N2CCCC12</smiles><smiles>O=C(O)CCCCCCCC(=O)O</smiles><smiles>CCCCCCCCCCCC(=O)O</smiles><smiles>CCCCCCCCCCCCCCCCCC(=O)O</smiles><smiles>CC(O)C(=O)Oc1ccccc1</smiles><smiles>CSCC[C@@H]1NC(=O)[C@@H]2CCCN2C1=O</smiles><smiles>NC1=NC(=O)N([C@@H]2O[C@H](CO)C(O)C2O)CC1</smiles><smiles>CCCCCCCCCCCCCCCCC(=O)O</smiles><smiles>CCCCCCC/C=C/CCCCCCCCC(=O)O</smiles><smiles>CCCCCCCCCCCCCCCC(=O)O</smiles>

Figure 3. Broad spectrum of antifungal metabolites produced by LAB.

1) propionic acid, 2) caproic acid, 3) phenyllactic acid, 4) cyclo (Pro-Pro), 5) mevalonolactone, 6) sodiumdecanoate, 7) acetic acid, 8) butyric acid, 9) valeric acid, 10) lactic acid, 11) benzoic acid, 12) 4vinyl phenol, 13) 1-methylhydantoin, 14) sodium acetate, 15) diacetyl peroxide, 16) benzeneacetic acid, 17) hydrogen peroxide, 18) 2-propenyl ester, 19) phenylacetic acid, 20) reuterin, 21) 5-oxododecanoic acid, 22) 3-hydroxydecanoic acid, 23) 3-hydroxydodecanoic acid, 24) 3-hydroxytetradecanoic acid, 25) 2hydroxy-4-methylpentanoic acid, 26) 2,6 diphenyl piperidine, 27) cyclo (Phe-Pro), 28) 3-hydroxy-5dodecanoic acid, 29) cyclo (Phe-4-OH-Pro), 30) 5,10-diethoxy-2,3,7,8-tetrahydro-1H, 31) cyclo (Phe-Pro), 32) cyclo (Leu-Pro), 33) cyclo (Leu-Leu), 34) cyclo (Ile-Pro), 35) diketopiperazines, 36) cyclo (Gly-Leu), 37) 4-hydroxyphenyllacetic acid, 38) cyclo(His-Pro), 39) cyclo(Tyr-Pro), 40) azelaic acid, 41) lauric acid , 42) stearic acid , 43) phenyl-lactate, 44) deoxycytidine, 45) cyclo(Met-Pro), 46) cytidine, 47) heptadecanoic acid, 48) 10-octadecenoic acid, 49) palmitic acid. 


\section{Genetic Engineering to Improve LAB Antifungal Properties}

The biosynthesis of some LAB compounds have been improved by means of genetic engineering. Genome shuffling, recombinant DNA technology and whole cells transformation using LAB vectors are some of the methods used to increase the yield and the purity of LABcompounds. In Table 2 some of the methods are partially described for the most important LAB: Lact. helveticus, Lact. lactis, Lact. pentosus, Lact. plantarum, Lact. rhamnosus and L. lactis.

Research on LAB genetic engineering focus mainly on the production of LA foruse as either a food additive (bio-preservatives) or as a bio based-chemical compound useful in chemistry, pharmacy and agriculture (Gaffoor et al., 2005; Dusselier et al., 2013; Hayek and Ibrahim 2013; Ghaffar et al.,2014; Dedenaro et al., 2016). It is important to highlight the great contribution that the latter is generating in the area of LAB genetic engineering, some methods generated for this purpose could be useful for the improvement of LAB antifungal strains foruse in the food industry. Examples of this bio-based chemical contribution are the heterologous expression of xylose assimilation-related genes in Lact. plantarum to produce cost effective D-LA ( Zhang et al., 2016) and the integration of LA biosynthesis-related genes in yeast (Ilmén et al., 2013) or in cyanobacteria (Angermayr et al., 2012) to improve LA production.

Although most of the research focus is on LA, some attempts have been made to improve PLA production. Using genome shuffling, Wang et al. (2013), produced a modified Lact. plantarum strain which can produce both, LA and PLA, showing an increase in antifungal activity compared to the wild-type. Zheng et al. (2015) increased PLA purity and yields by heterologous expression of $l d h L$ and formate dehydrogenase genes from Bacillus coagulans in E. coli and, similarly, Zhu et al. (2015) increased PLA yields in E. coli using the gene ldhD from Lact. pentosus.

Genetic engineering methods generated for LA and PLA production could also be used to improve other LAB antifungal compounds listed in the present review. However, knowledge of the biosynthetic pathway is necessary for most purposes and, up to now, it is only available for a few antifungal compounds. Genome sequence information present will help to increase the use of genetic engineering tools to expand these applications in this area. Many LAB genomes have been already sequenced (Klaenhammer and Dairy, 2002; Makarova et al., 2006; Wegmann et al., 2007), and the genes involved in the biosynthetic pathway of reutericyclin were described recently by Lin et al. (2015), while the gene cluster of nisin was described in 1993 (Kuipers et al., 1993).

Genome shuffling is an interesting method to improve LAB antifungal characteristics and does not require genome information. This method is based on the induction of genetic diversity (by mutagenesis for example), followed by recombination of the selected strains. This is repeated several times until there is a useful set of mutations in the population (Biot-Pelletier and Martin, 2014). For example, after chemical or physical mutagenesis, bacteria showing the highest antifungal activity can be selected and can be used for further recombination by protoplast fusion using another starter bacteria which exhibits a better growth rate, low $\mathrm{pH}$ tolerance, etc. In this way, the creation of a bacterial population showing an improved antifungal activity can be obtained. Using this method, Patnaik et al. (2002) improved the LA production in Lactobacillus 
sp. and Wang et al. (2013) increased the antifungal activity by up to $200 \%$ after three rounds of genome shuffling in Lact. Plantarum, mainly against Penicillium digitatum and P. citrinum.

Once the biosynthetic pathway is known then other methods could be used. The yield and the purity of LA were improved in E. coli by blocking the synthesis of ethanol, acetate, formate, and succinate thus redirecting the pathway to the desired LA route (Mazumdar et al. 2010; Chen et al. 2014). By homologous recombination, Jia et al. (2011) disrupted ldhL gene and integrated ldhD gene into Corynebacterium glutamicum genome to increase the purity of D(-)-LA. While Angermayr et al. (2012) integrated $l d h L$ gene from Bacillus subtilis into a cyanobacteria genome (Synechocystis sp.) to improve the yield of L(+)-LA. Another promising method is LAB whole cells transformation using constructed shuttle vectors that carry the desired genes. Those expression vectors have all machinery to allow gene expression, they are easily transformed, have to be cryptic (no effect in host phenotype) and stable in LAB (Landete, 2016). Some promising vectors have been constructed for LAB, such as pUL6erm, pLC494, pGID052, pRS4, pAMb1, pEL5.6, pEL5.7, pCU and pWV01 (Pérez-Arellano et al., 2001; Beltramo et al., 2004; Alegre et al., 2005; An and Miyamoto, 2006; Okano et al., 2007; Chang and Yan, 2014; Chen et al., 2014). Using a $p C U$ vector carrying the $x y l R A B$ genes for xylose assimilation, Shinkawa et al., (2011) improved the purity and yield of L(+)-LA from xylose.

Table 2. Description of some LAB genetic engineering methods.

\begin{tabular}{|c|c|c|c|c|}
\hline LAB & Compound & Improvement* & Method & Reference \\
\hline $\begin{array}{l}\text { Lact. } \\
\text { helveticus }\end{array}$ & $\mathrm{L}(+)-\mathrm{LA}$ & $\begin{array}{c}\text { Increase in L-LDH activity } \\
\text { (53 to } 93 \%) \text { and LA yield } \\
(76.2-91.6 \%)\end{array}$ & $\begin{array}{c}\text { Removal of promoter in } l d h D \text { gene to } \\
\text { increase } \mathrm{L}(+)-\mathrm{LA} \text { production. } \\
\text { Replacement of } l d h D \text { with an additional } \\
\text { copy of } l d h L .\end{array}$ & $\begin{array}{l}\text { Kylä-Nikkilä et al. } \\
(2000)\end{array}$ \\
\hline $\begin{array}{l}\text { Lactobacillus } \\
\text { sp. }\end{array}$ & LA & $\begin{array}{l}\text { Acid tolerance (3-fold LA } \\
\text { increase at } \mathrm{pH} 4)\end{array}$ & $\begin{array}{l}\text { Genome shuffling: Selection of a } \\
\text { population with } \mathrm{pH} \text { tolerance and } \\
\text { protoplast fusion with a poorly } \\
\text { characterize Lactobacillus } \mathrm{sp} \text {. }\end{array}$ & $\begin{array}{l}\text { Patnaik et al. } \\
\qquad(2002)\end{array}$ \\
\hline $\begin{array}{l}\text { Lact. } \\
\text { rhamnosus }\end{array}$ & LA & $\begin{array}{c}\text { Acid tolerance (2.6 and } \\
3.1 \text { fold increase at } \mathrm{pH} 3.8)\end{array}$ & $\begin{array}{c}\text { Genome shuffling: UV or } \\
\text { nitrosoguanidine as mutagens, selection } \\
\text { and protoplast fusion }\end{array}$ & Wang et al. (2007) \\
\hline $\begin{array}{l}\text { Lact. } \\
\text { rhamnosus }\end{array}$ & $\mathrm{L}(+)-\mathrm{LA}$ & Increase yield $(70 \%)$ & $\begin{array}{c}\text { Genome shuffling: UV or } \\
\text { nitrosoguanidine as mutagens, selection } \\
\text { and protoplast fusion }\end{array}$ & Yu et al. (2008) \\
\hline $\begin{array}{l}\text { Sporolactobac } \\
\text { illus inulinus }\end{array}$ & $\mathrm{D}(-)-\mathrm{LA}$ & $\begin{array}{l}\text { Acid tolerance }(119 \% \text { D- } \\
\text { LA increase at } \mathrm{pH} 5)\end{array}$ & $\begin{array}{l}\text { Genome shuffling: UV and diethyl } \\
\text { sulphate as mutagens, } \mathrm{pH} \text { gradient filter, } \\
\text { selection and protoplast fusion }\end{array}$ & Zheng et al. (2010) \\
\hline L. lactis & LA & $\begin{array}{l}\text { Acid tolerance (5-10-fold } \\
\text { survival increase at } \mathrm{pH} 3)\end{array}$ & $\begin{array}{l}\text { Increase in trehalose production using a } \\
\text { plasmid carrying trePP and } p g m B \text { genes } \\
\text { from } L \text {. lactis (trehalose operon) and the } \\
\text { ots } B \text { gene from } P \text {. freudenreichii }\end{array}$ & $\begin{array}{l}\text { Carvalho et al. } \\
\qquad(2011)\end{array}$ \\
\hline L. lactis & LA & $\begin{array}{l}\text { Increase in glucose uptake } \\
\text { and LA production }\end{array}$ & $\begin{array}{c}\text { Expression of gene encoding } \\
\text { phosphofructokinase ( } p f k A) \text { from } \\
\text { Aspergillus niger using recombinant } \\
\text { DNA technology }\end{array}$ & $\begin{array}{l}\text { Papagianni and } \\
\text { Avramidis (2011) }\end{array}$ \\
\hline
\end{tabular}




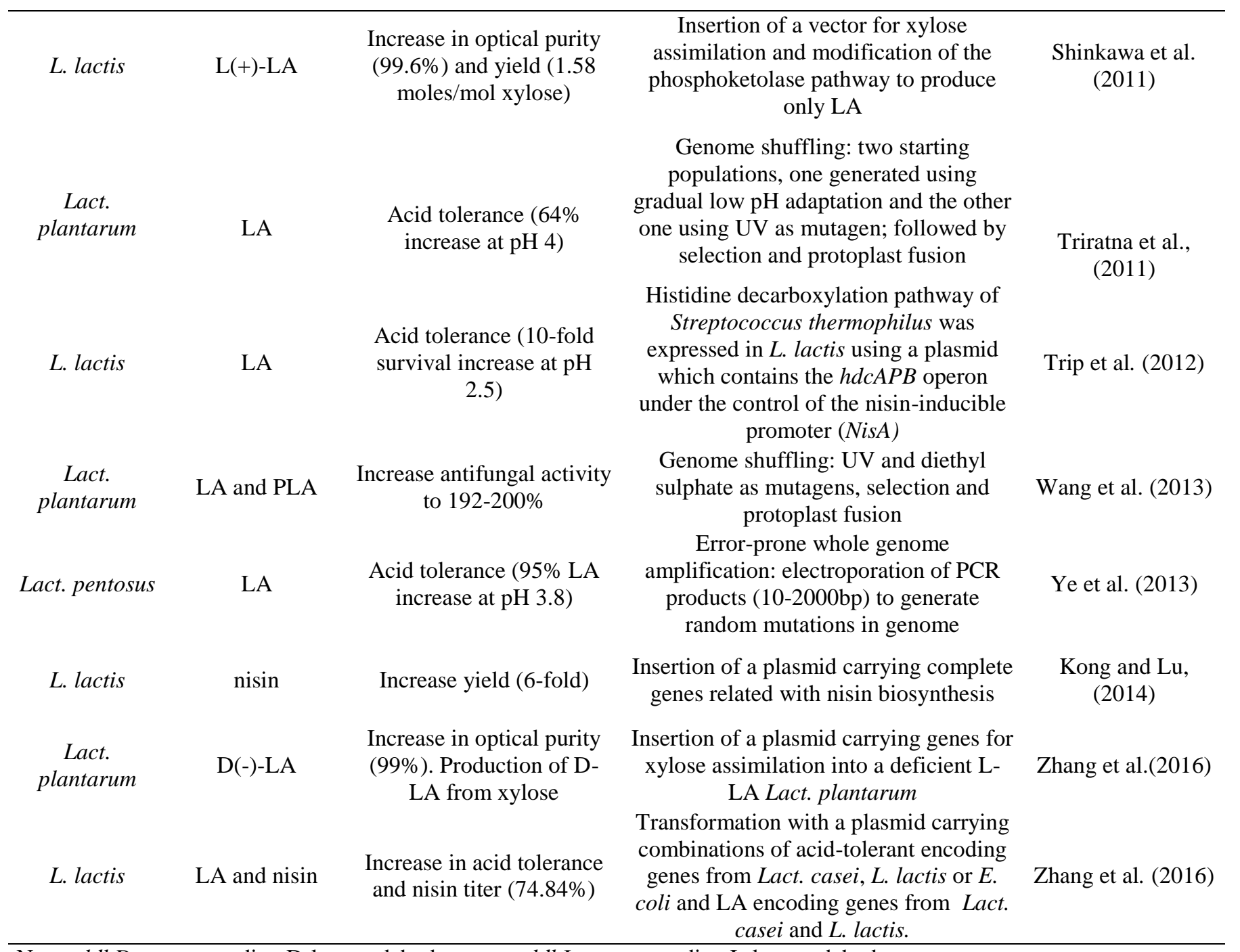

Notes: $l d h D$ : gene encoding D-lactate dehydrogenase. $l d h L$ : gene encoding L-lactate dehydrogenase.

*increase is always compared to the wild type.

In addition to the methods already mentioned and described briefly in Table 2, specific controlled gene expression systems can be used to improve the antifungal production. A good example could be the nisin-induced controlled gene expression system (NICE) derived from the L. lactis nis operon. In this system the induction of a gene of interest is achieved by inserting the genes involved in nisin signal transduction (nisRK) into a bacterial plasmid or the chromosome, and the inducible gene PnisA is carried on a plasmid upstream of the gene of interest, the addition of a certain amount of nisin will activate or inactivate the transcription of the gene (Kuipers et al. 1998). This system has two big advantages, one is that the concentration of the compound of interest can be regulated based on the amount of nisin added and NICE can also be used to control the whole operon which makes it useful for complex metabolic pathways (Boels et al., 2004; Mierau and Kleerebezem, 2005). Using the NICE system Trip et al. (2012) increased the acid tolerance of L. lactis by expressing the $h d c A P B$ operon for the histidine decarboxylation pathway. 
Other systems based on specific controlled gene expression are already available (Axelsson et al., 2003; Hickey et al., 2003; Mathiesen et al., 2004; Miyoshi et al., 2004; Linares et al., 2015).

One of the main challenges to increase the production of compounds by LAB is the $\mathrm{pH}$ range in which the bacteria, in spite of its metabolic activity (which causes $\mathrm{pH}$ decrease), can continue growing. Some research has been already done to increase LAB acid tolerance. Using genome shuffling, the ability of several Lactobacillus sp. to grow at low $\mathrm{pH}$ was enhanced, thus the production of LA was improved (Patnaik et al., 2002; Wang et al., 2007; Zheng et al., 2010; Triratna et al., 2011). The acid tolerance of Lact. pentosus was also enhanced by error-prone whole PCR amplification (Ye et al., 2013), while L. lactis was modified for the same purpose by heterologous expression of genes related with histidine decarboxylation (Trip et al., 2012), trehalose production (Carvalho et al., 2011) and acid-tolerance ( Zhang et al., 2016).

Based on the fact that LAB antifungal activity is usually attributed to more than one compound, techniques such as genome shuffling, in which several traits can be improved in the same strain, is a promising method to ensure good results. However, the stability of the improved traits after several generations must be taken into account. Methods including DNA modifications such as gene replacement, insertions and disruptions to redirect pathways are promising. However, the use of genetically modified LAB as a food additive is always of debate. On the other hand, food-grade shuttle expression vectors could be an interesting way to express desired antifungalrelated genes in LAB for use in the food industry and does not involve genome modifications. Moreover, improved LAB antifungal producers could be obtained using a combination of techniques, for example, an acid-tolerant LAB generated using genome shuffling, can be used further as a host strain for expression vectors including genes related to fungistatic agents produced by other bacteria, such as benzoic or propionic acids.

Regardless of the method, genetic engineering to improve the production of antifungal compounds by LAB could help to reduce the risk of fungal-mycotoxins food contamination and therefore increase food quality. LAB improvements could focus on the large-scale production of promising antifungal compounds in biofabrics for the direct addition into food or the modified bacteria showing enhance antifungal activity could be used directly as a food additive.

\section{Application of Antifungal LAB and Prospect in Food Industry}

Various types of LAB have emerged and been used as natural bio-preservatives on food products because their secondary metabolite substances are innocuous and possess inhibitory effects on harmful bacteria and fungi (Theron and Lues, 2011). In situ testing is essential to substantiate the potential application of these organisms, generally regarded as safe (GRAS) as bio-preservatives against toxigenic fungal and spoilage, as well their sensory and safety aspects.

LAB usage is still limited to the fermentation products, using bacteria strains that have been deemed as safe, for example, LAB has been applied as starter cultures for many years in the brewing industry. The addition of Lact. plantarum VTTE-78076, and Ped. pentosaceus VTTE-90 390 in the soaking water clearly proved that it could inhibit the growth of the fungus Fusarium during brewing, resulting in a potentially limited accumulation of trichothecene (Laitila et al., 
2002). LAB principle application can be seen in the fermentation of wine which controls Penicillium and Aspergillus that can cause ochratoxin contamination. Nevertheless, the introduction of large-scale food biopreservation systems in the food industry requires careful safety assessment including detailed risk analysis. Besides the possible influence of LAB culture and its metabolites towards sensory quality of food products mus talso be taken into account. Indeed, various studies have demonstrated the successful application of LAB alleviates fungal contamination in different foods conferring attributes similar to chemical preservatives substitutes or complements (Table 3).

Gautam and Sharma (2009) define the term bio-preservative:

a. The bio-preservative should not be toxic.

b. It should be accepted by recognized authorities.

c. It should be economical to the industries using it.

d. The product in which the bio-preservative is being used should not be affected by it and should not show any deleterious effect toward the organoleptic properties of that product.

e. The effect of the bio-preservative should be observed at relatively low concentrations.

f. The bio-preservative should be sufficiently stable when stored.

g. It should not have any medicinal use.

Table 3. Application of antifungal LAB in food system.

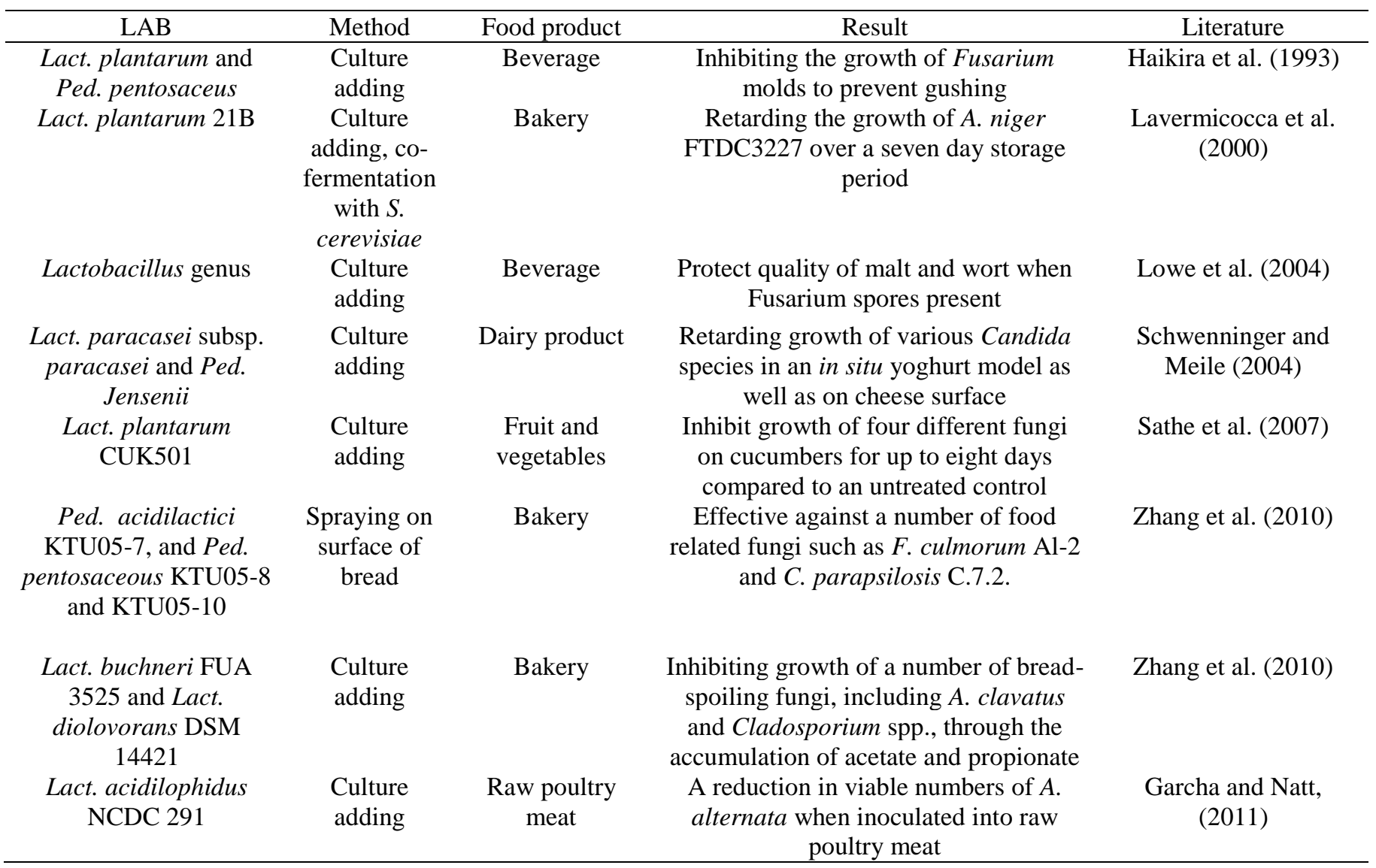




\begin{tabular}{|c|c|c|c|c|}
\hline $\begin{array}{c}\text { Lact. fermentum } \mathrm{Te} 007, \\
\text { Pediococcus } \\
\text { pentosaceus } \mathrm{Te} 010, \\
\text { Lact. pentosus } \mathrm{G} 004, \\
\text { and Lact. paracasei } \mathrm{D} 5\end{array}$ & $\begin{array}{l}\text { Culture } \\
\text { adding }\end{array}$ & Tomato puree & $\begin{array}{l}\text { Demostrating the antagonistic effects } \\
\text { against } A \text {. niger and } A \text {. oryzae }\end{array}$ & $\begin{array}{l}\text { Muhialdin et al. } \\
\text { (2011) }\end{array}$ \\
\hline $\begin{array}{c}\text { Lact. fermentum } \mathrm{Te} 007, \\
\text { Pediococcus } \\
\text { pentosaceus } \mathrm{Te} 010, \\
\text { Lact. pentosus } \mathrm{G} 004, \\
\text { and Lact. paracasei } \mathrm{D} 5\end{array}$ & CFS adding & Dairy product & $\begin{array}{c}\begin{array}{c}\text { Extent shelf-life of cheese slices and } \\
\text { cheese }\end{array}\end{array}$ & $\begin{array}{l}\text { Muhialdin et al. } \\
\qquad(2011)\end{array}$ \\
\hline $\begin{array}{l}\text { Lact. amylovorus DSM } \\
19280\end{array}$ & $\begin{array}{l}\text { Culture } \\
\text { adding }\end{array}$ & Bakery & $\begin{array}{l}\text { Extent shelf-life of wheat bread. } \\
\text { inhibition observed against Aspergillus, } \\
\text { Fusarium and Penicillium molds }\end{array}$ & Ryan et al. (2011) \\
\hline Lact. plantarum isolates & $\begin{array}{l}\text { Culture } \\
\text { adding }\end{array}$ & Dairy product & $\begin{array}{l}\text { Demonstrating anti-mold capabilities } \\
\text { when used as adjuncts during cheddar } \\
\text { cheese production }\end{array}$ & Zhao (2011) \\
\hline $\begin{array}{l}\text { Pediococcus and } \\
\text { Weisella isolates }\end{array}$ & $\begin{array}{l}\text { Culture } \\
\text { adding }\end{array}$ & $\begin{array}{l}\text { Fruit and } \\
\text { vegetables }\end{array}$ & $\begin{array}{l}\text { Penicillium spoilage was delayed on } \\
\text { apples, pears, plums and grapes }\end{array}$ & $\begin{array}{l}\text { Crowley et al. (2012); } \\
\text { Lan et al. (2012); } \\
\text { Rouse et al. (2008) }\end{array}$ \\
\hline $\begin{array}{l}\text { Lact. harbinensis } \\
\text { K.V9.3.1Np, and Lact. } \\
\text { rhamnosus K.C8.3.1I }\end{array}$ & $\begin{array}{l}\text { Culture } \\
\text { adding }\end{array}$ & Dairy product & $\begin{array}{l}\text { Exhibiting protective properties against } \\
\text { a number of fungi including } D \text {. } \\
\text { hansenii and } R \text {. mucilaginosa in } \\
\text { yoghurts, while they did not alter the } \\
\text { growth or acidification rates of the } \\
\text { yoghurt starters, nor did they affect the } \\
\text { pH, lactic or acetic acid levels }\end{array}$ & $\begin{array}{l}\text { Delavenne et al. } \\
\text { (2012). }\end{array}$ \\
\hline $\begin{array}{l}\text { Lact. rossiae LD108 } \\
\text { and Lact. } \\
\text { paralimentarius } \mathrm{PB} 127\end{array}$ & $\begin{array}{l}\text { Culture } \\
\text { adding }\end{array}$ & Bakery & $\begin{array}{l}\text { Preventing growth of } A \text {. japonicus with } \\
\text { shelf lives ranging from 11-32 days as } \\
\text { compared to bread prepared with } \\
\text { baker's yeast dough }\end{array}$ & Garofalo et al. (2012) \\
\hline $\begin{array}{l}\text { Lact. plantarum } \\
\text { IMAU10014 (mutant } \\
\text { strain) }\end{array}$ & CFS adding & $\begin{array}{l}\text { Fruit and } \\
\text { vegetables }\end{array}$ & $\begin{array}{l}\text { Elimination growth of Penicillium } \\
\text { digitatum KM08 on the surface of } \\
\text { kumquats compared to the wild type. }\end{array}$ & Wang et al. (2013) \\
\hline $\begin{array}{l}\text { Lact. plantarum } \\
\text { B.BS08 }\end{array}$ & $\begin{array}{l}\text { Culture } \\
\text { adding }\end{array}$ & Tempeh & $\begin{array}{l}\text { Preventing growth of } F \text {. proliferatum } \\
\text { BJ09.05 }\end{array}$ & $\begin{array}{l}\text { Anggriawan et al. } \\
\text { (unpublished) }\end{array}$ \\
\hline
\end{tabular}

Note: CFS (cell free supernatant)

\section{Future Research Trends}

Efforts to improve quality and food safety by replacing the traditional food preservation system have been increasing during the last decade. One of the most popular methods of food biopreservation is fermentation, a process based on the growth of microorganisms in food, either naturally or with the addition of starters (Ross et al., 2002; Ananouet al., 2007). About 25\% of dietary adjustments menu in Europe and $60 \%$ in many developing countries consists of fermented food (Stiles, 1996; Adebayo et al., 2013). LAB plays a major role in the fermentation process, it can be found in products such as cheese, yogurt, meat and vegetable fermentation, kefir, whey (buttermilk) and bread (Hammeset al., 1990; Caplice and Fitzgerald, 1999; Carr et al., 2002) and they are important for food preservation. Due to the nature of certain specific metabolites, LAB is of interest to the food industry because it can improve the taste, texture and nutritional value of food products (Guldfeldtet al., 2001; Arendt et al., 2007). 
Clearly, as stated in the present review, some LAB have antifungal properties and could potentially be used as safe bio-preservative agents for food processing and also effectively address yeast and mold fermentationsafety issues. However, until now there is no clear standardization of LAB isolation. A standardization process for LAB isolation and purification is indispensable to improve procedures and make them cost-effective. In-depth research on the nature and characteristics of LAB antifungal compounds is necessary before assessing the further potential of LAB antifungal properties.

Future research has to be oriented towards expanding our knowledge of the metabolic pathways of antifungal compounds and their genetic background. Genomic and transcriptomic information will contribute towards better descriptions, but also to determine the molecular targets of the antifungal metabolites, to discover new promising antifungal-related compounds and to improve, the antifungal properties of LAB through genetic engineering. Efforts have already been made to improve antifungal properties using genetic engineering; some methods are feasible and are already available which will facilitate a wider use of this technology in the near future. Undoubtedly, some methods including food-grade shuttle expression vectors carrying the genes of interest and controlled gene expression systems will be taken into account.

\section{Acknowledgement}

This paper was supported financially by Indonesia Endowment Fund for Education, Ministry of Finance, The Republic of Indonesia (Ref:1064/LPDP/2013).

\section{Conflict of Interest}

The authors declare no conflict of interest.

\section{References}

Adebayo, C.O. and Aderiye, B.I., 2010. Antifungal activity of bacteriocins of lactic acid bacteria from some Nigerian fermented foods. Research journal of microbiology, 5(11), pp.1070-1082.

Alegre, M.T., Rodríguez, M.C. and Mesas, J.M., 2005. Nucleotide sequence, structural organization and host range of pRS4, a small cryptic Pediococcus pentosaceus plasmid that contains two cassettes commonly found in other lactic acid bacteria. FEMS microbiology letters, 250(1), pp.151-156.

Amaike, S. and Keller, N.P., 2011. Aspergillus flavus. Annual review of phytopathology, 49, pp.107-133.

An, H.Y. and Miyamoto, T., 2006. Cloning and sequencing of plasmid pLC494 isolated from human intestinal Lactobacillus casei: construction of an Escherichia coli-Lactobacillus shuttle vector. Plasmid, 55(2), pp.128134.

Ando, M., Yoshiaki, S. and Natsuko, N., 2003. Lactic acid bacteria, fermented seasoning liquid containing the same, and a method for producing bread. United States Patent Application US 2003/0035860 A1.

Ando, M., Yoshiaki, S. and Natsuko, N., 2004. Lactic acid bacteria, fermented seasoning liquid containing the same, and a method for producing bread. United States Patent Application US 6827952 B2.

Angermayr, S.A., Paszota, M. and Hellingwerf, K.J., 2012. Engineering a cyanobacterial cell factory for production of lactic acid. Applied and environmental microbiology, 78(19), pp.7098-7106.

Arendt, E.K., Ryan, L.A. and Dal Bello, F., 2007. Impact of sourdough on the texture of bread. Food microbiology, 24(2), pp.165-174.

Arendt, E. K., Dal Bello, F. and Ryan, L.A.M., 2009. Increasing the shelf-life of bakery and patisserie products by using the antifungal Lactobacillus amylovorous DSM 19280. European Patent Application EP 2009/056229. 
Arendt, E. K., Dal Bello, F. and Ryan, L.A.M., 2011. Increasing the shelf-life of bakery and patisserie products by using the antifungal Lactobacillus amylovorous DSM 19280. European Patent Application US 2011/0200569 A1.

Axel, C., Brosnan, B., Zannini, E., Furey, A., Coffey, A. and Arendt, E.K., 2016. Antifungal sourdough lactic acid bacteria as biopreservation tool in quinoa and rice bread. International journal of food microbiology.

Axelsson, L., Lindstad, G. and Naterstad, K., 2003. Development of an inducible gene expression system for Lactobacillus sakei. Letters in applied microbiology, 37(2), pp.115-120.

Baek, E., Kim, H., Choi, H., Yoon, S. and Kim, J., 2012. Antifungal activity of Leuconostoc citreum and Weissella 29onfuse in rice cakes. Journal of microbiology, 50(5), pp.842-848.

Batish, V.K., Grover, S. and Lal, R., 1989. Screening lactic starter cultures for antifungal activity. Cultured dairy products journal.

Belser-Ehrlich, S., Harper, A., Hussey, J. and Hallock, R., 2013. Human and cattle ergotism since 1900: symptoms, outbreaks, and regulations. Toxicology and industrial health, 29(4), pp.307-316.

Beltramo, C., Oraby, M., Bourel, G., Garmyn, D. and Guzzo, J., 2004. A new vector, pGID052, for genetic transfer in Oenococcus oeni. FEMS microbiology letters, 236(1), pp.53-60.

Bhat, R.V. and Miller, J.D., 1991. Mycotoxins and food supply. Food, nutrition and agriculture.

Bhat, R., Rai, R.V. and Karim, A.A., 2010. Mycotoxins in food and feed: present status and future concerns. Comprehensive reviews in food science and food safety, 9(1), pp.57-81.

Biot-Pelletier, D. and Martin, V.J., 2014. Evolutionary engineering by genome shuffling. Applied microbiology and biotechnology, 98(9), pp.3877-3887.

Boels, I.C., Beerthuyzen, M.M., Kosters, M.H., Van Kaauwen, M.P., Kleerebezem, M. and De Vos, W.M., 2004. Identification and functional characterization of the Lactococcus lactis rfb operon, required for dTDPrhamnose biosynthesis. Journal of bacteriology, 186(5), pp.1239-1248.

Bünger, J., Westphal, G., Mönnich, A., Hinnendahl, B., Hallier, E. and Müller, M., 2004. Cytotoxicity of occupationally and environmentally relevant mycotoxins. Toxicology, 202(3), pp.199-211.

Carlile, M.J., Watkinson, S.C. and Gooday, G.W., 2001. The fungi. Gulf Professional Publishing.

Carvalho, A.L., Cardoso, F.S., Bohn, A., Neves, A.R. and Santos, H., 2011. Engineering trehalose synthesis in Lactococcus lactis for improved stress tolerance. Applied and environmental microbiology, 77(12), pp.41894199.

Chang, S.M. and Yan, T.R., 2014. Genetic engineering techniques for lactic acid bacteria: construction of a stable shuttle vector and expression vector for $\beta$-glucuronidase. Biotechnology letters, 36(2), pp.327-335.

Chen, X.Z., Tian, K.M., Niu, D.D., Shen, W., Algasan, G., Singh, S. and Wang, Z.X., 2014. Efficient bioconversion of crude glycerol from biodiesel to optically pure D-lactate by metabolically engineered Escherichia coli. Green chemistry, 16(1), pp.342-350.

Chen, Z., Lin, J., Ma, C., Zhao, S., She, Q. and Liang, Y., 2014. Characterization of pMC11, a plasmid with dual origins of replication isolated from Lactobacillus casei MCJ and construction of shuttle vectors with each replicon. Applied microbiology and biotechnology, 98(13), pp.5977-5989.

Cheong, E.Y., Sandhu, A., Jayabalan, J., Le, T.T.K., Nhiep, N.T., Ho, H.T.M., Zwielehner, J., Bansal, N. and Turner, M.S., 2014. Isolation of lactic acid bacteria with antifungal activity against the common cheese spoilage mould Penicillium commune and their potential as biopreservatives in cheese. Food control, 46, pp.91-97.

Chung, T.C., Axelsson, L., Lindgren, S.E. and Dobrogosz, W.J., 1989. In vitro studies on reuterin synthesis by Lactobacillus reuteri. Microbial ecology in health and disease, 2(2), pp.137-144.

Cizeikiene, D., Juodeikiene, G., Paskevicius, A. and Bartkiene, E., 2013. Antimicrobial activity of lactic acid bacteria against pathogenic and spoilage microorganism isolated from food and their control in wheat bread. Food control, 31(2), pp.539-545

Deraz, S.F., Shehata, M.G. and Khalil, A.A., 2015. Significant industrial properties of Enteriococus faecium SFD as a probiotic and bacteriocin-producing strain. Life science journal, 12(3).

Clarke, C.I., Schober, T.J. and Arendt, E.K., 2002. Effect of single strain and traditional mixed strain starter cultures on rheological properties of wheat dough and on bread quality. Cereal chemistry, 79(5), p.640.

Classen, H.G., Elias, P.S. and Hammes, W.P., 1987. In "Toxikologisch-hygienische Beurteilung von Lebelsmitelinhalts- und -zusatzstoffen sowie bedenklicher Verunreinigungen” (Paul Parey, Ed.). Berlin and Hamburg, Germany.

Coallier-Ascah, J. and Idziak, E.S., 1985. Interaction between Streptococcus lactis and Aspergillus flavus on production of aflatoxin. Applied and environmental microbiology, 49(1), pp.163-167. 
Coda, R., Rizzello, C.G., Nigro, F., De Angelis, M., Arnault, P. and Gobbetti, M., 2008. Long-term fungal inhibitory activity of water-soluble extracts of Phaseolus vulgaris cv. Pinto and sourdough lactic acid bacteria during bread storage. Applied and environmental microbiology, 74(23), pp.7391-7398.

Coloretti, F., Carri, S., Armaforte, E., Chiavari, C., Grazia, L. and Zambonelli, C., 2007. Antifungal activity of lactobacilli isolated from salami. FEMS microbiology letters, 271(2), pp.245-250.

Condon, S., 1987. Responses of lactic acid bacteria to oxygen. FEMS microbiology reviews, 3(3), pp.269-280.

Corsetti, A., Gobbetti, M., Rossi, J. and Damiani, P., 1998. Antimould activity of sourdough lactic acid bacteria: identification of a mixture of organic acids produced by Lactobacillus sanfrancisco CB1. Applied microbiology and biotechnology, 50(2), pp.253-256.

Corsetti, A., Gobbetti, M., De Marco, B., Balestrieri, F., Paoletti, F., Russi, L. and Rossi, J., 2000. Combined effect of sourdough lactic acid bacteria and additives on bread firmness and staling. Journal of agricultural and food chemistry, 48(7), pp.3044-3051.

Crowley, P., Schober, T.J., Clarke, C.I. and Arendt, E.K., 2002. The effect of storage time on textural and crumb grain characteristics of sourdough wheat bread. European food research and technology, 214(6), pp.489-496.

Crowley, S., Mahony, J. and van Sinderen, D., 2013. Broad-spectrum antifungal-producing lactic acid bacteria and their application in fruit models. Folia microbiologica, 58(4), pp.291-299.

Dal Bello, F., Clarke, C.I., Ryan, L.A.M., Ulmer, H., Schober, T.J., Ström, K., Sjögren, J., Van Sinderen, D., Schnürer, J. and Arendt, E.K., 2007. Improvement of the quality and shelf life of wheat bread by fermentation with the antifungal strain Lactobacillus plantarum FST 1.7. Journal of cereal science, 45(3), pp.309-318.

Dalié, D.K.D., Deschamps, A.M. and Richard-Forget, F., 2010. Lactic acid bacteria-Potential for control of mould growth and mycotoxins: A review. Food control, 21(4), pp.370-380.

Davidson, M. P., 2001. Chemical preservatives and natural antimicrobial compounds. In M. P. Doyle, L. R. Beuchat, and I. J. Montville (Eds.), Food microbiology: Fundamentals and frontiers (pp. 385-392). Washington: ASM press.

De Muynck, C., Leroy, A.I., De Maeseneire, S., Arnaut, F., Soetaert, W. and Vandamme, E.J., 2004. Potential of selected lactic acid bacteria to produce food compatible antifungal metabolites. Microbiological research, 159(4), pp.339-346.

Dedenaro, G., Costa, S., Rugiero, I., Pedrini, P. and Tamburini, E., 2016. Valorization of agri-food waste via fermentation: production of 1-lactic acid as a building block for the synthesis of biopolymers. Applied sciences, 6(12), p.379.

Deepthi, B.V., Rao, K.P., Chennapa, G., Naik, M.K., Chandrashekara, K.T. and Sreenivasa, M.Y., 2016. Antifungal attributes of Lactobacillus plantarum MYS6 against fumonisin producing Fusarium proliferatum associated with poultry feeds. PloS one, 11(6), p.e0155122.

Delavenne, E., Mounier, J., Déniel, F., Barbier, G. and Le Blay, G., 2012. Biodiversity of antifungal lactic acid bacteria isolated from raw milk samples from cow, ewe and goat over one-year period. International journal of food microbiology, 155(3), pp.185-190.

Dusselier, M., Van Wouwe, P., Dewaele, A., Makshina, E. and Sels, B.F., 2013. Lactic acid as a platform chemical in the biobased economy: the role of chemocatalysis. Energy \& environmental science, 6(5), pp.1415-1442.

El-Gendy, S.M. and Marth, E.H., 1981. Growth and Aflaxtoxin Production by Aspergillus parasiticus in the Presence of Lactobacillus casei. Journal of food protection, 44(3), pp.211-212.

Fernández, M., Hudson, J.A., Korpela, R. and de los Reyes-Gavilán, C.G., 2015. Impact on human health of microorganisms present in fermented dairy products: an overview. BioMed research international, 5, pp. 113.

Florianowicz, T., 2001. Antifungal activity of some microorganisms against Penicillium expansum. European food research and technology, 212(3), pp.282-286.

Fuchs, R. and Peraica, M., 2005. Ochratoxin A in human kidney diseases. Food additives and contaminants, 22(s1), pp.53-57.

Gaffoor, I., Brown, D.W., Plattner, R., Proctor, R.H., Qi, W. and Trail, F., 2005. Functional analysis of the polyketide synthase genes in the filamentous fungus Gibberella zeae (anamorph Fusarium graminearum). Eukaryotic Cell, 4(11), pp.1926-1933.

Gajbhiye, M., Prakash, D., Jagdale, S., Ahiwale, S., Patil, N. and Kapadnis, B., 2012. Pomegranate borne fungicidal lactic acid bacteria and their biodiversity. Proceedings of the national academy of sciences, India Section B: Biological Sciences, 82(3), pp.413-419.

Gerez, C.L., Carbajo, M.S., Rollan, G., Torres Leal, G. and Font de Valdez, G., 2010. Inhibition of citrus fungal pathogens by using lactic acid bacteria. Journal of food science, 75(6), pp.M354-M359. 
Gerez, C.L., Torino, M.I., Rollán, G. and De Valdez, G.F., 2009. Prevention of bread mould spoilage by using lactic acid bacteria with antifungal properties. Food control, 20(2), pp.144-148.

Gerbaldo, G.A., Barberis, C., Pascual, L., Dalcero, A. and Barberis, L., 2012. Antifungal activity of two Lactobacillus strains with potential probiotic properties. FEMS microbiology letters, 332(1), pp.27-33.

Ghaffar, T., Irshad, M., Anwar, Z., Aqil, T., Zulifqar, Z., Tariq, A., Kamran, M., Ehsan, N. and Mehmood, S., 2014. Recent trends in lactic acid biotechnology: A brief review on production to purification. Journal of radiation research and applied sciences, 7(2), pp.222-229.

Ghazvini, R.D., Kouhsari, E., Zibafar, E., Hashemi, S.J., Amini, A. and Niknejad, F., 2016. Antifungal activity and aflatoxin degradation of Bifidobacterium bifidum and Lactobacillus fermentum against toxigenic Aspergillus parasiticus. The open microbiology journal, 10, p.197.

Gourama, H. and Bullerman, L.B., 1995. Inhibition of growth and aflatoxin production of Aspergillus flavus by Lactobacillus species. Journal of food protection, 58(11), pp.1249-1256.

Gourama, H., 1997. Inhibition of growth and mycotoxin production of Penicillium by Lactobacillus species. LWTFood science and technology, 30(3), pp.279-283.

Gourama, H. and Bullerman, L.B., 1997. Anti-aflatoxigenic activity of Lactobacillus casei pseudoplantarum. International journal of food microbiology, 34(2), pp.131-143.

Gautam, N. and Sharma, N., 2009. Bacteriocin: safest approach to preserve food products. Indian journal of microbiology, 49(3), pp.204-211.

Gupta, R. and Srivastava, S., 2014. Antifungal effect of antimicrobial peptides (AMPs LR14) derived from Lactobacillus plantarum strain LR/14 and their applications in prevention of grain spoilage. Food microbiology, 42, pp.1-7.

Hamid, A.S., Tesfamariam, I.G., Zhang, Y. and Zhang, Z.G., 2013. Aflatoxin B1-induced hepatocellular carcinoma in developing countries: Geographical distribution, mechanism of action and prevention (Review). Oncology letters, 5(4), pp.1087-1092.

Harzallah, D. and Belhadj, H., 2013. Lactic acid bacteria as probiotics: characteristics, selection criteria and role in immunomodulation of human GI muccosal barrier. Lactic acid bacteria-R\&D for food, health and livestock purposes. InTech, Rijeka, Croatia.

Hassan, Y.I. and Bullerman, L.B., 2008. Antifungal activity of Lactobacillus paracasei ssp. Tolerans isolated from a sourdough bread culture. International journal of food microbiology, 121(1), pp.112-115.

Hickey, R.M., Twomey, D.P., Ross, R.P. and Hill, C., 2003. Potential of the enterocin regulatory system to control expression of heterologous genes in Enterococcus. Journal of applied microbiology, 95(2), pp.390-397.

Hofvendahl, K. and Hahn-Hägerdal, B., 2000. Factors affecting the fermentative lactic acid production from renewable resources 1. Enzyme and microbial technology, 26(2), pp.87-107.

Holzapfel, W.H.N. and Wood, B.J., 2012. The genera of lactic acid bacteria (Vol. 2). Springer Science \& Business Media.

Ilmén, M., Koivuranta, K., Ruohonen, L., Rajgarhia, V., Suominen, P. and Penttilä, M., 2013. Production of L-lactic acid by the yeast Candida sonorensis expressing heterologous bacterial and fungal lactate dehydrogenases. Microbial cell factories, 12(1), p.53.

International Agency for Research on Cancer (IARC), 2002. Traditional Herbal Medicines, Some Mycotoxins, Napthalene, and Styrene. Monographs on the Evaluation of Carcinogenic Risks to Humans. IARC, pp. 82171.

Jia, X., Liu, P., Li, S., Li, S. and Wen, J., 2011. D-lactic acid production by a genetically engineered strain Corynebacterium glutamicum. World journal of microbiology and biotechnology, 27(9), pp.2117-2124.

Jiang, Y., Jolly, P.E., Preko, P., Wang, J.S., Ellis, W.O., Phillips, T.D. and Williams, J.H., 2008. Aflatoxin-related immune dysfunction in health and in human immunodeficiency virus disease. Clinical and developmental immunology, 2008.

Jolly, P.E., Shuaib, F.M., Jiang, Y., Preko, P., Baidoo, J., Stiles, J.K., Wang, J.S., Phillips, T.D. and Williams, J.H., 2011. Association of high viral load and abnormal liver function with high aflatoxin B1-albumin adduct levels in HIV-positive Ghanaians: preliminary observations. Food additives \& contaminants: Part A, 28(9), pp.12241234.

Joshi, D.S., Singhvi, M.S., Khire, J.M. and Gokhale, D.V., 2010. Strain improvement of Lactobacillus lactis for Dlactic acid production. Biotechnology letters, 32(4), pp.517-520.

Kim, J.D., 2005. Antifungal activity of lactic acid bacteria isolated from Kimchi against Aspergillus fumigatus. Mycobiology, 33(4), pp.210-214.

King, S. W., Fowler, G. G. and Vandenbergh, P.A., 1987. Method for inhibiting fungi. European Patent Application EP 0221499 A2. 
King, S. W., Fowler, G.G. and Vandenbergh, P.A., 1990. Method for inhibiting fungi. United States Patent Application US 4956177.

Kivanc, M., Kivanc, S.A. and Pektas, S., 2014. Screening of lactic acid bacteria for antifungal activity against fungi. Journal of food processing and technology, 2014.

Klaenhammer, T., Altermann, E., Arigoni, F., Bolotin, A., Breidt, F., Broadbent, J., Cano, R., Chaillou, S., Deutscher, J., Gasson, M. and Van de Guchte, M., 2002. Discovering lactic acid bacteria by genomics. In Lactic Acid Bacteria: Genetics, Metabolism and Applications (pp. 29-58). Springer Netherlands.

Klewicka, E., 2007. Antifungal activity of lactic acid bacteria of genus Lactobacillus sp. in the presence of polyols. Acta alimentaria, 36(4), pp.495-499.

Kong, W. and Lu, T., 2014. Cloning and optimization of a nisin biosynthesis pathway for bacteriocin harvest. ACS synthetic biology, 3(7), pp.439-445.

Kuipers, O.P., Beerthuyzen, M.M., Siezen, R.J. and Vos, W.M., 1993. Characterization of the nisin gene cluster nisABTCIPR of Lactococcus lactis. European journal of biochemistry, 216(1), pp.281-291.

Kuipers, O.P., de Ruyter, P.G., Kleerebezem, M. and de Vos, W.M., 1998. Quorum sensing-controlled gene expression in lactic acid bacteria. Journal of biotechnology, 64(1), pp.15-21.

Kylä-Nikkilä, K., Hujanen, M., Leisola, M. and Palva, A., 2000. Metabolic engineering of Lactobacillus helveticus CNRZ32 for production of purel-(+)-lactic acid. Applied and environmental microbiology, 66(9), pp.38353841.

Laitila, A., Alakomi, H.L., Raaska, L., Mattila-Sandholm, T. and Haikara, A., 2002. Antifungal activities of two Lactobacillus plantarum strains against Fusarium moulds in vitro and in malting of barley. Journal of applied microbiology, 93(4), pp.566-576.

Lan, W.T., Chen, Y.S., Wu, H.C. and Yanagida, F., 2012. Bio-protective potential of lactic acid bacteria isolated from fermented wax gourd. Folia microbiologica, 57(2), pp.99-105.

Landete, J.M., 2016. A review of food-grade vectors in lactic acid bacteria: from the laboratory to their application. Critical reviews in biotechnology, pp.1-13.

Lavermicocca, P., Valerio, F., Evidente, A., Lazzaroni, S., Corsetti, A. and Gobbetti, M., 2000. Purification and characterization of novel antifungal compounds from the sourdough Lactobacillus plantarum strain 21B. Applied and environmental microbiology, 66(9), pp.4084-4090.

Lavermicocca, P., Valerio, F. and Visconti, A., 2003. Antifungal activity of phenyllactic acid against molds isolated from bakery products. Applied and environmental microbiology, 69(1), pp.634-640.

Lin, X.B., Lohans, C.T., Duar, R., Zheng, J., Vederas, J.C., Walter, J. and Gänzle, M., 2015. Genetic determinants of reutericyclin biosynthesis in Lactobacillus reuteri. Applied and environmental microbiology, 81(6), pp.20322041.

Linares, D.M., Alvarez-Sieiro, P., Rio, B., Ladero, V., Redruello, B., Martin, M.C., Fernandez, M. and Alvarez, M.A., 2015. Implementation of the agmatine-controlled expression system for inducible gene expression in Lactococcus lactis. Microbial cell factories, 14(1), p.208.

Lind, H., Jonsson, H. and Schnürer, J., 2005. Antifungal effect of dairy propionibacteria-contribution of organic acids. International journal of food microbiology, 98(2), pp.157-165.

Lind, H., Sjögren, J., Gohil, S., Kenne, L., Schnürer, J. and Broberg, A., 2007. Antifungal compounds from cultures of dairy propionibacteria type strains. FEMS microbiology letters, 271(2), pp.310-315.

Luchese, R.H. and Harrigan, W.F., 1990. Growth of, and aflatoxin production by Aspergillus parasiticus when in the presence of either Lactococcus lactis or lactic acid and at different initial $\mathrm{pH}$ values. Journal of applied bacteriology, 69(4), pp.512-519.

Le Lay, C., Mounier, J., Vasseur, V., Weill, A., Le Blay, G., Barbier, G. and Coton, E., 2016. In vitro and in situ screening of lactic acid bacteria and propionibacteria antifungal activities against bakery product spoilage molds. Food Control, 60, pp.247-255.

Le Lay, C., Coton, E., Le Blay, G., Chobert, J.M., Haertlé, T., Choiset, Y., Van Long, N.N., Meslet-Cladière, L. and Mounier, J., 2016. Identification and quantification of antifungal compounds produced by lactic acid bacteria and propionibacteria. International journal of food microbiology, 239, pp.79-85.

Lees-Haley, P.R., 2003. Toxic mold and mycotoxins in neurotoxicity cases: Stachybotrys, Fusarium, Trichoderma, Aspergillus, Penicillium, Cladosporium, Alternaria, Trichothecenes. Psychological reports, 93(2), pp.561584.

Li, H., Liu, L., Zhang, S., Cui, W. and Lv, J., 2012. Identification of antifungal compounds produced by Lactobacillus casei AST18. Current microbiology, 65(2), pp.156-161.

Li, H., Zhang, S., Lu, J., Liu, L., Uluko, H., Pang, X., Sun, Y., Xue, H., Zhao, L., Kong, F. and Lv, J., 2014. Antifungal activities and effect of Lactobacillus casei AST18 on the mycelia morphology and ultrastructure of Penicillium chrysogenum. Food Control, 43, pp.57-64. 
Lipińska, L., Klewicki, R., Klewicka, E., Kołodziejczyk, K., Sójka, M. and Nowak, A., 2016. Antifungal activity of Lactobacillus sp. bacteria in the presence of xylitol and galactosyl-xylitol. BioMed. Research international, 2016.

Magnusson, J., Ström, K., Roos, S., Sjögren, J. and Schnürer, J., 2003. Broad and complex antifungal activity among environmental isolates of lactic acid bacteria. FEMS microbiology letters, 219(1), pp.129-135.

Magnusson, J. and Schnürer, J., 2001. Lactobacillus coryniformis subsp. coryniformis strain Si3 produces a broadspectrum proteinaceous antifungal compound. Applied and environmental microbiology, 67(1), pp.1-5.

Makarova, K., Slesarev, A., Wolf, Y., Sorokin, A., Mirkin, B., Koonin, E., Pavlov, A., Pavlova, N., Karamychev, V., Polouchine, N. and Shakhova, V., 2006. Comparative genomics of the lactic acid bacteria. Proceedings of the national academy of sciences, 103(42), pp.15611-15616.

Mandal, V., Sen, S.K. and Mandal, N.C., 2007. Detection, isolation and partial characterization of antifungal compound (s) produced by Pediococcus acidilactici LAB 5. Natural product communications, 2(6), pp.671674.

Mäyrä-Mäkinen, A.K., Kristianinkatu, A. and Suomalainen, T.V., 1994. A novel microorganism strain, bacterial preparations comprising said strain, and use of said strain preparations for the controlling of yeasts and moulds. European Patent Application, 0,576,780 A, 2.

Mathiesen, G., Sørvig, E., Blatny, J., Naterstad, K., Axelsson, L. and Eijsink, V.G.H., 2004. High-level gene expression in Lactobacillus plantarum using a pheromone-regulated bacteriocin promoter. Letters in applied microbiology, 39(2), pp.137-143.

Mauch, A., Dal Bello, F., Coffey, A. and Arendt, E.K., 2010. The use of Lactobacillus brevis PS1 to in vitro inhibit the outgrowth of Fusarium culmorum and other common Fusarium species found on barley. International journal of food microbiology, 141(1), pp.116-121.

Mayra-Makinen, A., Kristianinkatu, and Suomalainen, T., 1994. A novel microorganism strain, bacterial preparations comprising said strain, and use of said strain and preparations for the controlling of yeast and moulds. European Patent Application EP 0576780 A2.

Mayra-Makinen, A., Suomalainen, T., 1995. Lactobacillus casei spp. rhamnosus, bacterial preparations comprising said strain, and use of said strain and preparations for the controlling of yeast and moulds. United States Patent Application US 5378458.

Mazumdar, S., Clomburg, J.M. and Gonzalez, R., 2010. Escherichia coli strains engineered for homofermentative production of D-lactic acid from glycerol. Applied and environmental microbiology, 76(13), pp.4327-4336.

Meissonnier, G.M., Pinton, P., Laffitte, J., Cossalter, A.M., Gong, Y.Y., Wild, C.P., Bertin, G., Galtier, P. and Oswald, I.P., 2008. Immunotoxicity of aflatoxin B1: impairment of the cell-mediated response to vaccine antigen and modulation of cytokine expression. Toxicology and applied pharmacology, 231(2), pp.142-149.

Mierau, I. and Kleerebezem, M., 2005. 10 years of the nisin-controlled gene expression system (NICE) in Lactococcus lactis. Applied microbiology and biotechnology, 68(6), pp.705-717.

Mitsuoka, I., 1990. Profile of Intestinal Bacterial Yakult. Horistia Co., Ltd., Tokyo, Japan.

Miyamoto, T. and Naito, Y., 2006. Novel lactic acid bacterium. European Patent Application EP 1726638 A1.

Miyamoto, T. and Naito, Y., 2008. Lactic acid bacteria. United States Application US 2008/0286406.

Miyamoto, T. and Naito, Y., 2011. Lactic acid bacteria. United States Application US 8029779 B2.

Miyoshi, A., Jamet, E., Commissaire, J., Renault, P., Langella, P. and Azevedo, V., 2004. A xylose-inducible expression system for Lactococcus lactis. FEMS microbiology letters, 239(2), pp.205-212.

Muhialdin, B.J., Hassan, Z. and Sadon, S.K., 2011. Antifungal activity of Lactobacillus fermentum Te007, Pediococcus pentosaceus Te010, Lactobacillus pentosus G004, and L. paracasi D5 on selected foods. Journal of food science, 76(7), pp.M493-M499.

Muhialdin, B.J., Hassan, Z., Abu Bakar, F., Algboory, H.L. and Saari, N., 2015. Novel antifungal peptides produced by Leuconostoc mesenteroides DU15 effectively inhibit growth of Aspergillus niger. Journal of food science, 80(5), pp.M1026-M1030.

Muhialdin, B.J., Hassan, Z., Bakar, F.A. and Saari, N., 2016. Identification of antifungal peptides produced by Lactobacillus plantarum IS10 grown in the MRS broth. Food control, 59, pp.27-30.

Muñoz, R., Arena, M.E., Silva, J. and González, S.N., 2010. Inhibition of mycotoxin-producing Aspergillus nomius VSC 23 by lactic acid bacteria and Saccharomyces cerevisiae. Brazilian journal of microbiology, 41(4), pp.1019-1026.

Nallala, V. and Jeevaratnam, K., 2015. Molecular characterization of bacteriocinogenic, antifungal and probiotic lactic acid bacteria isolated from chicken gastrointestinal tract. Advances in microbiology, 5(09), p.644.

Ndagano, D., Lamoureux, T., Dortu, C., Vandermoten, S. and Thonart, P., 2011. Antifungal activity of 2 lactic acid bacteria of the Weissella genus isolated from food. Journal of food science, 76(6), pp.M305-M311 
Ngang, E.J.J., Yadang, G., Sado Kamdem, S.L., Kouebou, C.P., Youte Fanche, S.A., Tsochi Kougan, D.L., Tsoungui, A. and Etoa, F.X., 2015. Antifungal properties of selected lactic acid bacteria and application in the biological control of ochratoxin A producing fungi during cocoa fermentation. Biocontrol science and technology, 25(3), pp.245-259.

Nielsen, P. V. and de Boer, E., 2000. Food preservatives against fungi. In R. A. Samson, E. S. Hoekstra, J. C. Frisvad, and O. Filtenborg (Eds.), Introduction to food-and airborne fungi (pp. 357-363). Utrecht: Centraal Bureau voor Schimmelcutures.

Niku-Paavola, M.L., Laitila, A., Mattila-Sandholm, T. and Haikara, A., 1999. New types of antimicrobial compounds produced by Lactobacillus plantarum. Journal of applied microbiology, 86(1), pp.29-35.

Nuraida, L., 2015. A review: Health promoting lactic acid bacteria in traditional Indonesian fermented foods. Food science and human wellness, 4(2), pp.47-55.

Odds, F.C., Brown, A.J. and Gow, N.A., 2003. Antifungal agents: mechanisms of action. Trends in microbiology, 11(6), pp.272-279.

Ogunbanwo, S.T., AA, A., Ayodele, M.A., Okanlawon, B.M. and Edema, M.O., 2008. Effects of lactic acid bacteria and Saccharomyces cerevisae co-cultures used as starters on the nutritional contents and shelf life of cassavawheat bread. Journal of applied biosciences (J. Appl. Biosci.)ISSN, 1997, p.5902.

Okano, K., Kimura, S., Narita, J., Fukuda, H. and Kondo, A., 2007. Improvement in lactic acid production from starch using $\alpha$-amylase-secreting Lactococcus lactis cells adapted to maltose or starch. Applied microbiology and biotechnology, 75(5), pp.1007-1013.

Papagianni, M. and Avramidis, N., 2011. Lactococcus lactis as a cell factory: a twofold increase in phosphofructokinase activity results in a proportional increase in specific rates of glucose uptake and lactate formation. Enzyme and microbial technology, 49(2), pp.197-202.

Patnaik, R., Louie, S., Gavrilovic, V., Perry, K., Stemmer, W.P., Ryan, C.M. and del Cardayré, S., 2002. Genome shuffling of Lactobacillus for improved acid tolerance. Nature biotechnology, 20(7), pp.707-712.

Peraica, M., Radic, B., Lucic, A. and Pavlovic, M., 1999. Toxic effects of mycotoxins in humans. Bulletin of the World Health Organization, 77(9), pp.754-766.

Pérez-Arellano, I., Zúñiga, M. and Pérez-Martínez, G., 2001. Construction of compatible wide-host-range shuttle vectors for lactic acid bacteria and Escherichia coli. Plasmid, 46(2), pp.106-116.

Perrier, L., Loysance-Paroux, C., Tirilly, Y., Fuhrmann, B. (2011). Use of Lactobacillus casei ssp. paracasei as antifungal agent. United States Patent Application US 2011/0045134 A1.

Peyer, L.C., Axel, C., Lynch, K.M., Zannini, E., Jacob, F. and Arendt, E.K., 2016. Inhibition of Fusarium culmorum by carboxylic acids released from lactic acid bacteria in a barley malt substrate. Food control, 69, pp.227-236.

Pitt, J. I., 2000. Toxigenic fungi and mycotoxins. British Medical Bulletin, 56, 184192.

Plockova, M., Stiles, J., Chumchalova, J. and Halfarova, R., 2001. Control of mould growth by Lactobacillus rhamnosus VT1 and Lactobacillus reuteri CCM 3625 on milk agar plates. Czech journal of food sciences, 19(2), pp.46-50.

Prathivadi Bayankaram, P. and Sellamuthu, P.S., 2016. Antifungal and anti-aflatoxigenic effect of probiotics against Aspergillus flavus and Aspergillus parasiticus. Toxin reviews, pp.1-6.

Prema, P., Smila, D., Palavesam, A. and Immanuel, G., 2010. Production and characterization of an antifungal compound (3-phenyllactic acid) produced by Lactobacillus plantarum strain. Food and bioprocess technology, 3(3), pp.379-386.

Prescott, S.C. and Dunn, C.G., 1959. The acetone-butanol fermentation. Industrial microbiology, 3rd ed. McGrawHill Book Co., New York, pp.250-284.

Rahayu, E.S. 2007. Laporan Kegiatan Peningkatan Produksi dan Keamanan Pangan pada Komoditi Jagung dan Kacang Tanah. Kerjasama antara Fakultas Teknologi Pertanian UGM dan Dinas Pertanian Tanaman Pangan Provinsi Jawa Tengah.

Rahayu, E.S. 2009. Mengantisipasi Bahaya Mikotoksin. Food Review, Bogor.

Rather, A. I., Seo, B.J., Rejish Kumar, V.J., Choi, U.H., Choi, K.H., Lim, J.H. and Park, Y.H., 2013. Isolation and characterization of a proteinaceous antifungal compound from Lactobacillus plantarum YML007 and its application as a food preservative. Letters in applied microbiology, 57(1), pp.69-76.

Reiter, B. and Härnulv, G., 1984. Lactoperoxidase antibacterial system: natural occurrence, biological functions and practical applications. Journal of food protection, 47(9), pp.724-732.

Rizzello, C.G., Cassone, A., Coda, R. and Gobbetti, M., 2011. Antifungal activity of sourdough fermented wheat germ used as an ingredient for bread making. Food chemistry, 127(3), pp.952-959.

Rodriguez, C.A.S., Bongiovanni, A.M. and de Borrego, L.C., 1985. An epidemic of precocious development in Puerto Rican children. The journal of pediatrics, 107(3), pp.393-396. 
Rouse, S., Harnett, D., Vaughan, A. and Sinderen, D.V., 2008. Lactic acid bacteria with potential to eliminate fungal spoilage in foods. Journal of Applied Microbiology, 104(3), pp.915-923.

Roy, U., Batish, V.K., Grover, S. and Neelakantan, S., 1996. Production of antifungal substance by Lactococcus lactis subsp. lactis CHD-28.3. International journal of food microbiology, 32(1-2), pp.27-34.

Roy, U. and Sunita, G., 2009. Partial purification of an antifungal protein produced b Enterococcus faecalis CHD 28.3. Annals of microbiology, 59(2), pp.279-284.

Russo, P., Arena, M.P., Fiocco, D., Capozzi, V., Drider, D. and Spano, G., 2016. Lactobacillus plantarum with broad antifungal activity: A promising approach to increase safety and shelf-life of cereal-based products. International journal of food microbiology.

Ryan, L.A., Zannini, E., Dal Bello, F., Pawlowska, A., Koehler, P. and Arendt, E.K., 2011. Lactobacillus amylovorus DSM 19280 as a novel food-grade antifungal agent for bakery products. International journal of food microbiology, 146(3), pp.276-283.

Ryu, E.H., Yang, E.J., Woo, E.R. and Chang, H.C., 2014. Purification and characterization of antifungal compounds from Lactobacillus plantarum HD1 isolated from kimchi. Food microbiology, 41, pp.19-26.

Sadeghi, A., Raeisi, M., Ebrahimi, M. and Sadeghi, B., 2016. Antifungal activity of Pediococcus pentosaceus isolated from whole barley sourdough. Journal of food quality and hazards control, 3(1), pp.30-36.

Saeed A, H. and Salam A, I., 2013. Current limitations and challenges with lactic acid bacteria: A review. Food and Nutrition Sciences, 2013.

Samaneh, S-K., Mohammad, R.K., Giti, E. and Mohammad M-A., 2016. Anti - Aspergillus flavus Activity of Lactobacillus plantarum and Pediococcus acidilactici Isolated from Breast Milk. International journal of medical research and health sciences, 5(12):265-273.

Sathe, S.J., Nawani, N.N., Dhakephalkar, P.K. and Kapadnis, B.P., 2007. Antifungal lactic acid bacteria with potential to prolong shelf-life of fresh vegetables. Journal of applied microbiology, 103(6), pp.2622-2628.

Schillinger, U. and Villarreal, J.V., 2010. Inhibition of Penicillium nordicum in MRS medium by lactic acid bacteria isolated from foods. Food control, 21(2), pp.107-111.

Schmale, D.G. and Munkvold, G.P., 2009. Mycotoxins in crops: A threat to human and domestic animal health. The plant health instructor, 3, pp.340-353.

Schwartz, G.G., 2002. Hypothesis: does ochratoxin A cause testicular cancer?. Cancer causes and control, 13(1), pp.91-100.

Sevgi, E. and Tsveteslava, I.I., 2015. Antifungal Activity of Lactic Acid Bacteria, Isolated from Bulgarian Wheat and Rye Flour. Journal of life sciences, 9, pp.1-6.

Sharma, R. P., 1993. Immunotoxicity of mycotoxins. Journal of diary science, 76, 892-897.

Shinkawa, S., Okano, K., Yoshida, S., Tanaka, T., Ogino, C., Fukuda, H. and Kondo, A., 2011. Improved homo Llactic acid fermentation from xylose by abolishment of the phosphoketolase pathway and enhancement of the pentose phosphate pathway in genetically modified xylose-assimilating Lactococcus lactis. Applied microbiology and biotechnology, 91(6), p.1537.

Stiles, M.E., 1996. Biopreservation by lactic acid bacteria. Antonie van leeuwenhoek, 70(2-4), pp.331-345.

Stone, R.A., 2009. Medical mystery in Middle China. Science, 324, 1378-1381.

Sweeney, M.J. and Dobson, A.D., 1998. Mycotoxin production by Aspergillus, Fusarium and Penicillium species. International journal of food microbiology, 43(3), pp.141-158.

Sjögren, J., Magnusson, J., Broberg, A., Schnürer, J. and Kenne, L., 2003. Antifungal 3-hydroxy fatty acids from Lactobacillus plantarum MiLAB 14. Applied and environmental microbiology, 69(12), pp.7554-7557.

Södergård, A. and Stolt, M., 2002. Properties of lactic acid based polymers and their correlation with composition. Progress in polymer science, 27(6), pp.1123-1163.

Stiles, J., Penkar, S., Plockova, M., Chumchalova, J. and Bullerman, L.B., 2002. Antifungal activity of sodium acetate and Lactobacillus rhamnosus. Journal of food protection, 65(7), pp.1188-1191.

Ström, K., Schnürer, J. and Melin, P., 2005. Co-cultivation of antifungal Lactobacillus plantarum MiLAB 393 and Aspergillus nidulans, evaluation of effects on fungal growth and protein expression. FEMS microbiology Letters, 246(1), pp.119-124.

Ström, K., Sjögren, J., Broberg, A. and Schnürer, J., 2002. Lactobacillus plantarum MiLAB 393 produces the antifungal cyclic dipeptides cyclo (L-Phe-L-Pro) and cyclo (L-Phe-trans-4-OH-L-Pro) and 3-phenyllactic acid. Applied and environmental microbiology, 68(9), pp.4322-4327.

Surono, I. 2004. Probiotik, Susu Fermentasi dan Kesehatan. PT Tri Cipta Karya, Jakarta.

Talarico, T.L., Casas, I.A., Chung, T.C. and Dobrogosz, W.J., 1988. Production and isolation of reuterin, a growth inhibitor produced by Lactobacillus reuteri. Antimicrobial agents and chemotherapy, 32(12), pp.1854-1858. 
Talarico, T.L. and Dobrogosz, W.J., 1989. Chemical characterization of an antimicrobial substance produced by Lactobacillus reuteri. Antimicrobial agents and chemotherapy, 33(5), pp.674-679.

Tatsadjieu, L.N., Tchikoua, R. and Funtong, C.M.M., 2016. Antifungal activity of lactic acid bacteria against molds isolated from corn and fermented corn paste. American journal of microbiological research, 4(4), pp.90100 .

Theron, M.M. and Lues, J.F.R., 2011. Organic acids and food preservation. Taylor \& Francis.

Trias, R., Bañeras, L., Seguí, E.M. and Romanyó, E.B., 2008a. Lactic acid bacteria from fresh fruit and vegetables as biocontrol agents of phytopathogenic bacteria and fungi. International microbiology: official journal of the Spanish society for microbiology, 11(4), pp.231-236.

Trias, R., Bañeras, L., Badosa, E. and Montesinos, E., 2008b. Bioprotection of golden delicious apples and iceberg lettuce against foodborne bacterial pathogens by lactic acid bacteria. International journal of food microbiology, 123(1), pp.50-60.

Trip, H., Mulder, N.L. and Lolkema, J.S., 2012. Improved acid stress survival of Lactococcus lactis expressing the histidine decarboxylation pathway of Streptococcus thermophilus CHCC1524. Journal of biological chemistry, 287(14), pp.11195-11204.

Triratna, L., Saksono, B., Sukmarini, L. and Suparman, A. 2011. Genome-shuffling-improved acid tolerance and lactic acid production in Lactobacillus plantarum for commercialization. Microbiology Indonesia, $5(1)$, p.4.

Tropcheva, R., Nikolova, D., Evstatieva, Y. and Danova, S., 2014. Antifungal activity and identification of Lactobacilli, isolated from traditional dairy product "katak". Anaerobe, 28, pp.78-84.

Tůma, Š., Vogensen, F., Plocková, M. and Chumchalová, J., 2007. Isolation of antifungally active lactobacilli from Edam cheese. Acta alimentaria, 36(4), pp.405-414.

Tulini, F.L., Hymery, N., Haertlé, T., Le Blay, G. and De Martinis, E.C., 2016. Screening for antimicrobial and proteolytic activities of lactic acid bacteria isolated from cow, buffalo and goat milk and cheeses marketed in the southeast region of Brazil. Journal of dairy research, 83(01), pp.115-124.

Valerio, F., Favilla, M., De Bellis, P., Sisto, A., de Candia, S. and Lavermicocca, P., 2009. Antifungal activity of strains of lactic acid bacteria isolated from a semolina ecosystem against Penicillium roqueforti, Aspergillus niger and Endomyces fibuliger contaminating bakery products. Systematic and applied microbiology, 32(6), pp.438-448.

Vandenbergh, P. A. and King, S.W., 1999. Process for producing yeast and mold inhibiting products by Lactobacillus. Unites States Patent Application US 5695414.

Vandenbergh, P. A. and King, S.W., 2001. Process for producing by culturing Lactobacillus casei var. rhamnosus yeast and mold inhibiting products. Unites States Patent Application US 6277374 B1.

Vandenbergh, P. A. and Kunka, B.S., 1989. Antifungal product. United States Patent Application 4877615.

Vandenbergh, P. A. and Kunka, B.S., 1990a. Process for using a novel antifungal product. United States Patent Application US 4906611.

Vandenbergh, P. A. and Kunka, B. S., 1990b. Process for producing a novel antifungal product. United States Patent Application US 4942032.

Venturini, M.E., Blanco, D. and Oria, R., 2002. In vitro antifungal activity of several antimicrobial compounds against Penicillium expansum. Journal of food protection, 65(5), pp.834-839.

Wang, H., Yan, Y., Wang, J., Zhang, H. and Qi, W., 2012. Production and characterization of antifungal compounds produced by Lactobacillus plantarum IMAU10014. PloS one, 7(1), p.e29452.

Wang, H., Yan, H., Shin, J., Huang, L., Zhang, H. and Qi, W., 2011. Activity against plant pathogenic fungi of Lactobacillus plantarum IMAU10014 isolated from Xinjiang koumiss in China. Annals of microbiology, 61(4), pp.879-885.

Wang, H., Sun, Y., Chen, C., Sun, Z., Zhou, Y., Shen, F., Zhang, H. and Dai, Y., 2013. Genome shuffling of Lactobacillus plantarum for improving antifungal activity. Food control, 32(2), pp.341-347.

Wang, Y., Li, Y., Pei, X., Yu, L. and Feng, Y., 2007. Genome-shuffling improved acid tolerance and L-lactic acid volumetric productivity in Lactobacillus rhamnosus. Journal of biotechnology, 129(3), pp.510-515.

Wegmann, U., O'Connell-Motherway, M., Zomer, A., Buist, G., Shearman, C., Canchaya, C., Ventura, M., Goesmann, A., Gasson, O.P. and van Sinderen, D., 2007. Complete genome sequence of the prototype lactic acid bacterium Lactococcus lactis subsp. cremoris MG1363. Journal of bacteriology, 189(8), pp.3256-3270.

Wessels, S., Axelsson, L., Hansen, E.B., De Vuyst, L., Laulund, S., Lähteenmäki, L., Lindgren, S., Mollet, B., Salminen, S. and von Wright, A., 2004. The lactic acid bacteria, the food chain, and their regulation. Trends in food science \& technology, 15(10), pp.498-505. 
Wiseman, D.W. and Marth, E.H., 1981. Growth and aflatoxin production by Aspergillus parasiticus when in the presence of Streptococcus lactis. Mycopathologia, 73(1), pp.49-56.

Wu, F., 2006. Mycotoxin reduction in Bt corn: potential economic, health, and regulatory impacts. Transgenic research, 15(3), pp.277-289.

Yang, V.W. and Clausen, C.A., 2005. Determining the suitability of Lactobacilli antifungal metabolites for inhibiting mould growth. World journal of microbiology and biotechnology, 21(6-7), pp.977-981.

Yang, X., Lai, Z., Lai, C., Zhu, M., Li, S., Wang, J. and Wang, X., 2013. Efficient production of L-lactic acid by an engineered Thermoanaerobacterium aotearoense with broad substrate specificity. Biotechnology for biofuels, 6(1), p.124.

Yang, E.J. and Chang, H.C., 2010. Purification of a new antifungal compound produced by Lactobacillus plantarum AF1 isolated from kimchi. International journal of food microbiology, 139(1), pp.56-63.

Ye, L., Zhao, H., Li, Z. and Wu, J.C., 2013. Improved acid tolerance of Lactobacillus pentosus by error-prone whole genome amplification. Bioresource technology, 135, pp.459-463.

Yu, L., Pei, X., Lei, T., Wang, Y. and Feng, Y., 2008. Genome shuffling enhanced L-lactic acid production by improving glucose tolerance of Lactobacillus rhamnosus. Journal of biotechnology, 134(1), pp.154-159.

Zanelli, L., 2000. Moulds, Bacteria and Solutions. Feed Industry Service, Italia.

Zhang, J., Caiyin, Q., Feng, W., Zhao, X., Qiao, B., Zhao, G. and Qiao, J., 2016. Enhance nisin yield via improving acid-tolerant capability of Lactococcus lactis F44. Scientific reports, 6.

Zhang, Y., Vadlani, P.V., Kumar, A., Hardwidge, P.R., Govind, R., Tanaka, T. and Kondo, A., 2016. Enhanced Dlactic acid production from renewable resources using engineered Lactobacillus plantarum. Applied microbiology and biotechnology, 100(1), pp.279-288.

Zheng, H., Gong, J., Chen, T., Chen, X. and Zhao, X., 2010. Strain improvement of Sporolactobacillus inulinus ATCC 15538 for acid tolerance and production of D-lactic acid by genome shuffling. Applied microbiology and biotechnology, 85(5), pp.1541-1549.

Zheng, Z., Zhao, M., Zang, Y., Zhou, Y. and Ouyang, J., 2015. Production of optically pure L-phenyllactic acid by using engineered Escherichia coli coexpressing L-lactate dehydrogenase and formate dehydrogenase. Journal of biotechnology, 207, pp.47-51.

Zhao, D., 2011. Isolation of antifungal lactic acid bacteria from food sources and their use to inhibit mold growth in cheese. MSc thesis.

Zhu, Y., Hu, F., Zhu, Y., Wang, L. and Qi, B., 2015. Enhancement of phenyllactic acid biosynthesis by recognition site replacement of D-lactate dehydrogenase from Lactobacillus pentosus. Biotechnology letters, 37(6), pp.1233-1241. 


\title{
Research Article 03
}

\section{Diversity and Biological Activity of Yeast and Lactic Acid Bacteria Isolates from Soak Water in Tempeh Production*}

*) Diversity part in this research has been presented partly in 4th International Conference on Biological Science ICBS 2015 Yogyakarta, Indonesia.

\author{
Riyan Anggriawan ${ }^{1}$, Sukanto $^{3}$, Antje Borzekowski², Katharina Pfohl ${ }^{1}$, and Petr Karlovsky ${ }^{1}$ \\ ${ }^{1}$ Molecular Phytopathology and Mycotoxin Research, University of Goettingen, Göttingen, Germany \\ ${ }^{2}$ Departement of Analytical Chemistry, Reference Materials, BAM Federal Institute for Materials \\ Research and Testing, Berlin, Germany \\ ${ }^{3}$ Faculty of Biology, Jenderal Soedirman University, Purwokerto, Indonesia
}

\begin{abstract}
Soaking is a spontaneous microbiological process. It is considered as an important step in the manufacture of high-quality tempeh. The objectives of this study were, 1) to characterize and investigate the diversity of dominant lactic acid bacteria (LAB) and yeast by analyzing soak water samples collected from different producers in Java, 2) to screen and investigate their potential antifungal activity against $F$. proliferatum, 3 ) to check their contribution to zearalenone (ZEN) biotransformation. The LAB counts in these samples varied between 5.21 and $8.88 \log \mathrm{CFU} / \mathrm{mL}$ whereas yeasts counts varied from 4.31 and $4.89 \log \mathrm{CFU} / \mathrm{mL}$, APC counts varied between 7.33 and $9.10 \log$ CFU/mL. In total, 165 isolates were obtained from these samples using selective media. Our results revealed a certain variety of culturable LAB and yeast in soak water. The principal yeast found to be responsible for fermentation were Candida tropicalis, Kluyveromyces marxianus, and Saccharomyces cerevisiae, while the dominant LAB were Lactobacillus plantarum, $L$. paracasei and Pediococcus pentosaceous. We found LAB species were less diverse than yeast species. Cell free supernatants (CFS) of $20 \mathrm{LAB}$ strains possessed antifungal properties against $F$. proliferatum BSM17, while none of the yeast isolates showed the activity. It was found that phenyl lactic acid (PLA) might has main role for the activity. The use of those selected LAB strains as part of starter culture has been proven to positively increase tempeh safety. The results obtained from screening 20 isolates belonging to 10 different species revealed that nearly all the tested organisms were able to reduce ZEN in range 10 to 96.9\%. In general, yeast and LAB isolates could only transform ZEN into two major transformation product $\alpha$-ZEL and $\beta$-ZEL. In all cases no conjugation product detected.
\end{abstract}

Keywords: soak water, tempeh, natural fermentation, lactic acid bacteria, yeast, antifungal activity, ZEN transformation

\section{Introduction}

Indonesian food tempe, or known as tempeh in foreign language, kind of beans that is fermented by fungi (such as Rhizopus sp.), which become solid and compact form and can be sliced. Besides beans or grains as its raw ingredients, tempeh also can be produced by other ingredients such other food processing byproduct, for example, tofu dregs and another. Yellow soybean is the most favoured source to produce tempeh (Nout and Kiers, 2005). 
Tempeh is a substantial food in Indonesia. As traditional food, tempeh has been consumed since long ago; even its consumption is increasing every year. It happens because tempeh has a delicious taste, contains high nutrition, cheap, and easy to be cooked (Pawiroharsono, 1994). Besides, tempeh is a functional healthy food, which contains B12 vitamin, and bioactive compounds (Keuth and Bisping, 1994; Astuti et al., 2000; Nout and Kiers, 2005; Nakajima et al., 2005; Shurtleff and Aoyagi, 2011). As a popular and healthy food, tempeh is not only consumed by Indonesian people, but also by foreign people, such as Dutch, Japanese, and American people (Naidoo,1996; Shurtleff and Aoyagi, 2011).

Tempeh-producing technology is handed down through generations and changes with experience. The manufacture process is quite complex, which divided into two stages. First, it is fermented by microorganisms (microbial consortia) process that occurs while soybeans are soaking. Then, the second is solid state fermentation process occurs by fungi after inoculation. There are some different process in producing tempeh in every region, and also depends on the producers (Astuti et al., 2000; Shurtleff and Aoyagi, 2011). However, there are some other similarities in producing tempeh, such as the process of soybean production, soybean peeling and soybean acidification, washing, inoculum mixing, packaging, and incubation (Hermana, 1996).

Like many other traditional foods in Indonesia, tempeh is produced as a small scale home industry with poorly controlled fermentation which is carried out without sufficient hygienic precautions even though the starter culture containing fungi are added at the beginning of fermentation. Therefore, there are various types of microorganisms that can participate during the process of fermentation, and natural contamination is always possible (Winarno, 1985; Barus et al., 2008; Seumahu et al., 2013). Moreover, there is no standard on making tempeh and its starter. This is the cause of many variations in the manufacture of tempeh in some areas (Astuti et al., 2000) which lead to nonhomogeneous quality and safety of traditional tempeh.

In 2015 we investigated possible contamination of toxigenic Fusarium in traditional tempeh. About 214 traditional tempeh samples from the six different regions were screened for $F$. proliferatum and $F$. solani contamination by real-time PCR. Contamination of traditional tempeh samples with $F$. proliferatum was found in $12 \%$ of the samples with amounts of $10-175 \mathrm{ng} / \mathrm{mg}$ fungal DNA. In these samples, the amount of FB1 and BEA ranged between 170-2680 $\mu \mathrm{g} / \mathrm{kg}$ and $20-50 \mu \mathrm{g} / \mathrm{kg}$, respectively. About $7 \%$ of the traditional tempeh samples were contaminated with $F$. solani in amounts of $20-129 \mathrm{ng} / \mathrm{mg}$ fungal DNA. This is allegedly caused by unhygienic process of making tempeh and the use of contaminated traditional starter.

The use of biological agents, antifungal microbes, has been researched and expected to overcome fungal contaminant in food production. Generally, microorganisms commonly used for prevention of mycotoxin contamination are lactic acid bacteria (LAB) because of their ability to inhibit growth of toxigenic fungi (Laitila et al., 2002; Hathout et al., 2011). Lactobacillus plantarum AF1 can produce a compound $\mathrm{C}_{12} \mathrm{H}_{22} \mathrm{~N}_{2} \mathrm{O}_{2}$, 3,6-bis (2-methylprophyl)-2.5, piperazinedon with $226 \mathrm{Da}$ of molecular weight. The compounds effectively inhibit Aspergillus flavus ATCC 22546 and A. fumigatus ATCC 96918 (Yang and Chang, 2010). Störm et al. (2002) have isolated $L$. plantarum from the antifungal silage. The antifungal substance of $L$. plantarum 
MiLAB 393 was isolated, and its structure was determined. The compound was identified as a 3phenyllactic acid with 9/1 ratio of $\mathrm{L}$ and $\mathrm{D}$ isomers, two cyclic dipeptides cyclo (L-Phe-L-Pro) and cyclo (L-Phe-trans-4-OH-L-Pro). Lavermicocca et al. (2000) also have isolated antifungal compounds from $L$. plantarum, such as phenyllactic acid and 4-hydroxy acid phenyllactic. Besides, yeast were also found to inhibit the growth of toxigenic fungi. Ramos et al. (2010) reported that some isolates of Debaryomyces hansenii (UFLACF 889 and UFLACF 847) and Pichia anomala (UFLACF 710 and UFLACF 951) were able to inhibit the growth of $A$. ochraceous, A. parasiticus, and Penicillium roqueforti. Other researchers have also found the role of Saccharomyces cerevisiae isolates as an inhibitor of toxigenic fungi (Munoz et al., 2010; Persons et al., 2013, and El-Mohamady et al., 2014).

Careful selection of specific strains of LAB and yeast with antifungal properties can be used as food preservatives reducing mold contamination, therefore, improving the shelf-life of many fermented food products (Corsetti et al., 2000; Clarke et al., 2002; Crowley et al., 2002; Arendt et al., 2007) and reducing health risks due to mycotoxins exposure (Gourama and Bullerman, 1995). Many research reports also indicate that LAB has beneficial health effects in humans (Masood et al., 2011; Florou-Paneri, 2013; Fernández et al., 2015; Nuraida et al., 2015). Moreover, due to certain specific metabolic properties, LAB are of particular interest in the food industry, since they can improve the sensory and nutritional value of food products (Crowley et. al., 2002; Arendt et al., 2007).

Rhizopus oligosporus is a major tempeh fermentation agent, but other involved microbial fermentation also grow especially since in the soaking process (Nout and Rombouts, 1990; Nout and Kiers, 2005). The presence of LAB (Nout et al., 1985) and yeast (Samson et al., 1987) in tempeh have been reported. Afterward, the LAB and yeast were also studied and reported by other researchers. Commonly, research of LAB and yeast at some stages of tempeh production process is conducted in laboratory, not in the tempeh industry. The presence of these microbes in a sample of tempeh has been reported, but only based on the final product (tempeh from a market). It was not reported comprehensively during production process, especially soaking process. Research of $\mathrm{LAB}$ and yeast are based on conventional approach which takes time, expense much effort, and limited on microbial analysis (Aslam et al., 2010). Up until now, LAB study of tempeh production is limited to the value of colony forming units (CFU). LAB population for tempeh production has been researched for tempeh producer in Malaysia (Moreno et al., 2002) and only laboratory research in Indonesia (Nuraida et al., 2008). Neither Moreno et al. (2002) and Nuraida et al. (2008) did not specifically study about yeast population, which was included in the value of CFU fungi. The study about the diversity of LAB and yeast during the soaking of mixture soybean-corn has never been researched, except for a list of some types of LAB and yeast which ever found in tempeh and only characterized phenotypically (Samson et al., 1987; Mulyowidarso et al., 1990; Ashenafi and Busse, 1991).

In the present study, we isolated and characterized lactic acid bacteria (LAB) and yeast by analyzing soak water samples collected from different producers and regions in Java. Screening and evaluating anti- $F$. proliferatum activity from the isolates was also conducted. Nature of the 
antifungal activity was also investigated. In addition, their potential protective application together with $R$. oligosporus as the main starter was studied in tempeh model.

Another safety problem in tempeh production is the use of corn as a substitute for soybean. Producers involve corn substitution for 10-30 percent to reduce cost production because the price of soybean is high nowadays. This generates a healthiness issue of produced tempeh because most Indonesian corn has been contaminated by toxigenic fungi such as Fusarium spp., Penicillium citrinum and P. chrysogenum (Ahmad et al., 2009; Kusumaningrum et al., 2010; Rahmawati et al., 2013). Rahmawati et al. (2013) also reported that toxigenic fungi are found in soaking corn, such as Fusarium spp. It is high possibly happens that those fungi produce mycotoxins during soaking process, then the toxins absorbed into the material that is used to produce tempeh. Moreover mycotoxins content in raw material itself also endangers consumer health. Fumonisin and zearalenone were found in some cereals in Indonesia especially maize (Maryam and Zahari, 1994; Yamashita et al. 1995; Ramahani 2003). Therefore safety aspect of tempeh cannot be guaranteed anymore. In this research we also study tempeh microorganisms`s contribution to biotransformation of zearalenone.

\section{Materials and Methods}

\section{Part I (Diversity of LAB and yeast)}

\subsubsection{Tempeh manufacturing in local producers}

Dry abrasion-dehulled yellow var. soybeans: local maize, the ratio depends on tempeh manufacture $(10 \mathrm{~kg})$ were rinsed twice with $50 \mathrm{~L}$ tap water of $50^{\circ} \mathrm{C}$, drained and soaked either for spontaneous fermentation in $30 \mathrm{~L}$ tapwater in a big container at room temperature for 18-32 h (some manufactures use recycled soak water). After draining the soak water, the beans were rinsed twice with $50 \mathrm{~L}$ tap water and boiled in $30 \mathrm{~L}$ fresh tap water for 60-90 min. After draining and discarding the boiling water, the hot mixture beans were immediately spread in a layer of approx $1 \mathrm{~cm}$ thickness on a wire-mesh and turned twice to facilitate the evaporation of adhering water. After approx. $20 \mathrm{~min}$, the beans were hand-dried and cooled to $20-25^{\circ} \mathrm{C}$ and were transferred into a container and mixed with spore suspension. After inoculation, 50-200 g beans were stiffly packed into a perforated plastic or dried banana leaf and incubated at room temperature for 36-48 h, yielding fresh tempeh.

\subsubsection{Sampling}

Samples (soak water) were collected from 6 tempeh manufactures from different regions in Java and approved by local government (sampling map can be seen in Figure 1). Samples of about 100 $\mathrm{mL}$ soak water were taken aseptically within $15 \mathrm{~min}$ at ambient temperatures into sterile glass bottles after thorough mixing in the bulk samples container. The samples were transported to nearby microbiology laboratory in a cooling box $\left(<10^{\circ} \mathrm{C}\right)$ containing ice packs. Microbiological and chemical analysis was carried out immediately after arrival. Each ten $\mathrm{mL}$ of sample were used to microbial count analysis and isolation. All experiments were conducted in triplicate. 


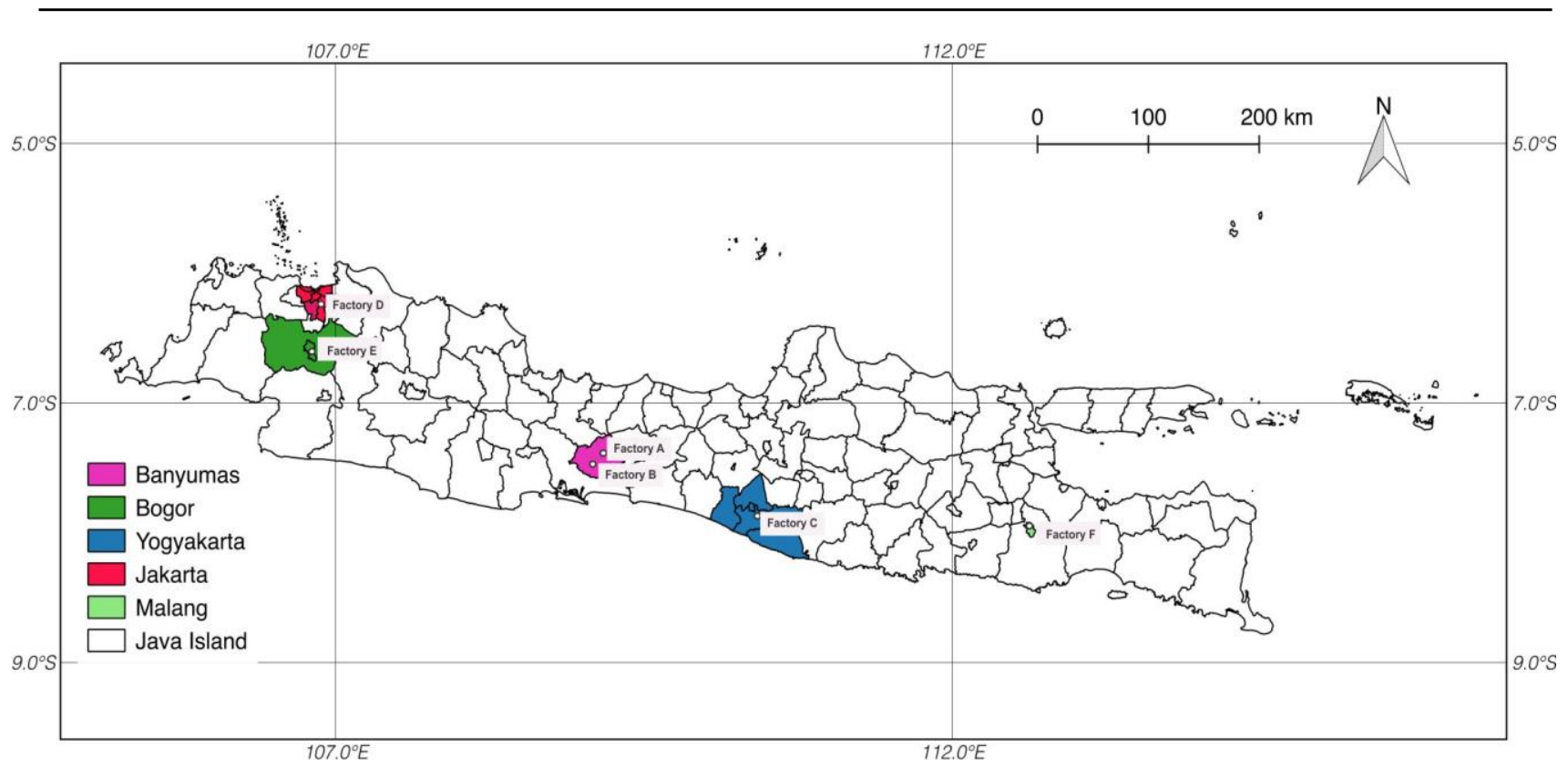

Figure 1. Sampling map (Java, Indonesia)

\subsubsection{Determination of $\mathrm{pH}$, titratable acidity (TTA), temperature and humidity in local factories \\ pH of soak water. The $\mathrm{pH}$ value of the soak-water was determined according to Association of Official Analytical Chemists (AOAC, 2000) and read with a digital pH meter (Hanna).}

TTA content of soak water. The amount of TTA produced in the fermenting soak-water was determined according to Lonner (1988). With $9 \mathrm{~mL}$ of sterile distilled water, $1 \mathrm{~mL}$ of the soakwater was diluted. Of the resultant mixture, $10 \mathrm{~mL}$ was then titrated against $1 \mathrm{~N} \mathrm{NaOH}$ with two drops of phenolphthalein as indicator. The TTA content was thus calculated from the formula.

Lactic acid $(\mathrm{mg} / \mathrm{mL})=\frac{\text { Average titre value } \times 90}{\text { Volume of sample }}$

90 is the lactic acid equivalent factor.

Temperature and humidity in workshops. Temperature was checked by portable infrared thermometer (OS-VIR50). Humidity was measured by portable digital hygrometer (Amarell).

\subsubsection{Microbiological analysis of the soak water}

The samples were homogenized using a vortex before plating.

Ten (10) $\mathrm{mL}$ of soak water were homogenized with $90 \mathrm{~mL}$ of $0.85 \%(\mathrm{w} / \mathrm{v})$ sterile saline water to make an initial dilution $\left(10^{-1}\right)$. The suspension was used for making suitable serial dilution up to $10^{-7}$ by incorporating one $\mathrm{mL}$ into nine $\mathrm{mL}$ sterile saline water in sterile tubes. The suspension was homogenized using a vortex before plating. Each $0.1 \mathrm{~mL}$ of appropriate dilutions were spreadplated in specific media.

Enumeration of LAB was determined with surface plating onto Mann Rogosa Sharp agar (MRS) and incubated anaerobically at $30^{\circ} \mathrm{C}$ for $48 \mathrm{~h}$. 
Yeast counts were performed by plating onto chloramphenicol bromophenol blue agar consisting of [ $(\mathrm{g} / \mathrm{l}$ in distilled water): yeast extract, $5 \mathrm{~g}$; glucose, $20 \mathrm{~g}$; chloramphenicol, $0.1 \mathrm{~g}$; bromophenol blue, $0.01 \mathrm{~g}$; agar, $15 \mathrm{~g}$; $\mathrm{pH}, 6-6.5)$ and incubated aerobically at $25^{\circ} \mathrm{C}$ for five days.

Aerobic mesophilic bacteria enumeration was done with Plate Count Agar. Aerobic incubation at $37^{\circ} \mathrm{C}$ for $48 \mathrm{~h}$.

Coliforms enumeration was done with Violet Red Bile Agar plates. The plates were incubated at $37^{\circ} \mathrm{C}$ for $24 \mathrm{~h}$. Purple-red colonies surrounded by a reddish zone of precipitated bile were counted as coliforms.

The total number of colonies that developed on the plates was recorded as colony forming units (CFU) per $\mathrm{mL}$ of samples. The calculation was based on standard plate count (SPC). All analyses were performed in triplicate, and the means \pm standard deviations were used as data.

\subsubsection{Isolation of culturable yeast and $L A B$}

After counting, single colonies with distinct morphological differences (color, shape, and size) were randomly picked from plates 30-300 colonies $\left(10^{-5}\right.$ dilution for LAB and $10^{-4}$ dilution for yeasts), and transferred in $10 \mathrm{~mL}$ of corresponding sterile broth media. The selected colonies were purified by repeated streaking on the specific agar media before being subjected for characterization. For long term storage, purified culture was stored $-80^{\circ} \mathrm{C}$ with $25 \%(\mathrm{v} / \mathrm{v})$ glycerol as cryoprotectant.

\subsubsection{Phenotypic characterization of culturable yeast and LAB}

LAB: Strains were characterized after $24 \mathrm{~h}$ of incubation at $30^{\circ} \mathrm{C}$ on MRS agar. Microscopic observation was done to examine cell shape. The preparations were analyzed using oil immersion and a light microscope (Leica Leitz DMRB) equipped with a color camera (Leica DFC420). All strains were subjected to Gram staining, catalase activity, hydrolysis of arginine, lactic acid isomer test, and gas production from glucose, growth test at different temperatures $\left(10,15,45\right.$ and $\left.50^{\circ} \mathrm{C}\right)$ for 7 days, tolerance of different salt levels $(2,3,4,6,6.5,8,10 \% \mathrm{NaCl} w / v)$ at $30^{\circ} \mathrm{C}$ for 2 days and $\mathrm{pH}(3,3.5,4,4.5,5,9,9.6$ adjusted with glacial acetic acid) for 3 days (Harrigan and McCance, 1976; Schillinger an Lücke, 1987; Kozaki et al., 1992; MacFaddin, 2000; Yu et al., 2011). Carbohydrate fermentation test was conducted with API 50CHL strips (API system, BioMerieux). The characterization results of LAB isolates were compared with reference to Bergey's Manual of Determinative Bacteriology (Holt et al., 1986).

Yeast: All the yeast isolates were characterized by the conventional method described by several authors (Deak and Beuchat, 1996; Kurtzman and Fell, 2000; Kurtzman et al., 2011). The isolates were cultured for 2 days in yeast extract-glucose-chloramphenicol-agar (YGCA) at $25^{\circ} \mathrm{C}$ and observed their colony characteristics (color, texture and topography of the surface and edges). Isolates were stained with lactophenol blue and observed under microscope after $24 \mathrm{~h}$ incubation on YGC broth. Yeasts were observed for cell shape, sporulation, and vegetative reproduction. All yeast isolates were also examined on urea hydrolysis, growth in presence of $0.01 \%(\mathrm{w} / \mathrm{v})$ cycloheximide, growth at $37^{\circ} \mathrm{C}$, vitamin requirement test and assimilation of $\mathrm{KNO}_{3}$. 
Yeast isolates were tested for their ability to assimilate various compounds by using the API ID 32C kits (API system, BioMerieux). The characterization results were compared with yeast identification keys of Barnett et al. (1990) and Kurtzman and Fell (2000).

\subsubsection{Molecular identification}

\section{DNA extraction of yeast and LAB isolates}

DNA extraction was achieved according to a modified method of Ausubel et al., (1987). $1.8 \mathrm{~mL}$ of $48 \mathrm{~h} \mathrm{LAB}$ culture on MRS broth (or 3 days yeast culture on YGC broth) was put into a $2 \mathrm{~mL}$ sterile tube and centrifuged during $10 \mathrm{~min}$ at $20^{\circ} \mathrm{C}$ and $14000 \mathrm{RPM}$. The supernatant was carefully drawn off, the pellet was resuspended in $576 \mu \mathrm{L}$ TE-buffer and $30 \mu \mathrm{L}$ of $10 \%$ SDS were added followed by $3 \mu \mathrm{L}$ proteinase $\mathrm{K}(20 \mathrm{mg} / \mathrm{mL})$, the mixtures were incubated for $1 \mathrm{~h}$ in a $37^{\circ} \mathrm{C}$ preheated water bath. $100 \mu \mathrm{L} \mathrm{NaCl} 5 \mathrm{M}$ and $80 \mu \mathrm{L} \mathrm{10 \%} \mathrm{CTAB} \mathrm{(in} 1 \times \mathrm{TE}, 0.7 \mathrm{M} \mathrm{NaCl}$ ) were respectively added to the mixture and incubated in a $65^{\circ} \mathrm{C}$ preheated water bath for $10 \mathrm{~min}$. After this incubation, $700 \mu \mathrm{L}$ of chloroform/isoamyl alcohol 24:1 (v/v) were added and the whole sample was thoroughly mixed and kept on ice for $10 \mathrm{~min}$. The tubes were then centrifuged at $14000 \mathrm{RPM}$ during $10 \mathrm{~min}$ in a $4^{\circ} \mathrm{C}$ precooled centrifuge. The aqueous viscous phase was recovered, and $30 \%$ PEG was added to a final concentration of $6.5 \%$ (divide volume of the aqueous phase by 3.6). The content of the tubes was cautiously mixed by tilting and left for precipitation for 20-30 min at room temperature. The samples were centrifuged for $10 \mathrm{~min}$ at $4^{\circ} \mathrm{C}$ and $14000 \mathrm{RPM}$. After centrifugation, the supernatant was discarded and the pellet washed twice with cold EtOH (70\%) with the precaution not to loose the pellet. After the second washing, the rest of EtOH was spinned down and removed as much as possible using a pipette. The pellet was dried at $30^{\circ} \mathrm{C}$ in the SpeedVac (Eppendorf concentrator 5301, $1400 \mathrm{RPM}$ ) for $10 \mathrm{~min}$ and resuspended in $50 \mu \mathrm{L}$ of TEbuffer overnight. To check for the success of the DNA extraction step, $2 \mu \mathrm{L}$ DNA solution, $1 \mu \mathrm{L}$ blue juice and $2 \mu \mathrm{L}$ of the standard Lambda-DNA ( $25 \mathrm{ng} / \mathrm{mL}$ Lambda DNA) were run on $0.8 \%$ agarose gel.

\section{DNA fingerprinting}

In the preliminary experiments, four arbitrary primers were tested with Random Amplified Polymorphic DNA (RAPD) with DNA extracted from pure cultures (yeast and LAB). List of primers can be seen on Table 1. Preliminary test determined the optimal concentration of the component in the PCR reaction mixture, amplification conditions and primer selection. Strong, unique, sharp and clearly reproducible bands were produced by primer $\mathrm{C} 2 \_1++$ inv_f and C7_1_seq_f2. For further analysis C2_1++inv_f was used.

Table 1. Primer and their sequences tested in preliminary RAPD analysis

\begin{tabular}{ll}
\hline \multicolumn{1}{c}{ Primers } & \multicolumn{1}{c}{ Sequence 5'-3' } \\
\hline C6.2_introns_2_R (C6_2_int_R3) & TGGCTCACGCAAGGGTGTAG \\
C2_1++inv_f & TGACGTCCTAGTTGATATCCTCG \\
C2_1++in__r & ACCGTTATGATCAATAAATATTTGACCA \\
C7_1_seq_f2 & AGGTTAGCTCGCGACTATCGGATC \\
\hline
\end{tabular}

In brief, the optimal condition of PCR as described below: 
The amplification reaction was carried out in a volume of $25 \mu \mathrm{L}$ containing $18.45 \mu \mathrm{L}$ water, $2.5 \mu \mathrm{L}$ 10x reaction buffer, $1.5 \mu \mathrm{L}$ dNTPs $150 \mu \mathrm{M}$ (Amersham Biosciences), $0.75 \mu \mathrm{L}$ of primer $0.3 \mu \mathrm{M}$ (GenXpress), $0.05 \mu \mathrm{L}$ of Taq DNA polymerase $0.25 \mathrm{U}$, and $1 \mu \mathrm{L}$ of DNA sample. For detection of any other kinds of DNA contaminants, a negative control of PCR-mix without any template DNA was used. The PCR program had initial denaturation at $94^{\circ} \mathrm{C}$ for $2 \mathrm{~min}, 2 \mathrm{x} 45$ cycles of: $20 \mathrm{~s}$ at $94^{\circ} \mathrm{C}, 37 \mathrm{~s}$ at $37^{\circ} \mathrm{C}, 20 \mathrm{~s}$ at $72^{\circ} \mathrm{C}$ and followed by final extension at $72^{\circ} \mathrm{C}$ for $5 \mathrm{~min}$, storage $15^{\circ} \mathrm{C}$ for $5 \mathrm{~min}$ (peQ STAR Thermocycler). Eight $\mu \mathrm{L}$ of the PCR products, and $0.5 \mu \mathrm{L}$ of size marker (100bp), respectively, is mixed with $2 \mu \mathrm{L}$ of blue juice and pipetted into the slots. The electrophoresis is carried out at $60 \mathrm{~V}$ for $90 \mathrm{~min}$. The EtBr-stained DNA fragments are visualized under a UV-transilluminator.

\section{Polymerase chain reaction and phylogenetic analysis} 16s rRNA gene sequences analysis for LAB

Molecular identification of the LAB isolates was achieved with the amplification partial sequence $16 \mathrm{~S}$ rRNA genes using the bacterial universal primers 27F (5'-AGAGTTTGATCMTGGCTCAG) (Lane, 1991) and bacterial primer 1100R (5'-AGGGTTGCGCTCGTTG) (Turner et al., 1999) with cycling conditions of $94^{\circ} \mathrm{C} 30 \mathrm{sec}, 10 \times\left(94^{\circ} \mathrm{C} 30 \mathrm{sec} ; 62^{\circ} \mathrm{C}-53^{\circ} \mathrm{C}-1^{\circ} \mathrm{C} /\right.$ cycle $\left.40 \mathrm{~min} ; 72^{\circ} \mathrm{C} 1 \mathrm{~min}\right)$, close loop $30 \times\left(30 \mathrm{x} 94^{\circ} \mathrm{C} 30 \mathrm{sec} ; 56^{\circ} \mathrm{C} 40 \mathrm{~min} ; 72^{\circ} \mathrm{C} 1 \mathrm{~min}\right)$, close loop $72^{\circ} \mathrm{C} 5 \mathrm{~min}$. The DNA was diluted $1 / 100$ and $1 / 1000$. PCR was carried out with a total volume of $25 \mu \mathrm{L}$ composed of $18.45 \mu \mathrm{L}$ water, $2.5 \mu \mathrm{L}$ 10x reaction buffer (New England BioLabs, Ipswich, MA, USA), $1.5 \mu \mathrm{L}$ dNTPs $150 \mu \mathrm{M}$ (Bioline, Luckenwalde, Germany), $0.75 \mu \mathrm{L}$ of each primer $0.3 \mu \mathrm{M}$ (Invitrogen by Thermo Fisher Scientific), $0.05 \mu \mathrm{L}$ of Taq DNA polymerase $0.25 \mathrm{U}$ (New England BioLabs, Ipswich, MA, USA) and $1 \mu \mathrm{L}$ of DNA sample. A control PCR without DNA was set up to check for nonspecific amplification. The PCR product was checked on a gel, prepared for sequencing and sequenced. To check for the success of the DNA extraction step, $2 \mu \mathrm{L}$ DNA solution, $1 \mu \mathrm{L}$ and $2 \mu \mathrm{L}$ of the standard Lambda-DNA (25 $\mathrm{ng} / \mathrm{mL}$ Lambda DNA) were run on $0.8 \%$ agarose gel as described above. Similarity searches in the sequences of the sequenced 16S rRNA gene, alignments and phylogenic analysis were performed.

\section{ITS/5.8S ribosomal DNA (rDNA) gene sequences analysis for yeast}

A touch down program was used for the amplification of the internal transcribed spacer region with the primers pairs (Invitrogen) ITS 4 (5'-TCCTCCGCTTATTGATATGC-3') and ITS 5 (5'GGAAGTAAAAGTCGTAACAAGG-3') (White et al., 1990). The cycling conditions included $94^{\circ} \mathrm{C}$ $30 \mathrm{sec}, 10 \times 94^{\circ} \mathrm{C} 30 \mathrm{sec}, 62^{\circ} \mathrm{C}-53^{\circ} \mathrm{C}-1^{\circ} \mathrm{C} /$ cycle $40 \mathrm{sec}, 72^{\circ} \mathrm{C} 1 \mathrm{~min}$, close loop $30 \times 94^{\circ} \mathrm{C} 30 \mathrm{sec}, 56^{\circ} \mathrm{C}$ $40 \mathrm{sec}, 72^{\circ} \mathrm{C} 1 \mathrm{~min}$, close loop $72^{\circ} \mathrm{C} 5 \mathrm{~min}$. The DNA was diluted $1 / 100$. A total volume of $25 \mu \mathrm{L}$ mixtures composed of $13.45 \mu \mathrm{L}$ water, $2.5 \mu \mathrm{L} 10 \mathrm{x}$ reaction buffer, $0.2 \mu \mathrm{L} \mathrm{MgCl} 2$ (Bioline), $1.5 \mu \mathrm{L}$ dNTPs $150 \mu \mathrm{M}$ (Bioline, Luckenwalde, Germany), $0.75 \mu \mathrm{L}$ of each primer $0.3 \mu \mathrm{M}$ (Invitrogen by Thermo Fisher Scientific), $0.05 \mu \mathrm{L}$ of DNA polymerase $0.25 \mathrm{U}$ and $6 \mu \mathrm{L}$ of DNA sample was used for PCR. A control PCR without DNA was set up to check for nonspecific amplification. The expected PCR products' size was 600-750 bp. For agarose gel electrophoresis of the PCR products, $2 \mu \mathrm{L}$ blue juice were mixed with $2 \mu \mathrm{L}$ digested lambda DNA $(25 \mathrm{ng} / \mathrm{mL})$. The PCR products were checked on agarose gel electrophoresis and purified using isopropanol precipitation and sent for sequencing as described above. The checking of the PCR product was performed on agarose gel electrophoresis as described above. The PCR products were purified using isopropanol precipitation and $5 \mu \mathrm{L}$ of the PCR product were sent to LCG Genomics GmbH (Berlin, Germany) for sequencing. 


\section{Part II (Screening and characterization of antifungal activity)}

\subsubsection{Antifungal activity assay}

\section{Fungal spore suspension preparation}

The fungus was grown on PDA petridishes for 7 days at $25^{\circ} \mathrm{C}$ until sporulation formed. Spores were collected in a sterile phosphate buffer solution containing $0.05 \%$ of Tween 20 and diluted to obtain final concentration containing $2 \times 10^{6}$ spores $/ \mathrm{mL}$ determined using hemocytometer.

\section{Cell free supernatant (CFS) preparation}

The selected LAB were cultured in $100 \mathrm{~mL}$ Erlenmeyer with an initial concentration of $10^{6} \mathrm{CFU} / \mathrm{mL}$ in $50 \mathrm{~mL}$ of MRS broth (pH 6.5) and was incubated at $30^{\circ} \mathrm{C}$ for $72 \mathrm{~h}$. Afterwards, CFS was prepared by centrifugation at $12000 \mathrm{RPM}$ for $5 \mathrm{~min}$ at $4^{\circ} \mathrm{C}$ (to remove the cells) and sterile filtration $(0.45 \mu \mathrm{m}$ pore size filter; Millipore). CFS was concentrated by ammonium sulfate precipitation method and dialyzed with phosphate buffered saline $\mathrm{pH} 7.4$ (PBS) and stored at $-20^{\circ} \mathrm{C}$ for further use. CFS obtained was used for determination of the antifungal activity.

\section{Screening of antifungal activity}

In the preliminary screening, modification of microtitre plate well method was used. In this method, $60 \mu \mathrm{L}$ of SCF, $40 \mu \mathrm{L}$ PDB and $20 \mu \mathrm{L}$ of a spore suspension $\left(2 \times 10^{6}\right.$ spores $\left./ \mathrm{mL}\right)$ were added to each well of a sterile 96-well microplate (Sarstedt AG \& Co., Nuembrecht, Germany). Microcultures containing $60 \mu \mathrm{L}$ of sterile tap water instead of SCF were used as a negative control. The commercial fungicide cycloheximide at $0.5 \mathrm{mg} / \mathrm{mL}$ was used as a positive control. All samples were placed in triplicate on the plates. Plates were kept in sterile glass petridish to avoid contamination from outside during incubation. Observation was done after 5 days of incubation at $25^{\circ} \mathrm{C}$.

Selected strains from pre-screening were tested again with well diffusion agar technique. Total of 10 $\mathrm{mL}$ of soft agar at $40^{\circ} \mathrm{C}$ containing $10^{6}$ spores $/ \mathrm{mL}$ were surface spread on the PDA (2\% agar) plates. Wells of $8 \mathrm{~mm}$ diameter were cork bored in the soft agar. Aliquots $(100 \mu \mathrm{L})$ of the CFS were poured into the wells, and the plates were incubated at $25^{\circ} \mathrm{C}$ for $72 \mathrm{~h}$. Un-inoculated MRS broth acidified at $\mathrm{pH} 4(\mathrm{HCl} 1 \mathrm{M})$ was used as negative control. After incubation, the plates were examined for the presence of a growth inhibition halo around each well. Experiments were performed in triplicates. The LAB isolates showing potent antifungal activity were selected for further study (Fungal biomass inhibition).

To determine the characteristics of the antifungal compounds, the CFS showing antifungal effect were subjected to heating $\left(100^{\circ} \mathrm{C}\right.$ for $\left.15 \mathrm{~min}\right)$, neutralization (adjust to $\mathrm{pH} 7$ ) with $3 \mathrm{~N} \mathrm{NaOH}$, and proteinase

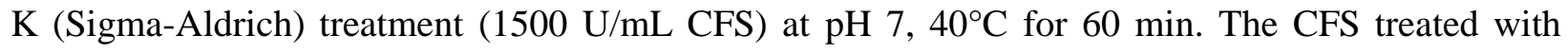
proteinase $\mathrm{K}$ were adjusted to $\mathrm{pH} 4$ before antifungal assay. Well diffusion agar technique used as described earlier.

\section{Fungal biomass inhibition}

Test was carried out by using selected CFS from screening step. Ten percent of CFS were prepared in $50 \mathrm{~mL}$ MRS medium and inoculated with a $8 \mathrm{~mm}$ diameter fungal disc. The flasks were incubated at $25^{\circ} \mathrm{C}$ for 12 days. Flask without CFS served as control. After incubation, fungal mat was harvested, filtered (Whatman No. 4 filter papers), washed twice thoroughly with distilled water and dried with freeze dryer. Fungal biomass of each treatment was weighed and compared with the control. The 
experiment was conducted in triplicate. Fungal growth inhibition (\%) was calculated according to the following formula:

$$
\text { Fungal growth inhibition }(\%)=\left[\frac{(\text { Total control weight }- \text { Total sample weight })}{\text { Total control weight }}\right] \times 100
$$

\section{Scanning Electron Microscopy (SEM) analysis}

SEM was employed to visualize the morphology and structure of $F$. proliferatum BJ09.05 and to know the possible mechanism or interaction between L. plantarum B.BS08 and F. proliferatum BJ09.05. SEM method was according to method of Alves et al. (2013) with modification. The samples were transferred to silica coverslip with suspension method and fixed with $2.5 \%$ (v/v) glutaraldehyde and $0.1 \%(\mathrm{v} / \mathrm{v})$ tannic acid overnight at fridge $\left(4^{\circ} \mathrm{C}\right)$ on aluminium cover. Post-fixing with $1 \%$ osmium tetraoxide for $45 \mathrm{~min}$. Rinsing three times in distilled water and then followed by dehydration in crescent series of ethanol $(30,50,70,80,90$ and 95\%), continue dehydration with $99 \%$ ethanol for three times and $100 \%$ ethanol for three times. Afterwards, the samples were transferred to a critical point dryer to complete the drying process with carbon dioxide as a transition fluid. The samples were air dried, mounted on aluminium stub using double sided carbon tape and liquid silver on two edge, and kept in vacuum dessicator until observing. Obervation was done with a Hitachi H-7600, equipped with a MegaView 3 CCD camera (SIS, Soft Ipawing Solutions, Münster, Germany) in Max Planck Institute Biophysical and Chemistry, Göttingen Germany.

\subsubsection{Antifungal Compounds Analysis PCR amplification of LDH encoding gene.}

PCR procedure has been described previously by Zhang et al. (2014) with litle modification. Forward primer: CATCAAAAAGTTGTGTTAGTCGGCG Backward primer: TCAGCTAAACCGTCGTTAAGCACTT PCR was performed in a final volume of $50 \mu \mathrm{L}$ of PCR Master Mix containing $4 \mu \mathrm{L}$ primers for the LDH gene, 5.0 $\mu \mathrm{L}$ dNTP, $19.0 \mu \mathrm{L}$ ddH2O, $2.0 \mu \mathrm{L}$ DNA, and 25.0 $\mu \mathrm{L}$ MIX high fidelity DNA Polymerase. Amplifications were carried out in peQ STAR Thermocycler (96 Universal Gradient) under the following programs: initial denaturation for $3 \mathrm{~min}$ at $94{ }^{\circ} \mathrm{C}$, followed by 30 cycles consisting of pre-denaturation $94{ }^{\circ} \mathrm{C}$ for $45 \mathrm{~s}$, annealing at $52{ }^{\circ} \mathrm{C}$ for $1 \mathrm{~min}$, and elongation at $72{ }^{\circ} \mathrm{C}$ for $1 \mathrm{~min}$. Amplification fragments were determined using electrophoresis on $0.8 \%$ agarose gel. After staining with ethidium bromide $\left(0.5 \mu \mathrm{g} \mathrm{mL}^{-1}\right)$ and destaining in demineralized water (each for $\left.10 \mathrm{~min}\right)$, DNA bands were visualized in UV light using a CCD camera (Vilber Lourmat, Marne La Vallee, France).

Titratable acidity (organic acid content)

Procedure (Lonner, 1988) as described earlier.

\section{Phenyllactic acid (PLA) extraction and determination with HPLC-MS/MS}

CFS are extracted using ethyl acetate $(1: 1, \mathrm{v} / \mathrm{v})$ in falcon tube. Two fraction were collected (polar an non polar fraction). Polar fractions were concentrated under reduced pressure (Büchi, Rotary Evaporator). The dried polar extracts were dissolved in $500 \mu \mathrm{L}\left(\mathrm{MeOH}: \mathrm{H}_{2} \mathrm{O}, 1: 1\right.$, v/v), and stored at $20^{\circ} \mathrm{C}$ until analysis commenced.

PLA separation and analysis were carried out using a high pressure liquid chromatography system equipped with an autosampler (ProStar 410, Varian, Darmstadt, Germany), a binary pump system, a 
degasser and a column oven (Jetstream 2 plus, Techlab, Germany) coupled to an electrospray ionization (ESI) source followed by an ion trap mass spectrometer (500 MS, Varian, Darmstadt, Germany). PLA separation was carried out by high pressure liquid chromatography using a reverse phase column Kinetex C18 $(50.0 \times 2.1 \mathrm{~mm}$, particle $2.6 \mu \mathrm{m})$ coupled with a C18 security guard cartridge ( $4 \mathrm{~mm} \times 2 \mathrm{~mm}$ i.d., both from Phenomenex, Aschaffenburg, Germany) maintained at a temperature of $40^{\circ} \mathrm{C}$. An aliquot of $10 \mu \mathrm{L}$ of the sample was used for injection. The mobile phase consisted of water with $5 \%$ acetonitrile (A) and methanol (B), both containing $0.01 \mathrm{mM}$ sodium acetate and $7 \mathrm{mM}$ acetic acid. The binary gradient used was: 0-3 min from 40 to $80 \% \mathrm{~B}, 3-8 \mathrm{~min}$ from 80 to $98 \% \mathrm{~B}, 8-11 \mathrm{~min}$ at $98 \% \mathrm{~B}, 11-11.5 \mathrm{~min}$ from 98 to $40 \% \mathrm{~B}$ and finally from $11.5-16.5$ at $40 \% \mathrm{~B}$. The flow rate was set to $0.2 \mathrm{~mL} \mathrm{~min}^{-1}$. ESI was operated in positive mode for all analytes with the following settings: spray chamber temperature $50^{\circ} \mathrm{C}$, nebulizing gas (nitrogen) $50 \mathrm{psi}$, drying gas (nitrogen) 25 psi at $350{ }^{\circ} \mathrm{C}$, shield voltage $600 \mathrm{~V}$, needle voltage $5000 \mathrm{~V}$, trap damping gas (helium) $0.8 \mathrm{~mL} \mathrm{~min}^{-1}$. The detector was operated in standard mode with $15.000 \mathrm{Da} \mathrm{sec}^{-1}$.

\subsubsection{New tempeh starter production and its application Modern tempeh starter production}

LAB dry starter production: Growing LAB starter on MRS medium at $37^{\circ} \mathrm{C}$ for $24 \mathrm{~h}$ with shaker. The production of dry starter for selected isolates was done using spray dryer with tapioca acid matrix as coating medium. A $500 \mathrm{~mL}$ sample was prepared by mixing $400 \mathrm{~mL}$ of a $1 \%$ (w / v) sterile matrix solution with $100 \mathrm{~mL}$ of LAB culture at the optimum growth stage, then dried with a spray dryer at an inlet temperature of $170^{\circ} \mathrm{C}$ and an outlet of $70^{\circ} \mathrm{C}$. Dry starter then kept in plastic container at fridge temperature $4^{\circ} \mathrm{C}$.

$R$. microsporus var. oligosporus dry starter production: Cassava was peeled, washed and then shredded roughly. Cassava was then steamed for $30 \mathrm{~min}$ then cooled (aerated). Innoculation with pure $R$. oligosporus culture done by adding $20 \mathrm{~mL}$ spore suspension $\left(2 \times 10^{6}\right.$ spores $\left./ \mathrm{mL}\right)$ into 500 gram steamed cassava and incubation for $60 \mathrm{~h}$ in $30^{\circ} \mathrm{C}$. Samples were dried by cabinet dryer in $40-45^{\circ} \mathrm{C}$ for $48 \mathrm{~h}$ and powdered in 120 mesh size. Dry starter then kept in plastic container at fridge temperature $4^{\circ} \mathrm{C}$.

Mixing starter: $R$. microsporus var. oligosporus and LAB starter powders were mixed with a ratio of 75:25 (w/w) to further use in tempeh making.

\section{Application in tempeh model}

Tempe making was done as follows: $60 \mathrm{~g}$ of soybeans as raw material were washed and boiled for 30 min (ratio tap water:raw materials $=5: 1$ ), then dehulled manually. The raw materials were soaked in tap water for $18 \mathrm{~h}$ at room temperature (ratio tap water : raw material $=3: 1$ ). Furthermore, materials were boiled again 30 min with the same ratio before, drained and dried-aired until ready at room temperature and inoculated with $5 \mathrm{~g}$ of dry starter. After inoculation, samples were placed on petridish and incubated at a temperature $30^{\circ} \mathrm{C}$ for $48 \mathrm{~h}$. Samples then frozen $-20^{\circ} \mathrm{C}$ and dried with freeze dryer. Samples were powdered and kept in $-20^{\circ} \mathrm{C}$ for analysis.

Treatment consists of: negative control (tempe made only with pure $R$. microsporus var. oligosporus starter), tempeh made with modern starter plus contamination of $F$. proliferatum, and positive control (tempe made only with $F$. proliferatum innoculation). Contamination was made by adding $3 \mathrm{~mL}$ of spore suspension $F$. proliferatum $\left(10^{6}\right.$ spores $\left./ \mathrm{mL}\right)$ to the raw materials. Analysis of $F$ proliferatum biomass done by qPCR technique. 


\section{Part III (Zearalenone biotransformation by tempeh yeast and LAB)}

\subsubsection{Microorganism and in vitro test (in liquid culture)}

Yeast and lactic acid bacteria (LAB) strains used for in vitro test could be seen on Table 2. In brief, Stock cultures were grown in specific liquid medium (Yeast Glucose Broth for yeast and de Man, Rogosa and Sharpe broth for LAB) for 3 days at $30^{\circ} \mathrm{C} 150$ RPM (Innova44, New Brunswick Scientific Co). Cell suspension of each isolates were arranged (OD $600=0.8$ ) using a spectrofotometer.

Liquid medium was used as media in in vitro screening. Fifty milliliters of the liquid medium was poured into the 250-mL Erlenmeyer flask, the flask was closed with a cellulose plug and then autoclaved $\left(120^{\circ} \mathrm{C}, 15 \mathrm{psi}, 15 \mathrm{~min}\right.$; Autoclave $\left.3870 \mathrm{EL}\right)$. The sterile liquid media was inoculated with $2 \mathrm{~mL}$ cell suspension $(\mathrm{OD} 600=0.8)$ and then incubated at $30^{\circ} \mathrm{C}$ for 2 days in a rotary shaker (Innova44, New Brunswick Scientific Co) at 150 RPM.

For the treatment, $1 \mathrm{~mL}$ working solution of zearalenone (Sigma-Aldrich Chemie GmbH, Steinheim, Germany) ( $c=5 \mu \mathrm{g} / \mathrm{mL}$; methanolic solution) was added to the liquid culture. Medium without culture was added with $1 \mathrm{~mL}$ working solution of zearalenone as positive control. Instead of zearalenone, $1 \mathrm{~mL}$ methanol was added to the culture as negative control. The incubation was continued in the rotary shaker for 1 day. Five hundred microliters of the liquid media was transferred into a 1.5-mL Eppendorf tube and $500 \mu \mathrm{L}$ of ice-cold acetonitrile (Th. Geyer Co) was added for protein precipitation. Samples were then stored overnight at $4{ }^{\circ} \mathrm{C}$ and centrifuged at 9800 RPM for 5 minutes. The supernatant was transferred to a HPLC (high performance liquid chromatography) vial and analyzed by HPLC hyphenated to tandem mass spectrometry (HPLCMS/MS).

Table 2. Some isolates of yeast and lactic acid bacteria (LAB) used for in vitro test.

\begin{tabular}{|c|c|c|c|}
\hline Microbes name & Original source & & $\begin{array}{c}\text { Year } \\
\text { sampling }\end{array}$ \\
\hline $\begin{array}{l}\text { Saccaromycopsis fibuligera } \\
\text { Y.BS01 (Y1) }\end{array}$ & $\begin{array}{l}\text { Soak water (natural acidification } \\
\text { Manufacture Banyumas }\end{array}$ & step), & 2015 \\
\hline $\begin{array}{l}\text { Saccaromycopsis fibuligera } \\
\text { Y.ASC06 (Y2) }\end{array}$ & $\begin{array}{l}\text { Soak water (natural acidification step), } \\
\text { Manufacture Bogor }\end{array}$ & & 2015 \\
\hline $\begin{array}{l}\text { Pichia kudriavzevii Y.BS09 } \\
\text { (Y3) }\end{array}$ & $\begin{array}{l}\text { Soak water (natural acidification step), } \\
\text { Manufacture Banyumas }\end{array}$ & & 2015 \\
\hline $\begin{array}{l}\text { Candida tropicalis Y.BS07 } \\
\text { (Y4) }\end{array}$ & $\begin{array}{l}\text { Soak water (natural acidification step), } \\
\text { Manufacture Banyumas }\end{array}$ & & 2015 \\
\hline $\begin{array}{l}\text { Kluyveromyces marxianus } \\
\text { Y.BS08 (Y5) }\end{array}$ & $\begin{array}{l}\text { Soak water (natural acidification step), } \\
\text { Manufacture Banyumas }\end{array}$ & & 2015 \\
\hline $\begin{array}{l}\text { Schizosaccaromyces pombe } \\
\text { Y.MSR02 (Y6) }\end{array}$ & $\begin{array}{l}\text { Soak water (natural acidification } \\
\text { Manufacture Malang }\end{array}$ & step), & 2015 \\
\hline $\begin{array}{l}\text { Meyerozyma guilliermondi } \\
\text { Y.KSM11 (Y7) }\end{array}$ & $\begin{array}{l}\text { Soak water (natural acidification step), } \\
\text { Manufacture Jogja }\end{array}$ & & 2015 \\
\hline $\begin{array}{l}\text { Schizosaccaromyces pombe } \\
\text { Y.MSR02 (Y8) }\end{array}$ & $\begin{array}{l}\text { Soak water (natural acidification step), } \\
\text { Manufacture Malang }\end{array}$ & & 2015 \\
\hline $\begin{array}{l}\text { Saccaromyces cerevisiae Y. } \\
\text { BSC09 (Y9) }\end{array}$ & $\begin{array}{l}\text { Soak water (natural acidification } \\
\text { Manufacture Banyumas }\end{array}$ & step), & 2015 \\
\hline
\end{tabular}




\begin{tabular}{|c|c|c|}
\hline $\begin{array}{l}\text { Saccaromyces cerevisiae } \mathrm{Y} . \\
\mathrm{BSC} 10 \text { (Y10) }\end{array}$ & $\begin{array}{l}\text { Soak water (natural acidification step), } \\
\text { Manufacture Banyumas }\end{array}$ & 2015 \\
\hline $\begin{array}{l}\text { Meyerozyma guilliermondi } \\
\text { Y.MSR11 (Y11) }\end{array}$ & $\begin{array}{l}\text { Soak water (natural acidification step), } \\
\text { Manufacture Malang }\end{array}$ & 2015 \\
\hline $\begin{array}{l}\text { Meyerozyma guilliermondi } \\
\text { Y.BS02 (Y12) }\end{array}$ & $\begin{array}{l}\text { Soak water (natural acidification step), } \\
\text { Manufacture Banyumas }\end{array}$ & 2015 \\
\hline$(+)$ control & $\begin{array}{l}\text { Yeast Glucose Broth without culture was added } \\
\text { with } 1 \mathrm{~mL} \text { working solution of ZEN }\end{array}$ & \\
\hline (-) control & $1 \mathrm{~mL}$ methanol was added to the culture & \\
\hline $\begin{array}{l}\text { Lactobacillus plantarum } \\
\text { B.BS10 (L1) }\end{array}$ & $\begin{array}{l}\text { Soak water (natural acidification step), } \\
\text { Manufacture Banyumas }\end{array}$ & 2015 \\
\hline $\begin{array}{l}\text { Pediococcus pentosaceus } \\
\text { B.BSC07 (L2) }\end{array}$ & $\begin{array}{l}\text { Soak water (natural acidification step), } \\
\text { Manufacture Banyumas }\end{array}$ & 2015 \\
\hline $\begin{array}{l}\text { Lactobacillus paracasei } \mathrm{B} . \\
\text { KSM06 (L3) }\end{array}$ & $\begin{array}{l}\text { Soak water (natural acidification step), } \\
\text { Manufacture Jogja }\end{array}$ & 2015 \\
\hline $\begin{array}{l}\text { Lactobacillus paracasei } \mathrm{B} . \\
\text { KSM11 (L4) }\end{array}$ & $\begin{array}{l}\text { Soak water (natural acidification step), } \\
\text { Manufacture Jogja }\end{array}$ & 2015 \\
\hline P. pentosaceus B.MSR10 (L5) & $\begin{array}{l}\text { Soak water (natural acidification step), } \\
\text { Manufacture Malang }\end{array}$ & 2015 \\
\hline L. plantarum B.BSC09 (L6) & $\begin{array}{l}\text { Soak water (natural acidification step), } \\
\text { Manufacture Banyumas }\end{array}$ & 2015 \\
\hline L. plantarum B.BS03 (L7) & $\begin{array}{l}\text { Soak water (natural acidification step), } \\
\text { Manufacture Banyumas }\end{array}$ & 2015 \\
\hline L. plantarum B.BS01 (L8) & $\begin{array}{l}\text { Soak water (natural acidification step), } \\
\text { Manufacture Banyumas }\end{array}$ & 2015 \\
\hline (+) control & $\begin{array}{l}\text { MRS broth without culture was added with } 1 \mathrm{~mL} \\
\text { working solution of ZEN }\end{array}$ & \\
\hline (-) control & $1 \mathrm{~mL}$ methanol was added to the culture & \\
\hline
\end{tabular}

\subsubsection{HPLC-MS/MS analysis}

Mycotoxin separation and analysis was carried out by high pressure liquid chromatography coupled with electrospray ionization and tandem mass spectrometry detection. HPLC-MS/MS was performed on an API 4000 mass spectrometer (AB Sciex, MA) connected to an Agilent 1100 series HPLC (Agilent Technologies GmbH, Böblingen, Germany). The analytical column was a ProntoSIL 120-5-C18 AQ (150 mm x 3 mm, $5 \mu \mathrm{m}$; Bischoff Chromatography, Leonberg, Germany), preceded by a ProntoSIL 120-5-C18 AQ guard column (10 mm x 3 mm, $5 \mu \mathrm{m})$. Mobile phase A was water with $5 \mathrm{mM}$ ammonium acetate and as mobile phase B acetonitrile/water (99: $1 \mathrm{v} / \mathrm{v}$ ) with $5 \mathrm{mM}$ ammonium acetate was used. Detailed protocol was according to Brodehl et al. (2014). 


\subsection{Results of Part I (Identification and characterization of tempeh yeast and LAB)}

Chemical and microbiological observation on soak water from different local tempeh factories

The measured $\mathrm{pH}$ and other parameter of the soak water taken from the local factories are shown in Table 3. The temperature and relative humidity in the workshop of all the six factories were around $26-29^{\circ} \mathrm{C}$ and $80-85 \%$, respectively. The temperature of supernatant in fermentation sinks was in the range of $28-30^{\circ} \mathrm{C}$, a little higher than the ambient temperature. The $\mathrm{pH}$ of the soak water in all factories decreased sharply from 7.3-7.5 to around 4.5-5.2 after $24 \mathrm{~h}$ of soaking time, while the TTA increased from 0.50 to around $6.01-6.77 \mathrm{mg} / \mathrm{mL}$ indicating that the medium was barely acidic. Organic acids of the supernatants mainly included lactic acid and acetic acid (data not shown), indicating that some of the LAB involved are heterofermentative and lactic acid was predominant among the two acids. The quite low acidity observed in the present work may be due to the fact that soak water contained sugar or starch that can be metabolized by LAB isolates. Warm temperature in the workshop might also support indigenous LAB and yeast to grow fast.

Table 3. Parameters obtained from local tempe factories.

\begin{tabular}{ccccccc}
\hline $\begin{array}{c}\text { Factories } \\
\text { (Locations) }\end{array}$ & $\begin{array}{c}\text { Material:water } \\
\text { ratio* }\end{array}$ & $\begin{array}{c}\text { Spontaneous } \\
\text { fermentation } \\
\text { (Soaking time) }\end{array}$ & $\begin{array}{c}\mathrm{pH} \text { value } \\
\text { of soak } \\
\text { water }\end{array}$ & $\begin{array}{c}\text { Titratable } \\
\text { acidity/TTA } \\
(\mathrm{mg} / \mathrm{mL})\end{array}$ & $\begin{array}{c}\text { Temperature } \\
\text { of soak } \\
\text { water } \\
\left({ }^{\circ} \mathrm{C}\right)\end{array}$ & $\begin{array}{c}\text { Temperature } \\
\left({ }^{\circ} \mathrm{C}\right) \text { and } \\
\text { humidity of } \\
\text { workshop } \\
(\%)\end{array}$ \\
\hline $\begin{array}{c}\text { Factory A } \\
\text { (Banyumas) } \\
\text { Factory B }\end{array}$ & $\mathrm{S}: \mathrm{C}: \mathrm{W}(5: 2: 8)$ & 24 & 5.2 & 6.13 & 28.3 & $27 ; 85$ \\
$\begin{array}{c}\text { (Banyumas) } \\
\text { Factory C }\end{array}$ & $\mathrm{S}: \mathrm{C}: \mathrm{W}(5: 2: 7)$ & 24 & 5.0 & 6.22 & 28.2 & $27 ; 85$ \\
$\begin{array}{c}\text { Yogyakarta) } \\
\text { Factory D } \\
\text { (Jakarta) }\end{array}$ & $\mathrm{S}: \mathrm{C}: \mathrm{W}(5: 3: 8)$ & 24 & 5.0 & 6.01 & 28.4 & $28 ; 86$ \\
$\begin{array}{c}\text { Factory E } \\
\text { (Bogor) }\end{array}$ & $\mathrm{S}: \mathrm{C}: \mathrm{W}(5: 2: 8)$ & 24 & 4.5 & 6.77 & 30.0 & $29 ; 85$ \\
$\begin{array}{c}\text { Factory F } \\
\text { (Malang) }\end{array}$ & $\mathrm{S}: \mathrm{C}: \mathrm{W}(5: 2: 9)$ & 24 & 4.8 & 6.25 & 28.3 & $26 ; 80$ \\
\hline
\end{tabular}

Note: *S: soybean, C: corn, W: tap water

The $\mathrm{pH}$ of tap water in all six factories was aroun 7.3-7.5

Table 4 shows the distribution of microorganisms in the soak water in the factories. The microbial numbers during fermentation differed among factories. LAB counts in soakwater varied between 5.21 and $8.88 \log \mathrm{CFU} / \mathrm{mL}$ whereas yeasts counts varied from 4.31 and $4.89 \log \mathrm{CFU} / \mathrm{mL}$ whereas APC counts varied between 7.33 and $9.10 \log$ CFU/mL. This result showed that the number of LAB is larger than yeast. Enterobacteriaceae was not detected in soak water with high LAB number. This seems dominant LAB could suppress the present of Enterobacteriaceae. The use of recycle soak water which applied by Factory D, E and F gave significant different microbial properties in their soak water, compared to Factory A, B and C (using only fresh soak water). 
Using previous soak water gave impact to higher number of LAB and avoid contamination Enterobacteriaceae. Daily addition of previous soakwater (backslopping) is a powerful method of obtaining a vigorous lactic fermentation. This 'accelerated natural lactic fermentation' results from the gradual selection of ecologically adapted acidifying organisms.

Table 4. Microbial counts $(\log \mathrm{CFU} / \mathrm{mL})$ of the soak water in six local factories

\begin{tabular}{lcccc}
\hline Factories & LAB & Yeast & APC & Enterobacteriaceae \\
\hline Factory A* & $5.36 \pm 0.33$ & $4.51 \pm 0.88$ & $7.45 \pm 0.41$ & $1.23 \pm 0.17$ \\
Factory B* & $5.21 \pm 0.51$ & $4.31 \pm 0.98$ & $7.33 \pm 0.42$ & $1.45 \pm 0.34$ \\
Factory C* & $7.11 \pm 0.77$ & $3.98 \pm 0.31$ & $7.50 \pm 0.63$ & $2.22 \pm 0.65$ \\
Factory D** & $8.88 \pm 0.35$ & $5.21 \pm 0.23$ & $9.10 \pm 0.13$ & ND \\
Factory E** & $8.31 \pm 0.34$ & $4.45 \pm 0.27$ & $8.80 \pm 0.55$ & ND \\
Factory F** & $8.22 \pm 0.29$ & $4.89 \pm 0.31$ & $8.50 \pm 0.23$ & ND \\
\hline
\end{tabular}

Note: LAB: lactic acid bacteria, APC: Aerobic plate count

Result given as means \pm SD of triplicate determination

ND refers to below detection level

* Using fresh soak water

** Use recycle/previous soak water (50\% total volume of soak water)

\section{Characterization and identification of LAB and yeast isolates from soak-water}

The species of LAB and yeast were identified according to phenotypic, and biochemical characterization. Identification into species level mainly on the basis of their sugar fermentation profiles in the API $50 \mathrm{CH}$ test for LAB. The isolated yeast strains were identified based on their physiologic and morphology characteristics as described in several authors (Kurtzman and Fell, 2000; Kurtzman et al., 2011). The identification into species level was performed based on API ID 32C test kit results, and also by the following tests: fermentation of sugars, assimilation of $\mathrm{KNO}_{3}$ and carbon compounds, assimilation of nitrogen compounds, growth in vitamin-free medium, growth at $37^{\circ} \mathrm{C}$, growth on $50 \%(\mathrm{w} / \mathrm{v})$ glucose yeast extract agar, resistance to $0.01 \%$ cyclo- heximide, and carbohydrate assimilation. To confirm the identification result we also check with DNA sequencing technique, by only choosing 1-4 representative strains from each species group that previously identified with API method.

One hundred yeast strains were isolated and identified as Schizosaccharomyces pombe (9 strains), Saccharomycopsis fibuligera (13 strains), Kluyveromyces marxianus (19 strains), Candida tropicalis (22 strains), Saccharomyces cerevisiae (22 strains), Meyerozyma guilliermondi (15 strains). Their physiologic, morphology, and API 32C identification are shown in Table 5 and Figure 2.

We isolated 22 S. cerevisiae species strains, oblong/eclipse, ovoid and (2-8) $\mathrm{x}(0.5-3.0) \mu \mathrm{m}$ that were detected after incubation for five days at $25{ }^{\circ} \mathrm{C}$. They produced ascospores but did not form pseudohyphae. Among them, 19 strains fermented glucose, galactose, sucrose, maltose, and raffinose, but not lactose. They could not assimilate cellobiose, lactose or inositol, but grew in a vitamin-free medium and also on 50\% (w/w) glucose yeast extract agar. Twenty-two smooth ovoid strains at sizes (1.5-3) x (5-7) $\mu \mathrm{m}$ were identified as $C$. tropicalis. Abundant pseudohyphae often radiating with clusters of blastoconidia at the center; variable appearance. Pseudohyphae is filament formed by the 


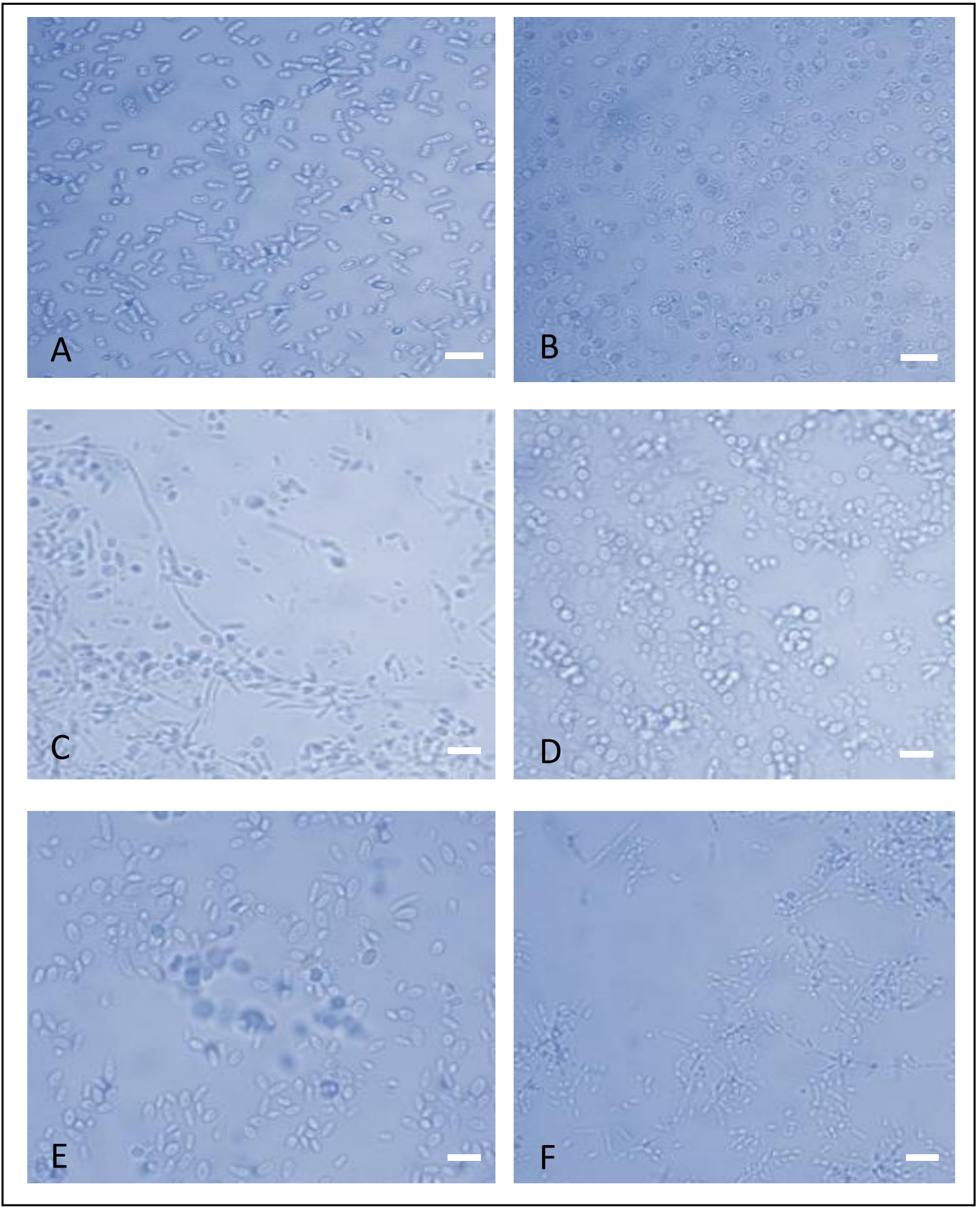

Figure 2. Yeast isolated from soak water (tempeh factories). A. Schizosaccharomyces pombe,

B. Saccharomycopsis fibuligera, C. Kluyveromyces marxianus, D. Candida tropicalis, E. Saccharomyces cerevisiae, F. Meyerozyma guilliermondi. Scale bar $=10 \mu \mathrm{m}$. 
budding of elongated cells which do not separate. The tip cell is short and there are constriction at the septa where the cells are connected. Nineteen spheroidal, ovoid or cylindrical strains at sizes (1.5-3) x (5-7) $\mu \mathrm{m}$ were identified as $K$. marxianus. They fermented glucose, galactose and lactose, and could assimilate glucose, galactose, sucrose, lactose, cellobiose, and trehalose. Fifteen ovoid and elongated yeasts strains at sizes of (3-11) x (2-4) $\mu \mathrm{m}$ were identified as Meyerozyma guilliermondi. They produced ascospores after incubation for five days at $25^{\circ} \mathrm{C}$ and formed pseudohyphae. They are most active in assimilating many kind of surgars. We found the three first yeast species group mentioned as dominant yeast in soak water. Detail explanation for other two yeast species group was also described in Table 5.

Sixty-five LAB strains were isolated and identified into three big group species. They are Lactobacillus plantarum (29 strains), L. paracasei (15 strains) and Pediococcus pentosaceus (21 strains). Their physiologic, morphology, and API $50 \mathrm{CH}$ test are shown in Table 6 . We found $L$. plantarum as dominant LAB in the soak water, followed by L. paracase $i$ and P. pentosaceus. They are recognized as heterofermentative $\mathrm{LAB}$.

To confirm the identification result from API system then sequencing assignment based on DNA were applied, by only choosing representative 2-4 strains from each species group of yeast and LAB. In addition to the restriction patterns, some of the yeast groups were also characterized by RAPD-PCR analysis. DNA fingerprinting were also used to see which strains identical and nonidentical from each species group (Figure 3). RAPD-PCR analysis has been reported to be a useful method for the differentiation of the yeast strains belonging to the same species (Dlauchy et al., 1999). Molecular identification of the LAB isolates was achieved with the amplification partial sequence 16S rRNA genes using the bacterial universal primers 27F (5'-AGA GTTTGATCMTGGCTCAG) (Lane, 1991) and bacterial primer 1100R (5'-AGGGTTGCG CTCGTTG) (Turner et al., 1999). For selected yeast, a touch down program was used for the amplification of the internal transcribed spacer region with the primers pairs (Invitrogen) ITS 4 (5'-TCCTCCGCTTATTGATATGC-3') and ITS 5 (5'GGAAGTAAAAGTCGTAACAAGG-3') (White et al., 1990). PCR amplification and DNA sequencing using the primer were successful, the blast of the sequenced regions gave conclusive results concerning the molecular taxonomy of the yeast and LAB. The phylogenetic tree can be seen in the Figure 4 and Figure 5.
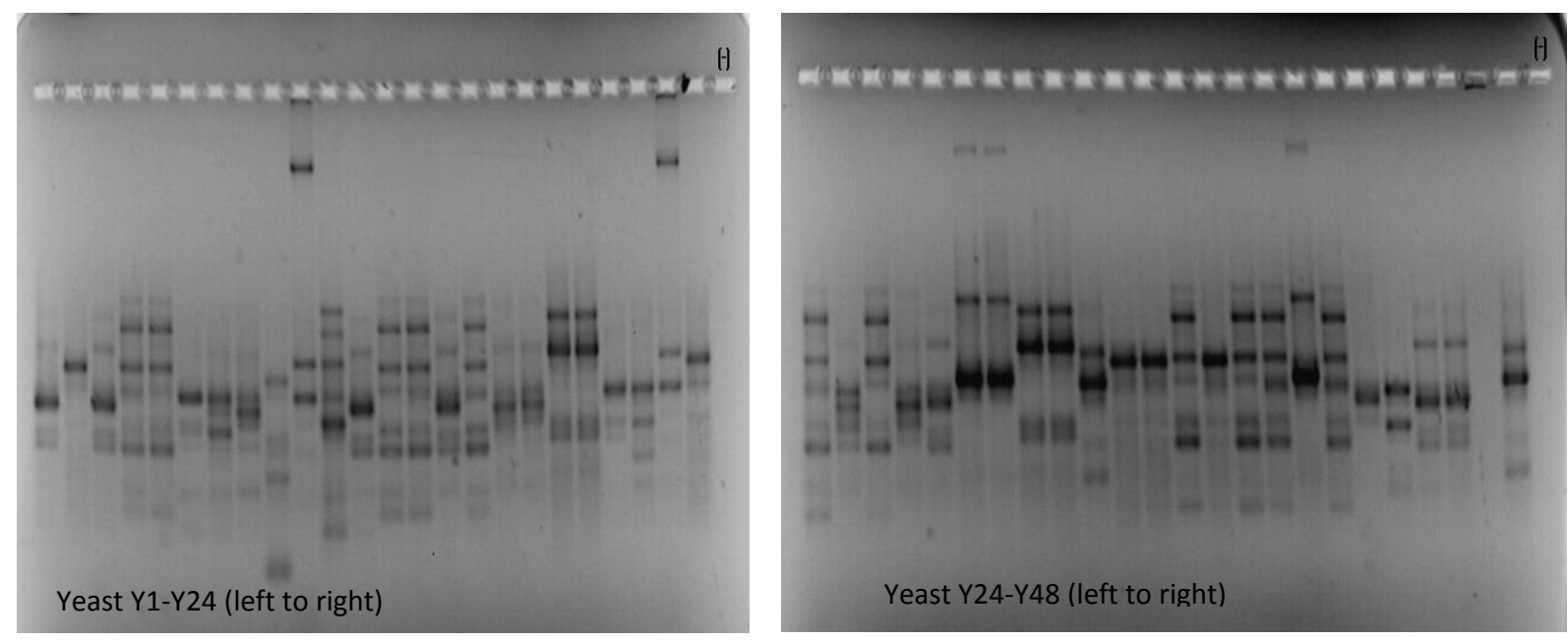

Figure 3. Some result of DNA fingerprinting from selected yeast isolates 


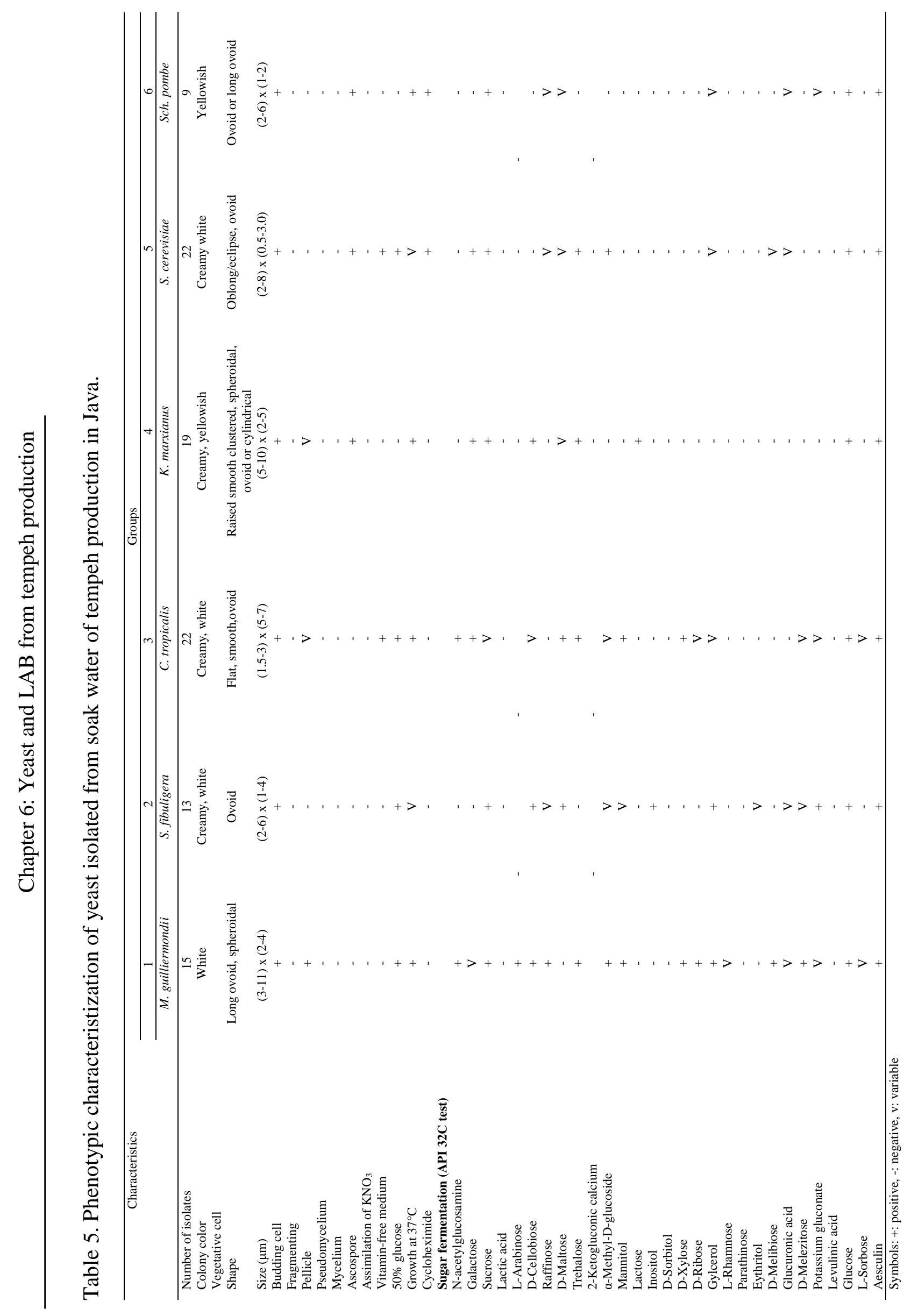


Table 6. Phenotypic characteristic of LAB isolated from soak water of tempeh production in Java.

\begin{tabular}{|c|c|c|c|}
\hline \multirow{2}{*}{ Characteristics } & \multicolumn{3}{|c|}{ Groups } \\
\hline & $\begin{array}{c}1: \\
\text { Pediococcus pentosaceus }\end{array}$ & $\begin{array}{c}2: \\
\text { Lactobacillus paracasei }\end{array}$ & $\begin{array}{c}\text { 3: } \\
\text { Lactobacillus } \\
\text { plantarum }\end{array}$ \\
\hline Number of isolates & 21 & 15 & 29 \\
\hline Shape & Coccus & Rod & Rod \\
\hline Gas from glucose & - & - & - \\
\hline Lactic acid isomer & DL & $\mathrm{L}$ & DL \\
\hline $\mathrm{NH} 3$ production from arginine & - & - & - \\
\hline \multicolumn{4}{|l|}{ Growth at $\mathrm{pH}$ value } \\
\hline 3.0 & - & - & - \\
\hline 3.5 & $\mathrm{~V}$ & $\mathrm{~V}$ & + \\
\hline 4.0 & + & + & + \\
\hline 4.5 & + & + & + \\
\hline 5.0 & + & + & + \\
\hline 9.0 & - & - & - \\
\hline 9.6 & - & - & - \\
\hline \multicolumn{4}{|l|}{ Growth in $\mathrm{NaCl}(w / v)$} \\
\hline $2.0 \%$ & + & + & + \\
\hline $3.0 \%$ & + & + & + \\
\hline $4.0 \%$ & + & + & + \\
\hline $6.0 \%$ & - & + & + \\
\hline $6.5 \%$ & - & + & + \\
\hline $8.0 \%$ & - & $\mathrm{V}$ & $\mathrm{V}$ \\
\hline $10.0 \%$ & - & - & - \\
\hline \multicolumn{4}{|l|}{ Growth at temperature $\left({ }^{\circ} \mathrm{C}\right)$} \\
\hline 10 & V & + & + \\
\hline 15 & + & + & + \\
\hline 45 & + & $\mathrm{V}$ & $\mathrm{V}$ \\
\hline 50 & - & - & - \\
\hline \multicolumn{4}{|l|}{$\begin{array}{l}\text { Sugar fermentation } \\
\text { (API 50CH test) }\end{array}$} \\
\hline $\mathrm{N}$-acetylglucosamine & + & + & + \\
\hline Amygdalin & + & + & + \\
\hline D-cellobiose & + & + & + \\
\hline Esculin & + & + & + \\
\hline D-Fructose & + & + & + \\
\hline D-Galactose & + & + & + \\
\hline D-Glucose & + & $\mathrm{V}$ & + \\
\hline Glycerol & + & + & + \\
\hline D-Lactose & V & V & + \\
\hline D-Maltose & - & + & + \\
\hline D-Mannitol & - & V & + \\
\hline D-Mannose & - & + & $\mathrm{V}$ \\
\hline D-Melibiose & - & - & $\mathrm{V}$ \\
\hline D-Raffinose & - & - & + \\
\hline D-Ribose & - & + & + \\
\hline Salicin & + & + & + \\
\hline D-Sucrose & + & + & + \\
\hline D-Trehalose & + & + & + \\
\hline
\end{tabular}

Symbols: +: positive, -: negative, v: variable 


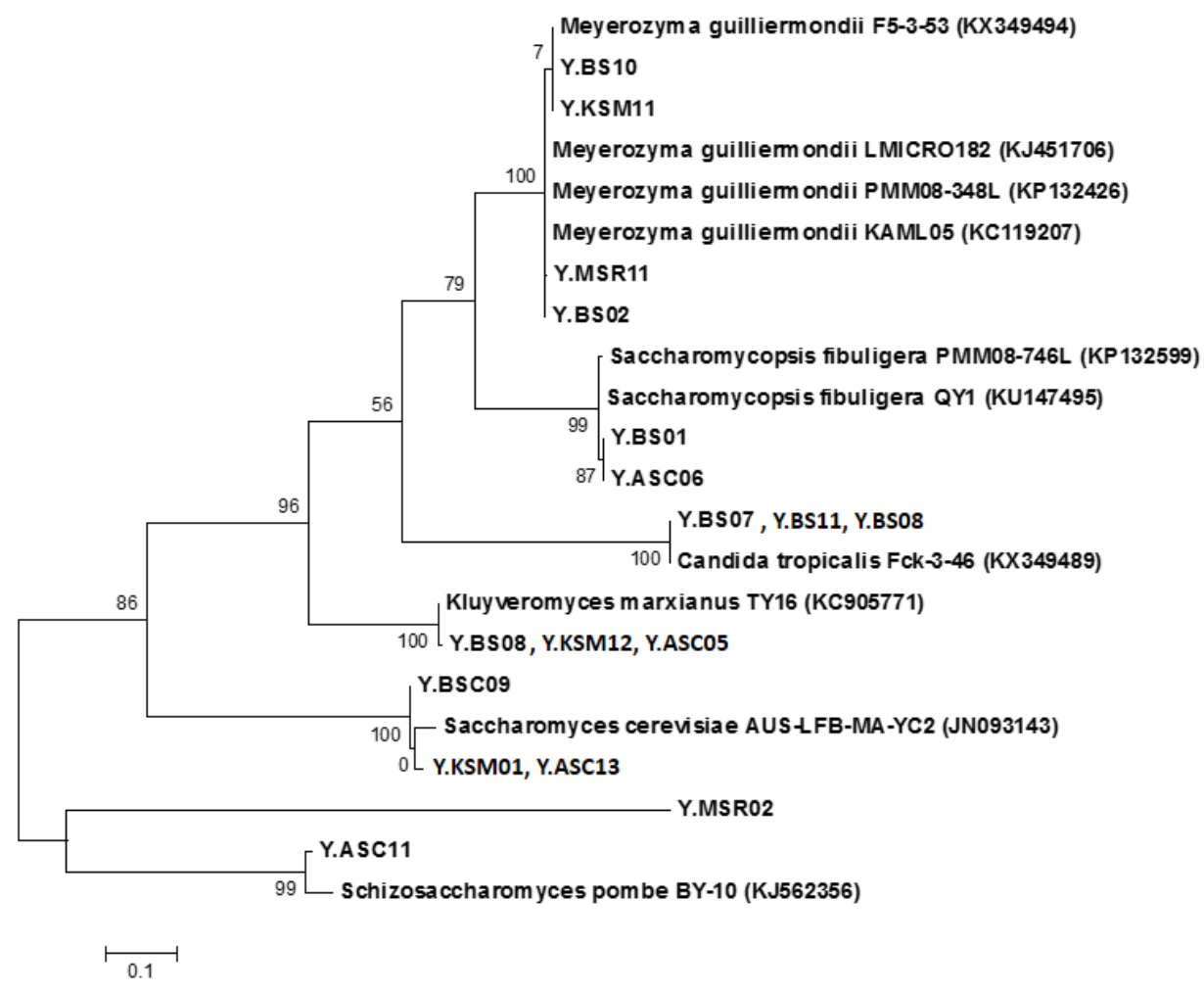

Figure 4. The tree was inferred from ITS sequence and constructed using maximum likelihood method (Yeast isolates). Numbers at nodes indicate levels of bootstrap support calculated from 1000 trees.

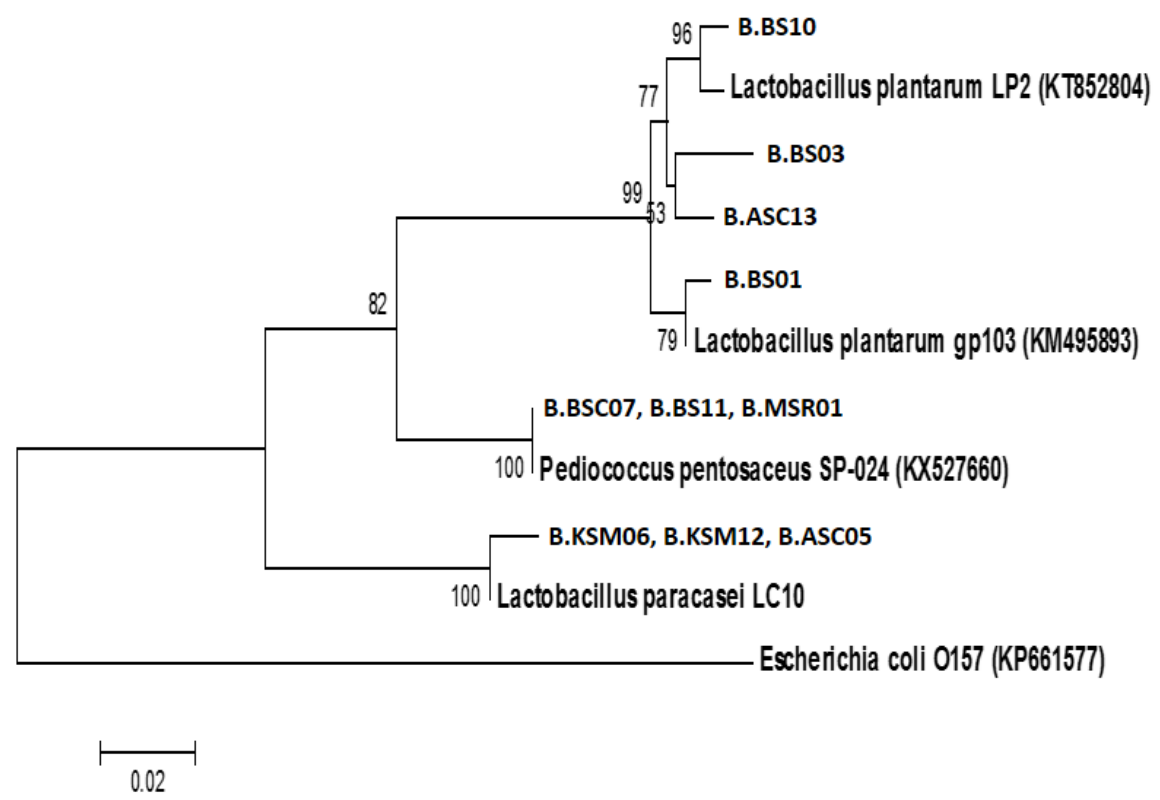

Figure 5. The tree was inferred from 16s RNA sequence and constructed using maximum likelihood method (LAB isolates). Numbers at nodes indicate levels of bootstrap support calculated from 1000 trees. 


\subsection{Discussion of Part I (Identification and characterization of tempeh yeast and LAB)}

The manufacture process of tempe was comprised two main fermentation stages, including a fermentation dominated by a natural bacterial microbiota during the preparatory soaking of soybeans and a fungal solid state fermentation stage, usually with Rhizopus microsporus var. oligosporus (Han and Nout 2000; Nout and Kiers 2005). There are a complex of microorganisms in soybean tempeh, their development start during the soaking of the raw ingredients (Nout and Kiers, 2005). This unique method preserves beneficial microorganisms and that indigenous microbiota plays a major role in the beginning tempeh production process, that may effect to end quality of the product especially the flavor and taste. In this study, we determined the composition of LAB and yeast, we also described their phenotypic, morphological and genotypic characteristics present in soak water from tempeh manufactures in Java.

The number of LAB and yeasts differed among manufatures and increased during soaking time. Steinkraus (1996) proposed that LAB create an acidic environment conducive to yeast proliferation while the yeasts provide vitamins and other growth factors such as amino acids for the lactic acid bacteria. The simultaneous increase in numbers of both LAB and yeasts may therefore be attributed to their symbiotic association. LAB counts in soak water varied between 5.21 and $8.88 \log \mathrm{CFU} / \mathrm{mL}$ whereas yeasts counts varied from 4.31 and $4.89 \log \mathrm{CFU} / \mathrm{mL}$ whereas APC counts varied between 7.33 and $9.10 \log \mathrm{CFU} / \mathrm{mL}$. This result showed that the number of $\mathrm{LAB}$ is larger than yeast. Enterobacteriaceae was not detected in soak water with high LAB number. This seems dominant LAB could suppress the present of Enterobacteriaceae. The use of recycle soak water which applied by Factory D, E and F gave significant different microbial properties in their soak water, compared to Factory A, B and C (using only fresh soak water). Using previous soak water gave impact to higher number of LAB and avoid contamination Enterobacteriaceae. Coliforms are known to be acid intolerant (Steinkraus, 1996). Similar results have also been reported for other fermented products (Mbugua, 1984; Nche et al., 1994). Other antimicrobial substances produced by the dominating lactic acid bacteria (Helander et al., 1997) in addition to lactic acid may also contribute to inhibition of Enterobacteriaceae (Nche et al., 1994). Daily addition of previous soakwater (backslopping) is a powerful method of obtaining a vigorous lactic fermentation. This 'accelerated natural lactic fermentation' results from the gradual selection of ecologically adapted acidifying organisms.

Moreno et al. (2002) reported the growth of lactic acid bacteria during in tempeh production in Malaysia. Count of LAB, bacteria on raw beans were low $\left(<10^{2} \mathrm{CFU} / \mathrm{g}\right)$. The number of $\mathrm{LAB}$ on the soaking water increased to $7.9-9.3 \log \mathrm{CFU} / \mathrm{mL}$ at the end of the soaking process and 7.8-9.2 $\log$ CFU/g in the soaked soybean. Second boiling of the beans results in reductions of $\mathrm{LAB}$ populations to less than $4 \log \mathrm{CFU} / \mathrm{g}$. The number increased sharply to 6.8-9.9 log CFU/g in final product (tempeh) (Moreno et al. 2002). Nuraida et al. (2008) and Efriwati et al. (2013) reported change in $\mathrm{LAB}$ number during tempeh preparation at a laboratory level. Nuraida et al. (2008) reported LAB population on soaked soybeans reached $9 \log$ CFU/g. However, the number decreased to $6 \log \mathrm{CFU} / \mathrm{g}$ on tempeh. Efriwati et al. (2013) reported two methods applied in producing $\mathrm{LAB}$ in tempeh preparation, namely one- and two-time boiling steps. At the end of 
soaking process, number of LAB produced from these two methods reach $6 \log \mathrm{CFU} / \mathrm{g}$. When soybeans are boiled once (one time boiling step), LAB number increases to $8 \log \mathrm{CFU} / \mathrm{g}$, greater than the population results in two-time boiling steps i.e. $6.5 \mathrm{log} \mathrm{CFU} / \mathrm{g}$.

The species of $\mathrm{LAB}$ and yeast were identified according to phenotypic, and biochemical characterization. Identification into species level mainly on the basis of their sugar fermentation profiles in the API $50 \mathrm{CH}$ test for LAB and API ID 32C test for yeast. One hundred yeast strains were isolated and identified as Schizosaccharomyces pombe (9 strains), Saccharomycopsis fibuligera (13 strains), Kluyveromyces marxianus (19 strains), Candida tropicalis (22 strains), Saccharomyces cerevisiae (22 strains), Meyerozyma guilliermondi (15 strains). Sixty-five LAB strains were isolated and identified into three big group species. They are Lactobacillus plantarum (29 strains), L. paracasei (15 strains) and Pediococcus pentosaceus (21 strains). We found $L$. plantarum as dominant LAB in the soak water, followed by L. paracase $i$ and P. pentosaceus. They are recognized as heterofermentative LAB. L. plantarum has been shown to be the dominant organism at the end of several natural cereal fermentations (Olasupo et al., 1997) as for instance in maize-derived products like ogi (Steinkraus, 1996). L. plantarum has also been identified as the predominant species in most vegetable fermentations (Oyewole and Odunfa, 1990). The dominance of $L$. plantarum at the late stages of fermentation has been attributed to its high acid tolerance (Hounhouigan et al., 1993).

To confirm the identification result from API system then sequencing assignment based on DNA were applied, by only choosing representative 2-4 strains from each species group of yeast and LAB. In addition to the restriction patterns, some of the yeast groups were also characterized by RAPD-PCR analysis. DNA fingerprinting were also used to see which strains identical and non-identical from each species group. RAPD typing was capable of producing discriminating DNA fingerprints of yeast isolates and indicated there were genetic differences among them. RAPD-PCR analysis has been reported to be a useful method for the differentiation of the yeast strains belonging to the same species (Dlauchy et al., 1999). Molecular identification of the LAB isolates was achieved with the amplification partial sequence 16S rRNA genes using the bacterial universal primers 27F (5'-AGAGTTTGATCMTGGCTCAG) (Lane, 1991) and bacterial primer 1100R (5'-AGGGTTGCGCTCGTTG) (Turner et al., 1999). For selected yeast, a touch down program was used for the amplification of the internal transcribed spacer region with the primers pairs ITS 4 (5'-TCCTCCGCTTATTGATATGC-3') and ITS 5 (5'-GGAAGTAAAAGTC GTAACAAGG-3') (White et al., 1990). PCR amplification and DNA sequencing using the primer were successful, the blast of the sequenced regions gave conclusive results concerning the molecular taxonomy of the yeast and LAB. The sequencing results are similar with API.

In conclusion, tempe is not the product of a pure culture fermentation with $R$. microsporus var. oligosporus, bacterial and yeast species are also essential components of the fermentation. The acidification of soak water was reported to be an important process step enabling the control of the growth of food-borne pathogens and ensuring the microbiological safety of the final tempe. In this study, culturable yeast and LAB isolates have been successfully identified from soak water in tempeh production from six different manufactures. 


\subsection{Results of Part II (Antifungal activity from tempeh yeast and LAB)}

\section{Screening and characterization of antifungal activity from tempeh yeast and LAB isolates}

Lactic acid bacteria (LAB) and yeast have been exploited for decades for their antibacterial activity. More recently, they have also received scientific attention because of their antifungal potential (Magnusson et al., 2003; Dal Bello et al., 2007). In this study, we searched LAB or yeast isolates that have antifungal activity against harmfull fungus $F$. proliferatum that found as contaminant in traditional tempeh.

In a first screening, out of 165 isolates tempeh yeast and LAB from natural acidification process (tempeh industry) were screened with 96 plates method using their CFS extract (cell-free supernatant). About $12 \%$ of total isolates showed antifungal activity against $F$. proliferatum. Of these, $20 \mathrm{LAB}$ strains have consistent antifungal activity. No antifungal activity was observed in all yeast isolates. Both the mycelium growth and sporulation mostly were inhibited by active CFS LAB (Figure 4).

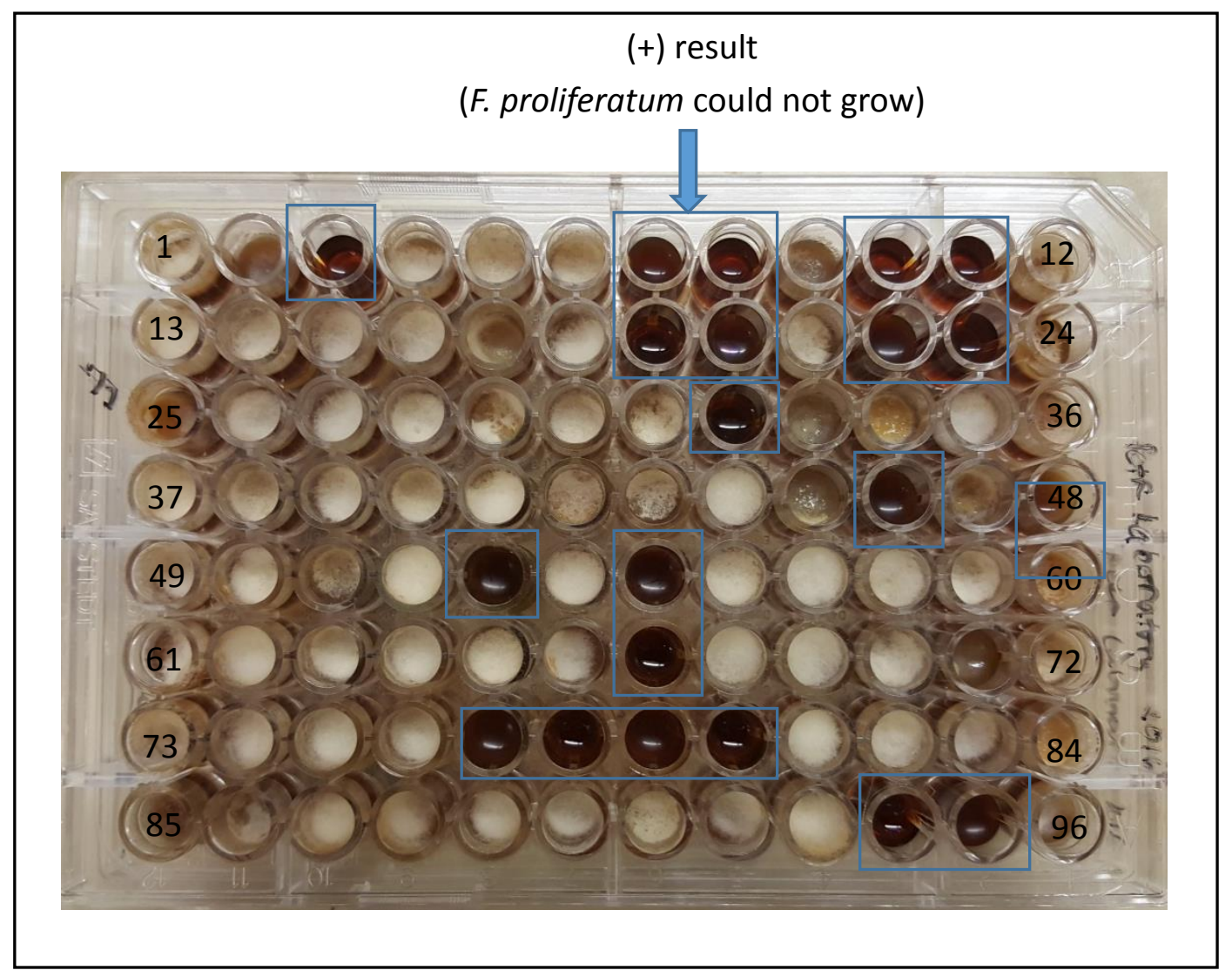

Figure 4. Screening of antifungal activity from tempeh yeast and LAB against $F$. proliferatum using their CFS (cell free supernatant) in 5 days incubation. (First 96 isolates screening) 
Positive screening results were checked again with well test method and biomass reduction test. The result confirmed that there is variation in inhibition of $F$. proliferatum (Figure $5 \& 6$, Table 7). In brief, three best strains were obtained, they are Lactobacillus plantarum B.BS08, $L$. plantarum B.BS10 and L. paracasei B.KSM06 with strong inhibitory activity and great reduction in fungal biomass production.

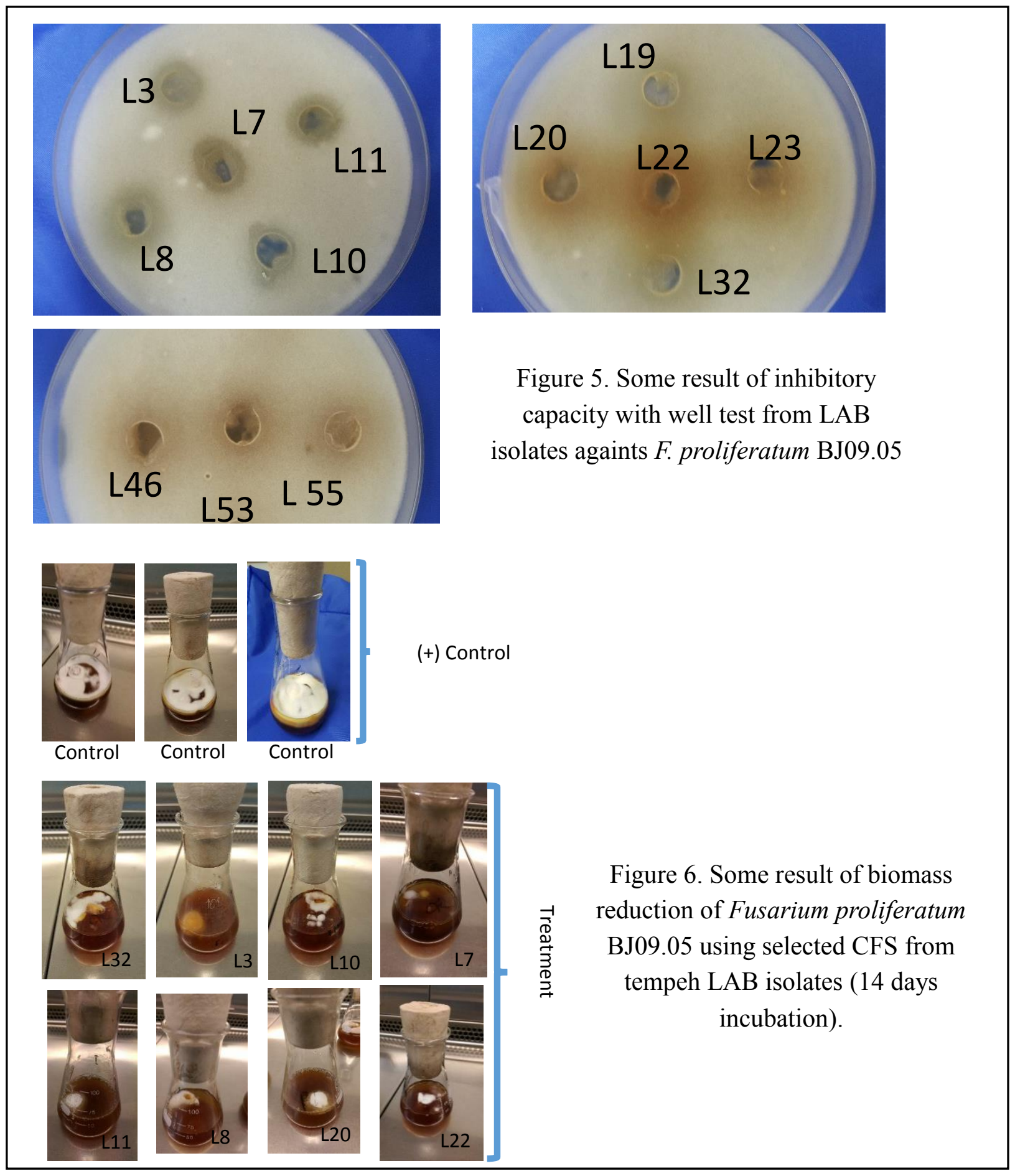


Table 7. Inhibiton and biomass reduction of Fusarium proliferatum by selected LAB isolates.

\begin{tabular}{|c|c|c|c|c|}
\hline \multirow{2}{*}{$\begin{array}{c}\text { Selected } \\
\text { LAB species }\end{array}$} & \multirow[b]{2}{*}{ Strains } & \multicolumn{2}{|c|}{ Inhibition againts } & \multirow{2}{*}{$\begin{array}{c}\% \text { Reduction of } \\
\text { Fusarium biomass } \\
\text { (in range) }\end{array}$} \\
\hline & & $\begin{array}{c}F . \\
\text { proliferatum } \\
\text { BJ09.05 }\end{array}$ & $\begin{array}{c}F . \\
\text { proliferatum } \\
\text { KU07.03 }\end{array}$ & \\
\hline L. plantarum & $\begin{array}{c}\text { B.BS01, B.BS02, } \\
\text { B.BS03, B.ASC13, } \\
\text { B.KSM05, B.MSR11 }\end{array}$ & ++ & ++ & $(50-60 \%)$ \\
\hline L. plantarum & B.BS08, B.BS10 & +++ & +++ & $(75-87 \%)$ \\
\hline L. paracasei & $\begin{array}{l}\text { B.MSR04, } \\
\text { B.KSM03, B.BS13, } \\
\text { B. KSM07, B.BS12, } \\
\text { B. KSM02 }\end{array}$ & ++ & ++ & $(45-60 \%)$ \\
\hline L. paracasei & $\begin{array}{c}\text { B.KSM06, B.ASC05, } \\
\text { B.KSM12 }\end{array}$ & +++ & ++ & $(65-73 \%)$ \\
\hline P. pentosaceus & $\begin{array}{l}\text { B.MSR01, B.BS11, } \\
\text { B.BSC07 }\end{array}$ & ++ & ++ & $(44-58 \%)$ \\
\hline
\end{tabular}

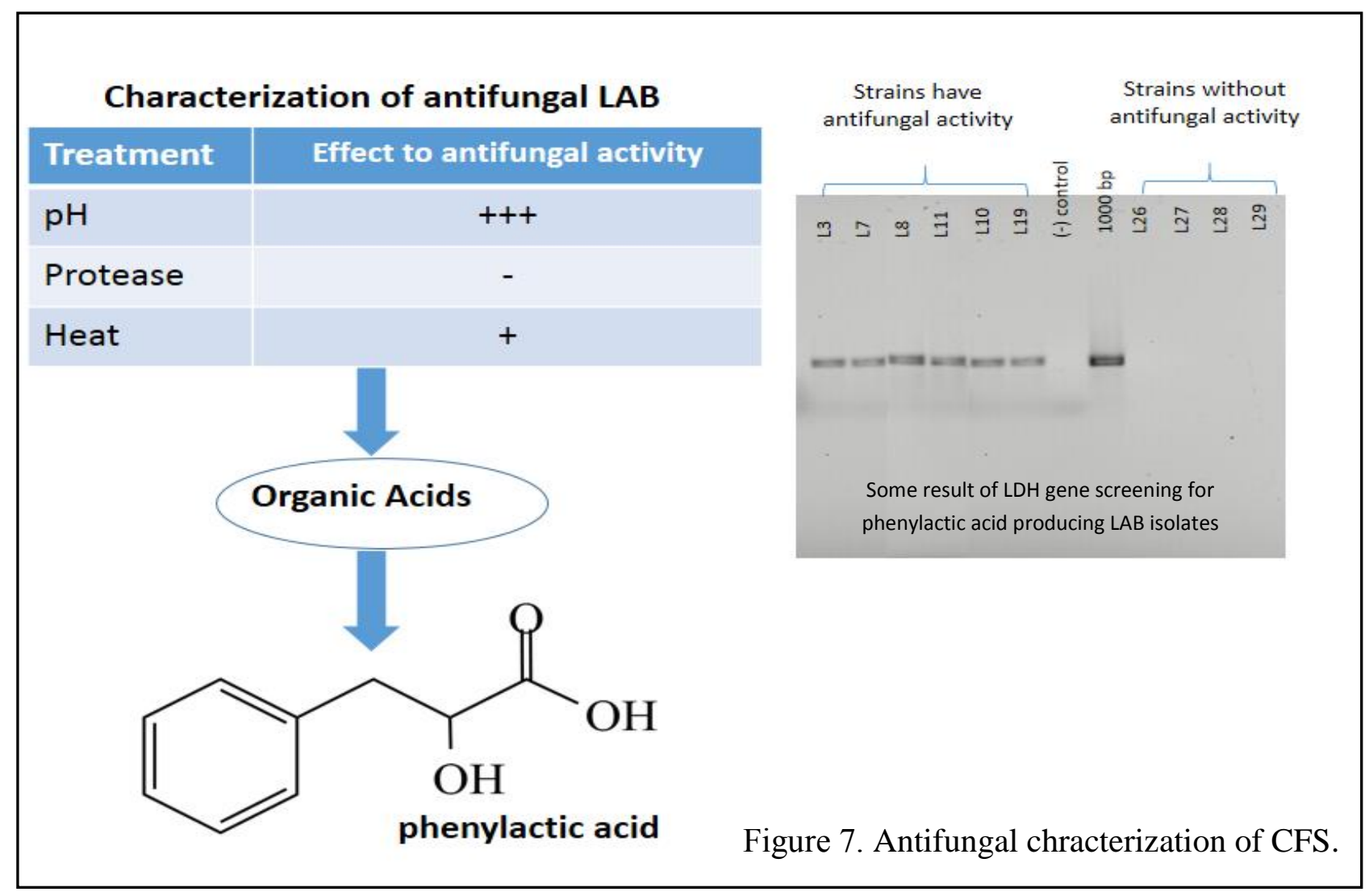


Following heat treatment, no reduction in the zone of inhibition against $F$. proliferatum was observed compared to untreated control showing that the antifungal CFSs are heat resistant and thus, non-volatile. Proteolytic enzymes presented no reduction in zone size compared to an untreated control. In contrast $\mathrm{pH}$ (neutralized $\mathrm{pH}$ ) gave significant effect to the activity. This suggests that organic acid may play a role in the antifungal activity (Figure 7). In this study we also found that active LAB isolates possed LDH gene, indicating they are phenylactic acid (PLA) producer. In contrast, all non-active LAB isolates lacked this gene. We found interesting finding that only active-LAB (with antifungal activity) have ability to produce PLA. This suggests that PLA might be the major antifungal compound. The active-LAB isolates produced PLA in range 45-221 $\mu \mathrm{g} / \mathrm{g}$ based on LC-MS/MS analysis.

Beside CFS effect, we also studied the interaction of LAB and $F$. proliferatum. The study on the linear growth of 3-days-old fungal mycelia in the paired culture with 3-days-old lactic acid bacteria in PDA medium is shown in Figure 9. The lowest increase of fungal biomass was shown at the presence of Lactobacillus plantarum B.BS08. The activity of the bacteria against the fungus $F$. proliferatum was dependent on their growth phase. The investigated LAB in paired culture showed the capacity for fungal mycelial growth inhibition in liquid MRS and solid PDA media. Their antagonistic interaction was also observed with SEM (as shown in Figure 8). From the scanning electron micrographs, we found some changes in $F$. proliferatum morphology, some damage was also visible (holes in hyphae structures). The LAB secreted something that may damage spores and hyphae. The LAB also stick into hyphae and might inject them into the fungal cell.
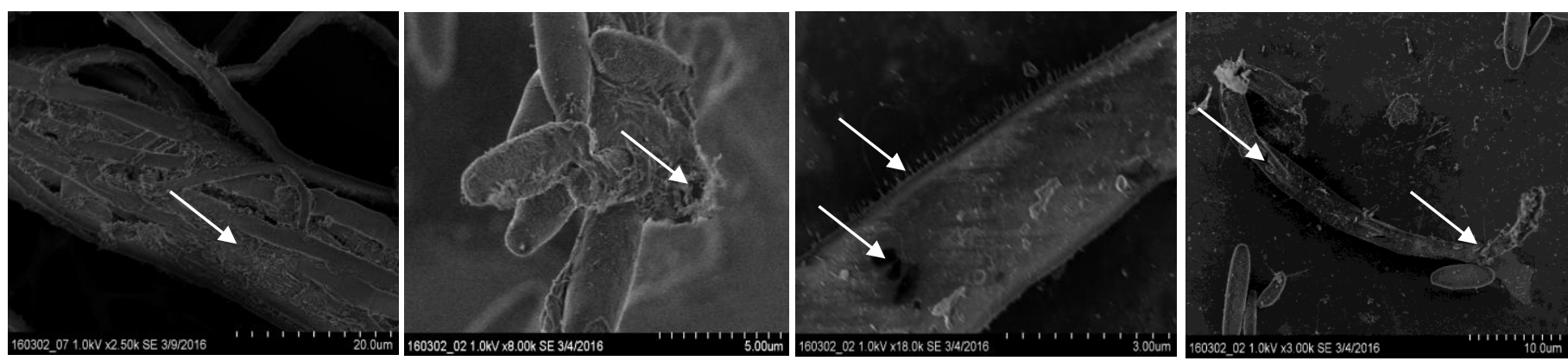

Fusarium proliferatum BJ.0905-L plantarum B.BS08 interaction
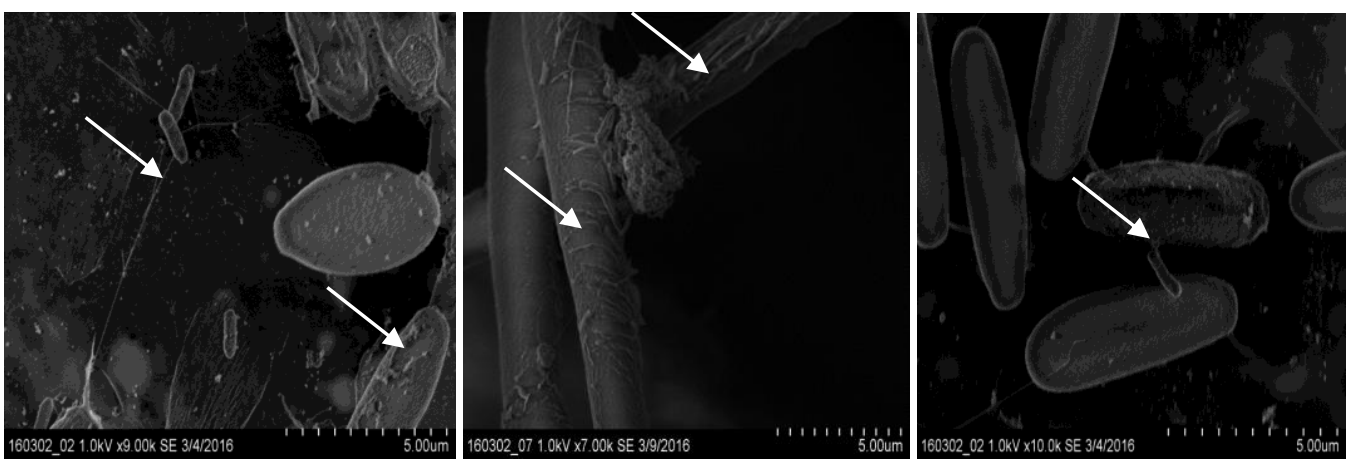

Fusarium proliferatum BJ.0905-L plantarum B.BS08 interaction

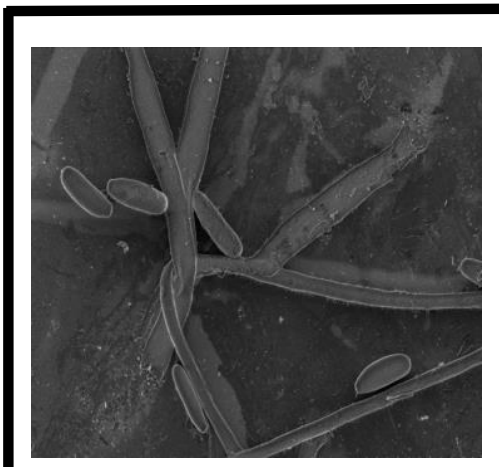

Normal Fusarium proliferatum BJ.0905

Figure 8. Antagonistic interaction between Fusarium proliferatum BJ09.05 and Lactobacillus plantarum B.BS08 under SEM observation. 


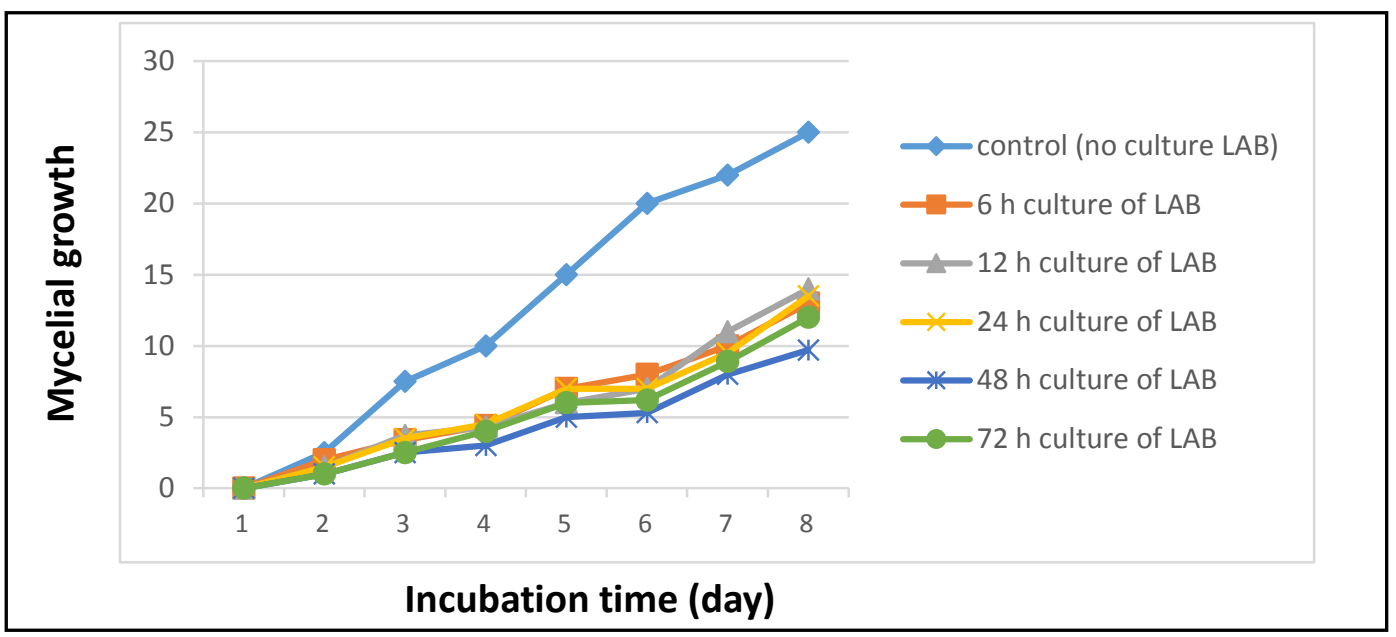

Figure 9. Mycelial growth of $F$. prolferatum BJ09.05 on PDA in mixed culture with L. plantarum B.BS08.

\section{Application of antifungal LAB in tempeh model}

The three best isolates obtained then tested again in tempeh-making (laboratory level). The qPCR result showed that three best isolates from L. plantarum could inhibit more than $70 \%$ growth of $F$. proliferatum. Lactobacillus plantarum B.BS10 was found as best $F$. proliferatum inhibitor that can be applied to the tempeh production (Figure 10). The result also showed that $R$. microsporus var. oligosporus could still grow well together with LAB isolates (Figure 11). However, this LAB application made $\mathrm{pH}$ of tempeh become lower ( $\mathrm{pH}$ in rage 5.1-5.5) than normal tempeh. This additional LAB culture into fermentation might change sensory characteristic of tempeh. Further research is necessary to cope this application problem.

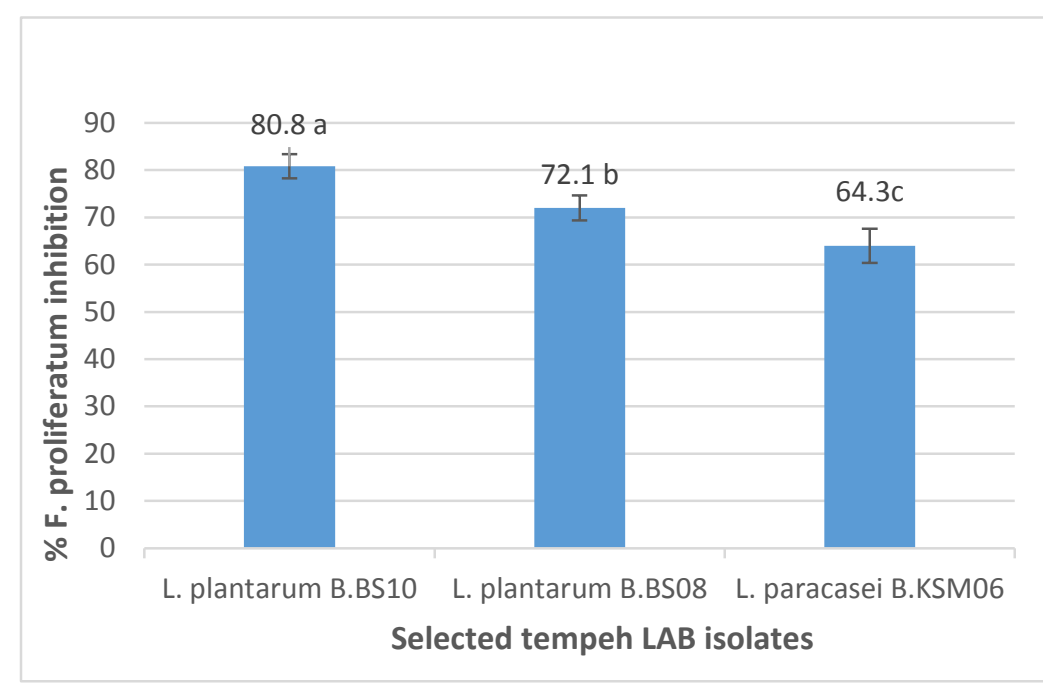

Figure 10. Graphic of Fusarium proliferatum BJ09.05 growth inhibition by selected LAB tempeh isolates. Markers carrying the same letter represent mean \pm standard deviation statistically not different $P>0.05 ; n=3$.

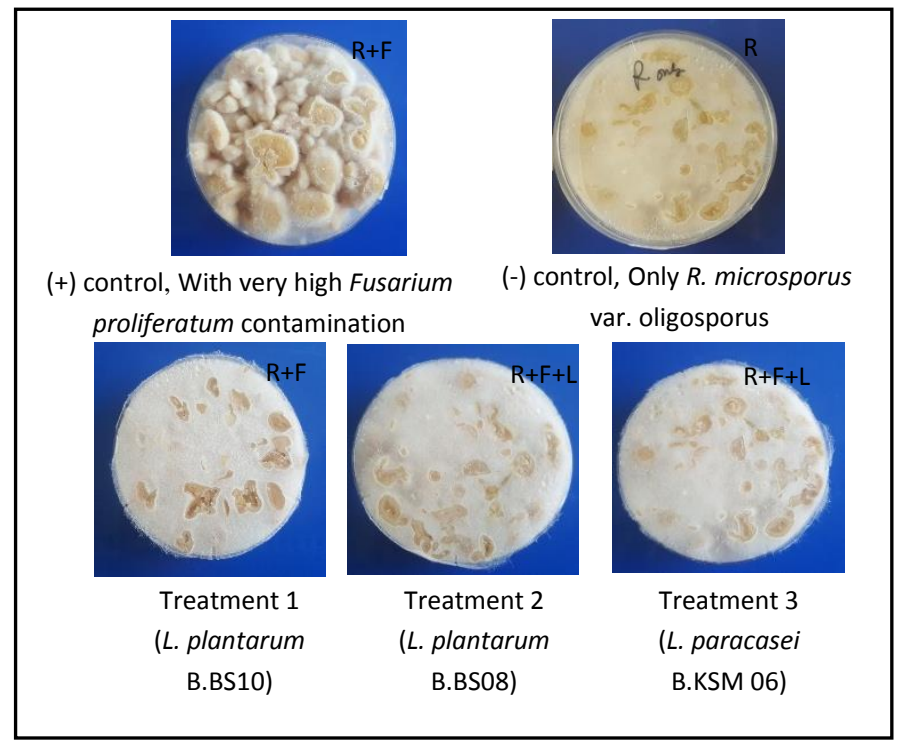

Figure 11. Application of selected three LAB isolates to inhibit $F$. proliferatum contamination during tempeh making. 


\subsection{Discussion of Part II (Antifungal activity from tempeh yeast and LAB)}

The trend for using natural-label friendly preservatives has drastically increased over the last years and has been replacing traditional preservation system. Biopreservation is an interesting alternative approach to physical and chemical preservation methods commonly applied in food. Biopreservation refers to the use of natural microflora or controlled microbiota or antibacterial products to extend shelf life and increase food safety (Stiles, 1996). Among natural biological antagonist, lactic acid bacteria (LAB) and yeast have potential applications as bio-preservative. LAB can play a vital role as preservatives since they have a long history in fermented food production, are generally recognized as safe (GRAS status), and they have a Qualified Presumption of Safety (QPS) status in the EU, consequently the scientific exploration of their potential as biocontrol agents have received a consistent and growing interest. These microorganisms occur naturally in many food systems and are also part of the intestinal microflora. In this study, we searched LAB or yeast isolates that have antifungal activity against harmfull fungus $F$. proliferatum that found as contaminant in traditional tempeh.

In a first screening, out of 294 isolates tempeh yeast and LAB from natural acidification process (tempeh industry) were screened with 96 plates method using their CFS extract (cell-free supernatant). Very few $(12 \%)$ of them possess antifungal activity against $F$. proliferatum. Of these, $20 \mathrm{LAB}$ strains have consistent antifungal activity. No antifungal activity was observed in yeast isolates. Both the mycelium growth and sporulation mostly were inhibited by active CFS LAB. Positive screening results were checked again with well test method and biomass reduction test. The result confirmed that there is variation in inhibition of $F$. proliferatum. In brief, three best strains were obtained, they are Lactobacillus plantarum B.BS08, L. plantarum B.BS10 and $L$. paracasei B.KSM06 with strong inhibitory activity and great reduction in fungal biomass production. Inhibitory activity of $L$. plantarum against antagonistic fungal species is in agreement with previous studies (Niku-Paavola et al. 1999; Lavermicocca et al. 2000; Magnusson et al.2003).

Beside CFS effect, we also studied the interaction of LAB and $F$. proliferatum. The study on the linear growth of 3-days-old fungal mycelia in the paired culture with 3-days-old lactic acid bacteria in PDA medium. The lowest increase of fungal biomass was shown at the presence of Lactobacillus plantarum B.BS08. The activity of the LAB against the fungus $F$. proliferatum was dependent on their growth phase. The investigated LAB in paired culture showed the capacity for fungal mycelial growth inhibition in liquid MRS and solid PDA media. Their antagonistic interaction was also observed with SEM. From the scanning electron micrographs, we found some changes in $F$. proliferatum morphology, some damage was also visible (holes in hyphae structures). The LAB secreted something that may damage spores and hyphae. The LAB also stick into hyphae and might inject secreted compounds into the fungal cell. Our results also indicate that L. plantarum B.BS08 and its secreted antifungal metabolites changes the structural integrity of fumonisin producing F. proliferatum BJ09.05 and might interfere with fungal cell development.

Sensibility of inhibitory CFS extract was also observed. Heat treatment showed that no reduction in the zone of inhibition against $F$. proliferatum compared to untreated control showing that the antifungal CFSs are heat resistant and thus, non-volatile. Proteolytic enzymes presented 
no reduction in zone size compared to an untreated control. This indicates that they are not proteinaceous substances. In contrast $\mathrm{pH}$ (neutralized $\mathrm{pH}$ ) gave significant effect to the activity. This suggests that organic acid may play main role in the antifungal activity. In this study we also found that active $\mathrm{LAB}$ isolates possed $\mathrm{LDH}$ gene, indicating they are phenylactic acid (PLA) producer. In contrast, all non-active LAB isolates lacked this gene. We found interesting finding that only active-LAB (with antifungal activity) have ability to produce PLA. This suggests that PLA might be the major antifungal compound. The active-LAB isolates produced PLA in range $45-221 \mu \mathrm{g} / \mathrm{g}$ based on LC-MS/MS analysis. However, purification of the compound continued with a single compound test for antifungal activity is still necessary to confirm whether PLA as main antifungal agent or not.

The role PLA and other organic acid as antifungal substances also observed by several authors. PLA mostly produced by $L$. plantarum with a broad spectrum antifungal activity (Lavermicocca et al., 2000, Magnusson and Schnürer 2001; Ström et al., 2002). Some other LABs can synthesize PLA and 4-hydroxy-acid phenyllactic (Valerio et al., 2004). 3-PLA is derived from the metabolism of phenylalanine. As follows, phenylalanine is transaminated to phenylpyruvic acid (PPA) (Li et al., 2007) and then PPA is converted to 3-phenyllactic acid (Mu et al., 2009). Supernatant of $L$. plantarum 21B inoculated with wheat starch hydrolysates reliably prevents the growth of several toxigenic fungi, namely A. niger, A. flavus, Monilia sitophila, F. graminearum, $P$. roqueforti, and $P$. expansum, (Lavermicocca et al., 2000; Lavermicocca et al., 2003). Broberg et al. (2007) reported that Pichia anomala and P. roqueforti are inhibited by L. plantarum strain MiLAB14 and L. coryniformis MiLAB 393 through their antifungal compounds, 3-PLA. Lavermicocca et al. (2000) reported that PLA was contained at the highest concentration in the bacterial culture filtrate and had the highest activity and inhibited all the tested fungi at a concentration of $50 \mathrm{mg}$ except for $P$. roqueforti IBT 18.687 and $P$. corylophilum IBT 6978 (166 $\mathrm{mg} / \mathrm{mL}$ ). PLA also inhibits the growth of Candida pulcherrima, C. parapsilosis and Rhodotorula mucilaginosa (Schwenninger et al., 2008). Prema et al. (2010) identify PLA in the culture supernatant of $L$. plantarum using NMR and IR spectroscopy, showing inhibitory effects against A. fumigatus. Ndagano et al. (2011) found PLA mixed with other organic acids and free fatty acids in the supernatant of $L$. plantarum VE56 and $W$. paramesenteroides LC11 inhibiting fungal growth Antifungal compounds from culture supernatant of $L$. plantarum 1.7 FST was isolated by Dal Bello et al. (2007), they were identified as cyclo (L-Leu-L-Pro), cyclo (L-Phe-L-Pro), and PLA. The main constituent of antifungal compounds were PLA and lactic acid. Gerez et al. (2010) revealed that PLA is the most effective organic acid.

The three best isolates obtained then applied in tempeh-making (laboratory level). The qPCR result showed that three best isolates from $L$. plantarum could inhibit more than $60 \%$ growth of $F$. proliferatum. Lactobacillus plantarum B.BS10 was found as best $F$. proliferatum inhibitor that can be applied to the tempeh production. The result also showed that $R$. microsporus var. oligosporus could still grow well together with $\mathrm{LAB}$ isolates. However, this $\mathrm{LAB}$ application made $\mathrm{pH}$ of tempeh become lower ( $\mathrm{pH}$ in rage 5.1-5.5) than normal tempeh (6.5-6.7). This additional LAB culture into fermentation might impart undesirable sensory characteristic of tempeh. Further research is necessary to cope this application problem before applied into large-scale production systems in traditional tempeh industry. 


\subsection{Results of Part III (Zearalenone biotransformation by tempeh yeast and LAB)}

In the present study, a total of 20 strains of yeast and lactic acid bacteria (LAB) species mostly from Part I that commonly found in natural acidification process (part of tempeh production) were screened for zearalenone (ZEN) metabolite formation in vitro (list of strains could be seen in supplemental Table 3). Twelve isolates yeast (seven different species) were used; they are Saccharomycopsis fibuligera, Pichia kudriavzevii, Candida tropicalis, Kluyveromyces marxianus, Schizosaccaromyces pombe, Meyerozyma guilliermondi, and Saccharomyces cerevisiae. Eight isolates LAB (three different species) were used, they are Lactobacillus plantarum, Pediococcus pentosaceus, and Lactobacillus paracasei. Isolates mentioned were investigated whether they can reduce ZEN and which metabolites they might produce preferentially.

ZEN $(c=0.3 \mu \mathrm{M})$ was added to liquid cultures of the fungi. After two days of incubation, the media were analyzed for metabolite formation by HPLC-MS/MS. Semi-quantitative measurements were conducted for ZEN-14-S, $\alpha$-ZEL-S, ZEN-14-Glc, and ZEN-16-Glc. ZEN- 14- S and a-ZEL-S were determined using relative response factors of ZEN-14-S to ZEN and $\alpha$-ZELS to $\alpha$-ZEL. Response factors were estimated by comparing the MS/MS peak area before and after quantitative sulfate ester cleavage. ZEN and $\alpha$-ZEL were determined by external calibration using the commercially available standard substances. Matrix-matched calibration was applied for semi-quantification of ZEN-14-Glc and ZEN-16-Glc. Detail semi-quantification data can be seen in Table 8 .

The results obtained from screening 20 isolates belonging to 10 different species revealed that nearly all the tested organisms were able to reduce ZEN in range 10 to $96.9 \%$ (Figure 12). In general, yeast and LAB isolates could only transform ZEN into two major transformation product $\alpha$-ZEL and $\beta$-ZEL. In all cases no conjugation product detected. Yeast isolates were more active than LAB isolates based on ZEN reduction and transformation point of view. Yeast isolates transformed ZEN primarily to the $\beta$-isomer, whereas $\alpha$-ZEL being the predominating product from LAB isolates. From yeast isolates, we found C. tropicalis, M. guilliermondi, and Saccharomyces cerevisiae are potential species to be used as biodetoxification agent, because they could reduce significant amount of ZEN (>70\% reduction) and mostly transformed to $\beta-Z E L$ (known less estrogenic). In LAB isolates, we found L. plantarum B.BS01 is most potential isolate because could reduce more than $90 \% \mathrm{ZEN}$, almost without $\alpha$-ZEL formed. An example of the chromatograms obtained for potential isolates is also depicted in Figure 4. The in vitro-screening showed that complex microorganism involved in tempeh production have potential for ZEN reduction. However to know are they agent of biodetoxification, further toxicity test with animal needed to confirm it. 

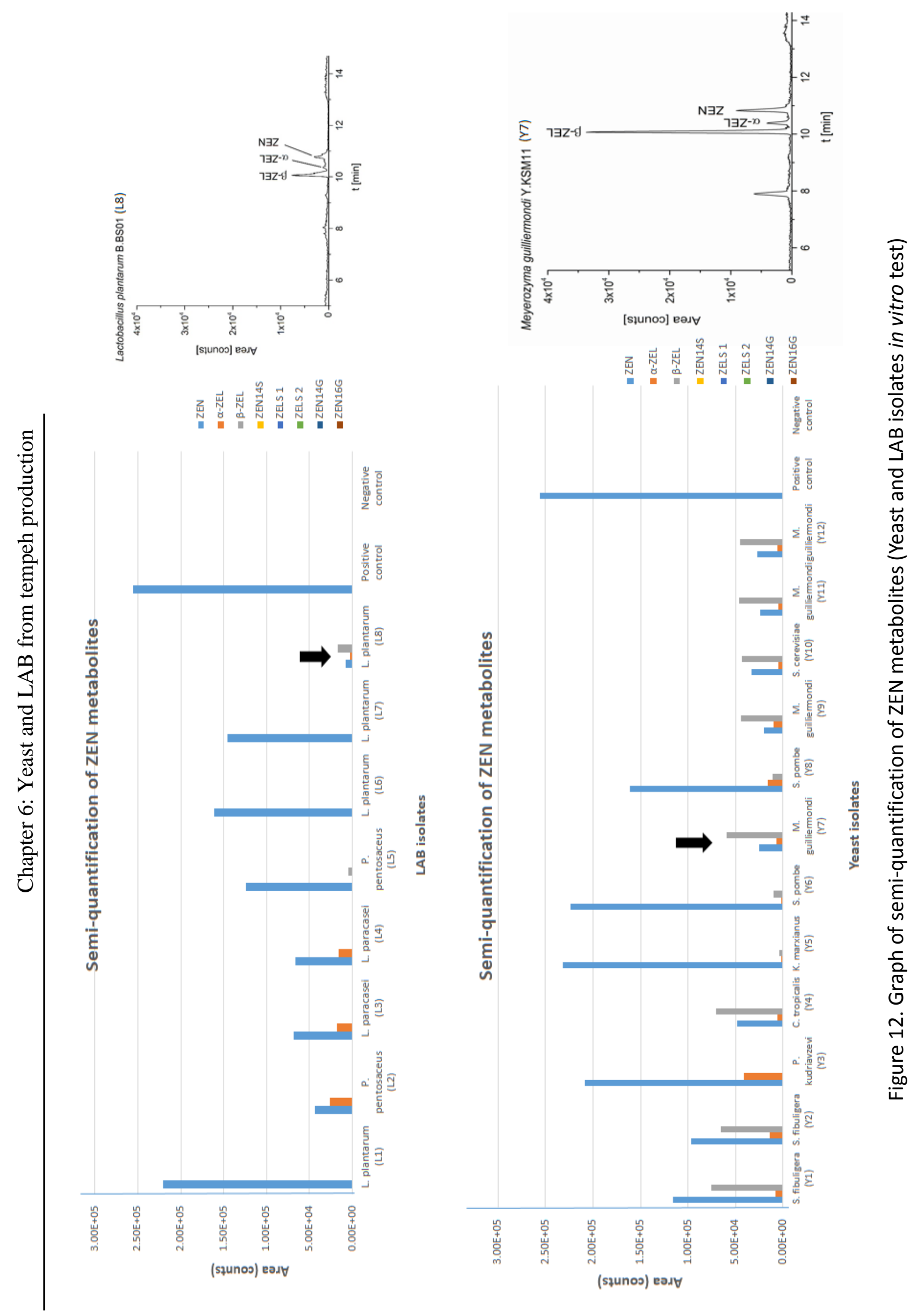
Chapter 6: Yeast and LAB from tempeh production

Table 8. HPLC-MS/MS result of ZEN transformation by tempeh yeast and LAB.

\begin{tabular}{|c|c|c|c|c|c|c|c|c|}
\hline & & \multicolumn{7}{|c|}{ Masked ZEN } \\
\hline & \multicolumn{8}{|c|}{ Area (count) after adjusted with response } \\
\hline & ZEN & $\alpha-Z E L$ & $\beta-Z E L$ & ZEN14S & $\begin{array}{c}\text { ZELS } \\
1\end{array}$ & $\begin{array}{c}\text { ZELS } \\
2\end{array}$ & ZEN14G & ZEN16G \\
\hline Y1 & $1.15 \mathrm{E}+05$ & $8.48 \mathrm{E}+03$ & $7.54 \mathrm{E}+04$ & 0 & 0 & 0 & 0 & 0 \\
\hline Y2 & $9.67 \mathrm{E}+04$ & $1.38 \mathrm{E}+04$ & $6.59 \mathrm{E}+04$ & 0 & 0 & 0 & 0 & 0 \\
\hline Y3 & $2.08 \mathrm{E}+05$ & $4.07 \mathrm{E}+04$ & 0 & 0 & 0 & 0 & 0 & 0 \\
\hline Y4 & $4.79 \mathrm{E}+04$ & $6.25 \mathrm{E}+03$ & $7.01 \mathrm{E}+04$ & 0 & 0 & 0 & 0 & 0 \\
\hline Y5 & $2.32 \mathrm{E}+05$ & $1.87 \mathrm{E}+03$ & $3.64 \mathrm{E}+03$ & 0 & 0 & 0 & 0 & 0 \\
\hline Y6 & $2.24 \mathrm{E}+05$ & $1.68 \mathrm{E}+03$ & $1.00 \mathrm{E}+04$ & 0 & 0 & 0 & 0 & 0 \\
\hline Y7 & $2.55 \mathrm{E}+04$ & $6.82 \mathrm{E}+03$ & $5.93 \mathrm{E}+04$ & 0 & 0 & 0 & 0 & 0 \\
\hline Y8 & $1.61 \mathrm{E}+05$ & $1.62 \mathrm{E}+04$ & $1.15 \mathrm{E}+04$ & 0 & 0 & 0 & 0 & 0 \\
\hline Y9 & $2.04 \mathrm{E}+04$ & $1.04 \mathrm{E}+04$ & $4.39 \mathrm{E}+04$ & 0 & 0 & 0 & 0 & 0 \\
\hline Y10 & $3.36 \mathrm{E}+04$ & $5.34 \mathrm{E}+03$ & $4.33 \mathrm{E}+04$ & 0 & 0 & 0 & 0 & 0 \\
\hline Y11 & $2.36 \mathrm{E}+04$ & $5.33 \mathrm{E}+03$ & $4.62 \mathrm{E}+04$ & 0 & 0 & 0 & 0 & 0 \\
\hline Y12 & $2.68 \mathrm{E}+04$ & $5.52 \mathrm{E}+03$ & $4.51 \mathrm{E}+04$ & 0 & 0 & 0 & 0 & 0 \\
\hline L1 & $2.21 \mathrm{E}+05$ & 0 & 0 & 0 & 0 & 0 & 0 & 0 \\
\hline L2 & $4.38 \mathrm{E}+04$ & $2.66 \mathrm{E}+04$ & 0 & 0 & 0 & 0 & 0 & 0 \\
\hline L3 & $6.81 \mathrm{E}+04$ & $1.76 \mathrm{E}+04$ & 0 & 0 & 0 & 0 & 0 & 0 \\
\hline L4 & $6.60 \mathrm{E}+04$ & $1.58 \mathrm{E}+04$ & 0 & 0 & 0 & 0 & 0 & 0 \\
\hline L5 & $1.24 \mathrm{E}+05$ & 0 & 0 & 0 & 0 & 0 & 0 & 0 \\
\hline L6 & $1.61 \mathrm{E}+05$ & 0 & 0 & 0 & 0 & 0 & 0 & 0 \\
\hline L7 & $1.45 \mathrm{E}+05$ & 0 & 0 & 0 & 0 & 0 & 0 & 0 \\
\hline L8 & $7.94 \mathrm{E}+03$ & $2.24 \mathrm{E}+03$ & $1.67 \mathrm{E}+04$ & 0 & 0 & 0 & 0 & 0 \\
\hline $\begin{array}{l}\text { Positive } \\
\text { control }\end{array}$ & $2.56 \mathrm{E}+05$ & 0 & 0 & 0 & 0 & 0 & 0 & 0 \\
\hline $\begin{array}{l}\text { Negative } \\
\text { control }\end{array}$ & 0 & 0 & 0 & 0 & 0 & 0 & 0 & 0 \\
\hline
\end{tabular}




\subsection{Discussion of Part III (Zearalenone biotransformation by tempeh yeast and LAB)}

Specific strains of lactic acid bacteria (LAB) and yeast may be able to remove mutagenic contaminants including mycotoxins in foods (Haskard et al., 2001; Peltonen et al., 2001; Shetty et al., 2007). LAB are a group of related bacteria (e.g., Streptococcus spp., Lactobacillus spp., Lactococcus spp., and Leuconostoc spp.) that produce lactic acid as a result of carbohydrate fermentation. LAB and yeast occur naturally in foods and are considered either harmless or possibly supportive of human health. However, when added to foods, these microorganisms are termed "starter culture."

In tempeh processing, complex microorganism consist of bacteria and yeast are important for soybeans acidification and tendering. However, it is not known whether bacteria are important in other processes during tempeh production, including about their role in food safety of this product. The soak water is rich in simple sugars such as glucose, fructose, and galactose. Glucose serves as primary substrate for microbial growth in soak water. The activity of the invertase enzyme and $\alpha$-galactosidase enzymes on soybean produce simple sugars in the soak water. Bacteria and yeasts are microbes found in that soak water (Mulyowidarso et al., 1991). In the present study, a total of 20 strains of yeast and lactic acid bacteria (LAB) species used from Part I, that commonly found in natural acidification process (part of tempeh production) were screened for zearalenone (ZEN) metabolite formation in vitro. Twelve isolates yeast (seven different species) were used; they are Saccharomycopsis fibuligera, Pichia kudriavzevii, Candida tropicalis, Kluyveromyces marxianus, Schizosaccaromyces pombe, Meyerozyma guilliermondi, and Saccharomyces cerevisiae. Eight isolates LAB (three different species) were used, they are Lactobacillus plantarum, Pediococcus pentosaceus, and Lactobacillus paracasei. Isolates mentioned were investigated whether they can reduce ZEN and which metabolites they might produce preferentially.

ZEN $(c=0.3 \mu \mathrm{M})$ was added to liquid cultures of the fungi. After two days of incubation, the media were analyzed for metabolite formation by HPLC-MS/MS. Semi-quantitative measurements were conducted for ZEN-14-S, $\alpha$-ZEL-S, ZEN-14-Glc, and ZEN-16-Glc. ZEN- 14$S$ and a-ZEL-S were determined using relative response factors of ZEN-14-S to ZEN and $\alpha$-ZELS to $\alpha$-ZEL. Response factors were estimated by comparing the MS/MS peak area before and after quantitative sulfate ester cleavage. ZEN and $\alpha$-ZEL were determined by external calibration using the commercially available standard substances. Matrix-matched calibration was applied for semiquantification of ZEN-14-Glc and ZEN-16-Glc.

The results obtained from screening 20 isolates belonging to 10 different species revealed that nearly all the tested organisms were able to reduce ZEN in range 10 to $96.9 \%$. In general, yeast and LAB isolates could only transform ZEN into two major transformation product $\alpha$-ZEL and $\beta$-ZEL. In all cases no conjugation product detected. Yeast isolates were more active than LAB isolates based on ZEN reduction and transformation point of view. Yeast isolates transformed ZEN primarily to the $\beta$-isomer, whereas $\alpha$-ZEL being the predominating product from LAB isolates. From yeast isolates, we found C. tropicalis, M. guilliermondi, and Saccharomyces cerevisiae are potential species to be used as biodetoxification agent because they could reduce 
significant amount of ZEN ( $>70 \%$ reduction) and mostly transformed to $\beta-$ ZEL (known less estrogenic). According to Shier et al. (2001), in vitro breast cancer cell stimulation experiments indicate that the $\alpha$-ZEL exhibits 92-fold higher estrogenicity, compared to ZEN. On the other hand, $\beta$-ZEL is less estrogenic, which only exhibits half of the ZEN activity. In LAB isolates, we found L. plantarum B.BS01 is most potential isolate because could reduce more than $90 \% \mathrm{ZEN}$, almost without $\alpha$-ZEL formed. An example of the chromatograms obtained for potential isolates is also depicted in Figure 4. The in vitro-screening showed that complex microorganism involved in tempeh-making process have potential for ZEN decontamination. However to know are they really agent of biodetoxification, further toxicity test with animal needed to confirm it.

The novel result of this study is not about tempeh LAB and yeast activity to reduce ZEN amount but their capability to transform ZEN by reducing the keto group into two major transformation product $\alpha$ - and $\beta$-ZEL. More important information is none of isolates could transform ZEN into ZEN conjugates, thus this microorganism will not contribute in producing masked-ZEN. Most of research in this area so far only highlight role of LAB and yeast as adsorbent (binding) agent of mycotoxins. El-Nezami et al. (2004) only demonstrated that, after co-incubation of ZEN and Lactobacillus, a considerable proportion $(38.0 \%-46.0 \%)$ of these mycotoxins were recovered from bacterial pellets. Bacteria showed capacity to adsorb toxins and, as expected, results demonstrated that the binding depended on bacterial concentration. Co-incubation of ZEN and -ZEL with bacteria significantly affected the percentage of toxin bound, suggesting that these toxins may share the same binding site. Tinyiro et al. (2011) using some Bacillus strains, showed that the adsorption percentage was high $(78.0 \%$ and $95.0 \%)$ and variation depended on the strain used. Haskard et al. (2001) reported reversible binding of aflatoxins to probiotic bacteria. Other authors reported partially reversible AFB1 binding with $L$. casei, L. rhamnosus and L. amylovorus (Hernandez-Mendoza et al., 2009; Peltonen et al., 2001). Pure yeast as well as yeast cell wall products is also known could adsorb ZEN (Yiannikouris et al., 2004; Fruhauf et al., 2012).

In biotechnology, yeast and LAB is used to catalyze the asymmetric reductive transformation of a variety of substrates containing a carbonyl group or a carbon-carbon double bond (Utaka et al., 1991). The advantages using microorganisms instead of classical synthesis are mainly the relatively broad substrate specificity, the regiospecific and stereospecific reactions, and the high purity of the products. A number of the strains investigated here might be considered for biotechnological applications. The potent $\beta$-isomer producing strains Saccharomycopsis fibuligera Y.BS01 or the potent $\alpha$-isomer-producing $P$. pentosaceus B.BSC07 may be particularly suitable for biotechnological syntheses.

In conclusion, $\mathrm{LAB}$ and yeast fermentation is a recommended method for reducing ZEN in contaminated raw material such as corn that usually used also in tempeh production, although safety of decontaminated food is not guaranteed because mode of action may not only involve transformation process but also reversible binding. We are planning to establish the mode of ZEN reduction in natural fermentation in our future studies. 


\section{Conclusion}

The present study revealed the following points:

- The LAB counts in these samples varied between 5.21 and $8.88 \log$ CFU/mL whereas yeasts counts varied from 4.31 and $4.89 \log \mathrm{CFU} / \mathrm{mL}$, APC counts varied between 7.33 and $9.10 \log \mathrm{CFU} / \mathrm{mL}$. In total, 165 isolates were obtained from these samples using selective media. Our results revealed a certain variety of culturable LAB and yeast in soak water. The principal yeast found to be responsible for fermentation were Candida tropicalis, Kluyveromyces marxianus, and Saccharomyces cerevisiae, while the dominant LAB were Lactobacillus plantarum, L. paracasei and Pediococcus pentosaceous. We found LAB species were less diverse than yeast species.

- Cell free supernatants (CFS) of 20 LAB strains possessed antifungal properties against $F$. proliferatum BSM17, while none of the yeast isolates showed the activity. It was found that phenyl lactic acid (PLA) might has main role for the activity. The use of those selected LAB strains as part of starter culture has been proven to positively increase tempeh safety. However, the additional LAB culture into fermentation might impart undesirable sensory characteristic of tempeh. Further research is necessary to cope this application problem before applied into large-scale production systems in traditional tempeh industry.

- All the tested yeast and LAB isolates were able to reduce ZEN in range 10 to $96.9 \%$. They could only transform ZEN into two major transformation product $\alpha$-ZEL and $\beta$-ZEL. In all cases no conjugation product detected. LAB and yeast fermentation is a recommended method for reducing ZEN in contaminated raw material such as corn that usually used also in tempeh production, although safety of decontaminated food is not guaranteed because mode of action may not only involve transformation process but also reversible binding. Further research to establish the mode of ZEN reduction in natural fermentation is needed.

\section{Acknowlegements}

I acknowledge Dr. Volker Cordes and his team (Max Planck Institute for Biophysical Chemistry) for helpful advice on using scanning electron microscope.

This research was supported financially by Indonesia Endowment Fund for Education, Ministry of Finance, The Republic of Indonesia (Ref:1064/LPDP/2013).

\section{References}

Alves, E., Lucas, G.C., Pozza, E.A. and Carvalho A.M., 2013. Scanning electron microscopy for fungal sample examination. In: Gupta V.K., M.G. Tuohy (eds.), Laboratory Protocols in Fungal Biology: Current Methods in Fungal Biology. Springer, Heidelberg, pp. 133-150.

Arendt, E.K., Ryan, L.A. and Dal Bello, F., 2007. Impact of sourdough on the texture of bread. Food microbiology, 24(2), pp.165-174.

Ashenafi, M. and Busse, M., 1991. Growth of Bacillus cereus in fermenting tempeh made from various beans and its inhibition by Lactobacillus plantarum. J. Appl. Microbiol. 70: 329-333.

Aslam, Z., Yasir, M., Khaliq, A., Matsui, K. and Ryun, Y., 2010. Mini Review: Too much bacteria still unculturable. Bioscience, 45, pp.600-609.

Astuti, M., Andreanyta, M., Fabien, S.D. and Mark, L.W., 2000. Tempe, a nutritious and healthy food from Indonesia. Asia Pac. J. Clin. Nutr. 9(4):322-325.

Ausubel, F.M., Brent, R., Kingston, R.E., Moore D.D., Seidman, J.G., Smith, J.A. and Struhl, K., 1987. Current Protocols in Molecular Biology. Greene Publishing Associates/Wiley Interscience, New York. 
Barnett, J.A., Payne, R.W. and Yarrow, D., 1990. Yeast Characteristics and Identification, 2nd Ed., Cambridge University Press, London, U.K.

Barus, T., Suwanto, A., Wahyudi, A.T. and Wijaya, H., 2010. Role of bacteria in tempe bitter taste formation: microbiological and molecular biological analysis based on 16S rRNA gene. Microbiology Indonesia, 2(1).

Brodehl, A., Möller, A., Kunte, H.J., Koch, M. and Maul, R., 2014. Biotransformation of the mycotoxin zearalenone by fungi of the genera Rhizopus and Aspergillus. FEMS microbiology letters, 359(1), pp.124-130.

Clarke, C.I., Schober, T.J. and Arendt, E.K., 2002. Effect of single strain and traditional mixed strain starter cultures on rheological properties of wheat dough and on bread quality. Cereal chemistry, 79(5), p.640.

Corsetti, A., Gobbetti, M., De Marco, B., Balestrieri, F., Paoletti, F., Russi, L. and Rossi, J., 2000. Combined effect of sourdough lactic acid bacteria and additives on bread firmness and staling. Journal of agricultural and food chemistry, 48(7), pp.3044-3051.

Crowley, P., Schober, T.J., Clarke, C.I. and Arendt, E.K., 2002. The effect of storage time on textural and crumb grain characteristics of sourdough wheat bread. European food research and technology, 214(6), pp.489-496.

Dal Bello, F., Clarke, C.I., Ryan, L.A.M., Ulmer, H., Schober, T.J., Ström, K., Sjögren, J., Van Sinderen, D., Schnürer, J. and Arendt, E.K., 2007. Improvement of the quality and shelf life of wheat bread by fermentation with the antifungal strain Lactobacillus plantarum FST 1.7. Journal of cereal science, 45(3), pp.309-318.

Deak, T. and Beuchat, L.R., 1996. Yeasts in specific types of foods. Handbook offood spoilage yeasts, pp.61-95.

El-Mohamady, R.S.R., Abdel-Kader, M.M., El-Mougy, N.S., El-Gammal, N.G. and Abd-Alla, M.A., 2014. Beneficial effect of some yeast and bio-fungicides on peanut mold infection. Inter. J. Eng. Innov. Tech., 3(12), pp.297-302.

Efriwati, E. and Nuraida, L., 2013. Effect of two production methods on macro nutrient and isoflavone-aglycone composition in tempeh produced by household industries. Health Science Journal of Indonesia, 4(2):.69-73.

Fernández, M., Hudson, J.A., Korpela, R. and de los Reyes-Gavilán, C.G., 2015. Impact on human health of microorganisms present in fermented dairy products: an overview. BioMed research international, 5, pp. 1-13.

Florou-Paneri, P., Christaki, E. and Bonos, E., 2013. Lactic acid bacteria as source of functional ingredients, in: Lactic Acid Bacteria - R \& D for Food, Health and Livestock Purposes, Edited by Marcelino Kongo, InTech pp. 589-614

Fruhauf, S., Schwartz, H., Ottner, F., Krska, R. and Vekiru, E., 2012. Yeast cell based feed additives: studies on aflatoxin B1 and zearalenone. Food additives \& contaminants: Part A, 29(2), pp.217-231.

Gerez, C.L., Carbajo, M.S., Rollan, G., Torres Leal, G. and Font de Valdez, G., 2010. Inhibition of citrus fungal pathogens by using lactic acid bacteria. Journal of food science, 75(6), pp.M354-M359.

Gourama, H. and Bullerman, L.B., 1995. Inhibition of growth and aflatoxin production of Aspergillus flavus by Lactobacillus species. Journal of food protection, 58(11), pp.1249-1256.

Harrigan, W.F. and McCance, M.E., 1976. Laboratory methods in food and dairy microbiology. Academic Press Inc.(London) Ltd.

Hathout, A.S., Mohamed, S.R., El-Nekeety, A.A., Hassan, N.S., Aly, S.E. and Abdel-Wahhab, M.A., 2011. Ability of Lactobacillus casei and Lactobacillus reuteri to protect against oxidative stress in rats fed aflatoxins-contaminated diet. Toxicon, 58(2), pp.179-186.

Helander, I., Von Wright, A. and Mattila-Sandholm, T.M., 1997. Potential of lactic acid bacteria and novel antimicrobials against Gram-negative bacteria. Trends in food Science \& technology, 8(5), pp.146-150.

Hernandez-Mendoza, A., Garcia, H.S. and Steele, J.L., 2009. Screening of Lactobacillus casei strains for their ability to bind aflatoxin B 1. Food and chemical toxicology, 47(6), pp.1064-1068.

Hermana, K.M., 1996. Pengembangan teknologi pembuatan tempe. Bunga rampai tempe Indonesia. Yayasan Tempe Indonesia, Jakarta, pp.151-168.

Holt, J.G., Peter, H.A., Mair, N.S. and Sharpe, M.E., 1986. Bergey's Manual of Systematic Bacteriology,William and Wilkins, Baltimore, MD.

Hounhouigan, D.J., Nout, M.J., Nago, C.M., Houben, J.H. and Rombouts, F.M., 1993. Characterization and frequency distribution of species of lactic acid bacteria involved in the processing of mawe, a fermented maize dough from Benin. International journal of food microbiology, 18(4), pp.279-287.

Keuth, S. and Bisping, B., 1994. Vitamin B12 production by Citrobacter freundii or Klebsiella pneumoniae during tempeh fermentation and proof of enterotoxin absence by PCR. Applied and environmental microbiology, 60(5), pp.14951499.

Kurtzman, C.P. and Fell, J.W., 2000. In: Kurtzman, C.P., Fell, J.W. (Eds.), The Yeasts: A Taxonomic Study. Elsevier, Amsterdam, pp. 1035.

Kurtzman, C.P., Fell, J.W., Boekhout, T. and Robert, V., 2011. Methods for isolation, phenotypic characterization and maintenance of yeasts. The yeasts, a taxonomic study, 1, pp.87-110.

Kozaki, M., Uchimura, T. and Okada, S., 1992. Experimental manual of lactic acid bacteria. Asakurasyoten, Tokyo, Japan, pp.34-37. 
Laitila, A., Alakomi, H.L., Raaska, L., Mattila-Sandholm, T. and Haikara, A., 2002. Antifungal activities of two Lactobacillus plantarum strains against Fusarium moulds in vitro and in malting of barley. Journal of applied microbiology, 93(4), pp.566-576.

Lane, D.J., 1991. 16S/23S rRNA sequencing. In: Nucleic acid techniques in bacterial systematics. Stackebrandt, E. and Goodfellow, M., eds., John Wiley and Sons, New York, NY: 115-175.

Lavermicocca, P., Valerio, F., Evidente, A., Lazzaroni, S., Corsetti, A. and Gobbetti, M., 2000. Purification and characterization of novel antifungal compounds from the sourdough Lactobacillus plantarum strain 21B. Applied and environmental microbiology, 66(9), pp.4084-4090.

Lonner, C., 1988. Starter cultures for rye sour dough. Ph.D. Dissertation. Dept. Applied.Microbiol. Lund University, Sweden.

MacFaddin, J.F., 2000. Biochemical Test for the Identification of Medical Bacteria, 3rd Ed.,Williams and Wilking Co., Baltimore, MD.

Magnusson, J., Ström, K., Roos, S., Sjögren, J. and Schnürer, J., 2003. Broad and complex antifungal activity among environmental isolates of lactic acid bacteria. FEMS microbiology letters, 219(1), pp.129-135.

Magnusson, J. and Schnürer, J., 2001. Lactobacillus coryniformis subsp. coryniformis strain Si3 produces a broadspectrum proteinaceous antifungal compound. Appl. Environ. Microbiol., 67(1):1-5.

Maryam, R, dan Zahari, P., 1994. Toksin Fusarium pada jagung yang berasal dari dataran tinggi dan dataran rendah. Makalah pada Kongres Perhimpunan Mikologi Kedokteran Manusia dan Hewan Indonesia I dan Temu Ilmiah. Bogor, 21-24 Juli 1994:289-293.

Masood, M.I., Qadir, M.I., Shirazi, J.H. and Khan I.U., 2011. Beneficial effects of lactic acid bacteria on human beings. Crit. Rev. Microbiol. 37:91-98

Moreno, M.R.F., Leisner, J.J., Tee, L.K., Ley, C., Radu, S., Rusul, G., Vancanneyt, M. and De Vuyst, L., 2002. Microbial analysis of Malaysian tempeh, and characterization of two bacteriocins produced by isolates of Enterococcus faecium. Journal of applied microbiology, 92(1), pp.147-157.

Mu, W., Liu, F., Jia, J., Chen, C., Zhang, T. and Jiang, B., 2009. 3-Phenyllactic acid production by substrate feeding and $\mathrm{pH}$-control in fed-batch fermentation of Lactobacillus sp. SK007. Bioresource technology, 100(21), pp.5226-5229.

Mulyowidarso, R.K., Fleet, G.H. and Buckle, K.A., 1990. Association of bacteria with the fungal fermentation of soybean tempe. Journal of applied bacteriology, 68(1), pp.43-47.

Muñoz, R., Arena, M.E., Silva, J. and González, S.N., 2010. Inhibition of mycotoxin-producing Aspergillus nomius VSC 23 by lactic acid bacteria and Saccharomyces cerevisiae. Brazilian journal of microbiology, 41(4), pp.1019-1026.

Nakajima, N., Nozaki, N., Ishihara, K., Ishikawa, A. and Tsuji, H., 2005. Analysis of isoflavone content in tempeh, a fermented soybean, and preparation of a new isoflavone-enriched tempeh. Journal of bioscience and bioengineering, 100(6), pp.685-687.

Nche, P.F., Nout, M.J.R. and Rombouts, F.M., 1994. The effect of cowpea supplementation on the quality of kenkey, a traditional Ghanaian fermented maize food. Journal of cereal science, 19(2), pp.191-197.

Ndagano, D., Lamoureux, T., Dortu, C., Vandermoten, S. and Thonart, P., 2011. Antifungal activity of 2 lactic acid bacteria of the Weissella genus isolated from food. Journal of food science, 76(6), pp.M305-M311.

Nout, M.J.R. and Kiers, J.L., 2005. Tempe fermentation, innovation and functionality: update into the third millenium. Journal of applied microbiology, 98(4), pp.789-805.

Nout, M.J.R. and Rombouts, F.M., 1990. Recent developments in tempe research. Journal of applied bacteriology, 69(5), pp.609-633.

Nuraida, L., Suliantari, A.N., Adawiyah, D.R., Novier, R. and Agustin, D., 2008. Evaluation of soybean varieties on production and quality of tempe. Prosiding Perkembangan Terkini Tentang Tempe, pp.1-15.

Nuraida, L., 2015. A review: Health promoting lactic acid bacteria in traditional Indonesian fermented foods. Food science and human wellness, 4(2), pp.47-55.

Olasupo, N.A., Olukoya, D.K. and Odunfa, S.A., 1997. Identification of Lactobacillus species associated with selected African fermented foods. Zeitschrift für naturforschung C, 52(1-2), pp.105-108.

Oyewole, O.B. and Odunfa, S.A., 1990. Characterization and distribution of lactic acid bacteria in cassava fermentation during fufu production. Journal of applied microbiology, 68(2), pp.145-152.

Pawiroharsono, S., 1994. Penggunaan Isolat untuk Peningkatan kualitas Makanan Fermentasi Tempe. Makalah disampaikan pada presentasi ilmiah Peneliti BPP Teknologi, pada tanggal, 13.

Peltonen, K., El-Nezami, H., Haskard, C., Ahokas, J. and Salminen, S., 2001. Aflatoxin B1 binding by dairy strains of lactic acid bacteria and bifidobacteria. Journal of dairy science, 84(10), pp.2152-2156.

Persons, K., Raines, J.M. and Rodriguez, J.M., 2013. Antagonistic effects of Saccharomyces cerevisiae on the growth of Aspergillus flavus and Aspergillus parasiticus at varying temperatures. Mycology, 4(1), pp.38-43. 
Prema, P., Smila, D., Palavesam, A. and Immanuel, G., 2010. Production and characterization of an antifungal compound (3-phenyllactic acid) produced by Lactobacillus plantarum strain. Food and bioprocess technology, 3(3), pp.379386.

Ramos, D.M.B., Silva, C.F., Batista, L.R. and Schwan, R.F., 2010. In vitro inhibition of toxigenic filamentous fungi by Pichia sp. and Debaryomyces sp. isolates from coffee (Coffea arabica) fruits. Acta scientiarum agronomy, 32, 397402.

Samson, R.A., Van Kooij, J.A. and De Boer, E., 1987. Microbiological quality of commercial tempeh in the Netherlands. Journal of food protection, 50(2), pp.92-94.

Schillinger, U. and Lücke, F.K., 1987. Identification of lactobacilli from meat and meat products. Food microbiology, 4(3), pp.199-208.

Schwenninger, S.M., Lacroix, C., Truttmann, S., Jans, C., Spoerndli, C., Bigler, L. and Meile, L., 2008. Characterization of low-molecular-weight antiyeast metabolites produced by a food-protective Lactobacillus-Propionibacterium coculture. Journal of food protection, 71(12), pp.2481-2487.

Seumahu, C.A., Suwanto, A. and Suhartono, M.T., 2010. Dinamika populasi Acetobacter selama proses fermentasi nata de coco. Microbiology Indonesia, 10(2).

Shetty, P.H., Hald, B. and Jespersen, L., 2007. Surface binding of aflatoxin B 1 by Saccharomyces cerevisiae strains with potential decontaminating abilities in indigenous fermented foods. International journal of food microbiology, 113(1), pp.41-46.

Shier, W.T., Shier, A.C., Xie, W. and Mirocha, C.J., 2001. Structure-activity relationships for human estrogenic activity in zearalenone mycotoxins. Toxicon, 39(9), pp.1435-143.

Shurtleff, W. and Aoyagi, A., 2011. History of Tempeh and Tempeh Products (1815-2011): Extensively Annotated Bibliography and Sourcebook. Soyinfo Center.

Steinkraus, K., 1996. Handbook of Indigenous Fermented Foods. Marcel Dekker, New York, USA.

Stiles, J., Penkar, S., Plockova, M., Chumchalova, J. and Bullerman, L.B., 2002. Antifungal activity of sodium acetate and Lactobacillus rhamnosus. Journal of food protection, 65(7), pp.1188-1191.

Ström, K., Sjögren, J., Broberg, A. and Schnürer, J., 2002. Lactobacillus plantarum MiLAB 393 produces the antifungal cyclic dipeptides cyclo (L-Phe-L-Pro) and cyclo (L-Phe-trans-4-OH-L-Pro) and 3-phenyllactic acid. Applied and environmental microbiology, 68(9), pp.4322-4327.

Tinyiro, S.E., Wokadala, C., Xu, D. and Yao, W., 2011. Adsorption and degradation of zearalenone by Bacillus strains. Folia microbiologica, 56(4), p.321.

Turner, S., Pryer, K.M., Miao, V.P.W. and Palmer, J.D., 1999. Investigating deep phylogenetic relationships among cyanobacteria and plastids by small subunit rRNA sequence analysis, Journal of Eukaryotic Microbiology, 46: 327-338.

Utaka, M., Sakai, T. and Tsuboi, S., 1991. Asymmetric reduction by effective use of bakers' yeast. Journal of synthetic organic chemistry, Japan, 49(7), pp.647-656.

Valerio, F., Favilla, M., De Bellis, P., Sisto, A., de Candia, S. and Lavermicocca, P., 2009. Antifungal activity of strains of lactic acid bacteria isolated from a semolina ecosystem against Penicillium roqueforti, Aspergillus niger and Endomyces fibuliger contaminating bakery products. Systematic and applied microbiology, 32(6), pp.438-448.

White, T.J., Bruns, T., Lee, S. and Taylor, J., 1990. Amplification and direct sequencing of fungal ribosomal RNA genes for phylogenetics. In: PCR Protocols: a guide to methods and applications, (Innis MA, Gelfand DH, Sninsky JJ, White TJ, eds), Academic Press, New York, USA: 315-322.

Winarno, F.G., 1985. Tempe Making on Various Substrates. In Di dalam: Asian Symposium on Non-Salted Soybean Fermentation Tsukuba.

Yamashita, A., Yoshizawa, T., Aiura, Y., Sanchez, P.C., Dizon, E.I., Arim, R.H. and Sardjono, 1995. Fusarium mycotoxins (fumonisins, nivalenol, and zearalenone) and aflatoxins in corn from Southeast Asia. Bioscience, biotechnology, and biochemistry, 59(9), pp.1804-1807.

Yang, E.J. and Chang, H.C., 2010. Purification of a new antifungal compound produced by Lactobacillus plantarum AF1 isolated from kimchi. International journal of food microbiology, 139(1), pp.56-63.

Yiannikouris, A., Francois, J., Poughon, L., Dussap, C.G., Bertin, G., Jeminet, G. and Jouany, J.P., 2004. Adsorption of zearalenone by $\beta$-D-glucans in the Saccharomyces cerevisiae cell wall. Journal of food protection, 67(6), pp.1195-1200.

Yu, J., Du, X., Wang, W., Zhang, J., Liu, W., Sun, Z., Sun, T. and Zhang, H., 2011. Phenotypic and genotypic characteristics of lactic acid bacteria isolated from sour congee in Inner Mongolia of China. The Journal of general and applied microbiology, 57(4), pp.197-206.

Zhang, X., Zhang, S., Shi, Y., Shen, F. and Wang, H., 2014. A new high phenyl lactic acid-yielding Lactobacillus plantarum IMAU10124 and a comparative analysis of lactate dehydrogenase gene. FEMS Microbiol. Lett., 356(1):89-96. 


\section{General Discussion}

Food is fundamental importance to life and the most essential for maintaining continued survival (De Vries et al., 1997). There is no sense in talking about food nutritional value, sensory or functional properties if the food product is not safe enough for consumption. Indonesia suffers a double burden of food safety problem. The first, related to fundamental issues of food safety; about the insufficient practice of Good Manufacturing Practices (GMP) principles that may lead to food poisoning for the consumer. The second, related explicitly to export-oriented food industries; Indonesia must face a variety of new food safety. One of the food product that needs attention for its safety is tempeh, a commonly consumed dish in Indonesia.

Tempeh is produced mostly on a small scale home industry with poorly controlled fermentation that carried out without sufficient hygienic precautions. Various types of microorganisms can participate during the process of fermentation, natural contamination is always possible (Winarno, 1985; Barus et al., 2008; Seumahu et al., 2013). Moreover, there is no standard on making tempeh and its starter. This causes many variations in the manufacture of tempeh in many areas and lead to inconsistencies in quality and safety of tempeh (Astuti et al., 2000). Tempeh, as important food is massively produced and consumed by Indonesian people. As a new export commodity, it really needs standardized starter and controlled processing to fulfill safety aspects.

The scope of this study was to address questions about microbiological and food safety in tempeh production in Indonesia. Researchs were divided into three main topics. Topic 1 (Chapter 3) dealt with the exploration of mucoralean fungi involved during tempeh production as well as solid fermentation process. Zygomycetes strains were isolated from Indonesian tempeh and starter and screened toxicologically and clinically to evaluate possible health risks for human consumption. In this topic, we also studied the role of tempeh fungi on zearalenone (ZEN) biotransformation. In Topic 2 (Chapter 4), we studied the toxigenic fungal contamination of usar (traditional tempeh inoculum). We characterized the contaminant strains and detect mycotoxins they produced. Mycotoxins contamination in traditional tempeh was also screened. In Topic 3 (Chapter 6), we characterized and investigated the diversity of lactic acid bacteria (LAB) and yeast by analyzing soak water samples collected from different tempe manufactures in Java. We also screened and investigated their potential antifungal activity against Fusarium proliferatum, and observed their contribution to ZEN biotransformation.

DNA sequences of genes such as ACT (actin) have been widely used for supporting morphological traits of mucoralean species (Voigt and Wonstemeyer, 2001; Abe et al., 2010; Dolatabadi et al., 2014). The results of sequence alignment by BLAST and phylogenetic analysis proved that ACT sequencing is suitable for accurate identification of tempeh fungal isolates. All the phylogenetic trees with high bootstrap supports revealed that the isolates had been successfully identified at the species level and further differentiated as particular strains within the same species. The dendrogram clearly showed distinct. The dendrogram indicated that Rhizopus spp. from Indonesian tempeh and inocula were placed into $R$. stolonifer clade (4 strains), R. delemar 
clade (7 strains), $R$. oryzae clade (8 strains), $R$. microsporus var. microsporus clade (10 strains), $R$. microsporus var. oligosporus clade ( 8 isolates) and $R$. microsporus var. chinensis clade (4 isolates). The $R$. delemar clade was sister to $R$. oryzae clade with $99 \%$ BS. The $R$. microsporus var. chinensis clade was sister to $R$. microsporus var. microsporus, and $R$. microsporus var. oligosporus clade with 100\% BS. The result clearly showed that the resolution of sequence from ACT region was sufficient in determining Rhizopus species into variety level, particularly in $R$. microsporus complex. This proved that DNA sequencing with ACT gene gave better taxonomy information until level of variety than morphological analysis in this genus. ACT is known as a housekeeping gene. Its expression is relatively stable under variable conditions. ACT encodes actin, a protein that is abundant in all eukaryotic cells, in which it is the major component of cytoplasmic microfilaments. The ACT gene has been used extensively to infer interspecies re1ationships across broad evolutionary distances, as the ACT gene of many species contains highly conserved (i.e. exon) and less well-conserved sequences, which are grouped as nuclear pre-mRNA introns (Donnelly et al., 1999).

There are three kind of threats to food safety associated with Rhizopus. First threat is about clinical infection. Most of the clinically important zygomycetes are in the order Mucorales and comprise approximately 60 genera. The genus Rhizopus exhibits the largest impact on mankind, being the main causing agent of mucormycosis, followed by Lichtheimia and Mucor (Skiada et al., 2011; Gomes et al., 2011). Our result showed that Rhizopus isolates from tempeh did not display a virulence potential. Mortality rates at four days after infection were found very low in the range $0-20 \%$ at G. mellonella model. Many reports explained that mucormycosis causing Rhizopus strains induce high mortality rates (80-100\%) (Ribes et al., 2000; Dolatabadi et al., 2014). Those results also supported by genetic data. Consequently, the tempeh fungi isolates probably are nonpathogenic isolates. This is also in line with the fact that tempeh production and consumption have been practiced in Indonesia for centuries and, to our knowledge, there is no single report on infectious disease associated with tempeh. The second threat is rhizonin and rhizoxin produced by symbiotic bacteria (Burkholderia rhizoxinica) that reside within Rhizopus microsporus cytosol (Partida-Martinez et al., 2007; Lackner et al., 2009). Our result indicated that no Burkholderia species occurs in fungal isolates from Indonesian tempeh. Only three fungal samples were contaminated. Those samples were isolated from fresh tempeh that was produced in non-hygienic workshops. They were identified as Enterobacter cloacae, Comamonas testosteron, and Ochrobactrum intermedium, classified as human pathogen causing gastroenteritis. More attention should be given since there were several gastroenteritis outbreaks regarding unpasteurized tempeh consumption reported recently in Indonesia. The third threat is about possibility of masked-ZEN produced by the fungal. Our result revealed that authentic fungal strains used in production of tempeh in Indonesia could convert ZEN to conjugated ZEN and ZEL derivatives in vitro. This study showed that the investigated fungal strains have a high potential for ZEN conjugation by metabolic processes. These transformations may also occur during fermentation of tempeh. As the conjugates can be hydrolyzed by human intestinal microbiota, also sulfates and glucosides represent a relevant source for the human exposure to ZEN. If the 
unprocessed grains for tempeh fermentation like mix soybeans-maize are contaminated with ZEN, upon analysis ZEN content of the final tempeh product may be underestimated, because ZEN has been conjugated during food processing.

Several types of tempeh fermentation starters can be distinguished. Natural starters made with plant leaves (e.g., Hisbiscus spp.), and soybeans, known as "usar" are still widely used in Indonesia. Usar is prepared by placing pieces of matured tempeh between two Hibiscus leaves. Until now traditional tempeh producers still involve waru lengis leaves (Hibiscus tiliaceus) for usar manufacture, even though these leaves may serve as a source of Fusarium spp (Nout et al., 1999; Suliantari 1996) We successfully identified Fusarium from traditional tempeh inocula (usar) which were collected from various markets and center of tempeh producers in 9 different areas. DNA sequences of genes such as TEF-1 $\alpha$ have been widely used for supporting morphological traits of Fusarium species (Yli-Mattila et al., 2002; Hsuan et al., 2011). In the present study, molecular investigation based on the TEF-1 $\alpha$ gene led to more precise identification of Fusarium isolates. We found two main species of Fusarium, identified as F. solani and F. proliferatum. We not only study their presence in usar but also in traditional tempeh product. Out of 214 traditional tempeh samples from the six clusters mentioned above were screened for $F$. proliferatum and $F$. solani contamination by real-time PCR. Contamination of traditional tempeh samples with $F$. proliferatum was found in $12 \%$ of the samples with amounts of 10-175 ng/mg fungal DNA. In these samples, the amount of fumonisin B1 (FB1) and beauvericin (BEA) ranged between 170$2682 \mu \mathrm{g} / \mathrm{kg}$ and $20-50 \mu \mathrm{g} / \mathrm{kg}$, respectively. About $7 \%$ of the traditional tempeh samples were contaminated with $F$. solani in amounts of $20-129 \mathrm{ng} / \mathrm{mg}$ fungal DNA. All samples had lower FB1 contents than legal limit in Indonesia $(2000 \mu \mathrm{g} / \mathrm{kg}$; SNI 7385:2009), except for one sample from Yogyakarta area that contained FB1 above the allowed limit. Although mycotoxin contamination was detected below the legal limit, the presence of mycotoxin should be controlled in traditional tempeh production. To help consumer distinguish between contaminated and non-contaminated tempeh, we assessed quality aspect of both tempeh. There were no differences between normal and contaminated tempeh on the compactness and physical characters (texture, $\mathrm{pH}$, and color). Interestingly we found that chemical contents were significantly different especially in protein and amino acid content. We suggest that consumer could distinguish contaminated tempeh by checking the taste of fresh tempeh before cooked. Contaminated tempeh is less umami than normal tempeh because of less L-aspartic acid and L-glutamic acid content, in other words, contaminated-tempeh is less delicious compared to the normal.

Our study was continued on finding the way to protect traditional tempeh from Fusarium contamination and also to reduce any possibility of ZEN or masked-ZEN contamination. Among natural biological antagonist, lactic acid bacteria (LAB) and yeasts have potential as biopreservative. $\mathrm{LAB}$ can play a vital role as preservatives since they have a long history in fermented food production, are generally recognized as safe (GRAS status), and they have a Qualified Presumption of Safety (QPS) status. In our study, we used soak water as source of LAB and yeast. The soak water is side product of natural acidification process in tempeh production. In total, 165 isolates were obtained from soak water samples using selective media. Our results revealed a 
certain variety of culturable LAB and yeast in soak water. The principal yeast found to be responsible for fermentation were Candida tropicalis, Kluyveromyces marxianus, and Saccharomyces cerevisiae, while the dominant LAB were Lactobacillus plantarum, L. paracasei and Pediococcus pentosaceous. We found that LAB species were less diverse than yeast species. Cell free supernatants (CFS) of 20 LAB strains possessed antifungal properties against $F$. proliferatum BJ0905, while none of the yeast isolates showed the activity. It was found that phenyllactic acid (PLA) might be involved in activity. The role of PLA and other organic acids as antifungal substances also observed by several authors. PLA is mostly produced by L. plantarum with a broad spectrum antifungal activity (Lavermicocca et al., 2000, Ström et al., 2002; Ndagano et al., 2011). Some other LABs can synthesize PLA and 4-hydroxy-acid phenyllactic (Valerio et al., 2004). The use of those selected LAB strains as part of starter culture has been proven to positively increase tempeh safety. However, this LAB addition made $\mathrm{pH}$ of tempeh become lower $(\mathrm{pH}$ in rage 5.1-5.5) than normal tempeh (6.5-6.7). The LAB culture addition might impart undesirable sensory characteristic of tempeh. Further research is necessary to cope with this application problem before it can be applied into large-scale production systems in traditional tempeh industry.

The results obtained from screening 20 yeast and LAB isolates belonging to 10 different species revealed that nearly all the tested organisms were able to reduce ZEN in range 10 to $96.9 \%$. In general, yeast and LAB isolates could only transform ZEN into two major transformation products $\alpha$-ZEL and $\beta$-ZEL. In all cases no conjugation product was detected. The novel result of the study is not about tempeh LAB and yeast activity to reduce ZEN amount but their capability to transform ZEN by reducing the keto group into two major transformation product $\alpha$ - and $\beta$-ZEL. More importantly, none of isolates could transform ZEN into ZEN conjugates, thus this microorganism will not contribute to producing of masked-ZEN. Most of research in this area so far only highlight the role of LAB and yeast as adsorbent (binding) agent of mycotoxins (ElNezami et al., 2004; Haskard et al., 2001). LAB and yeast fermentation is a recommended method for reducing ZEN in contaminated raw materials such as corn that usually used in tempeh production, although safety of decontaminated food is not guaranteed because mode of action may not only involve transformation process but also reversible binding. Further research is necessary to establish the mode of ZEN reduction in natural fermentation.

\section{References}

Abe, A., Asano, K. and Sone, T., 2010. A molecular phylogeny-based taxonomy of the genus Rhizopus. Bioscience, biotechnology, and biochemistry, 74(7), pp.1325-1331.

Astuti, M., Andreanyta, M., Fabien S.D. and Mark L.W., 2000. Tempe, a nutritious and healthy food from Indonesia. Asia Pac. J. Clin. Nutr. 9(4):322-325.

Barus, T., Suwanto, A., Wahyudi, A.T. and Wijaya, H., 2008. Role of bacteria in tempe bitter taste formation: microbiological and molecular biological analysis based on 16S rRNA gene. Microbiology Indonesia, 2(1).

Dolatabadi, S., Hoog, G.S., Meis, J.F. and Walther, G., 2014. Species boundaries and nomenclature of Rhizopus arrhizus (syn. R. oryzae). Mycoses, 57(s3), pp.108-127. 
Dolatabadi, S., Walther, G., Van Den Ende, A.G. and de Hoog, G.S., 2014. Diversity and delimitation of Rhizopus microsporus. Fungal diversity, 64(1), pp.145-163.

Donnelly, S.M., Sullivan, D.J., Shanley, D.B. and Coleman, D.C., 1999. Phylogenetic analysis and rapid identification of Candida dubliniensis based on analysis of ACT1 intron and exon sequences. Microbiology, 145(8), pp.18711882.

El-Nezami, H., Polychronaki, N., Lee, Y.K., Haskard, C., Juvonen, R., Salminen, S. and Mykkänen, H., 2004. Chemical moieties and interactions involved in the binding of zearalenone to the surface of Lactobacillus rhamnosus strains GG. Journal of agricultural and food chemistry, 52(14), pp.4577-4581.

Gomes, M.Z., Lewis, R.E. and Kontoyiannis, D.P., 2011. Mucormycosis caused by unusual mucormycetes, nonRhizopus,-Mucor, and-Lichtheimia species. Clinical microbiology reviews, 24(2), pp.411 -445.

Haskard, C.A., El-Nezami, H.S., Kankaanpää, P.E., Salminen, S. and Ahokas, J.T., 2001. Surface binding of aflatoxin B1 by lactic acid bacteria. Applied and environmental microbiology, 67(7), pp.3086-3091.

Hsuan, H.M., Salleh, B. and Zakaria, L., 2011. Molecular identification of Fusarium species in Gibberella fujikuroi species complex from rice, sugarcane and maize from Peninsular Malaysia. International journal of molecular sciences, 12(10), pp.6722-6732

Lackner, G. and Hertweck, C., 2011. Impact of endofungal bacteria on infection biology, food safety, and drug development. PLoS Pathog., 7(6), p.e1002096.

Lavermicocca, P., Valerio, F., Evidente, A., Lazzaroni, S., Corsetti, A. and Gobbetti, M., 2000. Purification and characterization of novel antifungal compounds from the sourdough Lactobacillus plantarum strain 21B. Applied and environmental microbiology, 66(9), pp.4084-4090.

Ndagano, D., Lamoureux, T., Dortu, C., Vandermoten, S. and Thonart, P., 2011. Antifungal activity of 2 lactic acid bacteria of the Weissella genus isolated from food. Journal of food science, 76(6), pp.M305-M311

Nout, M.J., Martoyuwono, T.D., Bonné, P.C. and Odamtten, G.T., 1992. Hibiscus leaves for the manufacture of usar, a traditional inoculum for tempe. Journal of the science of food and agriculture, 58(3), pp.339-346.

Partida-Martinez, L.P., Groth, I., Schmitt, I., Richter, W., Roth, M. and Hertweck, C., 2007. Burkholderia rhizoxinica sp. nov. and Burkholderia endofungorum sp. nov., bacterial endosymbionts of the plant-pathogenic fungus Rhizopus microsporus. International journal of systematic and evolutionary microbiology, 57(11), pp.25832590.

Ribes, J.A., Vanover-Sams, C.L. and Baker, D.J., 2000. Zygomycetes in human disease. Clinical microbiology reviews, 13(2), pp.236-301.

Seumahu, C.A., Suwanto, A. and Suhartono, M.T., 2010. Dinamika populasi Acetobacter selama proses fermentasi nata de coco. Microbiology Indonesia, 10(2).

Skiada, A., Pagano, L.I., Groll, A., Zimmerli, S., Dupont, B., Lagrou, K., Lass-Florl, C., Bouza, E., Klimko, N., Gaustad, P. and Richardson, M., 2011. Zygomycosis in Europe: analysis of 230 cases accrued by the registry of the European Confederation of Medical Mycology (ECMM) Working Group on Zygomycosis between 2005 and 2007. Clinical microbiology and infection 1;17(12):1859-67.

Ström, K., Sjögren, J., Broberg, A. and Schnürer, J., 2002. Lactobacillus plantarum MiLAB 393 produces the antifungal cyclic dipeptides cyclo (L-Phe-L-Pro) and cyclo (L-Phe-trans-4-OH-L-Pro) and 3-phenyllactic acid. Applied and environmental microbiology, 68(9), pp.4322-4327.

Suliantari, 1996. Pembuatan dan penanganan laru (inokulum) tempe. In: Syarief R (ed) Pengembangan industri kecil tempe. Kantor Menneg Urusan Pangan-IPB, Jakarta, pp 2.1 -2.24

Voigt, K. and Wöstemeyer, J., 2001. Phylogeny and origin of 82 zygomycetes from all 54 genera of the Mucorales and Mortierellales based on combined analysis of actin and translation elongation factor EF-1 $\alpha$ genes. Gene, 270(1), pp.113-120

Winarno, F.G., 1985. Tempe Making on Various Substrates. In Di dalam: Asian Symposium on Non-Salted Soybean Fermentation Tsukuba.

Yli-Mattila, T., 2010. Ecology and evolution of toxigenic Fusarium species in cereals in northern Europe and Asia. Journal of plant pathology, pp.7-18. 


\section{Summary}

Food safety is a prerequisite for a food product. There is no sense in talking about quality, nutritional value, sensory or functional properties if the food product is not safe for consumption. Indonesia suffers a double burden of food safety problem. The first, related to fundamental issues of food safety; especially about the insufficient practice of Good Manufacturing Practices (GMP) principles that may lead to food poisoning for the consumer. The second, related explicitly to export-oriented food industries; Indonesia must face a variety of new food safety issues. One of the food product that needs attention for its safety matter in Indonesia is tempeh.

Tempeh is traditional food from Indonesia made by fermenting soybeans with mold Rhizopus spp. It has solid form, distinctive aroma and white and slightly gray. Indonesia is known for the largest tempeh production in the world and has the largest soyfood market in Asia. About 2.4 million tons of tempeh produced a year by more than 81 thousand tempeh producers. Tempeh is produced mostly on a small scale home industry with poorly controlled fermentation and carried out without sufficient hygienic precautions. Therefore, there are various types of microorganisms that can participate during the process of fermentation, and natural contamination is always possible. Moreover, there is no standard on making tempeh and its starter. This causes many variations in the manufacture of tempeh in many areas and lead to inconsistencies in quality and safety of tempeh. Tempeh, as important food is massively produced and consumed by Indonesian people. As a new export commodity, it really needs standardized starter and controlled processing to fulfill safety aspect.

The scope of this study was to address questions about microbiological and food safety in tempeh production in Indonesia. Researchs were divided into three main topics. Topic 1 (Chapter 3) dealt with the exploration of mucoralean fungi involved during tempeh production as well as solid fermentation process. Zygomycetes strains were isolated from Indonesian tempeh and starter and screened toxicologically and clinically to evaluate possible health risks for human consumption. In this part we also studied the role of tempeh on zearalenone (ZEN) biotransformation. In Topic 2 (Chapter 4), we studied the toxigenic fungal contamination of usar (traditional tempeh inoculum). We characterized the contaminant strains and detect mycotoxins they produced. Mycotoxins contamination in traditional tempeh was also screened. In Topic 3 (Chapter 6), we characterized and investigated the diversity of lactic acid bacteria (LAB) and yeast by analyzing soak water samples collected from different tempe manufactures in Java. We also screened and investigated their potential antifungal activity against Fusarium proliferatum, and observed their contribution to ZEN biotransformation.

Result of Topic 1: A total of 557 pure fungi isolates were obtained from 247 samples fresh tempeh and inocula in 16 different provinces in Indonesia. Diverse fungal species found in Indonesian tempeh and inocula. RAPD typing was capable of producing discriminating DNA fingerprints of Rhizopus isolates and indicated there was genetic differences among them. Many distinct patterns were observed indicating that tempeh and inocula from different location in Indonesia composed 
of a quite wide number of strains. Combination of origin or geographical data and molecular identification showed that isolates (identified as Rhizopus oryzae, R. delemar, and R. stolonifer) dominantly used by tempeh producer from outside Java, whereas isolates (Rhizopus microsporus complex isolates, identified as $R$. microsporus var. chinensis, $R$. microsporus var. microsporus and $R$. microsporus var. oligosporus) were mostly used by tempeh producer from Java. Tempeh fungi isolates are safe for human consumption since they are not mucormycosis or toxication agent, but food safety supervision has to be given to some tempeh producer that applied unhygienic practice in tempeh production because we found few sample contaminated with bacteria classified as a human pathogen causing gastroenteritis. Fungal strains used in production of tempeh in Indonesia also could convert ZEN to conjugated ZEN and ZEL derivatives in vitro. More attention needs to be given to tempeh made with mix soybean-maize. If the unprocessed grains for tempeh fermentation like mix soybean-maize are contaminated with ZEN, upon analysis ZEN content of the final tempeh product may be underestimated, because ZEN has been conjugated during fermentation.

Result of Topic 2: In total, 650 fungal isolates recovered from traditional tempeh inocula (usar) in Java. Traditional inocula (usar) were collected from many markets and center of tempeh producers in 9 different areas in Central Java and Yogyakarta provinces, Indonesia. Six clusters (Banjarnegara, Banyumas, Gombong, Kebumen, Kudus, and Yogyakarta) showed a Fusarium contamination in usar, while no contamination was found in other remaining clusters. About 8.4\% of total fungal isolates recognized belongs to Fusarium genera. Fifty-five pure isolates of Fusarium sp were collected, then observed via microscopy and molecular approach. We found two main species of Fusarium, identified as $F$. solani and $F$. proliferatum. All $F$. poliferatum isolates included in our study lacked the TRI5 gene and possessed the FUM1 gene, indicating that they are presumably trichothecene non-producers and potentially fumonisin producers. This result was confirmed by different set of primers (FUM8, and FUM12) with identical result. In other hands, $F$. solani isolates lacked in both kind of genes, indicating they are not trichothecene or fumonisin producers. LC-MS/MS screening showed $F$. solani isolates were not able to produce any important mycotoxins, whereas $F$. proliferatum positively produced beauvericin (BEA), fumonisin B1 (FB1), and enniatins. Fusarium proliferatum extracts showed about 10-fold stronger activity as toxic agent toward $F$. solani extracts based on their value of LD50. About 214 traditional tempeh samples from the six clusters mentioned above were screened for $F$. proliferatum and $F$. solani contamination by real-time PCR. Contamination of traditional tempeh samples with $F$. proliferatum was found in $12 \%$ of the samples with amounts of $10-175 \mathrm{ng} / \mathrm{mg}$ fungal DNA. In these samples, the amount of FB1 and BEA ranged between 170-2682 $\mu \mathrm{g} / \mathrm{kg}$ and $20-50 \mu \mathrm{g} / \mathrm{kg}$, respectively. About $7 \%$ of the traditional tempeh samples were contaminated with $F$. solani in amounts of 20-129 ng/mg fungal DNA. All samples had lower FB1 contents than legal limit in Indonesia (2000 $\mu \mathrm{g} / \mathrm{kg}$; SNI 7385:2009), except for one sample from Yogyakarta area which contained FB1 above the allowed limit. Although mycotoxin contamination was detected below the legal limit, the presence of mycotoxin should be controlled in traditional tempeh production. There were no differences between normal and contaminated tempeh on the compactness and 
physical characters (texture, $\mathrm{pH}$, and color). Interestingly, we found that chemical contents were significantly different especially in protein and amino acid content. This suggest that consumer could distinguish contaminated tempeh by checking the taste of fresh tempeh before cooked. Contaminated tempeh is less umami than normal tempeh because of less L-aspartic acid and Lglutamic acid content, in other words, contaminated-tempeh is less delicious compare to the normal.

Result of Topic 3: The LAB counts in soak water samples varied between 5.21 and $8.88 \log$ $\mathrm{CFU} / \mathrm{mL}$ whereas yeasts counts varied from 4.31 and $4.89 \log \mathrm{CFU} / \mathrm{mL}$, APC counts varied between 7.33 and $9.10 \log \mathrm{CFU} / \mathrm{mL}$. In total, 165 isolates were obtained from these samples using selective media. Our results revealed a certain variety of culturable LAB and yeast in soak water. The principal yeast found to be responsible for fermentation were Candida tropicalis, Kluyveromyces marxianus, and Saccharomyces cerevisiae, while the dominant LAB were Lactobacillus plantarum, L. paracasei and Pediococcus pentosaceous. We found LAB species were less diverse than yeast species. Cell free supernatants (CFS) of 20 LAB strains possessed antifungal properties against $F$. proliferatum B.J0905, while none of the yeast isolates showed the activity. It was found that phenyllactic acid (PLA) might has main role for the activity. The use of those selected LAB strains as part of starter culture has been proven to positively increase tempeh safety. The results obtained from screening 20 isolates belonging to 10 different species revealed that nearly all the tested organisms were able to reduce ZEN in range 10 to $96.9 \%$. In general, yeast and LAB isolates could only transform ZEN into two major transformation product $\alpha$-ZEL and $\beta$-ZEL. In all cases no conjugation product detected.

Research outcome for society: Safe and defined strains for modern inoculum and tempeh production have been selected and formulated. In the near future, safe and high quality inoculum could be produced on a mass scale and distributed to tempeh manufactures, thus tempeh production would be controlled from the beginning process and indeed increase its safety. 


\section{Acknowledgements}

First of all, it is my great honor and pleasure to express my deepest gratitude and heartiest thanks to my principal supervisor Prof. Dr. Petr Karlovsky for his enthusiastic guidance, creative supervision, advice and encouragement during the whole period of the study. This study would not have been possible to complete unless his continuous and excellent guidance in exploring, generalizing and broadening new findings. I thank him also for the motivation and good discussion during whole period of the study. I am so grateful for the time and discussions that we had enriching my knowledge, skills and experiences. I learnt from him to be critical and to obtain insight in scientific research.

Furthermore, I would like to express my deepest thank Dr. Katharina Pfohl, who support me especially in HPLC-MS/MS analysis and give excellent advice during the study.

I am very grateful to have PD Dr. Franz Hadacek and Prof. Dr. Richard Splivallo as my Ph.D. committee members.

My thank goes to LPDP Ministry of Finance, The Republic of Indonesia for the doctoral scholarship funding.

I acknowledge former Rector of Jenderal Soedirman University Prof. Edi Yuwono Ph.D. for the help and motivated me to continue my study.

I acknowledge Dr. Antje Borzekowski, Maryeni Auliyati, and Prof. Dr. Ronald Maul for innovative and nice research collaboration about zearalenone transformation.

I am thankful to all members of the Karlovsky lab, in particular, Ruth Pilot and Heike Rollwage, for their constant advice and prompt technical support, especially during the first year. Apart from this, I thank Ruth Pilot for checking partly my thesis. I thank also our apprentices Christian Kolodziel and Jonas Waterott for their technical assistance.

I also acknowledge Dr. Israr Arbar from Ministry of Environment The Republic of Indonesia, providing me GIS (Geographic Information System) for my sampling area and making professional sampling map.

I acknowledge Dr. Volker Cordes and his team (Max Planck Institute for Biophysical Chemistry) for teaching and the helpful advice for using scanning electron microscopy (SEM). 
I acknowledge Dr. Daniel, Prof. Dr. Loekas Soesanto, Prof. Emeritus Rubiyanto Misman, Dr. Narongrit Muangmai, Dr. Nur Aini, for the support, encouragement and good scientific discussion.

I thank my colleagues Muhammad Sherif, Pervin Akter, Rosine G. Fotso, Olaf Henke, Samal, Maria Vinas, Yang Xu, Muhammad Al Hussein, Rassoul Abousaeedi, Zana J. Kareem, Vincent Ayugi, Albatol Alsarrag, Mareen and Ling Su for the nice working atmosphere.

I thank friends in Germany and abroad for all the fun and good scientific discussion.

My sincere thanks go to the whole division for the good working atmosphere and support, especially to Mr. Thomas Oesterreich, Mrs. Kistner, Mrs. Thinggaard and Mrs. Christine Schachtebeck for administrative support and patience.

I thank Mr. Subekti and his wife in Jakarta, for support, motivation and help.

Last but not least, I am thankful to my family for the endless support, love and motivation during the last years.

Danke Schön!

Thank you!

Terima kasih!

Göttingen, December 2017

Riyan Anggriawan 


\section{Curriculum Vitae}

\section{Personal information}

Name

: Riyan Anggriawan

Born

: Purbalingga, Indonesia

Date of birth

: 26.11.1988

E-mail

: anggriawan.ry@gmail.com; riyan.anggriawan@agr.uni-goettingen.de

Research interest

: Food safety, molecular and food microbiology, bioactive compound and food processing

\section{Academic Education}

2014 -now : International Ph.D. Program for Agricultural Sciences, Molecular Phytopathology and Mycotoxin Research Unit, Georg-August-University Göttingen, Germany. (Main supervisor: Prof. Dr. Petr Karlovsky). Funding: LPDP, Ministry of Finance, The Republic of Indonesia.

2010-2012 : M.P. (cum laude), Agronomy Postgraduate Program (Agroindustry Technology and Management), Jenderal Soedirman University, Indonesia (Joint program with Fishery Biology Department, Algae Bioresources Research Centre, Kasetsart University, Bangkok, Thailand) (Supervisors: Karseno, Ph.D., Prof. Loekas Soesanto, Ph.D., A. Ilal Qisny Insan, M.Sc, Prof. Anong Chirapart and Dr. Jantana Praiboon.) Funding: Excellent Scholarship, BPKLN, Ministry of Education and Culture, The Republic of Indonesia.

2006-2010 : S.TP. (cum laude), Food Science and Technology, Jenderal Soedirman University, Purwokerto, Indonesia. (Supervisors: Dr. Nur Aini, and Pepita Hariyanti, M.Sc.)

2003-2006 : SMA Negeri 2 Purwokerto.

\section{Recent International Seminar or Symposium (as main or co-author)}

- Antje Borzekowski, Maryeni Auliyati, Riyan Anggriawan, Hans-Jörg Kunte, Sascha Rohn, Matthias Koch, Petr Karlovsky, and Ronald Maul. 2017. Fungi isolated from Indonesian tempeh production capable of zearalenone conjugation. 39 ${ }^{\text {th }}$ Mycotoxin Workshop, Bydgoszcz, Poland.

- Riyan Anggriawan, Katharina Pfohl, and Petr Karlovsky. 2017. Mycotoxin-producing Fusarium species in Indonesian traditional tempeh and starter (usar). 39 ${ }^{\text {th }}$ Mycotoxin Workshop, Bydgoszcz, Poland.

- Riyan Anggriawan, and Petr Karlovsky. 2015. Genome shuffling for microbes from natural fermentation of tempeh against mycotoxin: constructing parent strains library. $2^{\text {nd }}$ ICBS, Yogyakarta, Indonesia. 
- Riyan Anggriawan, and Petr Karlovsky. 2015. Genome shuffling for zygomyceteus fungi from tempeh against mycotoxins: constructing parent strains library. $37^{\text {th }}$ Mycotoxin Workshop, Bratislava, Slovakia.

- Riyan Anggriawan, A. Ilalqisny Insan, Jantana Praiboon, Anong Chirapart, Loekas Soesanto, Aisyah Tri Septiana, and Karseno. 2015. Antioxidant activity and phytochemicals of lipophilic extract obtained from selected Indonesian brown seaweeds. $2^{\text {nd }}$ ISAPPROSH, Semarang, Indonesia.

- Riyan Anggriawan, Anong Chirapart, Jantana Praiboon, Karseno, and Loekas Soesanto. 2014. Assessment of phytochemical, antifungal activity and toxicity of selected brown seaweeds extract. $36^{\text {th }}$ Mycotoxin Workshop, Göttingen, Germany.

\section{Other Recent International Symposium (as observer)}

- $7^{\text {th }}$ European Conference on Prokaryotic and Fungal Genomics, Göttingen, Germany (19-22, September 2017)

- GlobalFood Symposium, Göttingen, Germany (28-29, April 2017)

- $2^{\text {nd }}$ ICONIC Industrial Revival, Hamburg, Germany (30 ${ }^{\text {th }}$ October 2016)

\section{Other Academic Experiences}

- Coordinator of reviewer for Food Industry field in ICONIC symposium, Hannover. (2018)

- Research for submitting in partial fulfillment of requirement of Master Degree with the research tittle "Assessment of phytochemical, antifungal, antioxidant activities and toxicity of selected brown seaweeds extract" (Funding No: 62875/A2.4/LN/2011). (2011-2012)

- Training of ISO 9001-2008 Quality Management System, held by PT. Jireh and Training Consultant. (2011)

- Assistant researcher for research " $\mathrm{FeSO}_{4}$ fortification in arrowroot biscuit enriched by protein from tempeh-fish flour to avoid anemia on pregnancy period" led by Dr. V. Prihananto. STRANAS Project (National Strategic Project)-LPPM UNSOED. (2010)

- Guest Speaker for workshop/dissemination "Improvement Training of Local Food Technology and Food Consumption Diversity", held by Badan Ketahanan Pangan and UNSOED. (2010)

- Research for submitting in partial fulfillment of requirement of Bachelor Degree "Effect of milling method on physical, chemical and functional properties of hybrid corn flour". (2009)

- 3rd winner on Local Food Product Development, held by Badan Ketahanan Pangan and Agriculture Faculty UNSOED. (2009)

- Guest Speaker for workshop/dissemination "Training for Small-Medium Food Company in Banyumas". Held by Badan Ketahanan Pangan and UNSOED. (2009)

- Assistant researcher for research "Formulation of instant breakfast food product based on talas flour (C. esculenta) and supplemented by fish-tempeh flour" led by Dr. Hidayah Dwiyanti, Coordination between Balitbang Jateng and LPPM UNSOED. (2008)

- Field Work Practice (PKL) in PTP Nusantara IX (Persero) Kebun Krumput- Banyumas (Ribbed Sheed Smoked Factory), supervised by Dr. Tri Yanto. (2008) 